RAISSA CRISTINA DA SILVA MAZARELI

\title{
Otimização da produção de hidrogênio a partir de resíduos de banana: avaliação da diversidade de bactérias autóctones e distribuição funcional
}

VERSÃO CORRIGIDA

São Carlos 



\section{Otimização da produção de hidrogênio a partir de resíduos de banana: avaliação da diversidade de bactérias autóctones e distribuição funcional}

Tese apresentada à Escola de Engenharia de São Carlos, da Universidade de São Paulo, como parte dos requisitos para obtenção do título de Doutor em Ciências: Engenharia Hidráulica e Saneamento.

Discente: Raissa Cristina da Silva Mazareli

Orientadora: Prof ${ }^{\mathrm{a}}$. Dr ${ }^{\mathrm{a}}$. Maria Bernadete Amâncio Varesche

São Carlos

2019 
Ficha catalográfica elaborada pela Biblioteca Prof. Dr. Sérgio Rodrigues Fontes da EESC/USP com os dados inseridos pelo(a) autor(a).

\begin{tabular}{|c|c|}
\hline \multirow[t]{3}{*}{$\begin{array}{c}M \\
1490\end{array}$} & $\begin{array}{l}\text { Mazareli, Raissa Cristina da Silva } \\
\text { Otimização da produção de hidrogênio a partir de } \\
\text { residuos de banana: avaliaçăo da diversidade de } \\
\text { bactérias autóctones e distribuição funcional / Raissa } \\
\text { Cristina da Silva Mazareli; orientadora Maria Bernadete } \\
\text { Amâncio Varesche. São Carlos, } 2019 \text {. }\end{array}$ \\
\hline & $\begin{array}{l}\text { Tese (Doutorado) - Programa de Pós-Graduaçăo em } \\
\text { Engenharia Hidráulica e Saneamento e Area de } \\
\text { Concentração em Hidráulica e Saneamento -- Escola de } \\
\text { Engenharia de Săo Carlos da Universidade de São Paulo, } \\
2019 \text {. }\end{array}$ \\
\hline & $\begin{array}{l}\text { 1. residuo fruticola. } 2 \text {. reator anaeróbio. } 3 . \\
\text { bioenergia. } 4 \text {. metagenồica. } 5 \text {. enzimas. I. Título. }\end{array}$ \\
\hline
\end{tabular}




\section{FOLHA DE JULGAMENTO}

Candidata: Licenciada RAISSA CRISTINA DA SILVA MAZARELI.

Título da tese: "Otimização da produção de hidrogênio a partir de resíduos de banana: avaliação da diversidade de bactérias autóctones e distribuição funcional".

Data da defesa: 03/05/2019.

\section{Comissão Julgadora:}

\section{Resultado:}

Profa. Associada Maria Bernadete Amancio Varesche Silva (Orientadora)

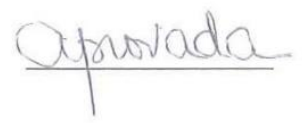
(Escola de Engenharia de São Carlos/EESC)

Dr. Tiago Palladino Delforno

(Pós-Doutorando/UNICAMP)

Prof. Dr. Guilherme Rossi Gorni

(Universidade de Araraquara/UNIARA)

Profa. Dra. Katia Sivieri

(Universidade Estadual Paulista "Júlio de Mesquita Filho"/UNESP - Araraquara)

Profa. Dra. Simone Damasceno Gomes

(Universidade Estadual do Oeste do Paraná/UNIOESTE)
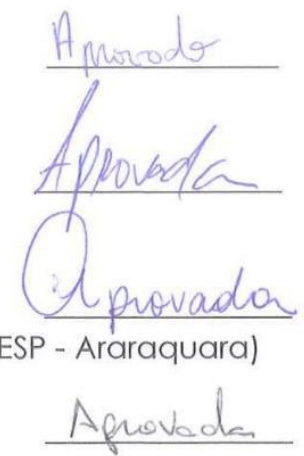

Coordenador do Programa de Pós-Graduação em Engenharia Hidráulica e Saneamento:

Prof. Dr. Eduardo Mario Mendiondo

Presidente da Comissão de Pós-Graduação:

Prof. Titular Murilo Araujo Romero 
Dedicatória

Ao Jose Luiz, Arlete e Rita, meus pilares. Ao Gustavo, meu amado companheiro. Ao meu filho, presente de Deus.

Com amor e carinho, Dedico. 


\section{Agradecimentos}

Aqui ficam os agradecimentos aqueles que me auxiliaram nesta caminhada, tanto para execução quanto para conclusão desta etapa acadêmica. Não tendo sido apenas um trabalho, mas sim um crescimento, uma aprendizagem pessoal e profissional, uma caminhada que exige esforço, porém muito gratificante.

A começar pela figura divina, Deus, por me inserir em um seio familiar, por sempre me fortalecer e permitir que continue em busca dos meus sonhos.

Aos meus pais, José Luis e Arlete, e a minha irmã Rita, nos quais me orgulho imensamente e que representam a forma mais simples de caráter e sabedoria.

Ao meu companheiro Gustavo, por toda atenção, paciência, carinho e amor em todos os momentos.

Ao meu filho, que apesar de estar ainda em meu ventre, contribuiu e me motivou ainda mais, para continuar e seguir em frente na busca pelo melhor.

A minha orientadora, Prof ${ }^{a}$. Dra . Maria Bernadete A. Varesche, pelos seus ensinamentos profissionais e pessoais, paciência, e a sua pronta disponibilidade e confiança em mim depositada.

Ao Prof ${ }^{\mathrm{o}}$. Dr ${ }^{\mathrm{o}}$. Edson Luis (Tininho), pela sua disponibilidade, auxílio e presteza concebida a mim durante a execução do projeto.

A minha companheira de apartamento, de laboratório e de vida, Alejandra (Shakira), por estar sempre comigo me ajudando de todas as formas possíveis e impossíveis.

Ao amigo prestativo Wesley e a toda família "Sancabadalada" por serem além de amigos, irmãos nos quais levarei por toda minha vida. Obrigada por toda força, carinho e solidariedade. Cada momento ao lado de vocês foi inesquecível \#Tusca \#oisumido

Aos amigos do LPB, que contribuíram com cada tijolo depositado na construção desta tese. Com certeza o dia-a-dia na pesquisa foi mais prazeroso com a presença de todos vocês, desde as idas ao "bandejão", até as noites de cinéticas. Cada ensinamento foi muito válido!

A equipe "Bernadetes" pela troca de conhecimento aliada ao bom convívio. Em especial, Ale, Fran, Vanessa, Fiaz, Marina e Henrique.

Aos professores, corpo técnico e administrativo do LPB e SHS, cada um com sua função especial contribuíram grandemente com a minha formação. Uma menção especial a Isabel, Janja e Juliana (Lab. Biologia).

As fiéis amigas UNESPIANAS, Bianca (pônei), Janaina (janinha) e Aline (pomba) por sempre estarem presentes, me dando força e incentivo, vocês são muito além de amigas, são irmãs! A reta final foi mais pacífica com a ajuda de vocês. 
A Fundação de Amparo e Pesquisa do Estado de São Paulo (FAPESP), processo ${ }^{\circ}$ 2016/20048-6, referente ao projeto de pesquisa Temático nº 2015/06246-7 e a Coordenação de Aperfeiçoamento de Pessoal de Nível Superior - Brasil (CAPES) - Código de Financiamento 001 - pelo fornecimento da bolsa e auxílio financeiro complementar na realização da pesquisa.

A Escola de Engenharia de São Carlos (EESC/USP), Programa de pós-graduação em Engenharia Hidráulica e Saneamento (PPG-SHS) e Laboratório de processos biológicos (LPB) por propiciar condições para minha formação de qualidade na obtenção do título de Doutora em Ciências.

Meus mais sinceros agradecimentos a todos! 
"A tarefa não é ver aquilo que ninguém viu, mas pensar o que ninguém ainda pensou sobre aquilo que todo mundo vê."

Arthur Schopenhauer 


\section{RESUMO}

Mazareli, Raissa Cristina da Silva. Otimização da produção de hidrogênio a partir de resíduos de banana: avaliação da diversidade de bactérias autóctones e distribuição funcional. 2019. 238 p. Tese (Doutorado em Engenharia Hidráulica e Saneamento). Escola de Engenharia de São Carlos, Universidade de São Paulo, São Carlos, 2019.

A banana (Musa spp.) está entre as culturas mais abundantes no mundo, e devido ao seu descarte, desde a colheita até a sua comercialização gera-se grande quantidade de resíduos sólidos. Neste cenário, buscou-se avaliar o potencial uso do resíduo de banana (RB) como substrato e fonte de bactérias fermentativas para produção de $\mathrm{H}_{2}$ e metabólitos solúveis. Obtevese a partir da fermentação natural do RB biomassa autóctone produtora de $\mathrm{H}_{2}$ sem necessidade do uso de fonte exógena de bactérias e custo adicional de fontes de carbono. Nesse consórcio foram identificadas bactérias semelhantes a Lactobacillus e Clostridium. Ensaios em reatores em batelada foram conduzidos para seleção do meio de cultivo (BAC, Noparati e PCS), das variáveis independentes ( $\mathrm{pH}$, temperatura, concentração do substrato, headspace e inóculo), seguido do delineamento composto central rotacional (DCCR) para otimização da produção de hidrogênio. Verificou-se que as condições nutricionais do meio PCS (extrato de levedura, peptona, $\mathrm{NaCl}$ e $\left.\mathrm{CaCO}_{3}\right)$ e $\mathrm{RB}$ resultaram na produção $(P)$ e rendimento $\left(\mathrm{YH}_{2}\right)$ máximo de $15,05 \mathrm{~mL}$ e $10,03 \mathrm{~mL} \mathrm{H}_{2} \cdot \mathrm{g}^{-1} \mathrm{CT}$ (carboidratos totais), respectivamente. Em relação às variáveis independentes $(\mathrm{pH}$, temperatura, concentração de substrato, volume do headspace e porcentagem de inóculo) obteve-se maiores valores de $P$ e velocidade de produção $(R m)$ de $\mathrm{H}_{2}$ de $38,08 \mathrm{~mL}$ e $3,07 \mathrm{~mL} . \mathrm{h}^{-1}$, respectivamente, em pH 7,5, $15 \mathrm{~g} . \mathrm{L}^{-1}, 44^{\circ} \mathrm{C}, 40 \%$ de headspace e $15 \%$ inóculo. Em relação às variáveis estatisticamente significativas ( $\mathrm{pH}$ e temperatura) via realização do DCCR observou-se que o aumento do $\mathrm{pH}$ (de 5,09 para 7,5) favoreceu, tanto $P$, quanto $R m$, todavia, maior temperatura (de 27,1 para $46,9^{\circ} \mathrm{C}$ ) associada ao menor $\mathrm{pH}(<6,5)$ foram condições desfavoráveis para esses parâmetros. Por outro lado, obteve-se redução do tempo de início de produção de hidrogênio $\left(\lambda \mathrm{H}_{2}\right)$ para maior temperatura $\left(44-46,9^{\circ} \mathrm{C}\right)$ associada ao menor $\mathrm{pH}(5,5)$ As condições operacionais ótimas estimadas via modelo foram em $\mathrm{pH}$ 7,0 e $37^{\circ} \mathrm{C}$, obtendo-se $70,09 \mathrm{~mL} \mathrm{H}, 12,43 \mathrm{~mL} \mathrm{H} \mathrm{H}_{2} \cdot \mathrm{h}^{-1}$ e $93 \mathrm{~mL} \cdot \mathrm{g}^{-1} \mathrm{CT}$, para $P$, $R m$ e $\mathrm{YH}_{2}$, respectivamente. Bacillus sp. isolada do RB cresceu em variedade de substratos (glicose, xilose, manose, galactose, frutose, maltose, celobiose, sacarose, amido e RB), e $71 \mathrm{~mL} \mathrm{H}_{2}$ foi obtido em 5 g. $L^{-1}$ de RB, pH 7 a $37^{\circ} \mathrm{C}$. Em todos os ensaios em reatores em batelada, independentemente das condições operacionais, verificou-se que as principais vias metabólicas foram do ácido acético butírico e ácido lático, principalmente com glicose e frutose como fonte de carbono. A acidificação dos reatores resultou na diminuição do $\mathrm{pH}$ inicial para valores $<4,0$ favorecendo a rota solventogênica. Na biomassa fermentativa autóctone e aquela dos reatores em batelada foi possível inferir sobre elevado potencial metabólico, devido a identificação de genes relacionados com enzimas do metabolismo de carboidratos.

Palavras-chave: resíduo frutícola, reator anaeróbio, bioenergia, metagenômica, enzimas. 


\begin{abstract}
Mazareli, Raissa Cristina da Silva. Optimization of hydrogen production from banana residue: evaluation of autochthonous bacteria diversity and functional distribution. 2019. 238 p. Doctor of Science Thesis. São Carlos School of Engineering, University of São Paulo, São Carlos, 2019.

Banana (Musa spp.) is among the most abundant crops in the world and, due to its discard, great quantity of solid waste is generated from the harvest until its commercialization. In this scenario, the potential use of banana residue (RB) as substrate and source of fermentative bacteria for the production of $\mathrm{H}_{2}$ and soluble metabolites was evaluated. It was obtained from $\mathrm{RB}$ natural fermentation native autochthonous $\mathrm{H}_{2}$-producing biomass without the need to use exogenous source of bacteria and additional costs from carbon sources. In this consortium, bacteria similar to Lactobacillus and Clostridium were identified. Batch reactor experiments were conducted to select culture medium (BAC, Noparati and PCS) and independent variables ( $\mathrm{pH}$, temperature, substrate concentration, headspace and inoculum), followed by central composite rotatable design (CCRD) experiments for optimization of hydrogen production. It was verified that the nutritional conditions provided by PCS medium (yeast extract, peptone, $\mathrm{NaCl}$ and $\left.\mathrm{CaCO}_{3}\right)$ and $\mathrm{RB}$ resulted in the maximum production $(\mathrm{P})$ and yield $\left(\mathrm{YH}_{2}\right)$ of 15.05 $\mathrm{mL}$ and $10.03 \mathrm{~mL} \mathrm{H}_{2} \mathrm{~g}^{-1} \mathrm{CT}$ (total carbohydrates), respectively. Regarding the independent variables $(\mathrm{pH}$, temperature, substrate concentration, headspace volume and percentage of inoculum), higher $\mathrm{P}$ and $\mathrm{H}_{2}$ production rate $(R m)$ were obtained $\left(38.08 \mathrm{~mL}\right.$ and $3.07 \mathrm{~mL} \mathrm{~h}^{-1}$, respectively) at $\mathrm{pH} 7.5,15 \mathrm{~g} \mathrm{~L}^{-1}$ of substrate, $44{ }^{\circ} \mathrm{C}, 40 \%$ headspace and $15 \%$ inoculum. In relation to the statistically significant variables ( $\mathrm{pH}$ and temperature), it was observed through CCRD that the increase in $\mathrm{pH}$ (from 5.09 to 7.5) favored both $\mathrm{P}$ and $R m$, however, a higher temperature (from 27.1 to $46.9^{\circ} \mathrm{C}$ ) associated with lower $\mathrm{pH}(<6.5)$ were unfavorable conditions for these parameters. On the other hand, a reduction in the hydrogen production start time $\left(\lambda \mathrm{H}_{2}\right)$ was obtained with higher temperature $\left(44-46.9^{\circ} \mathrm{C}\right)$ associated to lower $\mathrm{pH}(5.5)$. The optimum operational conditions, estimated by modeling, were $\mathrm{pH} 7.0$ and $37{ }^{\circ} \mathrm{C}$, yielding $70.09 \mathrm{~mL} \mathrm{H}_{2}$, $12.43 \mathrm{~mL} \mathrm{H}_{2} \mathrm{~h}^{-1}$ and $93 \mathrm{~mL} \mathrm{gCT}^{-1}$ for $\mathrm{P}, \mathrm{Rm}$ and $\mathrm{YH}_{2}$, respectively. Bacillus sp. isolated from $\mathrm{RB}$ grown on a variety of substrates (glucose, xylose, mannose, galactose, fructose, maltose, cellobiose, sucrose, starch and $\mathrm{RB}$ ), and $71 \mathrm{~mL} \mathrm{H}_{2}$ was obtained with $5 \mathrm{~g} \mathrm{~L}^{-1} \mathrm{RB}, \mathrm{pH} 7$ at 37 ${ }^{\circ} \mathrm{C}$. In all batch reactor experiments, regardless of operating conditions, the main metabolic pathways were acetic acid, butyric acid and lactic acid, mainly with glucose and fructose as carbon sources. Acidification of the reactors resulted in a decrease of the initial $\mathrm{pH}$ to values $<4.0$, favoring the solventogenic pathway. It was possible to infer about the high metabolic potential in the autochthonous fermentative biomass and in the biomass from the batch reactors due to the identification of genes related to enzymes of the carbohydrate metabolism.
\end{abstract}

Key words: fruit waste, anaerobic reactor, bioenergy, metagenomics, enzymes. 


\section{LISTA DE FIGURAS}

Figura 2.1. Vias metabólicas para conversão da biomassa vegetal em hidrogênio durante a

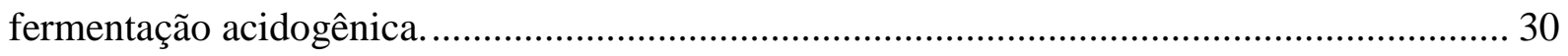

Figura 2.2. Diagrama de blocos representando a cadeia produtiva da fruticultura brasileira.. 32 Figura 2.3. Esquema geral da conversão da matéria orgânica até a etapa acetogênica associada as enzimas que catalisam cada reação. 44

Figura 4.1. Fluxograma experimental dos objetivos do trabalho nas diferentes etapas da pesquisa.

Figura 4.2. (A) Resíduo de banana (B) Peneiramento em malha de $2 \mathrm{~mm}$ do resíduo triturado. 50

Figura 4.3. Esboço do perfil de escoamento em um recipiente com chicanas com agitador montado co-axialmente. 50

Figura 4.4. Obtenção de consórcio de bactérias fermentativas autóctones. 51

Figura 4.5. Seleção do meio de cultivo a partir do resíduo de banana como fonte de carbono.

Figura 4.6. Imagem ilustrativa da técnica de diluição seriada e plaqueamento para obtenção de colônias isoladas.

Figura 4.7. Jarra anaeróbia utilizada para incubar as placas de Petri (A), placa de Petri com crescimento de colônias individuais após incubação $37^{\circ} \mathrm{C} / 24$ horas (B) e aumento da biomassa produtora de $\mathrm{H}_{2}(\mathrm{C})$

Figura 5.1. Curva de rarefação estável abrangendo o número total de famílias (A) e gêneros (B) na amostra do inóculo.

Figura 5.2. Abundância relativa dos (A) grupos taxonômicos predominantes do inóculo para Classe (B) e gêneros para as duas classes mais abundantes.

Figura 5.3. Espécies de Clostridium (A) e Lactobacillus (B) mais abundantes identificadas no consórcio de bactérias autóctones do resíduo de banana.

Figura 5.4. Curva de rarefação estável abrangendo o número total de KO atribuído pelo aumento do número de sequências na amostra do inóculo.

Figura 5.5. Distribuição funcional metabólica da categoria II do KEGG dos genes identificados na amostra da biomassa autóctone do resíduo de banana. 84

Figura 5.6. Abundância relativa dos genes relacionados as enzimas associadas ao metabolismo de carboidratos nas diferentes fases da fermentação. 88

Figura 5.7. Rotas metabólicas de degradação da sacarose, frutose e glicose do resíduo da banana. 
Figura 5.8. Produção de $\mathrm{H}_{2}$ em função do tempo nos ensaios em reatores em batelada com diferentes meios de cultivo.

Figura 5.9. Carboidratos totais ao longo do tempo nos ensaios em reatores em batelada com diferentes meios de cultivo.

Figura 5.10. Ácidos carboxílicos ao longo do tempo nos ensaios com reatores em batelada com diferentes meios de cultivo. 102

Figura 5.11. Grau de acidificação dos ácidos individuais (ácido acético, ácido butírico e ácido propiônico) e total nos ensaios em reatores em batelada com diferentes meios de cultivo. .. 104 Figura 5.12. Variação da produção de hidrogênio $(\mathrm{mL})$ para os diferentes meios de cultivo dos reatores em batelada.

Figura 5.13. Quantil-quantil (Q-Q plot) da normal do conjunto de dados para as diferentes condições nutricionais dos meios de cultivo dos reatores em batelada. 106

Figura 5.14. Microscopia de luz comum do consórcio de bactérias autóctones obtidos da fermentação natural do resíduo de banana (A-B) e após enriquecimento em meio de cultivo PCS (C-D).

Figura 5.15. Coloração de Gram do consórcio de bactérias autóctones obtidos da fermentação natural do resíduo de banana (A) e após enriquecimento em meio de cultivo PCS (B).

Figura 5.16. Produção temporal de hidrogênio a partir do delineamento experimental PlackettBurman (PB) na fermentação de resíduos de banana em reatores em batelada. 114

Figura 5.17. Concentração de DQO solúvel final e grau de acidificação dos ácidos individuais (ácido acético, lático, butírico e propiônico) e juntos para delineamento Plackett-Burman.. 123 Figura 5.18. Análise de Cluster do perfil de bandas do DGGE dos fragmentos de RNAr 16S para o inóculo e biomassa dos ensaios 3, 6 e 7 do delineamento PB.

Figura 5.19. Estimadores de riqueza e índices de diversidade para a biomassa do inóculo e de maior produção de hidrogênio (E6) do delineamento de Plackett-Burman. 132 Figura 5.20. Abundância relativa dos representantes pertencentes aos gêneros do domínio Bacteria da amostra do inóculo e do ensaio 6 do delineamento de Plackett-Burman. 135

Figura 5.21. Principais espécies de Clostridium identificadas na amostra de inóculo e E6 do delineamento de Plackett-Burman.

Figura 5.22. Principais espécies de Lactobacillus identificadas na amostra de inóculo e E6 do delineamento de Plackett-Burman.

Figura 5.23. Curva de rarefação abrangendo o número total de $\mathrm{KO}$ atribuído pelo aumento do número de sequências na amostra do ensaio E6. 141

Figura 5.24. Distribuição funcional metabólica dos genes observados na amostra do E6 ..... 142 
Figura 5.25. Produção temporal de $\mathrm{H}_{2}$ do delineamento experimental DCCR

Figura 5.26. Efeito do pH e temperatura na produção de hidrogênio $(\mathrm{P})$.

Figura 5.27. Valores experimentais versus valores preditos pelo modelo para as respostas $\mathrm{P}(\mathrm{A})$ e $\operatorname{Rm}(B)$

Figura 5.28. Superfície de resposta da interação entre o efeito do $\mathrm{pH}$ e temperatura na produção de hidrogênio $(\mathrm{P})(\mathrm{A})$ e velocidade de produção $(\mathrm{Rm})(\mathrm{B})$ em reatores em batelada. 154 Figura 5.29. Valores experimentais versus valores preditos pelo modelo para a resposta $\mathrm{YH}_{2}$.

Figura 5.30. Superfície de resposta e curva de contorno para rendimento de hidrogênio para pH e temperatura.

Figura 5.31. Eficiência de conversão de carboidratos totais $\left(\mathrm{EC}_{\mathrm{CT}}\right)$ nos ensaios do DCCR com variação de $\mathrm{pH}$ e temperatura.. 158

Figura 5.32. Produção de $\mathrm{H}_{2}$ nos ensaios do DCCR em função do $\mathrm{pH}$ e da produção de ácidos carboxílicos (AC). 159

Figura 5.33. Ácidos carboxílicos em função do tempo dos ensaios do DCCR

Figura 5.34. Relação HBu/HAc e produção de hidrogênio nos ensaios do DCCR em reatores em batelada.

Figura 5.35. Efeito do pH e temperatura na fermentação do resíduo da banana nos ensaios do DCCR em reator em batelada. 171

Figura 5.36. Açúcares solúveis nos ensaios do DCCR em reatores em batelada. 176

Figura 5.37. Cinética de produção de $\mathrm{H}_{2}$ nas condições otimizadas ( $\mathrm{pH} 7,0$ e $37^{\circ} \mathrm{C}$ ). 178 Figura 5.38. Cinética de produção de ácidos carboxílicos no ensaio de validação experimental em reatores em batelada. 180

Figura 5.39. Açúcares solúveis no ensaio de validação dos reatores em batelada. 182

Figura 5.40. Percentuais de acidificação dos metabólitos utilizados para o balanço de massa solúvel.

Figura 5.41. Análise de Cluster do perfil de bandas dos DGGE dos fragmentos de RNAr 16s para o inóculo e os ensaios 1, 5 e 11 do DCCR e ensaio de validação experimental. 184 Figura 5.42. Estimadores de riqueza e índices de diversidade para as amostras de inóculo, maior produção de etanol (E11) e ensaio de validação experimental. 186 Figura 5.43. Abundância relativa dos representantes das Ordens mais abundantes na biomassa do inóculo, ensaio E5 e ensaio de validação experimental. 188 Figura 5.44. Abundância relativa dos representantes semelhantes aos gêneros do domínio Bacteria da amostra do inóculo, E5 e validação experimental. 188 
Figura 5.45. Principais espécies de Clostridium (A) e Lactobacillus (B) pertencentes a amostra de inóculo, E5 e validação experimental.

Figura 5.46. Curva de rarefação estável abrangendo o número total de KO atribuído pelo aumento do número de sequências no E5 (A) e validação experimental (B).

Figura 5.47. Distribuição funcional metabólica dos genes observados na amostra do inóculo, E5 e ensaio de validação. 195

Figura 5.48. Rota de produção de $\mathrm{H}_{2}$ e ácidos carboxílicos associadas a degradação do resíduo de banana (A) e principais $\mathrm{KO}$ e genes das enzimas associadas ao metabolismo de carboidratos obtidos no E5 e ensaios de validação. 197

Figura 5.49. Dendograma de distância genética da sequência de DNAr 16S da cepa isolada.

Figura 5.50. Curva de crescimento (A) e Concentração de massa seca celular (B). 200

Figura 5.51. Efeito da fonte de carbono no crescimento de Bacillus sp. RM1 206

Figura 5.52. Curva de crescimento de Bacillus sp. RM1 com diferentes concentrações de celobiose. .208

Figura 5.53. Produção de hidrogênio e conversão de carboidratos a partir de Bacillus sp. RM1 em diferentes concentrações de celobiose (A) 0,5 g.L -1 $^{-1}$ (B) 2,0 g.L $\mathrm{L}^{-1}$ (C) 3,5 g.L (L) $^{-1}$ (D) 5,0 g.L $\mathrm{L}^{-1}$ (E) 6,5 g.L. ${ }^{-1}$. 210

Figura 5.54. Ácidos carboxílicos e etanol na fermentação com celobiose a partir de crescimento de Bacillus sp. RM1 (A) 0,5 g.L , (B) 2,0 g.L $^{-1}$ (C) 3,5 g.L (D) $^{-1}$ (D) 5,0 g.L -1 $^{-1}$ e (E) 6,5 g.L ${ }^{-1} .212$ Figura 5.55. Curva de crescimento e produção de hidrogênio a partir de Bacillus sp. RM1 utilizando resíduo de banana em reator em batelada. 


\section{LISTA DE TABELAS}

Tabela 2.1. Principais frutas frescas produzidas no Brasil (2016) ........................................ 31

Tabela 2.2. Rendimento de hidrogênio a partir da fermentação de resíduos de frutas ............ 33

Tabela 2.3. Mudanças químicas em casca de banana-nanica durante o amadurecimento (base seca). 36

Tabela 2.4. Condições otimizadas da produção de hidrogênio utilizando ferramentas estatísticas.

Tabela 2.5. Estratégias sequenciais para se atingir condições otimizadas .............................. 37

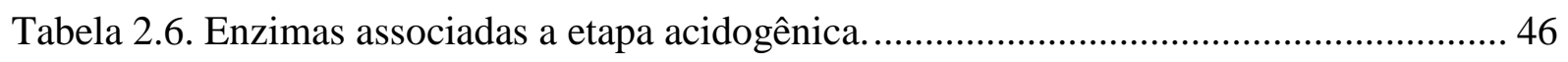

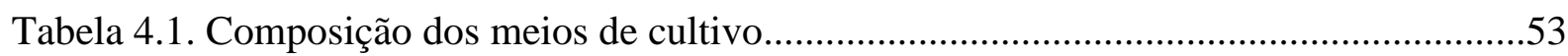

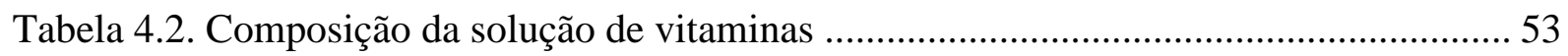

Tabela 4.3. Composição da solução de traço de metais........................................................... 54

Tabela 4.4. Valores das variáveis do planejamento Plackett-Burman (PB) e seus respectivos

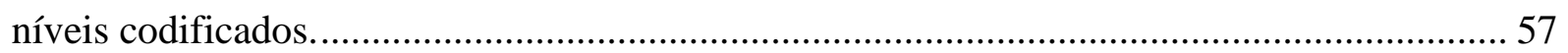

Tabela 4.5. Matriz do delineamento experimental Plackett-Burman (PB) ............................ 58

Tabela 4.6. Matriz do delineamento composto central rotacional (DCCR) com os valores das

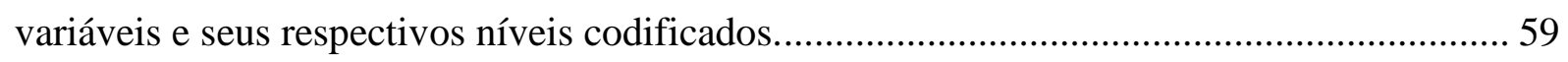

Tabela 4.7. Condições operacionais utilizadas no ensaio experimental para validação do modelo

Tabela 4.8. Métodos analíticos e frequência de análises empregado como monitoramento para avaliação dos reatores em batelada.

Tabela 4.9. Equacionamentos empregados no cálculo das variáveis respostas utilizadas para avaliação dos ensaios em reatores em batelada. 63

Tabela 4. 10. Amostras selecionadas para avaliação da diversidade bacteriana...................... 64

Tabela 4.11. Fatores de equivalência utilizados nos cálculos do balanço de massa.

Tabela 5.1. Caracterização físico-química e nutricional do resíduo de banana utilizado como substrato para alimentação dos reatores em batelada.

Tabela 5.2. Produção de hidrogênio e metabólitos solúveis a partir da fermentação natural de diferentes resíduos sem adição de inóculo.

Tabela 5.3. Abundância relativa total dos genes relacionados as enzimas e dos principais microrganismos envolvidos no metabolismo da frutose e sacarose na fermentação do resíduo de banana no inóculo. 
Tabela 5.4. Cinética de produção de hidrogênio via fermentação utilizando diferentes meios de cultivo em reatores em batelada com resíduo de banana

Tabela 5.5. Condições experimentais para a fermentação utilizando diferentes meios de cultivo.

Tabela 5.6. Transformação dos dados utilizando $\log (x+1)$. 107

Tabela 5.7. Análise dos efeitos para as variáveis respostas do planejamento Plackett-Burman (PB).

Tabela 5.8. Variáveis respostas da fermentação de resíduo de banana com biomassa autóctone para o Delineamento Plackett-Burman (PB) para os 15 ensaios em reatores em batelada. ... 113 Tabela 5.9. Respostas para pH final e produção de ácidos carboxílicos e etanol para o Delineamento de Plackett-Burman (PB).

Tabela 5.10. Análise comparativa das bactérias identificadas nas biomassas do inóculo e ensaio E6.

Tabela 5.11. Principais KO e genes das enzimas associadas ao metabolismo de carboidratos na fermentação de RB.

Tabela 5.12. Matriz do delineamento composto central rotacional (DCCR) e variáveis respostas.

Tabela 5.13. Coeficientes de regressão para as respostas produção de $\mathrm{H}_{2}(\mathrm{P})$ e velocidade de produção $\mathrm{H}_{2}(\mathrm{Rm})$. 152

Tabela 5.14. Testes para a falta de ajuste e para regressão linear para as produções de $\mathrm{H}_{2}(\mathrm{P}) \mathrm{e}$ velocidade de produção $\mathrm{H}_{2}(\mathrm{Rm})$ 152

Tabela 5.15. Coeficientes de regressão para a resposta rendimento de $\mathrm{H}_{2}\left(\mathrm{YH}_{2}\right)$ 156

Tabela 5.16. Testes para a falta de ajuste e para regressão linear para rendimento de $\mathrm{H}_{2} \ldots . .156$ Tabela 5.17. Produção de ácidos carboxílicos (AC), etanol e fenóis nos ensaios do DCCR em função do $\mathrm{pH}$ e temperatura.

Tabela 5.18. Condições operacionais utilizadas no ensaio experimental para validação dos modelos

Tabela 5.19. Balanço de massa da fase solúvel (BMS) do reator em batelada nas condições otimizadas

Tabela 5.20. Efeito de diferentes fontes de carbono na produção e rendimento de hidrogênio e conversão de carboidratos a partir Bacillus sp. RM1. 202 Tabela 5.21. Efeito da concentração de celobiose nos parâmetros cinéticos na produção de hidrogênio, rendimento de $\mathrm{H}_{2}$, conversão do substrato, $\mathrm{pH}$ e crescimento celular. 209 
Tabela 5.22. Rendimento de hidrogênio em reatores em batelada utilizando diferentes resíduos vegetais como fonte de carbono..

Tabela 5.23. Distribuição dos principais produtos de fermentação observados durante a operação de reatores anaeróbios em batelada alimentados com resíduos de banana $\left(5 \mathrm{~g} \mathrm{~L}^{-1}\right)$ inoculados com Bacillus sp. RM1

Tabela 6.1. Evolução da produção de hidrogênio mediante o emprego de estratégias experimentais previamente elaboradas pelas sub-hipóteses. 


\section{LISTA DE ABREVIATURAS E SIGLAS}

$\mathrm{AC}=$ Ácido carboxílico

$\mathrm{ACT}=$ Ácido carboxílico total

$\mathrm{ADP}=$ Adenosina difosfato

AMP = Adenosina 5' - monofosfato

ATP $=$ Adenosina trifosfato

Atm $=$ Atmosfera

$\mathrm{BAC}=$ Bactérias anaeróbias celulolíticas

$\mathrm{BAL}=$ Bactérias ácido láticas

$\mathrm{BCA}=$ Bagaço de cana-de-açúcar

$\mathrm{BM}=$ Bagaço de maçã

BMS = Balanço de massa da fase solúvel

$\mathrm{Ca}=$ Cálcio

$\mathrm{CaCl}_{2}=$ Cloreto de cálcio

$\mathrm{CaCO}_{3}=$ Carbonato de cálcio

$\mathrm{C}_{\mathrm{CT}}=$ Conversão de carboidratos totais

$\mathrm{CH}_{4}=$ Metano

$\mathrm{C}_{6} \mathrm{H}_{12} \mathrm{O}_{6}=$ Glicose

CNTP $=$ Condições normais de temperatura e pressão

$\mathrm{CT}=$ Carboidratos totais

$\mathrm{CoA}=$ Acetil-coenzima $\mathrm{A}$

$\mathrm{COT}=$ Carbono orgânico total

$\mathrm{CO}_{2}=$ Dióxido de Carbono

$\mathrm{Cu}=$ Cobre

$\mathrm{CPQ}=$ Carne, peixe e queijo

$\mathrm{CPQBA}=$ Centro Pluridisciplinar de Pesquisas Químicas, Biológicas e Agrícolas

DCCR $=$ Delineamento de composto central rotacional

DGGE = Eletroforese em gel de gradiente desnaturante

DHAP $=$ Fosfato de Diidroxiacetona

DNA = Ácido desoxirribonucleico

DNAr = Ácido desoxirribonucleico ribossômico

DQO = Demanda química de oxigênio

$\mathrm{DQO}_{\mathrm{s}}=$ Demanda química de oxigênio solúvel

$\mathrm{EC}_{\mathrm{CT}}=$ Eficiência de conversão de carboidratos totais

$\mathrm{EtOH}=$ Etanol

$\mathrm{F}_{\text {cal }}=$ Valor de $\mathrm{F}$ calculado

$\mathrm{Fe}=$ Ferro

$\mathrm{FW}=$ Resíduos de alimentos

$\mathrm{FeSO}_{4}=$ Sulfato de Ferro

FNI = Fração não identificada

FORM = Fração orgânica de resíduo municipal

GA = Grau de acidificação

G1P = Glicose-1-fosfato 
G3P = Gliceraldeído 3-fosfato

$H=$ Índice de diversidade de Shannon

$\mathrm{H}_{2}=$ Gás hidrogênio

$\mathrm{HAc}=$ Ácido acético

$\mathrm{HBu}=$ Ácido butírico

$\mathrm{HCa}=$ Ácido capróico

$\mathrm{HCB}=$ Hortaliças + cascas de batata

$\mathrm{HCl}=$ Ácido clorídrico

$\mathrm{HFo}=$ Ácido fórmico

$\mathrm{H}_{2} \mathrm{O}=$ Água

HIsv = Ácido isovalérico

His = Ácido isobutírico

HLac = Ácido lático

HLs = Ácido isovalérico

$\mathrm{HPr}=$ Ácido propiônico

HPLC = Cromatografia líquida de alta eficiência

$\mathrm{HVa}=$ Ácido valérico

$\mathrm{HX}^{-}=$Ácidos não-dissociados

$\mathrm{K}=$ Potássio

$\mathrm{KEGG}=$ Kyoto Encyclopedia of Genes and Genomes

$\mathrm{KH}_{2} \mathrm{PO}_{4}=$ Fosfato monopotássio

$\mathrm{K}_{2} \mathrm{HPO}_{4}=$ Fosfato dipotássio

$\mathrm{KO}=\mathrm{Kegg}$ orthology

LZT = Laboratório de Biotecnologia animal do Departamento de Zootecnia

$\mathrm{M}=$ Microrganismos

$\mathrm{Mg}=$ Magnésio

$\mathrm{MgSO}_{4}=$ Sulfato de Magnésio

$\mathrm{MgCl}_{2}=$ Cloreto de Magnésio

$\mathrm{MJ}=$ Mega Joules

$\mathrm{Mn}=$ Manganês

MSC $=$ Massa seca celular

MP = Fosfatase maltose

$\mathrm{N}=$ Nitrogênio

$\mathrm{N}_{2}=$ Gás nitrogênio

$\mathrm{Na}=$ Sódio

$\mathrm{NaCl}=$ Cloreto de sódio

ND = Não detectável

$\mathrm{NAD}^{+}=$dinucleótideo de nicotinamida e adenina

$\mathrm{NADH}=$ dinucleótideo de nicotinamida e adenina reduzido

$\mathrm{NaHCO}_{3}=$ Bicarbonato de sódio

$\mathrm{NH}_{4} \mathrm{Cl}=$ Cloreto de Amônio

$\mathrm{NaOH}=$ Hidróxido de sódio

$\mathrm{Ni}=$ Níquel

NTK = Nitrogênio total Kjeldahl 
OFOR = 2-oxoácido oxidorredutase

$\mathrm{P}=$ Fósforo

$P=$ Produção de hidrogênio

$\mathrm{Pa}=$ Pascal

$\mathrm{PB}=$ Plackett-Burman

$\mathrm{PCR}=$ Reação em cadeia polimerase

PCS - meio de cultivo peptona

PGM $=$ Fosfoglicomutase

PFK $=$ Fosfofrutoquinase

$\mathrm{PFL}=$ Piruvato formiato- liase

PFOR = Piruvato ferredoxina oxidoredutase

PFK1 = 1-fosfofrutoquinase

$\mathrm{pH}=$ Potencial hidrogeniônico

$\mathrm{pH}_{2}=$ Pressão parcial de hidrogênio

$\mathrm{PK}=$ Piruvato quinase

Q-Q plot = Quantil-quantil

$\mathrm{RB}=$ Resíduo de banana

$\mathrm{RFV}=$ Resíduo de frutas e vegetais

$\mathrm{Rm}=$ Velocidade de produção de hidrogênio

SPE $=$ Substâncias poliméricas extracelulares

ST $=$ Sólidos totais

SST = Sólidos suspensos totais

SSV = Sólidos suspensos voláteis

$\mathrm{SV}=$ Sólidos voláteis

$\mathrm{SQ}=$ Soro de queijo

S/A = Sem agitação

Spp. $=$ Subespécie

$t=$ tempo

TCD $=$ Detector de condutividade térmica

$\mathrm{Tg}=$ Tempo de geração

$\mathrm{TK}=$ Transcetolase

UASB $=$ Reator anaeróbio de Fluxo ascendente com manta de lodo

UDP $=$ Uridina disfofato

$\mathrm{V}=$ Vegetais

$\mathrm{Zn}=\mathrm{Zinco}$

$\mathrm{YH}_{2}=$ Rendimento de hidrogênio

$6 \mathrm{PG}=6$-Fosfogliconato

6PGD = 6-Fosfogliconato desidrogenase 


\section{LISTA DE SÍMBOLOS}

$\alpha=$ Alfa

$\%=$ Porcentagem

${ }^{\circ} \mathrm{C}=$ Graus Celsius

$\mathrm{cm}=$ Centímetro

$<=$ Menor que

$>=$ Maior que

$\sim=$ Aproximado/aproximadamente/valor estimado

$\lambda \mathrm{H}_{2}=$ Tempo de início de produção de hidrogênio

$\Delta \mathrm{G}=$ Energia livre de Gibbs

$\mathrm{A}=$ Absorbância

$\mathrm{OD}_{600}=$ Densidade ótica

$\mathrm{G}_{\mathrm{msc} .} \mathrm{L}^{-1}=$ grama por massa seca celular

$\mathrm{G}=$ Grama

g CT. $\mathrm{L}^{-1}=$ Grama de carboidratos totais por litro

g.dm ${ }^{-3}=$ Grama por decímetro cúbico

g DQO. L $^{-1}=$ Grama de DQO por litro

g HAc. $\mathrm{L}^{-1}=$ Grama de ácido acético por litro

g. $\mathrm{L}^{-1}=$ Grama por litro

g NaCl. $\mathrm{L}^{-1}=$ Grama de cloreto de sódio por litro

g SSV.L ${ }^{-1}=$ Grama de sólidos suspensos voláteis por litro

$\mathrm{g}^{-1} \mathrm{ST} . \mathrm{L}=$ Grama de sólidos totais por litro

$\mathrm{h}=$ Hora

$\mathrm{Kg}=$ Kilograma

$\mathrm{KJ} . \mathrm{g}^{-1}=$ Quilojoule por grama

$\mathrm{KJ} . \mathrm{mol}^{-1}=$ Quilojoule por mol

$\mathrm{L}=$ Litro

$\mathrm{L} \mathrm{H}_{2} \cdot \mathrm{L} \cdot \mathrm{d}^{-1}=$ Litro de gás hidrogênio por litro por dia

$\mathrm{L} \mathrm{H}_{2} \cdot \mathrm{kg}^{-1} \mathrm{COT}=$ Litro de gás hidrogênio por kilograma de carbono orgânico total

$\mathrm{M}=$ Molar

$\mathrm{mm}=$ Milímetro

$\mathrm{mg} \cdot \mathrm{L}^{-1}=$ Miligrama por litro

$\mathrm{mg} \mathrm{H}_{\mathrm{Ac}} \cdot \mathrm{L}^{-1}=$ Miligrama de ácido acético por litro

$\mathrm{mg} \mathrm{H} \mathrm{H}_{\mathrm{Bu}} \cdot \mathrm{L}^{-1}=$ Miligrama de ácido butírico por litro

$\min =$ Minutos

$\mathrm{mL}=$ Mililitro

$\mathrm{mL} \cdot \mathrm{g}^{-1}=$ Mililitro por grama

$\mathrm{mL} . \mathrm{g}^{-1} \mathrm{CT}=$ Mililitro por grama de carboidratos totais

$\mathrm{mL} \cdot \mathrm{g}^{-1} \mathrm{CT}_{\text {add }}=$ Mililitro por grama de carboidratos totais adicionados

$\mathrm{mL} \cdot \mathrm{g}^{-1} \mathrm{COT}=$ Mililitro por grama de carbono orgânico total

$\mathrm{mL} \cdot \mathrm{g}^{-1} \mathrm{DQO}=$ Mililitro por grama de DQO

$\mathrm{mL} \cdot \mathrm{g}^{-1} \mathrm{ST}=$ Mililitro por grama de sólidos totais

$\mathrm{mL} . \mathrm{g}^{-1} \mathrm{ST} . \mathrm{h}=$ Mililitro por grama de sólidos totais por hora 
$\mathrm{mL} \cdot \mathrm{g}^{-1} \mathrm{SV}=$ Mililitro por grama de sólidos voláteis

$\mathrm{mL} \cdot \mathrm{h}^{-1}=$ Mililitro por hora

$\mathrm{mL} . \mathrm{L}^{-1}=$ Mililitro por litro

$\mathrm{mL} \mathrm{H}_{2}=$ Mililitro de gás hidrogênio

$\mathrm{mL} \mathrm{H}_{2} \cdot \mathrm{g}^{-1}=$ Mililitro de gás hidrogênio por grama

$\mathrm{mL} \mathrm{H}_{2} \cdot \mathrm{h}^{-1}=$ Mililitro de gás hidrogênio por hora

$\mathrm{mL} \mathrm{H}_{2} \cdot \mathrm{L}^{-1} \cdot \mathrm{h}=$ Mililitro de gás hidrogênio por litro por hora

$\mathrm{mL} \mathrm{H} \mathrm{H}_{2} \cdot \mathrm{L}^{-1}=$ Mililitro de gás hidrogênio por litro

$\mathrm{mL} \mathrm{H} \mathrm{H}_{2} \cdot \mathrm{g}^{-1}=$ Mililitro de gás hidrogênio por grama

$\mathrm{mL} \mathrm{H}_{2} \mathrm{~g}^{-1}$ carboidratos = Mililitro de gás hidrogênio por grama de carboidratos

$\mathrm{mL} \mathrm{H}_{2} \mathrm{~g}^{-1} \mathrm{CT}=$ Mililitro de gás hidrogênio por grama de carboidratos totais

$\mathrm{mL} \mathrm{H}_{2} \cdot \mathrm{g}^{-1} \mathrm{CT}_{\text {add }}=$ Mililitro de gás hidrogênio por grama $\mathrm{CT}$ adicionados

$\mathrm{mL} \mathrm{H}_{2} \mathrm{~g}^{-1} \mathrm{COT}=$ Mililitro de gás hidrogênio por grama carbono orgânico total

$\mathrm{mL} \mathrm{H}_{2} \mathrm{~g}^{-1} \mathrm{SV}=$ Mililitro de gás hidrogênio por grama de sólidos voláteis

$\mathrm{mL} \mathrm{H}_{2} \mathrm{~g}^{-1} \mathrm{ST}=$ Mililitro de gás hidrogênio por grama de sólidos totais

$\mathrm{mL} \mathrm{H}_{2} \mathrm{~g}^{-1} \mathrm{DQO}=$ Mililitro de gás hidrogênio por grama de DQO

mol.g $=$ Mol por grama

mol.mol ${ }^{-1}=$ mol por mol

mmol. $\mathrm{L}^{-1}=$ Milimol por litro

mmol. $\mathrm{g}^{-1}=$ Milimol por grama

mmol $\mathrm{H}_{2} \cdot \mathrm{L}^{-1}=$ Milimol por litro

$\mathrm{mmol} . \mathrm{L}^{-1} \cdot \mathrm{h}=$ Milimol por litro por hora

$\mathrm{nm}=$ Nanômetro

$\mathrm{rpm}=$ Rotações por minuto

$\mathrm{t}=$ Tonelada

$\mu \mathrm{L}=$ Microlitro

$\mu \mathrm{m}=$ Micrômetro

$\mu_{\max }=$ Velocidade máxima

UV = Radiação ultravioleta

$\mathrm{V}=$ Volt 


\section{SUMÁRIO}

1. INTRODUÇÃ

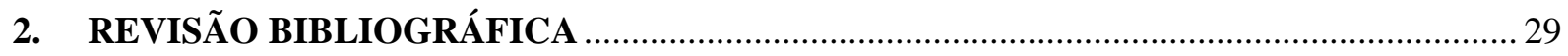

2.1. Fermentação acidogênica para produção de $\mathrm{H}_{2}$ : Utilização de biomassa sustentável ............29

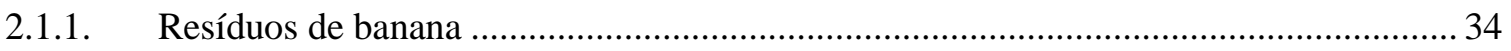

2.2. Planejamento Experimental e análise de superfície de resposta na produção de $\mathrm{H}_{2}$............. 36

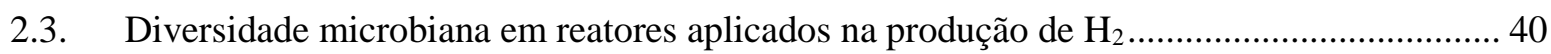

2.4. Enzimas relacionadas a fermentação para produção de hidrogênio ...................................... 43

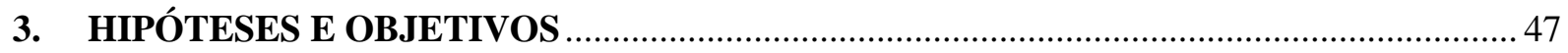

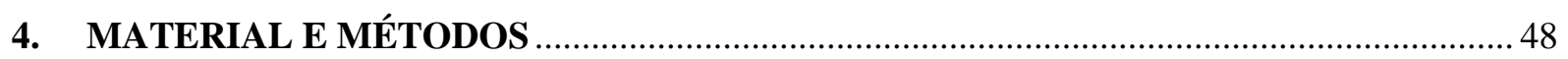

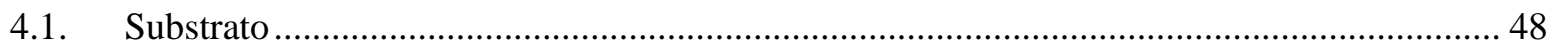

4.2. Obtenção do consórcio de bactérias fermentativas autóctones..............................................50

4.2.1. Fermentação natural do resíduo de banana..................................................................... 50

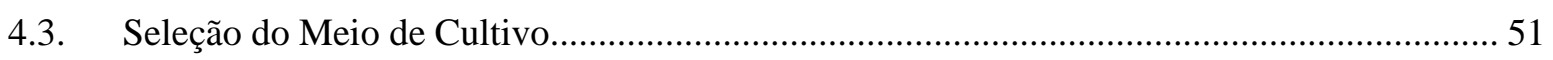

4.4. Isolamento de bactéria produtora de hidrogênio ............................................................... 54

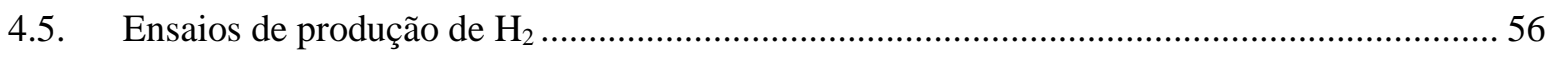

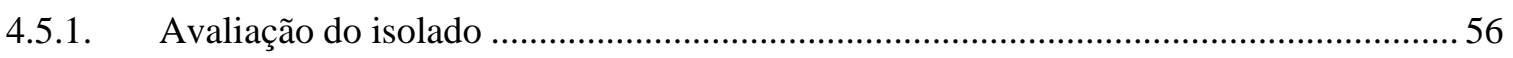

4.6. Seleção das variáveis independentes - Delineamento experimental de Plakett-Burman

(PB)

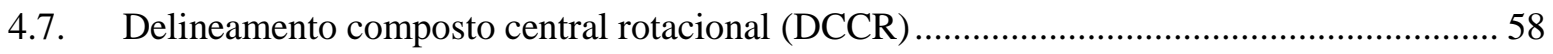

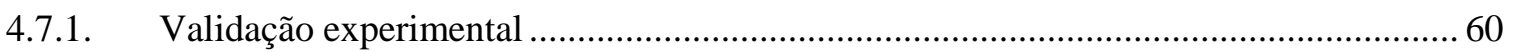

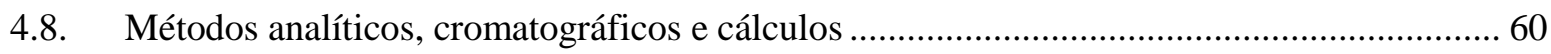

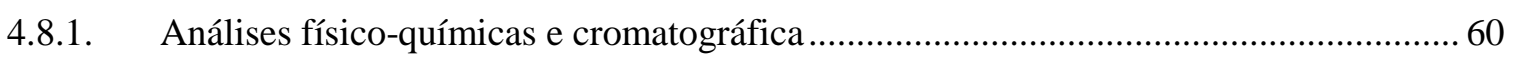

4.8.2. Ajuste ao Modelo de Gompertz e avaliação dos métodos estatísticos............................. 60

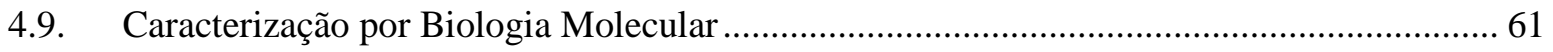

4.9.1. Identificação taxonômica e análise filogenética do isolado............................................ 61

4.9.2. Amostragem, extração de DNA e DGGE do consórcio de bactérias ............................... 64

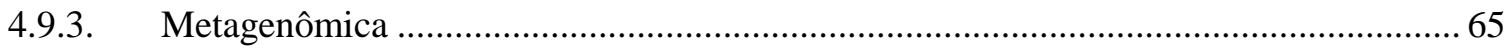

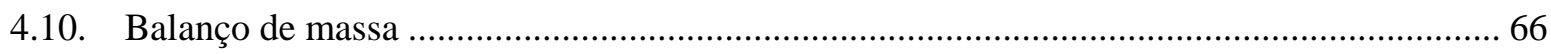


5.1. Caracterização do resíduo de banana in natura .......................................................................68

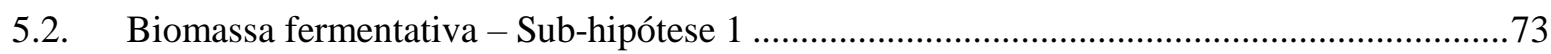

5.2.1. Caracterização molecular da biomassa do inóculo....................................................... 76

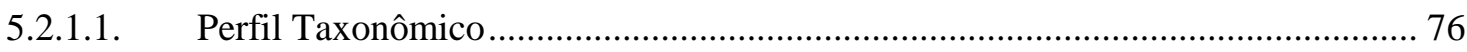

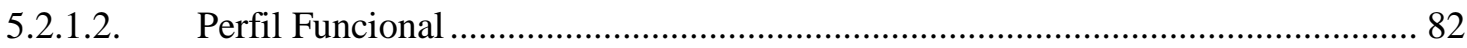

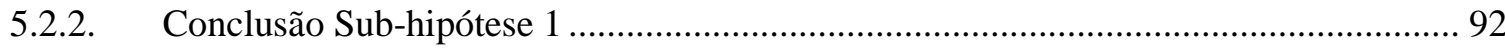

5.3. Avaliação dos meios de cultivo - Sub-hipótese 2 2..............................................................93

5.3.1. Efeito de Elementos Nutricionais na Produção de $\mathrm{H}_{2}$................................................. 93

5.3.2. Avaliação dos metabólitos solúveis nos diferentes meios de cultivo ............................ 101

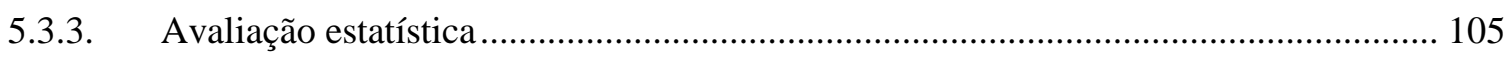

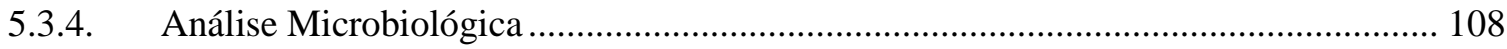

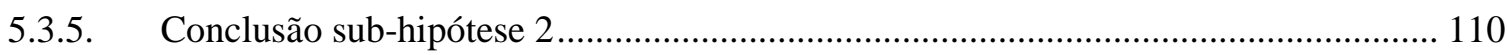

5.4. Avaliação dos efeitos das variáveis independentes .............................................................110

5.4.1. $\mathrm{pH}$

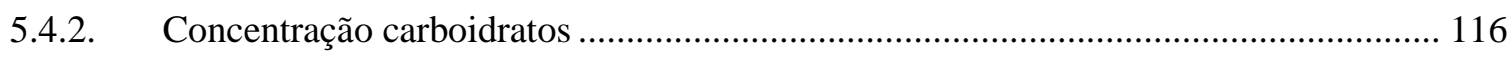

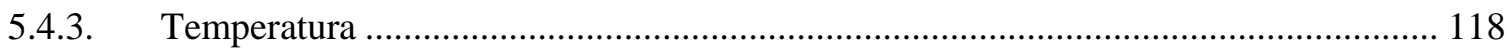

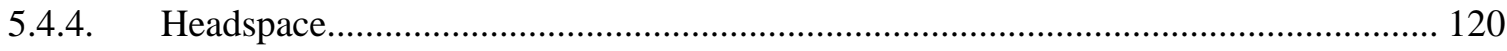

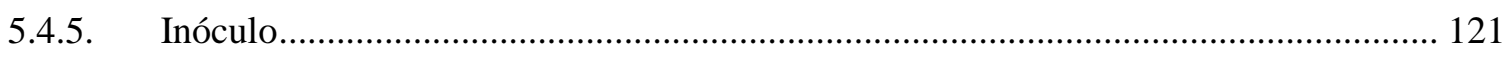

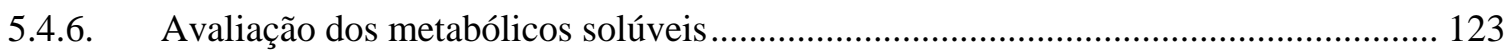

5.4.7. Avaliação da comunidade bacteriana do delineamento de Plakett-Burman................. 130

5.4.7.1. Efeito das variáveis independentes no perfil taxonômico ................................... 132

5.4.7.2. Metabolismo de carboidratos associado ao ensaio com maior produção de $\mathrm{H}_{2} .$.

5.4.8. Conclusão do delineamento de Plakett-Burman........................................................... 145

5.5. Otimização da produção de hidrogênio - Sub-hipótese 3 ....................................................146

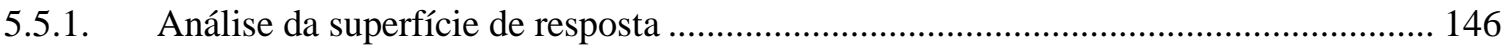

5.5.2. Avaliação dos metabólicos solúveis............................................................................ 159

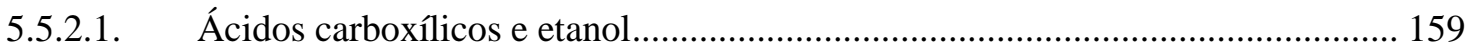

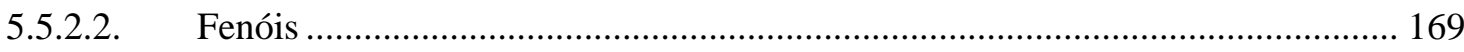




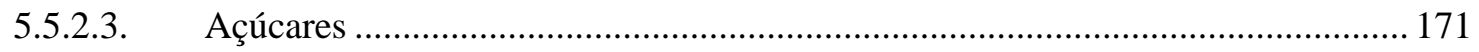

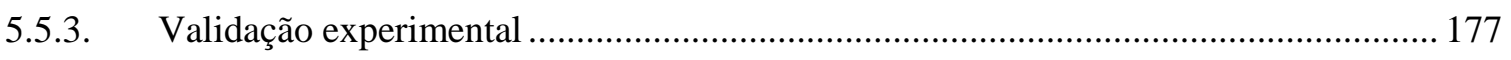

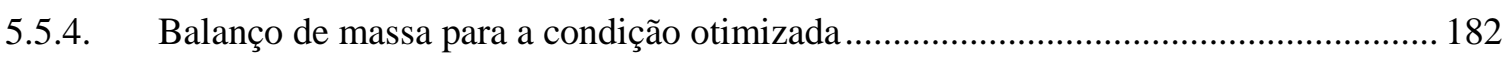

5.5.5. Avaliação da comunidade bacteriana do delineamento composto central rotacional.. 184

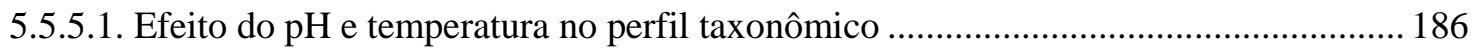

5.5.5.2. Metabolismo de carboidratos associado ao ensaio com maior produção de ácido lático

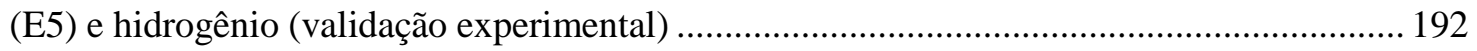

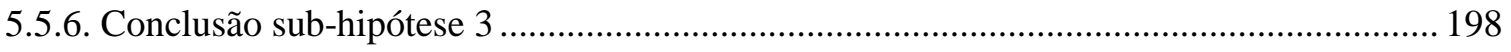

5.6. Produção de hidrogênio a partir do isolado - Sub-hipótese 4 ............................................ 199

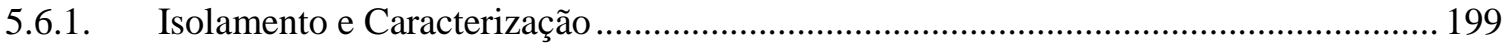

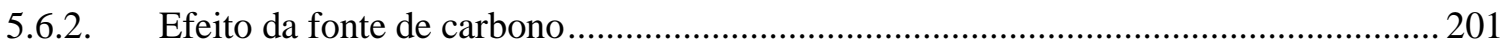

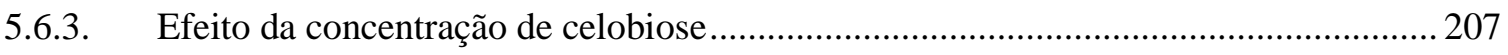

5.6.4. Substituição de açúcares simples por resíduo de banana na produção de hidrogênio 213

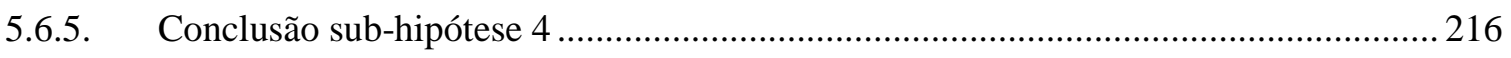

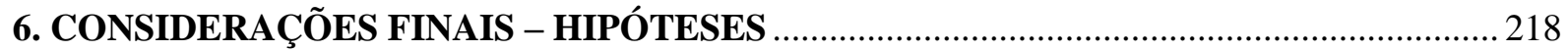

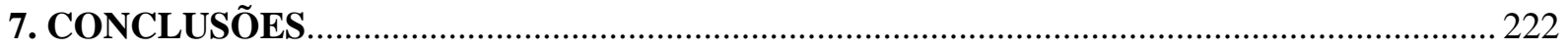

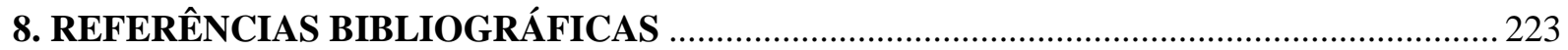




\section{INTRODUÇÃO}

A geração de resíduos lignocelulósicos do setor agrícola pode ser vista, como grande oportunidade de agregar valor a tais cadeias produtivas. Na Europa, a biomassa lignocelulósica contribui com $4 \%$ da energia total fornecida e até 2.020 o uso de energia renovável deve contribuir em 20\% (Gissén et al., 2014). Cerca de 200 bilhões de toneladas de biomassa lignocelulósica foram geradas mundialmente pelo setor agrícola primário (Guo et al., 2010). No Brasil, em função das atividades da agroindústria tem-se em média 597 milhões de toneladas de resíduos de várias culturas por ano (Ferreira-Leitão et al., 2010).

No Brasil, a Banana (Musa spp.) é uma das culturas no qual se obtém expressiva quantidade de biomassa produzida durante a colheita e pós-colheita. O desperdício da fruta pode chegar a 70\% desde a comercialização até o consumidor (Souza et al., 1995). Para cada tonelada de bananas colhidas, $100 \mathrm{~kg}$ de frutas são descartadas e cerca de 4 toneladas de resíduos lignocelulósicos são gerados (Fernandes et al. 2013). De acordo com Matheri et al. (2018) grande parte do resíduo de banana é constituído de cerca de 60-70\% de sólidos voláteis (SV), cujo teor de umidade é suficiente para sua conversão por micro-organismos durante a fermentação. Dentre o material carbonáceo presente neste resíduo, inclui a celulose $(50,15 \%)$, hemicelulose $(0,77 \%)$ e lignina (17,74\%) (Guimarães et al., 2009).

Neste cenário, o resíduo de banana torna-se viável para produção de energia em termos de biogás, devido ao alto conteúdo de matéria orgânica biodegradável, tornando o processo vantajoso do ponto de vista ambiental e econômico (Dahiya et al., 2015).

Apesar de nas últimas décadas, ter havido desenvolvimento e melhorias substanciais, tanto no rendimento, quanto na produção volumétrica de hidrogênio, para aplicações em larga escala, tais parâmetros devem superar consideravelmente o limiar metabólico de 4 mols $\mathrm{H}_{2}$.mol glicose. Deste modo, para tornar a produção de biogás competitiva em relação a energia convencional e garantir seus benefícios sustentáveis, avanços biotecnológicos, bem como a melhoria de conhecimento prático e científico são essenciais (Kumar et al., 2016). Desta forma, destaca-se a necessidade do estudo criterioso dos parâmetros operacionais aplicados ao reator, como $\mathrm{pH}$, temperatura, substrato, inóculo e nutrientes, tendo em vista a definição de condições adequadas que possibilitem maior produção de $\mathrm{H}_{2}$.

O uso de estratégias sequenciais de delineamentos fatoriais torna-se a melhor opção quando muitas variáveis estão envolvidas no processo. O delineamento experimental de Plackett-Burman é ferramenta excelente para avaliação prévia das variáveis e seleção daquelas 


\author{
Universidade de São Paulo \\ Escola de Engenharia de São Carlos \\ Programa de Pós-graduação em Hidráulica e Saneamento
}

que devem ser consideradas significativas, que permite chegar às condições otimizadas de um processo e avaliar individualmente o efeito de cada variável e de suas interações nas respostas desejadas (Rodrigues, 2014).

Ademais, mudanças nos parâmetros operacionais do reator podem selecionar e alterar as populações de bactérias nos consórcios microbianos, favorecendo determinadas rotas metabólicas, refletindo no desempenho do processo em relação à produção de hidrogênio. Geralmente, os microrganismos que estão envolvidos em processos fermentativos incluem bactérias anaeróbias facultativas e/ou obrigatórias, tais como Clostridium, Enterobacter, Ruminococcus, Bacillus e Escherichia (Lukajtis et al., 2018). No entanto, o motivo da alteração de rotas metabólicas ainda não está esclarecido, sendo necessários estudos moleculares aprofundados da biomassa fermentativa. Para isto, o conhecimento da diversidade funcional e taxonômica mediante ferramentas moleculares auxilia no entendimento do processo (An et al., 2018; Campanaro et al., 2018). Neste contexto, biorrefinaria de biocombustíveis e bioquímicos à base de biomassa utilizando microrganismos é alternativa competitiva das refinarias tradicionais de petróleo (Wang et al., 2018). O estudo dos aspectos microbiológicos na produção de hidrogênio a partir de resíduos frutícolas como a banana, é pouco explorado o que torna esse resíduo atrativo e foco de pesquisas futuras com objetivo de aproveitar o máximo possível da biomassa vegetal excedente.

Em resumo, os resultados apresentados nesta pesquisa possibilitam nova perspectiva para recuperar quantidade de energia a partir de resíduo de banana através da produção de hidrogênio, fornecendo dados concretos para modelagem e otimização de processos fermentativos, além de ajudar a compreender o papel da diversidade taxonômica e funcional da biomassa no estabelecimento de rotas metabólicas e na produção de $\mathrm{H}_{2}$. $\mathrm{O}$ grande interesse na produção de $\mathrm{H}_{2}$, esta relacionado a sua aplicabilidade como material de partida na indústria química, refinaria e indústrias farmacêuticas, além de ser utilizado como fonte de combustível devido ao seu alto poder calorífico líquido (122 kJ.g-1), (Lukajtis et al., 2018).

Portanto, o objetivo do presente estudo foi avaliar o potencial reuso do resíduo de banana madura (polpa e casca), gerado em grandes quantidades em função das atividades de agricultura e centrais de abastecimento, como substrato e fonte de bactérias fermentativas para produção de $\mathrm{H}_{2}$ e ácidos orgânicos, empregando delineamento experimental, tais como, Plackett-Burman (PB) para análise dos efeitos das variáveis e delineamento do composto central rotacional (DCCR) para otimização da produção de $\mathrm{H}_{2}$. Por fim, correlacionar o papel da diversidade de bactérias e distribuição funcional na produção de $\mathrm{H}_{2}$. 


\section{REVISÃO BIBLIOGRÁFICA}

\subsection{Fermentação acidogênica para produção de $\mathrm{H}_{2}$ : Utilização de biomassa sustentável}

Entre as rotas biológicas, a fermentação acidogênica (heterotrófica) é possibilidade prática e viável, por meio da qual recupera e concentra energia a partir de fontes orgânicas residuais. Tanto, o hidrogênio $\left(\mathrm{H}_{2}\right)$, quanto os ácidos carboxílicos são os principais produtos metabólicos gerados de valor agregado, que se recuperados corretamente torna o processo vantajoso do ponto de vista ambiental e econômico (Dahiya et al., 2015).

$\mathrm{O}$ grande interesse da aplicabilidade do hidrogênio como fonte energética, deve-se basicamente as suas propriedades combustíveis ${ }^{1}$ associadas a combustão limpa quando comparado aos combustíveis fósseis. Além disso, suas diversas aplicações como material de partida na indústria química, farmacêutica e em refinaria (Lukajtis et al., 2018) enobrecem a sua utilização nos setores químicos e petroquímicos. Já os ácidos carboxílicos, principalmente os de cadeia curta (2-6 carbonos), podem ser utilizados como material de partida para construção de álcoois, aldeídos, cetonas, ésteres, bioplásticos, conservantes de alimentos e produtos farmacêuticos (Cai et al., 2009; Singhania et al., 2013; Silva et al., 2013; Amulya et al., 2014; Spirito et al., 2014).

A produção de hidrogênio catalisada por micro-organismos (Figura 2.1) resulta no crescente uso de fontes renováveis de energia a partir de variedade de biomassa. Na ausência de receptores externos de elétrons, os organismos têm excesso de elétrons gerados nos processos metabólicos como resultado da redução de prótons produzindo moléculas de hidrogênio.

O mecanismo de fermentação via glicólise, no qual processos metabólicos resultam na produção de hidrogênio é regulado por duas enzimas chaves ( $\mathrm{FeFe}$ - hidrogenase e $\mathrm{NiFe}$ hidrogenase), no qual catalisam a reação reversível $\left(2 \mathrm{H}^{+}+2 \mathrm{e}^{-} \leftrightarrow \mathrm{H}_{2}\right)$. Os açúcares solúveis da biomassa lignocelulósica, são convertidos em piruvato, com a formação de uma molécula de ATP e de dinucleótido de nicotinamida e adenina (NADH). O piruvato, por sua vez, é oxidado mediante a Piruvato-ferrodoxina oxidoredutase na presença de ferrodoxina, havendo a síntese de hidrogênio molecular. Além de $\mathrm{H}_{2}$, a acetil-CoA pode ser convertida em vários compostos orgânicos, incluindo etanol, butanol, acetona, ácido butírico e ácido acético, com a simultânea oxidação de NADH e/ou formação de ATP (Lukajtis et al., 2018).

\footnotetext{
${ }^{1} \mathrm{O} \mathrm{H}_{2}$ tem rápida velocidade de queima. Em termos de poder calorífico, observa-se que o valor de $120 \mathrm{MJ} \mathrm{Kg}^{-1}$ para o $\mathrm{H}_{2}$ é cerca de 2,4 vezes superior ao do $\mathrm{CH}_{4}$ puro (50 $\mathrm{MJ} \mathrm{Kg}^{-1}$ ) (Heywood, 1988).
} 


\author{
Universidade de São Paulo \\ Escola de Engenharia de São Carlos \\ Programa de Pós-graduação em Hidráulica e Saneamento
}

Segundo Ruggeri et al. (2015), a FeFe-hidrogenase além de ser mais ativa na produção de $\mathrm{H}_{2}$ do que as $\mathrm{NiFe}$-hidrogenase, geralmente é mais sensível ao oxigênio $\left(\mathrm{O}_{2}\right)$. Além disso, a via de formação de $\mathrm{H}_{2}$ intermediada pela enzima PFOR é inibida pelo $\mathrm{H}_{2}$ no meio, estando ativa em pressões parciais de $\mathrm{H}_{2}$ de até $3 \times 10^{4} \mathrm{~Pa}$, enquanto para a via intermediada pela enzima NFOR ocorre inibição em pressões parciais de $\mathrm{H}_{2}>60 \mathrm{~Pa}$ (Sikora et al., 2013).

Figura 2.1. Vias metabólicas para conversão da biomassa vegetal em hidrogênio durante a fermentação acidogênica.

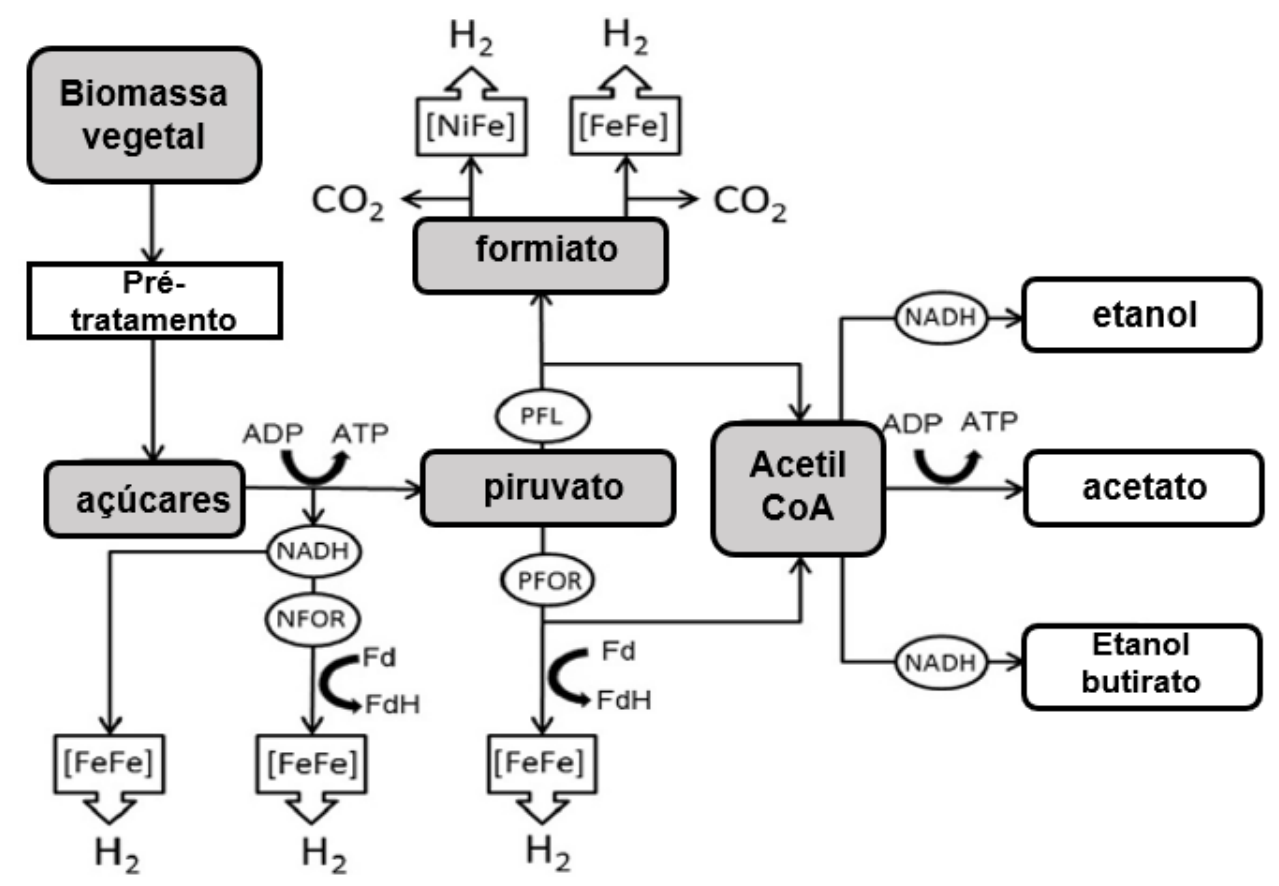

Nota: PFOR = piruvato Ferredoxina oxidoredutase PFL = piruvato formiato liase.

Fonte: Lukajtis et al. (2018)

Neste contexto, a produção de hidrogênio a partir de biomassa é considerada econômica, porque cerca de 60 a $80 \%$ da energia contida no substrato é convertida em hidrogênio (Logan et al., 2004). Todavia, para o substrato ser viável, a escolha da matéria-prima tem que ser adequada para produção de $\mathrm{H}_{2}$, tendo que estar prontamente disponível em grande quantidade, além de ser facilmente biodegradável (alta carga de carbono).

Os carboidratos de modo geral (mono, di e polissacarídeos) ${ }^{2}$ são as principais fontes de carbono para conversões metabólicas em processos fermentativos (Matheri et al., 2018). O uso

\footnotetext{
${ }^{2}$ Monossacarídeos (tais como glicose, xilose, frutose e galactose) e dissacarídeos (sacarose, lactose e maltose) são substratos altamente biodegradáveis, por isso são amplamente utilizados como substratos na fermentação acidogênica, além de não requerem processamento complicado (Ghimire et al., 2015).
} 
Universidade de São Paulo

Escola de Engenharia de São Carlos

Programa de Pós-graduação em Hidráulica e Saneamento

de matéria-prima rica em amido, que é prontamente hidrolisada em carboidratos simples, é particularmente conveniente, havendo pouca ou nenhuma necessidade de aplicação de prétratamento inicial (Bartacek et al., 2007; Hallenbeck et al., 2012). Dentre as matérias-primas que podem ser utilizadas em processos fermentativos (Algapani et al., 2016; Alibardi e Cossu et al., 2016; Wan et al., 2016; Eker e Sarp, 2017) as frutas e vegetais são compostas de açúcares livres, principalmente glicose, frutose e sacarose, que podem ser facilmente utilizados como fontes de carbono para a fermentação bacteriana. Ademais, apesar de presente, o baixo teor de lignina nos resíduos vegetais simplifica a hidrólise da hemicelulose e da celulose por microorganismos, diminuindo a grande necessidade de pré-tratamentos complexos (ácidos, básicos, enzimáticos e hidrotérmicos) para hidrolisar as frações de celulose e hemicelulose em açúcares de 5 carbonos (C5) e seis carbonos (C6) (Liakou et al., 2018). Além disso, frutas e vegetais também são ricos em compostos bioativos, como polifenóis e pectinas, que quando extraídos de modo correto podem ser reaproveitados, levando ao desenvolvimento de conceitos integrados de biorrefinaria (Burniol-Figols et al., 2016; Patsalou et al., 2017).

Cerca de 1,3 bilhões de toneladas/ano de alimentos produzidos mundialmente são desperdiçados (Dahiya et al., 2015). Em 2014, a produção mundial de frutas frescas foi de aproximadamente 35 milhões de toneladas, sendo que nos últimos cinco anos, a Ásia detém a maior parte da produção mundial $(73,3 \%)$, enquanto na Europa, a produção de frutas frescas foi de 512.000 t (FAO, 2017). Em relação ao Brasil, o país ocupa o terceiro lugar no ranking de maiores produtores de frutas e é responsável por 4,8\% do volume colhido com produção de 40 milhões de toneladas (Andrade, 2017), destacando-se a colheita de Laranja, Banana e Abacaxi (Tabela 2.1).

Tabela 2.1. Principais frutas frescas produzidas no Brasil (2016)

\begin{tabular}{ccc}
\hline Frutas & Área (hectares) & Produção (toneladas) \\
\hline Laranja & 772.589 & 17.018 .290 \\
Banana & 522.918 & 7.010 .471 \\
Abacaxi & 102.836 & 1.615 .906 \\
Uva & 75.839 & 1.515 .287 \\
Maçã & 33.572 & 1.254 .191 \\
\hline
\end{tabular}




\section{Universidade de São Paulo \\ Escola de Engenharia de São Carlos \\ Programa de Pós-graduação em Hidráulica e Saneamento}

Devido a extensão de área plantada e à alta produção de frutas no país, aumenta significantemente a geração de resíduos orgânicos provindos dessas culturas (frutos, cascas, sementes, polpas, pseudocaules). Uma das causas para os elevados volumes de frutas desperdiçados no Brasil é a ausência de uma logística eficiente na cadeia da fruticultura e de todo o complexo comercial de produtos, que atenuariam as perdas neste setor. Dentre as atividades da fruticultura tem-se extensa e complexa cadeia produtiva, que engloba desde os preparativos para o plantio, comercialização até o consumo final. Na Figura 2.2 estão incluídas a extensão e complexidade de configuração da cadeia de suprimentos da fruticultura.

Figura 2.2. Diagrama de blocos representando a cadeia produtiva da fruticultura brasileira

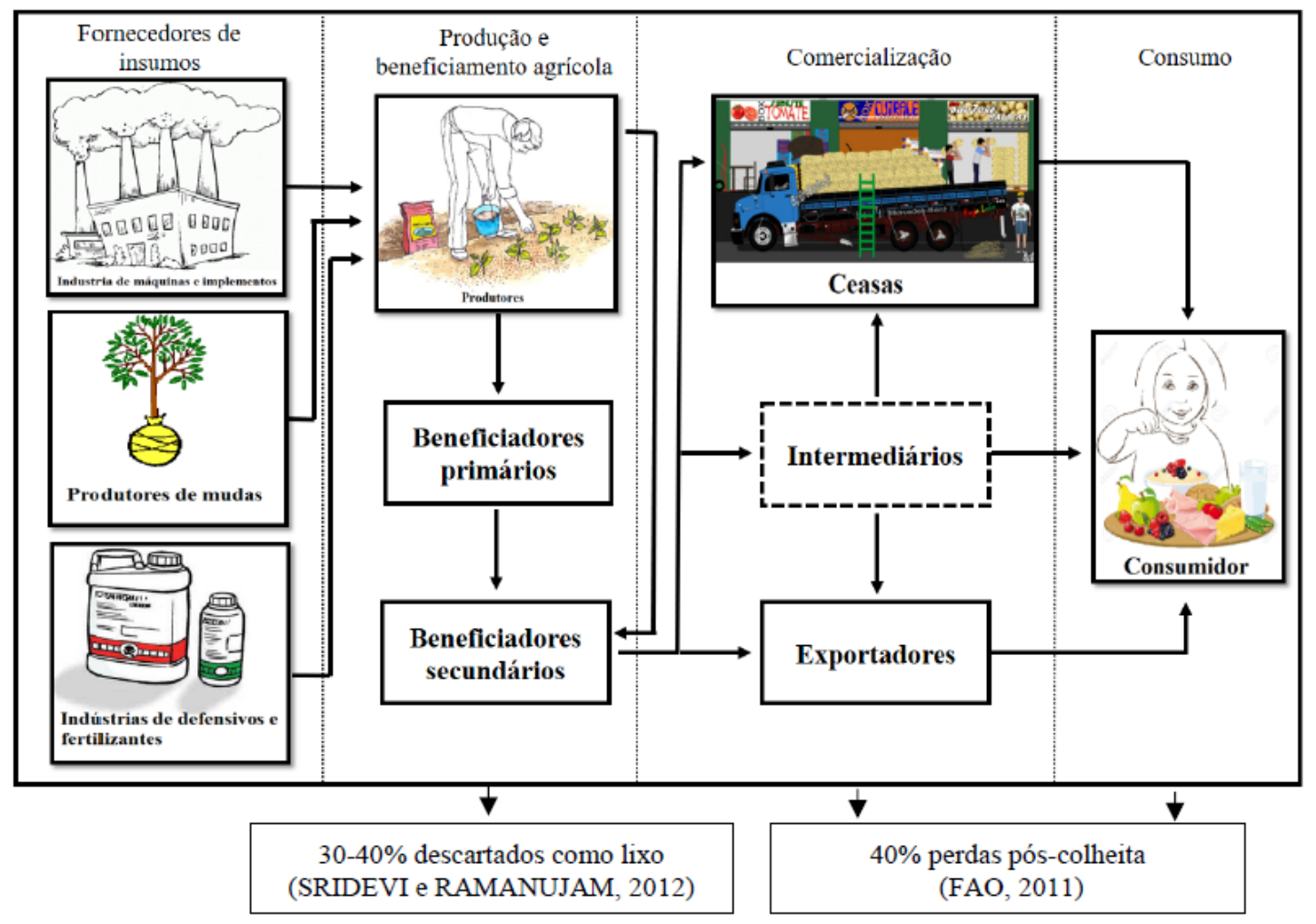

Fonte: Elaboração própria baseando-se em Buainain e Batalha (2007).

Durante a cadeia produtiva da fruticultura (Figura 2.2) têm-se percentuais de perdas ou desperdícios de frutas em cada etapa. Segundo a FAO (2011) os índices na América Latina são de $20 \%$ na agricultura, $10 \%$ pós-colheita, $15 \%$ no processamento, $7 \%$ na distribuição e cerca de 5\% no consumo. Produzir alimentos que não são consumidos acarreta em emissões desnecessárias de dióxido de carbono $\left(\mathrm{CO}_{2}\right)$, além de perda do valor econômico dos alimentos produzidos. 
Neste sentido, a produção de hidrogênio via fermentação utilizando resíduos de frutas como matéria-prima renovável pode levar à produção de importante fonte energética que pode ser empregada para o desenvolvimento de produção de energia sustentável. Em diversas pesquisas tem sido mencionado a utilização de resíduos de frutas para produção de $\mathrm{H}_{2}$ (Tabela 2.2), no qual tem cooperado com o avanço da pesquisa a partir deste tipo de substrato.

Tabela 2.2. Rendimento de hidrogênio a partir da fermentação de resíduos de frutas

\begin{tabular}{ccccc}
\hline Substrato & $\mathbf{p H}$ & Temperatura & Rendimento $\mathbf{H}_{2}$ & Referência \\
\hline Maça & 7,0 & $37^{\circ} \mathrm{C}$ & $101,08 \mathrm{~mL} \cdot \mathrm{g}^{-1} \mathrm{ST}$ & Feng et al. (2010) \\
Casca Banana & 6,0 & $37^{\circ} \mathrm{C}$ & $209,9 \mathrm{~mL} \cdot \mathrm{g}^{-1} \mathrm{SV}$ & Nathoa et al. (2014) \\
Polpa Pêssego & 6,5 & $37^{\circ} \mathrm{C}$ & $460,93 \mathrm{~mL} \cdot \mathrm{g}^{-1} \mathrm{DQO}$ & Argun et al. (2016) \\
Frutas maduras & 5,5 & $35^{\circ} \mathrm{C}$ & $188 \mathrm{~mL} \cdot \mathrm{g}^{-1} \mathrm{SV}$ & Alibardi e Cossu (2016) \\
Maça & 7,1 & $30,4^{\circ} \mathrm{C}$ & $111,85 \mathrm{~mL} \cdot \mathrm{g}^{-1} \mathrm{ST}$ & Lu et al. (2016) \\
\hline
\end{tabular}

Nota: $\mathrm{ST}$ = sólidos totais, $\mathrm{SV}=$ sólidos voláteis, $\mathrm{DQO}=$ demanda química de oxigênio.

A utilização de bagaço de maça (BM) como fonte de carbono em processos fermentativos para produção de hidrogênio foi avaliada por Feng et al. (2010). A condição fermentativa ótima para produção de $\mathrm{H}_{2}$ a partir do $\mathrm{BM}$ com consórcio microbiano foi a $37^{\circ} \mathrm{C}$, pH inicial 7,0 e 15 g. $\mathrm{L}^{-1}$ de substrato, no qual resultou em rendimento máximo acumulativo de hidrogênio de 101,08 mL. $\mathrm{g}^{-1}$ sólidos totais e taxa de produção de $8,08 \mathrm{~mL} \cdot \mathrm{g}^{-1} \mathrm{ST}$. h. Os principais produtos finais obtidos pelos autores foram $\mathrm{H}_{2}$, ácido acético, ácido propiônico, ácido butírico e etanol.

Nathoa et al. (2014) avaliaram a produção de hidrogênio a partir da casca de banana triturada em partículas de aproximadamente $0,5 \mathrm{~mm}$ em diferentes concentrações de substrato (23,75-95,0 g $\mathrm{g}^{-1} \mathrm{SV}$ L), correspondendo a fração A/M (alimento/micro-organismo) de 2,5-10. Os reatores em bateladas foram inoculados com lodo proveniente do tratamento de água residuária de manipueira. O melhor rendimento e conteúdo de hidrogênio de $209,9 \mathrm{~mL} \cdot \mathrm{g}^{-1} \mathrm{SV}$ e 35\%, respectivamente, foram observados para $\mathrm{A} / \mathrm{M}$ de $5,0,37^{\circ} \mathrm{C}$ e $\mathrm{pH}$ inicial de 6,0. Após 50 $\mathrm{h}$ de fermentação os autores observaram que o principal produto da fermentação foi o ácido acético, embora etanol e ácido propiônico também tenham sido observados em pequenas concentrações durante a rota de produção de $\mathrm{H}_{2}$.

Argun et al. (2016) avaliaram os efeitos da relação carbono/nitrogênio $(\mathrm{C} / \mathrm{N})$, carbono/fosfato $(\mathrm{C} / \mathrm{P})$, carbono/ferro $(\mathrm{C} / \mathrm{F})$ e carbono/níquel $(\mathrm{C} / \mathrm{Ni})$ no rendimento de 


\author{
Universidade de São Paulo \\ Escola de Engenharia de São Carlos \\ Programa de Pós-graduação em Hidráulica e Saneamento
}

hidrogênio na fermentação de resíduos de polpa de pêssego a $37^{\circ} \mathrm{C}$ e $\mathrm{pH}$ inicial 6,5 . Como inóculo, foi utilizado a microflora natural do próprio resíduo. Os autores relataram relação ótima de C/N/P/F/Ni de 100/2,09/3,89/0,047/0,043, respectivamente, no qual resultou no maior rendimento de 460,93 $\mathrm{mL} \mathrm{H}_{2} \mathrm{~g}^{-1}$ DQO.

Alibardi e Cossu, (2016) avaliaram quatro frações de resíduos orgânicos para produção de hidrogênio. Os resíduos testados foram: CPQ (carne, peixe, queijo); F (frutas); V (vegetais) e MP (massa de pão). Os reatores em batelada foram inoculados com lodo ( $9 \mathrm{~g}^{-1} \mathrm{ST}$ L) com relação A/M de $0,3 \mathrm{~g}^{-1} \mathrm{SV} / \mathrm{g}^{-1} \mathrm{SV}$. O rendimento máximo de hidrogênio de $188 \mathrm{~mL} \mathrm{H}_{2} \mathrm{~g}^{-1} \mathrm{SV}$ foi obtido a $35^{\circ} \mathrm{C}$ e $\mathrm{pH}$ inicial de 5,5 a partir dos resíduos de frutas constituído de 16\%; 98\%; $3 \%$ e $3 \%$ de ST, SV, carboidratos e celulose, respetivamente. Ácido acético e butírico foram os principais metabólitos solúveis produzidos. O substrato com maior teor de carboidratos influenciou na produção de ácido butírico próximo ao do ácido acético, obtendo relação $\mathrm{HBu} / \mathrm{HAc}$ maior que 0,8; enquanto para os demais substratos a relação obtida foi de 0,5 a 0,7.

Devido a vasta quantidade de maça podre gerada na China, Lu et al. (2016) avaliaram a produção de $\mathrm{H}_{2}$ na fermentação desses resíduos a partir da bactéria fotossintética (PSB) HAUM1. O rendimento máximo de hidrogênio de $111,85 \mathrm{~mL} \mathrm{H}_{2} \mathrm{~g}^{-1} \mathrm{ST}$ foi obtido a $30,46^{\circ} \mathrm{C}, \mathrm{pH}$ inicial 7,14, intensidade de luz de 3.029,67 lux, e relação sólido/líquido de 0,21. Em países produtores de maçã como a China, o sucesso da produção de hidrogênio a partir desse resíduo por PSB foi ótima alternativa e esperança para o uso sustentável.

Contudo, por meio de tais resultados verifica-se o potencial destes resíduos como substrato em processos fermentativos, com a possibilidade de superar os obstáculos impostos pelos resíduos frutícolas, permitindo aprimorar gradualmente o processo de produção de $\mathrm{H}_{2} \mathrm{e}$ ácidos orgânicos.

\title{
2.1.1. Resíduos de banana
}

De acordo com (FAO) (Food and Agriculture Organization) (2014), dentre as frutas, a banana é a mais produzida mundialmente. No Brasil, a produção em 2017 foi de 6,8 milhões de toneladas ${ }^{3}$, correspondendo a 16,7\% do volume total das frutas (Andrade, 2017). Porém, somente parcela do que é produzido, entre 50-60\%, chegam à mesa do consumidor devido ao

\footnotetext{
${ }^{3}$ Os altos índices de consumo deste fruto justificam sua alta produção no país. O favoritismo pode ser constatado em números, por exemplo, 99\% da produção nacional abasteceu o mercado interno em 2016.
} 
elevado índice de perdas ${ }^{4}$ na comercialização de bananas (Mascarenhas, 1999). Souza et al. (1995) determinaram as perdas pós-colheita, equivalentes às etapas da cadeia de produção de banana no Brasil e exibiram valores $>5 \%$ na lavoura; $>2 \%$ no processo de embalagem; 6 a 10 $\%$ no atacado; $10 \%$ a $15 \%$ no varejo e $5 \%$ a $8 \%$ no consumidor.

O elevado índice de perdas na cadeia de produção da banana contribui com o aumento de resíduos sólidos orgânicos. Estima-se que no Brasil, os resíduos sólidos orgânicos fermentáveis constituem em média 55\% (percentual em peso) dos resíduos sólidos urbanos produzidos, sendo constituídos em grande parte de frutas e vegetais (Abrelpe, 2014). Tais resíduos, geralmente não recebem destino adequado, ocasionando impactos econômicos e ambientais negativos. Para cada tonelada de bananas colhidas, $100 \mathrm{~kg}$ de frutas são descartadas e cerca de 4 toneladas de resíduos lignocelulósicos ( 3 toneladas de pseudocaule, $160 \mathrm{~kg}$ de talos, $480 \mathrm{~kg}$ de folhas e $440 \mathrm{~kg}$ de cascas) são gerados (Fernandes et al. 2013).

De acordo com Guimarães et al. (2009), a banana contém cerca de 50,15\% de celulose, 0,77\% de hemicelulose e $17,74 \%$ de lignina. O fruto in natura também contém seu valor nutritivo, como cálcio $(\mathrm{Ca})$, ferro $(\mathrm{Fe})$, sódio $(\mathrm{Na})$, magnésio $(\mathrm{Mg})$, zinco $(\mathrm{Zn})$, cobre $(\mathrm{Cu})$ e potássio (K) (Gondim et al., 2005).

Em termos gerais, sabe-se que a banana (Musa spp.) contem elevado material orgânico, que engloba amido, açúcares residuais, frações de minerais e compostos orgânicos intermediários formados em rotas metabólicas durante a fermentação natural do fruto. Além de ser altamente nutritiva, a banana, contêm em sua composição fenóis, compostos destacados como poderosos agentes antioxidantes (Singh et al., 2016).

Os resíduos de bananas foram caracterizados físico-quimicamente por Menezes et al. (2015). Os autores verificaram os seguintes valores de seus principais constituintes: $87 \%$ de umidade, 122,8 g.L. $\mathrm{L}^{-1}$ de sólidos totais (ST), 97,5 g.L $\mathrm{L}^{-1}$ de sólidos totais voláteis (STV), 54,2 g.L $\mathrm{L}^{-1}$ de carbono orgânico total (COT), 1,4 g.L $\mathrm{L}^{-1}$ de nitrogênio total Kjeldahl (NTK), pH 3,81 e DQO 67 g.L. - $^{-1}$

O elevado valor de DQO observado nestes resíduos (acima de 50 g.L $\mathrm{L}^{-1}$ ) indica seu potencial para aplicação em processos biotecnológicos anaeróbios. Na Tabela 2.3 estão delineadas as porcentagens de conversão do amido em sacarose e glicose, os quais constituem

\footnotetext{
${ }^{4}$ As razões das perdas não estão associadas exclusivamente à comercialização, mas a todos os setores envolvidos na produção e distribuição do fruto.
} 


\section{Universidade de São Paulo \\ Escola de Engenharia de São Carlos \\ Programa de Pós-graduação em Hidráulica e Saneamento}

os açúcares mais fáceis de serem fermentados e que oportuniza sua utilização como fonte de carbono.

Contudo, à parte da problemática ambiental, os elevados valores de DQO da banana (acima de $40 \mathrm{~g} . \mathrm{L}^{-1}$ ) indicam a existência de substrato com potencial na aplicação em processos fermentativos, tornando o processo economicamente e ambientalmente viável, considerando a possibilidade de reduzir a sobrecarga orgânica simultaneamente à recuperação de energia $\left(\mathrm{H}_{2}\right)$ e produção de compostos orgânicos de valor agregado.

Tabela 2.3. Mudanças químicas em casca de banana-nanica durante o amadurecimento (base seca).

\begin{tabular}{cccccc}
\hline $\begin{array}{c}\text { Tempo } \\
(\text { dias })\end{array}$ & $\begin{array}{c}\text { SV } \\
(\boldsymbol{\%})\end{array}$ & $\begin{array}{c}\text { Amido } \\
(\boldsymbol{\%})\end{array}$ & $\begin{array}{c}\text { Açúcares }^{\mathbf{t}} \\
\mathbf{( \% )}\end{array}$ & $\begin{array}{c}\text { Glicose } \\
(\boldsymbol{\%})\end{array}$ & $\begin{array}{c}\text { Sacarose } \\
(\boldsymbol{\%})\end{array}$ \\
\hline 0 & 76,47 & 35,03 & 0 & 0 & 0 \\
3 & 86,43 & 39,51 & 0 & 0 & 0 \\
6 & 88,61 & 48,54 & 0 & 0 & 0 \\
9 & 86,43 & 26,75 & 5,50 & 1,10 & 4,18 \\
12 & 80,41 & 20,02 & 2,20 & 0,5 & 1,62 \\
15 & 78,48 & 4,80 & 24,62 & 3,01 & 20,53 \\
18 & 84,75 & 0 & 19,27 & 8,25 & 10,47 \\
21 & 88,02 & 0 & 23,07 & 5,15 & 17,02 \\
23 & 89,45 & 0 & 17,72 & 14,74 & 2,83 \\
27 & 91,38 & 0 & 28,06 & 12,96 & 14,35 \\
\hline
\end{tabular}

Fonte: Adaptado de Castro-Gõmez (1988)

Notas: $\mathrm{SV}=$ sólidos voláteis, Açúcares ${ }^{\mathrm{t}}=$ açúcares totais.

\subsection{Planejamento Experimental e análise de superfície de resposta na produção de $\mathrm{H}_{2}$}

Nas últimas décadas, houve desenvolvimento e melhorias substanciais, tanto no rendimento, quanto na produção volumétrica de hidrogênio. Para aplicações em larga escala, tais parâmetros devem superar consideravelmente o limiar metabólico de 4 mols $\mathrm{H}_{2} \cdot \mathrm{mol}^{-1}$ glicose. No entanto, na prática o produto final é a mistura de vários compostos orgânicos, que reduz o rendimento de hidrogênio para 1-2,5 $\mathrm{mol} \mathrm{H}_{2} \cdot \mathrm{mol}^{-1}$ glicose, tornando o desempenho do processo mais dificultoso. Neste sentido, a compreensão dos fatores que favorecem a produção de hidrogênio é vital para otimizar o processo (Sikora et al., 2013).

O planejamento experimental, baseado em fundamentos estatísticos, é uma ferramenta que permite chegar às condições otimizadas do processo, possibilitando avaliar individualmente o 
Universidade de São Paulo

Escola de Engenharia de São Carlos

Programa de Pós-graduação em Hidráulica e Saneamento

efeito de cada variável e de suas interações nas respostas desejadas. Deste modo, o planejamento fatorial $^{5}$ tem sido amplamente utilizado em pesquisas para otimizar a produção de $\mathrm{H}_{2}$ (Tabela 2.4), a fim de se obter o rendimento próximo ao teórico.

Tabela 2.4. Condições otimizadas da produção de hidrogênio utilizando ferramentas estatísticas.

\begin{tabular}{|c|c|c|c|}
\hline $\begin{array}{l}\text { Método } \\
\text { aplicado }\end{array}$ & $\begin{array}{c}\text { Condições ótimas das variáveis } \\
\text { estudadas }\end{array}$ & $\begin{array}{c}\text { Valores máximos obtidos } \\
\text { (Produção ou rendimento de } \mathrm{H}_{2} \text { ) }\end{array}$ & Referências \\
\hline $\begin{array}{l}\text { Plackett- } \\
\text { Burman }\end{array}$ & $\begin{array}{c}\text { 23,75 g.L } \text { - }^{-1} \text { de glicose, } 0,159 \mathrm{M} \\
\text { de Tampão fosfato e } 13,3 \mathrm{~mL} / \mathrm{L} \\
\text { de Solução de Vitamina }\end{array}$ & $4165,9 \mathrm{~mL} \mathrm{H}_{2} \mathrm{~L}^{-1}$ & $\begin{array}{l}\text { Pan et al., } \\
\text { (2008) }\end{array}$ \\
\hline $\begin{array}{l}\text { Plackett- } \\
\text { Burman }\end{array}$ & $\begin{array}{c}25 \text { g. } \mathrm{L}^{-1} \text { de açúcares totais } \\
\mathrm{pH} 4,75 \text { e } 1,45 \text { g.L } \mathrm{L}^{-1} \text { de } \mathrm{FeSO}_{4}\end{array}$ & $6897 \mathrm{~mL} \mathrm{H}_{2} \mathrm{~L}^{-1}$ & $\begin{array}{l}\text { Saraphirom e } \\
\text { Reungsang, } \\
\text { (2010) }\end{array}$ \\
\hline $\begin{array}{l}\text { Plackett- } \\
\text { Burman e Box- } \\
\text { Behnken }\end{array}$ & $\begin{array}{l}\text { 16,15 g.. } \mathrm{L}^{-1} \text { de xilose, 0,25 g.L } \mathrm{L}^{-1} \\
\text { de } \mathrm{FeSO}_{4} \text { e 2,54 g.L } \mathrm{L}^{-1} \text { de Peptona }\end{array}$ & 2,0 $\mathrm{mol} \mathrm{H}_{2} \cdot \mathrm{mol}^{-1}$ xilose & $\begin{array}{l}\text { Long et al., } \\
\qquad(2010)\end{array}$ \\
\hline $\begin{array}{l}\text { Plackett- } \\
\text { Burman e Box- } \\
\text { Behnken }\end{array}$ & $\begin{array}{c}\text { pH: } 7,7,8,3 \text { g.L } L^{-1} \text { de triptona: e } \\
\text { 7,9 g.L } \mathrm{L}^{-1} \text { de levedura }\end{array}$ & $1,46 \mathrm{~mol} \mathrm{H}_{2} \cdot \mathrm{mol}^{-1}$ glicose & $\begin{array}{l}\text { Jiang et al., } \\
\text { (2014) }\end{array}$ \\
\hline Box-Behnken & $\begin{array}{c}26,30^{\circ} \mathrm{C}, \mathrm{pH} 6,2 \text { e } 25,31 \mathrm{~g} \cdot \mathrm{dm}^{-3} \\
\text { de glicose }\end{array}$ & $1,81 \mathrm{~mol} \mathrm{H}_{2} \cdot \mathrm{mol}^{-1}$ de glicose & $\begin{array}{c}\text { Alvarez- } \\
\text { Guzman et al., } \\
(2017) \\
\end{array}$ \\
\hline $\begin{array}{l}\text { Superfície de } \\
\text { resposta }\end{array}$ & $\begin{array}{l}\text { Relação inóculo/substrato (I/S) } \\
\text { 1,44 g SV.g. }{ }^{-1} \text { COT e pH 5,5 }\end{array}$ & $371 \mathrm{~L} \mathrm{H}_{2} \mathrm{~kg}^{-1} \mathrm{COT}_{\text {soro de leite }}$ & $\begin{array}{l}\text { Akhlaghi et al., } \\
\text { (2017) }\end{array}$ \\
\hline $\begin{array}{c}\text { Box Hunter- } \\
\text { Hunter e DCCR }\end{array}$ & $\begin{array}{c}3 \mathrm{~g} \cdot \mathrm{L}^{-1} \text { de extrato de levedura, } \\
60^{\circ} \mathrm{C}\end{array}$ & $17,7 \mathrm{mmol} . \mathrm{L}^{-1}$ & $\begin{array}{c}\text { Soares et al. } \\
(2017)\end{array}$ \\
\hline $\begin{array}{l}\text { Superfície de } \\
\text { resposta }\end{array}$ & $\begin{array}{c}7 \text { g.L }{ }^{-1} \text { de bagaço de cana de } \\
\text { açúcar, } \mathrm{pH} 7,2,37^{\circ} \mathrm{C}\end{array}$ & $23,10 \mathrm{mmol} . \mathrm{L}^{-1}$ & $\begin{array}{l}\text { Rabelo et al., } \\
\quad(2018)\end{array}$ \\
\hline
\end{tabular}

Quando muitas variáveis estão envolvidas no processo e/ou quando não se tem as condições otimizadas, o uso de estratégias sequenciais de delineamentos fatoriais (Tabela 2.5) é a melhor opção, sendo excelentes para avaliação prévia das variáveis e seleção daquelas que devem ser consideradas significativas até se chegar no delineamento completo central rotacional (DCCR) (Rodrigues, 2014).

São inúmeras as variáveis que podem ser estudadas, incluindo tipo e concentração de substrato, $\mathrm{pH}$, temperatura, inóculo e até mesmo condições nutricionais. Na mesma linha de pensamento, Pan et al. (2008) avaliaram o efeito da concentração de glicose (10-15 g.L $\left.\mathrm{L}^{-1}\right)$, peptona (2-3 g.L $\left.\mathrm{L}^{-1}\right)$, extrato de levedura (1-2 g.L $\left.\mathrm{L}^{-1}\right)$, solução de sais minerais (10-15 mL.L $\left.\mathrm{L}^{-1}\right)$, $\mathrm{FeSO}_{4}\left(100-400 \mathrm{mg} . \mathrm{L}^{-1}\right.$, tampão fosfato $(0,20-0,25 \mathrm{M})$, solução de vitaminas $\left(5-10 \mathrm{~mL} . \mathrm{L}^{-1}\right)$ e

\footnotetext{
${ }^{5}$ Introduzido na década de 50, o planejamento fatorial vem crescendo exponencialmente devido ao avanço na informática e desenvolvimento de softwares para análises estatísticas (Barros et al., 1996).
} 


\section{Universidade de São Paulo \\ Escola de Engenharia de São Carlos \\ Programa de Pós-graduação em Hidráulica e Saneamento}

pH inicial $(6,5-7,0)$ na produção de $\mathrm{H}_{2}$ por Clostridium sp. utilizando o delineamento de PlakettBurman. Após seleção das variáveis significativas, os autores obtiveram produção máxima de hidrogênio de $4165.9 \mathrm{~mL} \mathrm{H}$. $\mathrm{L}^{-1}$ por meio das condições otimizadas $\left(23,75\right.$ g. $\mathrm{L}^{-1}$ de glicose, 0,159 M de tampão fosfato e 13,3 mL. $\mathrm{L}^{-1}$ de solução de vitaminas).

Tabela 2.5. Estratégias sequenciais para se atingir condições otimizadas

\begin{tabular}{|c|c|c|}
\hline Etapas & Objetivos & Situação \\
\hline $\begin{array}{c}\text { Seleção de variáveis } \\
\text { (Fatorial fracionado ou de } \\
\text { Plackett-Burman - PB) }\end{array}$ & $\begin{array}{l}\text { Identificar e selecionar } \\
\text { variáveis importantes }\end{array}$ & $\begin{array}{c}\checkmark \checkmark \text { Muitos fatores } \\
\checkmark \quad \text { Pouco conhecimento do } \\
\text { processo/longe das condições } \\
\text { desejadas ou otimizadas }\end{array}$ \\
\hline $\begin{array}{c}\text { Otimização } \\
\text { (Fatorial completo - DCCR) }\end{array}$ & $\begin{array}{c}\text { Construir os modelos } \\
\text { preditivos }\end{array}$ & $\begin{array}{lll} & \checkmark & \text { Poucos fatores } \\
\checkmark & \text { Dentro da região ótima }\end{array}$ \\
\hline $\begin{array}{c}\text { Validação das condições } \\
\text { otimizadas }\end{array}$ & $\begin{array}{c}\text { Confirmar } \\
\text { experimentalmente os } \\
\text { resultados obtidos pela } \\
\text { análise de superfície de } \\
\text { resposta }\end{array}$ & $\checkmark \quad$ Condições otimizadas definidas \\
\hline
\end{tabular}

As variáveis $\mathrm{pH}(6,5-7,4)$, temperatura $\left(30-40^{\circ} \mathrm{C}\right)$, concentração de xilose $\left(5-10\right.$ g.L $\left.\mathrm{L}^{-1}\right)$, extrato de levedura (1-3 g.L $\left.{ }^{-1}\right)$, peptona (2-6 g.L $\left.\mathrm{L}^{-1}\right), \mathrm{FeSO}_{4}\left(100-200 \mathrm{mg} \cdot \mathrm{L}^{-1}\right)$ e $\mathrm{MgSO}_{4}(100-$ $800 \mathrm{mg} . \mathrm{L}^{-1}$ ) foram avaliadas por meio do delineamento de Plakett-Burman visando otimizar o meio de cultivo utilizado para produção de hidrogênio a partir de Enterobacter sp. Dentre as variáveis avaliadas, somente a concentração de xilose, peptona e $\mathrm{FeSO}_{4}$ foram estatisticamente significativas e utilizadas no delineamento de Box-Behnken para análise da superfície de resposta. A condição ótima consistiu na adição de $16,15 \mathrm{~g} . \mathrm{L}^{-1}$ de xilose, $250,17 \mathrm{mg} . \mathrm{L}^{-1}$ de $\mathrm{FeSO}_{4}$ e 2,54 g.L $\mathrm{L}^{-1}$ de peptona, no qual resultou na produção máxima de $1149,9 \mathrm{~mL} \mathrm{H}_{2} \mathrm{~L}^{-1}$ de meio (Long et al., 2010).

Novamente, delineamento experimental foi utilizado como ferramenta para otimização da produção de hidrogênio a partir de licor de sorgo (Saraphirom e Reungsang, 2010). Neste caso, as variáveis avaliadas por meio do delineamento de Plakett-Burman foram concentração de açúcares totais (5-15 g. $\left.\mathrm{L}^{-1}\right), \mathrm{pH}$ inicial (5-7), solução nutriente (1-10 mL.L $\left.\mathrm{L}^{-1}\right)$, concentração de $\mathrm{FeSO}_{4}\left(0,2-0,6\right.$ g.L $\left.\mathrm{L}^{-1}\right)$, peptona (1-3 g.L $\left.\mathrm{L}^{-1}\right)$ e bicarbonato de sódio (2,5-6,0 g.L $\left.\mathrm{L}^{-1}\right)$. Após seleção das variáveis significativas, a condição ótima obtida pelos autores para produção máxima de $\mathrm{H}_{2}$ estimada pelo modelo matemático utilizando o delineamento de Box-Behnken foi 25 g. $\mathrm{L}^{-1}$ de açúcares totais, $\mathrm{pH}$ inicial de 4,75 e 1,45 g.L.-1 de $\mathrm{FeSO}_{4}$, no qual resultou em 
produção de $6864 \mathrm{~mL} \mathrm{H}_{2} \cdot \mathrm{L}^{-1}$, diferindo-se em apenas $0,04 \%$ do valor predito $\left(6897 \mathrm{~mL} \mathrm{H} \mathrm{H}_{2} . \mathrm{L}^{-}\right.$ ${ }^{1}$ ), indicando a confiabilidade de modelo.

Jiang et al. (2014) avaliaram o efeito de oito variáveis, incluindo $\mathrm{NaCl}$ (2,5-3,5\%), glicose (6-12 g.L $\left.\mathrm{L}^{-1}\right)$, levedura (1-3 g.L $\left.\mathrm{L}^{-1}\right)$, triptona (2-5 g.L $\left.\mathrm{L}^{-1}\right), \mathrm{FeSO}_{4}\left(50-100 \mathrm{mg} . \mathrm{L}^{-1}\right)$ e $\mathrm{MgSO}_{4}$ (50-100 mg. $\left.\mathrm{L}^{-1}\right), \mathrm{pH}(6,5-7,5)$ e temperatura $\left(54-61^{\circ} \mathrm{C}\right)$ na produção de $\mathrm{H}_{2}$ a partir da espécie Caloranaerobacter azorensis. Utilizando o delineamento experimental de Plackett-Burman, os resultados mostraram que o $\mathrm{pH}$, concentração de triptona e levedura foram estatisticamente significativos $(\mathrm{p} \leq 0,05)$. Sendo assim estas variáveis foram otimizadas utilizando o método de Boxe-Behnken design, obtendo produção e rendimento máximo de $1,58 \mathrm{~L} \mathrm{H}_{2} \mathrm{~L}^{-1}$ e 1,46 mol H mol $^{-1}$ glucose a pH inicial 7,7 e concentração de triptona e levedura de 8,3 e 7,9 g.L $\mathrm{L}^{-1}$, respectivamente.

O método de superfície de resposta com design Box-Behnken foi aplicado para avaliar o efeito da temperatura $\left(13,25\right.$ e $\left.37^{\circ} \mathrm{C}\right), \mathrm{pH}(3,5,5$ e 8$)$ e concentração de glicose $(10,25$ e 40 g. $\mathrm{dm}^{-3}$ ) na produção de hidrogênio em reatores em batelada a partir da estirpe psicrofílica G088 [EU636029]. De acordo com o modelo matemático, as condições ótimas para produção e rendimento de $\mathrm{H}_{2}$ de $513 \mathrm{~mL}, 1,81 \mathrm{~mol} \mathrm{H}_{2} \cdot \mathrm{mol}^{-1}$ de glicose, respectivamente, foram a $26,30{ }^{\circ} \mathrm{C}$, $\mathrm{pH}$ 6,2 e de glicose 25,31 g. $\mathrm{dm}^{-3}$, o qual correspondeu ao valor predito a priori por meio do modelo matemático (Alvarez-Guzman et al., 2017). Akhlaghi et al. (2017) utilizaram o planejamento fatorial como ferramenta para avaliar a influência do $\mathrm{pH}$ e da relação inóculo/substrato (I/S), $\mathrm{g}^{-1} \mathrm{SV} / \mathrm{g}^{-1} \mathrm{COT}$, na produção de hidrogênio a partir da mistura de soro de queijo e água residuária de lodo ativado. Os autores verificaram aumento do rendimento de $\mathrm{H}_{2}$ de $61 \mathrm{~L} \mathrm{H}_{2} \mathrm{~kg}^{-1}$ COT soro de queijo (I/S $=0 \mathrm{~g}^{-1} \mathrm{SV} / \mathrm{g}^{-1} \mathrm{COT}$ e $\mathrm{pH}$ 7) para $371 \mathrm{~L} \mathrm{H}_{2} \mathrm{~kg}^{-1}$ COTsoro de queijo ( $\mathrm{I} / \mathrm{S}=1,44 \mathrm{~g}^{-1} \mathrm{SV} / \mathrm{g}^{-1} \mathrm{COT}$, $\mathrm{pH}$ 5,5) nas condições otimizadas. Ácido acético e butírico, seguido do etanol foram os principais produtos metabólicos observados. O ácido propiônico só foi observado quando a produção de $\mathrm{H}_{2}$ diminuiu significantemente.

A produção de hidrogênio a partir do bagaço de cana-de-açúcar (BCA) pré-tratado hidrotermicamente $\left(200{ }^{\circ} \mathrm{C}, 10 \mathrm{~min}, 16 \mathrm{bar}\right)$ foi avaliada por Soares et al. (2017) utilizando metodologia de superfície de resposta. As condições fixas operacionais incluiam inóculo (10\% v/v - 1,5 g.L. -1 $\left.^{-1} \mathrm{SSV}\right)$, substrato $\left(2\right.$ g.L. $\left.\mathrm{L}^{-1}\right)$ e pH inical 6,0, enquanto as variáveis avaliadas foram concentração de extrato de levedura $\left(0,58-3,42\right.$ g. $\left.\mathrm{L}^{-1}\right)$ e temperatura $\left(35,8-64,2^{\circ} \mathrm{C}\right)$. A produção máxima de hidrogênio $\left(17,7 \mathrm{mmol} . \mathrm{L}^{-1}\right)$ foi obtida no ensaio com $3 \mathrm{~g} . \mathrm{L}^{-1}$ de extrato de levedura a $60{ }^{\circ} \mathrm{C}$. Nestas condições foram produzidos ácido acético $\left(50,44 \mathrm{mg} . \mathrm{L}^{-1}\right)$, ácido butírico (209,71 mg.L $\left.\mathrm{L}^{-1}\right)$, etanol $\left(38,4 \mathrm{mg} . \mathrm{L}^{-1}\right)$ e metano $\left(6,27\right.$ mmol.L $\left.\mathrm{L}^{-1}\right)$. 


\author{
Universidade de São Paulo \\ Escola de Engenharia de São Carlos \\ Programa de Pós-graduação em Hidráulica e Saneamento
}

Os efeitos individuais do $\mathrm{pH}$ e concentração do substrato e a interação entre eles foram avaliados por Rabelo et al. (2018) na produção de $\mathrm{H}_{2}$ a partir do bagaço de cana de açúcar (BCA) por meio do delineamento composto central rotacional (DCCR). Dentre as concentrações de substrato (de 0,8 a 9,2 g. $\mathrm{L}^{-1}$ ) e pH (de 4,6 a 7,4) avaliados, a maior produção de $\mathrm{H}_{2}$ de 23,10 mmoL.L $\mathrm{L}^{-1}$ foi obtida a $37^{\circ} \mathrm{C}, 7,0$ g.L.-1 BCA e pH 7,2. Dentre os metabólitos produzidos, o ácido butírico $\left(0,66\right.$ a 1,88 g.L $\left.\mathrm{L}^{-1}\right)$ e succínico $\left(1,06\right.$ a 1,65 g. $\left.\mathrm{L}^{-1}\right)$ foram os principais ácidos orgânicos (AGV) observados no processo acidogênico.

Contudo, independentemente das variáveis avaliadas, a importância e aplicabilidade de delineamentos experimentais em processos fermentativos, certifica que o uso de ferramentas estatísticas contribui para otimização da produção de hidrogênio.

\title{
2.3. Diversidade microbiana em reatores aplicados na produção de $\mathbf{H}_{2}$
}

A diversidade microbiana representa amplo conjunto genético com potencial biotecnológico para diversas áreas de pesquisa, incluindo os processos fermentativos.

Como já mencionado anteriormente, a utilização de biomassa proveniente de fontes renováveis como fonte de energia é uma alternativa sustentável promissora. Neste sentido, a comunidade microbiana autóctone dessas biomassas torna-se atraente no intuito de descobrir novos biocatalizadores, com potencial celulolítico e fermentativo, para melhorar a eficiência da fermentação acidogênica e contribuir para o avanço biotecnológico. Deste modo, a utilização de abordagens baseadas na metagenômica pode contribuir para o desenvolvimento na área da bioenergia por meio da prospecção de novas enzimas, no qual catalisam reações lignocelulósica em $\mathrm{H}_{2}$ e outros produtos metabólicos de interesse, como o etanol e ácidos carboxílicos.

As abordagens para o estudo da diversidade microbiana em reatores associadas a produção de $\mathrm{H}_{2}$ inclui variedade de substrato e possibilidades de pré-tratamentos da biomassa lignocelulósica. $\mathrm{O}$ efeito de diferentes métodos de pré-tratamento ácido $(\mathrm{pH} \mathrm{2,3}$ e 4) na produção de $\mathrm{H}_{2}$ via fermentação de água residuária sintética rica em sacarose foi avaliada por Wan et al. (2016). O rendimento máximo de $\mathrm{H}_{2}$ de $1,61 \mathrm{~mol} \mathrm{H}_{2} \cdot \mathrm{mol}^{-1}$ de glicose foi obtido nos ensaios com lodo pré-tratado com butirato ( $\mathrm{pH} 2$ ), no qual a produção de $\mathrm{H}_{2}$ foi associada as cepas de bactérias Clostridium sp. HPB-16, Clostridium sp. HPB-46, Clostridium sp. HPB-2, Clostridium sp. HPB-4, bactéria semelhante a Oxalobacteraceae QD1 e Olsenella sp. clone J27. O pré-tratamento com ácido butírico pode ser também uma possibilidade eficaz para enriquecer as bactérias produtoras de $\mathrm{H}_{2}$ presentes em consórcio bacteriano. 
Pendyala et al. (2013) avaliariam o efeito do pH (4,5-6,5), concentração de DQO (5-10 g. $\left.\mathrm{L}^{-1}\right)$ e concentração de ácido linoleico $\left(0-2\right.$ g.L $\left.\mathrm{L}^{-1}\right)$ na produção de $\mathrm{H}_{2}$ utilizando como substrato resíduos de papel. O rendimento máximo de $\mathrm{H}_{2}$ de $87 \mathrm{~mL} \mathrm{~g}^{-1}$ foi obtido nas condições de 1,6 g.L $\mathrm{L}^{-1}$ de ácido linoleico, $\mathrm{pH}$ inicial de 5,93 e 9,34 g.L. $\mathrm{L}^{-1}$ de DQO inicial. As principais espécies bacterianas identificadas e associadas a produção de $\mathrm{H}_{2}$ no consórcio de bactérias incluíram Clostridium sp., Enterococcus asini, Enterococcus faecalis e Lactobacillus gallinarum.

O consórcio de bactérias do lodo de reator UASB de tratamento de esgoto foi avaliado quanto ao seu potencial de produção de $\mathrm{H}_{2}$ na fermentação de resíduos de alimentos sob diferentes relações alimento/microrganismos (A/M). Foi observado que os rendimentos máximos de hidrogênio $(0,39$ e 2,68 mol H2.mol) obtidos foram dependentes da relação A/M inicial e intimamente associados a predominância (>80\%) de Clostridium frigidicarnis. Verificou-se que inicialmente o resíduo de alimento era constituído principalmente por bactérias ácido láticas, mas que durante a fermentação houve mudança da comunidade bacteriana para representantes dos filos Proteobacteria, Bacteroidetes e Firmicutes, no qual bactérias semelhantes a Clostridium foram responsáveis tanto pela hidrólise do substrato, quanto pela produção de $\mathrm{H}_{2}$ (Laothanachareon et al., 2014).

Rabelo et al. (2018) avaliaram a comunidade bacteriana de reator acidogênico para produção de $\mathrm{H}_{2}$ na fermentação de bagaço de cana de açúcar (BCA). De acordo com os resultados, a máxima produção de $\mathrm{H}_{2}\left(23,10 \mathrm{mmoL} . \mathrm{L}^{-1}\right)$ obtida esteve associada principalmente a Clostridium. No entanto também foram identificadas bactérias semelhantes a Bacillus, Enterobacter, Paenibacillus e Lactobacillus no consórcio fermentativo. Mudanças significativas foram observadas na comunidade microbiana de acordo com as condições operacionais do reator, uma vez que os principais gêneros na condição de 5,0 g.L $\mathrm{L}^{-1}$ de BCA e pH 6,0 foram Lactobacillus, Escherichia e Clostridium e na condição de 7,0 g.L.1 de BCA e $\mathrm{pH}$ 7,2 foram Bacteroides e Enterobacter.

Fues et al. (2018) avaliaram o papel das diferentes comunidades bacterianas na fermentação de vinhaça para produção de $\mathrm{H}_{2}$. Os maiores níveis de produção de $\mathrm{H}_{2}$ foram associados a Thermoanaerobacterium, enquanto que bactérias produtoras de ácido lático compreendiam os gêneros dominantes, principalmente aquelas semelhantes a Lactobacillus e Leuconostoc. Os autores ainda afirmaram que a fermentação do lactato desempenhou duplo papel no reator, tanto na produção de $\mathrm{H}_{2}$ (ácido acético + ácido láctico $\rightarrow$ ácido butírico $+\mathrm{H}_{2}$ ), como sem produção de $\mathrm{H}_{2}$ (ácido láctico $\rightarrow$ ácido propiônico + ácido acético). De modo geral, 
em condições de escassez de carboidratos, o lactato é fonte primária de carbono alternativo em sistemas alimentados com vinhaça.

Soares et al. (2018) avaliaram a comunidade microbiana em reatores em batelada na fermentação de bagaço de cana de açúcar (BCA) com variação da concentração do substrato (3,58-6,42 g.L $\left.\mathrm{L}^{-1}\right)$ e extrato de levedura $\left(0,58-3,42\right.$ g.L $\left.\mathrm{L}^{-1}\right)$. A máxima produção de $\mathrm{H}_{2}$ obtida foi 1,50 mmol.L $\mathrm{L}^{-1}$ utilizando 2,77 e 5,84 g.L $\mathrm{L}^{-1}$ de extrato de levedura e BCA, respectivamente. Por meio da análise taxonômica foram identificadas bactérias semelhantes a Clostridium (33\% do total do Domínio Bacteria) e Methanothermobacter (40\% do Domínio Archaea) como as mais abundantes no reator com alto teor de hidrogênio.

An et al. (2018) avaliaram a produção fermentativa de $\mathrm{H}_{2}$ a partir de água residuária de indústria de papel utilizando consórcio de bactérias termofílicas $\left(55^{\circ} \mathrm{C}\right)$. Os autores observaram o predomínio de representantes pertencentes a Clostridiales e Thermoanaerobacterales, especificamente semelhantes a Ruminiclostridium e Thermoanaerobacterium, as quais foram associadas principalmente a hidrólise e produção de hidrogênio.

Por meio da análise dos resultados obtidos na literatura, observou-se que há diversidade de gêneros de bactérias que estão relacionados aos processos fermentativos na produção de $\mathrm{H}_{2}$ e que as condições impostas de operação dos reatores anaeróbios refletem na comunidade bacteriana. Destaca-se que grande parte das bactérias identificadas são anaeróbias estritas e/ou anaeróbias facultativas e que os filos de bactérias mais abundantes são geralmente Firmicutes, Bacteroidetes, Proteobacteria e Actinobacteria.

Dentre os gêneros com crescimento anaeróbio estrito, tanto Clostridium quanto o Thermoanaerobacterium são produtores de $\mathrm{H}_{2}$ e com potencial celulolítico (Sigurbjornsdottir e Orlygsson, 2012; Soares et al., 2018), o que pode ter contribuído com a conversão do substrato em metabólitos. Entre os gêneros facultativos (Bacillus, Enterobacter, Paenibacillus, Lactobacillus, Enterococcus, Ruminiclostridium e Leuconostoc) aqueles semelhantes a Lactobacillus e Leuconostoc são os principais produtores de ácido lático, no qual pode inferir em baixos rendimento de $\mathrm{H}_{2}$. Bacillus e Enterobacter também podem contribuir com a produção de $\mathrm{H}_{2}$ (Mishra et al., 2017 e Tandon et al., 2018), enquanto os demais gêneros de bactérias estão mais relacionados ao processo de degradação da matéria orgânica.

Atualmente, pouco se sabe a respeito da aplicação de bactérias autóctones do resíduo de banana na produção de $\mathrm{H}_{2}$, sendo escasso informações sobre o perfil taxonômico desta biomassa em reatores biológicos. No entanto, alguns autores, tem reportado a diversidade de microrganismos em reatores utilizando resíduos de frutas e vegetais como substrato. Wang et 
al. (2014) relataram a predominância de bactérias pertencentes a família Clostridiaceae, Rikinellaceae e Bacteroidaceae no reator acidogênico utilizando resíduo de frutas e palha de trigo como substrato. Li et al. (2017) reportaram a dominância de Bacteroidetes, Proteobacteria, Chloroflexi e Firmicutes em reatores acidogênicos alimentados com batata e repolho. No final da fermentação de resíduo de frutas e vegetais, Ros et al. (2017) observaram que houve predominância do gênero Clostridium e Turicibacter, ambos pertencentes ao filo Firmicutes, nos quais foram associadas as etapas de hidrólise, acidogênese e acetogênese.

Entretanto, os autores mencionados utilizaram resíduos de frutas e vegetais como substrato, mas, optaram por usar fonte externa de inóculo. No caso, há necessidade de conhecer o papel da microbiota autóctone na degradação de resíduos, incluindo resíduos de frutas como a banana, no âmbito de dispensar o uso de inóculo e passar a realizar fermentações naturais. A príncipio sabe-se que em frutas, contém ampla variedade de bactérias incluindo Lactobacillus, Bacillus, Leuconostoc, Enterobacter, Pseudomonas, Citrobacter, entre outras (Torrezan et al., 2000; Marcano et al., 2016), que podem auxiliar na degradação do fruto. Neste sentido a utilização de biomassa autóctone pode ser uma alternativa viável e sustentável na busca por enzimas com alto potencial metabólico.

\subsection{Enzimas relacionadas a fermentação para produção de hidrogênio}

O conhecimento a respeito do gene, expressão gênica e expressão proteica permite compreender as etapas fundamentais que ocorrem na fermentação através das reações enzimáticas, onde a real compreensão dos processos fermentativos possibilita buscar alternativas para favorecer a produção de $\mathrm{H}_{2}$ e consequentemente avançar nos estudos sobre energia renovável (Abram, 2015 e Kleinsteuber, 2018). Na Figura 2.3 está representada as etapas da conversão da matéria orgânica e suas respectivas enzimas envolvidas.

O processo fermentativo inicia-se na decomposição da matéria orgânica que ocorre por meio de ampla atividade enzimática, no qual estão envolvidas as enzimas hidrolases (Odnell et al., 2016). Os principais grupos de hidrolases envolvidos no processo de degradação de substratos orgânicos são as esterases, glicosidases e peptidases, as quais catalisam a clivagem de ligações éster, ligações glicosídicas e ligações peptídicas, respectivamente.

Durante a etapa acidogênica, há formação de $\mathrm{H}_{2}$ e $\mathrm{CO}_{2}$, bem como de ácidos carboxílicos de cadeia curta de baixo peso molecular e etanol. Nesta fase, cerca de 33\% da demanda química de oxigênio (DQO) pode ser convertida em metabólitos gasosos e orgânicos 


\author{
Universidade de São Paulo \\ Escola de Engenharia de São Carlos \\ Programa de Pós-graduação em Hidráulica e Saneamento
}

(Bartacek et al., 2007). Dependendo do metabólito produzido, a fermentação pode ser classificada como acético/butírica e/ou acético/etanólica.

Figura 2.3. Esquema geral da conversão da matéria orgânica até a etapa acetogênica associada as enzimas que catalisam cada reação.

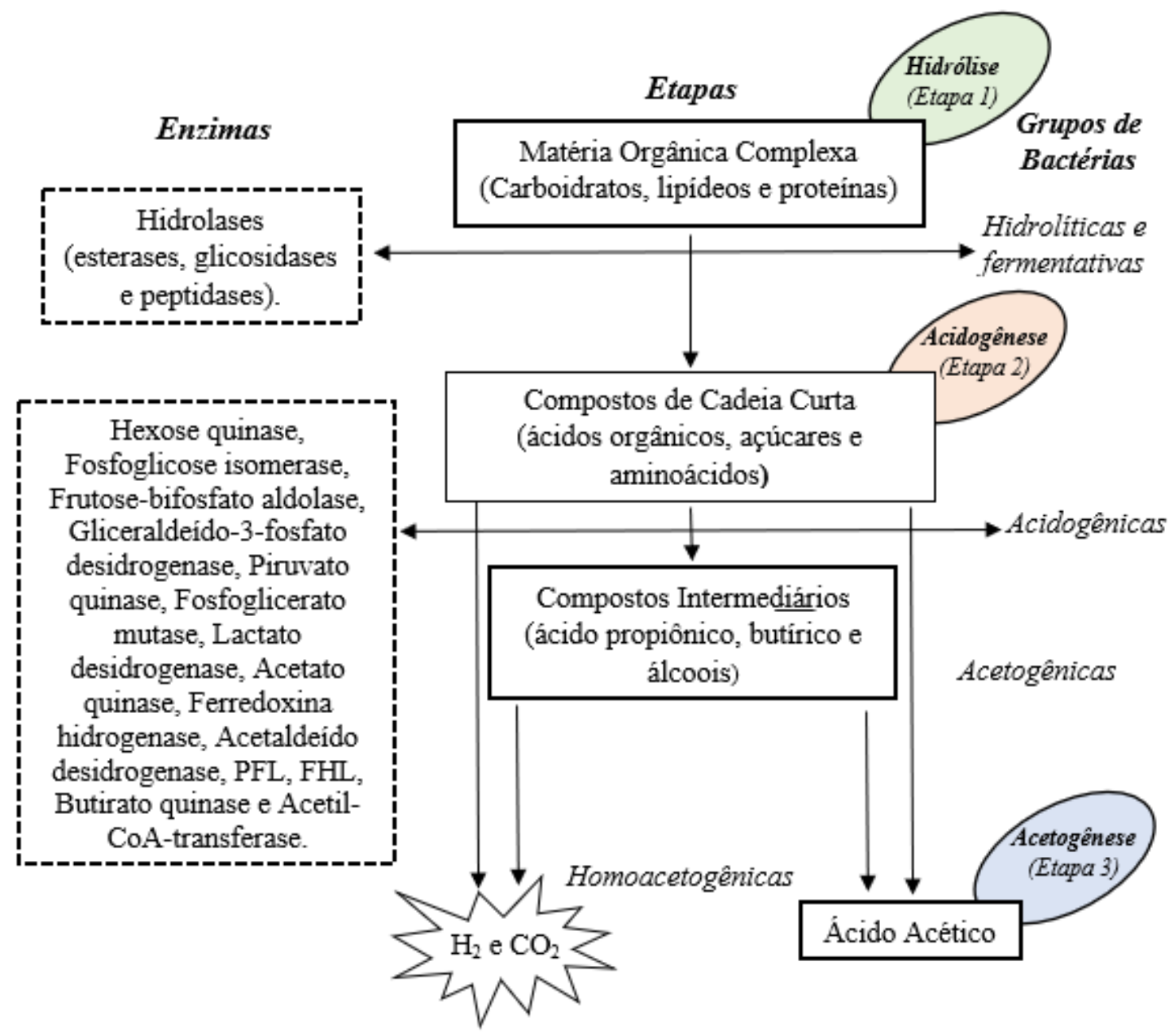

Nota: PFL = piruvato formiato liase; FHL = formiato hidrogênio liase Fonte: Elaboração Própria

Além destes componentes, também pode haver a produção de biomassa e metabólitos mais reduzidos (ácido lático, propiônico, etanol) acarretando em baixos rendimentos de $\mathrm{H}_{2}$ (Lee et al., 2010). São vastas as enzimas envolvidas nesta etapa, a título de exemplificação (Tabela 2.6) estão citadas algumas das enzimas ${ }^{6}$ envolvidas na acidogênese.

${ }^{6}$ A nomenclatura das enzimas provem da Enciclopédia de Kyoto de Genes e Genomas (KEGG). 
Universidade de São Paulo

Escola de Engenharia de São Carlos

Programa de Pós-graduação em Hidráulica e Saneamento

Como visto, a conversão da biomassa em $\mathrm{H}_{2}, \mathrm{CO}_{2}$ e ácidos carboxílicos é resultante do efeito da interação entre micro-organismos, sendo que esses processos ocorrem devido a maquinaria enzimática envolvida em vias metabólicas específicas. A operação dos reatores anaeróbios juntamente com a análise metagenômica é uma importante aliança no qual trará grandes benefícios para o entendimento, bem como melhoria do processo acidogênico. 
Universidade de São Paulo

Escola de Engenharia de São Carlos

Programa de Pós-graduação em Hidráulica e Saneamento

Tabela 2.6. Enzimas associadas a etapa acidogênica.

\begin{tabular}{|c|c|c|}
\hline Enzima & Reação & Referência \\
\hline \multicolumn{3}{|c|}{ Formação piruvato } \\
\hline Hexose quinase & D-Glicose + ATP $\rightarrow$ D-glicose-6-fosfato + ADP & \multirow{6}{*}{$\begin{array}{c}\text { Berg et al. (2015), } \\
\text { Angenent et al. (2004), } \\
\text { Hallenbeck (2005), } \\
\text { Kraemer e Bagley } \\
\text { (2007), Lee et al. (2011) }\end{array}$} \\
\hline Fosfoglicose isomerase & D-Glicose 6-fosfato $\rightarrow$ D-frutose 6-fosfato & \\
\hline Frutose-bifosfato aldolase & Frutose-1,6-bifosfato $\rightarrow$ dihidroxiacetona fosfato + gliceraldeido- 3 -fosfato & \\
\hline $\begin{array}{c}\text { Gliceraldeido-3-fosfato } \\
\text { desidrogenase }\end{array}$ & D- gliceraldeído 3-fosfato + fosfato $+\mathrm{NAD}^{+} \rightarrow$ 1,3-bifosfoglicerato $+\mathrm{NADH}+\mathrm{H}^{+}$ & \\
\hline Piruvato quinase & Fosfoenolpiruvato + ADP $\rightarrow$ piruvato + ATP & \\
\hline Fosfoglicerato mutase & 3-fosfoglicerato $\rightarrow 2$-fosfoglicerato & \\
\hline \multicolumn{3}{|c|}{ Conversão do piruvato } \\
\hline Lactato desidrogenase & Piruvato $+\mathrm{NADH} \rightarrow$ lactato $+\mathrm{NAD}^{+}$ & Sikora et al. (2013) \\
\hline Acetato quinase & ATP + acetato $\rightarrow$ ADP + acetil fosfato & Li et a. (2008) \\
\hline Ferredoxina hidrogenase & 2 Ferredoxina Red $+2 \mathrm{H}^{+} \rightarrow \mathrm{H}_{2}+2$ Ferredoxina ox & \multirow{6}{*}{$\begin{array}{c}\text { Berg et al. (2015), } \\
\text { Angenent et al. (2004), } \\
\text { Hallenbeck (2005), } \\
\text { Kraemer e Bagley } \\
\text { (2007), Lee et al. (2011) }\end{array}$} \\
\hline Acetaldeído desidrogenase & Acetaldeído $+\mathrm{CoA}+\mathrm{NAD}^{+} \rightarrow$ acetil-CoA $+\mathrm{NADH}+\mathrm{H}^{+}$ & \\
\hline PFL_piruvato formiato liase & Piruvato $+\mathrm{CoA} \rightarrow$ acetil-CoA + formiato & \\
\hline FHL_-formiato hidrogênio liase & Formiato $\rightarrow \mathrm{H}_{2}+\mathrm{CO}_{2}$ & \\
\hline Butirato quinase & Butanoil fosfato + ADP $\rightarrow$ butanoato + ATP & \\
\hline Acetil-CoA-transferase & Acetil-CoA + acetato $\rightarrow$ um ânion de ácido graxo + acetil-CoA & \\
\hline
\end{tabular}

Fonte: Sikora et al. (2013). 
Universidade de São Paulo

Escola de Engenharia de São Carlos

Programa de Pós-graduação em Hidráulica e Saneamento

\section{HIPÓTESES E OBJETIVOS}

A vertente da presente pesquisa esteve guiada em uma hipótese geral, na qual se certifica o potencial uso do resíduo de banana madura como substrato e fonte de bactérias fermentativas para produção de compostos de interesse biotecnológico.

Neste âmbito, o objetivo geral estipulado foi estabelecer condições ótimas operacionais para produção de hidrogênio e ácidos orgânicos via fermentação a partir de resíduo frutícola.

Deste modo, foram pautadas sub-hipóteses da pesquisa associadas aos seus respectivos objetivos específicos:

Sub-hipótese 1: O resíduo de banana in natura (casca e polpa) servirá como fonte de carbono e de bactérias fermentativas autóctones.

Objetivo 1: Avaliar as características fisico-químicas dos resíduos de banana como única fonte de carbono para fermentação.

Objetivo 2: Avaliar a produção de $\mathrm{H}_{2}$ e metabólitos orgânicos a partir de bactérias autóctones dos resíduos da banana.

Sub-hipótese 2: A adição de componentes nutricionais ao resíduo de banana pode influenciar o metabolismo bacteriano e consequentemente aumentar a produção de hidrogênio.

$\checkmark \quad$ Objetivo 3: Avaliar a produção de hidrogênio em reatores em batelada sob diferentes condições nutricionais.

Sub-hipótese 3: Estratégias sequenciais por meio de delineamento experimental auxiliará a maximização da produção de hidrogênio.

$\checkmark \quad$ Objetivo 4: Otimizar a produção de hidrogênio a partir do resíduo de banana como fonte de carbono.

$\checkmark \quad$ Objetivo 5: Avaliar o perfil taxonômico e funcional da biomassa fermentativa sob efeito das condições operacionais do reator.

Sub-hipótese 4: A produção de hidrogênio utilizando uma cepa bacteriana pura é maior quando comparado a produção utilizando consórcio de bactérias a partir do resíduo de banana.

$\checkmark \quad$ Objetivo 6: Isolar, identificar e caracterizar estirpe de bactéria produtora de $\mathrm{H}_{2}$ e comparar seu potencial na produção de hidrogênio com o consórcio de bactérias. 


\author{
Universidade de São Paulo \\ Escola de Engenharia de São Carlos \\ Programa de Pós-graduação em Hidráulica e Saneamento
}

\title{
4. MATERIAL E MÉTODOS
}

Nesse capítulo serão apresentados os procedimentos experimentais, as estratégias e ferramentas utilizadas para execução das sub-hipóteses previamente elaboradas. A etapa experimental do presente trabalho foi realizada a partir da operação de reatores em batelada, nos quais os métodos analíticos e cálculos utilizados para avaliação dos ensaios são explicitados a seguir. Para o cumprimento das atividades foi elaborado um fluxograma total de execução das atividades (Figura 4.1), buscando-se inserir os objetivos relacionados a cada etapa.

\subsection{Substrato}

Para realização dos ensaios, foram utilizados resíduos (casca e polpa) de bananas nanicas maduras, provenientes de supermercado, localizado na cidade de São Carlos/SP, Brasil. A escolha deste resíduo deve-se a elevada quantidade de perdas desse fruto na escala comercial. Para obtenção do substrato, os resíduos de bananas maduras (polpa e casca) (Figura 4.2 (A)) foram submetidos ao pré-tratamento físico através do processo de trituração em liquidificador industrial e posteriormente, peneirado em malha de $2 \mathrm{~mm}$ (Figura 4.2 (B)) a fim de reduzir o tamanho das partículas e aumentar a superfície de contato com os micro-organismos.

Devido à quantidade de sólidos suspensos na fração líquida dos resíduos da banana foi necessário utilizar um agitador e misturador mecânico com perfil de escoamento contendo chicanas, evitando a formação de vórtices na agitação de líquidos de viscosidade reduzida para garantir a homogeneidade do substrato quando da sua adição nos reatores em batelada. Para essa pesquisa foram confeccionadas 4 chicanas, montadas verticalmente duas a duas em posição oposta junto à parede do recipiente, mantendo-se um pequeno espaço entre elas (Figura 4.3). A rotação do agitador foi ajustada à $700 \mathrm{rpm}$ com eixo central posicionado à $10 \mathrm{~cm}$ da base do recipiente.

O substrato obtido é caracterizado pela sua alta deterioração devido à alta concentração de matéria orgânica. Para tanto, o substrato após misturado/agitado foi armazenado em reservatórios plásticos (volumes de $1 \mathrm{~L})$ e congelado ${ }^{7}\left(-20^{\circ} \mathrm{C}\right)$ buscando-se manter a sua integridade quanto a DQO e carboidratos.

\footnotetext{
${ }^{7} \mathrm{O}$ resíduo de banana é caracterizado pela sua alta deterioração devido à alta concentração de matéria orgânica, sendo necessário a rápida refrigeração para evitar a ocorrência da fermentação natural.
} 
Universidade de São Paulo

Escola de Engenharia de São Carlos

Programa de Pós-graduação em Hidráulica e Saneamento

Figura 4.1. Fluxograma experimental dos objetivos do trabalho nas diferentes etapas da pesquisa.

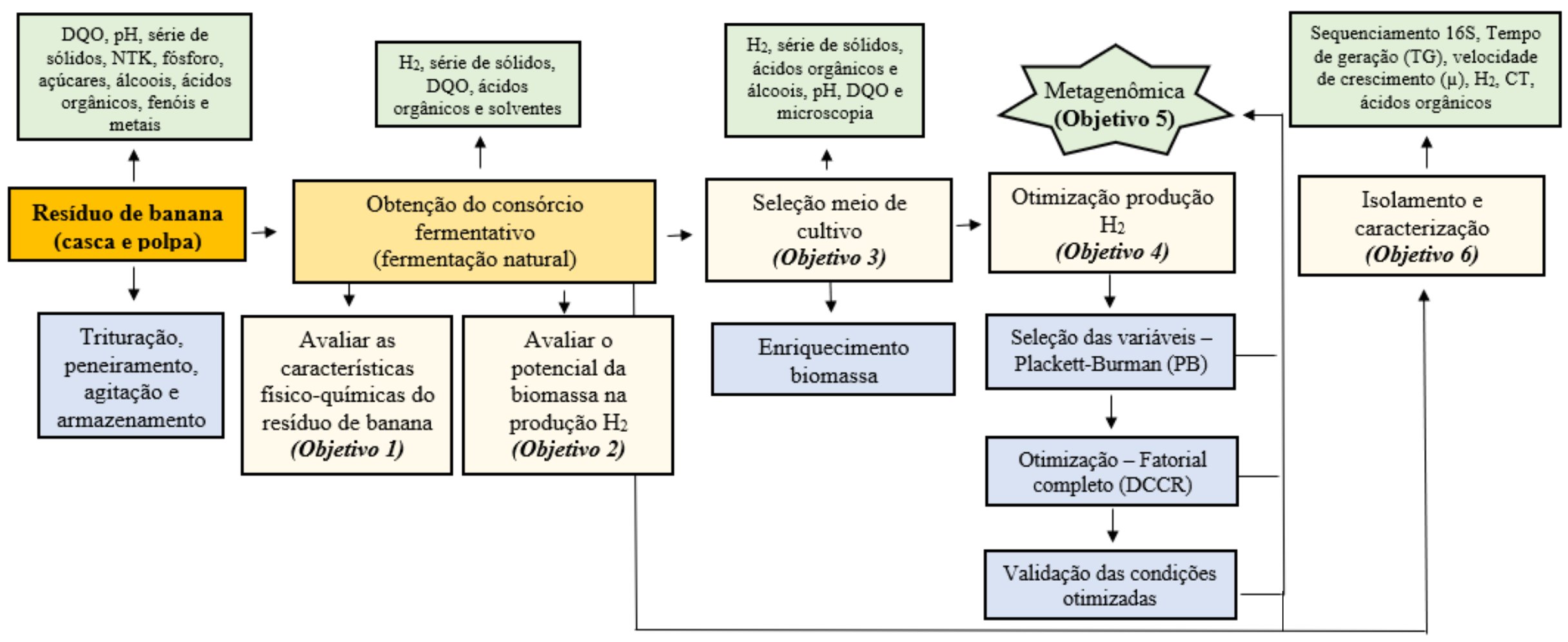

Fonte: Elaboração própria

Nota: $\mathrm{CT}=$ carboidratos totais 
Figura 4.2. (A) Resíduo de banana (B) Peneiramento em malha de $2 \mathrm{~mm}$ do resíduo triturado.
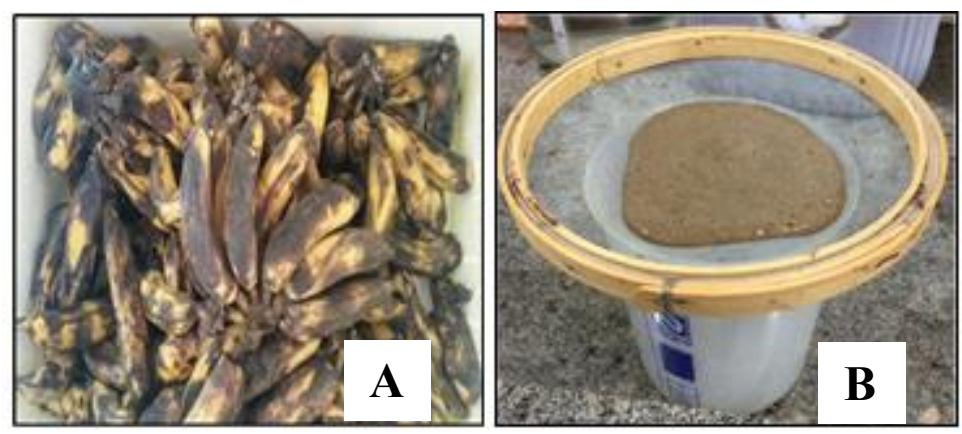

Figura 4.3. Esboço do perfil de escoamento em um recipiente com chicanas com agitador montado co-axialmente.

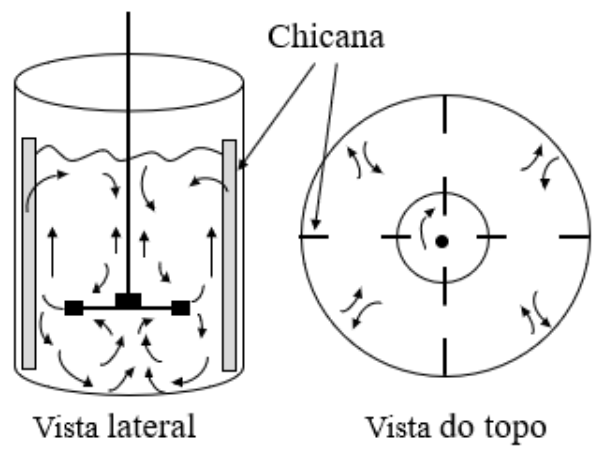

Fonte: Elaboração própria

\subsection{Obtenção do consórcio de bactérias fermentativas autóctones}

\subsubsection{Fermentação natural do resíduo de banana}

Para obtenção do consórcio de bactérias fermentativas (Sub-hipótese 1), reator em batelada de 2 L foi preenchido mantendo-se $50 \%$ de volume reacional (1 L) e $50 \%$ de headspace (1 L), utilizando o resíduo de banana $(\mathrm{RB})$, como única fonte de carbono e fonte natural de micro-organismos. Nesta etapa, dispensou-se o uso de fonte exógena de bactérias (alóctone), sendo que a microbiota autóctone do resíduo foi auto-inoculante. A concentração de matéria orgânica solúvel do substrato foi cerca de $50 \mathrm{~g} \mathrm{DQO}_{\mathrm{t}} \cdot \mathrm{L}^{-1}$, principalmente na forma de carboidratos totais $\left(\sim 30 \mathrm{~g} \mathrm{CT} . \mathrm{L}^{-1}\right)$. O pH nesta etapa não foi ajustado, mantendo-se o pH natural do resíduo $(\sim 5,87)$. O reator foi submetido à atmosfera de $\mathrm{N}_{2}(100 \%)$ durante 10 minutos para a troca gasosa no volume do headspace, e posteriormente, foi fechado com tampa de butila e rosca plástica e incubado por 24 horas em condição mesófila, $37^{\circ} \mathrm{C}$ sem agitação (Figura 4.4). 
Universidade de São Paulo

Escola de Engenharia de São Carlos

Programa de Pós-graduação em Hidráulica e Saneamento

Figura 4.4. Obtenção de consórcio de bactérias fermentativas autóctones

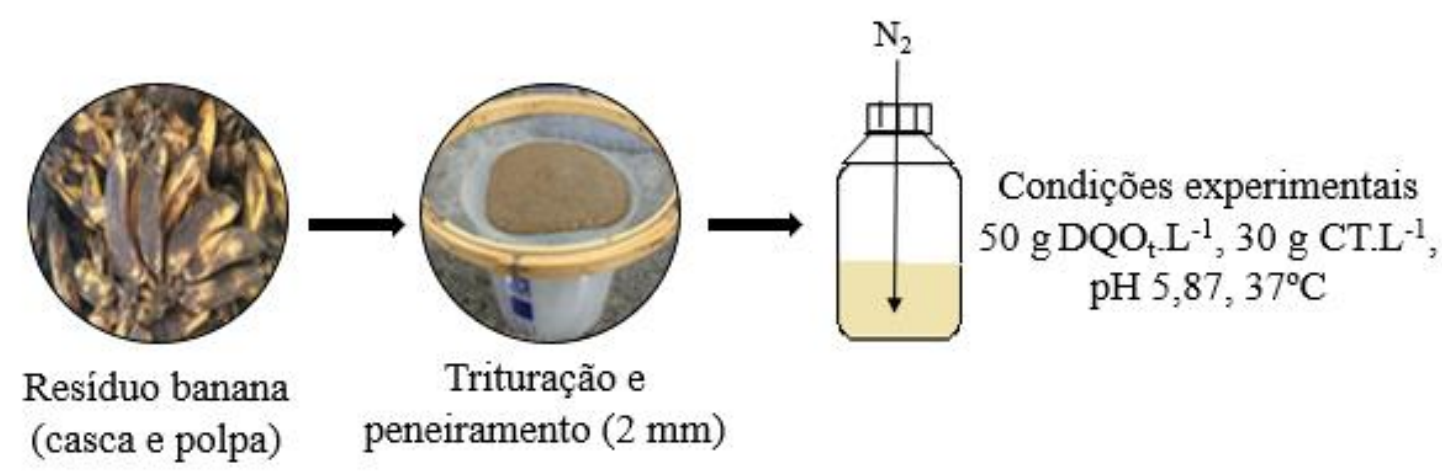

Após a obtenção do consórcio de bactérias anaeróbias autóctones, o frasco contendo a biomassa foi mantido refrigerado em geladeira, afim de reduzir a atividade metabólica, para posteriormente ser utilizado em todos os ensaios em reatores em batelada. Para garantir a homogeneidade dessa biomassa para todos os ensaios, o frasco era retirado da geladeira, e submetido à agitação constante, e logo após foi retirado o volume necessário de inóculo.

Foi coletada amostra da biomassa do consórcio obtido para observação microscópica de contraste de fase ou luz comum com lâmina colorida mediante à técnica de Gram, utilizando o microscópio Olympus BX60-FLA com software Image Pro-Plus.

\subsection{Seleção do Meio de Cultivo}

Três meios de cultivo foram avaliados quanto ao potencial nutricional para crescimento e aumento da atividade de bactérias fermentativas produtoras de hidrogênio utilizando somente o resíduo de banana in natura como fonte de carbono (Figura 4.5).

Figura 4.5. Seleção do meio de cultivo a partir do resíduo de banana como fonte de carbono.

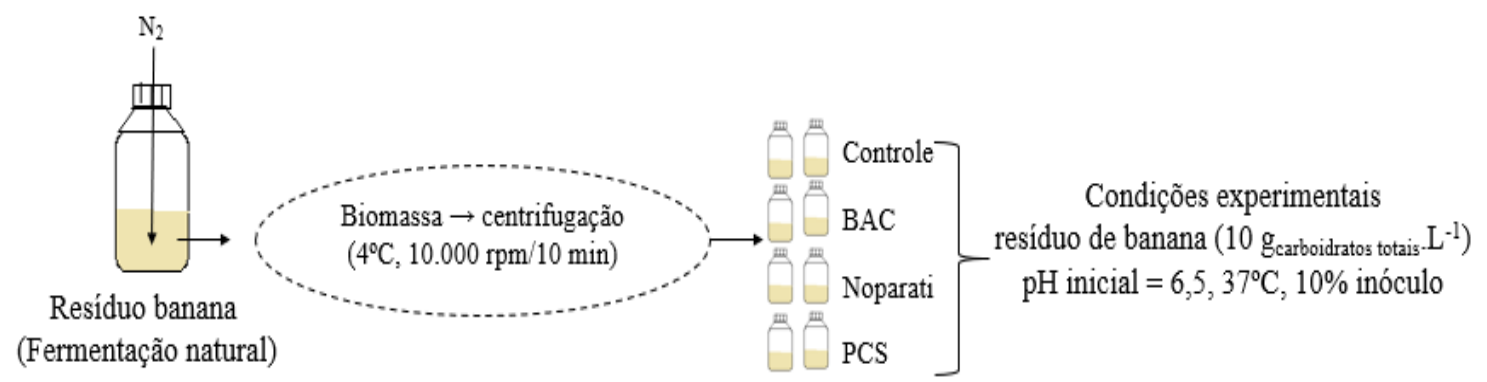

Nota: $\mathrm{BAC}=$ meio bactérias anaeróbias celulolíticas; $\mathrm{PCS}=$ meio peptona

Fonte: Elaboração própria. 


\author{
Universidade de São Paulo \\ Escola de Engenharia de São Carlos \\ Programa de Pós-graduação em Hidráulica e Saneamento
}

Os meios avaliados foram BAC (ATLAS, 2005), Noparati (Noparati et al., 2011) e PCS (Haruta et al., 2002) conforme descritos na Tabela 4.1. Frascos Duran ${ }^{\circledR}$ de $250 \mathrm{~mL}$ foram utilizados como reatores, mantendo-se $50 \%$ de volume reacional e $50 \%$ de headspace. Os reatores foram inoculados com biomassa obtida da fermentação natural. Para tanto, $12,5 \mathrm{~mL}$ dessa biomassa, equivalente a $10 \%$ do meio reacional, foi centrifugada à $4^{\circ} \mathrm{C}, 10.000 \mathrm{rpm}$ por 10 min., o sobrenadante foi descartado, sendo utilizado somente o precipitado, que foi adicionado em cada reator.

O substrato (resíduo de banana) foi utilizado como fonte de carbono em todos os ensaios em concentração de $10 \mathrm{~g}$ carboidratos totais. $\mathrm{L}^{-1}$ e adicionado junto ao meio de cultivo garantindo a correta concentração em cada reator. Outro ensaio foi realizado contendo somente o resíduo de banana (controle) como fonte de carbono para avaliar seu potencial na produção de $\mathrm{H}_{2}$ sem adição de meio nutritivo. Em todos os reatores o $\mathrm{pH}$ inicial foi ajustado a 6,5. Em todas as condições testadas foram feitas triplicatas de reatores em batelada mantidos sem agitação.

O meio de cultivo para bactérias anaeróbias celulolíticas (BAC) (ATLAS, 2005) apresentado na Tabela 4.1 foi modificado pela substituição de componentes contendo fontes de sulfato por aqueles contendo fontes de cloreto com as respectivas concentrações correspondentes. Para o preparo do meio, o volume específico de água ultrapurificada foi adicionado para solubilização de todos os componentes. Posteriormente, foi adicionado assepticamente o volume correspondente de vitaminas (Tabela 4.2) e traço de metais (Tabela 4.3), substrato (resíduo de banana) e finalmente preenchido com o volume de água restante. A solução total resultante (vitaminas + traço + substrato) não foi esterilizada.

A solução de vitaminas e traço de metais (ATLAS, 2005) foi preparada dissolvendo-se os componentes listados na Tabela 4.2 e 4.3 em água ultrapurificada. A solução final de vitamina e traço resultante foi esterilizada por filtração em membrana Millipore de poro 0,22 $\mu \mathrm{m}$, previamente esterilizada em autoclave a $121^{\circ} \mathrm{C}, 1$ atm por 20 minutos. Depois de esterilizadas, as soluções foram transferidas para recipiente apropriado sob fluxo de $\mathrm{N}_{2}(100 \%)$ em condições assépticas, sendo armazenadas sob refrigeração.

O meio de cultivo Noparati foi preparado adicionando-se os componentes e dissolvendo-os em água ultrapurificada juntamente com o resíduo de banana como fonte de carbono. Para correção do pH inicial de 6,5 de ambos os meios, BAC e Noparati, foi utilizado soluções de $\mathrm{HCl} 37 \%$ (P.A) e $\mathrm{NaOH} 50 \%$ (m/v). 
Universidade de São Paulo

Escola de Engenharia de São Carlos

Programa de Pós-graduação em Hidráulica e Saneamento

Tabela 4.1. Composição dos meios de cultivo

\begin{tabular}{|c|c|c|c|c|}
\hline \multirow[t]{2}{*}{ Componentes } & \multicolumn{4}{|c|}{ Quantidades - q.s.p. $1000 \mathrm{~mL}$ de água ultrapurificada } \\
\hline & Controle & BAC & Noparati & PCS \\
\hline Peptona & - & - & - & $5,0 \mathrm{~g}$ \\
\hline Extrato de levedura & - & $1,0 \mathrm{~g}$ & $1,0 \mathrm{~g}$ & $1,0 \mathrm{~g}$ \\
\hline $\mathrm{CaCO}_{3}$ & - & - & - & $5,0 \mathrm{~g}$ \\
\hline $\mathrm{NaCl}$ & - & - & - & $5,0 \mathrm{~g}$ \\
\hline $\mathrm{KH}_{2} \mathrm{PO}_{4}$ & - & $0,18 \mathrm{~g}$ & $1,5 \mathrm{~g}$ & - \\
\hline $\mathrm{K}_{2} \mathrm{HPO}_{4}$ & - & $0,29 \mathrm{~g}$ & $2,9 \mathrm{~g}$ & - \\
\hline Ureia & - & - & $2,1 \mathrm{~g}$ & - \\
\hline $\mathrm{MgCl}_{2} \cdot 6 \mathrm{H}_{2} \mathrm{O}$ & - & $0,09 \mathrm{~g}$ & $0,05 \mathrm{~g}$ & - \\
\hline $\mathrm{CaCl}_{2} .2 \mathrm{H}_{2} \mathrm{O}$ & - & $0.06 \mathrm{~g}$ & $0,0075 \mathrm{~g}$ & - \\
\hline $\mathrm{FeSO}_{4} .7 \mathrm{H}_{2} \mathrm{O}$ & - & - & $0,015 \mathrm{~g}$ & - \\
\hline $\mathrm{NH}_{4} \mathrm{Cl}$ & - & $0,80 \mathrm{~g}$ & - & - \\
\hline $\mathrm{NaHCO}_{3}$ & - & $2,10 \mathrm{~g}$ & - & - \\
\hline Substrato (RB) & $10,0 \mathrm{~g}$ & $10,0 \mathrm{~g}$ & $10,0 \mathrm{~g}$ & $10,0 \mathrm{~g}$ \\
\hline Vitaminas & - & $10 \mathrm{~mL}$ & - & - \\
\hline Traço de metais & - & $10 \mathrm{~mL}$ & - & - \\
\hline
\end{tabular}

Nota: Substrato $(\mathrm{RB})=$ substrato resíduo de banana $\left(\mathrm{g}\right.$ CT.L $\left.\mathrm{L}^{-1}\right)$

Tabela 4.2. Composição da solução de vitaminas

\begin{tabular}{cc}
\hline Componentes & Quantidades - q.s.p. 1000 mL de água ultrapurificada \\
\hline Piridoxina-HCl & $10,0 \mathrm{mg}$ \\
DL - pantotenato de cálcio & $5,0 \mathrm{mg}$ \\
Ácido lipóico & $5,0 \mathrm{mg}$ \\
Ácido nicotínico & $5,0 \mathrm{mg}$ \\
Ácido p-aminobenzóico & $5,0 \mathrm{mg}$ \\
Riboflavina & $5,0 \mathrm{mg}$ \\
Tiamina-HCl & $5,0 \mathrm{mg}$ \\
Biotina & $2,0 \mathrm{mg}$ \\
Ácido fólico & $2,0 \mathrm{mg}$ \\
Vitamina B12 & $0,1 \mathrm{mg}$ \\
\hline
\end{tabular}




$$
\begin{gathered}
\text { Universidade de São Paulo } \\
\text { Escola de Engenharia de São Carlos } \\
\text { Programa de Pós-graduação em Hidráulica e Saneamento }
\end{gathered}
$$

Tabela 4.3. Composição da solução de traço de metais.

\begin{tabular}{cc}
\hline Componentes & $\begin{array}{c}\text { Quantidades }- \text { q.s.p. 1000 } \mathbf{~ m L ~ d e ~ a ́ g u a ~} \\
\text { ultrapurificada }\end{array}$ \\
\hline Ácido bórico & $0,1 \mathrm{mg}$ \\
Sulfato de manganês & $5,7 \mathrm{mg}$ \\
Cloreto de zinco & $0,1 \mathrm{mg}$ \\
Ácido nitrilotriacético & $15,0 \mathrm{mg}$ \\
Cloreto de cobalto & $1,0 \mathrm{mg}$ \\
Cloreto férrico & $21,0 \mathrm{mg}$ \\
Sulfato de alumínio e potássio & $0,1 \mathrm{mg}$ \\
Molibdato de sódio & $0,1 \mathrm{mg}$ \\
Sulfato de Cobre & $0,067 \mathrm{mg}$ \\
\hline
\end{tabular}
Fonte: ATLAS (2005)

O meio de cultivo PCS foi preparado adicionando-se os componentes em quantidade de água ultrapurificada para permitir a solubilização dos mesmos. Gotas de $\mathrm{HCl} 37 \%$ (P.A) foram adicionadas até que o meio passasse de turvo para translúcido, neste ponto o $\mathrm{pH}$ encontrava-se baixo, cerca de 4,5, e posteriormente o $\mathrm{pH}$ foi ajustado ao valor de interesse $(\mathrm{pH} 6,5)$ com $\mathrm{NaOH}-50 \%(\mathrm{~m} / \mathrm{v})$.

\subsection{Isolamento de bactéria produtora de hidrogênio}

O meio nutriente (Ho et al., 2012) utilizado para isolamento, enriquecimento e cultivo de linhagens produtoras de $\mathrm{H}_{2}$ foi preparado da seguinte forma: 10,0 g.. $\mathrm{L}^{-1}$ de glicose, 10,0 g.L $\mathrm{L}^{-}$ ${ }^{1}$ de triptona e 5,0 g. $\mathrm{L}^{-1}$ de extrato de levedura. Os valores iniciais de $\mathrm{pH}$ do meio foram ajustados para 7,0 com $\mathrm{NaOH}$ a $50 \%(\mathrm{~m} / \mathrm{v})$ ou $\mathrm{HCl}$.

Para o isolamento bacteriano, utilizou-se o consórcio fermentativo autóctone (item 4.2.1) submetido a diluições seriadas $\left(10^{-1}\right.$ a $\left.10^{-15}\right)$, transferindo sucessivamente $1 \mathrm{~mL}$ da suspensão de cada diluição para $9 \mathrm{~mL}$ de meio nutriente. A cultura referente à diluição $10^{-15}$ foi semeada $(10 \mu \mathrm{L})$ em triplicata em placas de Petri contendo meio nutritivo acrescido de ágar $2 \%$ (Figura 4.6). Após 24 h de incubação em condições anaeróbias (Jarra Gas-pack 3,5 L, Figura 4.7 (A)), colônias individuais morfologicamente distintas (formato da borda, aparência seca ou gomosa) obtidas nas placas de Petri foram repicadas por mais de três vezes para garantir a pureza das cepas. 
Universidade de São Paulo

Escola de Engenharia de São Carlos

Programa de Pós-graduação em Hidráulica e Saneamento

Figura 4.6. Imagem ilustrativa da técnica de diluição seriada e plaqueamento para obtenção de colônias isoladas.

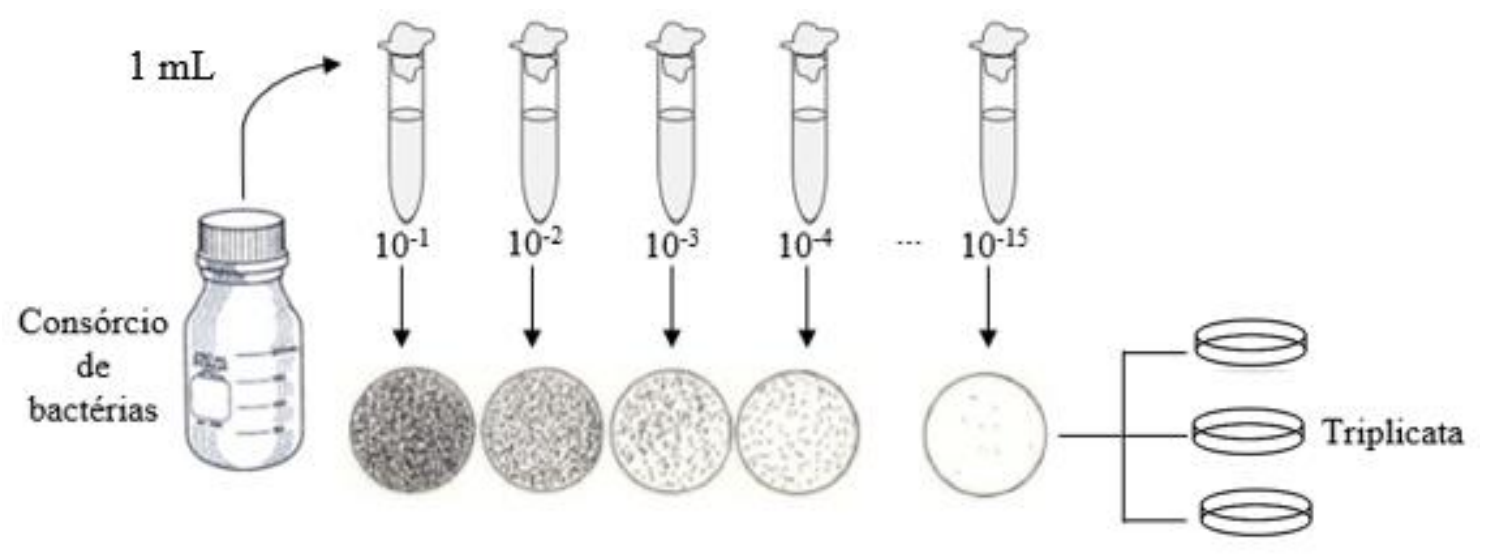

As colônias purificadas (Figua 4.7 (B)) foram coletadas com agulha de platina estéril e suspensas em frascos Duran ${ }^{\circledR}$ de $100 \mathrm{~mL}$ (volume reacional $50 \mathrm{~mL}$ ) contendo meio nutriente esterilizado por sistema de membrana filtrante 0,22 Millipore ${ }^{\circledR}$. Em seguida, os frascos foram submetidos à atmosfera de $\mathrm{N}_{2}(100 \%)$ durante 10 minutos para a troca gasosa no volume do headspace, e posteriormente, fechados com tampa de butila e rosca plástica e incubados em condição mesófila $\left(37^{\circ} \mathrm{C}\right)$ por $24 \mathrm{~h}$ sem agitação para promover o crescimento celular.

Figura 4.7. Jarra anaeróbia utilizada para incubar as placas de Petri (A), placa de Petri com crescimento de colônias individuais após incubação $37^{\circ} \mathrm{C} / 24$ horas (B) e aumento da biomassa produtora de $\mathrm{H}_{2}(\mathrm{C})$.
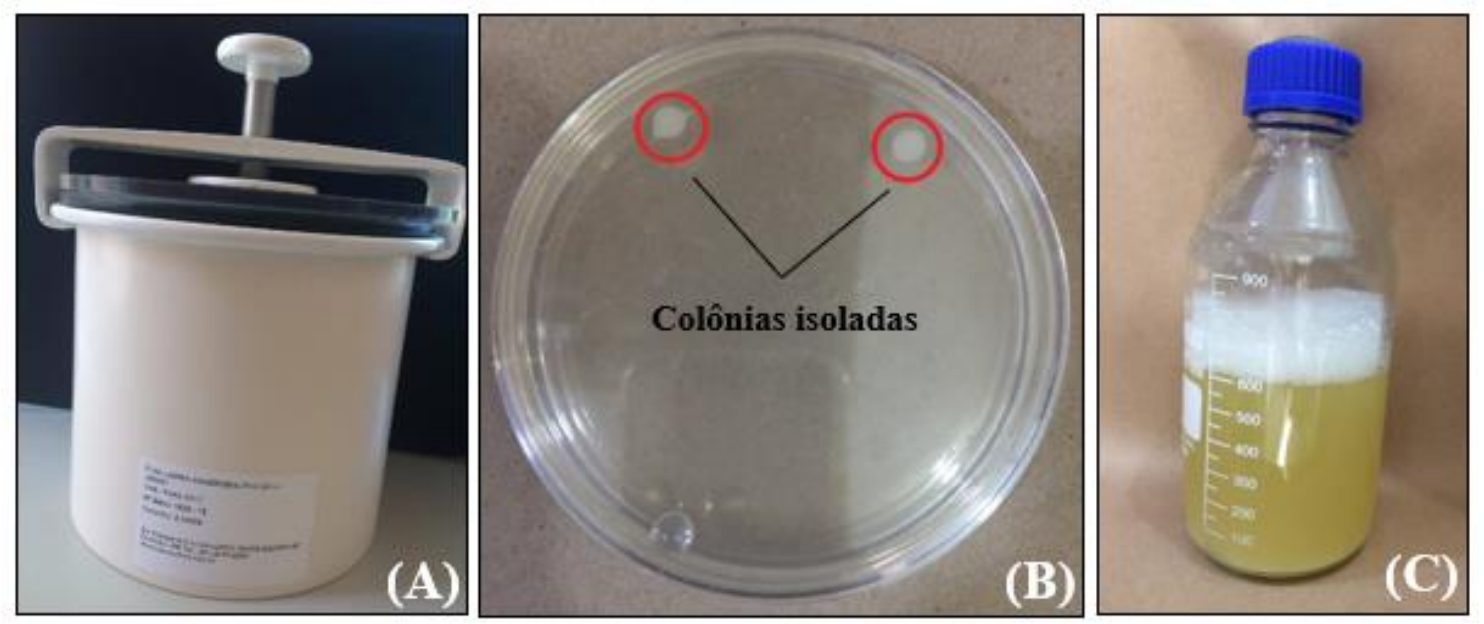

O crescimento celular foi quantificado pela turbidez do meio ( $\left.\mathrm{OD}_{600}\right)$ (APHA, 2015). O frasco contendo a colônia com alta atividade de produção de hidrogênio foi selecionado e 


\author{
Universidade de São Paulo \\ Escola de Engenharia de São Carlos \\ Programa de Pós-graduação em Hidráulica e Saneamento
}

reativado no meio nutriente sucessivas vezes até obtenção de 1 L de volume (Figura 4.7 (C)) e posteriormente, submetida à análise microscópica e sequenciamento de DNA de Sanger. A linhagem bacteriana isolada foi criopreservada em meio nutriente suplementado em $20 \%$ de glicerol e armazenada a $-85^{\circ} \mathrm{C}$ para a manutenção de suas características genéticas.

\title{
4.5. Ensaios de produção de $\mathrm{H}_{2}$
}

\subsubsection{Avaliação do isolado}

Os efeitos de parâmetros incluindo fontes de carbono, concentração de celobiose e substituição de açúcares puros por resíduos de banana como substrato na produção de hidrogênio pelo isolado foram estudados em testes de batelada. Os carboidratos glicose, xilose, amido, maltose, celobiose, manose, galactose, frutose e sacarose foram utilizados como fonte de carbono em 5,0 g.L $\mathrm{L}^{-1}$ cada. $\mathrm{O}$ efeito da concentração de celobiose foi conduzido em vários níveis de concentração desde 0,5 a 6,5 g.L $\mathrm{L}^{-1}$ (com incremento de 1,5 g.L $\mathrm{L}^{-1}$ a cada ensaio). A substituição de açúcares puros por resíduos de banana in natura como fonte de carbono foi avaliada considerando 5,0 g.L $\mathrm{L}^{-1}$ de carboidratos totais.

Todos os ensaios em batelada foram conduzidos em frascos Duran ${ }^{\circledR}$ (volume total de $250 \mathrm{~mL}$, reacional de $150 \mathrm{~mL}$ e $100 \mathrm{~mL}$ de headspace) e inoculados com Bacillus sp. RM1 (O.D600 igual a 0,4) isolado de resíduos de banana.

Nesses ensaios foi utilizado meio PCS descrito por Haruta et al. (2002) sendo constituído por 1,0 g.L $\mathrm{L}^{-1}$ de extrato de levedura; 5,0 g.L $\mathrm{L}^{-1} \mathrm{CaCO}_{3} ; 5,0$ g.L $\mathrm{L}^{-1}$ peptona e 5,0 g.L $\mathrm{L}^{-1}$ $\mathrm{NaCl}$. Para manter as condições assépticas, o meio de cultura PCS foi esterilizado usando sistema de membrana filtrante de 0,22 Millipore $^{\circledR}$. O valor inicial do $\mathrm{pH}$ do meio foi ajustado para 7,0 com $\mathrm{NaOH}$ a $50 \%(\mathrm{~m} / \mathrm{v})$ ou $\mathrm{HCl}$ (P.A). Todos os frascos foram submetidos a atmosfera de $\mathrm{N}_{2}(100 \%)$ durante 10 minutos para manter as condições anaeróbias requeridas e depois fechados com tampa de butila e rosca plástica e incubadas a $37{ }^{\circ} \mathrm{C}$ (sem agitação) até atingir a estabilidade da produção de hidrogênio.

Durante a fermentação descontínua, amostras líquidas foram periodicamente retiradas dos frascos com uma seringa estéril para determinação da concentração de carboidratos e concentração celular $\left(\mathrm{OD}_{600} \mathrm{~nm}\right)$. Todos os ensaios foram realizados em triplicata e os resultados são apresentados com o valor da média. 
Universidade de São Paulo

Escola de Engenharia de São Carlos

Programa de Pós-graduação em Hidráulica e Saneamento

\subsection{Seleção das variáveis independentes - Delineamento experimental de Plakett- Burman (PB).}

Para avaliar os efeitos das variáveis que pudessem interferir no processo fermentativo de produção de hidrogênio e metabólitos solúveis, foi utilizado o delineamento de screening design do tipo Plackett-Burman (PB) com 12 ensaios para as cinco variáveis estudadas em dois níveis, com adição de 3 pontos centrais totalizando 15 ensaios (em triplicata) calculado a partir do emprego da equação (1).

$$
r \times P B+c p=1 \times 12+3=15
$$

Sendo, $r=$ repetições $\mathrm{PB}=$ ensaios $; p=$ pontos centrais.

As variáveis e os níveis estudados estão apresentados nas Tabelas 4.4 e a matriz do delineamento experimental Plackett-Burman (PB) com todos os ensaios e condições experimentais deste planejamento estão apresentados nas Tabelas 4.5. Todos os ensaios foram realizados utilizando-se reatores em batelada ( $250 \mathrm{~mL}$ volume total) e resíduo de banana como substrato orgânico acrescido de meio de cultivo PCS. O inóculo (consórcio de bactérias obtido da fermentação natural) foi centrifugado à $6.000 \mathrm{rpm} / 10 \mathrm{~min}$ e adicionado aos reatores. Posteriormente, os reatores foram submetidos a atmosfera gasosa de $\mathrm{N}_{2}(100 \%)$ por 5 minutos e fechados com tampa de butila e rosca plástica.

Como respostas, foram avaliados a produção máxima de $\mathrm{H}_{2}(\mathrm{~mL})$, velocidade de produção $\left(\mathrm{mL} \mathrm{H}_{2} \cdot \mathrm{h}^{-1}\right)$, tempo de início de produção de $\mathrm{H}_{2}(\mathrm{~h})$, conversão de carboidratos totais (\%), rendimento de hidrogênio ( $\mathrm{mL} \mathrm{g}^{-1} \mathrm{CT}_{\text {adicionado }}$, produção de ácidos carboxílicos ( $\left.\mathrm{g} . \mathrm{L}^{-1}\right) \mathrm{e}$ etanol $\left(\mathrm{g} . \mathrm{L}^{-1}\right)$. Os resultados das médias de cada ensaio foram utilizados nas análises estatísticas dos efeitos das variáveis independentes sobre as respostas determinadas.

Tabela 4.4. Valores das variáveis do planejamento Plackett-Burman (PB) e seus respectivos níveis codificados.

\begin{tabular}{ccccc}
\hline Variáveis & Código & $\mathbf{- 1}$ & $\mathbf{0}$ & $\mathbf{1}$ \\
\hline $\mathrm{pH}$ & $\mathrm{X}_{1}$ & 5,5 & 6,5 & 7,5 \\
Carboidratos totais $\left(\mathrm{g} . \mathrm{L}^{-1}\right)$ & $\mathrm{X}_{2}$ & 3 & 9 & 15 \\
Temperatura $\left({ }^{\circ} \mathrm{C}\right)$ & $\mathrm{X}_{3}$ & 30 & 37 & 44 \\
Headspace $(\%)$ & $\mathrm{X}_{4}$ & 40 & 50 & 60 \\
Inóculo $(\%)$ & $\mathrm{X}_{5}$ & 5 & 10 & 15 \\
\hline
\end{tabular}


Tabela 4.5. Matriz do delineamento experimental Plackett-Burman (PB)

\begin{tabular}{ccccccccccc}
\hline Ensaios & $\mathbf{X}_{\mathbf{1}}$ & $\mathbf{X}_{\mathbf{2}}$ & $\mathbf{X}_{\mathbf{3}}$ & $\mathbf{X}_{\mathbf{4}}$ & $\mathbf{X}_{\mathbf{5}}$ & $\mathbf{p H}$ & $\begin{array}{c}\mathbf{C T} \\
\left(\mathbf{g . \mathbf { L } ^ { - 1 }}\right)\end{array}$ & $\begin{array}{c}\text { Temperatura } \\
\left({ }^{\mathbf{0}} \mathbf{C}\right)\end{array}$ & $\begin{array}{c}\text { Headspace } \\
(\boldsymbol{\%})\end{array}$ & $\begin{array}{c}\text { Inóculo } \\
(\boldsymbol{\%})\end{array}$ \\
\hline 1 & +1 & -1 & +1 & -1 & -1 & 7,5 & 3 & 44 & 40 & 5 \\
2 & +1 & +1 & -1 & +1 & -1 & 7,5 & 15 & 30 & 60 & 5 \\
4 & -1 & +1 & +1 & -1 & +1 & 5,5 & 15 & 44 & 40 & 15 \\
5 & +1 & -1 & +1 & +1 & -1 & 7,5 & 3 & 44 & 60 & 5 \\
6 & +1 & +1 & -1 & +1 & +1 & 7,5 & 15 & 30 & 60 & 15 \\
7 & -1 & +1 & +1 & -1 & +1 & 7,5 & 15 & 44 & 40 & 15 \\
8 & -1 & +1 & +1 & +1 & -1 & 5,5 & 15 & 44 & 60 & 5 \\
9 & -1 & -1 & -1 & +1 & +1 & 5,5 & 3 & 30 & 60 & 15 \\
10 & +1 & -1 & -1 & -1 & +1 & 7,5 & 3 & 30 & 40 & 15 \\
11 & -1 & +1 & -1 & -1 & -1 & 5,5 & 15 & 30 & 40 & 5 \\
12 & -1 & -1 & -1 & -1 & -1 & 5,5 & 3 & 30 & 40 & 5 \\
13 & 0 & 0 & 0 & 0 & 0 & 6,5 & 9 & 37 & 50 & 10 \\
14 & 0 & 0 & 0 & 0 & 0 & 6,5 & 9 & 37 & 50 & 10 \\
15 & 0 & 0 & 0 & 0 & 0 & 6,5 & 9 & 37 & 50 & 10 \\
\hline
\end{tabular}

Nota: $\mathrm{CT}=$ carboidratos totais

\subsection{Delineamento composto central rotacional (DCCR)}

A partir dos resultados dos cálculos dos efeitos do delineamento de Plackett- Burman (PB) foi possível estabelecer quais variáveis foram estatisticamente significativas e importantes a serem estudadas em próximo delineamento experimental completo, visando-se obter a otimização do processo. Sendo assim, as variáveis fixadas foram concentração de substrato (5 gCT.L $\left.\mathrm{L}^{-1}\right)$, headspace (60\%) e concentração de inóculo (10\%).

Definido as variáveis e as faixas a serem estudadas foi realizado o delineamento composto central rotacional (DCCR), do qual os níveis utilizados, os ensaios e condições experimentais deste planejamento estão apresentados na Tabela 4.6 A equação (2) apresenta a formulação empregada no cálculo para obtenção da matriz experimental.

$r \times(2 k+2 k)+c p=1 \times(22+2 \times 2)+3=11$ 
Universidade de São Paulo

Escola de Engenharia de São Carlos

Programa de Pós-graduação em Hidráulica e Saneamento

Sendo,

$r=$ repetições $; k=$ número de variáveis independentes; $c p=$ pontos centrais.

Tabela 4.6. Matriz do delineamento composto central rotacional (DCCR) com os valores das variáveis e seus respectivos níveis codificados.

\begin{tabular}{ccccc}
\hline Ensaios & $\mathbf{X}_{\mathbf{1}}$ & $\mathbf{X}_{\mathbf{2}}$ & $\mathbf{p H}$ & Temperatura $\left({ }^{\mathbf{0}} \mathbf{C}\right)$ \\
\hline 1 & -1 & -1 & 5,5 & 30 \\
2 & +1 & -1 & 7,5 & 30 \\
3 & -1 & +1 & 5,5 & 44 \\
4 & +1 & +1 & 7,5 & 44 \\
5 & $-1,41$ & 0 & 5,09 & 37 \\
6 & $+1,41$ & 0 & 7,91 & 37 \\
7 & 0 & $-1,41$ & 6,5 & 27,1 \\
8 & 0 & $+1,41$ & 6,5 & 46,9 \\
9 & 0 & 0 & 6,5 & 37 \\
10 & 0 & 0 & 6,5 & 37 \\
11 & 0 & 0 & 6,5 & 37 \\
\hline
\end{tabular}

Todos os ensaios foram realizados em triplicata em reatores batelada $(250 \mathrm{~mL}$ volume total), totalizando 33 reatores. O mesmo inóculo (consórcio de bactérias) e substrato (resíduo de banana) acrescido de meio de cultivo PCS foram utilizados neste experimento. Para isso, a concentração pré-estabelecida de inóculo foi centrifugado à $6.000 \mathrm{rpm} / 10 \mathrm{~min}$ e adicionado aos reatores. Posteriormente, os reatores foram submetidos a atmosfera gasosa de $\mathrm{N}_{2}(100 \%)$ por 5 minutos e fechados com tampa de butila e rosca plástica.

Após obtenção das respostas, foi elaborado o modelo preditivo em função das variáveis independentes e realizado o teste ANOVA para verificar a qualidade do modelo - Análise de variância - e em seguida, foi calculado as respostas através do modelo ajustado e os desvios entre a resposta experimental e a estimada pelo modelo.

Posteriormente, foi gerada a superfície de resposta e curva de contorno para analisar e definir as faixas ótimas operacionais de cada variável do processo. Por fim, foi realizada a validação experimental dos resultados realizando-se ensaios nas condições otimizadas.

As variáveis respostas avaliadas em cada ensaio incluíram: produção máxima de $\mathrm{H}_{2}$ (mL), velocidade de produção $\left(m L \cdot h^{-1}\right)$, tempo de início de produção de $\mathrm{H}_{2}(\mathrm{~h})$, conversão de 


\author{
Universidade de São Paulo \\ Escola de Engenharia de São Carlos \\ Programa de Pós-graduação em Hidráulica e Saneamento
}

carboidratos totais $(\%)$, rendimento de hidrogênio ( $\mathrm{mL} \mathrm{gCT}_{\mathrm{add}}$ ), fenóis (g.L $\mathrm{L}^{-1}$ ), ácidos carboxílicos (g.L $\left.\mathrm{L}^{-1}\right)$, etanol (g.L $\left.\mathrm{L}^{-1}\right)$ e açúcares solúveis (g.L $\left.\mathrm{L}^{-1}\right)$. Os resultados das médias de cada ensaio foram utilizados nas análises estatísticas dos efeitos das variáveis independentes sobre as respostas determinadas.

\title{
4.7.1. Validação experimental
}

A partir da análise da superfície de resposta foi possível determinar as condições do processo em que se obtêm a maior produção de $\mathrm{H}_{2}(P)(\mathrm{mL})$ e maior velocidade de produção $(R m)\left(\mathrm{mL} \cdot \mathrm{h}^{-1}\right)$. Tais condições de processo são apresentadas na Tabela 4.7.

Tabela 4.7. Condições operacionais utilizadas no ensaio experimental para validação do modelo.

\begin{tabular}{cc}
\hline Variável & Condição Experimental \\
\hline $\mathrm{pH}$ & 7,0 \\
Temperatura & $37^{\circ} \mathrm{C}$ \\
\hline
\end{tabular}

\subsection{Métodos analíticos, cromatográficos e cálculos}

\subsubsection{Análises físico-químicas e cromatográfica}

Os procedimentos analíticos empregados e frequência das amostragens da fase líquida e gasosa dos reatores em batelada durante os ensaios, estão apresentados na Tabela 4.8, sendo que na Tabela 4.9 são apresentados os equacionamentos para o cálculo das variáveis respostas referenciadas.

\subsubsection{Ajuste ao Modelo de Gompertz e avaliação dos métodos estatísticos}

Buscando-se identificar os valores máximos de produção de $\mathrm{H}_{2}(P)$, velocidade de produção de hidrogênio $(R m)$ e tempo de início de produção de $\mathrm{H}_{2}(\lambda)$ associado a cada parâmetro avaliado procurou-se ajustar aos pontos experimentais a função de Gompertz, utilizando o software OriginPro 9.1. Os equacionamentos empregados para o cálculo dos valores apresentados para as variáveis respostas referentes a produção de hidrogênio estão apresentados na Tabela 4.9.

Para avaliação dos métodos estatísticos e interpretação dos dados dos delineamentos experimentais (Plakett-Burman (PB) e Delineamento composto central rotacional (DCCR) 
utilizou-se o software Protimiza Experimental Design, que pode ser acessado .a partir da assinatura no site http://experimental-design.protimiza.com.br.

\subsection{Caracterização por Biologia Molecular}

\subsubsection{Identificação taxonômica e análise fillogenética do isolado}

O DNA genômico da cultura bacteriana isolada foi extraído utilizando o Kit Purilink ${ }^{\mathrm{TM}}$ Microbiome DNA Purification (Invitrogen). A concentração e pureza do DNA foram determinados em espectrofotômetro NanoDrop 1000 (ThermoFisher Scientific, EUA) e electroforese em gel de agarose $0,8 \%$. O DNA extraído foi utilizado como molde na PCR para amplificação do gene RNAr 16S. Na PCR foi utilizado os iniciadores 27F-1492R e GoTaq ${ }^{\circledR}$ Master Mixes (Promega) de acordo com as instruções do fabricante. O produto de PCR foi confirmado por electroforese em gel em agarose a 1,2\% e purificado utilizando kit de purificação Illustra GFX PCR DNA de acordo com as instruções do fabricante.

O fragmento do DNA do gene RNAr 16S foi sequenciado usando o método de Sanger utilizando o ABI 3130 DNA Analyser, sistema de análise de DNA de 16 capilares da Life Technologies - Applied Biosystems. As reações de sequenciamento foram feitas utilizando o BigDye® Terminator v3.1 Cycle Sequencing Kit. As corridas foram feitas em capilares de 50 $\mathrm{cm}$ utilizando o polímero POP7. As sequências foram analisadas via software Sequencing Analysis 5.3.1. 


\section{Universidade de São Paulo}

Escola de Engenharia de São Carlos

Programa de Pós-graduação em Hidráulica e Saneamento

Tabela 4.8. Métodos analíticos e frequência de análises empregado como monitoramento para avaliação dos reatores em batelada.

\begin{tabular}{|c|c|c|c|c|}
\hline Parâmetro & Frequência de análise & Delineamento & Método & Referência \\
\hline $\mathrm{pH}$ & Inicial e final & PB e DCCR & Potenciometria & APHA/AWWA/WEF (2005) \\
\hline DQOs & Inicial e final & PB e DCCR & Digestão/Espectrofotometria & APHA/AWWA/WEF (2005) \\
\hline SSV & Inicial e final & PB e DCCR & Gravimetria/calcinação & APHA/AWWA/WEF (2005) \\
\hline $\mathrm{CT}$ & Inicial e final & PB e DCCR & Espectrofotometria & Dubois et al. (1956) \\
\hline Fenóis & Inicial e final & DCCR & Espectrofotometria & Buchanan E Nicell (1997) \\
\hline Açúcares & Inicial e final & DCCR & Cromatografia líquida & Adorno et al. (2014) \\
\hline Ácidos carboxílicos & Inicial, intermediário e final & PB e DCCR & Cromatografia gasosa & Adorno et al. (2014) \\
\hline Etanol & Inicial, intermediário e final & PB e DCCR & Cromatografia gasosa & Adorno et al. (2014) \\
\hline $\begin{array}{l}\text { NTK, P, Ca, Mg, Na, K, } \\
\quad \mathrm{Fe}, \mathrm{Zn}, \mathrm{Ni}, \mathrm{Mn}, \mathrm{Cu}\end{array}$ & Inicial & - & - & APHA/AWWA/WEF (2005) \\
\hline Composição do biogás & periódicamente & PB e DCCR & Cromatografia gasosa & Perna et al. (2013) \\
\hline
\end{tabular}

$\mathrm{Mg}=$ magnésio, $\mathrm{Na}=$ sódio, $\mathrm{K}=$ potássio, $\mathrm{Fe}=$ ferro, $\mathrm{Zn}=$ zinco, $\mathrm{Ni}=$ níquel, $\mathrm{Mn}=$ manganês, $\mathrm{Cu}=$ cobre 
Universidade de São Paulo

Escola de Engenharia de São Carlos

Programa de Pós-graduação em Hidráulica e Saneamento

Tabela 4.9. Equacionamentos empregados no cálculo das variáveis respostas utilizadas para avaliação dos ensaios em reatores em batelada.

\begin{tabular}{|c|c|c|c|}
\hline Variável resposta & Unidade & Equacionamento & Parâmetro do cálculo \\
\hline $\begin{array}{c}{ }^{\text {a }} \text { Produção máxima de } \mathrm{H}_{2} \\
(P) \\
{ }^{\mathrm{a}} \text { Velocidade de produção } \\
(R m) \\
{ }^{\mathrm{a}} \text { Fase } L a g \\
(\lambda)\end{array}$ & $\begin{array}{c}\mathrm{mL} \\
\mathrm{mL} \mathrm{H}_{2} \cdot \mathrm{h}^{-1} \\
\text { Horas }\end{array}$ & $P_{a c}=P \times \exp \left\{-\exp \left[\frac{R m \times e}{P}(\lambda-\mathrm{t})+1\right]\right\}$ & $\begin{array}{c}P: \text { produção máxima de } \mathrm{H}_{2}(\mathrm{~mL}) \\
R m: \text { velocidade máxima de } \mathrm{H}_{2}\left(\mathrm{~mL} \mathrm{H}_{2} \cdot \mathrm{h}^{-1}\right) \\
\text { e: }=2,718281828 \\
\lambda \text { : tempo de início da fermentação }(\mathrm{h})\end{array}$ \\
\hline $\begin{array}{l}\text { Conversão carboidratos totais } \\
\qquad\left(\mathrm{C}_{\mathrm{CT}}\right)\end{array}$ & $\%$ & $C_{C T}=\left(\frac{C T_{i}-C T_{f}}{C T_{i}}\right) \times 100$ & $\begin{array}{l}\mathrm{CT}_{\mathrm{i}} \text { : concentração de carboidratos totais inicial }\left(\mathrm{g} \cdot \mathrm{L}^{-1}\right) \\
\mathrm{CT}_{\mathrm{f}} \text { : concentração de carboidratos totais final }\left(\mathrm{g} \cdot \mathrm{L}^{-1}\right)\end{array}$ \\
\hline $\begin{array}{l}\text { Rendimento de } \mathrm{H}_{2} \\
\text { (YH) }\end{array}$ & $\mathrm{mLH}_{2} \mathrm{gCT}_{\mathrm{add}}$ & $H Y=\frac{V H}{C T_{\text {add }} \cdot V R}$ & $\begin{array}{c}\text { VH: volume de } \mathrm{H}_{2}(\mathrm{~mL}) \\
\text { VR: volume reacional }(\mathrm{L}) \\
\mathrm{CT}_{\text {add: }} \text { concentração de carboidratos totais adicionados }\left(\mathrm{g} \cdot \mathrm{L}^{-1}\right)\end{array}$ \\
\hline $\begin{array}{l}\text { Grau de acidificação } \\
\text { (GA) }\end{array}$ & $\%$ & $G A=\left({ }^{C f} / C i\right) \times 100$ & $\begin{array}{l}\mathrm{C}_{\mathrm{i}} \text { : concentração inicial de substrato (DQO mg. } \mathrm{L}^{-1} \text { ) } \\
\mathrm{C}_{\mathrm{f}} \text { : concentração líquida de AC (final-inicial mg. } \mathrm{L}^{-1} \text { ) }\end{array}$ \\
\hline
\end{tabular}

Tempo de geração

$(\mathrm{Tg})$

$\mathrm{H}$

$\operatorname{Tg}=\frac{L n 2}{\mu}$

$\mu=$ velocidade de crescimento

Notas: Os valores apresentados referentes à produção de biogás correspondem às condições normais de temperatura e pressão $(\mathrm{CNTPs})$, i.e., 1 atm e $0^{\circ} \mathrm{C}(273,15 \mathrm{~K})$; ${ }^{2} \mathrm{Da}$ dos ajustados à equação de modelagem do crescimento microbiano de Gompertz. 


\author{
Universidade de São Paulo \\ Escola de Engenharia de São Carlos \\ Programa de Pós-graduação em Hidráulica e Saneamento
}

A sequências dos nucleotídeos obtidas foram processadas por meio do programa SeqMan do software DNASTAR (Lasergene sequence analysis). As sequências do RNAr 16S foram comparadas com a Banco de Dados Genbank (http://www.ncbi.nlm.nih.gov) and Ribosomal Data Base Project (http://rdp.cme.smu.edu) para aproximação da identidade filogenética. A similaridade e cobertura em nível do gênero com a sequência do isolado foi de 100\%. O dendograma de distância genética foi construida por meio do método NeighborJoining usando programa MEGA versão 7, com análise de bootstrap de 1000 repetições (Kumar et al., 2016), and Staphylococcus saprophyticus (LM643736.1) foi utilizado como Outgroup. A sequência do gene 16S rDNA foi depositada em Genbank sob o número de acesso MH779470, com o banco genético público no https://www.ncbi.nlm.nih.gov/nuccore/MH779470.

\title{
4.9.2. Amostragem, extração de DNA e DGGE do consórcio de bactérias
}

Oito amostras foram selecionadas para avaliação da diversidade bacteriana, incluindo inóculo, três amostras referente ao planejamento experimental de Plakett-Burman (PB) e quatro amostras a partir do delineamento composto central rotacional (DCCR) (Tabela 4.10).

Tabela 4. 10. Amostras selecionadas para avaliação da diversidade bacteriana

\begin{tabular}{ccc}
\hline & Amostras totais & Delineamento experimental \\
\hline 1 & Inóculo & Fermentação natural + enriquecimento da biomassa \\
2 & Menor produção de HPr & PB12 \\
3 & Maior produção de $\mathrm{H}_{2}$ & $\mathrm{~PB} 12$ \\
4 & Maior produção de EtOH & PB12 \\
5 & Maior produção de $\mathrm{H}_{2}$ & DCCR \\
6 & Menor produção de $\mathrm{H}_{2}$ & DCCR \\
7 & Maior produção de HLa & DCCR \\
8 & Validação experimental & DCCR - Otimização \\
\hline
\end{tabular}

A preparação das amostras consistiu na separação das células suspensas por meio de centrifugação $\left(10 \mathrm{~min}, 6.000 \mathrm{rpm}, 5^{\circ} \mathrm{C}\right)$ de modo a se obter amostras de no mínimo $1 \mathrm{~g}$ de biomassa. Em seguida as amostras foram lavadas com solução tampão PBSX1 (NaCl 8,2 g L' 1, $\left.\mathrm{Na}_{2} \mathrm{HPO}_{4} 1,05 \mathrm{~g} \mathrm{~L}^{-1}, \mathrm{NaH}_{2} \mathrm{PO}_{4}+\mathrm{H}_{2} \mathrm{O} 0,35 \mathrm{~g} \mathrm{~L}^{-1}\right)$ e centrifugadas novamente. Os pellets (biomassa úmida) foram armazenados a $-20^{\circ} \mathrm{C}$. Todas as amostras foram obtidas a partir da mistura dos reatores em triplicatas. 
O DNA metagenômico de cada amostra foi extraído utilizando-se o Kit fastDNA ${ }^{\circledR}$ SPIN para solos (MP Biomedicals, Irvine, CA, USA), baseando-se nas instruções do fabricante. A integridade do fragmento do DNA genômico foi verificada em eletroforese em gel de agarose de $0,8 \%$, a quantificação foi realizada no equipamento Nanodrop e a relação 260/280 para confirmar a pureza de DNA $(1,80-2,00)$.

Na etapa da PCR (reação em cadeia da polimerase), utilizou-se o conjunto de iniciadores 968FGC-1401R, referentes ao Domínio Bacteria (Nubel et al. 1996). O programa de corrida do termociclador (Eppendorf AG - 22331 Hamburg) foi de pré desnaturação de $95^{\circ} \mathrm{C}$ por 7 minutos; 35 ciclos de desnaturação a $95^{\circ} \mathrm{C}$ por 45 segundos; anelamento a $56^{\circ} \mathrm{C}$ por 45 segundos; extensão a $72^{\circ} \mathrm{C}$ por 60 segundos; extensão final a $72{ }^{\circ} \mathrm{C}$ por 10 minutos; resfriamento a $4^{\circ} \mathrm{C}$. Os amplicons foram verificados em eletroforese em gel de agarose de 1,2\% e em seguida separados por eletroforese em gel de poliacrilamida contendo gradiente desnaturante de 4565\% (Muyzer et al., 1993).

O DGGE (eletroforese em gel de gradiente desnaturante), foi realizado no DCode ${ }^{\mathrm{TM}}$ Universal Mutation Detection System (Bio-Rad). As condições de corrida do DGGE foi de 75V e temperatura de $60^{\circ} \mathrm{C}$ por 16 horas. A leitura do perfil padrão das bandas do DGGE foi realizado no Sistema de Fotodocumentação (L.PixTouch - Loccus Biotechnology) sob a exposição de $254 \mathrm{~nm}$ UV. A partir do perfil de bandas do DGGE foi utilizado o programa BioNumerics versão 7.0 para o cálculo do coeficiente de similaridade. O cálculo dos índices de diversidade de Shannon-Winner e Chao foram estimados no programa Phyloseq.

\subsubsection{Metagenômica}

Para realização da análise de metagenômica foram selecionadas apenas quatro amostras, incluindo inóculo, maior produção de $\mathrm{H}_{2}$ (PB12), maior produção de ácido lático (DCCR) e validação experimental (DCCR). O sequenciamento das amostras foi realizado pelo Laboratório de Biotecnologia animal, do Departamento de Zootecnia (LZT) - USP Piracicaba/Escola Superior de Agricultura "Luiz de Queiroz" (Esalq). A análise das sequências foi realizada pelo Centro Pluridisciplinar de Pesquisas Químicas, Biológicas e Agrícolas (CPQBA)/UNICAMP.

Os metagenômas de cada amostra foram utilizados para o sequenciamento utilizando o equipamento de genotipagem Illumina (HiScanSQ). As sequências obtidas foram analisadas no programa fastqc (https://www.bioinformatics.babraham.ac.uk/projects/fastqc/), sendo 


\author{
Universidade de São Paulo \\ Escola de Engenharia de São Carlos \\ Programa de Pós-graduação em Hidráulica e Saneamento
}

realizada a avaliação da qualidade do sequenciamento e possíveis filtragens para melhorar a qualidade.

Conforme a necessidade, as sequências foram filtradas usando a ferramenta Trimmomatic (Bolger, Lohse e Usadel, 2014), para retirada de adaptadores e sequências de baixa qualidade (phred score $\leq 20$ ). Em seguida, foi feita a montagem dos contigs e scaffolds pela ferramenta metaSPAdes (Bankevich et al., 2012, Nurk et al., 2013) utilizando os k-mers $21,31,41,51,61,71,81,91,101$. A qualidade da montagem foi avaliada via programa metaQUAST (Mikheenko et al., 2016). Contigs foram filtrados para tamanho mínimo de 150 pb. Os contigs foram escolhidos para as análises subsequentes, onde foram feitas a anotação funcional e taxonômica, pelo pipeline da ferramenta FMAP (Functional Mapping and Analysis Pipeline for metagenomics and metatranscriptomics studies, Kim et al., 2016). Para tanto, foi utilizado um cutoff de identidade de $80 \%$, e-value $<1$ e -3, e cobertura do gene $>80 \%$.

O pipeline FMAP utiliza as ferramentas BWA e samtools para o mapeamento de reads nos contigs; a ferramenta diamond para predizer ORFs e para alinhamento dos contigs contra proteínas do banco de dados Uniref 90 (Suzek et al. 2014) filtrados pelo número de ortologias do Kegg (Kyoto Encyclopedia of Genes and Genomes; Kanehisa e Goto, 2000; Kanehisa et al. 2016; Kanehisa et al. 2017); e análise taxonômica pela ferramenta Centrifuge (Kim et. al., 2016).

\title{
4.10. Balanço de massa
}

O balanço de massa em termos de DQO foi determinado utilizando-se os dados de monitoramento dos reatores referente à distribuição de compostos solúveis a partir da acidificação do resíduo de banana durante o processo de fermentação, denominado como balanço de massa da fase solúvel (BMS). A determinação de BMS foi realizado utilizando-se a equação (3).

$B M S=\left(\frac{D Q O_{\text {metabólitos }}+D Q O \text { carboidratos }+D Q O_{\text {fenóis }}}{D Q O S}\right) 100$

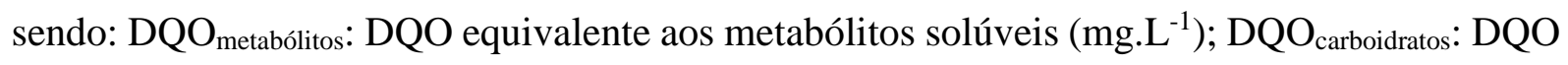
equivalente aos carboidratos totais $\left(\mathrm{mg}^{\mathrm{L}} \mathrm{L}^{-1}\right)$; DQOs: DQO solúvel; DQO fenóis : DQO equivalente aos fenóis $\left(\mathrm{mg} \cdot \mathrm{L}^{-1}\right)$. 
Universidade de São Paulo

Escola de Engenharia de São Carlos

Programa de Pós-graduação em Hidráulica e Saneamento

Na Tabela 4.11 estão apresentados os fatores de equivalência utilizados nos cálculos, considerando a oxidação completa dos compostos determinados analiticamente, como os ácidos orgânicos (ácido acético, butírico e propiônico), etanol, fenóis e carboidratos totais (utilizandose a equivalência com glicose).

Tabela 4.11. Fatores de equivalência utilizados nos cálculos do balanço de massa

\begin{tabular}{ccc}
\hline Metabólito solúvel & Reação de oxidação & Fator de equivalência \\
\hline Ácido lático & $\mathrm{C}_{3} \mathrm{H}_{6} \mathrm{O}_{3}+3 \mathrm{O}_{2} \rightarrow 3 \mathrm{CO}_{2}+3 \mathrm{H}_{2} \mathrm{O}$ & $1,07 \mathrm{gDQO} \mathrm{g} \mathrm{H}_{\mathrm{La}}$ \\
Ácido fórmico & $\mathrm{CH}_{2} \mathrm{O}_{2}+0.5 \mathrm{O}_{2} \rightarrow \mathrm{CO}_{2}+\mathrm{H}_{2} \mathrm{O}$ & $0,35 \mathrm{gDQO} \mathrm{g} \mathrm{H}_{\mathrm{Fo}}$ \\
Ácido acético & $\mathrm{C}_{2} \mathrm{H}_{4} \mathrm{O}_{2}+2 \mathrm{O}_{2} \rightarrow 2 \mathrm{CO}_{2}+2 \mathrm{H}_{2} \mathrm{O}$ & $1,07 \mathrm{gDQO} \mathrm{g} \mathrm{H}_{\mathrm{Ac}}$ \\
Ácido propiônico & $\mathrm{C}_{4} \mathrm{H}_{6} \mathrm{O}_{5}+3 \mathrm{O}_{2} \rightarrow 4 \mathrm{CO}_{2}+3 \mathrm{H}_{2} \mathrm{O}$ & $1,51 \mathrm{gDQO} \mathrm{g} \mathrm{H}_{\mathrm{Pr}}$ \\
Ácido butírico & $\mathrm{C}_{4} \mathrm{H}_{8} \mathrm{O}_{2}+5 \mathrm{O}_{2} \rightarrow 4 \mathrm{CO}_{2}+4 \mathrm{H}_{2} \mathrm{O}$ & $1,82 \mathrm{gDQO} \mathrm{g}^{-1} \mathrm{H}_{\mathrm{Bu}}$ \\
Ácido isobutítico & $\mathrm{C}_{4} \mathrm{H}_{8} \mathrm{O}_{2}+5 \mathrm{O}_{2} \rightarrow 4 \mathrm{CO}_{2}+4 \mathrm{H}_{2} \mathrm{O}$ & $1,82 \mathrm{gDQO} \mathrm{g}^{-1} \mathrm{H}_{\mathrm{Isb}}$ \\
Ácido isovalérico & $\mathrm{C}_{5} \mathrm{H}_{10} \mathrm{O}_{2}+6.5 \mathrm{O}_{2} \rightarrow 5 \mathrm{CO}_{2}+5 \mathrm{H}_{2} \mathrm{O}$ & $2,04 \mathrm{gDQO} \mathrm{g}^{-1} \mathrm{H}_{\mathrm{Isv}}$ \\
Ácido valérico & $\mathrm{C}_{5} \mathrm{H}_{10} \mathrm{O}_{2}+6.5 \mathrm{O}_{2} \rightarrow 5 \mathrm{CO}_{2}+5 \mathrm{H}_{2} \mathrm{O}$ & $2,04 \mathrm{gDQO} \mathrm{g}^{-1} \mathrm{H}_{\mathrm{Va}}$ \\
Ácido capróico & $\mathrm{C}_{6} \mathrm{H}_{12} \mathrm{O}_{2}+8 \mathrm{O}_{2} \rightarrow 6 \mathrm{CO}_{2}+6 \mathrm{H}_{2} \mathrm{O}$ & $2,21 \mathrm{gDQO} \mathrm{g} \mathrm{H}_{\mathrm{Ca}}$ \\
Etanol & $\mathrm{C}_{2} \mathrm{H}_{6} \mathrm{O}+3 \mathrm{O}_{2} \rightarrow 2 \mathrm{CO}_{2}+3 \mathrm{H}_{2} \mathrm{O}$ & $2,09 \mathrm{gDQO} \mathrm{g} \mathrm{E}_{\mathrm{t}} \mathrm{OH}$ \\
Fenóis & $\mathrm{C}_{6} \mathrm{H}_{6} \mathrm{O}+4 \mathrm{O}_{2} \rightarrow 3 \mathrm{CO}_{2}+3 \mathrm{H}_{2} \mathrm{O}$ & $1,36 \mathrm{gDQO} \mathrm{g} \mathrm{fenol}^{-1}$ \\
Carboidratos totais & $\mathrm{C}_{6} \mathrm{H}_{12} \mathrm{O}_{6}+6 \mathrm{O}_{2} \rightarrow 6 \mathrm{CO}_{2}+6 \mathrm{H}_{2} \mathrm{O}$ & $1,07 \mathrm{gDQO} \mathrm{g} \mathrm{CT}^{-1}$ \\
\hline
\end{tabular}




\author{
Universidade de São Paulo \\ Escola de Engenharia de São Carlos \\ Programa de Pós-graduação em Hidráulica e Saneamento
}

\title{
5. RESULTADOS E DISCUSSÃO
}

Neste capítulo serão apresentados os resultados de acordo com as hipóteses previamente formuladas. Primeiramente, é discutido as características do resíduo de banana (Objetivo 1) que foi utilizado como substrato para realização dos ensaios, buscando elencar seus componentes e relacionando-os com seu papel na fermentação para crescimento da biomassa e produção de $\mathrm{H}_{2}$ (Objetivo 2). Fez-se discussão sobre o processo de obtenção da biomassa, através da fermentação natural, e o método de avaliação do meio de cultivo (Objetivo 3).

Ainda neste contexto, foi discutido o processo de enriquecimento da biomassa para obtenção do inóculo com grande potencial na produção de $\mathrm{H}_{2}$. $\mathrm{O}$ uso da ferramenta de planejamento experimental e otimização de processos através de modelagem são discutidas ressaltando sua importância para avaliações prévias do processo seguida da validação das condições otimizadas (Objetivo 4). A dinâmica taxonômica e funcional da biomassa fermentativa foi comparada de acordo com as condições operacionais pré-estabelecidas no processo fermentativo (Objetivo 5). Por último, isolamento e caracterização da cepa é discutida realizando comparação entre sua produção de $\mathrm{H}_{2}$ com a do consórcio de bactérias (Objetivo 6).

\subsection{Caracterização do resíduo de banana in natura}

Os carboidratos são as principais fontes de carbono orgânico para produção anaeróbia de $\mathrm{H}_{2}$, e basicamente todas as frutas possuem carboidratos em sua composição, principalmente quando passam do estado maduro. Neste enquadramento, optou-se por utilizar os resíduos de bananas (RB) como fonte de carbono em processos fermentativos, pois além de carboidratos, o RB é rico em nutrientes e compostos orgânicos que podem auxiliar no crescimento das bactérias fermentativas (Tabela 5.1).

Verificou-se que o substrato contém concentrações elevadas de matéria orgânica na forma de sólidos suspensos totais (SST) e material solúvel (DQO) o que possibilita sua conversão em metabólitos de interesse como gás $\mathrm{H}_{2}$ e ácidos orgânicos. Observou-se 56 g.L -1 $^{-1}$ de DQO solúvel e 108 g.L.-1 de SST. Menezes et al. (2015) também caracterizaram o resíduo de banana e observaram valores semelhantes de DQO $\left(67\right.$ g.L $\left.\mathrm{L}^{-1}\right)$ e SST $\left(122,8\right.$ g.L $\left.\mathrm{L}^{-1}\right)$ ao do presente estudo. De acordo com Guo et al. (2014), altas concentrações de matéria orgânica no substrato podem resultar em maior concentração de biomassa, diminuição da fase lag de crescimento microbiano e, por fim influenciar positivamente nas etapas da fermentação. 
Universidade de São Paulo

Escola de Engenharia de São Carlos

Programa de Pós-graduação em Hidráulica e Saneamento

Tabela 5.1. Caracterização físico-química e nutricional do resíduo de banana utilizado como substrato para alimentação dos reatores em batelada.

\begin{tabular}{|c|c|}
\hline \multicolumn{2}{|c|}{ Componentes } \\
\hline $\mathrm{pH}^{*}$ & 4,4 \\
\hline DQO solúvel & 56,0 g. $\mathrm{L}^{-1}$ \\
\hline Fenóis & 0,2 g. $\mathrm{L}^{-1}$ \\
\hline SST & 108,0 g.L $\mathrm{L}^{-1}$ \\
\hline SSV & 24,0 g. $\mathrm{L}^{-1}$ \\
\hline \multicolumn{2}{|l|}{ Carboidratos } \\
\hline Carboidratos totais solúveis & 31 g. $\mathrm{L}^{-1}$ \\
\hline Frutose & 19 g. $\mathrm{L}^{-1}$ \\
\hline Glicose & 18 g. $\mathrm{L}^{-1}$ \\
\hline Sacarose & 3 g. $\mathrm{L}^{-1}$ \\
\hline \multicolumn{2}{|l|}{ Ácidos Orgânicos } \\
\hline Ácido cítrico & 0,14 g. $\mathrm{L}^{-1}$ \\
\hline Ácido málico & 0,21 g. $\mathrm{L}^{-1}$ \\
\hline Ácido succinico & 0,20 g. $\mathrm{L}^{-1}$ \\
\hline Ácido lático & 0,60 g. $\mathrm{L}^{-1}$ \\
\hline Ácido acético & 1,0 g. $\mathrm{L}^{-1}$ \\
\hline Ácido propiônico & 0,04 g..$L^{-1}$ \\
\hline Ácido isobutírico & 0,09 g. $\mathrm{L}^{-1}$ \\
\hline \multicolumn{2}{|l|}{ Nutrientes } \\
\hline NTK & 0,51 g. $\mathrm{L}^{-1}$ \\
\hline $\mathrm{P}$ & 0,04 g. $\mathrm{L}^{-1}$ \\
\hline $\mathrm{Ca}$ & 0,08 g. $\mathrm{L}^{-1}$ \\
\hline $\mathrm{Mg}$ & 0,08 g. $\mathrm{L}^{-1}$ \\
\hline $\mathrm{Na}$ & 0,003 g.L $\mathrm{L}^{-1}$ \\
\hline $\mathrm{K}$ & $1,8 \mathrm{~g} \cdot \mathrm{L}^{-1}$ \\
\hline $\mathrm{Fe}$ & 0,001 g..$L^{-1}$ \\
\hline $\mathrm{Zn}$ & $0,01 \mathrm{~g} \cdot \mathrm{L}^{-1}$ \\
\hline $\mathrm{Ni}$ & ND \\
\hline Mn & 0,002 g. $\mathrm{L}^{-1}$ \\
\hline $\mathrm{Cu}$ & $<0,01$ g. $\mathrm{L}^{-1}$ \\
\hline
\end{tabular}

*adimensional, SST $=$ Sólidos Suspensos Totais, SSV = Sólidos Suspensos Voláteis, NTK= Nitrogênio Total Kjeldahl, $\mathrm{P}=$ Fósforo, $\mathrm{Ca}=$ Cálcio, $\mathrm{Mg}=$ Magnésio, $\mathrm{Na}=$ Sódio, $\mathrm{K}=$ Potássio, $\mathrm{Fe}=$ Ferro, $\mathrm{Zn}=\mathrm{Zinco}, \mathrm{Ni}=$ Níquel, $\mathrm{Mn}=$ Manganês, $\mathrm{Cu}=$ Cobre, $\mathrm{ND}=$ Não Detectável.

Grande parte dos carboidratos estão na forma solúvel (31 g.L $\left.\mathrm{L}^{-1}\right)$, sendo a glicose, frutose e sacarose, os principais constituintes do resíduo de banana, respectivamente em 18, 19 e 3 g.L 


\section{Universidade de São Paulo \\ Escola de Engenharia de São Carlos \\ Programa de Pós-graduação em Hidráulica e Saneamento}

${ }^{1}$ (Tabela 5.1). Glicose e frutose também foram observados por Torquato et al. (2016) como sendo os principais carboidratos em resíduos frutícolas. Tais açúcares como principais carboidratos de frutas é devido a degradação do amido durante a maturação do fruto, liberando glicose e frutose, que poderá ser utilizado para o metabolismo microbiano (Doerflinger et al., 2015), tornando o processo de hidrólise fator determinante para disponibilização de açúcares solúveis. De acordo com Jesus et al. (2004) e Chitarra e Chitarra (2005) o tipo e a quantidade dos açúcares solúveis se alteram de acordo com as variedades, estádios de maturação e condições de cultivo das bananeiras.

$\mathrm{O}$ pH ácido no valor de 4,42 mensurado no resíduo pode ser justificado pela presença de ácidos orgânicos provindos da degradação do próprio substrato via fermentação natural. Valor de pH ácido, 3,81, também foi relatado por Menezes et al. (2015) na caracterização do resíduo de banana. Os ácidos orgânicos, tais como acético, propiônico, butírico e lático, promovem aumento de íons $\mathrm{H}^{+}$na solução, tais condições ácidas podem acarretar no aumento da taxa de degradação do amido e compostos lignocelulósicos do resíduo de banana e, consequentemente, aumentar ainda mais a concentração dos ácidos orgânicos e compostos inibitórios (Infantes et al., 2011).

Entre os ácidos orgânicos observados verificou-se maior concentração de ácido acético ( 1 g.L $\left.\mathrm{L}^{-1}\right)$. O ácido acético é o principal composto observado em hidrolisados e sua concentração depende do tipo de resíduo, e pode acumular-se no meio em níveis elevados sem causar qualquer alteração no processo, mas também pode ser altamente tóxico para alguns tipos de micro-organismos (Wang et al., 2008). Concentrações em excesso de ácido acético podem promover inibição do processo fermentativo devido a sua capacidade de difundir-se através da membrana, reduzindo o $\mathrm{pH}$ intracelular, provocando efeito tóxico no metabolismo e inibindo o crescimento microbiano (Rodriguez-Chong et al., 2004). Siqueira e Reginatto (2015) relataram redução da produção de $\mathrm{H}_{2}$ em concentrações iniciais de 0,5 a 5 g. $\mathrm{L}^{-1}$ de ácido acético utilizando 40 g. $L^{-1}$ de glicose como fonte de carbono. A adição de ácido acético no meio de 0,5, 1 e 5 g.L ${ }^{1}$ reduziu o rendimento de $\mathrm{H}_{2}$ de 1,38 mol/mol glicose (controle) para 1,13, 0,78 e 0,37 mol. $\mathrm{mol}^{-}$ ${ }^{1}$ glicose, respectivamente.

Ácido láctico inicial de 0,6 g.L $\mathrm{L}^{-1}$ foi observado no substrato (in natura) e relacionado principalmente com ação das bactérias láticas autóctones do resíduo de banana. Tais bactérias estão comumente presentes em ambientes ricos em carboidratos, como resíduos de frutas, e competem pelo substrato com outras bactérias, como as produtoras de hidrogênio (Sikora et al., 2013). 
Além dos ácidos orgânicos, observou-se fenóis $\left(0,2 \mathrm{~g} . \mathrm{L}^{-1}\right)$ no substrato in natura. Frutas, além de fornecerem componentes importantes para as funções básicas do organismo, são fontes de compostos antioxidantes, como os fenóis. Estes compostos têm sido relatados por afetarem membranas citoplasmáticas de bactérias resultando na redução da taxa de crescimento microbiano e mudanças de rotas metabólicas nos processos fermentativos, reduzindo e/ou inibindo a produção de $\mathrm{H}_{2}$ em concentrações a partir de 600 mg.L $\mathrm{L}^{-1}$ (Kumar et al., 2015; Siqueira e Reginatto, 2015; Madigou et al., 2016). Porém, nem sempre os fenóis são considerados vilões do processo fermentativo, e sua produção via fermentação é interessante devido as aplicações biotecnológicas que os fenóis representam, como antissépticos e germicidas.

Os macros e micronutrientes são elementos essenciais que auxiliam no metabolismo e crescimento bacteriano e no funcionamento e ativação de enzimas e co-enzimas, portanto, a presença destes em substratos utilizados para processos fermentativos torna-se crucial (Sinha e Pandey, 2011). Na caracterização do resíduo da banana verificou-se concentrações expressivas de nitrogênio total Kjeldahl (NTK) $\left(0,51\right.$ g. $\left.\mathrm{L}^{-1}\right)$ e potássio $(\mathrm{K})\left(1,87 \mathrm{mg} . \mathrm{L}^{-1}\right)$.

A exposição de resíduos orgânicos com altas concentrações de nitrogênio em aterros sanitários, como os resíduos de banana, pode provocar efeitos negativos ao ambiente, como saturação e perda da biodiversidade microbiana do solo. Verzeaux et al. (2016) relataram diminuição da biodiversidade bacteriana e redução das concentrações de $\mathrm{C}$ e $\mathrm{N}$, após suplementação nitrogenada no solo. Bactérias pertencentes ao filo Proteobacteria, Bacterioidetes e Verrucomicrobia foram altamente correlacionadas em solos sem fertilização nitrogenada, enquanto aquelas relacionadas a Acidobacteria e Cyanobacteria foram associados às altas concentrações de C e N. Além disso, altas concentrações de nitrogênio em corpos d'água provocam eutrofização e consequentemente perda da biodiversidade aquática.

De acordo com a RESOLUÇÃO No 357, DE 17 DE MARÇO DE 2005, que dispõe sobre a classificação dos corpos de água e diretrizes ambientais para o seu enquadramento, para classe 3 das águas, o limite máximo de nitrogênio amoniacal é de 13,3 mg.L $\mathrm{L}^{-1}$, cerca de 38 vezes menor que a concentração obtida através da caracterização do presente substrato. Portanto, a utilização do resíduo de banana em processos fermentativos é alternativa sustentável que reduz a sobrecarga orgânica e diminui os impactos negativos ao ambiente. Apesar de promover em alta concentração impactos negativos ao ambiente, o nitrogênio é essencial para o metabolismo microbiano, pois constitui as proteínas e ácidos nucléicos, além de vitaminas e outros compostos celulares, tornando-se vantajoso sua presença no substrato em estudo para aumento da biomassa nativa. 


\section{Universidade de São Paulo \\ Escola de Engenharia de São Carlos \\ Programa de Pós-graduação em Hidráulica e Saneamento}

Os demais nutrientes, tais como $\mathrm{P}\left(0,04 \mathrm{~g} . \mathrm{L}^{-1}\right), \mathrm{Ca}\left(0,08 \mathrm{~g} \cdot \mathrm{L}^{-1}\right), \mathrm{Mg}\left(0,08 \mathrm{~g} \cdot \mathrm{L}^{-1}\right)$, Na $\left(0,003\right.$ g.L $\left.\mathrm{L}^{-1}\right), \mathrm{Fe}\left(0,001\right.$ g.L $\left.\mathrm{L}^{-1}\right), \mathrm{Zn}\left(0,01\right.$ g.L $\left.{ }^{-1}\right), \mathrm{Mn}\left(0,002\right.$ g.L $\left.\mathrm{L}^{-1}\right)$ e $\mathrm{Cu}\left(<0,001\right.$ g.L $\left.\mathrm{L}^{-1}\right)$, também foram observados no substrato. O cálcio, sódio e ferro estão associados ao crescimento celular e consequentemente, a presença destes elementos no substrato auxilia para que bactérias produtoras de $\mathrm{H}_{2}$ sejam favorecidas (Wu et al., 2012). Lee et al. (2009) relataram que a suplementação de 5,4 - 27,2 mg. $\mathrm{L}^{-1}$ de $\mathrm{Ca}^{2+}$ no meio, resultou no aumento da produção de hidrogênio no processo. No entanto, concentrações de $\mathrm{Ca}^{2+}$ acima de $100 \mathrm{mg} . \mathrm{L}^{-1}$ e de $\mathrm{Na}^{+}$acima de $270 \mathrm{mg} . \mathrm{L}^{-1}$ tem sido referenciadas como inibitórias em processos fermentativos de produção de $\mathrm{H}_{2}$ devido ao consumo de hidrogênio para formação de outros metabólitos (mudança na via metabólica) (Yuan et al., 2010; Khanna et al., 2011).

O íon magnésio $\left(\mathrm{Mg}^{2+}\right)$ constitui paredes e membranas celulares e são utilizados como ativador e cofator de muitas enzimas, deste modo, concentração mínima de $\mathrm{Mg}^{2+}$ favorece o crescimento de bactérias fermentativas. No entanto, concentrações elevadas de $\mathrm{Mg}^{2+}$ de $20-118$ mg. $\mathrm{L}^{-1}$ tem sido relatadas como sendo inibitória, devido a retro regulação, ocasionada pelo aumento da concentração de metabólitos glicolíticos (Sinha e Pandey, 2011).

A concentração mínima de ferro no substrato para produção de $\mathrm{H}_{2}$ em processos fermentativos é extremamente importante, visto que este elemento auxilia no crescimento celular, síntese de enzimas, formação de hidrogenases e na transferência de elétrons para oxidação do piruvato à acetil-CoA (Bao et al., 2013). Contudo, concentração de ferro acima do necessário, pode resultar em inibição do processo de produção de $\mathrm{H}_{2}$ devido as atividades bacterianas reduzidas. Lee et al. (2009) relataram diminuição na atividade da hidrogenase e, consequentemente, redução do rendimento de $\mathrm{H}_{2}$ quando adicionado 4,0 mg.L $\mathrm{L}^{-1}$ de Ferro. Zhao et al., (2012), também relataram para $200 \mathrm{mg} . \mathrm{L}^{-1}$ de ferro inibição da produção de hidrogênio.

$\mathrm{O} \mathrm{Ni}{ }^{2+}$ não foi detectável (ND) no substrato, mas este elemento está envolvido com a enzima Ni-Fe hidrogenase. Concentrações mínimas de $\mathrm{Ni}^{2+}$ são recomendadas para suplementação da biomassa, no entanto, concentrações acima do requerimento mínimo, cerca de 50-60 mg.L ${ }^{-1}$, podem causar efeitos inibitórios e tóxicos (Srikanth et al., 2012).

Metais como $\mathrm{Zn}^{2+}, \mathrm{Cu}^{2+}$ e $\mathrm{Mn}^{+2}$ também são relevantes para crescimento da biomassa fermentativa. Porém, sua concentração no meio deve ser mínima ao ponto de evitar inibição por saturação. Zheng e Yu (2004) também relataram concentração inibidora de $\mathrm{Zn}$ e Cu na produção de $\mathrm{H}_{2}$, com limites de 250 e $400 \mathrm{mg} . \mathrm{L}^{-1}$, respectivamente.

Há déficit na literatura em relação as informações sobre a caracterização de resíduos frutícolas, portanto, a avaliação deste resíduo contribuiu para elucidação de sua constituição e 
facilitará o emprego deste substrato em processos biológicos em larga escala para produção de energia na forma de biogás, e na produção de compostos orgânicos de valor agregado.

\subsection{Biomassa fermentativa - Sub-hipótese 1}

Para avaliar o potencial do resíduo de banana (in natura) como fonte de carbono e biomassa fermentativa foi avaliada duas amostragens de biogás nos reatores em batelada da fermentação natural, após 10 e 24 h de incubação, como parâmetro de monitoramento indireto do crescimento celular e avaliação dos produtos gasosos. Por meio dessa análise confirmou-se a presença de bactérias fermentativas produtoras de hidrogênio. Obteve 4,5 mL e $5 \mathrm{~mL}$ de produção acumulada de $\mathrm{H}_{2}$ em $10 \mathrm{~h}$ e $24 \mathrm{~h}$, respectivamente, correspondendo a concentração de 36 e $40 \mathrm{~mL} \cdot \mathrm{L}^{-1}$. Essa produção ocorreu na relação alimento/micro-organismos (A/M) de 1,24 , correspondendo a 30,0 g CT.L $\mathrm{L}^{-1} / 24,0 \mathrm{~g} \mathrm{SSV}$. $\mathrm{L}^{-1}$; os quais correspondem aos valores de carboidratos totais (CT) e sólidos suspensos voláteis (SSV) do resíduo de banana bruto (sem diluição).

Destaca-se também a obtenção de compostos de valor agregado, como os ácidos orgânicos e álcoois. O HLa (1,26 g.L $\left.{ }^{-1}\right)$, HAc $\left(0,54\right.$ g.L $\left.L^{-1}\right), \mathrm{HBu}\left(0,63\right.$ g.L $\left.{ }^{-1}\right)$ e etanol $\left(0,5\right.$ g.L $\left.\mathrm{L}^{-1}\right)$ foram os principais metabólitos solúveis resultantes da fermentação natural do substrato, indicando que a produção de hidrogênio a partir de RB seguiu principalmente estas vias metabólicas. O ácido fórmico, isobutírico, propiônico, isovalérico e valérico também foram observados, porém em concentração inferior a 0,1 g.L.-1

A fermentação natural de resíduos orgânicos tem sido uma boa alternativa para selecionar biomassa fermentativa autóctone capaz de degradar o próprio resíduo e produzir hidrogênio. De acordo com Lin et al. (2017) bactérias autóctones tem maior capacidade de adaptação ao usar sua própria biomassa vegetal, para seu crescimento e metabolismo, quando comparado à aplicação em outros tipos de substrato.

Favaro et al. (2013), Marone et al. (2014) e Lin et al. (2017) tem reportado produção de $\mathrm{H}_{2}$ por meio da aplicação de variedade de substratos utilizando-se apenas biomassa autóctone proveniente da fermentação natural (Tabela 5.2). A título de exemplificação, Favaro et al. (2013) optaram pela fermentação natural mesofílica $\left(35^{\circ} \mathrm{C}\right)$ utilizando como substrato e fonte de biomassa autóctone a fração orgânica de resíduo municipal (FORM). Os autores relataram diminuição da produção de $\mathrm{H}_{2}$ de 416 para 160 mL.L $\mathrm{L}^{-1}$ quando aumentaram o valor de $\mathrm{pH}$ inicial de 5,5 para 7,0. Os principais metabólitos solúveis obtidos pelos autores foram o $\mathrm{HAc}, \mathrm{HBu}$, HPr e HIs. Do mesmo modo, Marone et al. (2014) obtiveram produção máxima de $\mathrm{H}_{2}$ de 3.680 


\section{Universidade de São Paulo \\ Escola de Engenharia de São Carlos \\ Programa de Pós-graduação em Hidráulica e Saneamento}

e $3.960 \mathrm{~mL} \cdot \mathrm{L}^{-1}$ a partir da fermentação natural de resíduos de hortaliças e casca de batata a 28 e $37^{\circ} \mathrm{C}$, respectivamente, em pH inicial igual à 7,0. HAc, $\mathrm{HBu}, \mathrm{HLa}, \mathrm{HPr}$ e EtOH também foram os principais metabólitos sintetizados durante a fermentação deste resíduo. $\mathrm{Na}$ presente pesquisa, o baixo valor de $\mathrm{pH}(\sim 4,0)$ do resíduo de banana foi suficiente para que houvesse o crescimento de biomassa e por seguinte produção de $\mathrm{H}_{2}$, corroborando com Favaro et al. (2013) no qual obtiveram maior produção de hidrogênio em $\mathrm{pH}$ ácido $(5,5)$. A temperatura operacional utilizada pelos autores, assim como nesta pesquisa, foi a mesófila, inferindo que esta faixa pode ser favorável para crescimento de biomassa autóctone em vista que se aproxima da temperatura ambiente no qual os resíduos são expostos.

Tabela 5.2. Produção de hidrogênio e metabólitos solúveis a partir da fermentação natural de diferentes resíduos sem adição de inóculo.

\begin{tabular}{|c|c|c|c|c|c|c|}
\hline Resíduo & $\begin{array}{c}\mathbf{p H} \\
\text { inicial }\end{array}$ & $\begin{array}{c}\mathbf{T} \\
\left({ }^{\circ} \mathbf{C}\right)\end{array}$ & $\begin{array}{c}\text { Agitação } \\
\text { (rpm) }\end{array}$ & $\begin{array}{c}\mathbf{H}_{2} \\
\left(\mathbf{m L} \cdot \mathbf{L}^{-1}\right)\end{array}$ & $\begin{array}{c}\text { Metabólitos } \\
\text { solúveis }\end{array}$ & Referência \\
\hline $\mathrm{FW}^{\mathrm{a}}$ & 8,0 & $\begin{array}{l}35 \\
50\end{array}$ & 100 & $\begin{array}{c}755^{\mathrm{b}} \\
6.275^{\mathrm{b}}\end{array}$ & $\begin{array}{l}\text { HAc, HBu, } \\
\text { HLa, HFo }\end{array}$ & Kim et al. (2011) \\
\hline FORM $^{a}$ & $\begin{array}{l}5,5 \\
7,0\end{array}$ & $\begin{array}{l}35 \\
35\end{array}$ & S/A & $\begin{array}{l}416^{\mathrm{b}} \\
160^{\mathrm{b}}\end{array}$ & $\begin{array}{c}\mathrm{HAc}, \mathrm{HBu}, \\
\text { HPr, HIs }\end{array}$ & Favaro et al. (2013) \\
\hline $\mathrm{HCB}^{\mathrm{a}}$ & 7,0 & $\begin{array}{l}28 \\
37\end{array}$ & 120 & $\begin{array}{l}3.680 \\
3.960\end{array}$ & $\begin{array}{l}\text { HAc, HBu, } \\
\text { HLa, HPr, } \\
\text { EtOH }\end{array}$ & Marone et al. (2014) \\
\hline Cogumelos $^{\mathrm{a}}$ & 8,0 & 55 & 150 & 852 & $\begin{array}{c}\text { HAc, HPr, } \\
\text { HBu, HVa, } \\
\text { EtOH }\end{array}$ & Lin et al. (2017) \\
\hline Banana $^{a}$ & 4,5 & 37 & S/A & 40 & $\begin{array}{c}\text { HAc, HLa, } \\
\text { HPr, HBu, } \\
\text { HVa, HIs, } \\
\text { EtOH }\end{array}$ & Presente pesquisa \\
\hline
\end{tabular}

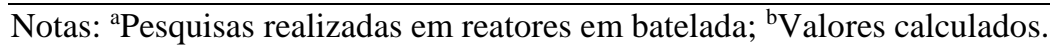

Siglas: $\mathrm{FW}=$ resíduos de alimentos, FORM = fração orgânica de resíduo municipal, $\mathrm{HCB}=$ hortaliças + casca de batata, $\mathrm{T}=$ temperatura, $\mathrm{S} / \mathrm{A}=$ sem agitação, HAc = ácido acético, HLa = ácido lático, HPr = ácido propiônico, $\mathrm{HBu}=$ ácido butírico, $\mathrm{HVa}=$ ácido valérico, $\mathrm{HIs}=$ ácido isovalérico, $\mathrm{EtOH}=$ etanol.

Kim et al. (2011) relataram aumento da produção de $\mathrm{H}_{2}$ de 755 para 6.275 mL.L ${ }^{-1}$ quando aumentaram a temperatura de 35 para $50^{\circ} \mathrm{C}$ na fermentação natural de resíduos de alimentos. Os autores obtiveram como principais metabólitos solúveis o HAc, HBu, HLa e HFo. Semelhantemente, utilizando-se resíduos de cogumelo como substrato, Lin et al. (2017) obtiveram máxima produção de $852 \mathrm{~mL} \cdot \mathrm{L}^{-1} \mathrm{H}_{2}$ à $55^{\circ} \mathrm{C}$ e $\mathrm{pH}$ inicial 8,0. Os autores também utilizaram biomassa autóctone como inóculo e relataram que o enriquecimento desta biomassa aumentou em $60 \%$ a produção de hidrogênio. O HAc, $\mathrm{HPr}, \mathrm{HBu}, \mathrm{HVa}$ e EtOH foram os 
principais metabólitos observados, sendo predominante a via do ácido acético. Nestes casos, a temperatura termofilica foi mais eficaz para produção de $\mathrm{H}_{2}$ do que a mesofílica utilizada nesta pesquisa, inferindo que dentre a biomassa fermentativa autóctone dos resíduos de alimentos e de cogumelos há microrganismos tolerantes a altas temperaturas tendo sua atividade ótima acima de $35^{\circ} \mathrm{C}$.

Como pode ser visto, a produção de $\mathrm{H}_{2}$ obtida na presente pesquisa (40 mL.L $\mathrm{L}^{-1}$ ), a partir da fermentação natural do resíduo de banana, foi inferior as reportadas para os demais resíduos (Tabela 5.2). No entanto, diferentes condições operacionais como pH, temperatura, concentração e tipo de substrato, relação A/M, agitação entre outras condições podem ter contribuído com essa diferença de produção de hidrogênio. Ademais, com exceção de Kim et al. (2011) que utilizaram somente o resíduo como substrato, os demais autores optaram por adicionar componentes nutricionais (meio de cultivo) ao substrato, afim de beneficiar a biomassa fermentativa. É importante ressaltar que, independentemente das condições impostas aos reatores, a composição dos metabólitos solúveis na fermentação natural de diferentes resíduos foi semelhante, com predominância da via do ácido acético, butírico e lático.

Outra consideração pertinente em relação à fermentação natural é o fato de que nenhuma atividade metanogênica foi reportada, tanto no presente trabalho, quanto nos demais trabalhos citados na Tabela 5.2. Portanto, esse tipo de procedimento para obtenção de biomassa fermentativa é vantajoso quando o objetivo é produzir hidrogênio, uma vez que, a presença de arqueias metanogênicas comprometeriam o processo. Ademais, a obtenção de biomassa fermentativa não metanogênica por meio da fermentação natural, pode ser favorável economicamente, considerando que a aplicação de pré-tratamentos para inibir as arqueias aumentaria o custo do processo.

Como relatado anteriormente, grande quantidade de ácidos carboxílicos foram observados na fermentação natural de resíduos orgânicos, principalmente àqueles compostos por carboidratos. Por serem facilmente biodegradáveis, os carboidratos são as principais fontes de carbono orgânico para produção anaeróbia de $\mathrm{H}_{2}$, no entanto, a rápida conversão deste tipo de substrato em ácidos carboxílicos faz como que o $\mathrm{pH}$ do meio se torne ácido rapidamente. Provavelmente, por esse motivo, o baixo valor de $\mathrm{pH}$ na fermentação viabilizou somente o crescimento e estabelecimento de bactérias hidrolíticas e acidogênicas no substrato.

Contudo, a fermentação natural de diferentes resíduos, incluindo os resíduos frutícolas como a banana, é alternativa viável e econômica para obtenção de biomassa hidrogenogênica, sem haver necessidade de adição de inóculo externo. No entanto, o enriquecimento desta 


\section{Universidade de São Paulo \\ Escola de Engenharia de São Carlos \\ Programa de Pós-graduação em Hidráulica e Saneamento}

biomassa autóctone com aditivos nutricionais pode ser alternativa crucial para obtenção de maior produção de hidrogênio.

\subsubsection{Caracterização molecular da biomassa do inóculo}

Para a biomassa do inóculo obtido a partir do enriquecimento de bactérias autóctones dos resíduos da banana foi obtido 4.521.381 sequências. Por meio da análise das curvas de rarefação (Figura 5.1) notou-se que para nível de família e gênero ambas atingiram platô, portanto, ampla cobertura amostral para essas categorias taxonômicas.

Figura 5.1. Curva de rarefação estável abrangendo o número total de famílias (A) e gêneros (B) na amostra do inóculo.
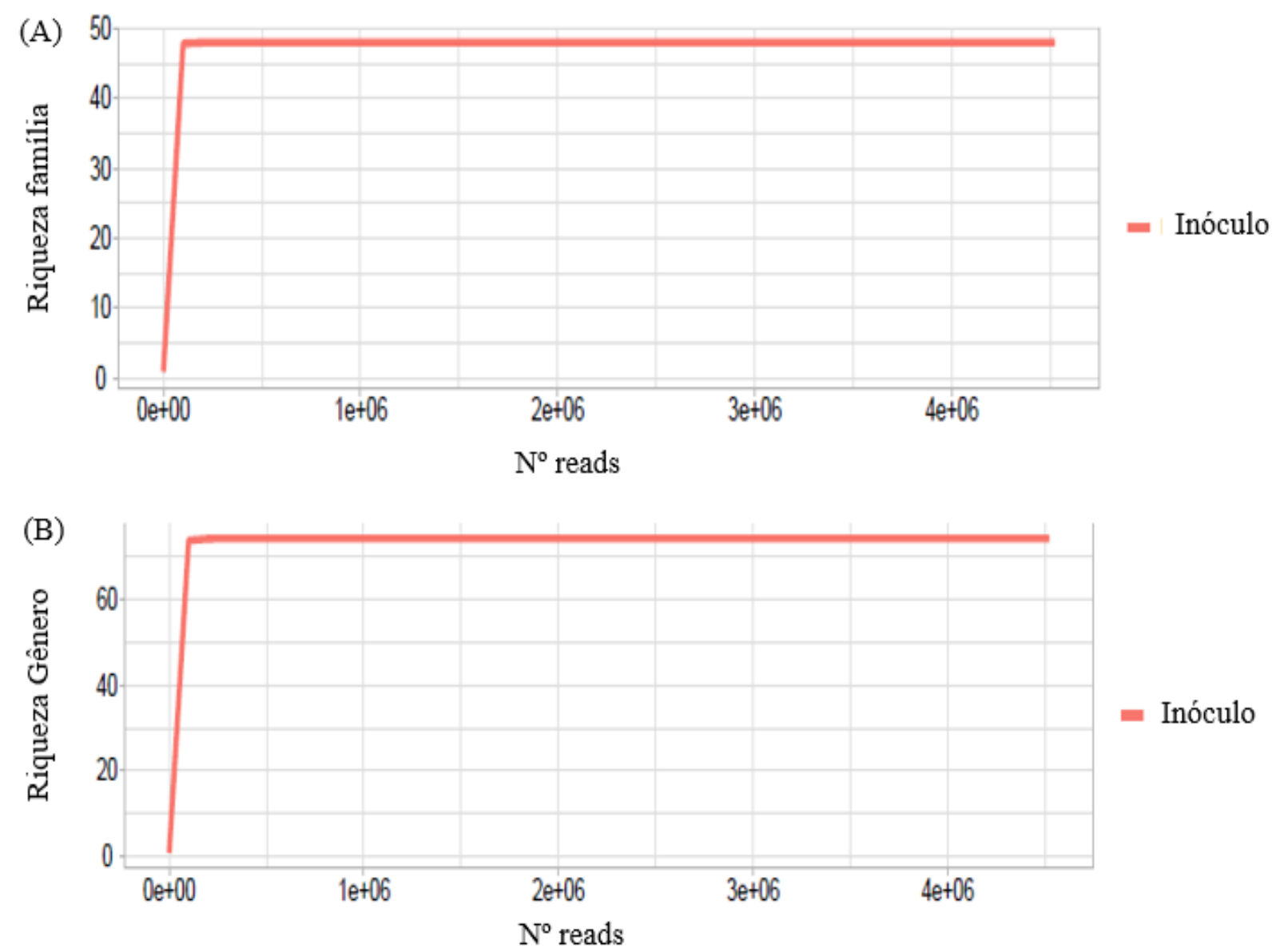

\subsubsection{Perfil Taxonômico}

Para avaliar o perfil taxonômico dos micro-organimos, procedeu-se a análise do sequenciamento metagenômico a partir do RefSeq. A diversidade microbiana fermentativa do inóculo foi totalmente constituída por representantes pertencentes ao Domínio Bacteria 
Universidade de São Paulo

Escola de Engenharia de São Carlos

Programa de Pós-graduação em Hidráulica e Saneamento

$(98,14 \%)$, sendo obtido também sequências remanescentes as quais não foram identificadas $(1,86 \%)$.

O filo dominante observado foi o Firmicutes (96,21\%), sendo que as classes predominantes foram afiliadas a Clostridia (42,13\%) e Bacilli (53,68\%) (Figura 5.2 A). Representantes do filo Firmicutes estão relacionadas com bactérias sintróficas que podem degradar vários ácidos carboxílicos (AC) (Garcia-Pena et al., 2011). Dentre as famílias mais abundantes do filo Firmicutes observou-se representantes pertencentes a Lactobacillaceae (2.382.606 sequências) e Clostridiaceae (1.563.135 sequências) de 52,70 e 34,57 \%, respectivamente. Observou-se que o gênero bacteriano mais relevante foi Clostridium $(34,44 \%)$ para a classe Clotridia e Lactobacillus $(52,61 \%)$ para a classe Bacilli (Figura 5.2 B).

Figura 5.2. Abundância relativa dos (A) grupos taxonômicos predominantes do inóculo para Classe (B) e gêneros para as duas classes mais abundantes.

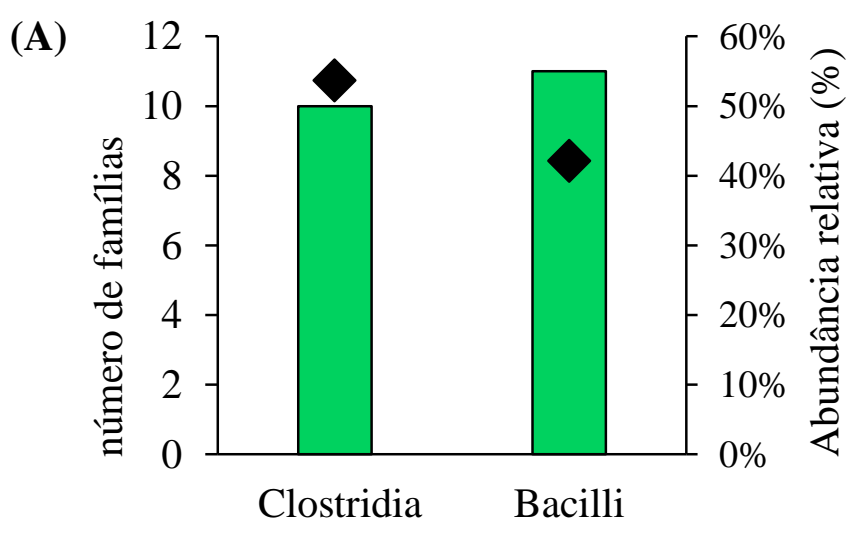

$\square$ número de famílias • Abundância relativa

(B)
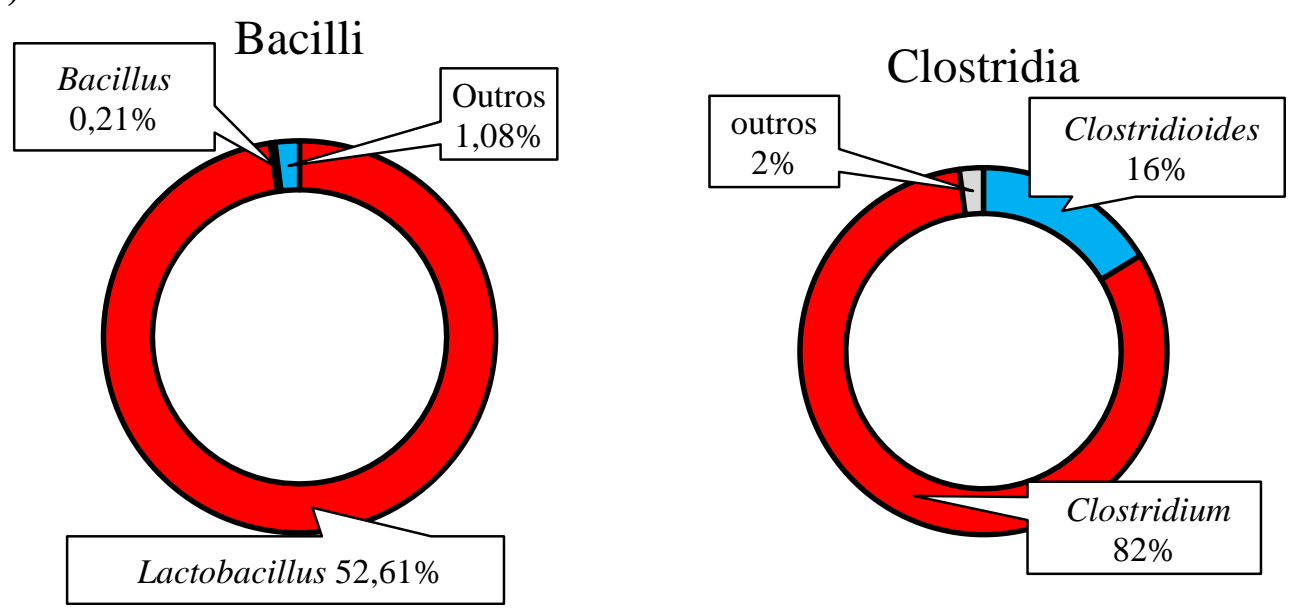


\section{Universidade de São Paulo \\ Escola de Engenharia de São Carlos \\ Programa de Pós-graduação em Hidráulica e Saneamento}

A prevalência de representantes do filo Firmicutes e principalmente semelhantes a Clostridium e Lactobacillus na fermentação de resíduos de frutas e vegetais é apoiada por estudos prévios com base no sequenciamento do gene RNAr 16S obtidos em amostras de reatores (Laothanachareon et al., 2014; Li et al., 2017; Zamorano-Lopez et al., 2018).

Bactérias semelhantes a Clostridium são celulolíticas associadas à hidrólise de substratos complexos e produção de $\mathrm{H}_{2}$ (An et al., 2018; Soares et al., 2018) e produção de ácido butírico e demais ácidos de cadeia longa (Chi et al., 2018; Park et al., 2018) e tem sido isoladas de variedade de ambientes, como lodo de reatores e aterros sanitários (Wong et al., 2018), sedimento de manguezal (Shanmugama et al., 2018), solos (Al-Shorgani et al., 2016) entre outros.

Bactérias semelhantes a Lactobacillus estão associadas à degradação proteolítica de resíduos vegetais, fermentação de vários tipos de carboidratos e até mesmo ácido acético, além da produção de ácido propiônico, ácido láctico, acetaldeído e piranoantocianinas (Ren et al., 2014, Wang et al., 2018). Geralmente, estão presentes em frutos e vegetais (Daughtry et al., 2018; Alan et al., 2018) e derivados de leite (Sunthornthummas et al., 2017).

Fuess et al. (2018) também relataram a predominância de bactérias semelhantes a Clostridium (19\%) e Lactobacillus (21,3\%) a partir da fermentação natural da vinhaça de canade-açúcar sob condições termofílicas $\left(55^{\circ} \mathrm{C}\right)$, inferindo que tais gêneros são pertencentes a comunidade autóctone de resíduos da agricultura e se sobressaem durante o processo de fermentação natural. Bactérias semelhantes a Clostridium também foram identificadas com expressiva abundância relativa (33\%), em consórcio microbiano obtido a partir da mistura de solo e resíduos de compostagem no final da fermentação de bagaço de cana-de-açúcar prétratado (Soares et al., 2018).

Nessa pesquisa, foi possível identificar espécies de Clostridium e Lactobacillus, a saber: Clostridium butyricum (28,90\%), Lactobacillus casei (27,91\%) e Lactobacillus paracasei (21,62\%) (Figura 5.3). De acordo com Yin e Wang (2017) C. butyricum utiliza várias fontes carbono incluindo glicose, xilose, sacarose, lactose, amido e glicerol para produção de hidrogênio, sendo o resíduo de banana, ótima fonte de carbono para seu metabolismo. Ademais, a condição ótima obtida pelos autores para atingir a produção e rendimento máximo de hidrogênio de $218 \mathrm{~mL}$ e 2,07 mols $\mathrm{H}_{2} / \mathrm{mol}$ hexose foi à $35^{\circ} \mathrm{C}, \mathrm{pH}$ inicial 7,0, glicose 10 g.L $\mathrm{L}^{-1} \mathrm{e}$ $10 \%$ de inóculo. Tais condições foram semelhantes às do presente trabalho, as quais favoreceram a predominância desta espécie no consórcio de bactérias. Por outro lado, L. casei é bactéria ácido lática que compete com $C$. butyricum pelo substrato, resultando em desvios de 
Universidade de São Paulo

Escola de Engenharia de São Carlos

Programa de Pós-graduação em Hidráulica e Saneamento

rotas metabólicas e baixos rendimentos de $\mathrm{H}_{2}$. Park et al. (2018) avaliaram a competitividade de L. casei e C. butyricum a partir de glicose e galactose durante a produção de hidrogênio. Os autores observaram redução da produção de $\mathrm{H}_{2}$ em menor concentração de glicose devido ao seu rápido consumo por bactérias ácido lática, quando comparada a bactéria produtora de hidrogênio. Corroborando com este resultado, Fuess et al. (2018) demonstraram que o ácido lático pode-se tornar fonte primária de carbono alternativo para biomassa em sistemas alimentados com vinhaça submetidos a condições de escassez de carboidratos.

Figura 5.3. Espécies de Clostridium (A) e Lactobacillus (B) mais abundantes identificadas no consórcio de bactérias autóctones do resíduo de banana.

(A) Clostridium carboxidivorans
Clostridium taeniosporum
Clostridium pasteurianum
Clostridium novyi
Clostridium baratii
Clostridium perfringens
Clostridium botulinum
Clostridium butyricum

(B)
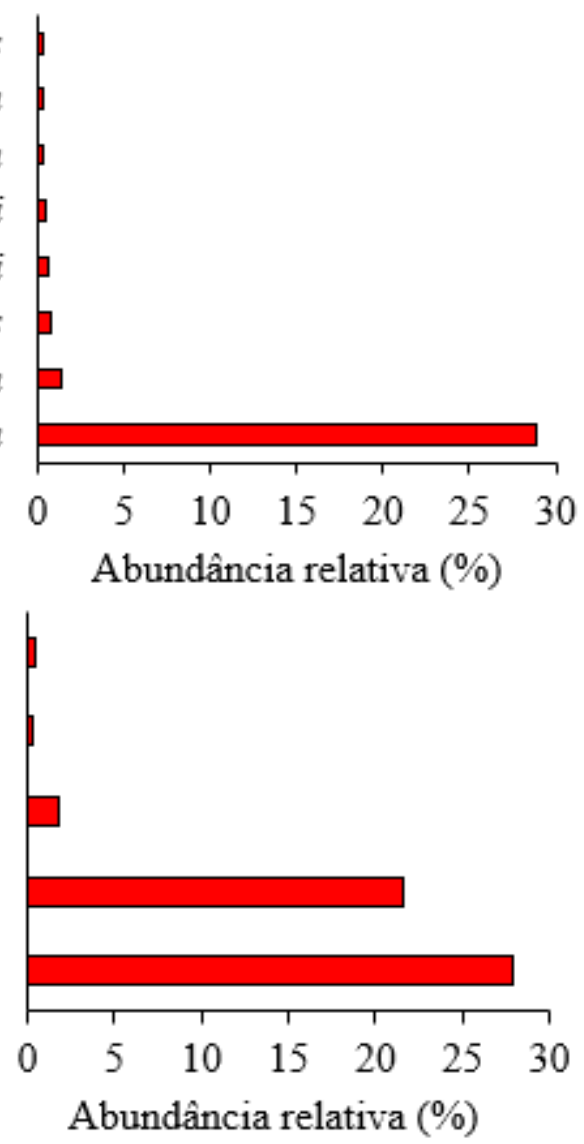

Ademais, a excreção de substâncias poliméricas extracelulares (SPE) por Lactobacillus implica em vantagens competitivas com outras bactérias (Rafrafi et al., 2013). Gudina et al. (2010) relataram a produção de bio-surfactante por uma cepa de L. paracasei isolada de indústria de laticínios. Os autores verificaram estabilidade do bio-surfactante com mudanças de pH entre 6 a 10, sendo mais efetivo em pH 7, e cuja atividade foi mantida após exposição a $60^{\circ} \mathrm{C}$ por $120 \mathrm{~h}$. Além disso, propriedades antimicrobianas e anti-adesivas para outros 


\section{Universidade de São Paulo \\ Escola de Engenharia de São Carlos \\ Programa de Pós-graduação em Hidráulica e Saneamento}

microrganismos foram observadas no bio-surfactante. Provavelmente, a predominância de Lactobacillus contribuiu para produção de ácido lático reduzindo a disponibilidade de piruvato para as vias produtoras de $\mathrm{H}_{2}$, e desta forma competindo com o Clostridium. Portanto, quando o objetivo é produzir $\mathrm{H}_{2}$ a formação de ácido lático deve ser evitada, pois consome o piruvato sem que haja formação de ferredoxina reduzida (via Clostridial) ou formação de formiato (via Enterobacterial) (Cai et al., 2011).

As demais espécies, tanto de Clostridium quanto Lactobacillus, foram identificadas, no entanto, em abundância relativa abaixo de $2 \%$ (Figura 5.3).

As bactérias semelhantes a Clostridium estão incluidas em um grupo heterogêneo decorrente da diversidade metabólica associada às diferentes espécies (Ferraz Jr. et al., 2015) e são frequentemente identificadas em reatores fermentativos de produção de $\mathrm{H}_{2}$ (Soares et al., 2018, Rabelo et al., 2018). A partir disso, pode-se pressupor que a principal via de produção de $\mathrm{H}_{2}$ nos reatores em batelada foi a Clostridial (Reações 1, 2, 3, 4 e 5), cujos açúcares solúveis são metabolizados em piruvato e ácidos orgânicos, principalmente ácido acético e butírico. Tal reação é mediada pela enzima FeFe-hidrogenase que catalisa a oxidação de ferredoxina seguida da redução de prótons a hidrogênio gasoso (Sikora et al., 2013). Ademais, Cai et al. (2011) relataram a formação de $\mathrm{H}_{2}$ por meio da redução de íons $\mathrm{H}^{+}$decorrente da oxidação simultânea do NADH e ferredoxina por hidrogenase bifurcativa.

Glicólise (Reação. 1, 2 e 3)

$$
\begin{array}{ll}
\mathrm{C}_{6} \mathrm{H}_{12} \mathrm{O}_{6}+2 \mathrm{NAD}^{+} \rightarrow 2 \text { piruvato }+2 \mathrm{NADH}+2 \mathrm{H}^{+} & \text {Reação (1) } \\
2 \mathrm{NADH}+2 \mathrm{Fd}_{\text {ox }} \rightarrow 2 \mathrm{NAD}^{+}+2 \mathrm{Fd}_{\text {red }} & \text { Reação (2) } \\
2 \mathrm{Fd}_{\text {red }}+2 \mathrm{H}^{+} \rightarrow 2 \mathrm{Fd}_{\text {ox }}+2 \mathrm{H}_{2} & \text { Reação (3) }
\end{array}
$$

$\underline{\text { Piruvato a acetil-CoA e } \mathrm{CO}_{2}}$ (via Clostridial) (Reação 4 e 5)

$$
\begin{array}{ll}
2 \text { piruvato }+2 \mathrm{CoA}+2 \mathrm{Fd}^{+} \rightarrow 2 \text { acetil }-\mathrm{CoA}+2 \mathrm{CO}_{2}+2 \mathrm{Fd}_{\text {red }}+2 \mathrm{H}^{+} & \text {Reação (4) } \\
2 \mathrm{Fd}_{\text {red }}+2 \mathrm{H}^{+} \rightarrow 2 \mathrm{Fd}_{o x}+2 \mathrm{H}_{2} & \text { Reação (5) }
\end{array}
$$

Nos reatores em batelada, apesar da via Clostridial ter sido predominante na produção de $\mathrm{H}_{2}$, a via Enterobacterial poder ter ocorrido concomitantemente, devido a identificação de representantes da família Enterobacteriaceae no consórcio de bactérias, como aquelas semelhantes a Escherichia. Além disso, observou-se abundância relativa de 0,21\% para bactérias semelhantes a Bacillus, na amostra de inóculo, as quais podem realizar ambas as vias 
de produção de hidrogênio (Sikora et al., 2013) cooperando para os rendimentos de hidrogênio obtidos nos reatores em batelada. Diferentemente da via Clostridial, a produção de $\mathrm{H}_{2}$ via Enterobacterial ocorre por meio da clivagem do ácido fórmico que é formado concomitantemente a partir da conversão de piruvato a acetil-CoA, catalisada pela enzima NiFe-hidrogenase (Reação 6) (Cai et al., 2011).

2 piruvato $+2 \mathrm{CoA} \rightarrow 2$ acetil $-\mathrm{CoA}+2$ formiato $\rightarrow 2 \mathrm{CO}_{2}+\mathrm{H}_{2}$ Reação (6)

Como visto, a predominância de L. casei no inóculo pode estar associado Á produção de ácido lático. Fuess et al. (2018) observaram para fermentação da vinhaça duas possibilidades em relação ao ácido lático: (1) produção de $\mathrm{H}_{2}$ (ácido acético + ácido lático $\rightarrow$ ácido butírico + $\mathrm{H}_{2}$ ) e (2) produção de outros ácidos carboxílicos (ácido lático $\rightarrow$ ácido propiônico + ácido acético), nesta forma a presença de $L$. casei no inóculo pode estar relacionada tanto com a produção de $\mathrm{H}_{2}$ (1) quanto para produção de ácido propiônico e acético (2). A via de produção de ácido lático pelas BAL, também caracteriza estratégia utilizada por estas bactérias para obter energia a baixos níveis de carboidratos. Ademais, Baghchehsaraee et al. (2009) sugeriram que a conversão do piruvato em ácido lático (Reação 7) resultaria no aumento de NADH, que por sua vez favoreceria ainda mais a produção de $\mathrm{H}_{2}$ por meio da reoxidação de moléculas de NADH em NAD ${ }^{+}$(Reação 8).

$$
\begin{aligned}
& \mathrm{CH}_{3} \mathrm{COCOOH}+\mathrm{NADH}+\mathrm{H}^{+} \rightarrow \mathrm{CH}_{3} \mathrm{CH}(\mathrm{OH}) \mathrm{COOH}+\mathrm{NAD}^{+} \\
& \mathrm{NADH}+\mathrm{H}^{+} \rightarrow \mathrm{H}_{2}+\mathrm{NAD}^{+}
\end{aligned}
$$$$
\text { Reação (7) }
$$

As correlações observadas entre a produção de $\mathrm{H}_{2}$ e as espécies de bactérias identificadas no inóculo foram importantes na dinâmica microbiana da fermentação de resíduo de banana. Clostridium e Lactobacillus, os gêneros mais abundantes na amostra, foram identificados e correlacionados como os responsáveis pela produção de hidrogênio e ácido lático, respectivamente.

Não foi observada atividade metanogênica durante a fermentação do resíduo de banana. Este fato pode ser confirmado pela inexistência de metano no biogás durante o tempo de operação dos reatores, além da ausência de arqueias metanogênicas no inóculo. Contudo, a caracterização taxônomica certificou o estabelecimento de bactérias fermentativas no inóculo 


\author{
Universidade de São Paulo \\ Escola de Engenharia de São Carlos \\ Programa de Pós-graduação em Hidráulica e Saneamento
}

consagrando a fermentação natural para obtenção de biomassa produtora de $\mathrm{H}_{2}$ a partir de resíduo de banana.

Deste modo, o resíduo de banana (polpa e casca) é um substrato que pode ser utilizado como fonte natural de microbiota fermentativa, assim como fonte de carbono (açúcares residuais) para crescimento da biomassa e produção de metabólitos.

\subsubsection{Perfil Funcional}

Duas abordagens foram utilizadas na análise do potencial funcional obtido do consórcio bacteriano do inóculo. Primeiramente, analisou-se funcionalmente as diferentes e principais rotas metabólicas em que as bactérias podem atuar, convergindo a discussão para a categoria Metabolismo de Carboidratos. Posteriormente analisou-se funcionalmente a correlação entre as enzimas dentro de cada etapa da fermentação e, por fim, foi discutido o papel das enzimas em vias metabólicas a partir dos principais carboidratos do resíduo de banana. Todas as informações foram obtidas através da utilização do banco de dados KEEG em nível de função e do número do KO (KEGG Orthology) de cada sequência e sua respectiva abundância relativa.

Utilizou-se os números de KO para confeccionar a curva de rarefação construída para determinar se a profundidade de sequenciamento foi suficiente para capturar toda a capacidade funcional da biomassa contida no inóculo (Figura 5.4). Observou-se relação assintótica entre os números de $\mathrm{KO}$ e as sequências, atingindo platô, por meio do qual pode-se inferir em ampla cobertura amostral funcional e em alta riqueza de funções metabólicas (>3000).

Figura 5.4. Curva de rarefação estável abrangendo o número total de KO atribuído pelo aumento do número de sequências na amostra do inóculo.

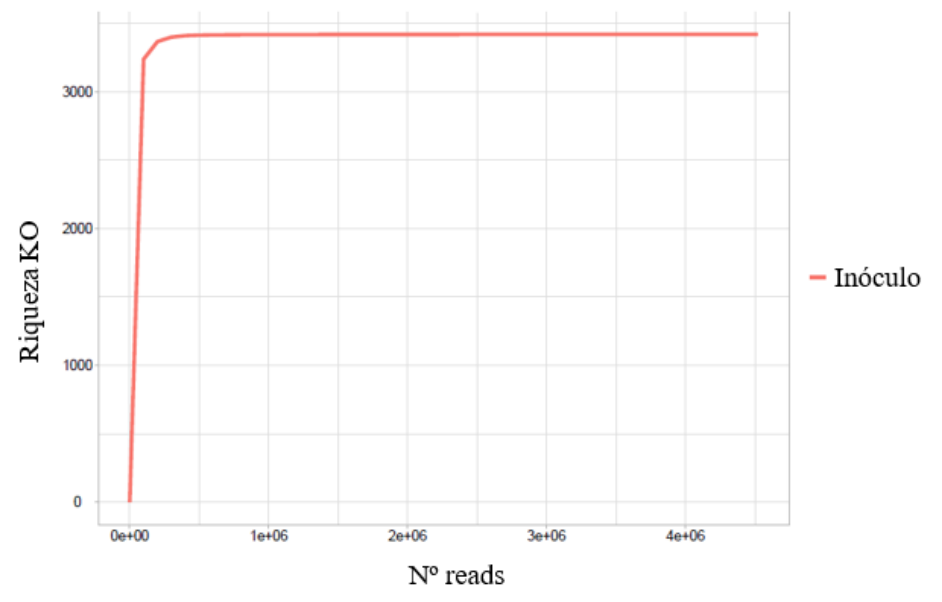


Para categoria II do KEGG observou-se que os principais genes funcionais identificados na amostra no inóculo foram relacionados principalmente com processo de replicação e reparação celular $(29,1 \%)$, transportes de membrana e catabolismo (16\%) e metabolismo de carboidratos $(9,4 \%)$ (Figura 5.5). A prevalência de genes relacionados aos processos de replicação e reparação celular é de fundamental importância, visto que a replicação com precisão pode garantir a eficiência e viabilidade celular bacteriana, entretanto, esse processo é crítico sendo necessário conter todos os componentes necessários para duplicar o DNA genômico sem que haja comprometimento funcional da célula (Li et al., 2018). Sendo assim, a alta abundância relativa de genes relacionados a esse processo garante certa estabilidade e oportuniza o crescimento bacteriano favorecendo os processos fermentativos.

Genes relacionados ao transporte de membrana e catabolismo também se tornam essenciais para a metabolismo celular, porque estão relacionados a absorção, consumo e eliminação de substâncias endocelulares, contribuindo com a vitalidade celular e manutenção metabólica. A identificação de genes relacionados ao metabolismo de carboidratos assegura que durante o processo fermentativo, esses genes estiveram associados aos processos que levam à produção de $\mathrm{H}_{2}$, como glicólise, metabolismo de açúcares (mono e dissacarídeos) e ácidos orgânicos (Soares et al., 2018). Desse modo, pode-se inferir sobre o potencial genético do consórcio de bactérias obtidos a partir de resíduos de banana e consequente obtenção de produtos metabólicos de valor agregado.

Genes relacionados ao metabolismo de aminoácidos foram também identificados em abundância relativa de 7,8\% (Figura 5.5). A hidrólise de proteínas, catalisada por enzimas proteolíticas, libera aminoácidos que serão utilizados para síntese de novas proteínas e ácidos nucleicos e/ou utilizados para compor esqueletos carbônicos que participarão do ciclo de Krebs para formação de oxaloacetato seguido de glicose. Tal sequência de reações induz o início da via glicolítica e consequentemente início dos processos fermentativos. Provavelmente, a fonte de proteínas pode ter sido o próprio resíduo de banana (Bezerra e Dias, 2009) ou os componentes do meio de cultivo, como o extrato de levedura e peptona.

Demais funções metabólicas como metabolismo enzimático, de energia, nucleotídeos, de cofatores e vitaminas, entre outros, também foram identificados na biomassa do inóculo, no entanto, obteve-se para esses casos abundâncias relativas inferiores a 5\% (Figura 5.5). Contudo, a identificação desses genes na biomassa de inóculo sugeriu elevado potencial metabólico, não sendo possível confirmar que os mesmos estiveram ativos durante a fermentação. Todavia, 


\author{
Universidade de São Paulo \\ Escola de Engenharia de São Carlos \\ Programa de Pós-graduação em Hidráulica e Saneamento
}

supõe-se que de alguma forma beneficiaram e/ou estiveram envolvidos no processo fermentativo.

Figura 5.5. Distribuição funcional metabólica da categoria II do KEGG dos genes identificados na amostra da biomassa autóctone do resíduo de banana.
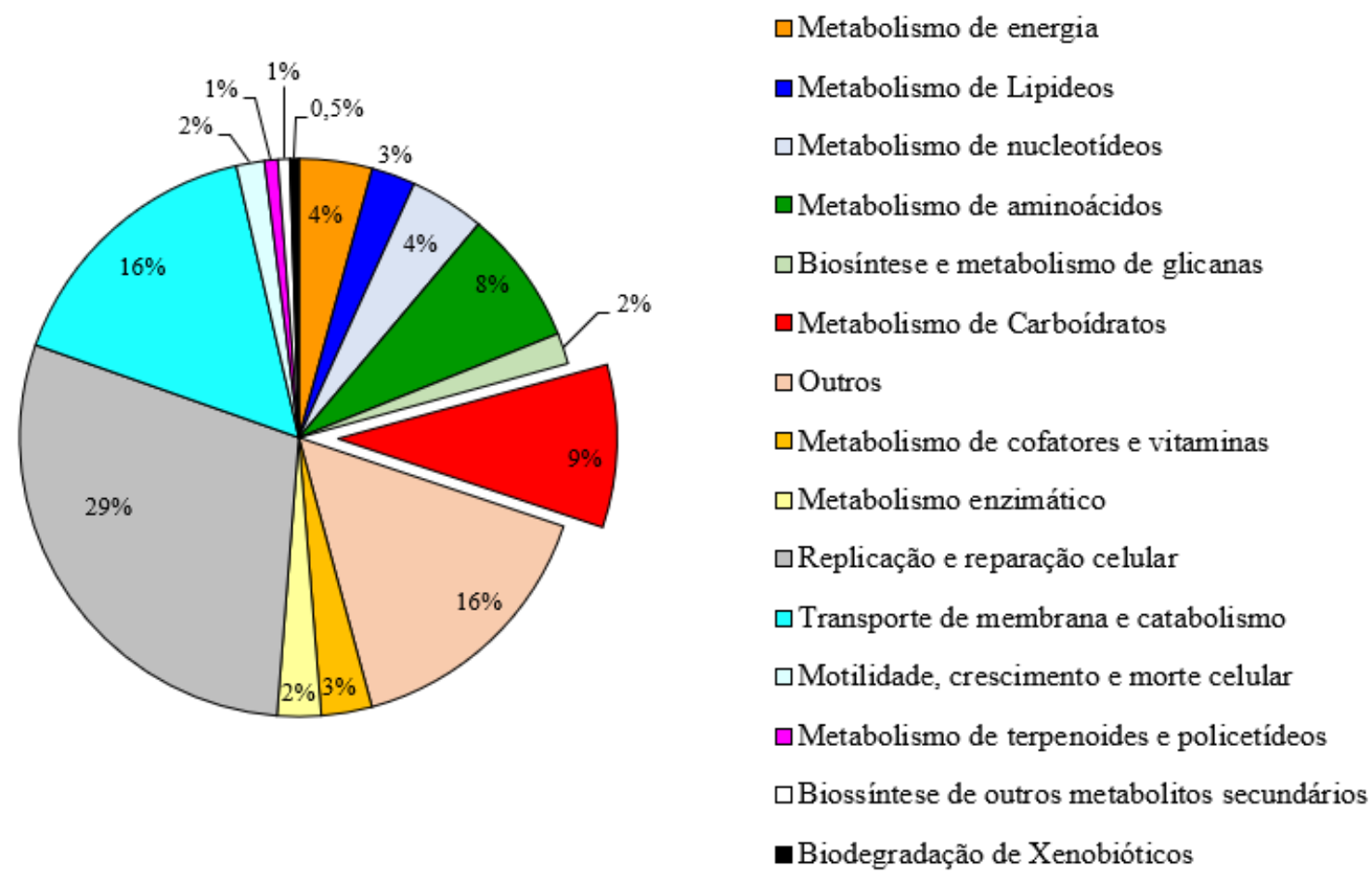

Nesta pesquisa, como o resíduo de banana é constituído praticamente por carboidratos, buscou-se, entender melhor quais enzimas estavam envolvidas e a atuação delas no processo metabólico. Para isto, foi realizada comparação de genes identificados para níveis de expressão significativamente diferentes e somente para o metabolismo de carboidratos (Figura 5.6). O número total de sequências identificadas no inóculo associadas aos $\mathrm{KO}$ relacionados ao metabolismo de carboidratos foi de 426.638,00.

Em relação a primeira etapa da fermentação (hidrólise) identificou-se genes relacionados a enzima transcetolase $(4,6 \%$ ) (EC 2.2.1.1), fosfogliconato desidrogenase (EC 1.1.1.44) (1,7\%) e fosfoglicomutase (EC 5.4.2.2) (1,6\%) (Figura 5.6). Genes relacionados a transcetolase foram mais abundantes em Clostridium (2,7\%), quando comparado a Lactobacillus $(0,1 \%)$. Em contrapartida, fosfogliconato desidrogenase foi expressa somente em Lactobacillus (1,7\%). Em relação a Transcetolase (TK), esta enzima transfere $2 \mathrm{C}$ de uma cetose para uma aldose (Kochetov e Solovjeva., 2014). É uma enzima chave da fase não oxidativa da 
via das pentoses fosfato do metabolismo de carboidratos, fornecendo a interação entre a via das pentoses e a glicólise (Hohmann e Meacock, 1998), sendo amplamente difundida na natureza. Ademais, além da TK ser enzima chave no cliclo de Calvin, também está relacionada com a síntese de precursores para formação de nucleotídeos, coenzimas, vitaminas e aminoácidos aromáticos (Mitschke et al., 2010).

A segunda enzima mais abundante, 6-fosfogliconato desidrogenase (6PGD), catalisa a terceira etapa da via das pentoses fosfato, convertendo o 6-fosfogliconato (6PG) em ribulose 5fosfato. O NADH produzido pelo 6PGD é crucial para a síntese de DNA e RNA promovendo o rápido crescimento celular (Ma e Cheng, 2018).

A terceira enzima mais abundante enzima identificada foi a Fosfoglicomutase, sintetizada em bactérias e catalisa a conversão de glicose-1-fosfato (G1P) em glicose-6-fosfato (G6P), sendo que a G6P pode eficientemente seguir a via glicolítica ou vias das pentoses fosfato, diferindo-se da G1P, no qual geralmente esta envolvida no metabolismo do glicogênio (Wilson, et al., 2010).

A enzima $\beta$-galactosidase (EC 3.2.1.23) e 1-fosfofrutoquinase (EC 2.7.1.56) também foram as mais abundantes identificadas $(0,1$ e 1,4\%), respectivamente. A $\beta$-galactosidase tem sido extensivamente estudada e acredita-se que esta associada a modificação da parede celular em bactérias (Chandrasekar e Van der Hoorn, 2016). É pertencente a família da glicosilhidrolase e está envolvida em vários processos biológicos, cuja expressão varia com as necessidades celulares. Caso a bactéria esteja crescendo em meio rico em lactose, sua expressão será alta, por outro lado, caso a fonte de carbono seja outro carboidrato, sua expressão será reduzida (Park et al., 2018). Desta forma, sua principal atuação esta associada na clivagem da lactose em glicose e galactose, que servirão como fonte de carbono para a célula (Liu et al., 2011), além de estarem relacionadas ao amadurecimento de frutos (Paniagua et al., 2016). Nesse caso, explicaria sua abundância na biomassa do resíduo de banana, em vista que se tratava de frutos bem maduros e podres, em fase de decomposição.

Embora, a $\beta$-galactosidase possa ser produzida a partir de variedade de bactérias (Seyis e Aksoz, 2004), espécies de Lactobacillus, como o Lactobacillus acidophilus, tem sido reportada como uma das bactérias com forte potencial de produção desta enzima (Akolkar et al., 2005). Portanto, a alta abundância relativa de Lactobacillus no inóculo (52,70\%) pode ser associada a presença de $\beta$-galactosidase na amostra.

A 1-fosfofrutoquinase (PFK1) é uma enzima alostérica que fosforila a frutose-6-fosfato (F6P), formando frutose-1,6-bifosfato (F1,6BP) (Mor et al., 2011). Esta reação é irreversível 


\section{Universidade de São Paulo \\ Escola de Engenharia de São Carlos \\ Programa de Pós-graduação em Hidráulica e Saneamento}

sob condições intracelulares normais e tem sido considerada como importante marco regulatório na via glicolítica, sendo que sua atividade enzimática é controlada pelo nível de energia celular ou pela relação ATP/AMP (adenosina 5'-monofosfato) (Uyeda, 1979). De todas as formas, essas enzimas associadas a etapa hidrolítica do metabolismo de carboidratros provavelmente estiveram envolvidas nas etapas de conversão dos carboidratos do resíduo de banana em subprodutos com formação de ácidos orgânicos e $\mathrm{H}_{2}$.

$\mathrm{Na}$ etapa acidogênica, onde há extensiva formação de ácidos carboxílicos concomitantemente a produção de $\mathrm{H}_{2}$, os genes identificados e relacionados as enzimas mais abundantes do inóculo foram a saber: piruvato formiato-liase (EC 2.3.1.54) (6,1\%), piruvato ferredoxina oxidorredutase (EC 1.2.7.1) (4,1\%), piruvato quinase (EC 2.7.1.40) (3,9\%) e frutose-1,6-bisfosfato aldolase (EC 4.1.2.13) (3,4\%) (Figura 5.6). Os genes da piruvato formiato-liase e piruvato ferredoxina oxidorredutase foram mais expressos em Clostridium (1,7 e 1,4\%, respectivamente) e Clostridioides (1,4 e 2,6\%, respectivamente), enquanto para frutose1,6-bisfosfato aldolase foi mais abundante $(2,2 \%)$ em Lactobacillus.

A piruvato formiato-liase (PFL) catalisa a conversão do piruvato em acetil-CoA e formiato em condições anaeróbias (Garczarek et al., 2007). A partir desta reação, pode-se inferir que parte da produção de $\mathrm{H}_{2}$ foi mediante atividade desta enzima, em vista que a produção de $\mathrm{H}_{2}$ via Enterobacterial ocorre através da clivagem de formiato que é formado concomitantemente a partir da conversão de piruvato a acetil-CoA, em bactérias semelhantes a Escherichia e Bacillus, entre outras. Ademais, alguns microrganismos que utilizam a via Clostridial também podem formar formiato a partir do piruvato pelo complexo PFL (Castro et al., 2013).

Destaca-se também que nas reações catalisadas por piruvato ferredoxina oxidorredutase (PFOR), via Clostridial, a conversão do piruvato a acetil-CoA e $\mathrm{CO}_{2}$ é acoplada à redução de Ferredoxina, por essa enzima, tornando-se o principal mecanismo de produção de $\mathrm{H}_{2}$ nesta via, pela subsequente oxidação da ferredoxina por FeFe-hidrogenases juntamente à redução de prótons (Castro et al., 2013). Levando em consideração a elevada abundância relativa de bactérias identificadas e semelhantes a Clostridium no inóculo $(34,44 \%)$, assumiu-se que a via principal de produção de $\mathrm{H}_{2}$ foi Clostridial acoplada a enzima PFOR e FeFe-hidrogenase.

A piruvato quinase (PK) catalisa o passo final, irreversível, na glicólise, no qual envolve a transferência de um grupo fosfato do fosfoenolpiruvato ao ADP para gerar piruvato e ATP (van Heerden et al., 2014). Ademais, a PK influencia as atividades de outras enzimas, 
conectando várias rotas metabólicas e, portanto, os genes relacionados a essa enzima foram importantes para a ocorrência da via glicolítica, acoplada a via das pentoses.

A D-frutose, observada na forma livre em muitas frutas e formada pela hidrólise da sacarose, pode ser fosforilada em C-1, em vez de C-6 formando a frutose 1-fosfato, que é clivada a D-gliceraldeído-3-fosfato e di-hidroxiacetona fosfato na glicólise e glicogênese pela enzima frutose-1,6-bifosfato aldolase (Nakahara et al., 2003). Assim, os dois produtos da hidrólise da frutose-1-fosfato entram na via glicolítica como gliceraldeído 3-fosfato. A identificação de genes relacionados a essa enzima no inóculo possibilita inferir que a frutose contida no RB pode ser uma das fontes de carbono utilizada para produção de $\mathrm{H}_{2}$.

Os demais genes identificados foram menos abundantes $(<3 \%)$, e relacionados a fosfopiruvato hidratase (EC 4.2.1.11) (2,9\%) que catalisa a desidratação de 2-fosfoglicerato a fosfoenolpiruvato, nos últimos passos da via glicolítica (Pancholi, 2001). Trata-se de metaloenzima que requer magnésio $\left(\mathrm{Mg}^{2+}\right)$ para ser cataliticamente ativa. Deve-se lembrar que no RB foi observado 0,08 g.L. $\mathrm{L}^{-1}$ de magnésio (Tabela 5.1), e que esta concentração pode ter sido suficiente para atividade desta enzima.

$\mathrm{Na}$ etapa acidogênica foram identificados outros genes e estão relacionados a acetato quinase, triose fosfato isomerase e fosfoglicerato mutase. A acetato quinase (EC 2.7.2.1) (2,5\%) também é importante na via glicolítica porque catalisa reversivelmente a fosforilação de ácido acético com a formação de acetil fosfato e ADP (acetil-P + ADP $\leftrightarrow$ ácido acético + ATP). A reação ocorre na direção de formação de ácido acético por ser termodinamicamente favorável $\left(\Delta \mathrm{G}^{\circ}{ }^{\circ}=-24 \mathrm{~kJ} / \mathrm{mol}\right)$ (Fowler et al., 2012). Entretanto, alguns microrganismos utilizam esta enzima para converter ácido acético em acetil-CoA (Yin et al., 2018).

Reações catalisadas por triose fosfato isomerase (EC 5.3.1.1) (2,7\%) estão relacionadas ao metabolismo do carbono da glicólise, glicoênese, via das pentoses e glicerol, além da inter conversão reversível de diidroxiacetona fosfato e D-Gliceraldeído-3-fosfato (Knowles, 1991).

A fosfoglicerato mutase (PGM; EC 5.4.2.12) (2,4\%) é uma enzima chave do metabolismo central da maioria dos organismos vivos, pois catalisa a isomerização reversível de 3-fosfoglicerato do catabolismo de açúcares na via glicolítica (Oost et al., 2002). A piruvato carboxilase (EC 6.4.1.1) (2,3\%) é uma enzima da classe das ligases que catalisa a carboxilação irreversível do piruvato para formar o oxaloacetato (piruvato $+\mathrm{HCO}_{3}{ }^{-}+\mathrm{ATP} \rightarrow$ oxaloacetato + ADP + P) (Adam et al., 2014). A lactato desidrogenase (EC 1.1.1.27) (2,2\%) tranforma o piruvato em ácido lático durante o metabolismo heterolático (Abdel-Rahman et al., 2013), corroborando com a presença de Lactobacillus na amostra de inóculo. 
Figura 5.6. Abundância relativa dos genes relacionados as enzimas associadas ao metabolismo de carboidratos nas diferentes fases da fermentação.

Inóculo: $100.1 \%$

Acidogênese: $76 \%$

Fosfoglicerato-mutase: $2.4 \%$ Piruvato quinase: $3.9 \%$

Lactato desidrogenase: $2.2 \%$ Piruvato: ferredoxina oxidorredutase: $4.1 \%$

Piruvato formiato-liase: $6.1 \%$

Acetogênese: 1.6\% Frutose-1.6-bisfosfato aldolase: $3.4 \%$

Triose fosfato isomerase: $2.7 \%$

Fosfopiruvato hidratase: $2.9 \%$

Acetato quinase: $2.5 \%$

Piruvato carboxilase: $2.3 \%$

Aconitato hidratase: $0.9 \%$

2-oxoácido oxidorredutase: $0.7 \%$

Nota: Para distribuição funcional das enzimas, seus genes foram associados aos KO relacionados ao metabolismo de carboidratos, sendo que o número de reads dos genes mais abundantes relacionados as enzimas foram utilizadas para o cálculo da abundância relativa (\%).

$\mathrm{Na}$ etapa acetogênica, obteve-se maior abundância relativa de genes relacionados a aconitato hidratase (EC 4.2.1.3) (0,9\%) e 2-oxoácido oxidorredutase (EC 1.2.7.11) (0,7\%) do metabolismo de carboidratos (Figura 5.6). A enzima aconitato hidratase catalisa a isomerização reversível do citrato a isocitrato (Britten, 1969), enquanto a 2-oxoácido oxidorredutase (OFOR) oxida 2-oxoácidos (acetoácidos) dividindo a ligação de $\mathrm{CO}_{2}-\mathrm{C} \alpha$, produzindo elétrons que 
Universidade de São Paulo

Escola de Engenharia de São Carlos

Programa de Pós-graduação em Hidráulica e Saneamento

reduzem as ferredoxinas (Gibson et al., 2016), essas por sua vez são proteínas ferro-enxofre que estão relacionadas a produção de $\mathrm{H}_{2}$, e portanto a OFOR torna-se essencial no metabolismo microbiano (Ragsdale, 2003) e principalmente no processo fermentativo. Tanto os genes relacionados a aconitato hidratase, quanto a 2-oxoácido oxidorredutase não foram expressos em Lactobacillus, sendo mais abundantes em Clostridium (0,9\%) e Clostridioides (0,7\%), respectivamente.

Dentre os carboidratos, a sacarose e seus produtos de hidrólise, glicose e frutose, são os principais açúcares encontrados em frutas. Geralmente o acúmulo de sacarose ocorre no estágio final da maturação dos frutos (Dai et al., 2011; Huang et al. 2017), o que justifica a alta concentração destes carboidratos no resíduo de banana, já que esses resíduos já estavam bem maduros. Neste sentido, buscou-se relacionar os genes relacionados a enzimas e suas respectivas funções do metabolismo da sacarose, frutose e glicose, de modo a construir um mapa metabólico para a degradação do RB (Figura 5.7).

A sacarose na presença de fosfato pode ser fosforilada em frutose e glicose-1-fosfato mediada pela sacarose fosforilase (EC 2.4.1.7). A frutose, por sua vez, é fosforilada em frutose1-fosfato pela enzima frutoquinase (EC 2.7.1.4) utilizando ATP como doador de fosfato. Genes relacionados a esta enzima foi um dos mais abundantes no inóculo $(0,56 \%)$ e mais expressos em Clostridium (0,53\%) do que em Lactobacillus (0,03\%) (Tabela 5.3), principais gêneros identificados na biomassa do inóculo. A frutose-1-fosfato é clivada pela frutose-1-fosfato aldolase (EC 4.1.2.13), produzindo diidroxiacetona-fosfato (DHAP) e gliceraldeído, sendo este último catalisado pela trioquinase (EC 2.7.1.28) para produzir o gliceraldeído 3-fosfato (G3P). A abundância total de genes da frutose-1-fosfato aldolase no inóculo foi de 3,36\%, sendo expressa principalmente em Lactobacillus (2,25\%), seguido de Clostridium (1,11\%). 
Figura 5.7. Rotas metabólicas de degradação da sacarose, frutose e glicose do resíduo da banana.

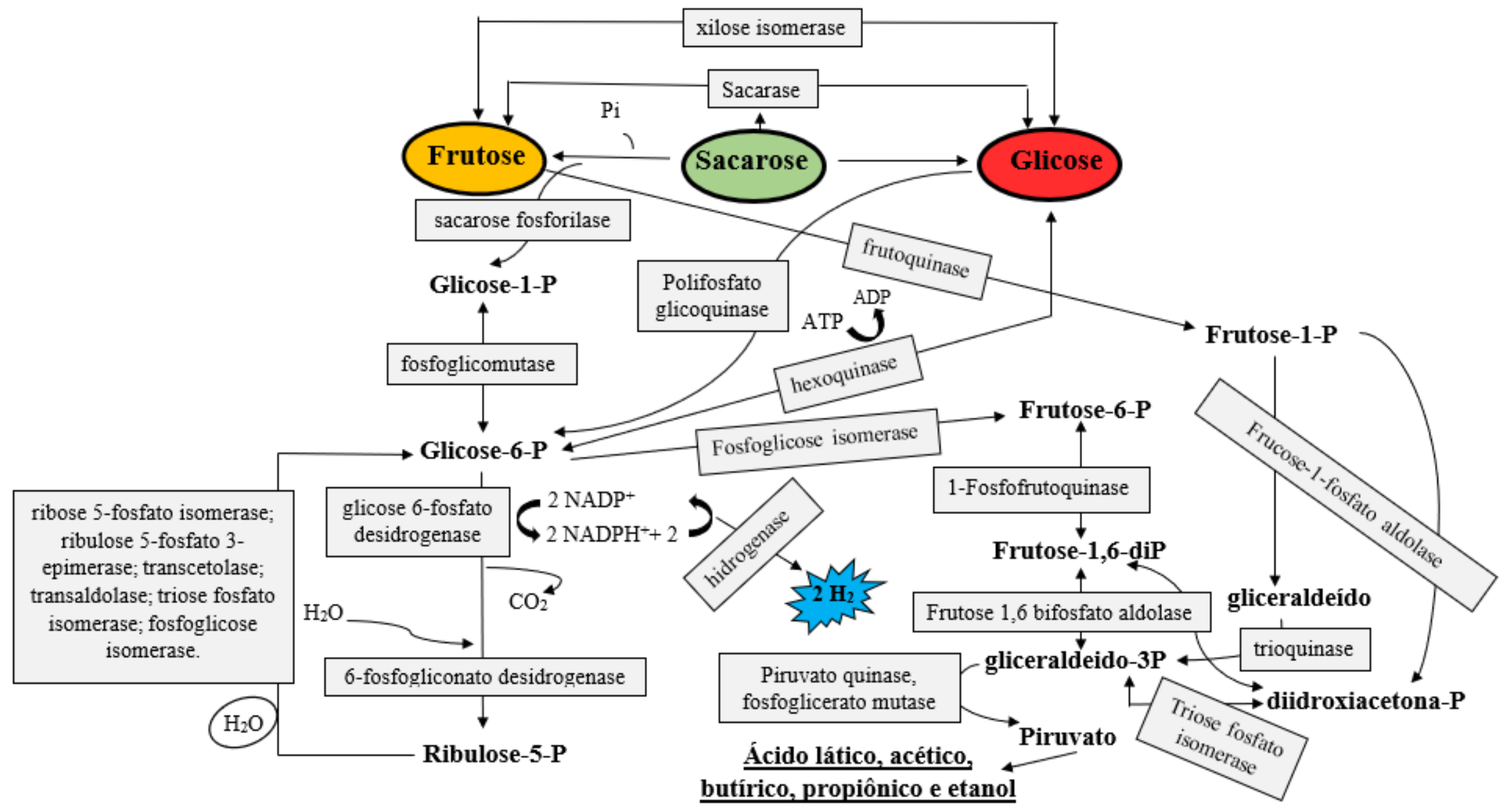

Fonte: Elaboração própria 
Ambos produtos (DHAP e G3P) derivados de frutose podem ser tanto utilizados para síntese de glicogênio, como de intermediários da glicólise. Uma vez que o G3P pode ser diretamente degradado na via glicolítica, enquanto a diidroxiacetona fosfato pode ser rapidamente convertida em gliceraldeído 3-fosfato em reação reversível pela triosefosfato isomerase (EC 5.3.1.1) (2,68\%). A abundância total de genes da triosefosfato isomerase no inóculo foi de 3,36\%, sendo expressos principalmente por Lactobacillus (2,25\%), seguido de Clostridium (1,11\%).

Baseando-se no fato de que o gene da enzima frutose-1-fosfato aldolase esteve presente em Lactobacillus, pode-se inferir que a produção de ácido lático e etanol nos ensaios pode ser sido decorrente do desvio da rota glicolítica para a fermentativa com utilização do gliceraldeído provindo da hidrólise da frutose. Por outro lado, enquanto a frutoquinase catalisa a frutose no carbono 1 a hexoquinase catalisa a frutose no carbono 6, convertendo-se, portanto, em frutose6-P (Liao et al., 2012). Isso ocorre quando as concentrações de glicose são baixas, uma vez que a hexoquinase tem maior afinidade por glicose do que pela frutose. Portanto, a degradação da frutose pela hexoquinase é mais lenta quando comparada a degradação pela frutoquinase. A frutose quando convertida em frutose-6-P vai ser catalisada pela fosfofrutoquinase (EC 2.7.1.56). A abundância relativa de genes relacionados a essa enzima na biomassa do inóculo foi de 1,44\%, correspondendo a 0,91\% em Lactobacillus e 0,54\% em Clostridium.

Ao mesmo tempo que ocorre a formação de produtos a partir da frutose (subproduto da degradação da sacarose), a glicose-1-fosfato gerada pela sacarose fosforilase é convertida em glicose 6-fosfato mediado pela fosfoglicomutase (EC 5.4.2.2) (1,6\%), sendo semelhantemente expressa por Lactobacillus (0,74\%) e Clostridium (0,86\%). Como resultado, uma molécula de sacarose pode gerar 2 moles de glicose-6-fosfato utilizando um grupo fosforil doado a partir de polifosfato via pentose fosfato (Figura 5.7). Em meio aquoso, a glicose-6-fosfato pode gerar dois $\mathrm{NADH}$, uma ribulose 5-fosfato e uma molécula de $\mathrm{CO}_{2}$ através da atividade de duas enzimas, a glicose 6-fosfato desidrogenase (EC 1.1.1.49) e a 6-fosfogliconato desidrogenase (EC 1.1.1.44), correspondendo a abundância relativa total dos genes relacionados a elas de 0,69 e 1,70\% na amostra de inóculo, respectivamente.

Entre as reações de oxidação-redução entre o NAD e NADH mediada pela enzima hidrogenase pode haver a produção de $2 \mathrm{H}_{2}$. Provavelmente, essa rota pode ter sido favorecida nos ensaios em reatores em batelada. A ribulose-5-fosfato pode ser regenerada a glicose-6fosfato através da via não oxidativa das pentoses fosfato (com adição de $\mathrm{H}_{2} \mathrm{O}$ ) ou via glicogênese. Ambas utilizam uma série de enzimas, nos quais os genes mais abundantes 


\author{
Universidade de São Paulo \\ Escola de Engenharia de São Carlos \\ Programa de Pós-graduação em Hidráulica e Saneamento
}

relacionados a elas foram identificados na fermentação do $\mathrm{RB}$, incluindo a ribose 5-fosfato isomerase (EC 5.3.1.6) (0,87\%), a ribulose 5-fosfato 3-epimerase (EC 5.1.3.1) (0,64\%), transcetolase (EC 2.2.1.1) (4,65\%), transaldolase (EC 2.2.1.2) (0,85\%), triose fosfato isomerase (EC 5.3.1.1) (6,69\%) e fosfoglicose isomerase (EC 5.3.1.9) (1,32\%) (Tabela 5.3, Figura 5.7).

Tabela 5.3. Abundância relativa total dos genes relacionados as enzimas e dos principais microrganismos envolvidos no metabolismo da frutose e sacarose na fermentação do resíduo de banana no inóculo.

\begin{tabular}{|c|c|c|c|c|c|}
\hline \multirow[b]{2}{*}{ Carboidratos } & \multirow{2}{*}{ Enzima } & \multirow{2}{*}{ KO } & \multicolumn{3}{|c|}{ Abundância relativa (\%) } \\
\hline & & & Total $^{1}$ & Lactobacillus $^{2}$ & Clostridium $^{3}$ \\
\hline \multirow{5}{*}{ Frutose } & \multirow{2}{*}{ 1-fosfofrutoquinase } & K00882 & 1,44 & 0,91 & 0,54 \\
\hline & & K04041 & 0,65 & 0,65 & 0 \\
\hline & frutose-1-fosfato aldolase & K01624 & 3,36 & 2,25 & 1,11 \\
\hline & frutoquinase & K00847 & 0,56 & 0,03 & 0,53 \\
\hline & triose fosfato isomerase & K01803 & 2,68 & 1,6 & 0,35 \\
\hline \multirow{12}{*}{ Sacarose } & fosfoglicomutase & K01835 & 1,6 & 0,74 & 0,86 \\
\hline & glicose 6-fosfato desidrogenase & K00036 & 0,69 & 0,69 & 0 \\
\hline & 6-fosfogliconato desidrogenase & K00033 & 1,7 & 1,7 & 0 \\
\hline & \multirow{2}{*}{ Ribose 5-fosfato isomerase } & K01807 & 0,87 & 0,87 & 0 \\
\hline & & K01808 & 0,3 & 0 & 0,3 \\
\hline & Ribulose 5-fosfato-3-epimerase & K01783 & 0,64 & 0,34 & 0,3 \\
\hline & transcetolase & K00615 & 4,56 & 0,07 & 2,69 \\
\hline & transaldolase & K00616 & 0,85 & 0,02 & 0,83 \\
\hline & triose fosfato isomerase & K01803 & 2,68 & 1,6 & 0,35 \\
\hline & frutose-bifosfate aldolase & K01624 & 3,36 & 2,25 & 1,11 \\
\hline & frutose-1,6-bifosfatase & K04041 & 0,65 & 0,65 & 0 \\
\hline & fosfoglicose isomerase & K01810 & 1,32 & 0,5 & 0,75 \\
\hline
\end{tabular}

Nota: Total $^{1}=$ abundância relativa calculada a partir no número total de reads referente ao KO de cada enzima; Lactobacillus $^{2}=$ abundância relativa calculada a partir no número de reads obtido para Lactobacillus referente ao KO de cada enzima; Clostridium $^{3}$ = abundância relativa calculada a partir do número de reads obtido para gênero Clostridium referente ao KO de cada enzima.

\title{
5.2.2. Conclusão Sub-hipótese 1
}

Nesta etapa, pode-se confirmar a primeira sub-hipótese elencada inicialmente " $O$ resíduo de banana in natura (casca e polpa) servirá como fonte de carbono e de bactérias fermentativas autóctones.", uma vez que a fermentação natural do resíduo de banana permitiu a obtenção da biomassa, incluindo Clostridium, Bacillus e Lactobacillus, sem necessidade do uso de fonte externa de bactérias e custo adicional de fontes de carbono, demonstrando o potencial uso deste resíduo como matéria-prima em processos acidogênicos. Entretanto, a produção máxima acumulada de $\mathrm{H}_{2}$ nesta etapa $(5 \mathrm{~mL})$ não foi satisfatória. Deste modo, para 
maior produção de $\mathrm{H}_{2}$ utilizando este tipo de substrato e biomassa, deve-se considerar a possibilidade de adição de nutrientes ao substrato para beneficiar e enriquecer a biomassa produtora de $\mathrm{H}_{2}$.

\subsection{Avaliação dos meios de cultivo - Sub-hipótese 2}

\subsubsection{Efeito de Elementos Nutricionais na Produção de $\mathrm{H}_{2}$}

Por meio da fermentação natural do resíduo de banana obteve-se a biomassa fermentativa e produção de $\mathrm{H}_{2}$. Entretanto, nas condições avaliadas somente com resíduo de banana a produção obtida não foi satisfatória $(5 \mathrm{~mL})$.

A presença de macro e micronutrientes e vitaminas no meio reacional é um dos parâmetros importantes para a produção de $\mathrm{H}_{2}$, porque são fonte de co-fatores e co-enzimas, além de auxiliarem no crescimento da biomassa. Neste sentido foi avaliada a seguinte questão: A adição de elementos nutricionais contribuirá para o aumento da produção de hidrogênio utilizando o RB como única fonte de carbono?

Nesta perspectiva, a produção de $\mathrm{H}_{2}$ utilizando três diferentes meios de cultivo (PCS, BAC e Noparati) foi avaliada e comparada com a condição controle (sem adição de meio de cultivo). Em todas as condições avaliadas foi usado resíduo de banana como única fonte de carbono. Observou-se nas primeiras 6 horas de fermentação que não houve produção de $\mathrm{H}_{2}$, exceto para os ensaios com meio de cultivo PCS. Provavelmente, o período anterior a 6 horas, foi restrito ao crescimento e adaptação da biomassa às condições nutricionais. No entanto, após o período de adaptação da biomassa, houve expressiva produção de $\mathrm{H}_{2}$ em todas as condições nutricionais avaliadas, cuja produção máxima foi observada em $10 \mathrm{~h}$ de fermentação, e estabilidade em $20 \mathrm{~h}$ (Figura 5.8). Para todos os ensaios verificou-se tempo reduzido (entre 3,74 - 7,94 h) de início de produção de hidrogênio $\left(\lambda \mathrm{H}_{2}\right)$. Provavelmente, o tempo reduzido pode ser atribuído à utilização do resíduo de banana, com alta concentração de açúcares dissolvidos, por conseguinte favoreceu a rápida produção hidrogênio (Hwang et al., 2011). Ademais, a utilização de biomassa autóctone pode ter favorecido a rápida adaptação ao substrato (Lin et al., 2017) cooperando para a rápida conversão do substrato.

Verificou-se que os diferentes componentes nutricionais contidos nos meios de cultivo favoreceram a produção de $\mathrm{H}_{2}(P)$ e velocidade de produção de hidrogênio $(R m)$ (Tabela 5.4). Obervou-se para $P$ e $R m$ valores entre 1,37 e $15,05 \mathrm{~mL}$ e 0,63 e 5,39 $\mathrm{mL} . \mathrm{h}^{-1}$, respectivamente. Valor máximo e mínimo de $P$ e $R m$ foi obtido para as condições nutricionais do meio PCS e controle, respectivamente. 
Figura 5.8. Produção de $\mathrm{H}_{2}$ em função do tempo nos ensaios em reatores em batelada com diferentes meios de cultivo.

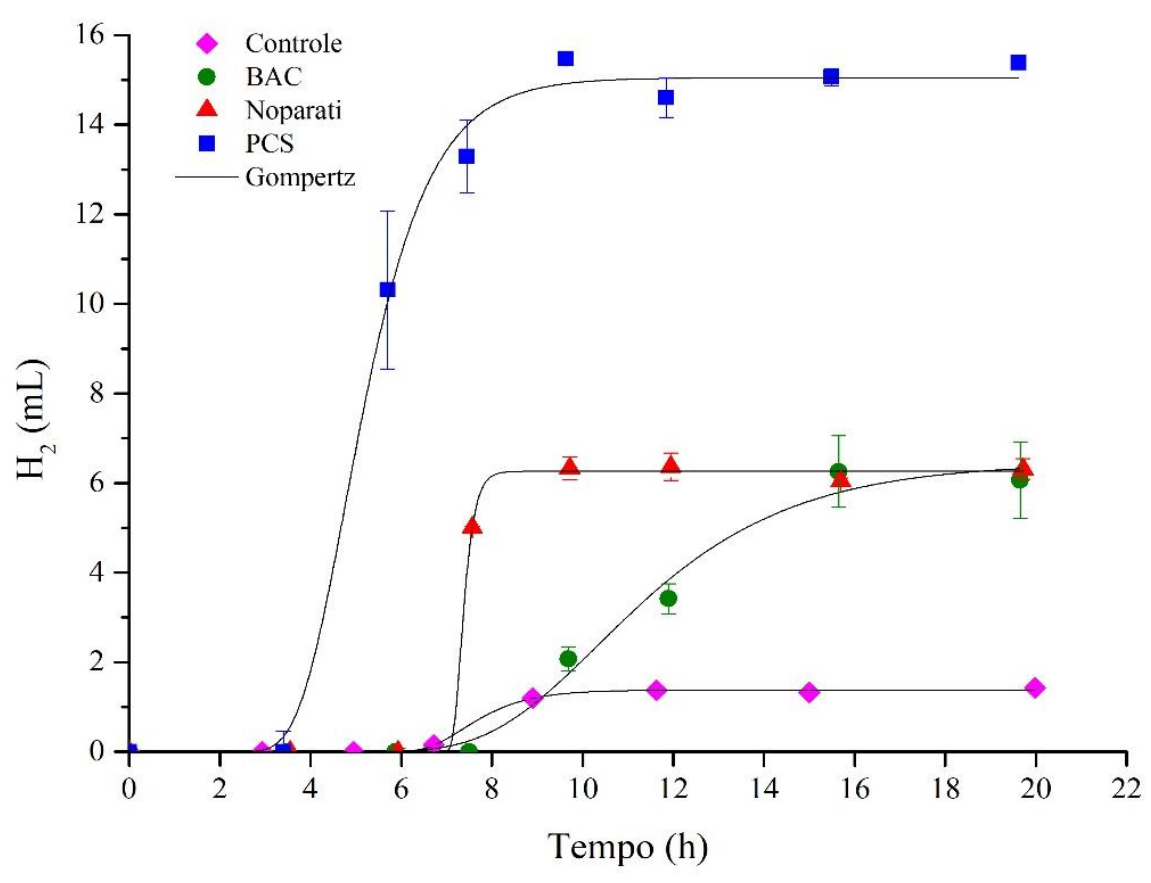

Tabela 5.4. Cinética de produção de hidrogênio via fermentação utilizando diferentes meios de cultivo em reatores em batelada com resíduo de banana.

\begin{tabular}{ccccc}
\hline $\begin{array}{c}\text { Meios de } \\
\text { cultivo/Parâmetros }\end{array}$ & Controle & BAC & Noparati & PCS \\
\hline $\begin{array}{c}P \\
\left(\mathrm{~mL} \mathrm{H}_{2}\right)\end{array}$ & $1,37 \pm 0,01^{\mathrm{a}}$ & $6,45 \pm 0,92^{\mathrm{a}}$ & $6,26 \pm 0,21^{\mathrm{a}}$ & $15,05 \pm 0,01^{\mathrm{b}}$ \\
\hline $\begin{array}{c}R m \\
\left(\mathrm{~mL} \mathrm{H}_{2} \cdot \mathrm{h}^{-1}\right)\end{array}$ & $0,63 \pm 0,06$ & $0,99 \pm 0,10$ & $0,89 \pm 0,13$ & $5,39 \pm 0,78$ \\
\hline $\begin{array}{c}\lambda \mathrm{H}_{2} \\
(\mathrm{~h})\end{array}$ & $6,56 \pm 0,00$ & $7,94 \pm 0,04$ & $7,14 \pm 0,01$ & $3,74 \pm 0,28$ \\
\hline $\begin{array}{c}\mathrm{P}_{\mathrm{CO} 2} \\
(\mathrm{~mL})\end{array}$ & $14,91 \pm 0,30$ & $24,15 \pm 0,62$ & $26,40 \pm 0,66$ & $40,55 \pm 0,06$ \\
\hline $\begin{array}{c}\mathrm{C}_{\mathrm{CT}} \\
(\%)\end{array}$ & $38,0 \pm 0,23$ & $86,6 \pm 0,30$ & $95,3 \pm 0,19$ & $90,1 \pm 0,3$ \\
\hline $\begin{array}{c}\mathrm{YH} \mathrm{H}_{2} \\
\left(\mathrm{~mL} \mathrm{H} \mathrm{g}^{-1} \mathrm{CT} \text { add }\right)\end{array}$ & $0,91 \pm 0,01$ & $4,30 \pm 0,92$ & $4,17 \pm 0,21$ & $10,03 \pm 0,01$ \\
\hline $\mathrm{pH}$ final & $5,34 \pm 0,35$ & $3,95 \pm 0,02$ & $3,73 \pm 0,01$ & $3,9 \pm 0,04$ \\
\hline
\end{tabular}

Nota: Letras diferentes significam diferença estatística (Tukey $\mathrm{p} \leq 0,05)$.

Siglas: $P=$ produção de hidrogênio, $R m=$ velocidade de produção de hidrogênio, $\lambda \mathrm{H}_{2}=$ tempo de início da produção de hidrogênio, $\mathrm{P}_{\mathrm{CO} 2}=$ produção máxima de gás carbônico, $\mathrm{C}_{\mathrm{CT}}=$ conversão de carboidratos totais, $\mathrm{YH}_{2}$ $=$ rendimento de hidrogênio. 
Como visto, maior produção e velocidade de produção de $\mathrm{H}_{2}$ foi obtida no ensaio com meio de cultivo PCS $\left(15,05 \mathrm{~mL} \mathrm{H}_{2}\right.$ e 5,39 $\left.\mathrm{mL}^{-1}\right)$, seguido do meio de cultivo BAC $(6,45 \mathrm{~mL}$ e $\left.0,99 \mathrm{~mL} \cdot \mathrm{h}^{-1}\right)$, Noparati $\left(6,26 \mathrm{~mL}\right.$ e $\left.0,89 \mathrm{~mL} \cdot \mathrm{h}^{-1}\right)$ e controle $\left(1,37 \mathrm{~mL}\right.$ e $\left.0,63 \mathrm{~mL} \cdot \mathrm{h}^{-1}\right)$. A menor produção de $\mathrm{H}_{2}$ obtida no ensaio controle demonstra a necessidade da adição de elementos nutricionais para o crescimento de biomassa, incluindo elementos a base de fonte de nitrogênio (extrato de levedura e peptona), sódio $\left(\mathrm{NaCl}\right.$ e $\left.\mathrm{NaHCO}_{3}\right)$ e cálcio $\left(\mathrm{CaCO}_{3}\right.$ e $\left.\mathrm{CaCl}_{2}\right)(\mathrm{Keskin} \mathrm{et}$ al., 2018).

Corroborando com o presente trabalho, Gomez-Romero et al. (2014) verificaram o efeito de alguns elementos traços e vitaminas na produção de hidrogênio a partir de resíduos de frutas e vegetais. Os autores obtiveram maior velocidade de produção e rendimento de hidrogênio de 239,23 mL.h ${ }^{-1}$ e 449,84 mL H2.g DQO, respectivamente, no processo de codigestão de soro de queijo (SQ) e resíduo de frutas e vegetais (RFV) para relação $\mathrm{C} / \mathrm{N}$ de 21 , $\mathrm{pH} 5,5$ a $37^{\circ} \mathrm{C}$. Este resultado foi resultante do sinergismo positivo estabelecido entre SQ e $\mathrm{RFV}$, que permitiu balanço de nutrientes adequado e controle natural do $\mathrm{pH}$. Provavelmente o controle do pH e a utilização de inóculo previamente adaptado pode ter contribuído com os altos valores de velocidade de produção e rendimento de $\mathrm{H}_{2}$ obtidos pelos autores.

Do mesmo modo, Saidi et. al. (2018) obtiveram produção total de $\mathrm{H}_{2}$ de $2.830 \mathrm{~mL}$ utilizando resíduos de frutas e vegetais como fonte de carbono e energia, e ainda relataram que o uso de resíduo de frutas e vegetais pode substituir componentes $\left(\mathrm{CaCl}_{2}, \mathrm{MgCl}_{2}\right.$, extrato de levedura, $\mathrm{KH}_{2} \mathrm{PO}_{4}$ e $\mathrm{K}_{2} \mathrm{HPO}_{4}$ ) presentes em meios de cultivo. No entanto, fontes de nitrogênio e enxofre permaneceram necessárias para a produção de hidrogênio. A alta produção de $\mathrm{H}_{2}$ obtida pelos autores pode ser decorrente pela utilização da bactéria Thermotoga maritima na qual tem sido reportada como produtora eficiente de hidrogênio (Tam et al., 2008 e Maru et al., 2013). Além disso, os autores utilizaram um meio de cultivo extremamente complexo, alta temperatura $\left(80^{\circ} \mathrm{C}\right)$, e adição constante de $\mathrm{N}_{2}$ para manter o ambiente anaeróbio. Tais condições podem ter favorecido o metabolismo desta bactéria resultando na alta produção. Entretanto, o gasto enérgico adquirido pelos autores para manutenção do sistema (biorreator, banho de calor, condensador, regulador de $\mathrm{pH}$ e análise periódica do gás) é uma questão a ser considerada, o que contradiz a proposta da presente pesquisa no qual tendeu à minimização de gastos energéticos e nutricionais.

Dos três meios de cultivo avaliados, somente o BAC tinha adição de solução com elementos traço (Tabela 5.5). Keskin et al. (2018) avaliaram o efeito dos elementos traços na produção de hidrogênio a partir de resíduos de frutas e vegetais, $\mathrm{pH} 7,0$ e $55^{\circ} \mathrm{C}$. A produção 


\section{Universidade de São Paulo \\ Escola de Engenharia de São Carlos \\ Programa de Pós-graduação em Hidráulica e Saneamento}

mínima de $\mathrm{H}_{2}$ de $31 \mathrm{~mL}$ foi obtida no ensaio contendo somente resíduo e inóculo (controle), enquanto, produção máxima de $\mathrm{H}_{2}$ de $74 \mathrm{~mL}$ foi obtida no ensaio com adição de elementos traços ao meio, resultando no aumento de cerca de 2 a 3 vezes, quando comparado ao reator controle. Os autores ainda estabeleceram que as concentrações de 75, 8,7, 29,48 e 79,76 mg.L-

${ }^{1}$ de $\mathrm{Fe}, \mathrm{Co}, \mathrm{Ni}$ e $\mathrm{Zn}$, respectivamente, são ideais para a produção de $\mathrm{H}_{2}$ a partir do inóculo termofílico utilizando resíduos de frutas e vegetais. Do mesmo modo, na presente pesquisa observou-se aumento da produção de $\mathrm{H}_{2}$ de 1,37 mL (controle) para 6,45 mL (meio BAC), sendo 4,7 vezes superior ao controle, demonstrando a importância da suplementação nutricional para o crescimento da biomassa.

Tabela 5.5. Condições experimentais para a fermentação utilizando diferentes meios de cultivo.

\begin{tabular}{|c|c|c|c|c|}
\hline Componentes & Controle & BAC & Noparati & PCS \\
\hline Peptona & - & - & - & + \\
\hline Extrato de levedura & - & $t^{*}$ & $+^{*}$ & $t^{*}$ \\
\hline $\mathrm{CaCO}_{3}$ & - & - & - & + \\
\hline $\mathrm{NaCl}$ & - & - & - & + \\
\hline $\mathrm{KH}_{2} \mathrm{PO}_{4}$ & - & $t^{*}$ & $+^{*}$ & - \\
\hline $\mathrm{K}_{2} \mathrm{HPO}_{4}$ & - & $+*$ & $+^{*}$ & - \\
\hline Ureia & - & - & + & - \\
\hline $\mathrm{MgCl}_{2} \cdot 6 \mathrm{H}_{2} \mathrm{O}$ & - & $+^{*}$ & $+*$ & - \\
\hline $\mathrm{CaCl}_{2} \cdot 2 \mathrm{H}_{2} \mathrm{O}$ & - & $+^{*}$ & $t^{*}$ & - \\
\hline $\mathrm{FeSO}_{4} .7 \mathrm{H}_{2} \mathrm{O}$ & - & - & + & - \\
\hline $\mathrm{NH}_{4} \mathrm{Cl}$ & - & + & - & - \\
\hline $\mathrm{NaHCO}_{3}$ & - & + & - & - \\
\hline Substrato (RB) & $t^{*}$ & $+^{*}$ & $t^{*}$ & $+^{*}$ \\
\hline Vitaminas & - & + & - & - \\
\hline Traço de metais & - & + & - & - \\
\hline
\end{tabular}

Nota: (+) presença, (-) ausência, (+*) semelhança entre os meios de cultivo.

A primeira fase da fermentação, hidrólise, é dependente do crescimento e estabelecimento de biomassa fermentativa com suas respectivas enzimas hidrolíticas. Neste caso, o nitrogênio $(\mathrm{N})$, sódio $(\mathrm{Na})$ e cálcio $(\mathrm{Ca})$ são elementos essenciais durante a fermentação 
atuando principalmente em processos anabólicos como síntese de biomassa (Keskin et al., 2018).

Comparando-se estes elementos nos diferentes meios de cultivo observou-se que a principal fonte de nitrogênio foi extrato de levedura adicionado em todas as condições nutricionais avaliadas (BAC, Noparati e PCS). No entanto, na composição do meio de cultivo PCS era adicionada também peptona. Provavelmente, nessas condições pode ter contribuído para o crescimento e estabelecimento de bactérias hidrolíticas, resultando em maior produção de $\mathrm{CO}_{2}(40,55 \mathrm{~mL})$, utilizada como indicativo de atividade metabólica. Deste modo, a peptona demonstrou ser um componente de extrema importância, por ter contribuído como fonte de carbono, nitrogênio e demais metabólitos, incluindo aminoácidos hidrolisados, para o crescimento e metabolismo celular (Wang et al., 2016).

Além de fonte de proteína e aminoácidos, algumas bactérias necessitam também de sódio (Na) para seu crescimento. De acordo com Maret e Wedd (2014), algumas espécies de Clostridium requerem elevada concentração de sódio para seu crescimento. Especificamente,

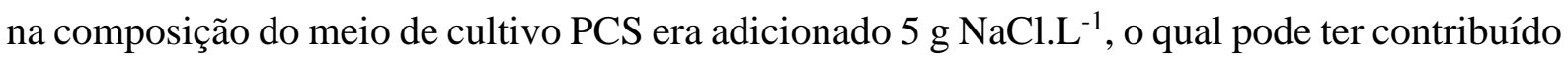
para o crescimento da biomassa neste ensaio. No caso do meio de cultivo BAC, a fonte de sódio foi na forma de bicarbonato de sódio. No entanto, a concentração adicionada ( 2 g. $\left.\mathrm{L}^{-1}\right)$ pode não ter contribuído para o crescimento da biomassa, em vista que o $\mathrm{NaHCO}_{3}$ foi utilizado como tampão e pode ter sido rapidamente consumido para neutralizar o meio. No caso do meio de cultivo Noparati, nenhuma fonte de sódio foi adicionada. No entanto, não foi verificado efeito negativo, haja vista que $\mathrm{CO}_{2}$ de 24,15 e 26,40 mL foram obtidos nos ensaios BAC e Noparati, respectivamente, correspondendo aos ensaios com e sem adição de fonte de sódio no meio.

Como fonte de cálcio teve-se carbonato de cálcio $\left(\mathrm{CaCO}_{3}\right)$ no meio PCS e cloreto de cálcio bihidratado $\left(\mathrm{CaCl}_{2} .2 \mathrm{H}_{2} \mathrm{O}\right)$ nas condições dos meios BAC e Noparati. Ambos os componentes podem ter atuado na agregação de células e estabilidade de enzimas como celulases e amilases, porque a presença de cálcio, geralmente esta associada ao crescimento celular e atividade enzimática (Brahmachari et al., 2017). Neste caso, a adição de concentração maior de cálcio no meio PCS, quando comparado aos demais meios de cultivo, pode ter sido vantajosa durante a primeira etapa da fermentação.

Acidogênese é a etapa da fermentação cujos compostos orgânicos são convertidos em ácidos carboxílicos (AC), acompanhado por formação de hidrogênio. Nesta etapa, os elementos traço, como ferro, níquel, zinco e selênio são importantes principalmente para atividade de enzimas atuando como co-fatores. Por exemplo, sulfato de ferro $\left(\mathrm{FeSO}_{4}\right)$ e cloreto de magnésio 


\section{Universidade de São Paulo \\ Escola de Engenharia de São Carlos \\ Programa de Pós-graduação em Hidráulica e Saneamento}

$\left(\mathrm{MgCl}_{2}\right)$ fizeram parte da composição dos meios de cultivo BAC e Noparati. Além do mais, para as condições do meio de cultivo BAC fez-se a suplementação com elementos traço de metais (Tabela 4.3) e vitaminas (Tabela 4.2). Provavelmente, nesse último caso, tais condições podem ter favorecido a produção de $\mathrm{H}_{2}$. Todavia, a máxima produção $(15,05 \mathrm{~mL})$ e rendimento de $\mathrm{H}_{2}\left(10,03 \mathrm{~mL} \mathrm{H}_{2} \cdot \mathrm{g}^{-1} \mathrm{CT}_{\text {add }}\right)$ foram obtidos no ensaio com meio de cultivo PCS, no qual nenhum destes componentes foram adicionados. Nas condições do meio PCS faziam parte peptona, extrato de levedura, cloreto de sódio e carbonato de cálcio, condições essas que favoreceram maior produção de hidrogênio. Ademais, o suplemento de elementos traço de metais nem sempre são biodisponíveis para o consumo pelos micro-organismos (Zitomer et al., 2008). De fato, a biodisponibilidade de metais traço em biorreatores depende da interação entre metais na fase sólida e líquida.

Alguns autores (Takashima et al., 2011; Qiang et al., 2012; Banks et al., 2012), tem reportado alguns requisitos mínimos de oligoelementos para sistemas acidogênicos mesofílicos para obtenção de altos rendimentos de biomassa. No entanto, até a atual pesquisa ordem consolidada de concentrações de elementos traço para bactérias acidogênicas ainda é inexiste.

Solução de vitaminas fez parte da composição do meio de cultivo BAC. Várias bactérias acidogênicas e celulolíticos necessitam de vitaminas e/ou aminoácidos para exercer suas atividades (Scott e Dehority, 1965). A ausência de vitamina B12 no meio pode favorecer o desvio de rotas metabólicas reduzindo a produção de $\mathrm{H}_{2}$ (Chen e Wolin, 1981; Strobel, 1992). No entanto, mesmo adicionando-se a solução de vitaminas ao meio de cultivo BAC, não tornou este ensaio o mais favorável para obtenção maior produção de hidrogênio, em relação aos demais ensaios sem adição de vitaminas. Pan et al. (2008) relataram o efeito positivo da produção de $\mathrm{H}_{2}$ quando aumentaram a concentração de vitaminas de 10 para cerca de 13,3 mL.L ${ }^{-1}$. Todavia, nessa pesquisa com resíduo de banana a adição de vitaminas não incrementou a produção de $\mathrm{H}_{2}$, de certa forma possibilitando a redução de custos em caso de implementação da fermentação em maior escala ou piloto. Por meio desses resultados, observa-se também que o resíduo de banana, fonte de aminoácidos hidrolisados da peptona, além das vitaminas do complexo B e aminoácidos (lisina, fenilalanina, leucina, valina, metionina, cistina, triptofano, treonina, isoleucina, ácido aspártico e prolina) do extrato de levedura, juntamente com cálcio e cloreto de sódio foram condições favoráveis para obtenção de maior produção de hidrogênio (Aly et al., 2018). Na composição dos meios de cultivo BAC e Noparati faziam parte o fosfato de potássio monobásico $\left(\mathrm{KH}_{2} \mathrm{PO}_{4}\right)$ e fosfato de potássio dibásico $\left(\mathrm{K}_{2} \mathrm{HPO}_{4}\right)$ como fontes inorgânicas de potássio e fosfato, o que os difere também do meio PCS (Tabela 5.5). Tais 
elementos são essenciais na composição de macromoléculas, tais como DNA, RNA, ATP entre outras (Pan et al., 2008), além de auxiliarem no crescimento bacteriano e produção de $\mathrm{H}_{2}$ (Liu et al., 2015). A ausência destes elementos no meio PCS não afetou negativamente o desempenho do reator, pelo contrário, foi neste ensaio onde foi obtido a maior produção e velocidade de produção de $\mathrm{H}_{2}$ (Tabela 5.4). Em contrapartida, Pan et al. (2008) reportaram que quando aumentaram a concentração de fonte de fosfato, a produção de $\mathrm{H}_{2}$ aumentou, indicando sua forte influência em processos fermentativos. Deve-se lembrar que na composição do resíduo da banana foi observado $49 \mathrm{mg} . \mathrm{L}^{-1}$ de potássio, $80 \mathrm{mg} . \mathrm{L}^{-1}$ de cálcio, $87 \mathrm{mg} . \mathrm{L}^{-1}$ de magnésio, os quais provavelmente, contribuíram com elementos traços para as condições nutricionais do meio PCS e das demais condições avaliadas.

No resíduo de banana foi observado 1,8 g.L $\mathrm{L}^{-1}$ de potássio (K) (Tabela 5.1). Desse modo, a fonte desse elemento foi proporcionada pelo próprio resíduo nas condições nutricionais do meio PCS e das demais condições avaliadas.

O ensaio com meio de cultivo Noparati era a única condição com adição de componente contendo enxofre ( $\left.\mathrm{FeSO}_{4} .7 \mathrm{H}_{2} 0\right)$. Segundo Huber e Harning (2006) e Boileau et al. (2016) os compostos de enxofre sob diferentes formas (enxofre elementar, cisteína, sulfeto de sódio, tiossulfato, etc.) são essenciais para o crescimento de algumas bactérias além de serem aceptores de elétrons, contribuindo para o controle da pressão parcial de hidrogênio no meio. Apesar disso, não foi verificada nenhum aumento da produção de $\mathrm{H}_{2}$ neste ensaio, sendo que os rendimentos obtidos foram bem semelhantes a outros ensaios sem algum tipo de vestígio de enxofre.

Os traços de metais que foram adicionados ao meio BAC estiveram abaixo da concentração de toxidade relatada por Hendriks et al. (2018) demonstrando que não houve possível inibição da biomassa. Entretanto, a adaptação da biomassa frente às concentrações de oligoelementos pode ocorrer ao longo do tempo, resultante de mudanças internas na população bacteriana (Chen et al., 2008). Isso explica os maiores tempos requeridos para início da produção de $\mathrm{H}_{2}\left(\lambda \mathrm{H}_{2}\right)$ de 7,94 h e obtenção da produção máxima (15 h) no ensaio com meio de cultivo BAC, quando comparado aos demais ensaios em que não houve suplementação de traços de metais.

Embora, a exigência de traço de metais seja extremamente baixa, uma deficiência em metais traços essenciais pode limitar o crescimento de micro-organismos, resultando na instabilidade do processo (Rajeshwari et al., 2000). Neste caso, apesar dos meios de cultivo BAC e Noparati serem mais complexos, em questão de composição, contendo elementos 


\section{Universidade de São Paulo \\ Escola de Engenharia de São Carlos \\ Programa de Pós-graduação em Hidráulica e Saneamento}

essenciais como $\mathrm{Cu}, \mathrm{Co}, \mathrm{Fe}$ e $\mathrm{Zn}$ para atividade enzimática da hidrogenase e crescimento de micro-organismos, a produção de $\mathrm{H}_{2}$ obtida nos ensaios contendo esses meios foi cerca de 2,3 vezes menor à obtida a partir do meio de cultivo PCS que é relativamente mais simples. Sob tais condições, pode-se inferir que $\mathrm{CaCO}_{3}, \mathrm{NaCl}$, extrato de levedura e peptona foram suficientes para suplementar e propiciar o crescimento de bactérias hidrogenogênicas (Wu et al., 2012).

Em contrapartida, o controle, que é o ensaio sem adição de meio de cultivo (contendo somente o resíduo de banana), foi o ensaio em que obteve-se menor atividade metabólica, resultando na mínima produção $(1,37 \mathrm{~mL})$ e rendimento de $\mathrm{H}_{2}\left(0,91 \mathrm{~mL} \mathrm{H} \cdot \mathrm{g}^{-1} \mathrm{CT}_{\text {add }}\right)$, além da menor conversão de carboidratos totais (inferior à 40\%) e concentrações reduzidas de ácidos carboxílicos, quando comparado aos demais ensaios. A mínima produção de $\mathrm{H}_{2}$ obtida neste ensaio pode ser resultante da concentração de carboidratos solúveis presente no resíduo de banana, além das concentrações residuais de N, P, Ca, Mg, K e Zn. Portanto, o fato de não adicionar nenhum tipo de suplemento no ensaio controle limitou o processo fermentativo, resultando em resultados bem inferiores $\left(P, R m, \mathrm{YH}_{2}\right.$ e $\left.\mathrm{C}_{\mathrm{CT}}\right)$ quando comparado aos ensaios com adição de meio de cultivo.

A ausência de macronutrientes no ensaio controle pode ter limitado a produção de energia, crescimento e manutenção de funções celulares exigidas pelo consórcio de bactérias fermentativas presente no inóculo, pois estes elementos estão intimamente relacionados à síntese de proteínas cooperando para maior crescimento da biomassa fermentativa e consequentemente em maior produção de $\mathrm{H}_{2}$. Neste sentido, a adição de elementos nutricionais foi essencial para o crescimento da biomassa e produção de $\mathrm{H}_{2}$. De acordo com Boileau et al. (2016) a ausência de extrato de levedura pode limitar o crescimento da biomassa. Além disso, Maru et al. (2012) e Soares et al. (2017) relataram que a redução do nível de extrato de levedura na fermentação pode afetar negativamente a produção de $\mathrm{H}_{2}$.

Em relação à conversão de carboidratos totais $\left(\mathrm{C}_{\mathrm{CT}} \%\right)$ observou-se entre 38 e $95 \%$ para todas as condições avaliadas (Figura 5.9). No ensaio controle, a conversão máxima de carboidratos após sete horas de fermentação foi de apenas 3\%, enquanto para as condições dos reatores com meio de cultivo BAC, Noparati e PCS obteve-se conversões de 35,6 \%, 59,5 \% e $51,2 \%$, respectivamente, neste mesmo período. Após 12 horas de fermentação verificou-se aumento para $62,3 \%, 91,8 \%$ e $79,8 \%$, respectivamente, enquanto para as condições do ensaio controle essa conversão foi de apenas $5 \%$. A conversão de carboidratos solúveis foi quase completa nos ensaios com as diferentes condições nutricionais do meio de cultivo; ou seja, com 
conversões acima de $85 \%$ no final da fermentação (20 h), diferindo-se do ensaio controle, onde a conversão máxima foi de 38,0\% (Tabela 5.4 e Figura 5.9). Portanto, a adição de alguns elementos nutricionais nos meios de cultivo influenciou positivamente o consumo e conversão de açúcares totais, principalmente no início da fermentação, em razão do crescimento da biomassa acelerado e maior conversão em produtos metabólicos, como $\mathrm{CO}_{2}, \mathrm{H}_{2}$ e ácidos orgânicos.

Figura 5.9. Carboidratos totais ao longo do tempo nos ensaios em reatores em batelada com diferentes meios de cultivo.

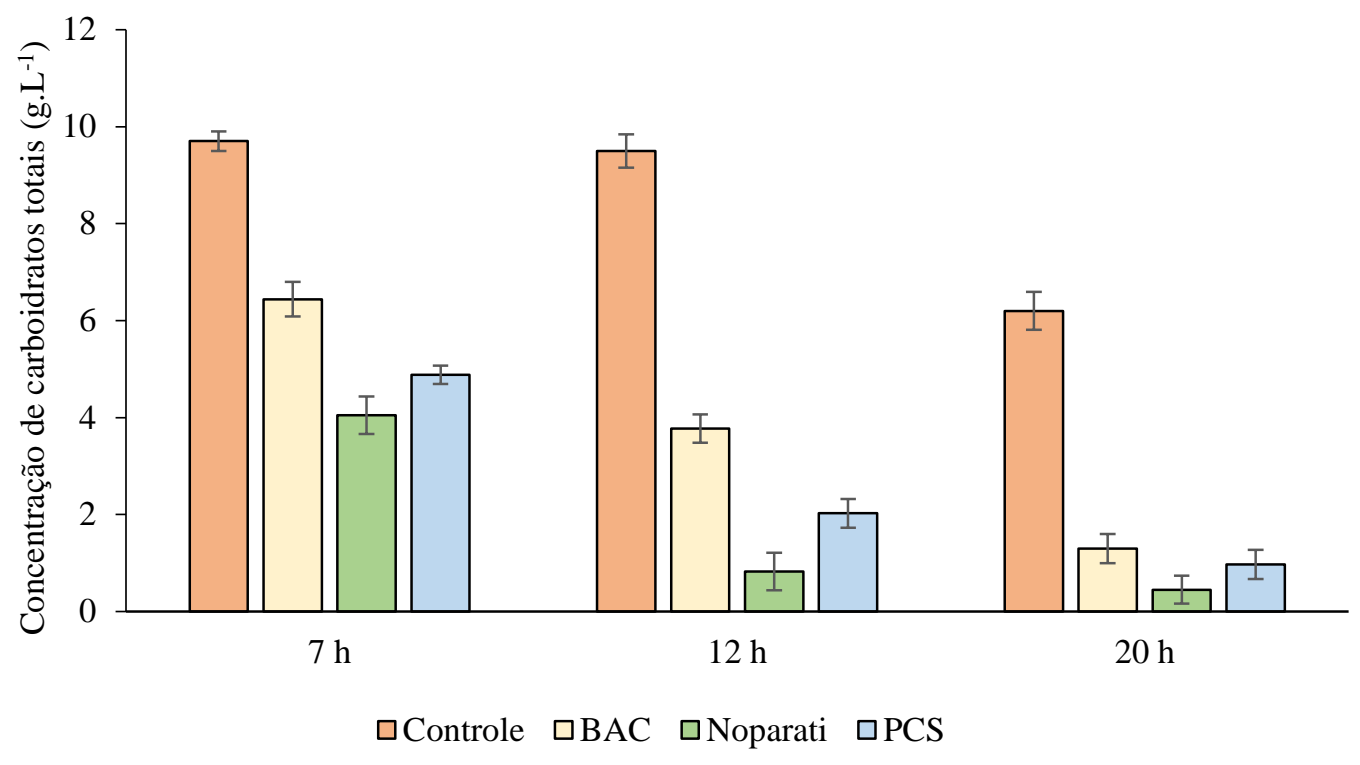

\subsubsection{Avaliação dos metabólitos solúveis nos diferentes meios de cultivo}

$\mathrm{O}$ valor de $\mathrm{pH}$ inicial em todos os ensaios foi ajustado a 6,5, entretanto, no final da fermentação com meios de cultivo verificou-se diminuição significativa dos valores de $\mathrm{pH}$ de 6,5 para cerca de 3,8 (Tabela 5.4), mesmo com adição de componentes tamponantes (Tabela $5.5)$.

$\mathrm{Na}$ ausência de aceptores de elétrons externos, os compostos orgânicos são catabolizados em compostos intermediários ricos em energia durante a hidrólise via fosforilação a nível de substrato (Lukajtis et al., 2018). A concentração e composição dos principais ácidos carboxílicos (AC) produzidos em função dos diferentes ensaios com meios de cultivos ao longo do tempo de operação dos reatores estão ilustrados na Figura 5.10. Dentre os ácidos carboxílicos, observou-se para HLa maiores concentrações (entre 0-2,34 g.L.1), seguido por HAc (entre 0-1,16 g.L $\left.\mathrm{L}^{-1}\right)$ e $\mathrm{HBu}\left(0-0,36\right.$ g. $\left.\mathrm{L}^{-1}\right)$. 
Universidade de São Paulo

Escola de Engenharia de São Carlos

Programa de Pós-graduação em Hidráulica e Saneamento

Figura 5.10. Ácidos carboxílicos ao longo do tempo nos ensaios com reatores em batelada com diferentes meios de cultivo.
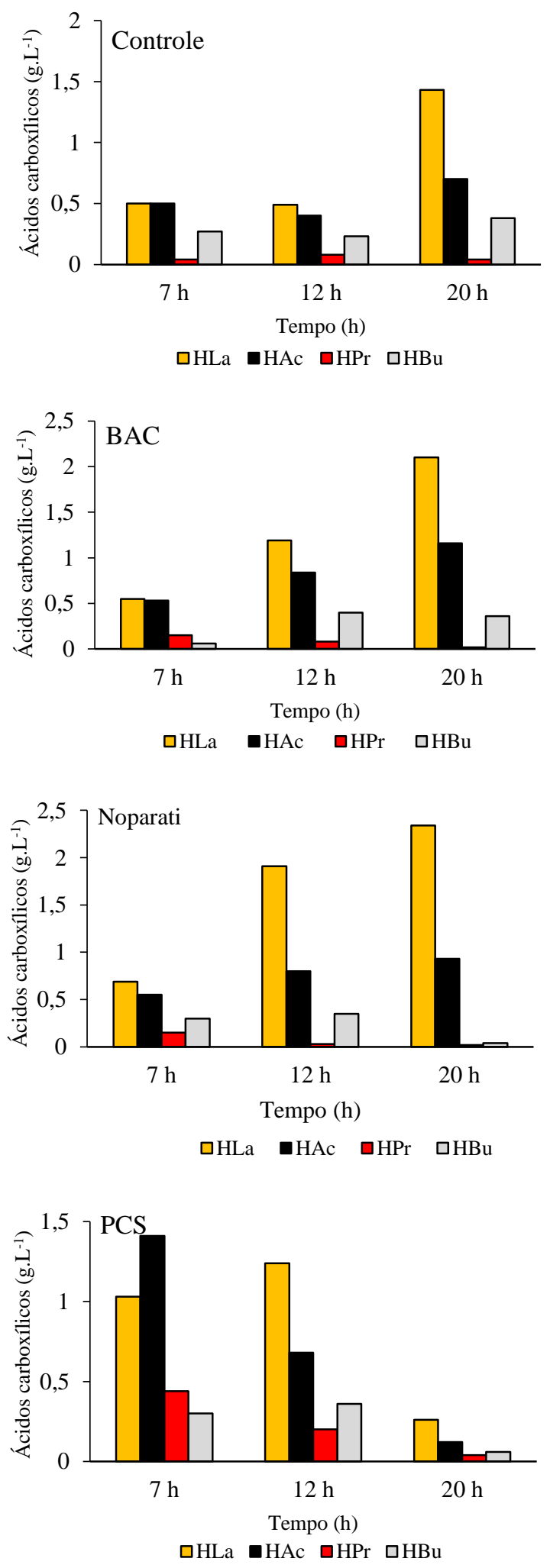

Nota: $\mathrm{HLa}=$ ácido lático, $\mathrm{HAc}=$ ácido acético, $\mathrm{HPr}=$ ácido propiônico, $\mathrm{HBu}=$ ácido butírico 
A produção de AC e solventes foi analisada em ciclos de 7, 12 e 20 horas de operação dos reatores em batelada. Em todos os ensaios a conversão e produção de AC ocorreu logo nas primeiras horas de fermentação, evidenciando atividade das bactérias acidogênicas (BA). Normalmente, as BA têm rápido crescimento, com tempo mínimo de duplicação de cerca de 30 min, convertendo a fração orgânica solúvel do substrato dentro de curto período (Dahiya et al., 2015).

Em relação às 12 primeiras horas de fermentação, verificou-se aumento da concentração de HLa, principalmente nos ensaios com adição de meio de cultivo, sendo este ácido predominante em todos os ensaios. Ocorreu significativa diminuição da concentração de HAc no período de 7 a 12 h no ensaio com meio de cultivo PCS, inferindo que a diminuição deste ácido foi devido a sua conversão em $\mathrm{H}_{2} / \mathrm{e}$ ou outros metabólitos. Por outro lado, para as demais condições dos ensaios (controle, BAC e Noparati) verificou-se aumento da concentração de HAc desde o início até o final da fermentação.

Em relação ao HPr observou-se aumento nas primeiras horas de fermentação, sendo reduzidos a valores $<0,05$ g. $\mathrm{L}^{-1}$ no final da fermentação para todas as condições analisadas. Para o $\mathrm{HBu}$ verificou-se sua produção no decorrer das fermentações, sendo reduzido nos ensaios para as condições nutricionais com meio Noparati e PCS.

A partir dos dados de produção de AC, foi possível calcular o grau de acidificação (GA) (Figura 5.11), que representa a eficiência de formação de ácidos carboxílicos em relação à degradação e convesão do substrato, em termos de DQO, por meio da relação descrita por Amulya et al. (2014). O grau de acidificação foi maior no ensaio com meio de cultivo PCS, seguido por Noparati. Nos ensaios controle e BAC o grau de acidificação observado de 9,08 e $8,94 \%$, respectivamente, foram semelhantes.

É interessante notar que a rota de produção do ácido lático foi a que mais contribuiu no processo de acidificação do meio, principalmente no meio Noparati. Esta rota foi predominante devido à forte influência da composição de uma biomassa ácida lática que fez parte do consórcio bacteriano autóctone. De acordo com Yang et al. (2016) cepas naturais de Lactobacillus são frequentemente isoladas de resíduos de frutos como espécies dominantes, crescendo em baixos valores de $\mathrm{pH}$ e promovendo a fermentação do ácido lático (HLa).

Em contrapartida, verificou-se pouca contribuição do $\mathrm{HAc}$ e $\mathrm{HBu}$, provavelmente, devido a conversão destes ácidos em $\mathrm{H}_{2}$ a partir da via acetogênica e butírica, ambas são termodinamicamente favoráveis, $\Delta \mathrm{G}^{\circ}$ ' $=-206$ e -254 , respectivamente, possibilitando altos rendimentos $\mathrm{H}_{2}$. A conversão dos açúcares solúveis do $\mathrm{RB}$ em ácido propiônico foi baixa, 


\section{Universidade de São Paulo \\ Escola de Engenharia de São Carlos \\ Programa de Pós-graduação em Hidráulica e Saneamento}

portanto sua contribuição no grau de acidificação foi bem reduzida $(<2 \%)$ em todos os ensaios, com maior e menor grau de acidificação nos ensaios com meio Noparati e PCS. Portanto, o grau de acidificação é amplamente influenciado pelo tipo de AGV produzido como consequência do tipo de meio de cultivo utilizado.

Figura 5.11. Grau de acidificação dos ácidos individuais (ácido acético, ácido butírico e ácido propiônico) e total nos ensaios em reatores em batelada com diferentes meios de cultivo.

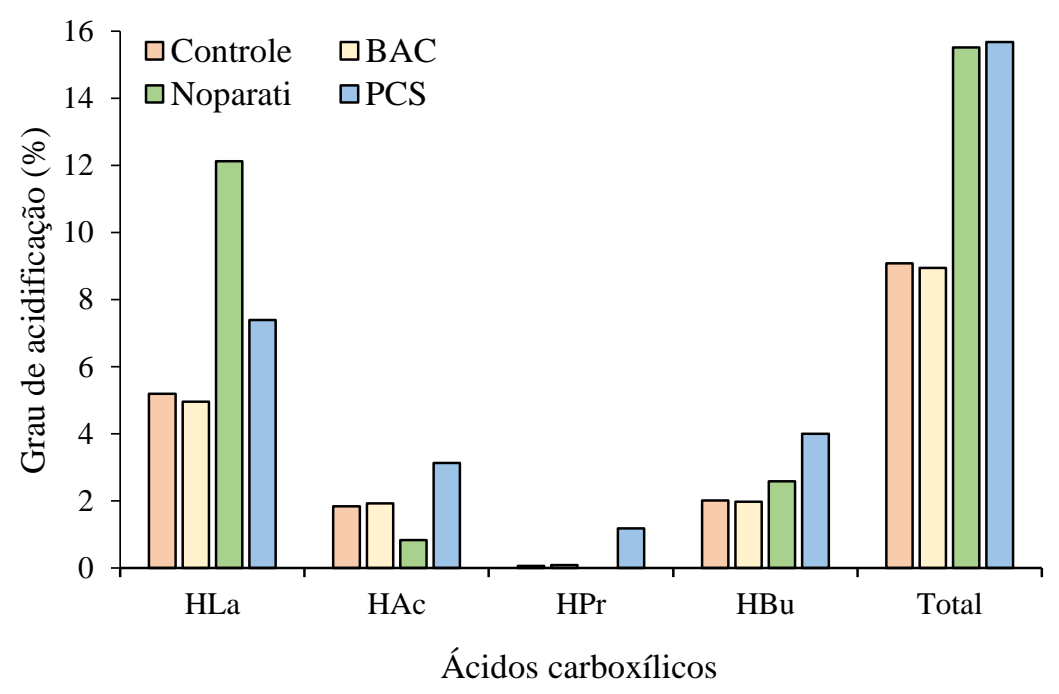

Além da composição do meio de cultivo, a produção de AC é influenciada por muitos fatores, como o pH. O acúmulo de ácidos graxos de cadeia curta acarreta em diminuição do valor de $\mathrm{pH}$, tornando-se tóxico para a biomassa fermentativa principalmente em $\mathrm{pH}$ abaixo de 6 (Hwang et al., 2004). A rápida estabilização da produção de $\mathrm{H}_{2}$ pode ter sido resultante da acidificação do meio, provocada pela mudança de $\mathrm{pH}$, de 6,5 para cerca de 3,8, durante a fermentação e consequentemente redução das atividades metabólicas da biomassa fermentativa. Sendo assim, o acúmulo de ácidos graxos desequilibra o sistema de tamponamento no meio, mesmo com adição inicial de alcalinizantes, resultando na desestabilização do sistema (Dahiya et al., 2015).

O acúmulo de AC, principalmente no final da fermentação, também pode ser explicado pelas características dos micro-organismos. Durante a acetogênese, os AC são convertidos em ácido acético e $\mathrm{H}_{2}$ seguido pela metanogênese, onde o ácido acético, $\mathrm{H}_{2}$ e $\mathrm{CO}_{2}$ são convertidos em $\mathrm{CH}_{4}$ e $\mathrm{H}_{2} \mathrm{O}$ em faixa de $\mathrm{pH}$ entre 6,8-7,2 por arqueias acetoclásticas e hidrogenotróficas (Lettinga et al., 1996). No entanto, nesta pesquisa não foi observada nenhuma atividade metanogênica durante o tempo de operação dos reatores nos diferentes ensaios com meio de 
cultivo, deste modo, pode se inferir que houve acúmulo de sub-produtos da fermentação, em vista que na ausência das arqueias metanogênicas não há remoção de grande quantidade de carbono convertido em outros metabólitos (Dahiya et al., 2015).

De modo geral, a diferença na composição dos meios de cultivo influenciou significativamente a síntese e o perfil dos ácidos carboxílicos. De acordo com Djellouli et al. (2017) o ácido láctico e acético foram os principais produtos do processo de fermentação suplementados com fontes de nitrogênio. A contribuição de extrato de levedura ainda não foi consolidada, mas de algum modo fornece importante papel no processo de fermentação, fornecendo nitrogênio, elementos minerais, aminoácidos e/ou vitaminas para o crescimento de bactérias (Soares et al., 2018).

\subsubsection{Avaliação estatística}

Para comparar graficamente mais de um conjunto de dados com respeito à média, à dispersão e à distribuição, foi utilizado o Box plot (Figura 5.12). A partir da análise do gráfico Box Plot, verificou-se que no ensaio controle obteve-se menor dispersão dos dados e produção de hidrogênio, até 1,43 mL. Todavia, nos ensaios adicionando-se meios de cultivo observou-se valores de até $15,48 \mathrm{~mL}$.

Figura 5.12. Variação da produção de hidrogênio $(\mathrm{mL})$ para os diferentes meios de cultivo dos reatores em batelada.

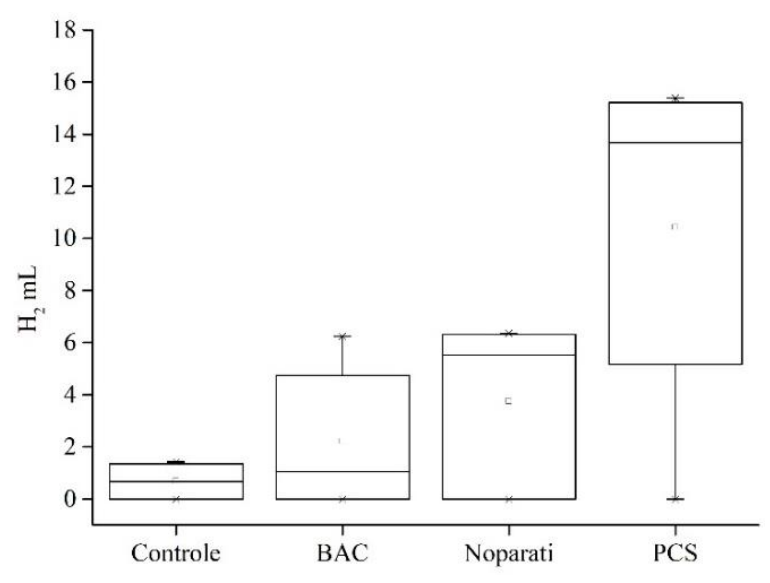

No ensaio utilizando meio de cultivo PCS obteve-se maior produção de $\mathrm{H}_{2}$ e dispersão dos dados, sendo que 25 e $50 \%$ dos valores do conjunto de dados da produção de $\mathrm{H}_{2}$ são correspondentes a concentrações inferiores e superiores a $4,5 \mathrm{~mL}$, respectivamente. Para o conjunto de dados observados, somente para as condições do ensaio controle observou-se distribuição simétrica, enquanto para os demais obteve-se distribição assimétrica. Nas 


\section{Universidade de São Paulo \\ Escola de Engenharia de São Carlos \\ Programa de Pós-graduação em Hidráulica e Saneamento}

condições do meio BAC observou-se resultados positivamente assimétricos, enquanto para os meios com meio Noparati e PCS foram negativamente assimétricos.

Devido a sobreposição de dados, verificou-se a necessidade da aplicação do teste de hipóteses para verificar se o controle e os ensaios utilizando diferentes meios de cultivo diferiram entre si, ou seja, se a adição de meio de cultivo ao substrato (resíduo de banana) favoreceu a produção de $\mathrm{H}_{2}$ durante a fermentação.

Antes de iniciar as análises estatísticas deve-se elaborar a hipótese nula a ser testada. A primeira hipótese refere-se para o teste de normalidade, como segue: $\mathrm{H}_{0}$ : A distribuição dos dados é normal e $\mathrm{H}_{1}$ : A distribuição dos dados não é normal. Deste modo, foram plotados os gráficos quantil-quantil (Q-Q Plot) (Figura 5.13), por meio do qual verifica-se visualmente se os valores $y 1, y 2 \ldots \ldots y n$, neste caso, os valores da produção de $\mathrm{H}_{2}$ obtida a partir da cinética, tem distribuição normal.

Figura 5.13. Quantil-quantil (Q-Q plot) da normal do conjunto de dados para as diferentes condições nutricionais dos meios de cultivo dos reatores em batelada.
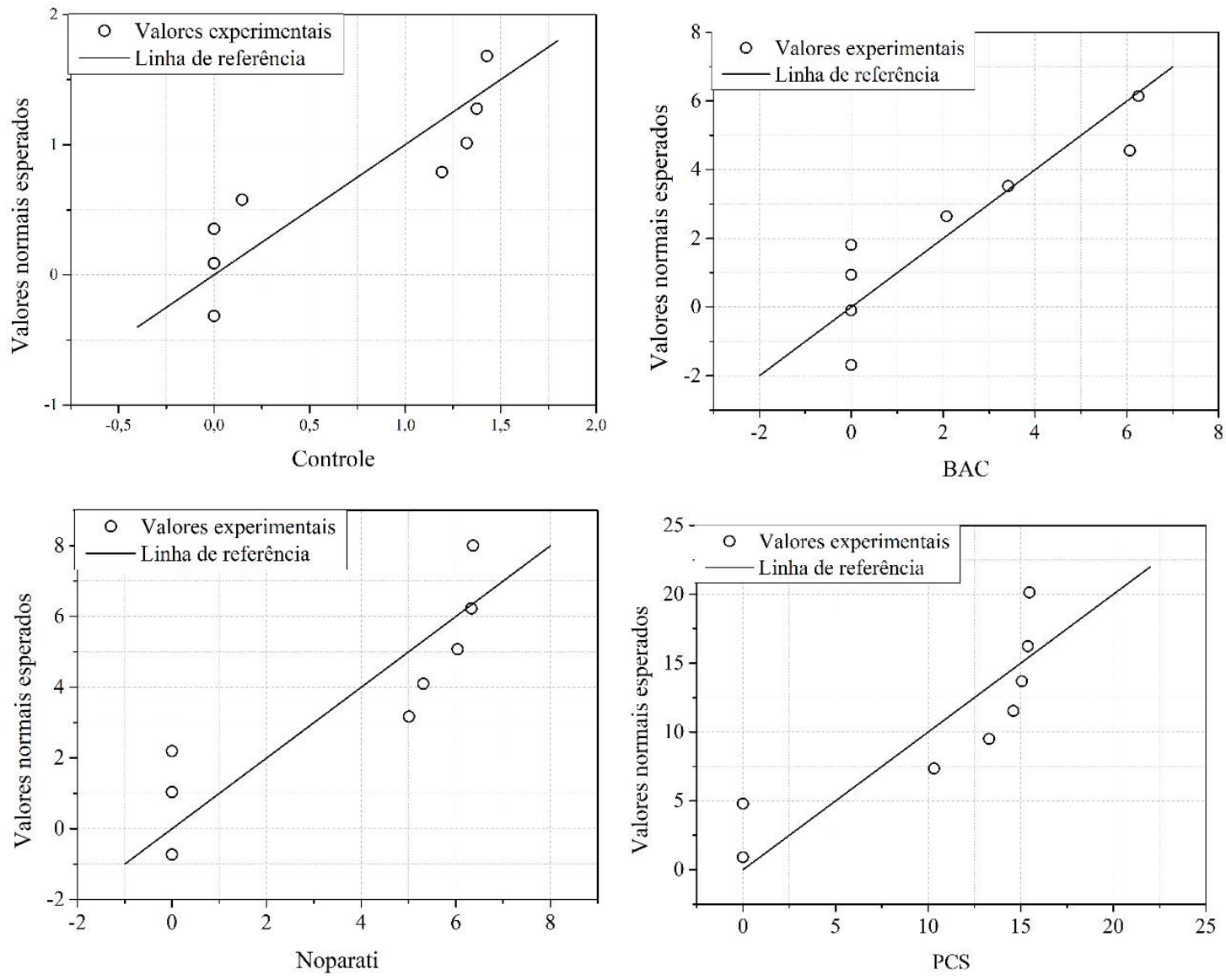
Se os dados obtidos de fato seguissem a distribuição normal os pontos da Figura 5.13 ficariam próximos a linha reta, no entanto, não se obteve essa premissa. Sendo assim, rejeitouse $\mathrm{H}_{0}$ e assumiu-se que os conjuntos de dados obtidos foram não-normais. Quando a premissa de normalidade não é satisfeita, não deve ser aplicado testes paramétricos. Deste modo, tem-se duas alternativas: $1^{\circ}$ tranformação dos dados e $2^{\circ}$ aplicação de teste não-paramétricos. Neste caso, optou-se por transformar os dados utilizando log $(x+1)$, como apresentados na Tabela 5.6 .

Tabela 5.6. Transformação dos dados utilizando $\log (x+1)$

\begin{tabular}{cccccccc}
\hline \multicolumn{2}{c}{ CONTROLE } & \multicolumn{2}{c}{ BAC } & \multicolumn{2}{c}{ NO } & \multicolumn{2}{c}{ PCS } \\
$\begin{array}{c}\mathrm{H}_{2} \mathrm{~mL} \\
(\mathrm{x})\end{array}$ & $\log (x+1)$ & $\begin{array}{c}\mathrm{H}_{2} \mathrm{~mL} \\
(\mathrm{x})\end{array}$ & $\log (x+1)$ & $\begin{array}{c}\mathrm{H}_{2} \mathrm{~mL} \\
(\mathrm{x})\end{array}$ & $\log (x+1)$ & $\begin{array}{c}\mathrm{H}_{2} \mathrm{~mL} \\
(\mathrm{x})\end{array}$ & $\log (x+1)$ \\
\hline 0,00 & 0,00 & 0,00 & 0,00 & 0,00 & 0,00 & 0,00 & 0,00 \\
0,00 & 0,00 & 0,00 & 0,00 & 0,00 & 0,00 & 0,00 & 0,00 \\
0,00 & 0,00 & 0,00 & 0,00 & 0,00 & 0,00 & 10,32 & 1,05 \\
0,15 & 0,06 & 0,00 & 0,00 & 5,01 & 0,78 & 13,29 & 1,16 \\
1,19 & 0,34 & 2,08 & 0,49 & 6,33 & 0,87 & 15,48 & 1,22 \\
1,38 & 0,38 & 3,42 & 0,65 & 6,37 & 0,87 & 14,60 & 1,19 \\
1,32 & 0,37 & 6,25 & 0,86 & 6,04 & 0,85 & 15,06 & 1,21 \\
1,43 & 0,39 & 6,07 & 0,85 & 5,31 & 0,80 & 15,39 & 1,21 \\
\hline
\end{tabular}

Após transformação dos dados, é possível a aplicação de testes paramétricos. A segunda hipótese a ser formulada é: $\mathrm{H}_{0}$ : controle $=\mathrm{BAC}=$ Noparati $=\mathrm{PCS}$ e $\mathrm{H}_{1}$ : pelo menos uma das médias é diferente. De acordo com o teste ANOVA, o valor de $p=0,05$ foi menor que o erro padrão $(p<0,05)$, portanto, rejeitou-se $\mathrm{H}_{0}$, e assumiu-se que a produção de hidrogênio foi maior ou menor para alguma ou para algumas das condições nutricionais dos meios de cultivo avaliados $(\alpha=95 \%)$. Portanto, pode-se concluir previamente que houve diferença significativa entre as condições nutricionais dos meios de cultivo avaliados na produção de $\mathrm{H}_{2}$. Ao rejeitar $\mathrm{H}_{0}$, deve-se executar os testes à posteriori para indicar qual é o melhor meio de cultivo. Neste caso, foi aplicado o teste de Tukey, assumindo que a premissa foi aceita e que os dados são paramétricos. 


\section{Universidade de São Paulo \\ Escola de Engenharia de São Carlos \\ Programa de Pós-graduação em Hidráulica e Saneamento}

De acordo com o teste de Tukey pode-se afirmar que dentre as 4 condições nutricionais dos meios de cultivo avaliados, somente aquela do meio de cultivo PCS foi estatisticamente significativa $(p \leq 0,05)$ e a produção de $\mathrm{H}_{2}$ nestas condições diferiu das demais avaliadas (Controle, BAC e Noparati). Deste modo, concluiu-se que as condições nutricionais do meio PCS foram as mais favoráveis para compor o meio reacional para obtenção de $\mathrm{H}_{2}$ utilizando resíduo de banana como fonte de carbono, sendo este meio utilizado nos ensaios subsequentes.

\subsubsection{Análise Microbiológica}

Como visto anteriormente, as condições nutricionais do meio cultivo PCS foram consideradas as mais apropriadas para compor o meio reacional dos reatores, em vista que proporcionou melhor produção de $\mathrm{H}_{2}$, quando comparado aos demais meios de cultivo. Afim de comparar morfologicamente as bactérias presentes no consórcio microbiano, antes (fermentação natural) e depois da fermentação com adição do meio de cultivo PCS, foi realizada análise de microscopia óptica comum e técnica de coloração de Gram. Em ambas as amostras, pôde-se observar a presença de cocos e predominância de bacilos simples e em cadeias com dimensões variadas, e endósporos terminais (Figura 5.14 A-D). No entanto, para a amostra dos reatores em batelada com meio de cultivo PCS (Figura 5.14 C-D), observou-se predomínio de endósporos terminais, além de bacilos em cadeias mais longas formando filamentos.

Além dessas diferenças morfológicas, verificou-se também bacilos Gram positivos e Gram negativos em ambas as amostras (Figura 5.15). Entretanto, após enriquecimento com meio de cultivo PCS, verificou-se predominância de bacilos Gram positivos (Figura 5.15 B), quando comparado com a amostra correspondente a fermentação natural (Figura 5.15 A).

O enriquecimento do inóculo após adição de meio de cultivo PCS pode ter favorecido o crescimento de alguns tipos de bactérias produtoras de $\mathrm{H}_{2}$, como Clostridium (An et al., 2018), que são bactérias formadores de endósporos e Gram positivas, refletindo no aumento da produção de $\mathrm{H}_{2}$ neste ensaio, cerca de 3 vezes superior, quando comparado à produção de $\mathrm{H}_{2}$ durante a fermentação natural do resíduo de banana. 
Universidade de São Paulo

Escola de Engenharia de São Carlos

Programa de Pós-graduação em Hidráulica e Saneamento

Figura 5.14. Microscopia de luz comum do consórcio de bactérias autóctones obtidos da fermentação natural do resíduo de banana (A-B) e após enriquecimento em meio de cultivo PCS (C-D).

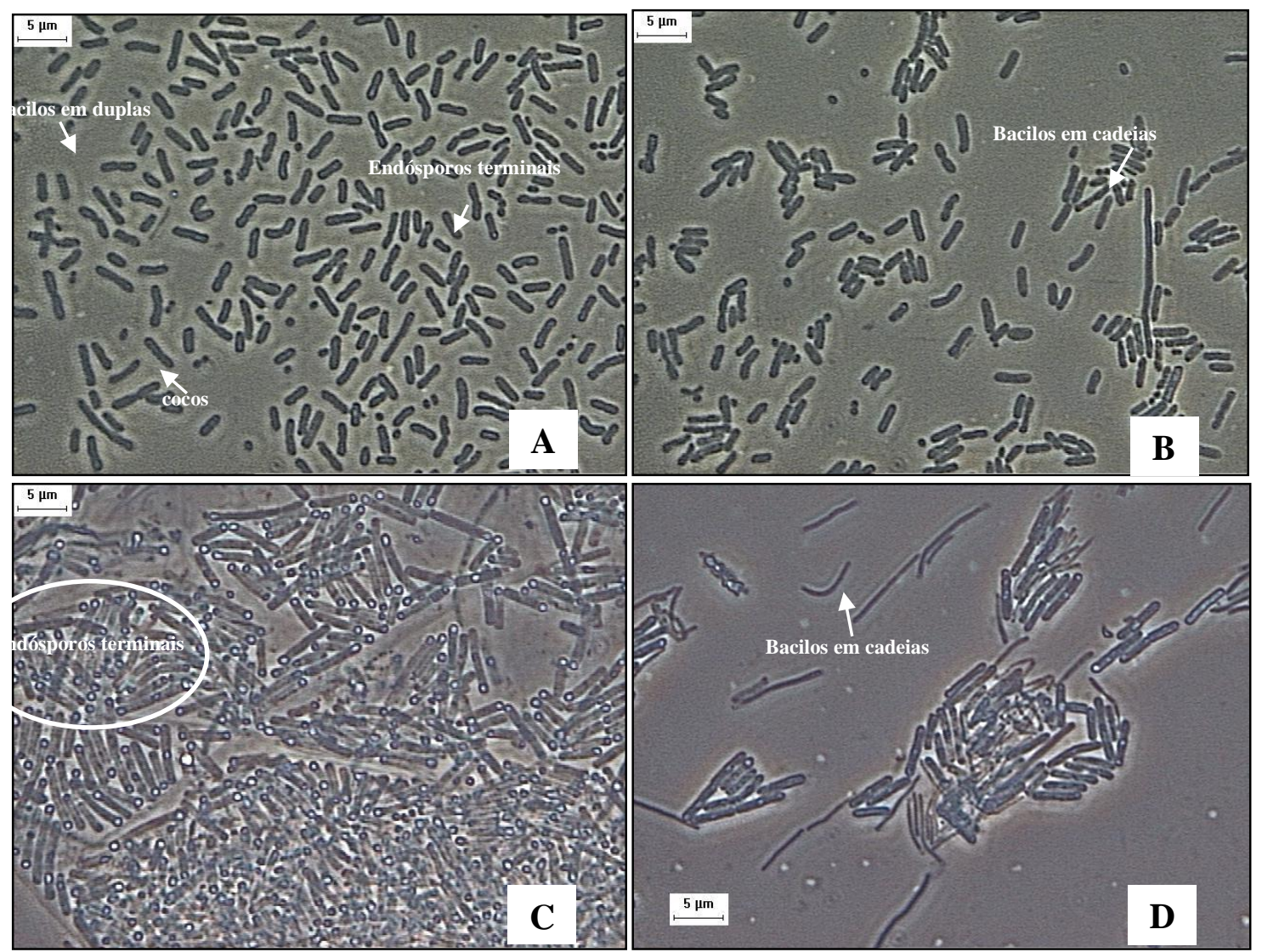

Figura 5.15. Coloração de Gram do consórcio de bactérias autóctones obtidos da fermentação natural do resíduo de banana (A) e após enriquecimento em meio de cultivo PCS (B).

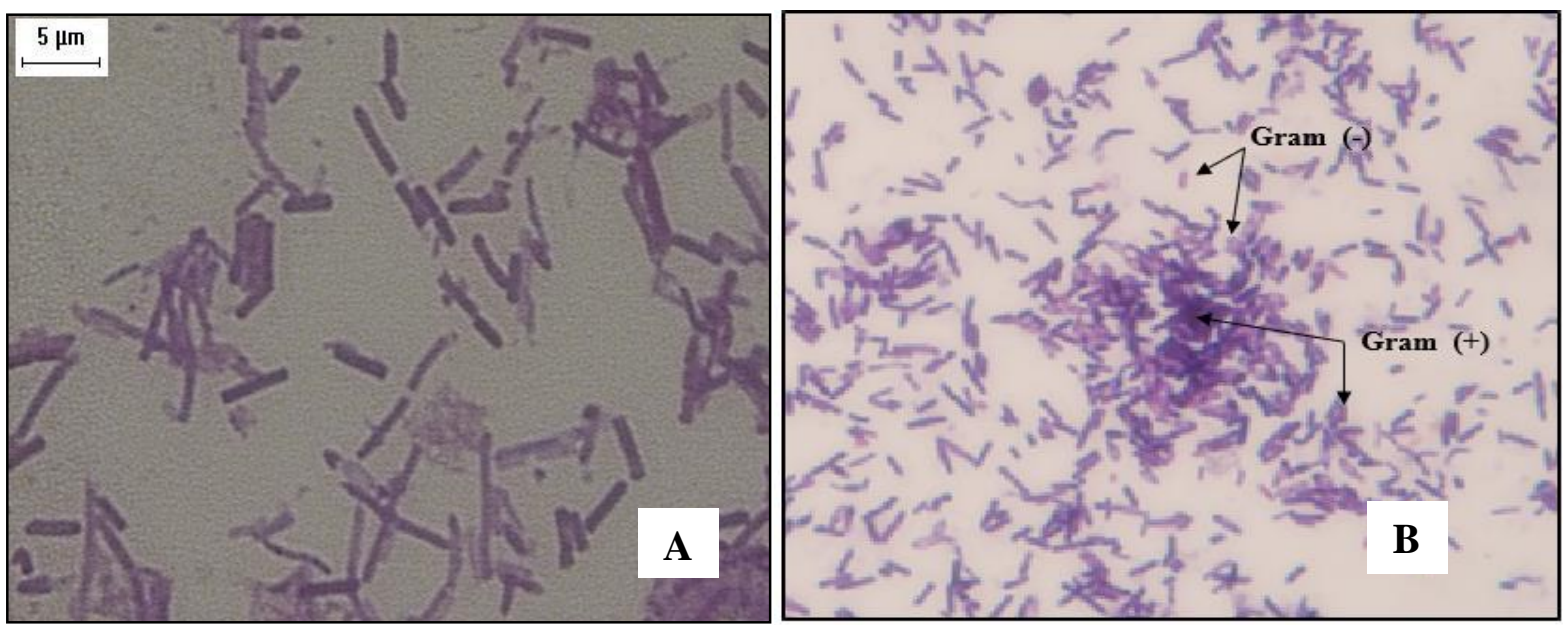




$$
\begin{gathered}
\text { Universidade de São Paulo } \\
\text { Escola de Engenharia de São Carlos } \\
\text { Programa de Pós-graduação em Hidráulica e Saneamento }
\end{gathered}
$$

\subsubsection{Conclusão sub-hipótese 2}

Por meio desta etapa da pesquisa verificou-se que o fornecimento de alguns elementos, como extrato de levedura, peptona, $\mathrm{NaCl}$ e $\mathrm{CaCO}_{3}$ ao resíduo de banana (RB) resultou na produção e rendimento máximo de $\mathrm{H}_{2}$ de $15,05 \mathrm{~mL}$ e $10,03 \mathrm{~mL} \mathrm{H}_{2} \cdot \mathrm{g}^{-1} \mathrm{CT}$ proporcionado pelo crescimento da biomassa fermentativa nestas condições. Pode-se mencionar que adição do meio de cultivo PCS favoreceu o estabelecimento de bactérias produtoras de hidrogênio, semelhantes a Clostridium.

A utilização de apenas resíduo de banana, sem adição de meio de cultivo restringiu o crescimento da biomassa resultando em baixa produção de $\mathrm{H}_{2}$ de $1,37 \mathrm{~mL}$ e na baixa eficiência de conversão de carboidratos totais $\left(\mathrm{C}_{\mathrm{CT}}\right)$ de $38 \%$. No entanto, a utilização de RB como única fonte de carbono foi suficiente para conversão dos carboidratos solúveis a produtos metabólicos como $\mathrm{H}_{2}$ e ácidos carboxílicos, tais como ácido acético, butírico, lático e propiônico. Durante a fermentação observou-se diminuição do valor de $\mathrm{pH}$ de 6,5 para cerca de 3,8 devido à produção de ácidos carboxílicos, nos ensaios com adição de meio cultivo, enquanto para as condições do ensaio controle obteve-se pouca variação do $\mathrm{pH}$ (de 6,5 para 5,8).

A produção de $\mathrm{H}_{2}$ a partir deste tipo de resíduo, sem adição de outra fonte de carbono é um avanço nos processos biológicos que impulsionam a redução do custo associado ao processo. No entanto, a adição de componentes nutricionais auxilia no crescimento da biomassa e consequentemente favorecem a produção de $\mathrm{H}_{2}$. Deste modo, a segunda sub-hipótese elencada “A adição de componentes nutricionais ao resíduo de banana pode influenciar o metabolismo bacteriano e consequentemente aumentar a produção de hidrogênio." pode ser confirmada, em vista que os valores de produção de $\mathrm{H}_{2}$ obtidos foram estatisticamente diferentes, demonstrando que a diferença da composição dos meios de cultivo influenciou a atividade hidrogenogênica nos reatores em batelada.

\subsection{Avaliação dos efeitos das variáveis independentes}

Devido à diversidade de fatores que influenciam o processo fermentativo, buscou-se primeiramente avaliar os efeitos das variáveis que influenciam o processo e identificar as possíveis relações entre a produção de hidrogênio, ácidos orgânicos, etanol e comunidade bacteriana.

Neste sentido, por meio da aplicação do delineamento experimental Plackett-Burman (PB) pode-se calcular o efeito de cinco variáveis independentes, incluindo $\mathrm{pH}$, concentração de 
carboidratos totais $\left(\mathrm{g} . \mathrm{L}^{-1}\right)$, temperatura $\left({ }^{\circ} \mathrm{C}\right)$, volume de headspace $(\% \mathrm{v} / \mathrm{v})$ e inóculo $(\% \mathrm{p} / \mathrm{v})$ na fermentação de resíduos de banana a partir de biomassa autóctone enriquecida com meio de cultivo. O uso da concentração de carboidratos totais (CT) como parâmetro, é porque a produção de $\mathrm{H}_{2}$ a partir de processos fermentativos ocorre principalmente a partir de substratos ricos em carboidratos (Alibardi e Cossu, 2015; Rafieenia et al., 2017;) e ainda, o tipo e concentração dos carboidratos predominantes pode estabelecer condições específicas e, consequentemente, favorecer determinadas bactérias e rotas metabólicas (Lima et al. 2013).

Na Tabela 5.7 estão apresentados os valores médios, efeitos principais e erro padrão para as variáveis respostas. O número entre parênteses do valor t foi igual a 9 graus de liberdade, ou seja, 15 ensaios menos 6 informações determinadas (5 efeitos + média). Afim de minimizar o risco de excluir da etapa seguinte algum fator importante para o processo, foram considerados significativos os parâmetros com valores $p$ - menores que $10 \%(\mathrm{p}<0,1)$ para seleção das variáveis.

Os valores das respostas referentes à produção máxima de $\mathrm{H}_{2}(P)$, velocidade de produção $(R m)$, tempo de início da produção $\left(\lambda \mathrm{H}_{2}\right)$, eficiência de conversão de carboidratos totais $\left(\mathrm{EC}_{\mathrm{CT}}\right)$ e rendimento de hidrogênio $\left(\mathrm{YH}_{2}\right)$ frente ao delineamento Plakett-Burman estão apresentados na Tabela 5.8.

Em geral, o tempo de início de produção de $\mathrm{H}_{2}\left(\lambda \mathrm{H}_{2}\right)$ foi nas primeiras horas de fermentação, variando entre 2,6 e 9,8 horas, com produção máxima em torno de 18 h e estabilização em 30 horas de operação (Figura 5.16). A produção máxima de $\mathrm{H}_{2}(P)$ e velocidade de produção $(R m)$ dentro da faixa avaliada para as variáveis estudadas foram de 6,32 a 38,08 mL e de 1,5 a 4,54 mL.h ${ }^{-1}$, respectivamente. Em relação a eficiência de conversão de carboidratos $\left(\mathrm{EC}_{\mathrm{CT}}\right)$ e rendimento de hidrogênio $\left(\mathrm{YH}_{2}\right)$ observou-se valores mínimo e máximos para os 15 ensaios entre 49,9-96,6\% e 3,2-104 $\mathrm{mL} \mathrm{H}_{2} \mathrm{~g}^{-1} \mathrm{CT}$, respectivamente.

\subsection{1. $\mathrm{pH}$}

Observou-se para produção máxima de $\mathrm{H}_{2}$ valores entre 31,01-38,08 mL em pH 7,5 e valores inferiores, entre 6,32 e $29 \mathrm{~mL}$ para faixa de $\mathrm{pH}$ entre 5,5 e 6,5. Do mesmo modo, verificou-se para a velocidade máxima de produção de $\mathrm{H}_{2}$ aumento de 1,50 para 4,54 mL.h ${ }^{-1}$ nos ensaios cujo $\mathrm{pH}$ inicial era de 5,5 e 7,5, respectivamente. Portanto, o aumento do $\mathrm{pH}$ de 5,5 para 7,5 resultou nos valores máximos de $P$ e $R m$ de $38,08 \mathrm{~mL}$ e 4,54 mL.h ${ }^{-1}$ nos ensaios E6 e E1, respectivamente. 
Tabela 5.7. Análise dos efeitos para as variáveis respostas do planejamento Plackett-Burman (PB).

\begin{tabular}{|c|c|c|c|c|c|c|c|}
\hline \multicolumn{2}{|c|}{ Variáveis Respostas } & Média & pH & $\underset{\left(\mathrm{g} . \mathrm{L}^{-1}\right)}{\mathbf{C T}}$ & $\begin{array}{c}\text { Temperatura } \\
\left({ }^{\circ} \mathrm{C}\right)\end{array}$ & $\begin{array}{c}\text { Headspace } \\
(\%)\end{array}$ & $\begin{array}{c}\text { Inóculo } \\
(\%)\end{array}$ \\
\hline \multirow{4}{*}{$\underset{\mathrm{mL}}{P}$} & Efeito & 21,68 & 12,44 & $-3,90$ & $-6,71$ & $-12,54$ & $-0,73$ \\
\hline & e.p & 1,53 & 3,07 & 3,07 & 3,07 & 3,07 & 3,07 \\
\hline & $t(9)$ & 14,14 & 2,25 & $-1,27$ & $-2,19$ & $-4,09$ & $-0,24$ \\
\hline & $p$-valor & 0,000 & 0,0546 & 0,2391 & 0,0602 & $\mathbf{0 , 0 0 3 5}$ & 0,8175 \\
\hline \multirow{4}{*}{$\underset{\mathbf{m L} \cdot \mathbf{h}^{-1}}{\mathbf{R m}}$} & Efeito & 6,25 & 0,98 & $-0,55$ & $-0,35$ & $-0,93$ & $-0,23$ \\
\hline & e.p & 0,22 & 0,45 & 0,45 & 0,45 & 0,45 & 0,45 \\
\hline & $t(9)$ & 14,49 & 2,18 & $-1,22$ & $-0,79$ & $-2,07$ & $-0,51$ \\
\hline & $p$-valor & 0,0000 & 0,0610 & 0,2574 & 0,4533 & 0,725 & 0,6267 \\
\hline \multirow{4}{*}{$\underset{h}{\lambda \mathbf{H}_{2}}$} & Efeito & 6,85 & 1,14 & $-0,71$ & $-3,53$ & $-0,76$ & $-1,33$ \\
\hline & e.p & 0,19 & 0,38 & 0,38 & 0,38 & 0,38 & $-3,45$ \\
\hline & $t(9)$ & 35,62 & 2,98 & $-1,84$ & $-9,18$ & $-1,98$ & $-6,26$ \\
\hline & $p$-valor & 0,0000 & $\mathbf{0 , 0 1 7 7}$ & 0,1027 & 0,0000 & 0,0829 & 0,0086 \\
\hline \multirow{4}{*}{$\begin{array}{c}\mathbf{E} C_{\mathbf{C T}} \\
\%\end{array}$} & Efeito & 78,37 & $-10,57$ & $-27,86$ & 15,59 & $-2,57$ & 3,07 \\
\hline & e.p & 3,11 & 6,21 & 6,21 & 6,21 & 6,21 & 6,21 \\
\hline & $t(9)$ & 25,24 & $-1,70$ & $-4,49$ & 2,51 & $-0,41$ & 0,49 \\
\hline & $p$-valor & 0,0000 & 0,1271 & 0,0020 & 0,0364 & 0,6903 & 0,6348 \\
\hline \multirow{4}{*}{$\begin{array}{c}\mathbf{Y H} \\
\mathbf{m L} / \mathrm{gCT}_{\text {add }}\end{array}$} & Efeito & 35,63 & 15,39 & $-49,88$ & $-9,03$ & $-11,71$ & $-4,60$ \\
\hline & e.p & 1,87 & 3,75 & 3,75 & 3,75 & 3,75 & 3,75 \\
\hline & $t(9)$ & 19,02 & 4,11 & $-13,32$ & $-2,41$ & $-3,13$ & $-1,23$ \\
\hline & $p$-valor & 0,0000 & 0,0034 & 0,0000 & 0,0425 & 0,0141 & 0,2542 \\
\hline \multirow{4}{*}{$\begin{array}{l}\text { HAc } \\
\text { g.L }{ }^{-1}\end{array}$} & Efeito & 0,26 & $-0,04$ & $-0,02$ & 0,23 & 0,04 & $-0,19$ \\
\hline & e.p & 0,06 & 0,12 & 0,12 & 0,12 & 0,12 & 0,12 \\
\hline & $t(9)$ & 4,44 & $-0,39$ & $-0,13$ & 1,96 & 0,36 & $-1,61$ \\
\hline & $p$-valor & 0,0022 & 0,7097 & 0,9009 & 0,0860 & 0,7302 & 0,1451 \\
\hline \multirow{4}{*}{$\begin{array}{c}\text { HLac } \\
\text { g.L. }\end{array}$} & Efeito & 1,31 & $-1,09$ & 1,34 & 0,34 & $-0,01$ & 0,05 \\
\hline & e.p & 0,20 & 0,40 & 0,40 & 0,40 & 0,40 & 0,40 \\
\hline & $t(9)$ & 6,57 & $-2,72$ & 3,34 & 0,84 & $-0,04$ & 0,13 \\
\hline & $p$-valor & 0,0002 & 0,0261 & 0,0102 & 0,4264 & 0,9710 & 0,9040 \\
\hline \multirow{4}{*}{$\begin{array}{l}\text { HBu } \\
\text { g.L } L^{-1}\end{array}$} & Efeito & 0,50 & 0,55 & 0,62 & $-0,25$ & 0,20 & 0,42 \\
\hline & e.p & 0,21 & 0,43 & 0,43 & 0,43 & 0,43 & 0,43 \\
\hline & $t(9)$ & 2,35 & 1,28 & 1,45 & $-0,59$ & 0,46 & 0,98 \\
\hline & $p$-valor & 0,0468 & 0,2360 & 0,1844 & 0,5727 & 0,6554 & 0,3570 \\
\hline \multirow{4}{*}{$\begin{array}{l}\text { HPr } \\
\text { g.L.-1 }\end{array}$} & Efeito & 0,06 & 0,07 & $-0,03$ & $-0,05$ & 0,03 & $-0,03$ \\
\hline & e.p & 0,02 & 0,04 & 0,04 & 0,04 & 0,04 & 0,04 \\
\hline & $t(9)$ & 2,85 & 1,79 & $-0,73$ & $-1,22$ & 0,65 & $-0,65$ \\
\hline & $p$-valor & 0,0215 & 0,1111 & 0,4846 & 0,2568 & 0,5331 & 0,5331 \\
\hline \multirow{4}{*}{$\begin{array}{c}\text { Etanol } \\
\text { g. } \mathbf{L}^{-1}\end{array}$} & Efeito & 0,25 & $-0,21$ & 0,14 & 0,22 & 0,04 & 0,00 \\
\hline & e.p & 0,03 & 0,06 & 0,06 & 0,06 & 0,06 & 0,06 \\
\hline & $t(9)$ & 8,79 & $-3,61$ & 2,43 & 3,79 & 0,71 & $-0,02$ \\
\hline & $p$-valor & 0,0000 & 0,0069 & 0,0410 & $\mathbf{0 , 0 0 5 3}$ & 0,4995 & 0,9865 \\
\hline
\end{tabular}

Nota: $P$ = produção máxima de $\mathrm{H}_{2}, R m=$ velocidade de produção de $\mathrm{H}_{2}, \lambda \mathrm{H}_{2}=$ tempo de início da produção de $\mathrm{H}_{2}, \mathrm{EC}_{\mathrm{CT}}=$ eficiência de conversão de carboidratos totais, $\mathrm{YH}_{2}=$ rendimento de hidrogênio, $\mathrm{HAc}=$ ácido acético, $\mathrm{HLac}=$ ácido lático, $\mathrm{HBu}=$ ácido butírico, $\mathrm{HPr}=$ ácido propiônico. e.p = erro padrão 
Universidade de São Paulo

Escola de Engenharia de São Carlos

Programa de Pós-graduação em Hidráulica e Saneamento

Tabela 5.8. Variáveis respostas da fermentação de resíduo de banana com biomassa autóctone para o Delineamento Plackett-Burman (PB) para os 15 ensaios em reatores em batelada.

\begin{tabular}{|c|c|c|c|c|c|c|c|c|c|c|}
\hline Ensaios & pH & $\begin{array}{c}\text { Concentração } \\
\text { Carboidratos totais } \\
(\text { g...-1) }\end{array}$ & $\begin{array}{c}\text { Temperatura } \\
\left({ }^{\circ} \mathrm{C}\right)\end{array}$ & $\begin{array}{c}\text { Headspace } \\
(\%)\end{array}$ & $\begin{array}{c}\text { Inóculo } \\
(\%)\end{array}$ & $\begin{array}{c}P \\
\mathbf{m L}\end{array}$ & $\underset{\mathrm{mL} \cdot \mathrm{h}^{-1}}{\mathrm{Rm}}$ & $\begin{array}{c}\lambda \mathbf{H}_{2} \\
\text { (h) }\end{array}$ & $\begin{array}{l}\mathrm{C}_{\mathrm{CT}} \\
(\%)\end{array}$ & $\underset{\left(\mathrm{mL} \mathrm{g} \mathrm{g}^{-1} \mathrm{CT}_{\text {add }}\right)}{\text { Rendimento } \mathrm{H}_{2}}$ \\
\hline 1 & 7,5 & 3 & 44 & 40 & 5 & 31,01 & 4,54 & 6,8 & 91,8 & 103,0 \\
\hline 2 & 7,5 & 15 & 30 & 60 & 5 & 20,60 & 2,49 & 8,3 & 96,6 & 9,0 \\
\hline 3 & 5,5 & 15 & 44 & 40 & 15 & 6,32 & 2,47 & 4,03 & 90,3 & 4,2 \\
\hline 4 & 7,5 & 3 & 44 & 60 & 5 & 19,12 & 3,44 & 6,78 & 94,2 & 41,8 \\
\hline 5 & 7,5 & 15 & 30 & 60 & 15 & 21,43 & 4,37 & 8,57 & 50,0 & 9,6 \\
\hline 6 & 7,5 & 15 & 44 & 40 & 15 & 38,08 & 3,07 & 4,28 & 62,0 & 26,0 \\
\hline 7 & 5,5 & 15 & 44 & 60 & 5 & 6,42 & 2,01 & 4,72 & 88,2 & 3,0 \\
\hline 8 & 5,5 & 3 & 44 & 60 & 15 & 9,03 & 2,89 & 3,89 & 90,2 & 19,4 \\
\hline 9 & 5,5 & 3 & 30 & 60 & 15 & 15,87 & 1,50 & 6,54 & 93,0 & 35,1 \\
\hline 10 & 7,5 & 3 & 30 & 40 & 15 & 37,18 & 4,50 & 9,79 & 93,7 & 123,9 \\
\hline 11 & 5,5 & 15 & 30 & 40 & 5 & 25,55 & 3,43 & 9,06 & 49,3 & 17,6 \\
\hline 12 & 5,5 & 3 & 30 & 40 & 5 & 29,60 & 4,25 & 9,41 & 90,6 & 98,6 \\
\hline 13 & 6,5 & 9 & 37 & 50 & 10 & 29,37 & 2,54 & 4,83 & 93,2 & 13,9 \\
\hline 14 & 6,5 & 9 & 37 & 50 & 10 & 29,34 & 2,90 & 4,48 & 94,4 & 13,3 \\
\hline 15 & 6,5 & 9 & 37 & 50 & 10 & 29,49 & 3,15 & 4,10 & 87,64 & 13,3 \\
\hline
\end{tabular}

Notas: $P=$ produção máxima de $\mathrm{H}_{2}, R m=$ velocidade de produção de $\mathrm{H}_{2}, \lambda \mathrm{H}_{2}=$ tempo de início da produção de $\mathrm{H}_{2}$, $\mathrm{C}_{\mathrm{CT}}=$ eficiência de conversão de carboidratos totais, Y $\mathrm{H}_{2}$ $=$ rendimento de hidrogênio. 
Figura 5.16. Produção temporal de hidrogênio a partir do delineamento experimental PlackettBurman (PB) na fermentação de resíduos de banana em reatores em batelada.
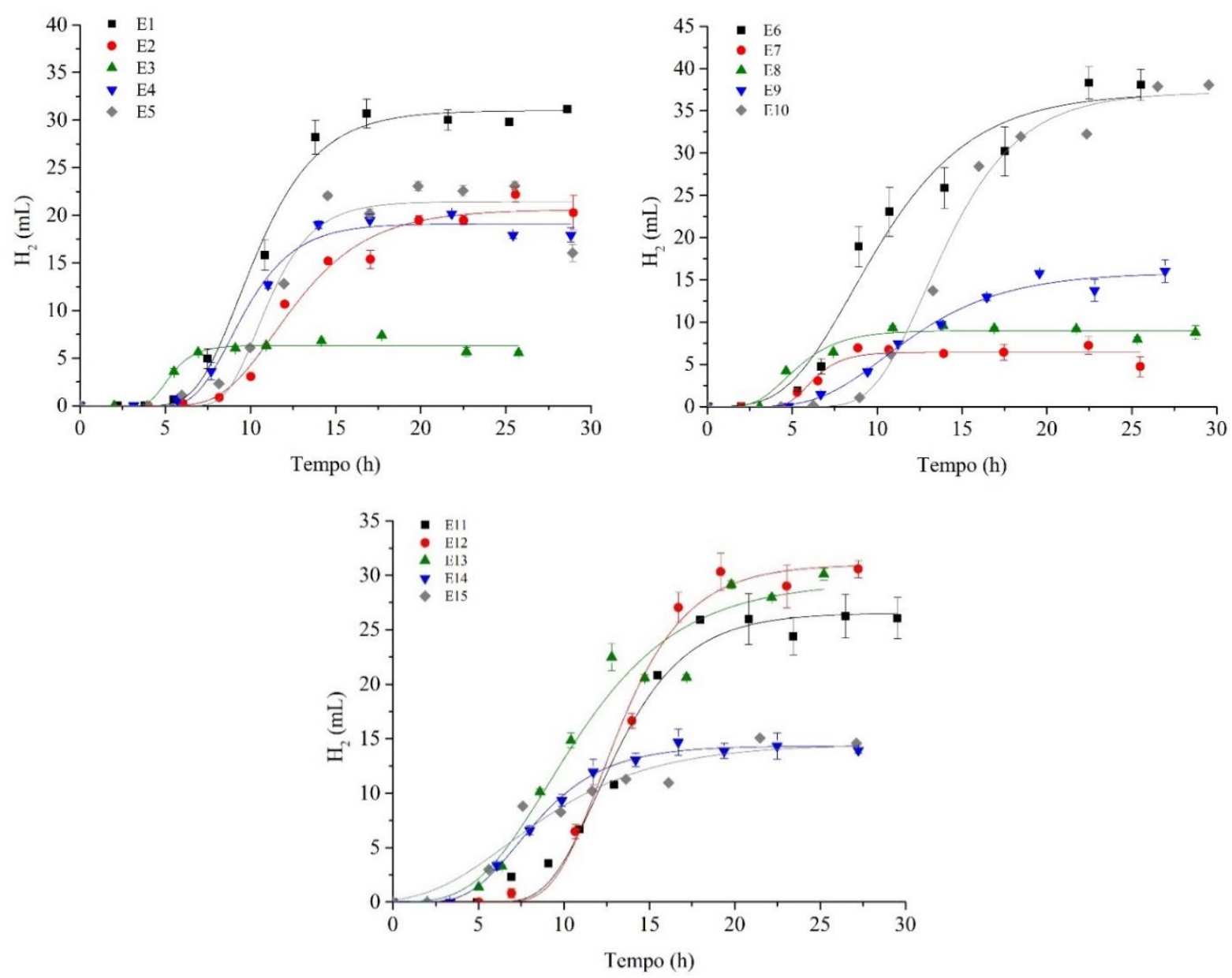

Nota: $\mathbf{E 1}=$ pH 7,5, CT 3 g.L $\mathrm{L}^{-1}, 44^{\circ} \mathrm{C}$, headspace 40\%, inóculo 5\%; $\mathbf{2} 2=$ pH 7,5, CT 15 g.L.-1 , 30 ${ }^{\circ} \mathrm{C}$, headspace 60\%, inóculo 5\%; E3 = pH 5,5, CT 15 g.L $\mathrm{L}^{-1}, 44^{\circ} \mathrm{C}$, headspace 40\%, inóculo 15\%; $\mathbf{E 4}=7,5$, CT 3 g.L. $\mathrm{L}^{-1}, 44^{\circ} \mathrm{C}$, headspace 60\%, inóculo 5\%; $\mathbf{E 5}=\mathrm{pH} 7,5$, CT 15 g.L $\mathrm{L}^{-1}, 30^{\circ} \mathrm{C}$, headspace 60\%, inóculo 15\%; E6 = pH 7,5, CT 15 g.L $\mathrm{L}^{-1}, 44^{\circ} \mathrm{C}$, headspace 40\%, inóculo 15\%; $\mathbf{E} 7=\mathrm{pH} 5,5, \mathrm{CT} 15$ g.. $\mathrm{L}^{-1}, 44^{\circ} \mathrm{C}$, headspace $60 \%$, inóculo 5\%; E8 = pH 5,5, CT 3 g.L $\mathrm{L}^{-1}, 44^{\circ} \mathrm{C}$, headspace 60\%, inóculo 15\%; $\mathbf{E 9}=\mathrm{pH} 5,5$, CT 3 g.L $\mathrm{L}^{-1}, 30^{\circ} \mathrm{C}$, headspace $60 \%$, inóculo $15 \%, \mathbf{E 1 0}=\mathrm{pH} 7,5$, CT 3 g.L. ${ }^{-1}, 30^{\circ} \mathrm{C}$, headspace $40 \%$, inóculo $15 \%$, $\mathbf{E 1 1}=$ pH 5,5, CT 15 g.L $\mathrm{L}^{-1}, 30^{\circ} \mathrm{C}$, headspace $40 \%$, inóculo $5 \% ; \mathbf{E 1 2}=$ pH 5,5, CT 3 g.L $\mathrm{L}^{-1}, 30^{\circ} \mathrm{C}$, headspace 40\%, inóculo 5\%; $\mathbf{E 1 3}=$ pH 6,5, 9 g.L $\mathrm{L}^{-1}, 37^{\circ} \mathrm{C}$, headspace $50 \%$, inóculo $10 \% ; \mathbf{E 1 4}=$ pH 6,5, 9 g.L $\mathrm{L}^{-1}, 37^{\circ} \mathrm{C}$, headspace $50 \%$, inóculo $10 \%$, E15 = pH 6,5, 9 g.L.- $\mathrm{L}^{-1}, 37^{\circ} \mathrm{C}$, headspace $50 \%$, inóculo $10 \%$.

A discrepância entre a produção de hidrogênio associada aos ensaios com baixos e altos valores de $\mathrm{pH}$ confirma a forte atuação desta variável no metabolismo bacteriano, uma vez que exerce influência principalmente sobre a atividade das hidrogenases e na seleção de rotas metabólicas (Dareioti et al., 2014).

Estudos prévios corroboram com os resultados obtidos nesta pesquisa. Qi et al. (2018) reportaram aumento da produção de hidrogênio de 97 para $99 \mathrm{~mL}$ quando o $\mathrm{pH}$ do meio foi de 5,5 para 6,5 na fermentação de casca de amendoim e glicose. Os autores relataram que a faixa de pH ideal foi entre 6,5-7,0. Kim et al. (2011) avaliaram o efeito do pH inicial (5-9) na produção de hidrogênio utilizando resíduos de alimentos como substrato. Assim, como no 
presente estudo, os autores reportaram aumento da $P$ de 470 para $1.240 \mathrm{~mL}$ com aumento do pH de 5 para 9, obtendo-se produção máxima de 1.340 mL em pH 8.

Perdas do desempenho em processos acidogênicos operados em baixos valores de $\mathrm{pH}$ estão frequentemente relacionadas ao efeito inibitório da biomassa pelo acúmulo de ácidos orgânicos no meio, potencializando esse efeito em processos sob maiores condições de temperatura. Portanto, baixa produção de hidrogênio (E3, E7 e E8) associada ao pH ácido (pH $5,5)$ e alta temperatura $\left(44^{\circ} \mathrm{C}\right)$ pode ser decorrente do gasto de energia das vias catabólicas para manutenção do pH intracelular, que inicialmente já era baixo, evitando que essa energia fosse utilizada para síntese de biomassa. Neste sentido, a baixa atividade microbiana expressa pela produção de $\mathrm{CO}_{2}(80,86 \mathrm{~mL})$, principalmente em $\mathrm{E} 3$, justifica a baixa produção de $\mathrm{H}_{2}$ neste ensaio. Por outro lado, nos ensaios E5 e E6, não houve o efeito de ambas as variáveis (pH 5,5 e temperatura $44^{\circ} \mathrm{C}$ ), obtendo-se e obteve-se produção de $\mathrm{CO}_{2}$ máxima de 624,96 e 415,52 mL, respectivamente.

Em relação ao tempo de início de produção de $\mathrm{H}_{2}\left(\lambda \mathrm{H}_{2}\right)$ verificou-se aumento do $\lambda \mathrm{H}_{2}$ em valores de $\mathrm{pH}$ maior, sendo assim, baixos valores de $\mathrm{pH}$ reduziram em horas (de $9 \mathrm{~h}$ para cerca de 3 h) o tempo de início de produção de hidrogênio, principalmente nos ensaios com alta temperatura $\left(44^{\circ} \mathrm{C}\right)$, baixo volume de headspace $(40 \%)$ e alta porcentagem de inóculo (15\%) (Tabela 5.8). Estudos prévios relatados na literatura corroboram com a presente pesquisa. A título de exemplo, Hwang et al. (2011) reportaram tempo de início de produção $\left(\lambda \mathrm{H}_{2}\right)$ de 3-4 horas na fermentação de resíduos de uvas em reatores em batelada com pH inicial de 5,4-5,2, tempo este semelhante ao presente estudo (2,6-3,8 h em pH 5,5). Feng et al. (2010) relataram que o tempo de início de produção de $\mathrm{H}_{2}$ aumentou de 5,5 h (pH inicial 5,5) para $13 \mathrm{~h}$ (pH inicial $9,0)$ na fermentação de bagaço de maça. Tempos reduzidos de $\lambda \mathrm{H}_{2}$ entre 1,1-2,4 horas em baixos valores de $\mathrm{pH}(4,6-6)$ também foram reportados por Tang et al. (2008). Vasmara e Marchetti (2017) estudaram a influência do pH (4-10) na fermentação de resíduos ricos em lactose e relataram que apesar da produção de $\mathrm{H}_{2}$ ter sido maior em $\mathrm{pH}$ 8,0 o tempo de início de produção de $\mathrm{H}_{2}\left(\lambda \mathrm{H}_{2}\right)$ ocorreu somente em condições de baixo $\mathrm{pH}(6,0)$, assemelhando-se com a presente pesquisa no qual obteve-se tempos reduzidos de $\lambda \mathrm{H}_{2}$ em condições iniciais ácidas.

Temperaturas elevadas estão relacionadas ao aumento das taxas metabólicas além de estarem intimamente associadas a enzima Fe-hidrogenase. Neste sentido, a ativação dessa enzima em condições de temperatura de $44^{\circ} \mathrm{C}$ e $\mathrm{pH}$ 5,5 pode ter contribuído para obtenção de tempos reduzidos de $\lambda \mathrm{H}_{2}$. Provavelmente, menor valor de $\mathrm{pH}$ e maior temperatura contribuíram para o rápido crescimento de bactérias hidrolíticas e fermentativas, resultando no aumento da 


\section{Universidade de São Paulo \\ Escola de Engenharia de São Carlos \\ Programa de Pós-graduação em Hidráulica e Saneamento}

concentração de açúcares disponíveis. A disponibilidade de açúcares solúveis possibilitou que este fosse convertido rapidamente a $\mathrm{H}_{2}$ e ácidos orgânicos, diminuindo assim o tempo $\lambda \mathrm{H}_{2}$ nestes ensaios. No entanto, a rápida produção de metabólitos, como ácidos orgânicos, pode ter contribuido na mudança da rota metabólica de produção para inibição do processo de produção de $\mathrm{H}_{2}$.

Verificou-se com o aumento do $\mathrm{pH}$ (de 5,5 para 7,5) diminuição da eficiência de conversão do substrato, principalmente nos ensaios com alta concentração de carboidratos (15 g. $\left.\mathrm{L}^{-1}\right)$ e baixas temperaturas $\left(30^{\circ} \mathrm{C}\right)$. De acordo com Guo et al. (2010) e Silva et al. (2017), normalmente baixos valores de $\mathrm{pH}$ aumentam a atividade das bactérias hidrolíticas e, consequentemente aumentam a degradação do substrato, o que justifica as baixas eficiências de remoção de 50 e $62 \%$ nos ensaios E5 e E6, em pH inicial 7,5. Deste modo, pode-se inferir que as condições de hidrólise variaram em função do $\mathrm{pH}$, a saber para a seguinte tendência: condições ácidas > condições alcalinas. Ravi et al. (2018) avaliaram o grau de acidificação do substrato (resíduos de vegetais) com variação do $\mathrm{pH}$ e reportaram maior grau de degradação $(57,12 \%)$ em pH 6 condizendo com o resultado obtido nesta pesquisa.

Em contrapartida, o aumento do $\mathrm{pH}$ refletiu em maiores rendimentos de hidrogênio $\left(\mathrm{YH}_{2}\right)$, sendo estatisticamente significativo ( $\left.\mathrm{p}<0,1\right)$. Neste sentido os altos $\mathrm{YH}_{2}$ de 103,3 e 122,3 $\mathrm{mL} \mathrm{H}_{2} \mathrm{~g}^{-1}$ carboidratos adicionados foram obtidos nos ensaios $\mathrm{E} 1 \mathrm{e} \mathrm{E} 10$, em $\mathrm{pH}$ inicial de 7,5. Provavelmente, as condições de $\mathrm{pH}$ 5,5 foram favoráveis para o crescimento de bactérias hidrolíticas e acidogênicas, enquanto em $\mathrm{pH}$ 7,5 favoreceu o estabelecimento de bactérias produtoras de $\mathrm{H}_{2}$. Valor de $\mathrm{pH}$ inicial 5,5 vinculado aos ensaios com alta temperatura $\left(44^{\circ} \mathrm{C}\right)$, concentração de carboidratos (15 g. $\left.\mathrm{L}^{-1}\right)$ e headspace $(60 \%)$ contribuíram para baixos rendimentos de $\mathrm{H}_{2}$ de 3,2 e 4,9 $\mathrm{mL} \mathrm{H}_{2} \mathrm{~g}^{-1}$ carboidratos nos ensaios $\mathrm{E} 7 \mathrm{e} \mathrm{E} 3$, respectivamente.

Contudo, o pH ideal para produção de $\mathrm{H}_{2}$ a partir de consórcios varia muito devido à presença de populações bacterianas complexas e aos tipos de substratos utilizados. Portanto, o controle do $\mathrm{pH}$ em faixa ótima é necessário, intensificando os processos fermentativos para produção de $\mathrm{H}_{2}$ levando aos máximos rendimentos de $\mathrm{H}_{2}$ no sistema.

\subsubsection{Concentração carboidratos}

Em relação a variável concentração de carboidratos totais iniciais (CT) não foi observado valores significativos $(\mathrm{p}>0,1)$ para $P, R m$ e $\lambda \mathrm{H}_{2}$, no entanto, o aumento da concentração de carboidratos de 3 para 15 g. $\mathrm{L}^{-1}$ contribuiu para redução dos valores de $P, R m$ e $\lambda \mathrm{H}_{2}$. Estudos prévios, de maneira similar ao presente estudo, reportaram que o aumento da 
concentração de substrato diminui a produção de $\mathrm{H}_{2}$. Eker e Sarp. (2017) avaliaram a produção de hidrogênio de consórcio microbiano com diferentes concentrações $\left(3,84-45,5\right.$ g.L $\left.\mathrm{L}^{-1}\right)$ de resíduo de papel, e obtiveram maior produção de hidrogênio acumulado (129 mL) para 18,9 g.L. $\mathrm{L}^{-1}$, e inibição do processo para valores acima dessa concentração. Lin et al. (2017) obtiveram redução de $P$ de 69,4 para $60,3 \mathrm{~mL}$ quando a concentração de substrato foi aumentada de 60 para 80 g.L $\mathrm{L}^{-1}$ na fermentação de resíduos de cogumelos.

Altas concentrações de carboidratos vinculada aos ensaios com menor valor de $\mathrm{pH}(5,5)$ e maior temperatura $\left(44^{\circ} \mathrm{C}\right)$ pode ter contribuído com as baixas produções de $\mathrm{H}_{2}$ de 6,32 e 6,42 mL nos ensaios E3 e E7, respectivamente. A condição de alta concentração de carboidratos (sobrecarga orgânica) pode acarretar no acúmulo de biomassa e subprodutos metabólicos, como $\mathrm{H}_{2}$ e ácidos orgânicos (Eker e Sarp., 2017). De acordo com Anzola-Rojas e Zaiat. (2016) o aumento da biomassa ocasionada por sobrecarga orgânica facilita a troca de elétrons interespecífica, entre diferentes espécies microbianas, levando ao estabelecimento de populações não hidrogenogênicas, refletindo em baixas produções de $\mathrm{H}_{2}$, justificando os resultados obtidos neste estudo.

Todavia, não há valor de concentração ideal para os vários substratos e inóculos utilizados na produção fermentativa de $\mathrm{H}_{2}$ (Li e Fang, 2007). A título de exemplo, a máxima produção de $\mathrm{H}_{2}$ 26,07 mmol.L $\mathrm{L}^{-1}$ obtida por Pachapur et al. (2015) foi utilizando 5 g.L.-1 de bagaço de maça e 15 g.L $\mathrm{L}^{-1}$ de glicerol como substrato em reatores em batelada. Enquanto a máxima produção reportada por Shiyan et al. (2013) de 8,74, 8,69 e 8,30 mmol H2. $\mathrm{L}^{-1}$ foram obtidas utilizando 5 g. $\mathrm{L}^{-1}$ de amido, sacarose e efluente da indústria de suco de manga, respectivamente. Provavelmente, tais resultados divergentes são decorrentes da tolerância da biomassa fermentativa frente ao tipo e concentração de substrato e inóculo. No caso específico com RB obteve-se a máxima produção de $\mathrm{H}_{2}$, com 15 g. $\mathrm{L}^{-1}$ de $\mathrm{RB}, \mathrm{pH} 7,5$ a $44^{\circ} \mathrm{C}$.

Por outro lado, para a variável concentração de carboidratos obteve-se valores significativos $(\mathrm{p}<0,1)$ para conversão de carboidratos totais $\left(\mathrm{C}_{\mathrm{CT}}\right)$ (Tabela 5.7). As menores $\mathrm{EC}_{\mathrm{CT}}(<65 \%)$ foram obtidas principalmente nos ensaios (E5, E6 e E11) com alta concentração de carboidratos (15 g.L $\left.\mathrm{L}^{-1}\right)$. De acordo com Hussy et al. (2003) a etapa hidrolítica durante a fermentação torna-se limitante em altas concentrações de carboidratos, reduzindo a solubilização e conversão da matéria orgânica. A redução da $\mathrm{C}_{\mathrm{CT}}$ frente ao aumento de CT pode ser atribuída, a saber: (1) ao acúmulo de ácidos carboxílicos, principalmente ácido lático, com diminuição do $\mathrm{pH}$ do meio, e consequente inibição do processo de hidrólise (Guimire et al., 2018) e (2) a mudanças de rotas metabólicas em consequência do acúmulo de $\mathrm{H}_{2}$ (Motte et al. 


\author{
Universidade de São Paulo \\ Escola de Engenharia de São Carlos \\ Programa de Pós-graduação em Hidráulica e Saneamento
}

(2014). Portanto, a maior eficiência de conversão do substrato (>90\%) ocorreu nos ensaios com baixa concentração de carboidratos (3-9 g.L $\left.\mathrm{L}^{-1}\right)$. Do mesmo modo, Ramos et al. (2012) observaram que baixas concentrações de sólidos totais (ST) resultaram em alta remoção de substrato (>80\%). Os autores verificaram que ao aumentar a concentração de ST de 10 para 90 g.L $L^{-1}$ a remoção diminuiu de $85 \%$ para $10 \%$. Silva et al. (2017) também relataram baixa remoção de carboidratos $(20 \%)$ ao aumentar a concentração de resíduos de alimentos (frutas e vegetais, grãos e carne) em reatores em batelada sob condição mesofílica $\left(35^{\circ} \mathrm{C}\right)$.

Além da produção, verificou-se diminuição do rendimento de hidrogênio $\left(\mathrm{YH}_{2}\right)$ com o aumento da concentração de carboidratos, sendo assim, os máximos $\mathrm{YH}_{2}$ de 103,4, 104,7 e $122,3 \mathrm{~mL} \mathrm{~g}^{-1}$ carboidratos foram obtidos nos ensaios cuja concentração de carboidratos foi baixa (3 g. $\mathrm{L}^{-1}$ ), enquanto os baixos rendimentos de 3,2 e 4,9 $\mathrm{mL} \mathrm{g}^{-1}$ carboidratos foram obtidos nos ensaios com alta concentração de carboidratos (15 g.L. $\left.\mathrm{L}^{-1}\right)$. Segundo Yang e Wang (2019) baixos rendimentos de hidrogênio sob altas concentrações de substrato podem estar relacionados ao acúmulo excessivo de produtos metabólicos seguido da diminuição significativa do $\mathrm{pH}$, inibindo a atividade metabólica e diminuindo a eficiência de conversão do substrato em hidrogênio. Tais resultados corroboram com os obtidos na literatura. Lazaro et al. (2014) avaliaram a produção de hidrogênio de consórcio microbiano utilizando diferentes concentrações de vinhaça de cana-de-açúcar (2-12 g DQO. $\left.\mathrm{L}^{-1}\right)$ à 37 e $55^{\circ} \mathrm{C}$. O aumento da concentração de substrato causou diminuição do $\mathrm{YH}_{2}$ de 2,31 para $0,44 \mathrm{mmol} \mathrm{H} \mathrm{g}^{-1}$ DQO. Eker e Sarp (2017) reportaram diminuição do rendimento de $\mathrm{H}_{2}$ com aumento da concentração de substrato de 3,84 para 45,5 g.L $\mathrm{L}^{-1}$, sendo que o maior $\mathrm{YH}_{2}$ (140 mL de $\mathrm{H}_{2} \mathrm{~g}^{-1}$ carboidratos totais) foi observado no ensaio com baixa concentração de substrato $\left(3,84\right.$ g. $\left.\mathrm{L}^{-1}\right)$. Segundo os autores, houve inibição da biomassa devido ao acúmulo de ácidos graxos voláteis (AGVs) produzidos durante a hidrólise de resíduos de papel. Portanto, conclui-se que o aumento da concentração de $\mathrm{RB}$ nos ensaios provocou diminuição do rendimento de $\mathrm{H}_{2}$, provavelmente provocado pela desestabilização da fermentação frente ao acúmulo de subprodutos metabólicos.

\title{
5.4.3. Temperatura
}

Em relação a temperatura verificou-se que aumento de 30 para $44^{\circ} \mathrm{C}$ desfavoreceu a produção de $\mathrm{H}_{2}(P)$, velocidade de produção de $\mathrm{H}_{2}(R m)$ e rendimento de $\mathrm{H}_{2}\left(\mathrm{YH}_{2}\right)$. Sendo assim, o baixo valor de $P(6,32 \mathrm{~mL}), \mathrm{Rm}\left(2,01 \mathrm{mmol}^{-1}\right)$ e $\mathrm{YH}_{2}\left(2,79 \mathrm{~mL} \mathrm{H}_{2} \mathrm{~g}^{-1} \mathrm{CT}\right.$ add $)$ foram obtidos principalmente nos ensaios (E7 e E3) a $44^{\circ} \mathrm{C}, \mathrm{pH} 5,5$ e 15 g. $\mathrm{L}^{-1}$ de carboidratos. 
Altas temperaturas podem ter aumentado a permeabilidade da membrana à ácidos orgânicos não-dissociados, inibindo a biomassa hidrogenogênica (Infantes et al. 2011), resultando em baixas produções e rendimentos de hidrogênio. Os resultados obtidos nesta pesquisa foram semelhantes aos reportados na literatura indicando que para diferentes tipos de substrato e inóculo, o aumento da temperatura pode inibir a produção e rendimento de hidrogênio. Sattar et al. (2016) relataram diminuição de $P$ (3.085 para $1.723 \mathrm{~mL})$ e $R m(54,73$ para 41,21 mL.h ${ }^{-1}$ ) quando aumentou- a temperatura de 37 para $55^{\circ} \mathrm{C}$ na fermentação de resíduos de arroz. Feng et al. (2010) avaliaram o efeito da temperatura $\left(33-41^{\circ} \mathrm{C}\right)$ no rendimento de hidrogênio e reportaram que o aumento de 33 para $37^{\circ} \mathrm{C}$ proporcionou inicialmente aumento do rendimento de $\mathrm{H}_{2}$ de 40,80 para 90,06 $\mathrm{mL} \mathrm{g}^{-1} \mathrm{ST}$. No entanto, para aumento de 37 para $41^{\circ} \mathrm{C}$ obtiveram diminuição de $\mathrm{YH}_{2}$ para valores $<10 \mathrm{~mL} \mathrm{~g}^{-1} \mathrm{ST}$. Wang e Wan (2008) observaram diminuição de $P$ e $R m$ com o aumento da temperatura de $20^{\circ} \mathrm{C}$ para $55^{\circ} \mathrm{C}$, com $P$ máxima de $269,9 \mathrm{~mL}$ à $40^{\circ} \mathrm{C}$ e $R m$ de $31,9 \mathrm{~mL} \cdot \mathrm{h}^{-1}$ à $35^{\circ} \mathrm{C}$. Ademais, verificaram para o tempo de início de produção de hidrogênio $\left(\lambda \mathrm{H}_{2}\right)$ diminuição (de 34 para $7 \mathrm{~h}$ ) com aumento crescente da temperatura de $20^{\circ} \mathrm{C}$ à $40^{\circ} \mathrm{C}$. Os autores ainda verificaram diminuição acentuada do rendimento para $5,41 \mathrm{~mL} \mathrm{~g}^{-1} \mathrm{ST}$, quando a temperatura passou de $37^{\circ} \mathrm{C}$ para $41^{\circ} \mathrm{C}$. Além disso, concluíram que a temperatura mais adequada para a conversão de bagaço de maça em $\mathrm{H}_{2}$ via fermentação foi $37{ }^{\circ} \mathrm{C}$ e $\mathrm{pH}$ inicial de 7,0. Desta forma, para a biomassa autóctone do resíduo de banana, altas temperaturas podem influenciar negativamente o metabolismo das bactérias e consequentemente resultar em baixas produções e rendimentos de $\mathrm{H}_{2}$.

Os tempos reduzidos de início de produção de hidrogênio $\left(\lambda \mathrm{H}_{2}\right)$ de 4,03 e 3,89 h sob altas temperaturas $\left(44^{\circ} \mathrm{C}\right)$ pode estar intimamente associado à enzima Fe-hidrogenase. De acordo com Vasconcelos et al. (2016) o processo de produção de hidrogênio é dependente desta enzima, que é diretamente afetada pela temperatura. Ngo et al. (2011) relatam aumento da eficiência da enzima Fe-hidrogenase com aumento da temperatura de 25 à $75^{\circ} \mathrm{C}$, demonstrando sua eficiência em sistema termofílico, quando comparado ao mesofílicos. Sendo assim, a temperatura de $44^{\circ} \mathrm{C}$ aplicada ao ensaio E3 e E8, pode ter favorecido a atividade da $\mathrm{Fe}$ hidrogenase e, consequentemente com diminuição do tempo para o início da produção de hidrogênio, principalmente em menor valor de $\mathrm{pH}(5,5)$ e maior concentração de inóculo $(15 \%)$.

Sattar et al. (2016) relataram redução de $\lambda \mathrm{H}_{2}$ de 10,26 para $1,25 \mathrm{~h}$, de 22,89 para 12,33 h e de 10,87 para 9,89 h na fermentação de palha, casca e farelo de arroz, respectivamente, quando aumentaram a temperatura de 37 para $55^{\circ} \mathrm{C}$. Os autores concluíram que o aumento da temperatura favoreceu o crescimento da biomassa hidrolítica e produtora de hidrogênio 


\section{Universidade de São Paulo \\ Escola de Engenharia de São Carlos \\ Programa de Pós-graduação em Hidráulica e Saneamento}

refletindo em menores tempo de início de produção de hidrogênio. Em condições de baixa temperatura, a atividade metabólica de bactérias produtoras de $\mathrm{H}_{2}$ é relativamente lenta resultando em maior $\lambda \mathrm{H}_{2}$ (Feng et al., 2010).

Em relação a conversão dos carboidratos totais $\left(\mathrm{C}_{\mathrm{CT}}\right)$ verificou-se aumento da eficiência de conversão do substrato com aumento da temperatura de 30 para $44^{\circ} \mathrm{C}$. Isso porque, a mudança de temperatura afeta as atividades fisiológicas das bactérias produtoras de $\mathrm{H}_{2}$ e pode estabelecer mudança na via metabólica de $\mathrm{H}_{2}$ favorecendo o estabelecimento das bactérias hidrolíticas e acidogênicas, as quais utilizam o substrato para manutenção celular e produção de ácidos orgânicos e solventes. Wang e Wan (2008) verificaram aumento da eficiência de conversão do substrato com aumento da temperatura de 20 para $40^{\circ} \mathrm{C}$, no entanto, diminuição com o aumento da temperatura de 40 para $55^{\circ} \mathrm{C}$.

Por meio destes resultados pode-se inferir que em intervalos apropriados, o aumento da temperatura pode favorecer maior eficiência de conversão do substrato em culturas mistas, em virtude do aumento do metabolismo das diferentes populações microbianas (mesofílicos e termofílicos). É importante ressaltar que o baixo desempenho do consórcio de bactérias autóctones produtoras de $\mathrm{H}_{2}$ em altas temperaturas é confirmado pelos rendimentos de hidrogênio inferiores obtidos nos ensaios à $44^{\circ} \mathrm{C}$, quando comparado aos valores obtidos para aqueles à $37^{\circ} \mathrm{C}$. $\mathrm{O}$ baixo desempenho do consórcio de bactérias autóctones na produção de $\mathrm{H}_{2}$ em altas temperaturas pode estar associado ao fato de que o processo de obtenção e enriquecimento do consórcio foi realizado em condições mesofílicas, uma vez que, ocorreu seleção prévia das populações microbianas à $37^{\circ} \mathrm{C}$.

\subsubsection{Headspace}

Alterações do volume do headspace possibilita avaliar o efeito da pressão parcial de $\mathrm{H}_{2}$ $\left(\mathrm{pH}_{2}\right)$ na fermentação, uma vez que quanto menor o volume do heasdapace, maior será a pressão exercida pelo biogás. Normalmente, o acúmulo de $\mathrm{H}_{2}$ dissolvido ou a $\mathrm{pH}_{2}$ no headspace altera o fluxo de elétrons nas reações bioquímica catalisadas por microrganismos, afetando a eficiência e a conversão dessas reações (Valdez-Vazquez et al., 2006; Cazier et al., 2015;), resultando em baixas produções de $\mathrm{H}_{2}$. No entanto, efeito adverso foi obtido na presente pesquisa, no qual a diminuição do volume do headspace (de 60 para 40\%) contribuiu para obtenção de maiores valores de $P(31,01-38,08 \mathrm{~mL}), R m\left(4,25-4,54 \mathrm{~mL} \cdot \mathrm{h}^{-1}\right)$ e $\lambda \mathrm{H}_{2}(6,8-9,79 \mathrm{~h})$. Provavelmente, ocorreu seleção de microrganismos adaptados e resistentes a altas $\mathrm{pH}_{2}$, ou a $\mathrm{pH}_{2}$ exercida nos reatores em batelada não ultrapassou o limiar de inibição. Resultado 
semelhante foi obtido por Ciranna et al. (2014) na fermentação da glicose em reator em batelada, no qual a alta $\mathrm{pH}_{2}$ no meio não exerceu efeito negativo no crescimento da biomassa, que foi resistente a altas pressões de biogás. Segundo Valdez-Vazquez et al. (2006), a fermentação de resíduo sólidos orgânicos em temperaturas mesofílica $\left(35^{\circ} \mathrm{C}\right)$ aumenta significativamente a $\mathrm{pH}_{2}$ quando comparados em condições de temperatura termofílica $\left(55^{\circ} \mathrm{C}\right)$. Neste sentido, a condição de temperatura aplicada no ensaio E6 $\left(44^{\circ} \mathrm{C}\right)$ pode ter favorecido a redução da $\mathrm{pH}_{2}$ evitando que ocorresse inibição da biomassa, refletindo na alta produção de hidrogênio $(P)$. Além disso, à baixa solubilidade de $\mathrm{H}_{2}$ sob condições termofílicas quando comparada às mesofílicas também pode ter contribuído com as maiores detecções deste gás no headspace (Lazaro et al., 2014).

Apesar de não significativo ( $>0,1)$, o aumento do headspace diminuiu a conversão de carboidratos $\left(\mathrm{C}_{\mathrm{CT}} \%\right)$. Zhou et al. (2017) e Cazier et al. (2015) relataram diminuição das reações de conversão do substrato devido à alta $\mathrm{pH}_{2}$ no meio em sistemas acidogênicos. Normalmente, durante a fermentação acidogênica a $\mathrm{pH}_{2}$ no reator pode aumentar decorrente do acúmulo de $\mathrm{H}_{2}$ dissolvido ou devido aos baixos volumes de headspace. Neste caso, o aumento do volume de headspace teve feito negativo na $\mathrm{E}_{\mathrm{CT}} \mathrm{e}$, portanto, diferentemente da literatura, a $\mathrm{pH}_{2}$ no meio não influenciou diretamente na conversão dos carboidratos totais. Segundo Sakar et al. (2017) a conversão de carboidratos em sistemas acidogênicos ocorre a partir de reações espontâneas e geralmente não são afetadas pelo aumento da pressão de $\mathrm{H}_{2}$. Tal observação também foi verificada por Guimire et al. (2018), cuja $\mathrm{pH}_{2}$ não teve relação com a remoção do substrato.

Assim como a $P$, o rendimento de hidrogênio $\left(\mathrm{YH}_{2}\right)$ diminuiu significantemente $(\mathrm{p}<0,1)$ com aumento do volume de headspace de 40 para $60 \%$. Deste modo, o baixo volume de hesdapace (40\%) não resultou no aumento excessivo da $\mathrm{pH}_{2}$ ao ponto de inibir a biomassa hidrogenogênicas, tornando possíveis (termodinamicamente favoráveis, $\Delta \mathrm{G}^{\mathrm{o}}$ negativo) as reações de conversões de matéria orgânica em $\mathrm{H}_{2}$ (Li, 2009).

\subsubsection{Inóculo}

O aumento da porcentagem de inóculo de 5 para $15 \%$ diminuiu a $P, R m, \lambda \mathrm{H}_{2}$ e $\mathrm{YH}_{2}$, em contrapartida aumentou a conversão de carboidratos totais $\left(\mathrm{C}_{\mathrm{CT}} \%\right)$. Deste modo, baixas concentrações de células favoreceram a alta produção e velocidade de produção de $\mathrm{H}_{2}$, mas por períodos mais longos (8,30-9,79 h). Resultados semelhantes foram obtidos por Eker e Sarp (2017) no qual reportaram maior $P(105 \mathrm{~mL}), R m\left(7,12 \mathrm{~mL} \cdot \mathrm{h}^{-1}\right)$ e $\lambda \mathrm{H}_{2}(40,89 \mathrm{~h})$ em baixas concentrações de biomassa $\left(0,25\right.$ g. $\left.\mathrm{L}^{-1}\right)$. Argun e Dao (2017) verificaram diminuição do $\lambda \mathrm{H}_{2}$ de 


\section{Universidade de São Paulo \\ Escola de Engenharia de São Carlos \\ Programa de Pós-graduação em Hidráulica e Saneamento}

11 para $7 \mathrm{~h}$ com o aumento da porcentagem de inóculo de 0 a 5\% (v/v) na fermentação de resíduos de polpa de pêssego.

As menores produções $\left(6,32\right.$ e 9,03 mL) e rendimento de hidrogênio $\left(2,79 \mathrm{~mL} \mathrm{H}_{2} \mathrm{~g}^{-}\right.$ ${ }^{1}$ carboidrato) nos ensaios com maior concentração de inóculo pode ser devido ao consumo de hidrogênio por bactérias homoacetogênicas, inibição por biomassa e/ou inibição das bactérias produtoras de hidrogênio ao acúmulo de ácidos orgânicos. Possivelmente, a alta concentração de inóculo resultou em deslocamento da via metabólica da produção de $\mathrm{H}_{2}$ para formação de outros produtos (Argun e Dao, 2017).

Normalmente, altas concentrações de células resultam em aumento da produção de ácidos orgânicos, acidificando o meio e comprometendo a eficiência das reações bioquímicas de conversão de carboidratos em hidrogênio. Além do mais, densidade celular excessiva leva a diminuição da relação alimento/microrganismo (A/M) e consequentemente reduz a disponibilidade de substrato para o metabolismo bacteriano, enquanto baixa $\mathrm{A} / \mathrm{M}$ pode resultar na ineficácia da via produtora de hidrogênio devido a limitação da hidrólise microbiana (Cappai et al., 2015).

Verificou-se para concentração de inóculo valores não estatisticamente significativos $(\mathrm{p}>0,1)$ para $\mathrm{C}_{\mathrm{CT}}(\%)$. No entanto, efeito positivo foi observado quando se aumentou de 5 para $15 \%$ o inóculo. De acordo com Vasconcelos et al. (2016) o aumento da remoção de carboidratos por meio da adição do inóculo pode ser decorrente da maior diversidade metabólica e de microrganismos que consomem os carboidratos para a manutenção celular e produção de $\mathrm{H}_{2} \mathrm{e}$ outros produtos metabólicos. Semelhante a presente pesquisa, Argun e Dao (2017) obtiveram remoção máxima de carbono orgânico total (COT) de 25,17\% quando aumentou a concentração de inóculo de 0 (zero) para 10\%. Portanto, assim como na literatura, as maiores remoções de CT\%, apesar de não estatisticamente significativas, foram maiores (cerca de 93\%) nos ensaios $(3,8,9,10,13,14$ e 15) com concentração máxima de inóculo (15\%).

Assim como para $\mathrm{EC}_{\mathrm{CT}}$ a variável inóculo não foi estatisticamente significativa $(\mathrm{p}>0,1)$ para rendimento de hidrogênio $\left(\mathrm{YH}_{2}\right)$, todavia, o aumento da concentração de inóculo contribuiu para a sua diminuição. Portanto, os baixos rendimentos obtidos $\left(4,9-13,7 \mathrm{~mL} \mathrm{H}_{2} \mathrm{~g}^{-}\right.$ ${ }^{1}$ carboidratos) ocorreram principalmente nos ensaios (E3, E13, E14 e E15) com 10 e $15 \%$ de inóculo, enquanto os máximos rendimentos (103,3 e 104,7 mL H $\mathrm{H}_{2} \mathrm{~g}^{-1}$ carboidratos) foram obtidos nos ensaios E1 e E12, correspondendo aos ensaios com $5 \%$ de inóculo. Resultado semelhante ao presente trabalho foi obtido por Argun e Dao (2017) quando avaliaram o efeito da concentração de inóculo (0-10\%) na fermentação de resíduos de polpa de pêssego e 
Universidade de São Paulo

Escola de Engenharia de São Carlos

Programa de Pós-graduação em Hidráulica e Saneamento

obtiveram maior $\mathrm{YH}_{2}\left(123,27 \mathrm{~mL} \mathrm{H} \mathrm{g}^{-1} \mathrm{COT}\right)$ com adição de 5\% de inóculo. Todavia, para valores maiores (7,5-10\%) verificaram diminuição do $\mathrm{YH}_{2}$ de 123 para $107 \mathrm{~mL} \mathrm{H}_{2} \mathrm{~g}^{-1} \mathrm{COT}$. Tais resultados apontam a importância de fornecer quantidade adequada de biomassa inicial para degradação do substrato em sistemas acidogênicos.

\subsubsection{Avaliação dos metabólicos solúveis}

Ácidos orgânicos de cadeia curta (C1-C5) são os principais produtos da fermentação, além de solventes como etanol, metanol e acetona. A diferença das condições operacionais nos ensaios (1-15) do delineamento Plackett-Burman influenciou significativamente a síntese e o perfil dos ácidos orgânicos e etanol. Os principais compostos observados a partir da fermentação de resíduo de banana utilizando biomassa autóctone, incluiram o ácido acético (HAc), ácido butírico (HBu), ácido lático (HLa) e ácido propiônico (HPr) (Tabela 5.9).

Observou-se maior grau de acidificação (GA\%) para os ensaios em pH ácido e maior concentração de substrato (Figura 5.17).

Figura 5.17. Concentração de DQO solúvel final e grau de acidificação dos ácidos individuais (ácido acético, lático, butírico e propiônico) e juntos para delineamento Plackett-Burman.

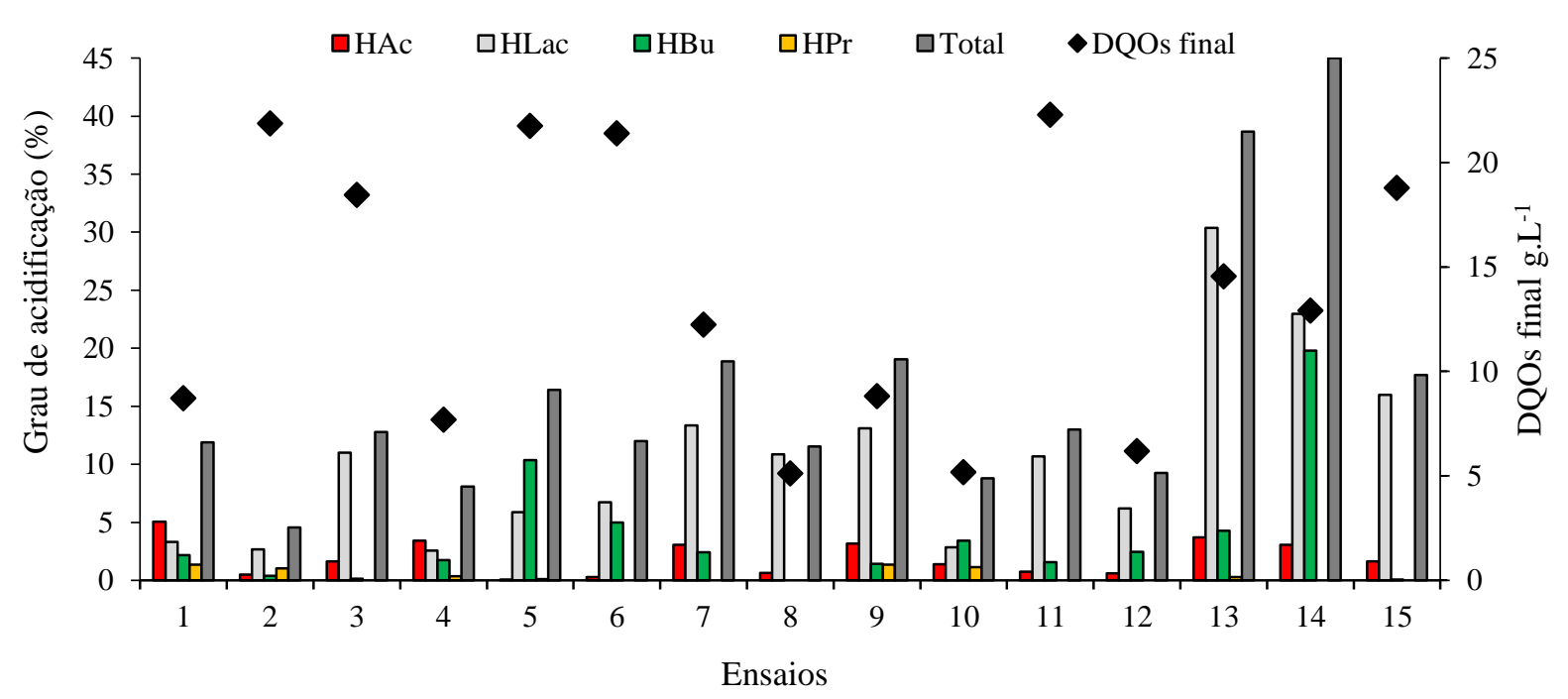

Nota: $\mathrm{HAc}=$ ácido acético, $\mathrm{HLac}=$ ácido lático, $\mathrm{HBu}=$ ácido butírico, $\mathrm{HPr}=$ ácido propiônico, DQOs = demanda química de oxigênio solúvel. $\mathbf{E 1}=$ pH 7,5, CT 3 g.L $\mathrm{L}^{-1}, 44^{\circ} \mathrm{C}$, headspace $40 \%$, inóculo $5 \%$; $\mathbf{E 2}=\mathrm{pH} 7,5, \mathrm{CT} 15$ g.L $\mathrm{L}^{-1}, 30^{\circ} \mathrm{C}$, headspace $60 \%$, inóculo 5\%; E3 = pH 5,5, CT 15 g.L $\mathrm{L}^{-1}, 44^{\circ} \mathrm{C}$, headspace $40 \%$, inóculo 15\%; E4 = 7,5, CT 3 g.L $\mathrm{L}^{-1}, 44^{\circ} \mathrm{C}$, headspace $60 \%$, inóculo 5\%; E5 = pH 7,5, CT 15 g.L $\mathrm{L}^{-1}, 30^{\circ} \mathrm{C}$, headspace 60\%, inóculo 15\%; E6 = pH 7,5, CT 15 g.L $\mathrm{L}^{-1}, 44^{\circ} \mathrm{C}$, headspace 40\%, inóculo 15\%; E7 = pH 5,5, CT 15 g.L $\mathrm{L}^{-1}, 44^{\circ} \mathrm{C}$, headspace $60 \%$, inóculo $5 \% ; \mathbf{E 8}=\mathrm{pH}$ 5,5, CT 3 g.L $\mathrm{L}^{-1}, 44^{\circ} \mathrm{C}$, headspace $60 \%$, inóculo 15\%; E9 $=$ pH 5,5, CT 3 g.L $\mathrm{L}^{-1}, 30^{\circ} \mathrm{C}$, headspace $60 \%$, inóculo $15 \%, \mathbf{E 1 0}=\mathrm{pH} 7,5$, CT 3 g.L $\mathrm{L}^{-1}, 30^{\circ} \mathrm{C}$, headspace $40 \%$, inóculo 15\%, E11 = pH 5,5, CT 15 g.L $\mathrm{L}^{-1}, 30^{\circ} \mathrm{C}$, headspace 40\%, inóculo 5\%; $\mathbf{E 1 2}=\mathrm{pH} 5,5, \mathrm{CT} 3 \mathrm{~g} . \mathrm{L}^{-1}, 30^{\circ} \mathrm{C}$, headspace 40\%, inóculo 5\%; E13 $=\mathrm{pH} 6,5,9$ g. $\mathrm{L}^{-1}, 37^{\circ} \mathrm{C}$, headspace 50\%, inóculo 10\%; $\mathbf{E 1 4}=\mathrm{pH} 6,5,9$ g.L $\mathrm{L}^{-1}, 37^{\circ} \mathrm{C}$, headspace 50\%, inóculo $10 \%, \mathbf{E 1 5}=$ pH 6,5, 9 g.L $\mathrm{L}^{-1}, 37^{\circ} \mathrm{C}$, headspace $50 \%$, inóculo $10 \%$. 


\section{Universidade de São Paulo \\ Escola de Engenharia de São Carlos \\ Programa de Pós-graduação em Hidráulica e Saneamento}

É interessante notar que a rota de produção do ácido lático foi predominante e a que mais contribuiu no processo de acidificação do meio (GA entre 8 e $45 \%$ ). Em contrapartida, a rota do HAc e HBu pouco contribuiu com a acidificação do meio, GA máximo de 5,7 e 19\%, respectivamente. Provavelmente, a conversão destes ácidos em $\mathrm{H}_{2}$ a partir da via acetogênica $\left(\Delta \mathrm{G}^{\circ},=-206\right)$ e butírica $\left(\Delta \mathrm{G}^{\circ},=-254\right)$ contribuiu para redução destes ácidos durante a fermentação e, consequentemente, diminuiu o acúmulo de HAc e $\mathrm{HBu}$ no final do processo. Verificou-se baixa produção de $\operatorname{HPr}$ nos ensaios, portanto sua contribuição no grau de acidificação foi bem reduzida $(<2 \%)$ em todos os ensaios. Pode-se inferir, portanto que o grau de acidificação é amplamente influenciado pelo tipo de ácido orgânico produzido em consequência das condições impostas ao reator.

Para concentração final de matéria orgânica solúvel (DQOs) como parâmetro de hidrólise observou-se que o aumento da concentração de carboidratos totais (CT) de 3 para 15 g.L $\mathrm{L}^{-1}$ favoreceu o aumento da concentração de DQOs no final dos ensaios, principalmente em E2, E5, E6 e E11 (Figura 5.17). Provavelmente, a maior disponibilidade do substrato oportuniza o crescimento de várias populações de bactérias hidrolíticas e acidogênicas resultando no aumento da hidrólise do substrato (DQOs $>20$ g.L $\mathrm{L}^{-1}$ ) e produção de ácidos orgânicos totais (>4 g. $\mathrm{L}^{-1}$ ) nos ensaios com maior concentração de carboidratos. Resultados similares foram obtidos por Bermudes-Penabad (2017), no qual verificaram aumento da produção de ácidos orgânicos e DQOs nos ensaios com maior porcentagem de sólidos (8\%) na fermentação de resíduos de atum.

De acordo com Liu et al. (2012) e Lee et al. (2014), além da concentração de substrato, a faixa de $\mathrm{pH}$ a ser utilizada determina o estabelecimento de populações hidrolíticas e acidogênicas, inferindo em baixa ou alta conversão do substrato em ácidos orgânicos. Neste estudo, a variável $\mathrm{pH}$ não foi estatisticamente significativa $(\mathrm{p}>0,1)$ para produção total de ácido orgânicos. No entanto, observou-se maior produção de ácidos orgânicos (3-6 g.L $\left.{ }^{-1}\right)$ na faixa de pH entre 6,5 e 7,5, correspondendo aos ensaios 5, 7, 11, 13, 14 e 15. Os resultados obtidos nesta pesquisa corroboram com aqueles observados por Ravi et al. (2018) e Xu et al. (2012), no qual relataram maior produção de ácidos orgânicos na fermentação de resíduos vegetais e restos de alimentos, respectivamente, em pH 6,0. Babel et al. (2004) estudaram o efeito do pH (5-8) na acidogênese de resíduo de abacaxi e obtiveram maior produção de ácidos orgânicos totais (21 g.L $\mathrm{L}^{-1}$ ) em $\mathrm{pH}$ 7. Os mesmos autores também observaram redução de ácidos carboxílicos pela metade em pH acima de 7. Resultados divergentes foram obtidos por Zhao et al. (2018) e 
Bermúdez-Penabad et al. (2017) onde a atividade de bactérias acidogênicas foi favorecida na faixa de $\mathrm{pH}$ entre 8-9, resultando em maior produção de ácidos orgânicos.

$\mathrm{O}$ acúmulo de ácidos orgânicos de cadeia curta acarreta na diminuição do valor de $\mathrm{pH}$ (Tabela 5.9), podendo afetar negativamente a biomassa produtora de $\mathrm{H}_{2}$ (Hwang et al., 2004), justificando a rápida estabilização da produção de $\mathrm{H}_{2}(\sim 20$ h) nos 15 ensaios. O pH final em todos os ensaios foi inferior ao $\mathrm{pH}$ inicial, variando entre 3,52 a 5,29. Além disso, a diminuição do $\mathrm{pH}$ foi mais acentuada quando aumentou a temperatura de 30 para $44^{\circ} \mathrm{C}$. Resultados semelhantes foram obtidos por Wang e Wan et al. (2008), no qual relataram diminuição do pH de 7,0 para 4,5 com o aumento da temperatura de $20^{\circ} \mathrm{C}$ para $45^{\circ} \mathrm{C}$. O menor valor de $\mathrm{pH}$ final obtido pelos autores foi 3,34 à $35^{\circ} \mathrm{C}$. As razões para diminuição do $\mathrm{pH}$ durante a fermentação são decorrentes da alta produção de ácidos orgânicos nestas condições de alta temperatura e a alta taxa de conversão de carboidratos em hidrogênio e metabólitos solúveis.

Tanto, o ácido Butírico ( $\mathrm{HBu})$, quanto propiônico (HPr) não foram estatisticamente significativos $(\mathrm{p}>0,1)$ para as variáveis estudadas. No entanto, para ambos os ácidos o aumento do $\mathrm{pH}(5,5$ para 7,5$)$ e aumento do volume do headspace (40 para 60\%) tiveram efeito positivo, o que justifica as maiores concentrações de HBu e HPr nos ensaios em pH 7,5 e 60\% headspace. Resultados semelhantes ao presente estudo foram obtidos por Stein et al. (2017) onde o pH 5,5 proporcionou as menores concentrações de ácido butírico, independentemente da temperatura, enquanto em pH 9,0 foi obtida a máxima produção de $\mathrm{HBu}$ de 8,5 g.L $\mathrm{L}^{-1}$ na fermentação de restos de alimentos. Nenhuma produção de HPr foi obtida nos ensaios em $\mathrm{pH} 5,5$ a $44^{\circ} \mathrm{C}$, inferindo que tais condições inibem essa rota metabólica para o RB. Do mesmo modo, Wang e Wan (2008) reportaram que entre 35 e $40^{\circ} \mathrm{C}$ não houve produção de $\mathrm{HPr}$.

Por outro lado, o aumento da concentração de carboidratos totais (3 para 15 g.L $\mathrm{L}^{-1}$ ) e inóculo (5 para 15\%) contribuíram com o aumento da produção de $\mathrm{HBu}$ e diminuição da produção de HPr. Observou-se HBu até 2,6 g.L $\mathrm{L}^{-1}$, com produção máxima no ensaio E5 e E14, correspondendo a faixa de $\mathrm{pH}$, concentração de carboidrato, temperatura e inóculo entre 6,57,5, 9-15 g.L $\mathrm{L}^{-1}, 30-37^{\circ} \mathrm{C}, 10-15 \%$, respectivamente. Para HPr, observou-se valores de até 0,23 g. $\mathrm{L}^{-1}$ (cerca de 11 vezes inferior ao $\mathrm{HBu}$ ), cujo valor máximo foi observado no ensaio E2, correspondendo ao $\mathrm{pH}$, concentração de carboidrato, temperatura e inóculo de 7,5, 15 g.L $\mathrm{L}^{-1}$, $30^{\circ} \mathrm{C}, 5 \%$, respectivamente. Os valores de $\mathrm{pH}$ finais para estes ensaios foram em média igual a 4,0 (Tabela 5.9).

Normalmente, a ocorrência das reações de produção de HPr (Reação 9 e 10) estão associadas as menores $P$, devido ao consumo de hidrogênio para síntese deste ácido. Neste 


\section{Universidade de São Paulo \\ Escola de Engenharia de São Carlos \\ Programa de Pós-graduação em Hidráulica e Saneamento}

sentido, as maiores $P(38,08$ e 37,18 mL) obtidas nos ensaios 6 e 10 podem ser decorrentes da menor produção de HPr (valor abaixo do LD do método cromatográfico até 0,1 g.L $\mathrm{L}^{-1}$ ) nestes ensaios.

$$
\begin{array}{lr}
3 \mathrm{CH}_{3} \mathrm{CH}(\mathrm{OH}) \mathrm{COOH} \rightarrow 2 \mathrm{CH}_{3} \mathrm{CH}_{2} \mathrm{COOH}+\mathrm{CH}_{3} \mathrm{COOH}+\mathrm{CO}_{2} & \text { Reação } 9 \\
\mathrm{C}_{6} \mathrm{H}_{12} \mathrm{O}_{6}+\mathrm{H}_{2} \rightarrow 2 \mathrm{CH}_{3} \mathrm{CH}_{2} \mathrm{COOH}+2 \mathrm{H}_{2} \mathrm{O} & \text { Reação } 10
\end{array}
$$

Geralmente, o acúmulo de HPr em sistemas acidogênicos estão associadas as condições operacionais do reator. Santos et al. (2014) e Ferraz Jr et al. (2014) obtiveram valores de produção máxima de $\operatorname{HPr}$ de 3,65 e $1.200 \mathrm{mg} . \mathrm{L}^{-1}$, respectivamente, consideravelmente inferiores aos valores obtidos aos do presente estudo. Esses autores associaram esta produção a sobrecarga orgânica imposta ao reator. Tal afirmação corrobora com os valores máximos obtidos na presente pesquisa, principalmente nos ensaios com adição de alta concentração de carboidratos totais (15 g.L $\left.\mathrm{L}^{-1}\right)$, sendo possível inferir que a sobrecarga orgânica pode afetar negativamente a produção de $\mathrm{H}_{2}$ devido ao desvio de rota para produção de HPr. Apesar disso, não foi detectado acúmulo excessivo de HPr nos reatores, conforme previamente descrito, sugerindo a baixa influência deste ácido na $P$ obtidas.

Por outro lado, reações de produção de ácido butírico contribuem para a produção de hidrogênio, mas em baixos rendimentos ( 2 mols $\mathrm{H}_{2}$. mol glicose) (Reação 11). Provavelmente, essa via metabólica foi observada no E6, E14 e E15, correspondendo aos ensaios com maiores concentrações de $\mathrm{HBu}\left(1-2,66\right.$ g.L $\left.\mathrm{L}^{-1}\right)$.

$\mathrm{C}_{6} \mathrm{H}_{12} \mathrm{O}_{6}+2 \mathrm{H}_{2} \mathrm{O} \rightarrow \mathrm{CH}_{3}\left(\mathrm{CH}_{2}\right)_{2} \mathrm{COOH}+2 \mathrm{CO}_{2}+2 \mathrm{H}_{2}$

Reação 11

Diferentemente da via butírica, a via de produção de ácido acético é mais favorável para a produção de $\mathrm{H}_{2}$, uma vez que possibilita altos rendimentos $\mathrm{H}_{2}$ (4 mols de $\mathrm{H}_{2}$. mol glicose, Reação 12). A maior produção de $\operatorname{HAc}\left(0,63\right.$ e 0,72 g.L $\left.\mathrm{L}^{-1}\right)$ foi obtida nos ensaios 1 e 7 , a $44^{\circ} \mathrm{C}$, a qual foi crucial para o estabelecimento desta rota, sendo estatisticamente significativa $(\mathrm{p}<0,1)$. Neste sentido, de alguma forma a temperatura afetou o metabolismo das bactérias autóctones, influenciando positivamente a atividade de algumas enzimas essenciais, como as hidrogenases para produção de hidrogênio. 
Universidade de São Paulo

Escola de Engenharia de São Carlos

Programa de Pós-graduação em Hidráulica e Saneamento

Tabela 5.9. Respostas para pH final e produção de ácidos carboxílicos e etanol para o Delineamento de Plackett-Burman (PB).

\begin{tabular}{|c|c|c|c|c|c|c|c|c|c|c|c|c|}
\hline \multirow{2}{*}{ Ensaios } & \multirow{2}{*}{ pH } & \multirow{2}{*}{$\begin{array}{c}\text { Concentração } \\
\text { Carboidratos totais } \\
\left(\mathrm{g} . \mathrm{L}^{-1}\right)\end{array}$} & \multirow{2}{*}{$\begin{array}{l}\text { Temperatura } \\
\quad\left({ }^{\circ} \mathbf{C}\right)\end{array}$} & \multirow{2}{*}{$\begin{array}{c}\text { Headspace } \\
(\%)\end{array}$} & \multirow{2}{*}{$\begin{array}{c}\text { Inóculo } \\
(\%)\end{array}$} & \multicolumn{5}{|c|}{ Ácidos orgânicos (g.L $\left.\mathrm{L}^{-1}\right)$} & \multirow{2}{*}{$\begin{array}{l}\text { EtOH } \\
\text { g.L.'-1 }\end{array}$} & \multirow{2}{*}{$\begin{array}{l}\mathrm{pH} \\
\text { final }\end{array}$} \\
\hline & & & & & & HAc & HBu & HLa & HPr & Total & & \\
\hline 1 & 7,5 & 3 & 44 & 40 & 5 & 0,63 & 0,26 & 0,4 & 0,16 & 1,43 & 0,19 & 5,29 \\
\hline 2 & 7,5 & 15 & 30 & 60 & 5 & 0,11 & 0,09 & 0,58 & 0,23 & 1,01 & 0,14 & 4,33 \\
\hline 3 & 5,5 & 15 & 44 & 40 & 15 & 0,35 & 0,03 & 2,37 & $<\mathrm{LD}$ & 2,76 & 0,61 & 3,57 \\
\hline 4 & 7,5 & 3 & 44 & 60 & 5 & 0,41 & 0,21 & 0,31 & 0,04 & 0,97 & 0,17 & 5,19 \\
\hline 5 & 7,5 & 15 & 30 & 60 & 15 & 0,02 & 2,6 & 1,47 & 0,03 & 4,12 & 0,14 & 4,11 \\
\hline 6 & 7,5 & 15 & 44 & 40 & 15 & 0,07 & 1,19 & 1,6 & $<\mathrm{LD}$ & 2,86 & 0,13 & 4,21 \\
\hline 7 & 5,5 & 15 & 44 & 60 & 5 & 0,72 & 0,57 & 3,14 & $<\mathrm{LD}$ & 4,44 & 0,64 & 3,55 \\
\hline 8 & 5,5 & 3 & 44 & 60 & 15 & 0,06 & $<\mathrm{LD}$ & 1,07 & $<\mathrm{LD}$ & 1,13 & 0,38 & 3,72 \\
\hline 9 & 5,5 & 3 & 30 & 60 & 15 & 0,31 & 0,14 & 1,27 & 0,13 & 1,85 & 0,13 & 3,86 \\
\hline 10 & 7,5 & 3 & 30 & 40 & 15 & 0,13 & 0,31 & 0,26 & 0,11 & 0,81 & 0,08 & 4,31 \\
\hline 11 & 5,5 & 15 & 30 & 40 & 5 & 0,19 & 0,4 & 2,73 & $<\mathrm{LD}$ & 3,33 & 0,23 & 3,60 \\
\hline 12 & 5,5 & 3 & 30 & 40 & 5 & 0,06 & 0,23 & 0,57 & $<\mathrm{LD}$ & 0,85 & 0,11 & 3,95 \\
\hline 13 & 6,5 & 9 & 37 & 50 & 10 & 0,61 & 1,72 & 5,14 & 0,05 & 7,52 & 0,36 & 3,53 \\
\hline 14 & 6,5 & 9 & 37 & 50 & 10 & 0,41 & 2,66 & 3,08 & $<\mathrm{LD}$ & 6,15 & 0,32 & 3,47 \\
\hline 15 & 6,5 & 9 & 37 & 50 & 10 & 0,58 & 1,01 & 4,77 & $<\mathrm{LD}$ & 6,36 & 0,35 & 3,52 \\
\hline
\end{tabular}

Nota: $\mathrm{HAc}=$ ácido acético, $\mathrm{HLac}=$ ácido lático, $\mathrm{HBu}=$ ácido butírico, $\mathrm{HPr}=$ ácido propiônico, EtOH = etanol.

$<=$ valor abaixo do Limite de Detecção (LD) do método cromatográfico. 


\section{Universidade de São Paulo \\ Escola de Engenharia de São Carlos \\ Programa de Pós-graduação em Hidráulica e Saneamento}

Resultado semelhante foi obtido por Wang e Wan (2008), sendo observado aumento de HAc de 3,1 a 16,5 mmol.L $\mathrm{L}^{-1}$, quando aumentaram a temperatura de 20 para $35^{\circ} \mathrm{C}$, cuja concentração máxima foi obtida na faixa de $35-40^{\circ} \mathrm{C}$. Temperaturas superiores a esta foram inibitórias, reduzindo a produção pela metade.

Além disso, como foi produzido concomitantemente HAc e etanol em todos os ensaios, pode-se inferir que uma parte do HAc produzido pode ser sido proveniente da acetogênese (Reação 13). Por outro lado, em sistemas onde há abundância de ácido lático, o aumento da concentração de ácido acético pode ser decorrente da conversão do ácido lático à ácido acético e propiônico (Reação 9).

$$
\begin{aligned}
& \mathrm{C}_{6} \mathrm{H}_{12} \mathrm{O}_{6}+2 \mathrm{H}_{2} \mathrm{O} \rightarrow 2 \mathrm{CH}_{3} \mathrm{COOH}+2 \mathrm{CO}_{2}+4 \mathrm{H}_{2} \\
& \mathrm{CH}_{3} \mathrm{CH}_{2} \mathrm{OH}+\mathrm{H}_{2} \mathrm{O} \rightarrow \mathrm{CH}_{3} \mathrm{COOH}+2 \mathrm{H}_{2}
\end{aligned}
$$

Além destes ácidos, houve produção relevante de ácido lático (HLa), representando 60\% dos ácidos totais produzidos. A maior produção de HLa, entre 2,37 e 5,14 g.L.' , foi obtida nos ensaios E3, E7, E11, E13, E14 e E15. Dentre as variáveis analisadas, somente as variáveis pH e concentração de carboidratos foram estatisticamente significativas $(\mathrm{p}<0,1)$ para produção de HLa, sendo estas inversamente proporcionais, ou seja, o aumento do valor de $\mathrm{pH}$ reduziu a produção de HLa, enquanto o aumento da concentração de carboidratos totais aumentou sua produção. Wang et al., (2014) e Wang et al., (2015) reportaram a forte influência dos parâmetros pH e concentração do substrato na produção de ácidos orgânicos. A título de exemplificação, semelhante ao presente trabalho, Bermúdez-Penabad et al. (2017) avaliaram o efeito da variação do pH (5-10) na produção de ácidos orgânicos e obtiveram maior produção de HLac em pH ácido (pH 5,0). De acordo com Antonopoulou et al. (2016), em pH ácido é favorecida a formação de compostos mais reduzidos, como por exemplo o ácido lático.

Park et al. (2018) avaliaram o efeito da concentração do substrato na produção de metabólitos solúveis e verificaram que o aumento de 0,2 para $5,8 \mathrm{~g} . \mathrm{L}^{-1}$ de glicose resultou em maior concentração de HLa. Yousuf et al. (2018) relataram aumento de HLac de 19,56 para 31,2 g.L.-1 quando aumentou a concentração de substrato (restos de comida) de 41,6 para 53,2 g DQO.L ${ }^{-1}$. Provavelmente, bactérias produtoras de ácido láctico (e.g. Lactobacillus) tem maior afinidade pelo substrato quando comparada as demais bactérias, como as produtoras de hidrogênio (e.g. Clostridium) (Park et al., 2018). 
As baixas produções de $\mathrm{H}_{2}$ de 6,32 e 6,42 mL obtidas nos ensaios E3 e E7 também podem estar associadas às altas produções de $\operatorname{HLa}\left(2,37\right.$ e 3,14 g.L $\mathrm{L}^{-1}$, respectivamente), visto que as condições propícias para produção de ácido lático (pH 5,5 e 15 g. $\mathrm{L}^{-1}$ de CT) não foram benéficas para produção de $\mathrm{H}_{2}$.

É importante ressaltar, que a via de produção de ácido lático foi a heteroláctica, onde além do ácido lático, os açúcares são convertidos em outros bio-produtos, como o etanol (Abdelrahman et al., 2013) (Reação 14), justificando a observação destes metabólitos em todos os ensaios. Evidências da fermentação heterolática em sistemas acidogênicos também foram relatados na literatura (Sreela-et al., 2011 e Fues et al., 2018), corroborando com a presente pesquisa.

$\mathrm{C}_{6} \mathrm{H}_{12} \mathrm{O}_{6} \rightarrow \mathrm{CH}_{3} \mathrm{CH}(\mathrm{OH}) \mathrm{COOH}+\mathrm{CH}_{3} \mathrm{CH}_{2} \mathrm{OH}+\mathrm{CO}_{2}$

Reação 14

As demais variáveis (temperatura, headspace e inóculo) não foram estatisticamente significativas $(\mathrm{p}<0,1)$ para produção de ácido lático. Kim et al. (2006) e Park et al. (2018) relataram que a diferença nos perfis de produção de ácidos orgânicos, como o ácido lático deveu-se principalmente na diferença das atividades metabólicas da comunidade bacteriana e não devido à quantidade de células. Tais resultados corroboram com a presente pesquisa, porque o aumento da porcentagem de inóculo (5 para 10\%) não foi estatisticamente significativa.

Durante a fermentação pode haver o desvio de rotas metabólicas, de ácidos para etanol, principalmente em valores de $\mathrm{pH}<4,0$ (Dareioti et al., 2014; Guimire et al., 2015). No presente estudo, a maior produção de etanol de 0,61 e 0,64 g.L. $\mathrm{L}^{-1}$, ocorreram principalmente nos ensaios cujo valor de $\mathrm{pH}$ final foi 3,5, correspondendo aos ensaios com baixa produção de hidrogênio (6,32 e 6,42 mL). Geralmente, baixa produção de hidrogênio pode estar associadas à produção de etanol, pois durante o processo de conversão do substrato à etanol (Reação 15) e conversão de ácidos orgânicos, como o acético à etanol (Reação 16), não há produção de $\mathrm{H}_{2}$.

Outra rota de produção de etanol inclui a conversão da matéria orgânica em etanol e $\mathrm{H}_{2}$ (reação 17), no entanto, essa rota foi desprezível na presente pesquisa, visto que há produção concomitante de bicarbonato $\left(\mathrm{HCO}_{3}^{-}\right)$, o que elevaria o valor de $\mathrm{pH}$, mas, como visto na Tabela 5,9, o valor de $\mathrm{pH}$ final foi baixo, quando comparado ao inicial, descartando essa via metabólica. A produção de etanol também pode estar associada ao metabolismo de bactérias heteroláticas, como discutido anteriormente, no qual fermentam carboidratos para produzir HLa e etanol (Reação 15). 
$\mathrm{C}_{6} \mathrm{H}_{12} \mathrm{O}_{6} \rightarrow 2 \mathrm{CH}_{3} \mathrm{CH}_{2} \mathrm{OH}+2 \mathrm{CO}_{2}$

Reação 15

$\mathrm{CH}_{3} \mathrm{COOH}+2 \mathrm{H}_{2} \rightarrow \mathrm{CH}_{3} \mathrm{CH}_{2} \mathrm{OH}+4 \mathrm{H}_{2} \mathrm{O}$

Reação 16

$\mathrm{C}_{6} \mathrm{H}_{12} \mathrm{O}_{6}+2 \mathrm{H}_{2} \mathrm{O}+2 \mathrm{NADH} \rightarrow 2 \mathrm{CH}_{3} \mathrm{CH}_{2} \mathrm{OH}+2 \mathrm{HCO}_{3}+\mathrm{NAD}^{+}+2 \mathrm{H}_{2}$

Ademais, a alta concentração de etanol foi associada aos ensaios com $\mathrm{pH}$ inicial 5,5, 15 g. $\mathrm{L}^{-1}$ de carboidratos a $44^{\circ} \mathrm{C}$, sendo estas variáveis estatisticamente significativas $(\mathrm{p}<0,1)$. Resultados semelhantes a presente pesquisa foram relatados na literatura. A título de exemplificação, Kim et al., (2008) associaram a diminuição da produção de etanol com aumento do valor de $\mathrm{pH}$ inicial de 5,0 para 9, indicando condições desfavoráveis para $P$ em condições ácidas. Yang e Wang (2019) relataram aumento da concentração de etanol de cerca de 10 para 120 mmol.L $\mathrm{L}^{-1}$ quando aumentaram de 5 para 80 g.. $\mathrm{L}^{-1}$ o substrato, respectivamente. Wang e Wan et al. (2008) observaram aumento da concentração de etanol de 0,7 a $8,1 \mathrm{mmol}^{-1} \mathrm{~L}^{-1} \mathrm{com}$ o aumento da temperatura de $20^{\circ} \mathrm{C}$ para $35^{\circ} \mathrm{C}$. Provavelmente, as mudanças na composição dos produtos metabólicos no presente estudo, associado ao aumento da temperatura foi resultante do deslocamento da via metabólica induzida pelas diferentes bactérias que foram predominantes em cada temperatura $\left(30,37\right.$ e $\left.44^{\circ} \mathrm{C}\right)$.

\subsubsection{Avaliação da comunidade bacteriana do delineamento de Plakett-Burman}

A população bacteriana do inóculo foi comparada com a população dos ensaios em reatores em batelada onde não houve produção de ácido propiônico (ensaio E3), maior produção de $\mathrm{H}_{2}$ (ensaio E6) e maior produção de EtOH (ensaio E7). Objetivou-se, com as escolhas destas amostras, analisar o DGGE (Eletroforese em Gel de Gradiente Desnaturante) (Figura 5.18) e verificar se as condições impostas aos reatores influenciaram no estabelecimento de algumas rotas metabólicas.

A similaridade da composição microbiana das amostras da biomassa sugere que tal estratégia de screening design não estabeleceu grande diferença na comunidade bacteriana. Verificou-se menor alteração das populações entre os ensaios, ou seja, 98\% de similaridade entre E3 e E7 e 95\% de similaridade entre o E6 e os demais ensaios. Provavelmente, a alta similaridade entre as populações desses ensaios sem produção de $\mathrm{HPr}$ (E3) e maior produção de EtOH (E7) deveu-se, principalmente, ao fato de que em ambos, as condições eram bem

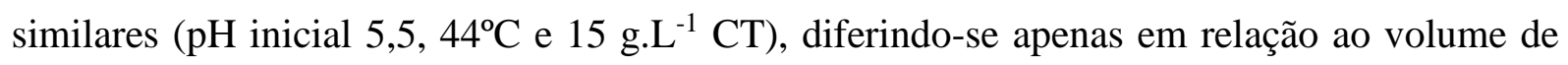
headspace (40 e 60\%, respectivamente) e concentração de inóculo (15 e 5\%, respectivamente). 
No entanto, como estas variáveis não foram estatisticamente significativas $(\mathrm{p}>0,1)$ para produção de HPr e etanol, assumiu-se que o headspace e inóculo foram desprezíveis para o estabelecimento de rotas metabólicas.

Figura 5.18. Análise de Cluster do perfil de bandas do DGGE dos fragmentos de RNAr 16S para o inóculo e biomassa dos ensaios 3, 6 e 7 do delineamento PB.

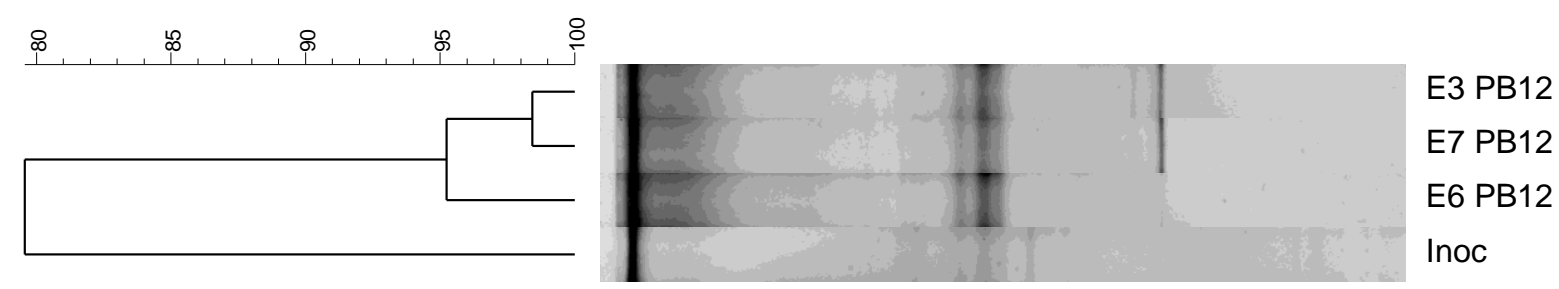

Nota: $\mathbf{E 3}=\mathrm{pH}$ 5,5, CT 15 g. $. \mathrm{L}^{-1}, 44^{\circ} \mathrm{C}$, headspace 40\%, inóculo 15\%; inóculo 5\%; $\mathbf{E 6}=\mathrm{pH}$ 7,5, CT 15 g.L $\mathrm{L}^{-1}, 44^{\circ} \mathrm{C}$, headspace $40 \%$, inóculo $15 \% ; \mathbf{E 7}=\mathrm{pH} 5,5, \mathrm{CT} 15 \mathrm{~g} . \mathrm{L}^{-1}, 44^{\circ} \mathrm{C}$, headspace $60 \%$, inóculo $5 \%$.

A variável $\mathrm{pH}$ foi altamente significativa $(\mathrm{p}<0,1)$ para a produção de $\mathrm{H}_{2}$ e, provavelmente, devido ao aumento de 5,5 para 7,5, resultou em pequena diferença nas populações de bactérias (similaridade de 95\%) entre aquelas do ensaio E6, E3 e E7. Em relação as demais variáveis, concentração de carboidratos totais (CT) e temperatura, obteve-se similaridade igual para os três ensaios.

A menor similaridade (80\%) foi obtida para o inóculo em relação aos três ensaios. Provavelmente, a variedade de condições operacionais ( $\mathrm{pH}$, temperatura, concentração de carboidratos totais, volume do headspace e concentração de inóculo) impostas nos ensaios do delineamento de PB pode ter contribuído para essa diferença do coeficiente de similaridade entre o inóculo e os ensaios. Neste caso, algumas condições operacionais, como pH e temperatura, podem ter influenciado para o estabelecimento de algumas populações de bactérias e rotas metabólicas em detrimento a outras.

A amostra de maior produção de $\mathrm{H}_{2}$ (E6) foi selecionada para análise metagenômica e foi comparada com o inóculo. A fim de avaliar a diversidade da comunidade bacteriana foram estimados os índices de diversidade Shannon (H), Simpson (1-D) e dominância (D) e estimador de riqueza Chao-1 (Figura 5.19). Em relação ao estimador de riqueza (Chao-1) notou-se maior riqueza para a amostra E6, quando comparado ao inóculo. Provavelmente, as condições operacionais neste ensaio ( $\mathrm{pH} 7,5, \mathrm{CT} 15 \mathrm{~g} . \mathrm{L}^{-1}, 44^{\circ} \mathrm{C}$, headspace 40\%, inóculo 15\%) representou forte pressão seletiva resultando em maior quantidade de bactérias hidrogenogênicas, em vista que neste ensaio obteve-se produção máxima de $38,08 \mathrm{~mL} \mathrm{H}_{2}$. 


\section{Universidade de São Paulo \\ Escola de Engenharia de São Carlos \\ Programa de Pós-graduação em Hidráulica e Saneamento}

Figura 5.19. Estimadores de riqueza e índices de diversidade para a biomassa do inóculo e de maior produção de hidrogênio (E6) do delineamento de Plackett-Burman.

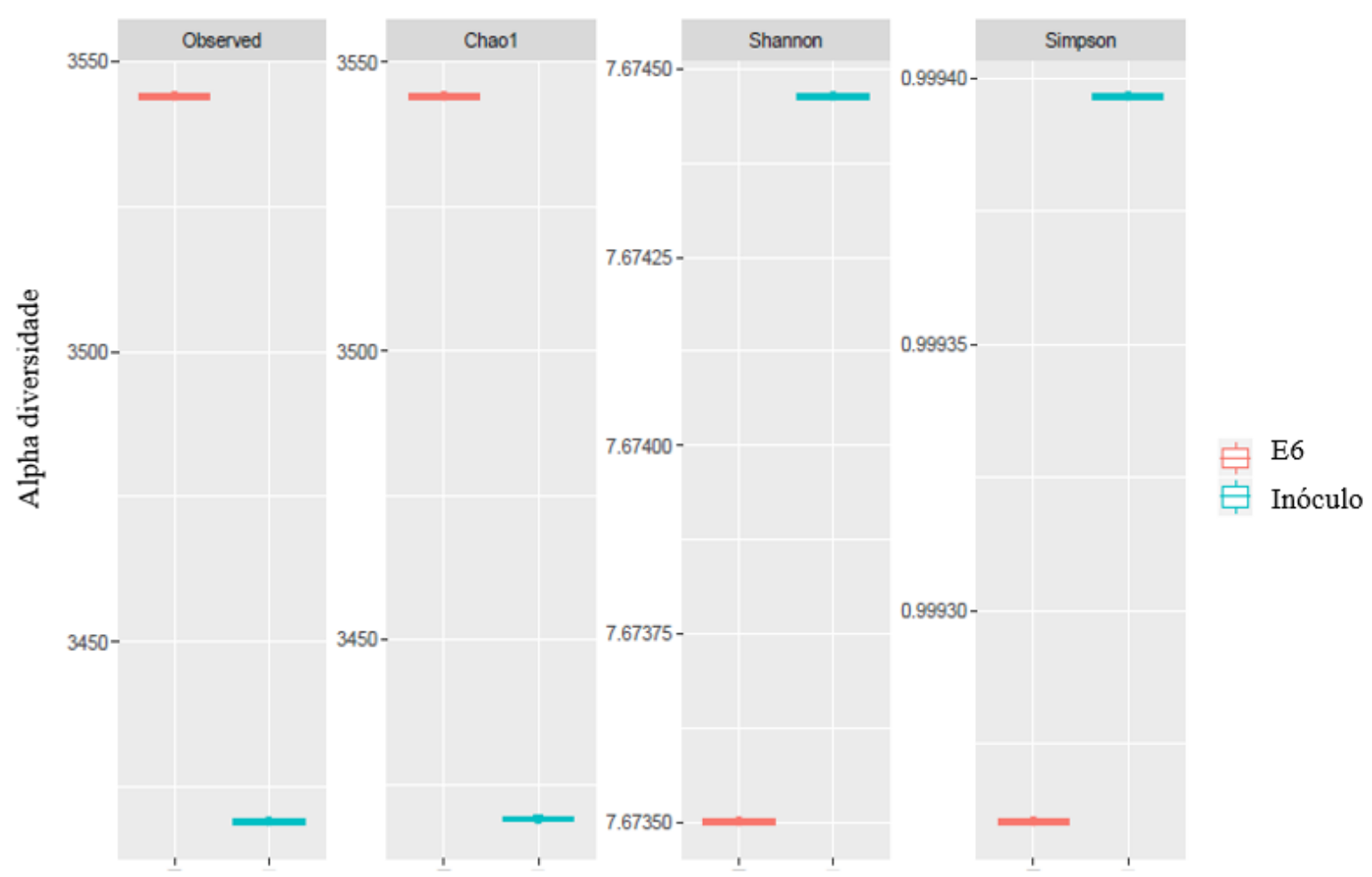

Em relação aos índices de diversidade (Shannon e Simpson) observou-se pouca variação entre as amostras. Para ambos os índices, verificou-se alta diversidade. Para o índice de Shannon $(\mathrm{H})$ observou-se valores acima de 7, indicando alta diversidade, enquanto que para o índice de Simpson (1-D) observou-se valores próximos a 1; ou seja, elevada diversidade e distribuição pouco equânime. Apesar de semelhantes, os índices de diversidade do E6 foram ligeiramente maiores em relação aqueles do inóculo, inferindo que de certa forma as condições operacionais do ensaio E6 contribuíram para maior diversidade e riqueza.

\subsubsection{Efeito das variáveis independentes no perfil taxonômico}

O filo Firmicutes foi o principal filo representante, tanto na amostra inicial da biomassa (inóculo), quanto para amostra da biomassa do E6 (maior produção de $\mathrm{H}_{2}$ ), com abundância relativa de 96 e 94\%, respectivamente. Destaca-se que este filo é um dos maiores do domínio Bacteria, abrangendo diversidade de gêneros, o que reflete em ampla variedade metabólica. Observou-se que para ambas as amostras, as classes dominantes foram, a saber: Bacilli $(39,66 \%)$ e Clostridia $(53,73 \%)$, tanto para o inóculo quanto em E6. 
Universidade de São Paulo

Escola de Engenharia de São Carlos

Programa de Pós-graduação em Hidráulica e Saneamento

Bactérias pertencentes as ordens Clostridiales, Lactobacillales e Bacilalles foram identificadas nas amostras. Dentre essas três, verificou-se menor abundância para Bacilalles (0,69\% inóculo e 1,22\% E6), quando comparado ao Lactobacillales (53\% inóculo e 38,44\% E6) e Clostridiales (41,77\% inóculo e 53,06\% E6) (Tabela 5.10). Em relação a classe Bacilli e ordem Bacilalles identificou-se representantes pertencentes a família Lactobacillaceae, com $52,7 \%$ dos representantes da biomassa do inóculo e 38,06\% do E6 e, também representantes da família Bacillaceae, sendo 0,47\% do inóculo e 0,90\% do E6.

Em relação a classe Clostridia e ordem Clostridiales identificou-se representantes de bactérias pertencentes a família Clostridiaceae (34,57\% inóculo e 40,9\% E6) e a Peptostreptococcaceae (7,04\% inóculo e 12,78\% E6). Geralmente, na família Clostridiaceae estão incluídas espécies envolvidas na degradação da celulose (Ozbayram et al., 2017; Chi et al., 2018), fornecendo substratos fermentáveis (carboidratos solúveis) para as bactérias hidrogenogênicas e produtoras de ácidos orgânicos.

Tabela 5.10. Análise comparativa das bactérias identificadas nas biomassas do inóculo e ensaio E6.

\begin{tabular}{|c|c|c|c|c|c|}
\hline \multirow[t]{2}{*}{ Filo } & \multirow[t]{2}{*}{ Classe } & \multirow[t]{2}{*}{ Ordem } & \multirow[t]{2}{*}{ Família } & \multicolumn{2}{|c|}{$\begin{array}{l}\text { Abundância } \\
\text { relativa (\%) }\end{array}$} \\
\hline & & & & Inóculo* & E6* \\
\hline \multirow{4}{*}{ Firmicutes } & \multirow{2}{*}{ Clostridia } & \multirow{2}{*}{ Clostridiales } & Clostridiaceae & 34,57 & 40,9 \\
\hline & & & Peptostreptococcaceae & 7,04 & 12,78 \\
\hline & \multirow{2}{*}{ Bacilli } & Lactobacillales & Lactobacillaceae & 52,7 & 38,06 \\
\hline & & Bacilalles & Bacillaceae & 0,47 & 0,90 \\
\hline
\end{tabular}

Nota: * = abundância relativa referente a família.

Os principais gêneros predominantes identificados nas amostras do inóculo e E6 estão representados na Figura 5.20. Observou-se que os gêneros predominantes em ambas as amostras foram Clostridium e Lactobacillus, seguido de Clotridioides, Fusobacterium, Gottschalkia e Bacillus. Como já mencionado anteriormente, prevalência dos gêneros Clostridium e Lactobacillus na fermentação de resíduos de frutas e vegetais é apoiada por estudos prévios com base no sequenciamento do gene RNAr 16S obtidos em amostras de reatores (Laothanachareon et al., 2014; Li et al., 2017; Zamorano-Lopez et al., 2018). 


\section{Universidade de São Paulo \\ Escola de Engenharia de São Carlos \\ Programa de Pós-graduação em Hidráulica e Saneamento}

É importante ressaltar que houve mudança na comunidade bacteriana quando as condições operacionais mudaram, ou seja, no inóculo a predominância foi de Lactobacillus $(52,61 \%)$, enquanto em E6 a predominância foi de Clostridium (38,02\%). Tais resultados justificam a alta produção de $\mathrm{H}_{2}$ em E6, uma vez que, espécies de Clostridium têm sido associada a alta produção de hidrogênio em processos fermentativos.

As condições operacionais do $\mathrm{E} 6$ foram $\mathrm{pH} 7,5$, CT 15 g. $\mathrm{L}^{-1}, 44^{\circ} \mathrm{C}, 40 \%$ de headspace e 15\% de inóculo. Provavelmente, tais condições favoreceram a predominância de Clostridium neste ensaio. Similarmente a presente pesquisa, Ziara et al. (2019) reportaram que Clostridium foi o gênero mais abundante na fermentação de água residuária rica em lactato, principalmente em pH inicial de $6,5,7,5$ e 8,5 a 35 e $45^{\circ} \mathrm{C}$. Além disso, bactérias semelhantes a Clostridium são resistentes a condições de estresse, como altas pressões parciais de hidrogênio $\left(\mathrm{pH}_{2}\right)$ proporcionada por diminuição do headspace. Neste caso, a diminuição do volume do headspace para $40 \%$ não afetou a população hidrogenogênica, cooperando com a prevalência de Clostridium neste ensaio. Park et al. (2018) relataram que em condições de baixa concentração de substrato, bactérias semelhantes a Lactobacillus têm vantagem competitiva em relação a Clostridium. Provavelmente, como no ensaio E6 foi utilizado maior concentração de carboidratos totais $\left(15\right.$ g. $\left.\mathrm{L}^{-1}\right)$, tais condições podem ter sido favoráveis para tais bactérias, resultando em maior abundância relativa nesse ensaio.

Verificou-se aumento da abundância relativa de Clostridioides do inóculo $(6,80 \%) \mathrm{em}$ relação ao E6 (12,32\%). Para Fusobacterium obteve-se 0,62 e 0,79\%, respectivamente. Em relação a Gottschalkia e Bacillus obteve-se para inóculo (0,31 e 0,21\%, respectivamente) e para E6 (0,56 e 0,47\%, respectivamente) (Figura 5.20). De modo geral observou-se maior abundância relativa para esses gêneros na biomassa do ensaio E6 em relação aquela do inóculo.

Espécies de Clostridioides, por exemplo Clostridioides difficile, são onipresentes em ambientes naturais, incluindo solos e água, bem como na água não tratada e águas residuárias (Candel-Pérez et al., 2019). Provavelmente, a identificação dessa espécie no consórcio de bactérias do RB pode ter ocorrido devido a contaminação pela irrigação ou lavagem com água contaminada. De acordo com Riedel et al. (2017) esta espécie pode metabolizar variedade de substratos, incluindo glicose e aminoácidos, o que ustifica sua presença no RB, sendo que os principais produtos da fermentação são ácido acético, etanol, butanoato, ácido propiônico, ácido lático, 1-butanol, ente outros metabólitos produzidos no final da fermentação. 
Fusobacterium foi reportada por metabolizar gama de aminoácidos e glicose e produzir como principais metabólitos solúveis ácido acético, butírico, lático e fórmico (Loesche e Gibbons, 1968).

As bactérias do gênero Bacillus, da mesma forma que Clostridium, são bacilos Grampositivas, produtoras de hidrogênio e ácidos orgânicos, incluindo espécies de Bacillus macerans, Bacillus cloacae, Bacillus macerans, Bacillus licheniformis e Bacillus polymyxa (Lukajtis et al., 2018). Bacillus são bem conhecidos por suas diversas aplicações, como secreção de proteínas, síntese de produtos químicos, biopolímeros, desenvolvimento de produtos farmacêuticos e nutracêuticos, tais como Condroitina, $\mathrm{N}$-acetilglicosamina e ácido poligamaglutâmico (Yim et al., 2011; Liu et al., 2015; Mohapatra et al., 2017), ), sendo extremamente importante o isolamento e caracterização de novas linhagens.

Para a classe "outros organismos" obteve-se abundância relativa de 3,15 e 4,74\% para inóculo e E6, respectivamente, sendo que os gêneros pertencentes a esta categoria foram menos abundantes $(<0,2 \%)$, e por isso foram englobados nesta categoria.

Figura 5.20. Abundância relativa dos representantes pertencentes aos gêneros do domínio Bacteria da amostra do inóculo e do ensaio 6 do delineamento de Plackett-Burman.

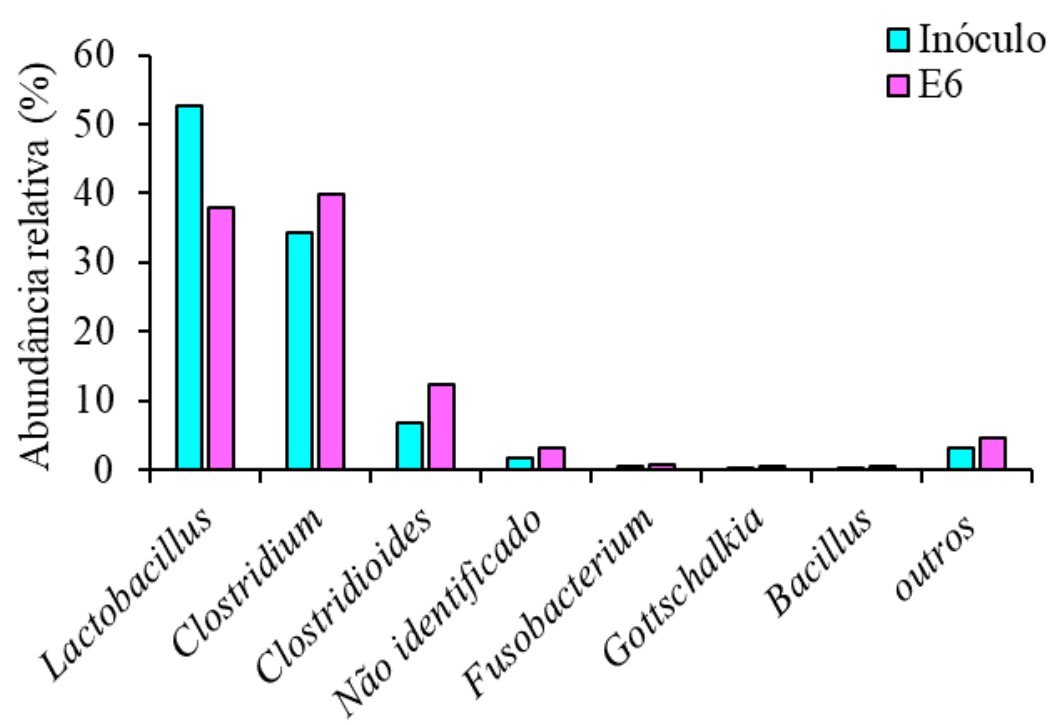

Como os membros do gênero Clostridium são associados à hidrólise de substratos complexos e principalmente a produção de $\mathrm{H}_{2}$, ácido butírico (Chi et al., 2018) e acético (Zhang et al., 2019). A predominância deste gênero, tanto no inóculo, quanto no E6 pode estar intimamente associada a produção de $\mathrm{H}_{2}$, ácido acético e butírico em todos os ensaios. Além 


\section{Universidade de São Paulo \\ Escola de Engenharia de São Carlos \\ Programa de Pós-graduação em Hidráulica e Saneamento}

disso, a versatilidade de Clostridium em metabolizar vários carboidratos, incluindo glicose, xilose, sacarose, lactose, amido para produção de hidrogênio (Yin e Wang, 2017) faz com que sua predominância no RB seja vantajosa, em vista que este resíduo é constituído basicamente de carboidratos, principalmente glicose e frutose.

$\mathrm{Na}$ presente pesquisa as principais espécies de Clostridium identificadas no inóculo e no ensaio E6 são apresentadas na Figura 5.21. As principais espécies de Clostridium foram relacionadas a $C$. butyricum, $C$. botulinum e $C$. perfringens, Dentre as três espécies mais abundantes, duas delas são produtoras de $\mathrm{H}_{2}$ (C. butyricum e C. perfringens) (Wang et al., 2011; Kanchanasuta et al., 2017; Aly et al., 2018; Hamilton et al., 2018; Wong et al., 2018).

Figura 5.21. Principais espécies de Clostridium identificadas na amostra de inóculo e E6 do delineamento de Plackett-Burman.

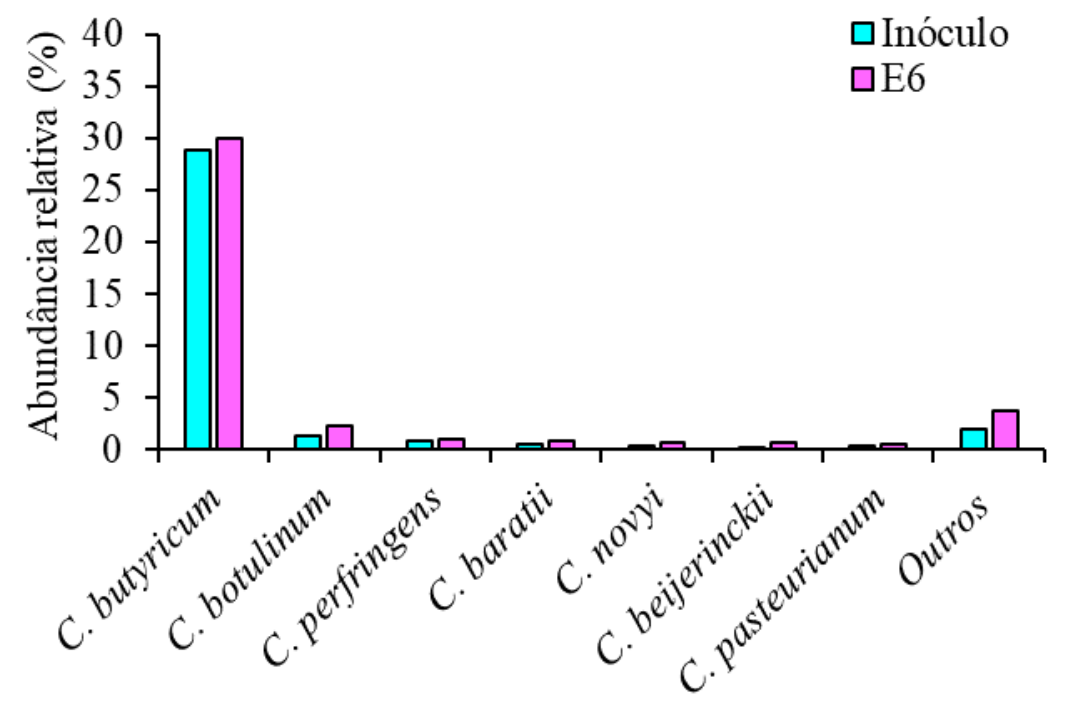

A título de exemplificação, Yin e Wang et al. (2017) avaliaram o desempenho da produção de hidrogênio pelo isolado $C$. butyricum INET1 a partir de variedade de substratos. $\mathrm{O}$ efeito da temperatura, $\mathrm{pH}$ inicial, concentração de substrato e proporção de inóculo foram avaliados quanto a produção de hidrogênio. A máxima produção de $\mathrm{H}_{2}$ de $218 \mathrm{~mL} / 100 \mathrm{~mL}$ foi obtida na condição ótima de $35^{\circ} \mathrm{C}, \mathrm{pH}$ inicial 7,0, glicose 10 g.L $\mathrm{L}^{-1}$ e $10 \%$ de inóculo. Os principais metabólitos produzidos durante a fermentação foram ácido acético, butírico e propiônico. Na presente pesquisa, o C. butyricum foi a espécie mais abundante no E6. Assim como Yin e Wang et al. (2017), a produção máxima de $\mathrm{H}_{2}(38,08 \mathrm{~mL})$ foi obtida em pH próximo ao neutro ( $\mathrm{pH} 7,5), 15$ g. $\mathrm{L}^{-1}$ de carboidratos totais do RB e 15\% inóculo, diferindo-se na temperatura, no qual no E6 a alta produção foi obtida a $44^{\circ} \mathrm{C}$. Apesar de na presente pesquisa 
ser utilizado consórcio de bactérias ao invés de isolado, os metabólitos sintetizados foram semelhantes, incluindo ácido acético, butírico e propiônico.

A identificação destas espécies no RB pode ser devido a sua vasta ocorrência em amostras provenientes de variedade de solos com variedade de culturas, incluindo Solanum tuberosum (batata), Phaseolus vulgaris (feijão verde), Beta vulgaris var. rapaceum (beterraba), Cucurbita pepo (abóbora), Allium cepa (cebola), Cucumis sativus (pepino) e Capsicum annum (pimenta), podendo estas estarem presentes também no solo de cultivo de frutas (Voidarou et al., 2011). Além disso, a predominância de C. perfringens nas amostras pode ser decorrente de sua tolerância a produtos químicos (Charlebois et al., 2017) e a produção de exótoxinas (Shrestha et al., 2016), uma vantagem seletiva em relação as demais bactérias.

Dentre as demais espécies de Clostridium, destaca-se o C. pasteurianum no qual também tem sido reportada como produtora de $\mathrm{H}_{2}$ (Srivastava et al., 2017), de ácido butírico e butanol (Regestein et al., 2015; Krasnan et al., 2018;). Apesar de ter sido identificada em baixa abundância relativa, 0,32 e 0,56\%, no inóculo e E6 respectivamente; pode ter contribuído também com a produção de hidrogênio e ácidos carboxílicos.

Outra espécie que apesar da baixa abundância (0,26 \% inóculo e 0,40\% E6) merece atenção é Clostridium carboxidivorans no qual tem sido associada a produção de ácidos carboxílicos, etanol e butanol (Zhang et al., 2016; Sun et al., 2018;) e pode ter sido uma das responsáveis pela diversidade de metabólitos solúveis e desvios de rotas metabólicas na fermentação do resíduo de banana.

Clostridium beijerinckii também tem sido reportado como produtor de $\mathrm{H}_{2}$, e foi mais abundante no E6 $(0,62 \%)$ do que no inóculo $(0,12 \%)$. Representantes desta espécie podem ter contribuído para a hidrólise e acidogênese do RB. A maior abundância no E6, quando comparado ao inóculo deveu-se as condições deste ensaio, as quais favoreceram seu crescimento. Uma das variáveis que pode ser contribuído com o aumento da abundância desta espécie no E6 foi $\mathrm{pH}(7,5)$, temperatura $\left(44^{\circ} \mathrm{C}\right)$ e concentração do substrato $\left(15\right.$ g.L $\left.\mathrm{L}^{-1}\right)$. De acordo com Valentin-Reyes et al. (2018) C. beijerinckii é muito sensível ao meio ácido (pH $<5,0)$ e o ajuste do pH em 7,5 no E6 pode ter contribuído com seu crescimento. An et al. (2014) reportaram que as condições ótimas para obtenção de rendimento de hidrogênio e taxa de produção de 2,33 mol. $\mathrm{mol}^{-1}$ xilose e $311,3 \mathrm{~mL} \mathrm{H}_{2} \cdot \mathrm{L} \cdot \mathrm{h}^{-1}$, respectivamente, foi em $\mathrm{pH} 8,0,40^{\circ} \mathrm{C}$ e 10 g.L $\mathrm{L}^{-1}$ de substrato, condições estas semelhantes do E6. De maneira geral, todas espécies de Clostridium podem ter contribuído para fermentação do RB e produção de $\mathrm{H}_{2}$, entretanto o $\mathrm{pH}$ ácido $(<4,0)$ no final da fermentação pode ter contribuído com a rápida estabilização da 


\section{Universidade de São Paulo \\ Escola de Engenharia de São Carlos \\ Programa de Pós-graduação em Hidráulica e Saneamento}

produção de hidrogênio, em vista que essa espécie demonstrou ser sensível em meio muito ácido.

As bactérias ácido láticas (BAL) são Gram-positivas e exercem dois tipos de fermentação: fermentação homolática e heterolática. Na fermentação homolática, duas moléculas de piruvato, que são formadas durante a glicólise, são convertidas em lactato, enquanto na fermentação heterolática, uma molécula de piruvato é convertida em lactato e a outra é convertida em etanol e dióxido de carbono (Sikora et al., 2013). Portanto, a presença destas bactérias desempenha papel importante na produção de ácido lático, principalmente a partir de glicose, contribuindo com a redução do valor de $\mathrm{pH}$ a valores <4,0 (Yang et al., 2016).

Devido ao alto requisito nutricional, as BAL são geralmente identificadas em ambientes ricos em carboidratos, aminoácidos e ácidos nucléicos. Por outro lado, apresentam adaptação considerável a condições adversas, que lhes permite habitar ampla variedade de habitats (Korhonen, 2010), tornando-as onipresentes no meio ambiente. Tais informações podem justificar a presença natural de Lactobacillus no RB e sua predominância as variações operacionais, como pH entre 4,0 a 7,0 e concentração de carboidratos entre 5-10 g.L $\mathrm{L}^{-1}$.

Curiosamente, as BAL são frequentemente identificadas em consórcios de bactérias produtoras de hidrogênio (Sikora et al., 2013), corroborando com a presente pesquisa, no qual foi verificado predominância de Lactobacillus no consórcio de bactérias juntamente com outros gêneros produtores de $\mathrm{H}_{2}$, com Clostridium. Chojnacka et al. (2011) reportaram a predominância de representantes da família Clostridiaceae, Enterobacteriaceae e bactérias de fermentação heteroláticas, principalmente Leuconostocaeae, em consórcios de bactérias produtoras de hidrogênio. Os autores ainda reportaram o papel significativo das BAL na produção de hidrogênio, baseando-se no fato de que, quanto maior o número de BAL na comunidade produtora de hidrogênio, mais hidrogênio foi produzido, além disso, associaram o consumo completo de ácido láctico com o aumento significativo da concentração de ácido butírico e ao maior rendimento de hidrogênio. Reforçando essa ideia, Yang et al. (2007) e Fues et al. (2018) relataram que a presença de bactérias acido láticas está relacionada a produção de $\mathrm{H}_{2}$ (Reação 9). Baghchehsaraee et al. (2009) sugeriram que a conversão do piruvato em lactato pode resultar no aumento de NADH, que por sua vez, favoreceria ainda mais a produção de $\mathrm{H}_{2}$ através da reoxidação de moléculas de $\mathrm{NADH}$ em $\mathrm{NAD}^{+}$.

Matsumoto e Nishimura (2007) avaliaram a produção de hidrogênio por cepa de Clostridium isolada, utilizando pasta de batata contendo grandes quantidades de ácidos orgânicos. A produção de hidrogênio foi acompanhada por diminuição das concentrações de 
ácido acético e ácido láctico e co-produção de ácido butírico. A capacidade de produzir hidrogênio a partir de ácido láctico e acético parece ser amplamente conservada em Clostridium. No entanto, a produção de hidrogênio a partir de ácido lático e ácido acético foi extremamente dependente do $\mathrm{pH}$ e situou-se em faixa de $\mathrm{pH}(\sim 5,8-7,4)$. Jo et al. (2008) reportaram que a conversão de ácido lático e ácido acético em ácido butírico e hidrogênio por Clostridium foi inibida devido à diminuição do $\mathrm{pH}$ de 5,5 para 4,6. Tal resultado pode explicar a predominância de ácido lático no final da fermentação do E6, na qual o pH observado foi abaixo de 4,0. Portanto, presença mútua de Lactobacillus e Clostridium no inóculo e no E6 pode ter favorecido e contribuído com a produção de hidrogênio nestas amostras, além da produção de ácido acético, lático e butírico.

No gênero Lactobacillus estão incluídas mais de 145 espécies. Na presente pesquisa, as espécies mais abundantes identificadas foram Lactobacillus casei $(27,91 \%$ inóculo e 15,46\% E6), Lactobacillus paracasei (21,62\% inóculo e 12,16\% E6) e Lactobacillus fermentum (1,85\% inóculo e 9,18\% E6) (Figura 5.22). Exceção a L. fermentum, para as demais espécies observouse diminuição da abundância relativa do inóculo para E6. Provavelmente, isso foi devido as condições impostas no ensaio E6 (pH 7,5, CT 15 g.L $\mathrm{L}^{-1}, 44^{\circ} \mathrm{C}$, headspace 40\%, inóculo 15\%), as quais não beneficiaram as outras espécies de Lactobacillus, quando comparado as condições do inóculo $\left(37^{\circ} \mathrm{C}, \mathrm{pH} \sim 4,5\right)$. Estes resultados corroboram com o obtido por Probst et al. (2013) no qual reportaram que a abundância relativa de espécies de Lactobacillus, foi afetada pelo pH e temperatura.

Assim como na presente pesquisa, Wu et al. (2015) observaram alta abundância relativa $(94,2 \%)$ de Lactobacillus na fermentação de resíduos de frutas e vegetais, sendo que as principais espécies identificadas incluem Lactobacillus points (32\%), Lactobacillus frumenti (10\%), Lactobacillus acidophilus (8\%) e Lactobacillus amylovorus (6\%). Ademais, Yang et al. (2016) relataram a presença natural de Lactobacillus plantarum (54,9\%), Lactobacillus paraplantarum (3,6\%), Lactobacillus nagelii (8,5\%), Lactobacillus perolens (4,9\%), Lactobacillus casei $(11,0 \%)$ e Lactobacillus fermentum $(9,8 \%)$ na fermentação de resíduos de frutas (banana, abacaxi e mamão). De acordo com os autores Lactobacilos plantarum e Lactobacillus casei são espécies frequentemente isoladas de resíduos de frutas, e podem crescer em pH baixo e produzir mais ácido lático do que outros isolados. Como no final da fermentação o pH esteve extremamente ácido ( 3,5), pode-se inferir que a alta abundância relativa $(38,02 \%)$ de BAL no final da fermentação no E6 pode ser decorrente de sua afinidade em menor $\mathrm{pH}$. 


\section{Universidade de São Paulo \\ Escola de Engenharia de São Carlos \\ Programa de Pós-graduação em Hidráulica e Saneamento}

Figura 5.22. Principais espécies de Lactobacillus identificadas na amostra de inóculo e E6 do delineamento de Plackett-Burman.

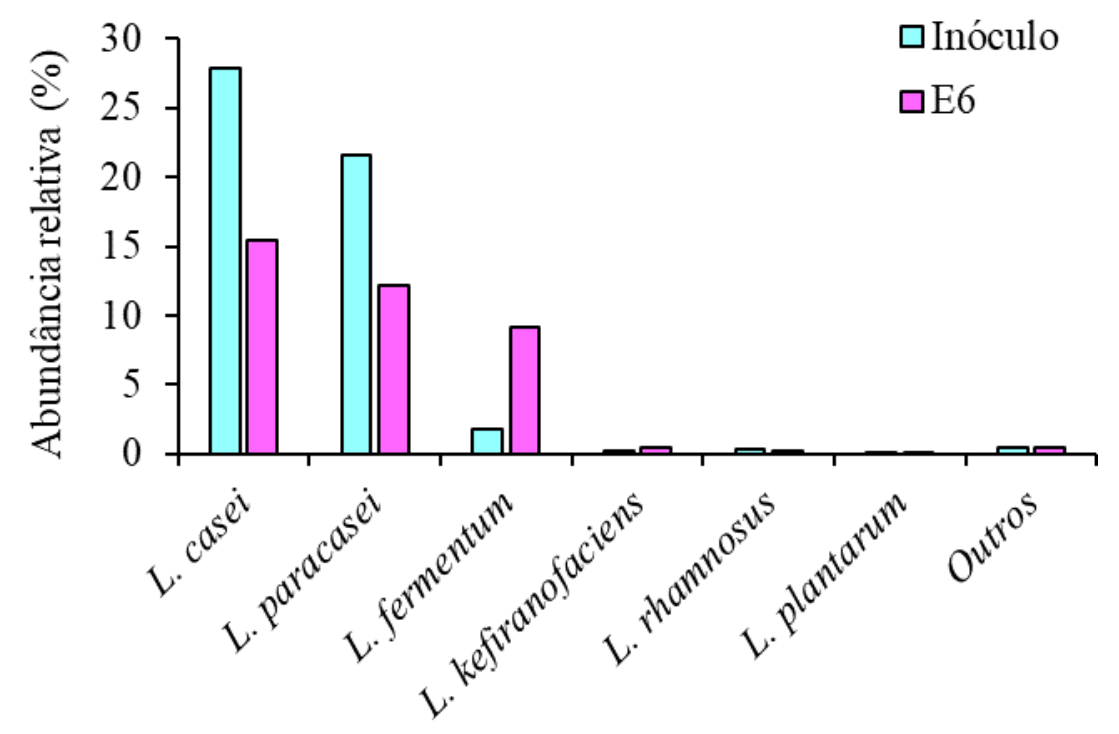

Em relação as demais espécies (L. kefiranofaciens, L. rhamnosus e L. plantarum), observou-se que independente da condição operacional a abundância relativa no inóculo e E6 foram similares (Figura 5.22). Contudo, pode-se inferir que o uso da metodologia de screening desing pode ser uma das alternativas que ajuda a conduzir ao estabelecimento de uma rota metabólica a partir da mudança da comunidade bacteriana frente às condições operacionais dos reatores.

\subsubsection{Metabolismo de carboidratos associado ao ensaio com maior produção de $\mathbf{H}_{2}$}

Foi realizada análise funcional dos genes, incluindo enzimas e principais rotas metabólicas, do consórcio de bactérias referente ao ensaio no qual foi obtida maior produção de hidrogênio (E6: pH 7,5, CT 15 g.L $\mathrm{L}^{-1}, 44^{\circ} \mathrm{C}$, headspace 40\%, inóculo 15\%). Todas as informações foram obtidas por meio da utilização do banco de dados KEEG em nível de função através do número do KO (KEGG Orthology) de cada sequência e sua respectiva abundância relativa.

Por meio dos números de KO obteve-se curva de rarefação referente as sequencias do E6 (Figura 5.23). Pode-se inferir que a qualidade do sequenciamento foi satisfatória, abrangendo toda a capacidade funcional da biomassa contida nesta amostra. Deste modo, por meio da relação assintótica entre os números de $\mathrm{KO}$ e as sequências, obteve-se um platô. 
Portanto, ampla cobertura amostral e funcional foi obtida, inferindo em alta riqueza de funções metabólicas (>3000).

Figura 5.23. Curva de rarefação abrangendo o número total de $\mathrm{KO}$ atribuído pelo aumento do número de sequências na amostra do ensaio E6.

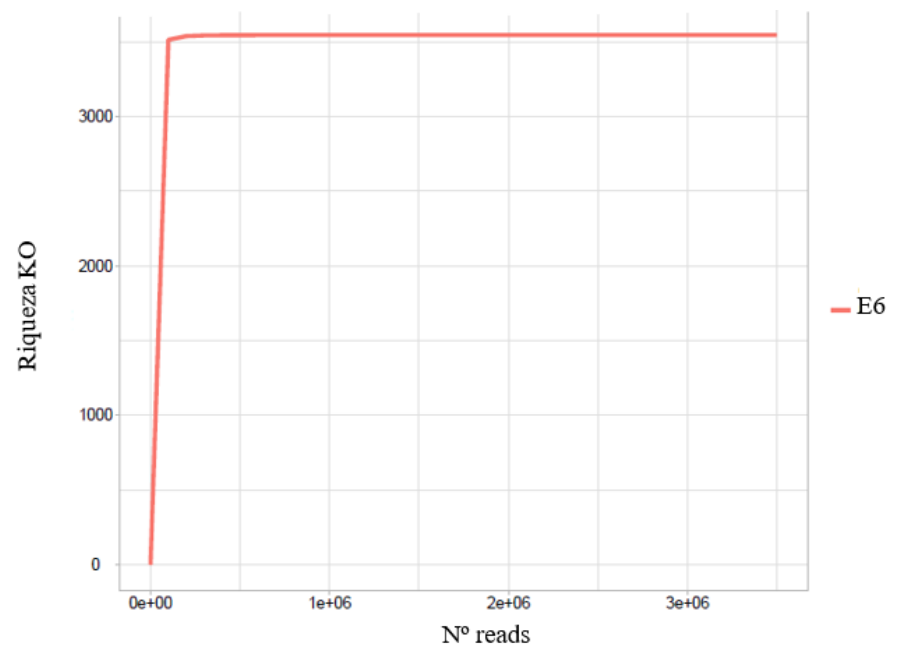

Assim como, no inóculo, observou-se que dentre as principais categorias funcionais dos genes identificados na amostra no E6, esta o metabolismo de carboidratos (9\%) (Figura 5.24). A abundância relativa de genes relacionados ao metabolismo de carboidratos assegura que durante o processo fermentativo, a produção de $\mathrm{H}_{2}$ e ácidos orgânicos, assim como, metabolismo de açúcares (mono, di e polissacarídeos) estiveram associados a presença de microrganismos com potencial genético para produção de $\mathrm{H}_{2}$ e ácidos carboxílicos. Em vista que o resíduo de banana é praticamente constituído por carboidratos infere-se sobre a ocorrência no E6 de rotas de conversão de carboidratos, incluindo glicólise, glicogênese, metabolismo de pentoses, fermentação entre outros. Esses resultados são consistentes com estudos metagenômicos aplicados a reatores biológicos na produção de hidrogênio, cuja metabolismo de carboidratos foi um dos metabolismos mais abundantes (Soares et al., 2018 e Rabelo et al., 2018).

Foram identificadas 305.780 sequências cujos KO estão associados ao metabolismo de carboidratos. Os $\mathrm{KO}$ e enzimas mais abundantes relacionados ao metabolismo de carboidratos e a produção de hidrogênio e ácidos orgânicos são apresentados na Tabela 5.11. Pelo heatmap foi possível visualizar maior abundância relativa para os KO cuja a cor verde foi atribuída. 


\section{Universidade de São Paulo \\ Escola de Engenharia de São Carlos \\ Programa de Pós-graduação em Hidráulica e Saneamento}

Figura 5.24. Distribuição funcional metabólica dos genes observados na amostra do E6

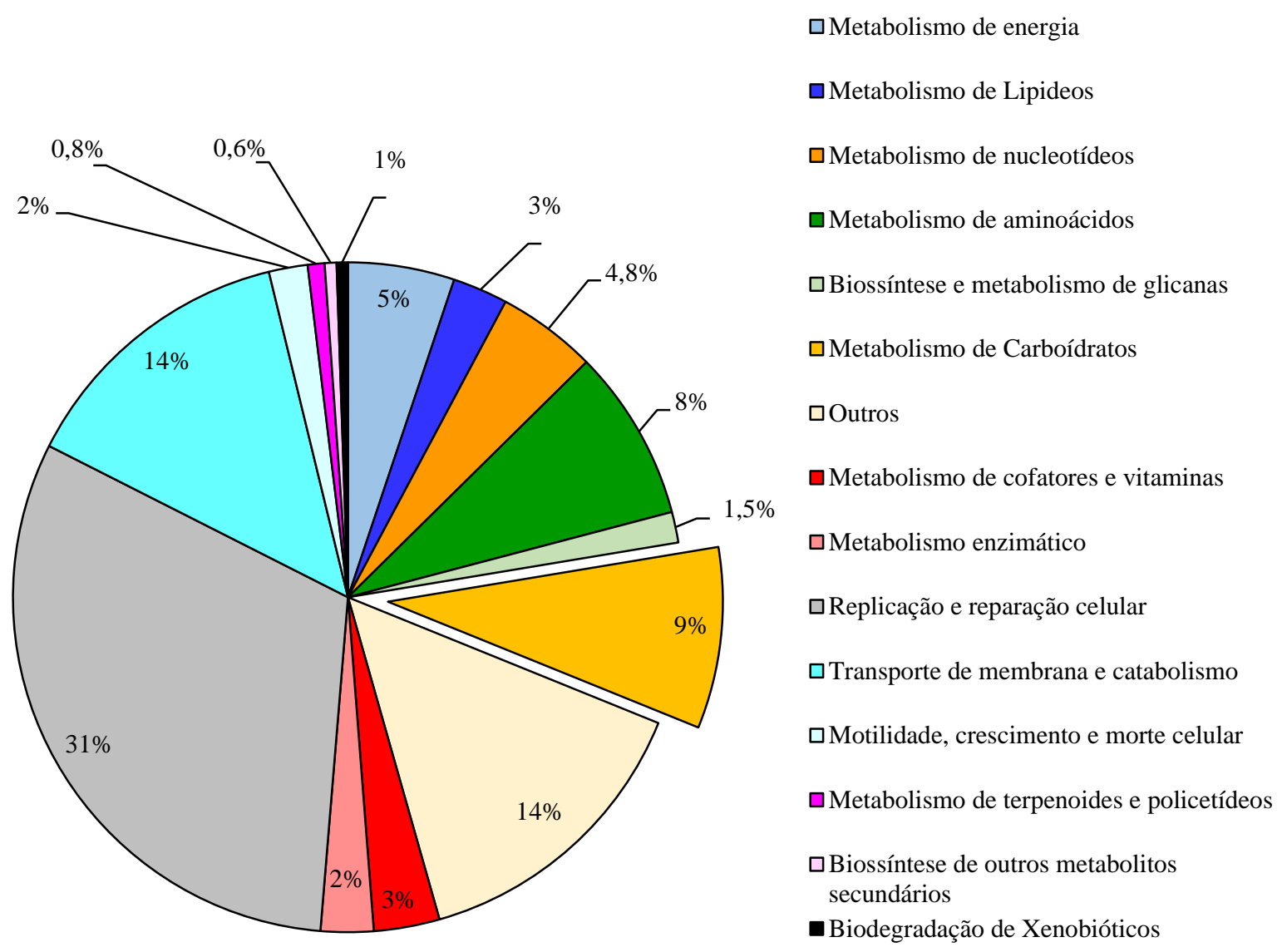

Nota: E6 = Maior produção de $\mathrm{H}_{2}$ do PB12

Genes relacionados a piruvato-ferredoxina oxidorredutoase (PFOR) (EC 1.2.7.1; K03737) foram identificados com abundância relativa de 19,21\% no E6. Esta enzima realiza a conversão de piruvato em acetil-CoA, transferindo elétrons para a síntese de hidrogênio (Hallenbeck and Benemann, 2002). De acordo com Castro et al. (2013) na via Clostridial, a conversão do piruvato a acetil-CoA é acoplada à redução de Ferredoxina, tornando-se o principal mecanismo de produção de $\mathrm{H}_{2}$, pela subsequente oxidação da ferredoxina por FeFehidrogenases juntamente à redução de prótons. Levando em consideração a abundância relativa dos genes desta enzima no E6, assume-se que esta rota foi uma das principais vias produtoras de $\mathrm{H}_{2}$. Além desta via, de $\mathrm{H}_{2}$, o piruvato pode ser oxidado pela PFOR a acetil-CoA para formação de etanol, ácido acético e $\mathrm{H}_{2}$ (Reação 18). 
Neste sentido, a síntese de etanol e ácido acético obtida no ensaio 6 pode ter sido resultante da atuação desta enzima. Ademais, tanto o etanol como o ácido acético, são subprodutos, que podem ser metabolizados posteriormente para produção de $\mathrm{H}_{2}$ (Reação 13 e 21), e com isso, a PFOR assume importante papel no metabolismo de carboidratos como enzima catalisadora de reações que levam a produção de $\mathrm{H}_{2}$, ácidos e etanol.

Tabela 5.11. Principais KO e genes das enzimas associadas ao metabolismo de carboidratos na fermentação de RB.

\begin{tabular}{cccc}
\hline \multirow{2}{*}{ KO } & \multicolumn{2}{c}{ Abundância relativa $(\%)$} & Enzima \\
\cline { 2 - 3 } & Inóculo & E6 & piruvato-ferredoxina (EC 1.2.7.1) \\
\hline K03737 & 18,68 & 19,21 & L-lactato desidrogenase (EC 1.1.1.27) \\
K00016 & 9,98 & 6,04 & D-lactato desidrogenase (EC 1.1.1.28) \\
K03778 & 4,85 & 3,87 & acetato quinase (EC 2.7.2.1) \\
K00925 & 11,55 & 10,36 & 3-hidroxibutiril-CoA desidrogenase (EC 1.1.1.157) \\
K00074 & 2,35 & 1,61 & formiato-tetrahidrofolato ligase (EC 6.3.4.3) \\
K01938 & 12,72 & 13,54 & acetil-CoA sintase (EC 2.3.1.169) \\
K14138 & 9,50 & 12,41 & alcool desidrogenase (EC:1.1.1.1) \\
K00001 & 2,70 & 1,51 & acetaldeido desidrogenase (EC 1.2.1.10) \\
K04072 & 5,89 & 3,33 &
\end{tabular}

Tanto a L-lactato desidrogenase (6,04\%; K00016) quanto e D-lactato desidrogenase (3,97\%; K03778) catalisam a síntese de diferentes estereoisômeros de ácido lático (L ou D) através da redução do piruvato (Abdel-Rahman et al., 2013). O fato de que os genes associados a enzima lactato desidrogenase foi abundante tanto no inóculo quanto no E6 (Tabela 5.11), pode-se inferir que esta enzima foi responsável pela produção de grande parte do ácido lático $\left(1,6\right.$ g. $\left.\mathrm{L}^{-1}\right)$ neste ensaio.

Outra enzima que pode ter contribuído com a alta produção de $\mathrm{H}_{2}$ no E6 foi a 3hidroxibutiril-CoA desidrogenase (EC 1.1.1.157; K00074), cuja abundância relativa dos genes relacionados a ela no E6 foi de 1,61\%. Esta enzima catalisa a síntese de butiril-CoA, molécula intermediária para a geração de butanol ou ácido butírico. Esse ácido por sua vez, contribui para a produção de hidrogênio, em baixos rendimentos ( 2 mols $\mathrm{H}_{2}$. mol glicose), e, portanto, auxilia nos processos fermentativos. 


\section{Universidade de São Paulo \\ Escola de Engenharia de São Carlos \\ Programa de Pós-graduação em Hidráulica e Saneamento}

Verificou-se para os genes relacionados a enzimas formiato-tetrahidrofolato ligase (EC 6.3.4.3; K01938) e acetato quinase (EC 2.7.2.1; K00925) abundância relativa de 13,54\% e $10,36 \%$, respectivamente. Ambas as enzimas podem atuar no metabolismo homoacetogênico autotrófico (utilizando $\mathrm{H}_{2}$ e $\mathrm{CO}_{2}$ como doador de elétrons), heterotrófico (utilizando compostos orgânicos, incluindo açúcares, álcoois, metanol e 2,3-butanodiol) e mixotrófico (utilizando vários substratos simultaneamente), no qual os principais sub-produtos destas vias são o ácido acético, lático, propiônico, butírico, etanol, entre outros (Saady, 2013). Normalmente, bactérias homoacetogênicas são anaeróbias estritas formadoras de endósporos, tolerantes a altas $\mathrm{pH}_{2} \mathrm{e}$ sobrevivem em amplo intervalo de temperatura $\left(4-80^{\circ} \mathrm{C}\right)$ com faixa de $\mathrm{pH}$ ótimo entre $6,8 \mathrm{e}$

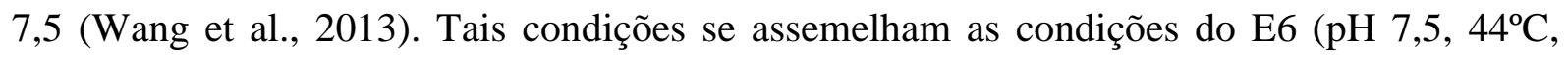
headspace 40\%). Ademais, bactérias homoacetogênicas são associadas ao gênero Clostridium (Latif et al., 2013), cuja suas características versáteis permitem a adaptação a diversas condições, abrangendo condições de estresse, esgotamento de substrato e limitação de nutrientes, desta forma, a redução da concentração de carboidratos totais, assim como diminuição do $\mathrm{pH}$ para valores $<4,0$ no final da fermentação do RB podem ter favorecido o metabolismo homoacetogênico, resultando na expressão dos genes relacionados as enzimas formiato-tetrahidrofolato ligase e acetato quinase na amostra da biomassa deste ensaio.

A acetato quinase bacteriana, em condições anaeróbias, catalisa a reação reversível (acetil fosfato $+\mathrm{ADP} \leftrightarrow$ acetato $+\mathrm{ATP}$ ), no qual também pode disponibilizar ácido acético para possível conversão em $\mathrm{H}_{2}$ (Abdel-Rahman et al., 2013). Por outro lado, a formiatotetrahidrofolato ligase catalisa a reação reversível de 10-formiltetra-hidrofolato a partir de formiato e tetra-hidrofolato, na presença de ATP (ATP + formiato + tetrahidrofolato $\leftrightarrow$ ADP + fosfato + 10-formiltetrahidrofolato (Sikora et al., 2013).

Tanto, a atividade da enzima álcool desidrogenase (EC:1.1.1.1; K00001) quanto da acetaldeído desidrogenase (EC 1.2.1.10; K04072) estão relacionadas a reação bifuncional $\left(\right.$ Etanol $+\mathrm{NAD}^{+} \rightarrow$ acetaldeído $+\mathrm{NADH}+\mathrm{H}^{+}$e acetaldeído $+\mathrm{NAD}^{+}+\mathrm{CoA} \rightarrow$ acetil-CoA + $2 \mathrm{NADH}+\mathrm{H}^{+}$) (Sikora et al., 2013). O primeiro passo no metabolismo do álcool é a oxidação do acetaldeído pela álcool desidrogenase, no qual esta enzima converte o álcool em acetaldeído, enquanto que a enzima acetaldeído desidrogenase, por sua vez, converte o acetaldeído em ácido acético. Esse ácido pode ser utilizado como substrato para produção de $\mathrm{H}_{2}$, etanol e ácido butírico (Reação 18 e 21) (Matsumoto e Nishimura, 2007). A acetil-CoA sintase (ACS) (EC 2.3.1.169; K14138) (12,41\%) catalisa a reação irreversível, no qual converte ácido acético e ATP ao intermediário acetiladenilato ligado a enzima (acetil-AMP). Em seguida, o acetil-AMP 
é convertido a acetil-CoA com a liberação AMP (Krivoruchko et al., 2015). O acetil-CoA, por sua vez, pode seguir diversas vias, incluindo a via heterolática (Abdel-Rahman et al., 2013) e vias de produção de etanol, ácido acético, butano e ácido butírico (Lukajtis et al., 2018). Portanto, essas enzimas provavelmente atuaram na etapa acidogênica, contribuindo com a produção de hidrogênio $(38,08 \mathrm{~mL})$, ácido acético $\left(0,07 \mathrm{~g} . \mathrm{L}^{-1}\right)$, etanol $\left(0,14 \mathrm{~g} . \mathrm{L}^{-1}\right)$ e ácido butírico $\left(1,19\right.$ g.L $\left.{ }^{-1}\right)$.

No geral, todas estas enzimas mencionadas anteriormente foram importantes para a catálise multifuncional de conversão dos carboidratos do RB. Como todas as enzimas tem sua atividade ótima em determinadas condições de $\mathrm{pH}$, temperatura, substrato e etc, assume-se que as condições operacionais do reator referente ao $\mathrm{E} 6\left(\mathrm{pH} 7,5, \mathrm{CT} 15 \mathrm{~g} . \mathrm{L}^{-1}, 44^{\circ} \mathrm{C}, 40 \%\right.$ headspace, $15 \%$ inóculo) foram adequadas para o crescimento celular e síntese de genes relacionados a todas essas enzimas. Diferença significativa não foi observada entre a abundância relativa dos genes dessas enzimas para a biomassa do inóculo e E6, sendo possível inferir que, neste caso, a mudança de $\mathrm{pH}$, temperatura, concentração de substrato, headspace e porcentagem de inóculo não exerceram influência direta no metabolismo enzimático.

\subsubsection{Conclusão do delineamento de Plakett-Burman}

As variáveis independentes $\mathrm{pH}$, temperatura, concentração de substrato, volume do headspace e porcentagem de inóculo são parâmetros importantes que influenciaram na fermentação de resíduos de banana e estabeleceram o predomínio de rotas metabólicas, seja elas para produção de $\mathrm{H}_{2}$ ou outros metabólitos solúveis.

Valores máximos de produção e velocidade de produção de $\mathrm{H}_{2}$ de 38,08 $\mathrm{mL}$ e 3,07 $\mathrm{mL} \cdot \mathrm{h}^{-1}$, respectivamente, foram obtidas em condições de $\mathrm{pH} 7,5,15$ g. $\mathrm{L}^{-1}, 44^{\circ} \mathrm{C}, 40 \%$ de headspace e $15 \%$ inóculo. $\mathrm{O}$ aumento da temperatura de $30^{\circ} \mathrm{C}$ para $44^{\circ} \mathrm{C}$ associado a redução do $\mathrm{pH}$ inicial de 7,5 para 5,5 reduziu em horas o tempo de início de $P$ de 9,79 para 3,89 h. O aumento da concentração de carboidratos totais (CT) de 3 para 15 g.L.-1 reduziu a eficiência de remoção de carboidratos e rendimento de $\mathrm{H}_{2}$. Os principais metabólitos solúveis observados a partir da fermentação da banana foi o ácido lático, butírico e acético. A diminuição do pH inicial para valores $<4,0$ favoreceram a rota solventogênica, com produção de etanol.

Lactobacillus e Clostridium foram as bactérias mais abundantes no E6. Estas bactérias estão relacionadas a maior produção de $\mathrm{H}_{2}$ neste ensaio, uma vez que genes associados a enzimas produtoras de $\mathrm{H}_{2}$, HAc, $\mathrm{HBu}$ e HLa foram identificadas na biomassa. 


\section{Universidade de São Paulo \\ Escola de Engenharia de São Carlos \\ Programa de Pós-graduação em Hidráulica e Saneamento}

A utilização da metodologia de screening design para triagem e análise dos efeitos das variáveis permitiu a seleção de condições operacionais apropriadas para obter alta produção de hidrogênio. Dentre as variáveis avaliadas o $\mathrm{pH}$ e temperatura foram indispensáveis para o estabelecimento da atividade hidrogenogênica, tendo em vista as limitações no controle do $\mathrm{pH}$ e acúmulo de ácidos orgânicos em reatores em batelada. Desta forma, tanto o pH quanto a temperatura foram selecionadas para realização do fatorial completo (DCCR) e construção dos modelos preditivos, visando a otimização da produção de $\mathrm{H}_{2}$ utilizando resíduos de banana e biomassa autóctone.

\subsection{Otimização da produção de hidrogênio - Sub-hipótese 3}

\subsubsection{Análise da superfície de resposta}

Nesta etapa, o principal objetivo foi comparar os parâmetros cinéticos, tais como produção de $\mathrm{H}_{2}(P)$, velocidade de produção $(R m)$ e tempo de início de produção $\left(\lambda \mathrm{H}_{2}\right)$ por meio de diferentes níveis de $\mathrm{pH}$ e temperatura. Estas variáveis foram selecionadas através do Delineamento experimental Plackett-Burman (PB) como sendo altamente significativas no processo fermentativo para produção de hidrogênio utilizando resíduo de banana como única fonte de carbono acrescido de meio de cultivo PCS.

Respeitando a cinética do processo, para cada ensaio do DCCR (E1-11) foram retiradas amostras em função do tempo para determinação da produção de $\mathrm{H}_{2}$ (Figura 5.25). De modo geral, observou-se que o tempo de início de produção de $\mathrm{H}_{2}\left(\lambda \mathrm{H}_{2}\right)$ iniciou-se logo nas primeiras horas de fermentação, variando entre 1,06 e 7,15 horas, enquanto a estabilização da produção de $\mathrm{H}_{2}$ foi observada até 20 horas de fermentação, tempo no qual a produção foi estável para todos os ensaios. Pode-se inferir que a $P$ está associada ao crescimento celular, corroborando com os resultados obtidos por Jayasinghearachchi et al. (2009), Khanna et al. (2011) e Ulhiza et al. (2018). Esses autores relataram que o hidrogênio foi produzido logo que o inóculo foi adicionado, e após algumas horas observaram fase de estabilização do crescimento celular, enquanto para $P$ observaram estabilização da produção.

Os menores valores de $\lambda \mathrm{H}_{2}$ de 1,06 h (E8) e 2,68 h (E3) foram obtidos principalmente nos ensaios em pH ácido (6,5 e 5,5) e alta temperatura $\left(46,90\right.$ e $\left.44^{\circ} \mathrm{C}\right)$ (Tabela 5.12). Nos ensaios em que o valor de $\mathrm{pH}$ inicial foi 6,5 e 5,5 mas com temperaturas de 37 e $30^{\circ} \mathrm{C}$, o tempo de início de produção de $\mathrm{H}_{2}$ aumentou para faixa de 4-5 h. Sob outra perspectiva, o maior valor de $\lambda \mathrm{H}_{2}$ de 7,15 h (E2) foi obtido em pH 7,5 e 30 ${ }^{\circ} \mathrm{C}$. No entanto, observou-se diminuição para 3,47 h quando a temperatura passou de 30 para $44^{\circ} \mathrm{C}$. 
Universidade de São Paulo

Escola de Engenharia de São Carlos

Programa de Pós-graduação em Hidráulica e Saneamento

Figura 5.25. Produção temporal de $\mathrm{H}_{2}$ do delineamento experimental DCCR
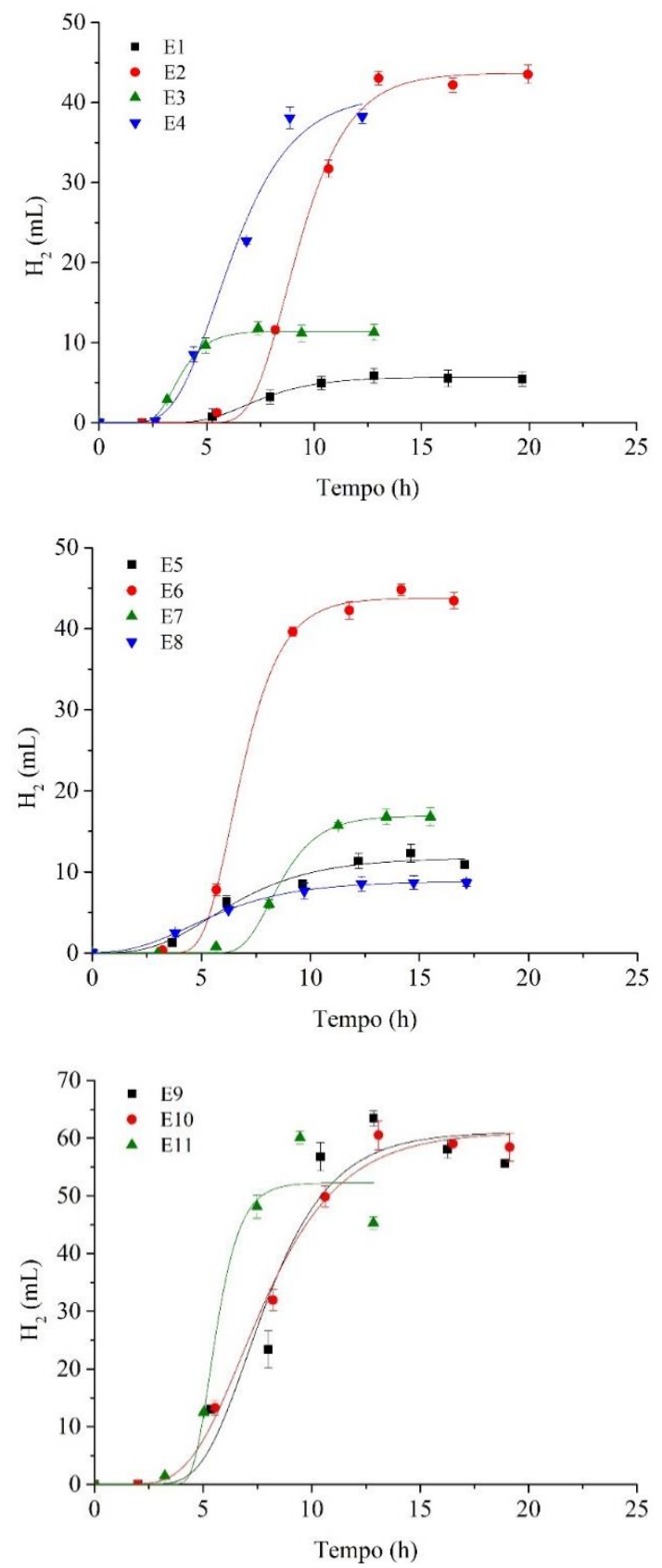

Notas: $\mathbf{E} 1=\mathrm{pH} 5,5$ e temperatura $30^{\circ} \mathrm{C}, \mathbf{E 2}=\mathrm{pH} 7,5$ e temperatura $30^{\circ} \mathrm{C}, \mathbf{E} 3=\mathrm{pH} 5,5$ e temperatura $44^{\circ} \mathrm{C}, \mathbf{E} \mathbf{4}=$ $\mathrm{pH} 7,5$ e temperatura $44^{\circ} \mathrm{C}, \mathbf{E 5}=5,09$ e temperatura $37^{\circ} \mathrm{C}, \mathbf{E} \mathbf{6}=7,91$ e temperatura $37^{\circ} \mathrm{C}, \mathbf{E} 7=\mathrm{pH} 6,5$ e temperatura $27,10^{\circ} \mathrm{C}, \mathbf{E 8}=6,5$ e temperatura $46,90^{\circ} \mathrm{C}, \mathbf{E 9}, \mathbf{E 1 0}$ e $\mathbf{E 1 1}=$ pH 6,5 e temperatura $37^{\circ} \mathrm{C}$.

Da mesma maneira, observou-se diminuição do $\lambda \mathrm{H}_{2}$ de 6,98 para $3,12 \mathrm{~h}$, quando a temperatura passou de 27,10 para $37^{\circ} \mathrm{C}$. Portanto, para obter rápida produção de $\mathrm{H}_{2}$ a partir de $\mathrm{RB}$ utilizando biomassa autóctone, baixos valores de $\mathrm{pH}$ e em temperaturas maiores ou iguais a $37^{\circ} \mathrm{C}$ devem ser empregadas. Entretanto, tais condições não foram favoráveis para obtenção 


\section{Universidade de São Paulo \\ Escola de Engenharia de São Carlos \\ Programa de Pós-graduação em Hidráulica e Saneamento}

de altas $P$, sendo neste caso, necessário utilizar condições de $\mathrm{pH}$ próximo a neutralidade e temperatura em torno de $37^{\circ} \mathrm{C}$.

Resultados semelhantes a presente pesquisa foram obtidos por Infantes et. al (2011), que relataram baixos valores de $\lambda \mathrm{H}_{2}$ de 1,69 e 1,65 h nos ensaios em pH 5 e 6, respectivamente, à $40^{\circ} \mathrm{C}$. Yossan et al. (2012) relataram diminuição de $\lambda \mathrm{H}_{2}$ de 33,57 para 8,24 h, quando aumentaram a temperatura de 25 para $55^{\circ} \mathrm{C}$, na fermentação de efluente de fábrica do óleo de palma. Ziara et al. (2018) reportaram tempo reduzido de $\lambda \mathrm{H}_{2}$ de $9,5 \mathrm{~h}$ a $45^{\circ} \mathrm{C}$ e $\mathrm{pH} 6,5$, enquanto os maiores $\lambda \mathrm{H}_{2}$ (26-27 h) foram obtidos quando houve diminuição da temperatura para $35^{\circ} \mathrm{C} \mathrm{e}$ elevação do $\mathrm{pH}$ para 7,5 e 8,5. Efeito adverso do $\mathrm{pH}$ no $\lambda \mathrm{H}_{2}$ foi relatado por Jo et al. (2008), no qual relacionaram os baixos valores de $\mathrm{pH}$ inicial aos maiores $\lambda \mathrm{H}_{2}$, enquanto em menor $\lambda \mathrm{H}_{2}$ foi obtido nos ensaios $\mathrm{pH}$ inicial 6,5-6,7. Provavelmente, as diferenças no $\lambda \mathrm{H}_{2}$ esta relacionada ao favorecimento de diferentes populações microbianas, por conseguinte, vias metabólicas distintas, frente às condições impostas nos diferentes ensaios em reatores em batelada.

Para as variáveis avaliadas observou-se para $P$ e $R m$ valores entre 6,06 a 62,43 mL e de 1,13 a $12,56 \mathrm{~mL} \cdot \mathrm{h}^{-1}$, respectivamente. Os valores máximos de $P(60$ a $62 \mathrm{~mL})$ foram obtidos nos ensaios 9, 10 e 11 (pontos centrais). A maior $P$ obtida nestes ensaios, provavelmente, foi devido ao enriquecimento da biomassa utilizada como inóculo nas mesmas condições experimentais desses ensaios, ou seja, a $37^{\circ} \mathrm{C}$ e pH 6,5. Em contrapartida, baixo $P(6$ a $11 \mathrm{~mL})$ foi obtido principalmente nos ensaios em $\mathrm{pH}$ ácido $(5,5-6,5)$ e temperatura abaixo de $30^{\circ} \mathrm{C}$ e superior a $40^{\circ} \mathrm{C}$ (Figura 5.26).

Nesta perspectiva, obteve-se aumento de $P$ e $R m$ de 6,06 para 40,10 $\mathrm{mL}$ e de 1,13 para $10,15 \mathrm{~mL} \cdot \mathrm{h}^{-1}$, respectivamente, para valores de $\mathrm{pH}$ de 5,5 a 7,5 à $30^{\circ} \mathrm{C}(\mathrm{E} 1 \mathrm{e} \mathrm{E} 2$, respectivamente). Do mesmo modo, à $44^{\circ} \mathrm{C}$, tanto para $P$, quanto para $R m$ observou-se de 11,10 a 37,09 mL e de 5,32 para 7,72 mL.h ${ }^{-1} \mathrm{em} \mathrm{pH}$ de 5,5 a 7,5, respectivamente. Por outro lado, observou-se aumento de $P$ de 11,65 para 62,43 mL com valor de $\mathrm{pH}$ inicial de 5,09 a 6,5. No entanto, verificou-se diminuição de $P$ de 62,43 para $44,32 \mathrm{~mL}$ com o aumento do $\mathrm{pH}$ de 6,5 para 7,91. Em contrapartida, observou-se para $R m$ aumento de 2,05 para $12,56 \mathrm{~mL} . \mathrm{h}^{-1}$, para $\mathrm{pH}$ de 5,0 a 7,91 , respectivamente. 
Universidade de São Paulo

Escola de Engenharia de São Carlos

Programa de Pós-graduação em Hidráulica e Saneamento

Tabela 5.12. Matriz do delineamento composto central rotacional (DCCR) e variáveis respostas.

\begin{tabular}{cccccccc}
\hline Ensaios & $\mathbf{p H}$ & $\begin{array}{c}\text { Temperatura } \\
\left({ }^{\mathbf{O}} \mathbf{C}\right)\end{array}$ & $\begin{array}{c}\boldsymbol{P} \\
(\mathbf{m L})\end{array}$ & $\begin{array}{c}\mathbf{R m} \\
\left(\mathbf{m L} \cdot \mathbf{h}^{-1}\right)\end{array}$ & $\begin{array}{c}\lambda \mathbf{H}_{2} \\
(\mathbf{h})\end{array}$ & $\begin{array}{c}\mathbf{C}_{\mathbf{C T}} \\
(\boldsymbol{\%})\end{array}$ & $\begin{array}{c}\mathbf{Y H}_{\mathbf{2}} \\
\left(\mathbf{m L} \mathbf{g}^{-1} \mathbf{C T}_{\text {add }}\right)\end{array}$ \\
\hline 1 & 5,5 & 30 & $6,06 \pm 0,0$ & $1,13 \pm 0,0$ & $5,43 \pm 0,3$ & $82,2 \pm 1,4$ & $8,07 \pm 0,3$ \\
2 & 7,5 & 30 & $40,10 \pm 0,0$ & $10,15 \pm 0,1$ & $7,15 \pm 0,2$ & $88,5 \pm 1,4$ & $53,46 \pm 0,0$ \\
3 & 5,5 & 44 & $11,10 \pm 0,0$ & $5,32 \pm 0,0$ & $2,68 \pm 0,1$ & $89,2 \pm 2,8$ & $14,80 \pm 0,2$ \\
4 & 7,5 & 44 & $37,09 \pm 0,1$ & $7,72 \pm 0,1$ & $3,47 \pm 0,1$ & $81,7 \pm 0,2$ & $49,45 \pm 0,9$ \\
5 & 5,09 & 37 & $11,65 \pm 0,0$ & $2,05 \pm 0,0$ & $3,12 \pm 0,1$ & $88,5 \pm 1,4$ & $15,53 \pm 0,6$ \\
6 & 7,91 & 37 & $44,32 \pm 0,0$ & $12,56 \pm 0,1$ & $5,12 \pm 0,3$ & $89,5 \pm 2,1$ & $59,09 \pm 0,2$ \\
7 & 6,5 & 27,10 & $16,93 \pm 0,0$ & $5,16 \pm 0,0$ & $6,98 \pm 0,1$ & $71,7 \pm 0,7$ & $22,57 \pm 0,3$ \\
8 & 6,5 & 46,90 & $10,67 \pm 0,0$ & $1,55 \pm 0,0$ & $1,06 \pm 0,6$ & $77,0 \pm 0,7$ & $14,23 \pm 0,2$ \\
9 & 6,5 & 37 & $61,64 \pm 0,1$ & $9,55 \pm 0,0$ & $4,62 \pm 0,1$ & $91,7 \pm 1,4$ & $82,18 \pm 1,2$ \\
10 & 6,5 & 37 & $62,43 \pm 0,1$ & $8,55 \pm 0,0$ & $4,25 \pm 0,6$ & $91,0 \pm 2,1$ & $83,24 \pm 1,5$ \\
11 & 6,5 & 37 & $60,50 \pm 0,4$ & $9,63 \pm 0,4$ & $4,54 \pm 0,1$ & $91,3 \pm 0,7$ & $80,67 \pm 2,0$
\end{tabular}

Notas: $P=$ produção de hidrogênio, $R m=$ velocidade de produção de hidrogênio, $\lambda \mathrm{H}_{2}=$ tempo de início de produção de hidrogênio, $\mathrm{C}_{\mathrm{CT}}=$ eficiência de remoção de carboidratos totais, $\mathrm{YH}_{2}=$ rendimento de hidrogênio . 


\section{Universidade de São Paulo \\ Escola de Engenharia de São Carlos \\ Programa de Pós-graduação em Hidráulica e Saneamento}

Figura 5.26. Efeito do pH e temperatura na produção de hidrogênio $(P)$.

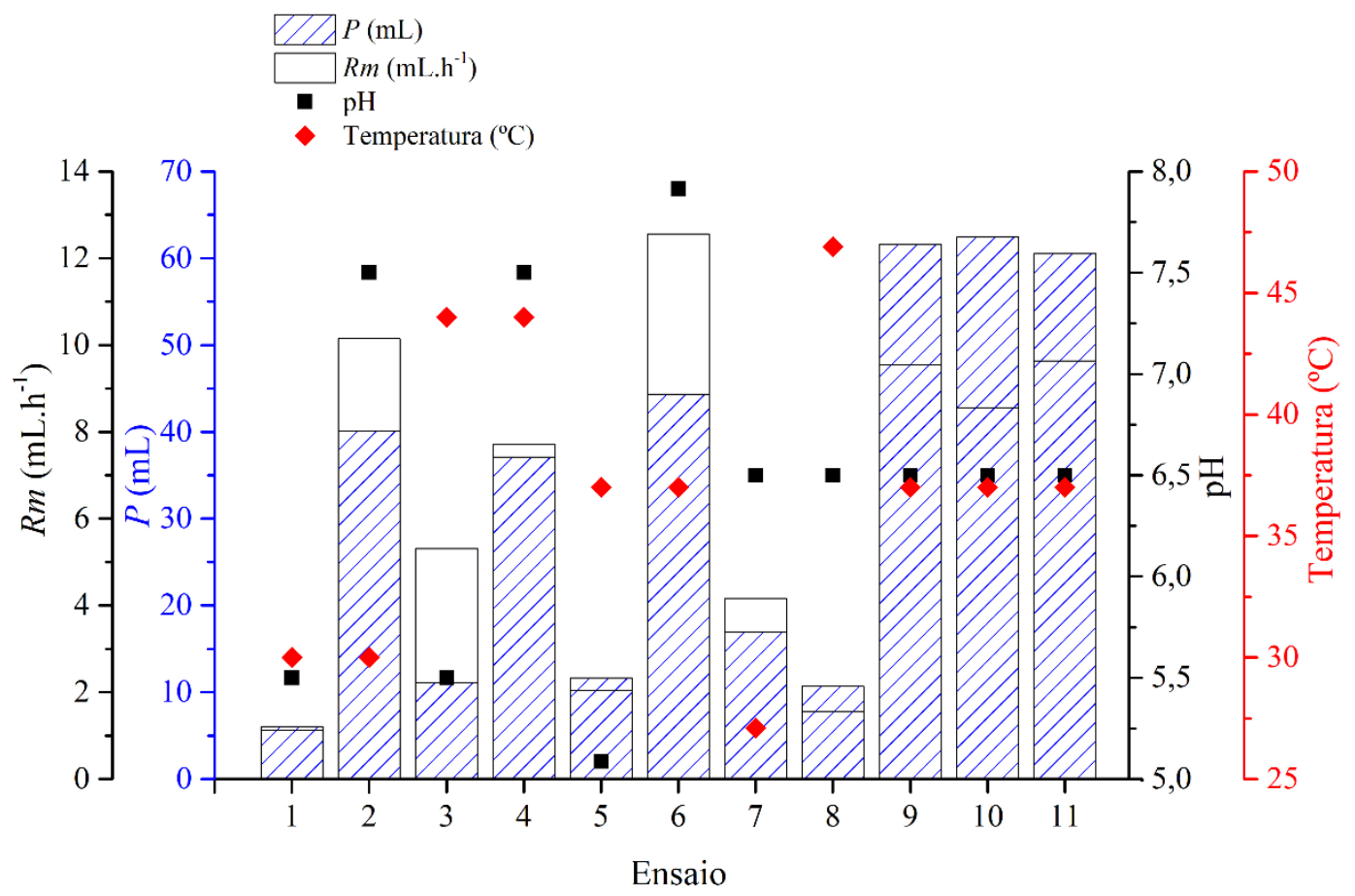

Nota: $\mathbf{E 1}=$ pH 5,5 e temperatura $30^{\circ} \mathrm{C}, \mathbf{E 2}=$ pH 7,5 e temperatura $30^{\circ} \mathrm{C}, \mathbf{E 3}=$ pH 5,5 e temperatura $44^{\circ} \mathrm{C}, \mathbf{E 4}=$ $\mathrm{pH} \mathrm{7,5} \mathrm{e} \mathrm{temperatura} 44^{\circ} \mathrm{C}, \mathbf{E 5}=5,09$ e temperatura $37^{\circ} \mathrm{C}, \mathbf{E 6}=7,91$ e temperatura $37^{\circ} \mathrm{C}, \mathbf{E} 7=\mathrm{pH} 6,5$ e temperatura $27,10^{\circ} \mathrm{C}, \mathbf{E 8}=6,5$ e temperatura $46,90^{\circ} \mathrm{C}, \mathbf{E 9}, \mathbf{E 1 0}$ e $\mathbf{E 1 1}=\mathrm{pH} 6,5$ e temperatura $37^{\circ} \mathrm{C}$.

Tais resultados corroboram com os obtidos por Lin et al. (2008) e Rabelo et al. (2018), nos quais avaliaram o efeito do $\mathrm{pH}$ de 5,5 a 9,0 e de 4,5 a 7,4 na produção de $\mathrm{H}_{2}$ utilizando amido e bagaço de cana-de-açúcar, respectivamente. De acordo com os autores, a maior produção de hidrogênio foi obtida na faixa de $\mathrm{pH}$ entre 6-7. Resultado semelhante foi obtido por Yossan et al. (2012), que relataram aumento de $P$ de 686,78 para 693,95 mL.L - $^{-1}$ e diminuição de $R m$ de 73,71 para 69,53 $\mathrm{mL} \mathrm{H}_{2} \cdot \mathrm{L} \mathrm{h}^{-1}$, para pH inicial de 5,5 a 6,5 na fermentação de efluente da fábrica de óleo de palma. Lay et al. (2012) relataram $P$ máxima (261 mL) na fermentação de resíduos de batata doce em pH inicial 7,0, sendo que valores superiores a 7,0 ( $\mathrm{pH} 7,5-9,0)$ desfavoreceram a produção de hidrogênio. Por outro lado, Lin et al. (2017) obtiveram $P$ máxima de 29,6 mL em pH 8 na fermentação de resíduos de cogumelos. O ajuste do $\mathrm{pH}$ inicial a valor superior a 7 pode ter contribuído com a neutralização do $\mathrm{pH}$ e consequentemente reduzido o efeito negativo da acidificação do meio (Tang et al., 2016) durante a fermentação da banana.

Observou-se diminuição dos valores de $P$ e $R m$ para as condições extremas de temperatura $\left(27^{\circ} \mathrm{C}, \mathrm{E} 7\right)$ e $\left(46,90^{\circ} \mathrm{C}, \mathrm{E} 8\right)$, ou seja, de 16,93 para $10,67 \mathrm{~mL} \mathrm{H}_{2}$ e de 5,16 para 1,55 
$\mathrm{mL} \cdot \mathrm{h}^{-1}$ em pH 6,5. Alvarez-Guzman também relataram baixas $P(12$ e $24 \mathrm{~mL})$ em condições de baixa temperatura $\left(13^{\circ} \mathrm{C}\right)$ e $\mathrm{pH} 5,5$.

O efeito negativo das elevadas temperaturas (ponto extremo) na cinética de crescimento celular e nas reações enzimáticas pode ter contribuído para a diminuição da expressão da enzima hidrogenase. No entanto, isso é dependente do tipo de biomassa utilizada. A título de exemplificação, a concentração máxima de hidrogênio $\left(416,2 \mathrm{~mL} \cdot \mathrm{L}^{-1}\right)$ obtida neste estudo a $37^{\circ} \mathrm{C}$ utilizando biomassa autóctone do resíduo de banana foi cerca de 1,06 e 1,68 vezes maior do que a obtida por Yokoyama et al. (2007) na fermentação de esterco de vaca a $60^{\circ} \mathrm{C}(392$ $\left.\mathrm{mL} . \mathrm{L}^{-1}\right)$ e $75^{\circ} \mathrm{C}\left(248 \mathrm{~mL} . \mathrm{L}^{-1}\right)$, utilizando biomassa autóctone.

Contudo, os níveis máximos de $\mathrm{pH}(+1 \mathrm{e}+1,41)$ contribuíram para a maior $P$ e $R m$, como visto nos ensaios 2 e 6 . No entanto, para obtenção de maior $P$ em pH 5,5 a temperatura precisa ser mantida até $37^{\circ} \mathrm{C}$, pois acima desta $\left(44^{\circ} \mathrm{C}\right)$, terá efeito negativo para biomassa hidrogenogênica, sugerindo que, para esta biomassa específica, o aumento crescente da temperatura pode exercer efeitos negativos sobre a expressão e catálise da hidrogenase. Por outro lado, em pH 6,5 foi viável a produção de $\mathrm{H}_{2}(60-62 \mathrm{~mL})$, para condições de temperatura a $37^{\circ} \mathrm{C}(\mathrm{E} 9, \mathrm{E} 10$ e E11).

Este efeito pode ser explicado pela combinação do efeito da temperatura e pH no processo de fermentação. Por um lado, verificiou-se para pH inicial ácido maior concentração de ácidos orgânicos não dissociados provenientes da fermentação do substrato, e por outro lado, para temperatura mais elevada, provavelmente favoreceu maior atividade metabólica e aumentou a permeabilidade da membrana (Zoetemeyer et al., 1982; Infantes et al., 2011), que subsequentemente aumentou a energia necessária para manutenção celular, resultando em inibição da biomassa produtora de $\mathrm{H}_{2}$ devido ao efeito líquido de ambos os aspectos. Portanto, em pH ácido, a produção de $\mathrm{H}_{2}$ não seria favorecida pelo aumento da temperatura, porque pode aumentar a permeabilidade da membrana celular e por fim reduzir a produção de hidrogênio nestes ensaios.

Foram considerados estatisticamente significativos os parâmetros ao nível de significância de $5 \%(\mathrm{p}<0,05)$ para $P$ e de $10 \%(\mathrm{p}<0,10)$ para $R m$. Assim, para $P$ só foram significativos o termo linear $\left(\mathrm{x}_{1}\right)$ e quadrático $\left(\mathrm{x}_{1}^{2}\right)$ do $\mathrm{pH}$ e o termo quadrático da temperatura $\left(\mathrm{x}_{2}{ }^{2}\right)$. Para $R m$, os termos significativos foram os seguintes: linear do $\mathrm{pH}\left(\mathrm{x}_{1}\right)$, quadrático da temperatura $\left(\mathrm{x}_{2}^{2}\right)$ e a interação entre $\mathrm{pH}$ e temperatura $\left(\mathrm{x}_{1} \mathrm{x}_{2}\right)$, tendo sido incorporados aos resíduos para cálculo da ANOVA apresentada na Tabela 5.13. 


\section{Universidade de São Paulo \\ Escola de Engenharia de São Carlos \\ Programa de Pós-graduação em Hidráulica e Saneamento}

Tabela 5.13. Coeficientes de regressão para as respostas produção de $\mathrm{H}_{2}(P)$ e velocidade de produção $\mathrm{H}_{2}(R m)$.

\begin{tabular}{c|cccccccc}
\hline \multirow{3}{*}{ Fatores } & \multicolumn{4}{|c}{$\boldsymbol{P}$} \\
& $\begin{array}{c}\text { Coeficientes } \\
\text { de regressão }\end{array}$ & $\begin{array}{c}\text { Erro } \\
\text { padrão }\end{array}$ & $\mathrm{t}(5)$ & $\mathrm{p}$ - valor & $\begin{array}{c}\text { Coeficientes } \\
\text { de regressão }\end{array}$ & $\begin{array}{c}\text { Erro } \\
\text { padrão }\end{array}$ & $\mathrm{t}(5)$ & $\mathrm{p}$ - valor \\
\hline Média & 61,52 & 1,92 & 32,10 & 0,0000 & 9,24 & 0,72 & 12,72 & 0,0000 \\
$\mathrm{X}_{1}$ & 13,28 & 1,17 & 11,31 & $\mathbf{0 , 0 0 0 1}$ & 3,28 & 0,44 & 7,38 & $\mathbf{0 , 0 0 0 7}$ \\
$\mathrm{X}_{1}{ }^{2}$ & $-16,10$ & 1,40 & $-11,52$ & $\mathbf{0 , 0 0 0 1}$ & $-0,71$ & 0,52 & $-1,35$ & 0,2320 \\
$\mathrm{X}_{2}$ & $-0,85$ & 1,17 & $-0,73$ & 0,5007 & $-0,24$ & 0,44 & $-0,54$ & 0,6085 \\
$\mathrm{X}_{2}{ }^{2}$ & $-23,19$ & 1,40 & $-16,60$ & $\mathbf{0 , 0 0 0 0}$ & $-1,57$ & 0,32 & $-4,98$ & $\mathbf{0 , 0 0 4 2}$ \\
$\mathrm{X}_{1} \mathrm{X}_{2}$ & $-2,01$ & 1,66 & $-1,21$ & 0,2792 & $-0,81$ & 0,38 & $-2,15$ & $\mathbf{0 , 0 8 4 4}$ \\
\hline
\end{tabular}

$\mathrm{O}$ fato de que houve interação significativa entre temperatura e $\mathrm{pH}$ para $\mathrm{Rm}$ significa que em diferentes $\mathrm{pH}$ o crescimento de algumas populações é favorecido quando submetidas a diferentes temperaturas.

Em relação ao $\mathrm{F}_{\text {calc }}$ para regressão (Tabela 5.14) obteve-se valor altamente significativo, sendo que os coeficientes de correlação $\left(\mathrm{R}^{2}\right)$ pelos modelos foram satisfatórios, correspondendo à 99,47 e 92,69 para $P$ e $R m$. Desse modo, pode-se concluir que os dados experimentais se ajustaram adequadamente ao modelo empregado. Ademais, a falta de ajuste não foi significativa para os dois parâmetros $(P$ e $R m)$ demonstrando que os modelos são confiáveis.

Por meio das equações a seguir descreveu-se a produção de $\mathrm{H}_{2}(P)$ e velocidade de produção $(R m)$ em função das variáveis codificadas (pH e temperatura) na faixa estudada, no modelo reparametrizado que contém apenas os termos estatisticamente significativos.

$$
\begin{aligned}
& P=61,53+13,28 x_{1}-16,10 x_{1^{2}}-23,19 x_{2^{2}} \\
& R m=8,51+3,29 x_{1}-2,53 x_{2^{2}}-1,66 x_{1} x_{2}
\end{aligned}
$$

Modelo 1

Modelo 2

É imediato observar que se todos os parâmetros do modelo completo são significativos, o método exposto não se aplica.

Os valores observados experimentalmente e os valores previstos pelo modelo associados às respostas $P$ e $R m$ estão representados na Figura 5.27 A-B. Observa-se boa concordância entre eles, como era de se esperar com base nos resultados das análises de variâncias. 
Universidade de São Paulo

Escola de Engenharia de São Carlos

Programa de Pós-graduação em Hidráulica e Saneamento

Tabela 5.14. Testes para a falta de ajuste e para regressão linear para as produções de $\mathrm{H}_{2}(P)$ e velocidade de produção $\mathrm{H}_{2}(R m)$.

\begin{tabular}{cccccc|ccccc}
\hline $\begin{array}{c}\text { Fonte de } \\
\text { variação }\end{array}$ & SQ & GL & QM & $\mathbf{F}_{\text {calc }}$ & $\begin{array}{c}\mathbf{p} \text { - } \\
\text { valor }\end{array}$ & SQ & GL & QM & $\mathbf{F}_{\text {calc }}$ & $\begin{array}{c}\mathbf{p} \text { - } \\
\text { valor }\end{array}$ \\
\hline Regressão & 4978,9 & 3 & 1659,6 & 150,6 & 0,0000 & 143,5 & 3 & 47,8 & 29,6 & 0,0002 \\
Resíduos & 77,1 & 7 & 11,0 & & & 11,3 & 7 & 1,6 & & \\
\hline $\begin{array}{c}\text { Falta de } \\
\text { ajuste }\end{array}$ & 75,2 & 5 & 15,0 & 15,9 & 0,05989 & 10,5 & 5 & 2,1 & 5,8 & 0,1518 \\
Erro puro & 1,88 & 2 & 0,94 & & & 0,7 & 2 & 0,3 & & \\
\hline Total & 50,56 & 10 & & & & 154,8 & 10 & & & \\
\hline
\end{tabular}

$\mathrm{SQ}=$ soma dos quadrados, $\mathrm{GL}=$ graus de liberdade, $\mathrm{QM}=$ quadrado médio

\% variação explicada $\left(\mathrm{R}^{2}\right)=98,47 \% ; \mathrm{F}_{3} ; 7 ; 0,05=4,35$

$\%$ variação explicada $\left(R^{2}\right)=92,69 \% ; F_{3 ; 7 ; 0,10}=8,45$

Figura 5.27. Valores experimentais versus valores preditos pelo modelo para as respostas $P(\mathrm{~A})$ e $R m(\mathrm{~B})$.
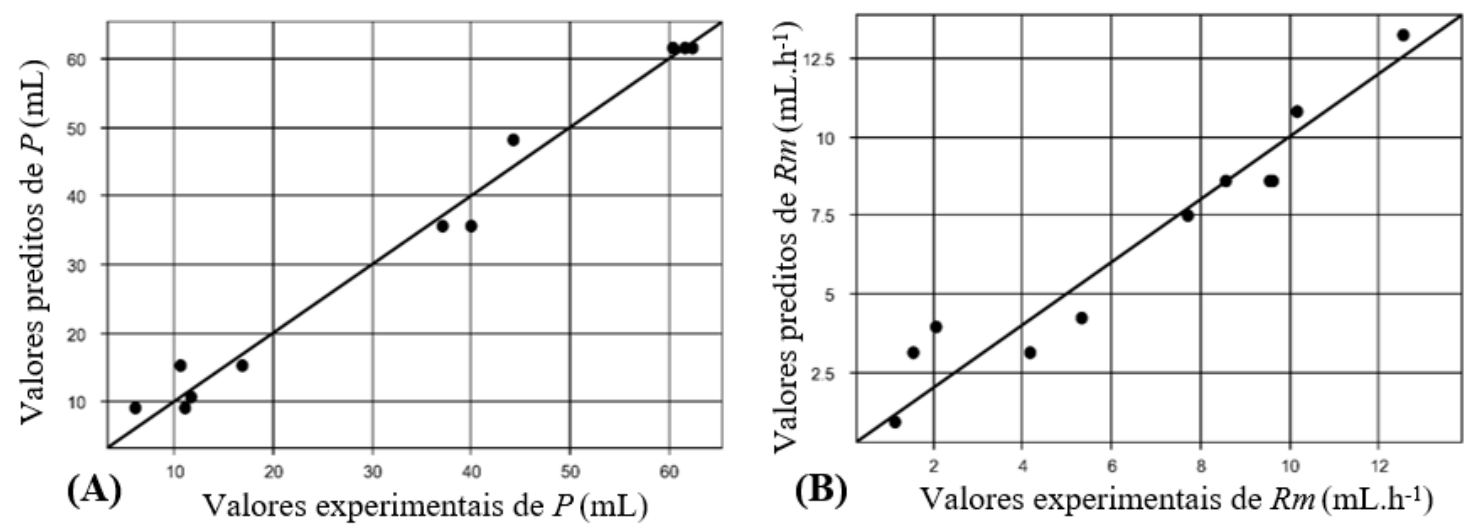

Os gráficos de superfícies de resposta para $P$ e $R m$, descritas pela equação de regressão (Modelo 1 e 2) são mostradas na Figura 5.28 (A-B). Por meio dessa análise, verificou-se que para a obtenção de maior produção de $\mathrm{H}_{2}$ a faixa ótima de $\mathrm{pH}$ foi de 6,42 a 7,40 e para temperatura entre 34,30 e $39,8^{\circ} \mathrm{C}$. Por outro lado, a faixa de $\mathrm{pH}$ ótima obtida para $\mathrm{Rm}$ foi entre 7,5 e 8,0 e temperatura entre 28 e $39^{\circ} \mathrm{C}$, sendo que, fora destas faixas estabelecidas tanto, os valores de $P$, quanto $R m$ foram menores. 


\section{Universidade de São Paulo \\ Escola de Engenharia de São Carlos \\ Programa de Pós-graduação em Hidráulica e Saneamento}

Figura 5.28. Superfície de resposta da interação entre o efeito do $\mathrm{pH}$ e temperatura na produção de hidrogênio $(P)(\mathrm{A})$ e velocidade de produção $(R m)(\mathrm{B})$ em reatores em batelada.
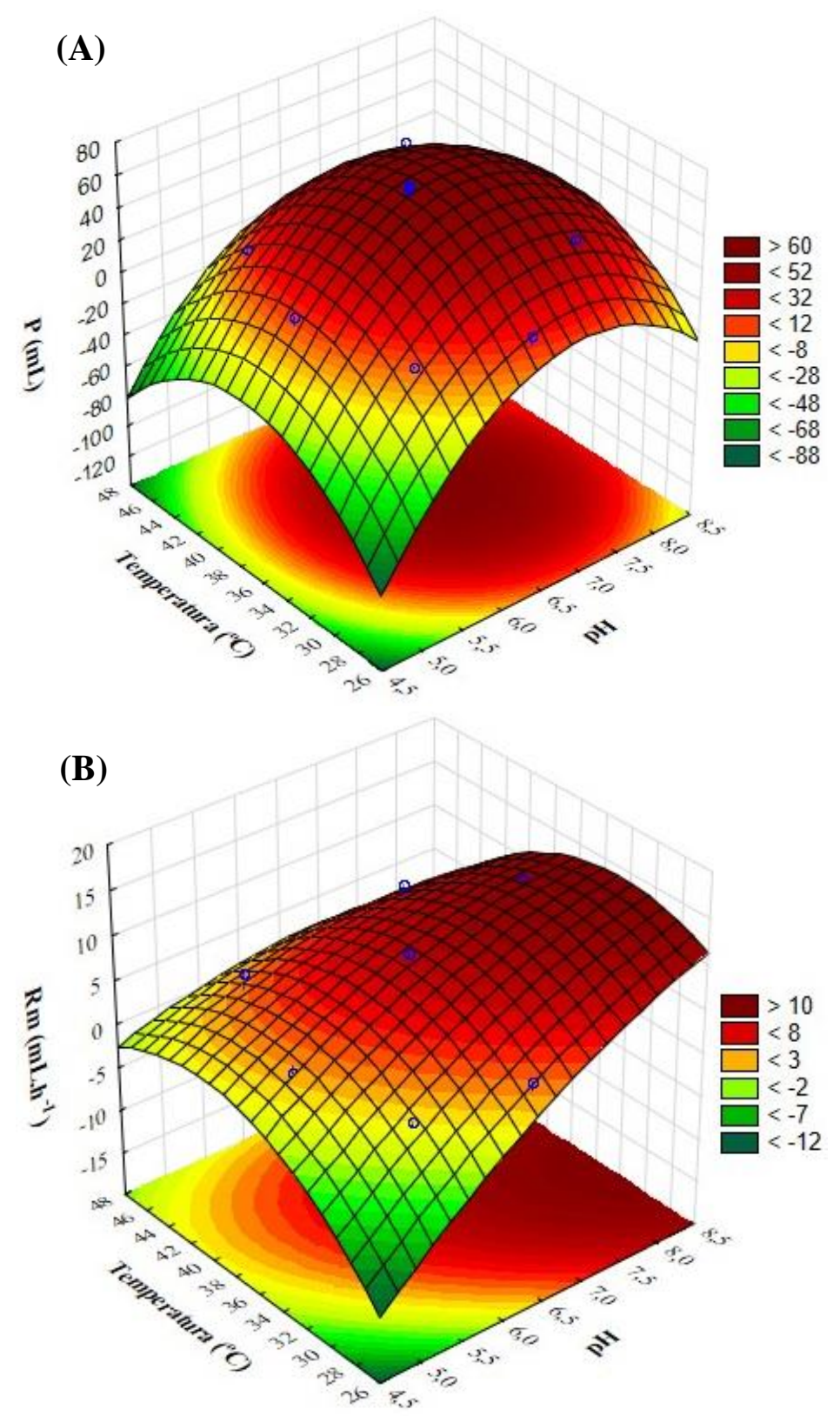

Em relação a $P$ verificou-se que foi influenciada pelas duas variáveis independentes. O aumento do $\mathrm{pH}\left(\mathrm{x}_{1}\right)$ resultou em maior taxa de crescimento de biomassa e, consequente aumento de $P$, enquanto o aumento da temperatura $\left(\mathrm{x}_{2}\right)$ resultou no decréscimo de $P$, devido a seleção de bactérias não produtoras de $\mathrm{H}_{2}$ ou inibição da biomassa. Logo, para o intervalo de estudo pré-estabelecido pode-se inferir que a maior $P$ foi obtida nos níveis médios de $\mathrm{pH}(6,5)$ e a $37^{\circ} \mathrm{C}$. De acordo com Alvarez-Guzman et al. (2017) a temperatura ideal está entre a faixa mesófila e termófila, no entanto isso é dependente da fonte de inóculo. Neste caso, especificamente, para a faixa de temperatura avaliada $\left(27,1\right.$ e $\left.46,9^{\circ} \mathrm{C}\right)$, o metabolismo da 
biomassa a partir da fermentação natural de resíduo de banana foi favorecido entre $30-37^{\circ} \mathrm{C}$, sendo que para valores acima desta faixa foi observada diminuição de $P$, refletindo no efeito negativo da temperatura acima de $40^{\circ} \mathrm{C}$.

Em relação ao rendimento de hidrogênio $\left(\mathrm{YH}_{2}\right)$, aumento do $\mathrm{YH}_{2}$ de 49,45 para 53,46 $\mathrm{mL} \cdot \mathrm{g}^{-1} \mathrm{CT}$ quando aumentou a temperatura de 30 para $44^{\circ} \mathrm{C}$ em $\mathrm{pH} 7,5$. Em pH 6,5 observou-se aumento do rendimento (de 22,57 para 83,24 mL.g ${ }^{-1} \mathrm{CT}$ ) com aumento da temperatura de 27 para $37^{\circ} \mathrm{C}$. Porém, observou-se diminuição de $\mathrm{YH}_{2}$ para $14,23 \mathrm{~mL} \cdot \mathrm{g}^{-1} \mathrm{CT}$ quando a temperatura foi $46,90^{\circ} \mathrm{C}$.

Verificou-se efeito positivo do $\mathrm{pH}$ no $\mathrm{YH}_{2}$, sendo observado maiores valores a $30^{\circ} \mathrm{C}$. Deste modo, observou-se aumento de $\mathrm{YH}_{2}$ de 8,07 para $53,46 \mathrm{~mL} \cdot \mathrm{g}^{-1} \mathrm{CT}$ quando o valor de $\mathrm{pH}$ aumentou de 5,5 para 7,5. O mesmo ocorreu a $44^{\circ} \mathrm{C}$, para condição de $\mathrm{pH}$ de 5,5 para 7,5, onde obteve-se aumento de $\mathrm{YH}_{2}$ de 14,80 para $49,45 \mathrm{~mL} \cdot \mathrm{g}^{-1} \mathrm{CT}$. No entanto, a $37^{\circ} \mathrm{C}$ observou aumento de $\mathrm{YH}_{2}$ de 15,53 para 83,24 mL.g ${ }^{-1} \mathrm{CT}$ para condição de $\mathrm{pH}$ de 5,09 e 7,91, mas diminuição para 59,09 $\mathrm{mL} \cdot \mathrm{g}^{-1} \mathrm{CT}$ quando o $\mathrm{pH}$ foi superior a $\mathrm{pH} 7,91$. Neste sentido, o rendimento máximo obtido foi de $83,24 \mathrm{~mL} \cdot \mathrm{g}^{-1} \mathrm{CT}$ para DCCR $\left(\mathrm{pH} 6,5\right.$ e $\left.37^{\circ} \mathrm{C}\right)$. Todavia, para pH 5,5 e $30^{\circ} \mathrm{C}$ observou-se baixo $\mathrm{YH}_{2}$ de $8,07 \mathrm{~mL} \cdot \mathrm{g}^{-1} \mathrm{CT}$.

A equação a seguir descreve o rendimento de hidrogênio $\left(\mathrm{YH}_{2}\right)$ em função das variáveis codificadas ( $\mathrm{pH}$ e temperatura) na faixa estudada, no modelo reparametrizado (Modelo 3) que contém apenas os termos estatisticamente significativos. Assim, para rendimento de $\mathrm{H}_{2}\left(\mathrm{YH}_{2}\right)$ só foram significativos o termo linear $\left(\mathrm{x}_{1}\right)$ e quadrático $\left(\mathrm{x}_{1}^{2}\right)$ do $\mathrm{pH}$ e o termo quadrático da temperatura $\left(\mathrm{x}_{2}{ }^{2}\right)$, tendo sido incorporados aos resíduos para cálculo da ANOVA apresentada na Tabela 5.15 .

Como os $\mathrm{F}_{\text {calc }}$ para regressão foi altamente significativo, a porcentagem de variação explicada $\left(\mathrm{R}^{2}\right)$ pelo modelo foi satisfatória $(98,48 \%)$ e a falta de ajuste não foi estatisticamente significativa $(p>0,05)$ (Tabela 5.16). A partir dessas considerações pode-se mencionar que os dados experimentais ajustaram ao modelo (Figura 5.29).

A superfície de resposta para $\mathrm{YH}_{2}$, descrita pela equação de regressão (Modelo 3) é mostrada na Figura 5.30. É possível verificar que para obtenção de maiores $\mathrm{YH}_{2}$ a faixa ótima de $\mathrm{pH}$ foi de 6,22 a 7,90 e para temperatura entre 32,90 e $41,10^{\circ} \mathrm{C}$, sendo que, fora destas faixas estabelecidas observou-se diminuição de $\mathrm{YH}_{2}$. 
Universidade de São Paulo

Escola de Engenharia de São Carlos

Programa de Pós-graduação em Hidráulica e Saneamento

Tabela 5.15. Coeficientes de regressão para a resposta rendimento de $\mathrm{H}_{2}\left(\mathrm{YH}_{2}\right)$

\begin{tabular}{c|cccc}
\hline & $\begin{array}{c}\text { Coeficientes de } \\
\text { regressão }\end{array}$ & Erro padrão & $\mathrm{t}(5)$ & $\mathrm{p}$ - valor \\
\hline Média & 82,02 & 2,56 & 32,10 & 0,0000 \\
$\mathrm{X}_{1}$ & 17,71 & 1,56 & 11,32 & $\mathbf{0 , 0 0 0 1}$ \\
$\mathrm{X}_{1}^{2}$ & $-21,46$ & 1,86 & $-11,52$ & $\mathbf{0 , 0 0 0 1}$ \\
$\mathrm{X}_{2}$ & $-1,13$ & 1,56 & $-0,72$ & 0,5010 \\
$\mathrm{X}_{2}{ }^{2}$ & $-30,92$ & 1,86 & $-16,60$ & $\mathbf{0 , 0 0 0 0}$ \\
$\mathrm{X}_{1} \mathrm{X}_{2}$ & $-2,68$ & 2,21 & $-1,21$ & 0,2792 \\
\hline
\end{tabular}

Tabela 5.16. Testes para a falta de ajuste e para regressão linear para rendimento de $\mathrm{H}_{2}$

\begin{tabular}{cccccc}
\hline Fonte de variação & SQ & GL & QM & F calc & p - valor \\
\hline Regressão & 8851,6 & 3 & 2950,5 & & \\
Resíduos & 137,1 & 7 & 19,6 & 150,7 & 0,0000 \\
\hline Falta de ajuste & 133,7 & 5 & 26,7 & \multirow{2}{*}{16,0} & 0,0597 \\
Erro puro & 3,3 & 2 & 1,7 & & \\
\hline Total & 8988,7 & 10 & & &
\end{tabular}

$\mathrm{SQ}=$ soma dos quadrados, $\mathrm{GL}=$ graus de liberdade, $\mathrm{QM}=$ quadrado médio

$\%$ variação explicada $\left(\mathrm{R}^{2}\right)=98,48 \% ; \mathrm{F}_{3} ; 7 ; 0,05=4,35$

Figura 5.29. Valores experimentais versus valores preditos pelo modelo para a resposta $\mathrm{YH}_{2}$.

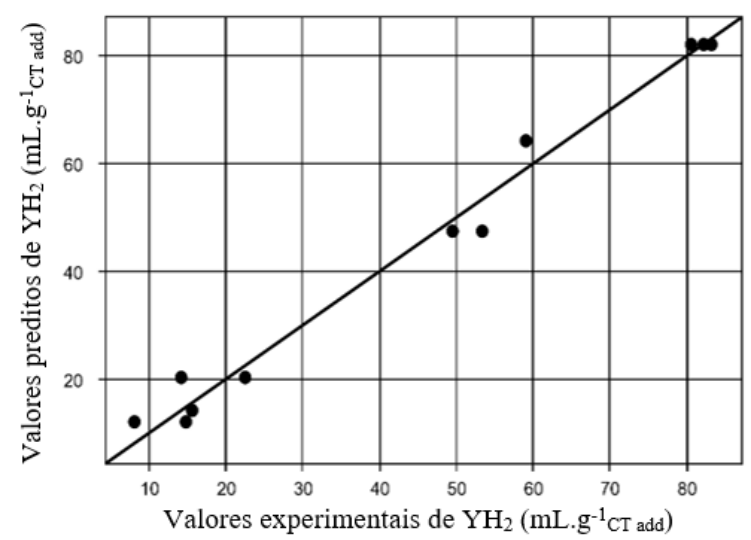


Universidade de São Paulo

Escola de Engenharia de São Carlos

Programa de Pós-graduação em Hidráulica e Saneamento

Figura 5.30. Superfície de resposta e curva de contorno para rendimento de hidrogênio para pH e temperatura.

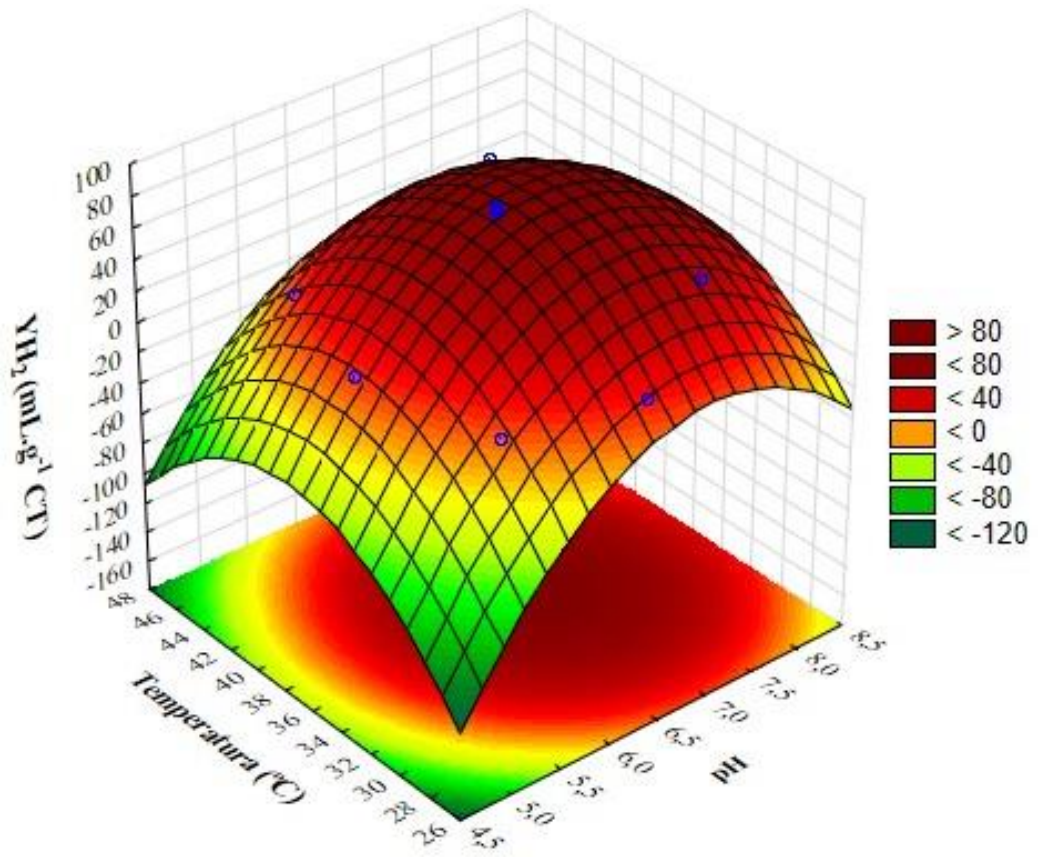

O rendimento máximo de hidrogênio obtido neste estudo a $37^{\circ} \mathrm{C}$ foi de 1,4 e 2,14 vezes maior do que os obtidos por Pan et al., (2008) a partir de restos de alimentos a 50 e $35^{\circ} \mathrm{C}$, respectivamente. Por outro lado, Wang e Wan (2008) obtiveram rendimentos superiores, 3,4 vezes maior, na fermentação de glicose em relação a presente pesquisa. Todavia, os autores também observaram que o aumento da temperatura de 30 para $40^{\circ} \mathrm{C}$ e do $\mathrm{pH}$ de 6 para 7 contribuiu para o aumento do $\mathrm{YH}_{2}$, no entanto o aumento da temperatura superior a $40^{\circ} \mathrm{C}(45 \mathrm{e}$ $\left.48,4^{\circ} \mathrm{C}\right)$ e do $\mathrm{pH}$ inicial superior a 7 (8 e 8,7), proporcionaram diminuição do $\mathrm{YH}_{2}$. Os autores reportaram que as condições ótimas para obtenção do rendimento máximo de hidrogênio (289,8 $\mathrm{mL} \cdot \mathrm{g}^{-1}$ de glicose) foi obtido a $38,6^{\circ} \mathrm{C}, \mathrm{pH}$ inicial de 7,2 e 23,9 g.L $\mathrm{L}^{-1}$ de glicose. Yossan et al. (2012) observaram aumento do $\mathrm{YH}_{2}$ de 22,08 para 27,09 $\mathrm{mL} \cdot \mathrm{g}^{-1}$ DQO com aumento da temperatura de 25 para $37^{\circ} \mathrm{C}$. No entanto, verificaram diminuição de $\mathrm{YH}_{2}$ para $26,63 \mathrm{~mL} \cdot \mathrm{g}^{-1}$ DQO a $55^{\circ} \mathrm{C}$. Em condição de temperatura elevada pode-se favorecer aumento da permeabilidade da membrana à ácidos orgânicos não-dissociados, inibindo a biomassa hidrogenogênica (Infantes et al., 2011). $\mathrm{N}$ presente pesquisa, os menores valores de $\mathrm{YH}_{2}$ menores foram observados, principalmente nos ensaios com temperatura acima de $40^{\circ} \mathrm{C}$.

Observou-se que a eficiência de conversão de carboidratos totais $\left(\mathrm{EC}_{\mathrm{CT}} \%\right)$ foi quase completa (>90\%) em pH 6,5 e $37^{\circ} \mathrm{C}$, referente aos ensaios 13, 14 e 15 . Por outro lado, menores 


\author{
Universidade de São Paulo \\ Escola de Engenharia de São Carlos \\ Programa de Pós-graduação em Hidráulica e Saneamento
}

$\mathrm{EC}_{\mathrm{CT}}$ de 73,30 e $70 \%$ foram observadas para os ensaios com baixa $\left(27,10^{\circ} \mathrm{C}\right)$ e alta temperatura $(46,90 \%)$, respectivamente, principalmente em pH ácido $(<7,0)$ (Figura 5.31).

Figura 5.31. Eficiência de conversão de carboidratos totais $\left(\mathrm{EC}_{\mathrm{CT}}\right)$ nos ensaios do DCCR com variação de $\mathrm{pH}$ e temperatura.

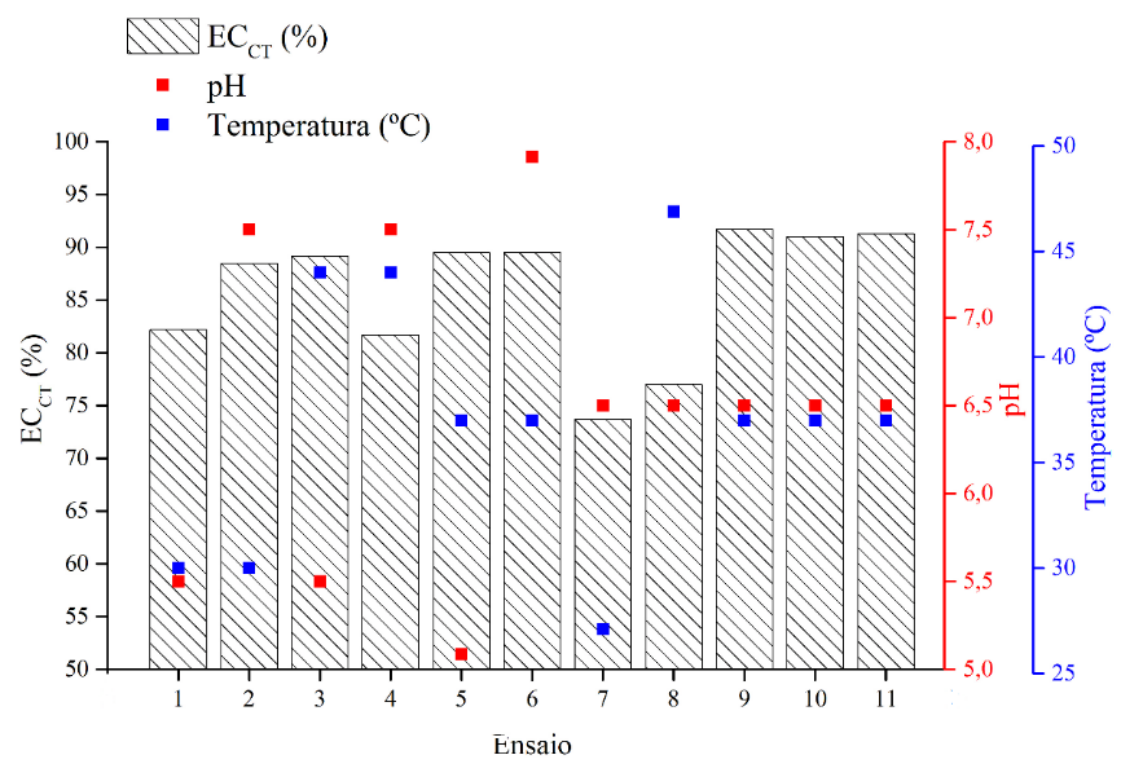

Nota: $\mathbf{E 1}=$ pH 5,5 e temperatura $30^{\circ} \mathrm{C}, \mathbf{E 2}=$ pH 7,5 e temperatura $30^{\circ} \mathrm{C}, \mathbf{E 3}=$ pH 5,5 e temperatura $44^{\circ} \mathrm{C}, \mathbf{E} 4=$ $\mathrm{pH} 7,5$ e temperatura $44^{\circ} \mathrm{C}, \mathbf{E 5}=5,09$ e temperatura $37^{\circ} \mathrm{C}, \mathbf{E 6}=7,91$ e temperatura $37^{\circ} \mathrm{C}, \mathbf{E} 7=\mathrm{pH} 6,5$ e temperatura $27,10^{\circ} \mathrm{C}, \mathbf{E 8}=6,5$ e temperatura $46,90^{\circ} \mathrm{C}, \mathbf{E 9}, \mathbf{E 1 0}$ e $\mathbf{E 1 1}=\mathrm{pH} 6,5$ e temperatura $37^{\circ} \mathrm{C}$.

Verificou-se significativa interação entre temperatura e $\mathrm{pH}$ inicial na $\mathrm{EC}_{\mathrm{CT}} \%(\mathrm{p}<0,05)$. Wang e Wan (2008) obtiveram eficiência máxima de conversão do substrato de 96,9\% a 39,3 ${ }^{\circ} \mathrm{C}$ e pH inicial de 7,0, condições estas semelhantes as obtidas nesta pesquisa. Provavelmente, os diferentes valores de $\mathrm{pH}$ iniciais foram favoráveis para o crescimento de bactérias hidrolíticas e acidogênicas, quando submetidas a determinadas faixas de temperatura.

Em todos os ensaios, os carboidratos adicionados inicialmente não foram totalmente consumidos permanecendo uma fração residual no final da fermentação. Provavelmente, o o momento que as células atingiram a fase estacionária houve redução do metabolismo celular e consequentemente diminuição do consumo de carboidratos para manutenção das funções celulares. Em função disso, os carboidratos presentes até o momento não foram convertidos a produtos metabólicos, permanecendo na fração líquida do reator. 


\subsubsection{Avaliação dos metabólicos solúveis}

\subsubsection{1. Ácidos carboxílicos e etanol}

Pode-se observar que independente do $\mathrm{pH}$ inicial nos ensaios, todos os valores de $\mathrm{pH}$ final observados estiveram na faixa entre 3 a 5 (Tabela 5.17). Claramente, a diminuição do valor de pH está associada ao acúmulo de metabólitos orgânicos sintetizados durante a fermentação de resíduos de banana nos diferentes ensaios do DCCR, em vista que em sistemas acidogênicos a produção de $\mathrm{H}_{2}$ utilizando consórcio de bactérias fermentativas é sempre acompanhada pela produção de ácidos carboxílicos. Mudanças nas vias metabólicas durante a fermentação é reflexo de mudanças no metabolismo microbiano, que por sua vez se altera de acordo com as condições operacionais do reator. Está claro que o pH é uma variável que influencia fortemente o metabolismo das bactérias hidrogenogênicas, por afetar a atividade das enzimas hidrogenases (Sharma e Li, 2009, Infantes et al., 2011; Trchounian et al., 2017), bem como vias metabólicas. Portanto, a produção de $\mathrm{H}_{2}$ pode ser estimada em função do $\mathrm{pH}$ e da produção de ácidos carboxílicos (AC) (Figura 5.32).

Figura 5.32. Produção de $\mathrm{H}_{2}$ nos ensaios do DCCR em função do $\mathrm{pH}$ e da produção de ácidos carboxílicos (AC).

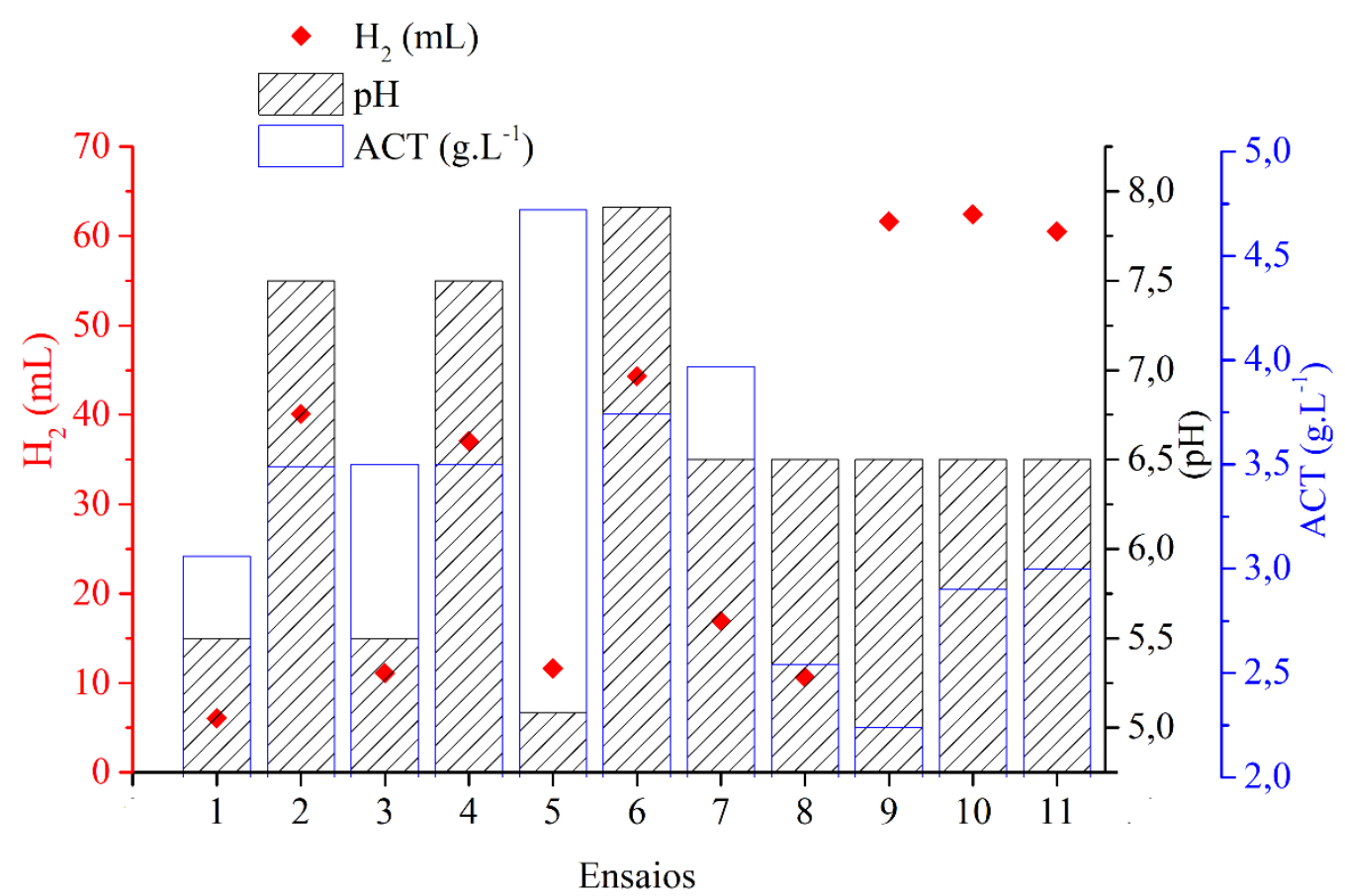

Nota: $\mathbf{E 1}=\mathrm{pH} 5,5$ e temperatura $30^{\circ} \mathrm{C}, \mathbf{E} 2=\mathrm{pH} 7,5$ e temperatura $30^{\circ} \mathrm{C}, \mathrm{E} 3=\mathrm{pH} 5,5$ e temperatura $44^{\circ} \mathrm{C}, \mathbf{E} 4=$ $\mathrm{pH} 7,5$ e temperatura $44^{\circ} \mathrm{C}, \mathbf{E 5}=5,09$ e temperatura $37^{\circ} \mathrm{C}, \mathbf{E} \mathbf{6}=7,91$ e temperatura $37^{\circ} \mathrm{C}, \mathbf{E} 7=\mathrm{pH} 6,5$ e temperatura $27,10^{\circ} \mathrm{C}, \mathrm{E} 8=6,5$ e temperatura $46,90^{\circ} \mathrm{C}, \mathbf{E 9}, \mathbf{E} 10$ e $\mathbf{E 1 1}=\mathrm{pH} 6,5$ e temperatura $37^{\circ} \mathrm{C}$. 


\section{Universidade de São Paulo \\ Escola de Engenharia de São Carlos \\ Programa de Pós-graduação em Hidráulica e Saneamento}

Na presente pesquisa não foi verificado efeito significativo da temperatura $(p>0,05)$ na produção de AC, corroborando com os dados obtidos por Yuan et al. (2011) e Yu et al. (2013), no qual reportaram que o aumento da temperatura não teve nenhum efeito na produção de AC.

Observou-se que a maior $P$ foi obtida no E9, E10 e E11, correspondendo aos enaios em pH 6,5 e baixa concentração de AC (2-3 g.L $\left.\mathrm{L}^{-1}\right)$ produzidos. Enquanto, menor $P$ corresponderam aos ensaios com alta concentração de ACT, principalmente em E5 (pH 5,09 e ACT 4,72 g.L $\mathrm{L}^{-1}$ ). Resultado similar foi obtido por Infantes et al. (2011) no qual verificaram menor $P$ em altas concentrações de ácidos orgânicos produzidos.

Normalmente, maior concentração de AC são relacionadas à pH ácido (Xu et al., 2012; Ravi et al., 2018), justificando os resultados obtidos nesta pesquisa, onde

A produção total de AC foi maior em $\mathrm{pH}$ inicial 5,09 do que em $\mathrm{pH}$ acima de 7,0 (Figura 5.32). Semelhante ao presente trabalho, Babel et al. (2004) estudaram o efeito do pH (5-8) na acidogênese de resíduo de abacaxi e obtiveram maior concentração de AC ( 21 g.L $\left.\mathrm{L}^{-1}\right)$ até a faixa de $\mathrm{pH} 7$, sendo que valores acima deste reduziram pela metade a produção de ácidos. De acordo com Ruggeri et al. (2015) e Lay et al. (2012), a produção de complexos enzimáticos e reações catabólicas são dependentes das condições ambientais e principalmente do $\mathrm{pH}$.

Na presente pesquisa, a composição dos AC foi dependente da alteração no valor do $\mathrm{pH}$ $(\mathrm{p}<0,05)$. Verificou-se que ácido acético (HAc) e ácido lático (HLac) foram os principais ácidos gerados durante a fermentação do resíduo de banana, variando entre 0,03-0,79 g.L L $^{-1}$ e 0,04-3,98 g. $\mathrm{L}^{-1}$, respectivamente, seguido pelo ácido butírico $(\mathrm{HBu})\left(0,3-1,24\right.$ g. $\left.\mathrm{L}^{-1}\right)$ e propiônico (HPr) (0,2-0,62 g. $\left.\mathrm{L}^{-1}\right)$ (Tabela 5.17 e Figura 5.33). Provavelmente, a co-existência de diversidade de populações resultou em capacidade metabólica diversa (Liu e Wang, 2017).

Verificou-se expressiva produção de HLa em todos os ensaios, independentemente do pH e temperatura. Ao longo da operação dos reatores, observou-se o aumento crescente da concentração deste ácido até o final da fermentação cujo valor máximo de 3,98 e 3,16 g.L $\mathrm{L}^{-1}$ foi observado em E5 $\left(37^{\circ} \mathrm{C}\right.$ e pH 5,09) e E6 $\left(37^{\circ} \mathrm{C}\right.$ e pH 7,91). Sob tais condições, pode-se inferir sobre a versatibilidade metabólica das bactérias em ampla faixa de pH (Ren et al., 2007; Zhang et al., 2017). Resultados similares a presente pesquisa foi obtido por Tang et al. (2016), no qual os autores reportaram de maior produção de $\mathrm{HLa}\left(30,4\right.$ g.L $\left.\mathrm{L}^{-1}\right)$ em $\mathrm{pH}$ 6,0 à $37^{\circ} \mathrm{C}$, enquanto que Bermúdez-Penabad et al. (2017) obtiveram maior produção de HLac em pH 5,0.

Embora, algumas bactérias ácido lácticas (BAL) produzam ácido lático em condições de $\mathrm{pH}$ extremamente baixo ( $\mathrm{pH}=3,5$ ) (Itoh et al., 2012), a maioria delas são sensíveis a pH inferiores a 4,0 (Tang et al., 2016). Isso porque a energia livre de Gibbs e as taxas de reação 
metabólica são afetadas pelo $\mathrm{pH}, \operatorname{logo}$ baixos níveis de $\mathrm{pH}$ são capazes de inibir a via ácido lática (Ziara et al., 2018).

Por outro lado, baixa concentração de HLa (1,58-1,78 g.L $\left.\mathrm{L}^{-1}\right)$ foi obtida nos ensaios E9, E10, E11 ( $37^{\circ} \mathrm{C}$ e pH 6,5), correspondendo aos ensaios com maior produção de $\mathrm{H}_{2}$ (61-62 mL), confirmando o pressuposto de que a via produtora de HLac contribui para as baixas produções de $\mathrm{H}_{2}$ (Reação 14 e Reação 19). Semelhante ao presente estudo, Motte et al. (2014) e Guimire et al. (2018) associaram a diminuição da produção de hidrogênio ao desvio de rota metabólica para produção de ácido lático.

$\mathrm{C}_{6} \mathrm{H}_{12} \mathrm{O}_{6} \rightarrow 2 \mathrm{CH}_{3} \mathrm{CHOHCOOH}+\mathrm{H}^{+}$

Seguindo esta linha de raciocínio, como explicar o alto valor de $P(44,32 \mathrm{~mL})$ no E6, sendo que neste ensaio foi observado maior concentração de HLa. Em sistemas onde há abundância de ácido lático, pode haver o aumento da concentração de ácido acético (Reação 19) e este último, pode ser convertido em $\mathrm{H}_{2}$ em baixas $\mathrm{pH}_{2}$ (Thauer et al., 1997). Neste sentido, tanto o HLa quanto o HAc podem ser utilizados como substratos para produção de $\mathrm{H}_{2}, \mathrm{CO}_{2}$ e HBu (Reação 20; Matsumoto e Nishimura, 2007).

Outro ponto de vista a ser considerado, é que a maior concentraçãode HLa obtida não foi inibitória para a biomassa hidrogenogênica, levando a co-produção de $\mathrm{HLa}$ e $\mathrm{H}_{2}$ no mesmo ensaio. Assim, como o presente estudo, Ziara et al (2018) reportaram produção eficiente de $\mathrm{H}_{2}$ utilizando água residuária rica em HLa com varição do $\mathrm{pH}(6,5-8,5)$ e temperatura $\left(35\right.$ e $\left.45^{\circ} \mathrm{C}\right)$. As maiores produções de $\mathrm{H}_{2}$ obtidas (1384 e $1562 \mathrm{~mL}$ ) foram associadas aos ensaios a $45^{\circ} \mathrm{C}$ e $\mathrm{pH}$ de 7,5 e 8,5. Tais resultados evidenciam a possibilidade de produção de $\mathrm{H}_{2}$ nos ensaios cujo o HLa esta presente.

$\mathrm{CH}_{3} \mathrm{COOH}+2 \mathrm{CH}_{3} \mathrm{CH}(\mathrm{OH}) \mathrm{COOH} \rightarrow \mathrm{H}_{2}+3 / 2 \mathrm{CH}_{3}\left(\mathrm{CH}_{2}\right)_{2}+\mathrm{COOH}+2 \mathrm{CO}_{2}+\mathrm{H}_{2} \mathrm{O}$

Reação 21

As variações na concentração de ácido acético (HAc) são mostradas na Figura 5.33. Observou-se que houve crescente produção de ácido acético (HAc) até 10 h de fermentação em todos os ensaios, e após esse período observou-se diminuição desse ácido orgânico.

A conversão direta dos carboidratos em HAc (Reação 12) fornece maior rendimento de $\mathrm{H}_{2}$. Provavelmente, a expressiva produção deste ácido na fase exponencial contribuiu para os 


\section{Universidade de São Paulo \\ Escola de Engenharia de São Carlos \\ Programa de Pós-graduação em Hidráulica e Saneamento}

altos rendimentos de $\mathrm{H}_{2}$ obtidos, principalmente a $37^{\circ} \mathrm{C}$. A medida que a produção deste ácido cessou (após 10 h) observou-se estabilização da produção de $\mathrm{H}_{2}$. A fim de correlacionar a via acética como a principal via produtora de $\mathrm{H}_{2}$, observou-se que a concentração máxima de HAc (0,71-0,79 g. $\left.\mathrm{L}^{-1}\right)$ foi obtida principalmente nos ensaios com alta produção de $\mathrm{H}_{2}$ (E6, E9, E10 e E11), enquanto que a concentração mínima $\left(0,42 \mathrm{~g} . \mathrm{L}^{-1}\right)$ foi obtida no E1, correspondendo ao ensaio com menor produção de $\mathrm{H}_{2}(6,06 \mathrm{~mL})$.

Antonopoulou et al. (2011) e Shanmugam et al. (2014) afirmam que a faixa de pH entre 6,0 a 7,0 oportuniza a síntese de HAc, corroborando com a presente pesquisa, no qual a máxima e mínina produção de HAc foi obtida em pH 6,5 e 5,5, respectivamente. Ramos et al. (2012) também reportaram que o valor de $\mathrm{pH} 6$ foi ideal para obtenção de altas concentrações $\left(4\right.$ g.L $\mathrm{L}^{-}$ $\left.{ }^{1}\right)$ de HAc. No entanto, o estabelecimento desta rota em todas as condições avaliadas permite inferir que a produção de HAc ocorre em amplo intervalo de pH (Dionisi e Silva, 2016), possivelmente pela complexidade durante a síntese, diversidade de microrganismos, nutrientes, substratos, e parâmetros operacionais que influenciam a produção deste metabólito (Islam et al., 2015). A título de exemplificação, Lay et al. (2012) reportaram produção de HAc (22 a 8367 mg. $\mathrm{L}^{-1}$ ) em ampla faixa de $\mathrm{pH}$ (4-9). No entanto, concentrações máximas (5747-8367 mg.L $\mathrm{L}^{-1}$ ) foram obtidas em faixa de $\mathrm{pH}$ entre 7,5 e 9.

A concentração máxima de HAc obtida neste estudo $\left(0,79\right.$ g.L $\left.\mathrm{L}^{-1}\right)$ foi 15 vezes superior $\left(0,05\right.$ g HAc. $\left.\mathrm{L}^{-1}\right)$, a obtida por Soares et al. (2017) nas condições otimizadas $\left(60^{\circ} \mathrm{C}\right.$ e 3 g.L $\mathrm{L}^{-1}$ extrato de levedura) na fermentação de bagaço de cana de açúcar e 26 vezes superior $(0,03 \mathrm{~g}$ HAc. $L^{-1}$ ) a obtida por Saraphirom e Reungsang (2010) na fermentação de licor de sorgo (25 g.L $\mathrm{L}^{-1}$ carboidratos totais, $\mathrm{pH} 4,75$ e 1,45 g. $\mathrm{L}^{-1} \mathrm{FeSO}_{4}$ ). Por meio dessas considerações, pode-se indicar o potencial uso do resíduo de banana para produção de ácidos orgânicos, como o HAc, quando comparado aos demais substratos.

Além da conversão direta do substrato (Reação 12), tanto o $\mathrm{HAc}$ como o $\mathrm{H}_{2}$ pode ter sido produzido a partir da conversão do etanol (Reação 13) e/ou a partir de moléculas mais reduzidas como o HLa (Reação 9 e 20).

Ramos et al. (2012) relataram a ocorrência de homoacetogênese (Reação 21), em sistemas cujo pH é superior a 7. A utilização de consórcio bacteriano muitas vezes contribui para o aparecimento do metabolismo homoacetogênico, uma vez que este tipo de inóculo é constituído de microrganismos consumidores de $\mathrm{H}_{2}$ (De Sá et al., 2014). No entanto, na presente pesquisa, foi descartada a produção de ácido acético via homoacetogênese, pois de acordo com Ryan et al. (2008) a cinética de crescimento de bactérias homoacetogênicas apresentam longos 
períodos de $\lambda \mathrm{H}_{2}$, cerca de 60 a 100 h, seguido do consumo de $\mathrm{H}_{2}$ e aumento da concentração de HAc. Neste caso, durante o tempo de fermentação curto $(20$ h) a produção de HAc ocorreu até $10 \mathrm{~h}$ e foi descrescendo até o final da fermentação (Figura 5.18). Ademais, ao final da fermentação da banana, observou-se pH extremamente baixo ( $\mathrm{pH} 3-4)$ na maioria dos ensaios, impossibilitando o estabelecimento da via homoacetogênica. De acordo com Ghimire et al. (2015), a via homoacetogênica em processos fermentativos é inibida em valor de $\mathrm{pH}$ igual ou inferior a 5,5. Portanto, assume-se que a via principal de produção e rendimento de $\mathrm{H}_{2}$ foi a do ácido acético (heterotrófica) gerado pelo metabolismo das bactérias produtoras de $\mathrm{H}_{2}$ desprezando a interferência da homoacetogênese (autotrófica).

$4 \mathrm{H}_{2}+2 \mathrm{CO}_{2} \rightarrow \mathrm{CH}_{3} \mathrm{COOH}+2 \mathrm{H}_{2} \mathrm{O}$

Reação 22

O ácido butírico $(\mathrm{HBu})$ foi o terceiro metabólito mais produzido na fermentação da banana a partir da biomassa autóctone. De acordo com Tapia-Venegas et al. (2015), a utilização de consórcio microbiano favorece o estabelecimento da rota butírica, uma vez que inóculos mistos levam à produção de ácido butírico como principal metabólito dissolvido.

Observou-se produção de $\mathrm{HBu}$ logo nas primerias 5 horas de fermentação, atingindo concentração máxima principalmente em E2 (1,1 g.L $\left.\mathrm{L}^{-1}\right)$, E3 $\left(1,03\right.$ g.L $\left.\mathrm{L}^{-1}\right)$ e E7 (1,24 g.L $\left.\mathrm{L}^{-1}\right)$ (Figura 5.33). Por outro lado, concentrações míninas $\left(0,04-0,07\right.$ g. $\left.\mathrm{L}^{-1}\right)$ foram observadas nos ensaios 4, 5 e 8 . Não foi observado relação expressiva entre maior e menor concentração de $\mathrm{HBu}$ em relação ao $\mathrm{pH}$ e temperatura $(\mathrm{p}>0,05)$. Desta forma, a produção de $\mathrm{HBu}$ em todos os ensaios pode ser associada ao tipo de microrganismo presente na biomassa e não às condições operacionais. No entanto, apesar do $\mathrm{pH}$ não ter sido intimamente associado à produção de $\mathrm{HBu}$, Luo et al., (2018) reportaram que o controle do pH entre 5,5 e 7,0 é uma boa alternativa para obtenção de altas concentrações de $\mathrm{HBu}$. Resultados similares foram obtidos por Lay et al. (2012) na fermentação de resíduos de batata doce, sendo que as maiores concentrações de $\mathrm{HBu}$ (10-11 mg.L $\left.\mathrm{L}^{-1}\right)$ foram obtida em faixa de $\mathrm{pH}$ entre 6,5 e 7,5, e para valores inferiores e superiores a estes observou-se menor concentração deste ácido. Ademais, os autores reportaram que não foi detectada nenhuma produção de $\mathrm{HBu}$ em $\mathrm{pH}<5,0$. 
Tabela 5.17. Produção de ácidos carboxílicos (AC), etanol e fenóis nos ensaios do DCCR em função do pH e temperatura.

\begin{tabular}{|c|c|c|c|c|c|c|c|c|c|c|}
\hline \multirow{2}{*}{ Ensaios* } & \multirow{2}{*}{ pH } & \multirow{2}{*}{$\begin{array}{c}\text { Temperatura } \\
\left(\text { g. } L^{-1}\right)\end{array}$} & \multicolumn{5}{|c|}{ Ácidos orgânicos finais (g.L $\left.{ }^{-1}\right)$} & \multirow{2}{*}{$\begin{array}{c}\text { EtOH } \\
\text { g.L } L^{-1}\end{array}$} & \multirow{2}{*}{$\begin{array}{c}\mathrm{pH} \\
\text { final }\end{array}$} & \multirow{2}{*}{$\begin{array}{l}\text { Fenóis } \\
\text { mg.L }^{-1}\end{array}$} \\
\hline & & & HAc & HBu & HLa & HPr & Total & & & \\
\hline 1 & 5,5 & 30 & 0,15 & $<\mathrm{LD}$ & 2,91 & $<\mathrm{LD}$ & 3,06 & 0,01 & 5,29 & $5,81 \pm 0,0$ \\
\hline 2 & 7,5 & 30 & 0,39 & 0,48 & 2,45 & 0,17 & 3,49 & 0,06 & 4,33 & $9,88 \pm 0,0$ \\
\hline 3 & 5,5 & 44 & 0,59 & $<\mathrm{LD}$ & 2,66 & 0,25 & 3,5 & 0,14 & 3,57 & $11,05 \pm 0,1$ \\
\hline 4 & 7,5 & 44 & 0,66 & 0,40 & 2,31 & 0,13 & 3,5 & 0,04 & 5,19 & $3,49 \pm 0,0$ \\
\hline 5 & 5,09 & 37 & 0,22 & 0,41 & 3,98 & 0,11 & 4,72 & 0,09 & 4,11 & $20,93 \pm 0,0$ \\
\hline 6 & 7,91 & 37 & 0,44 & $<\mathrm{LD}$ & 3,16 & 0,14 & 3,74 & 0,07 & 4,21 & $16,86 \pm 0,0$ \\
\hline 7 & 6,5 & 27,10 & 0,51 & 1,24 & 2,02 & 0,20 & 3,97 & 0,00 & 3,55 & $7,56 \pm 0,1$ \\
\hline 8 & 6,5 & 46,90 & 0,28 & $<\mathrm{LD}$ & 2,26 & $<\mathrm{LD}$ & 2,54 & 0,14 & 3,72 & $12,21 \pm 0,0$ \\
\hline 9 & 6,5 & 37 & 0,26 & 0,63 & 1,58 & 0,10 & 2,24 & 0,05 & 3,86 & $5,23 \pm 0,0$ \\
\hline 10 & 6,5 & 37 & 0,33 & 0,72 & 1,74 & 0,11 & 2,9 & 0,04 & 4,31 & $7,88 \pm 0,1$ \\
\hline 11 & 6,5 & 37 & 0,31 & 0,77 & 1,78 & 0,14 & 3 & 0,03 & 3,60 & $6,40 \pm 0,0$ \\
\hline
\end{tabular}

Nota: < = valor abaixo do Limite de Detecção (LD) do método cromatográfico. 
Universidade de São Paulo

Escola de Engenharia de São Carlos

Programa de Pós-graduação em Hidráulica e Saneamento

Figura 5.33. Ácidos carboxílicos em função do tempo dos ensaios do DCCR
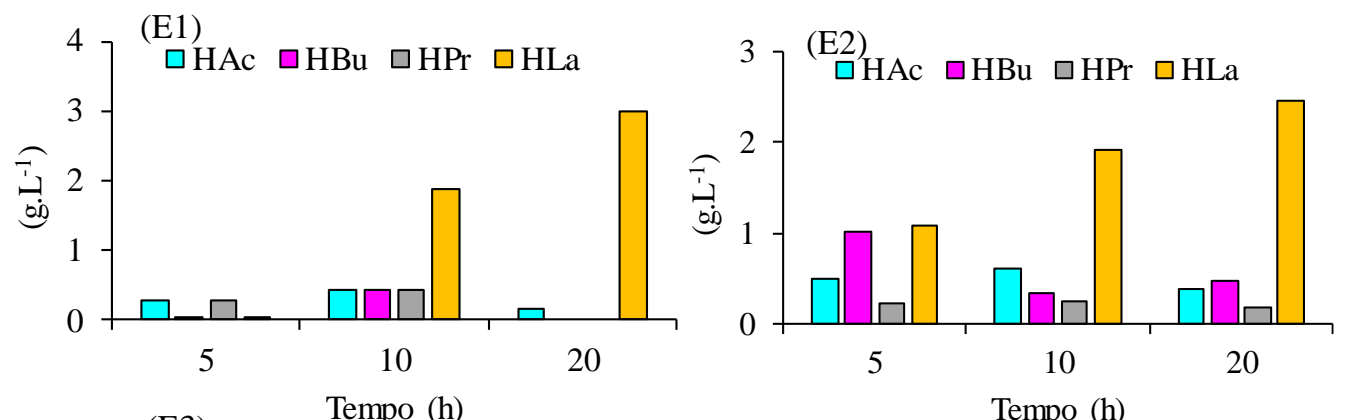

(E3)
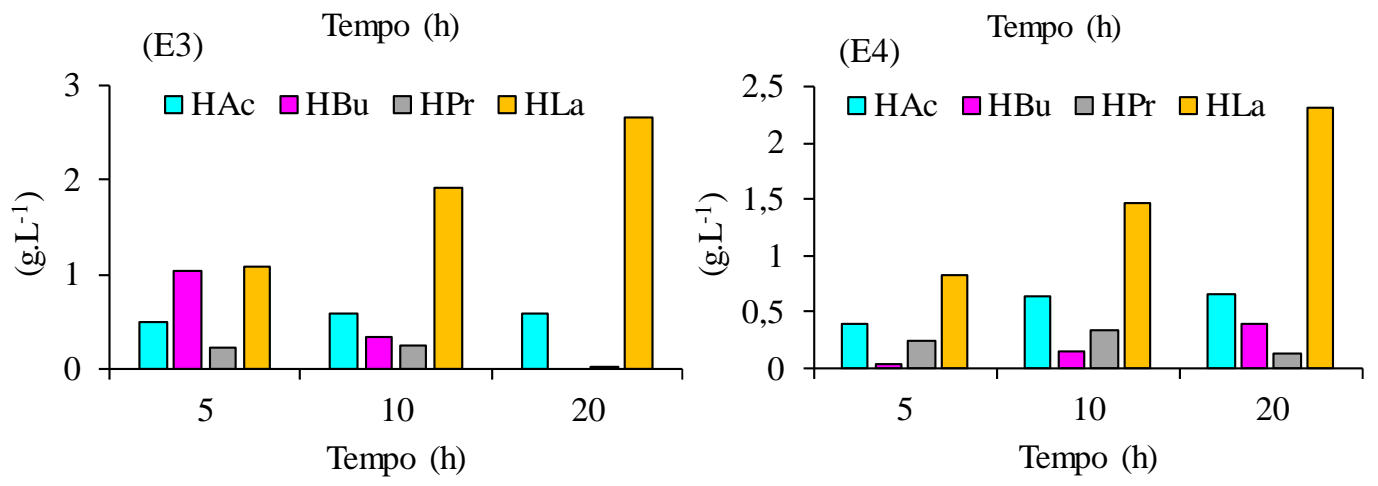

(E5)

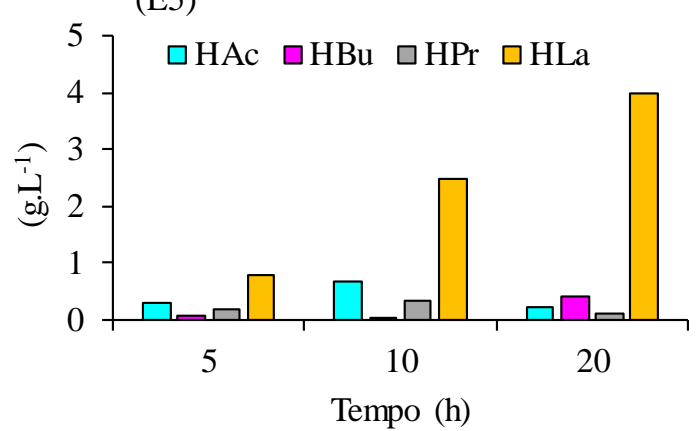

(E6)

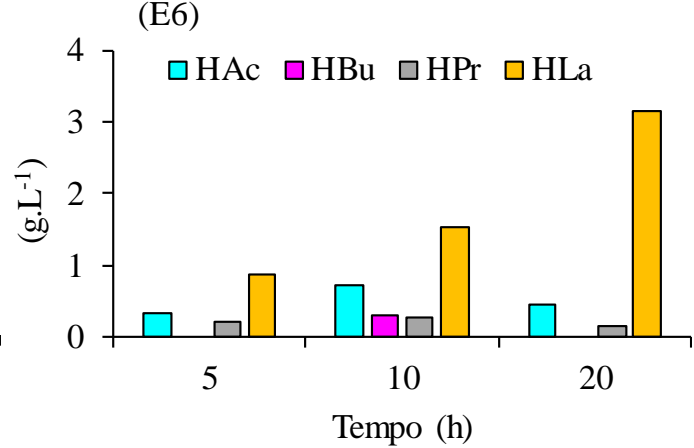

(E7)

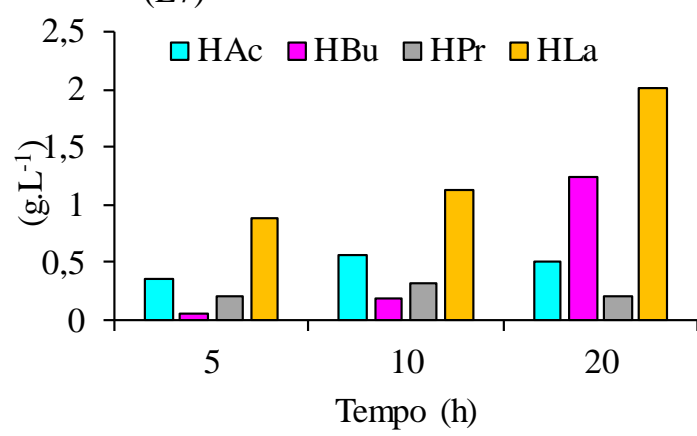

(E8)

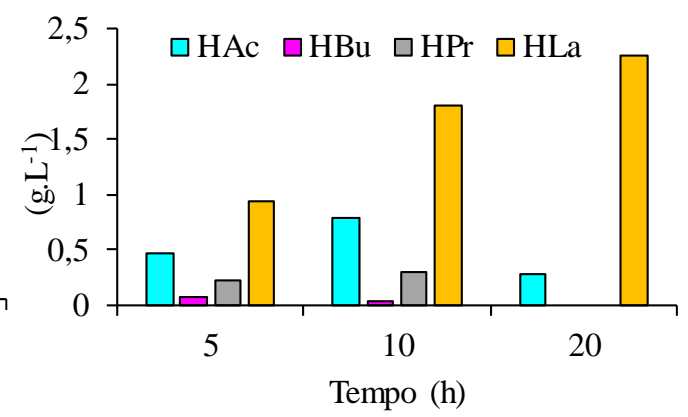

(E10)
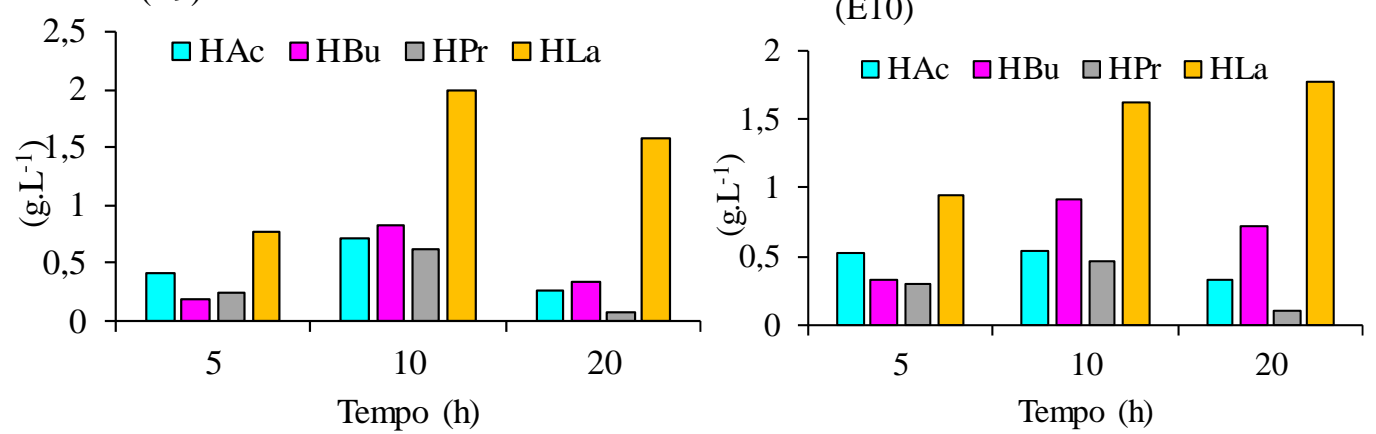
(E11)

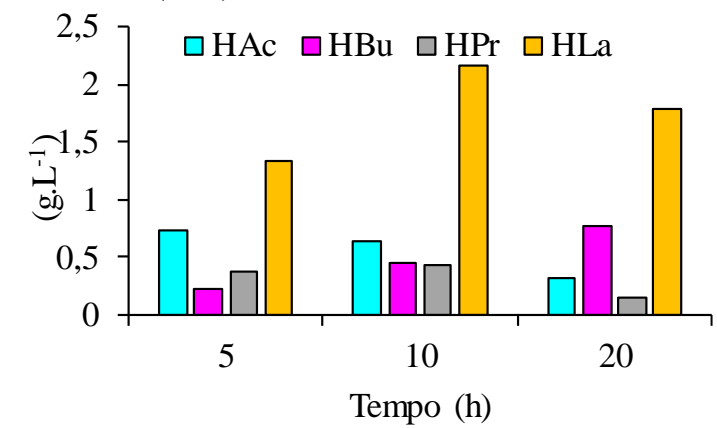

Com exceção do $\mathrm{E} 7$ ( $\mathrm{pH} 6,5,27,1^{\circ} \mathrm{C}$ ), nos demais ensaios verificou-se diminuição contínua da concentração de ácido butírico, de $10 \mathrm{~h}$ até o final da fermentação. Por meio de tais resultados pode-se inferir que a conversão do resíduo de banana em HBu (Reação 11) nas primerias horas da fermentação contribuiu com a produção de $\mathrm{H}_{2}$ (até 2 mols $\mathrm{H}_{2}$. mol glicose) podendo estar associado aos reduzidos tempos de início de produção de hidrogênio $\left(\lambda \mathrm{H}_{2}\right)$ entre 1-7 horas. No entanto, no decorrer da fermentação, houve alteração da rota metabólica, cessando a produção de $\mathrm{HBu}$, onde o residual deste ácido foi consumido ou convertido em $\mathrm{H}_{2}$ e $\mathrm{CO}_{2}$.

Diferentes são os substratos utilizados como substrato na produção de $\mathrm{HBu}$. A título de exemplificação Daiya et al. (2015) obtiveram máxima produção de HBu de 1,8 g.L $\mathrm{L}^{-1}$ em $36 \mathrm{~h}$ de fermentação de resíduos de alimentos, enquanto na presente pesquisa obteve-se $1,1 \mathrm{~g} . \mathrm{L}^{-1} \mathrm{em}$ 5 horas de fermentação, cerca de 7 vezes mais rápido. Soares et al. (2018) e Rabelo et al. (2018) obtiveram produção similar a presente pesquisa de 1,1 e 1,92 g. $\mathrm{L}^{-1}$ a $37^{\circ} \mathrm{C}$ e $\mathrm{pH} 6,0$ na fermentação de bagaço de cana de açúcar, respectivamente. Nas mesmas condições ( $\mathrm{pH}$ 6,0 e $37^{\circ} \mathrm{C}$ ), Tang et al. (2016) obtiveram produção máxima de $\mathrm{HBu}$ de 2,9 g. $\mathrm{L}^{-1}$ na fermentação de restos de alimentos utilizando biomassa autóctone. Independente do substrato utilizado, a condição de $\mathrm{pH} 6,0$ e $37^{\circ} \mathrm{C}$ são ditas como ideiais para obtenção de altas concentrações de $\mathrm{HBu}$ (Fu et al., 2017; Suo et al., 2017).

A razão $(\mathrm{HBu} / \mathrm{HAc})$ pode variar dependendo das condições experimentais na fermentação, e pode ser utilizado como um indicador do tipo de metabolismo predominante (Tang et al., 2008). Observando-se os valores da relaçãoHBu/HAc (Figura 5.34), pode-se associar os ensaios com maior produção de $\mathrm{H}_{2}$ aos maiores valores da razão $\mathrm{HBu} / \mathrm{HAc}(>1,0)$. Por outro lado, menor produção de hidrogênio foi associada ao baixo relação $\operatorname{HBu} / \operatorname{HAc}(<0,5)$, principalmente nos ensaios 1, 3 e 8, corroborando com os resultados obtidos por Tang et al. (2008) e Wong et al. (2014), nos quais para a alta relação HBu/HAc geralmente indica maior produção de hidrogênio. Zaira et al. (2018) reportaram que baixa relação HBu/HAc $(0,06-0,11)$ 
foi associada a baixa produção de $\mathrm{H}_{2}$, enquanto, alta relação $\mathrm{HBu} / \mathrm{HAc}(0,88-1,92)$ foi associada a maior produção de $\mathrm{H}_{2}$.

Estes resultados diferiram daqueles obtidos por Anzola-Rojas et al. (2015) e Barca et al. (2015), no qual associaram maior produção de $\mathrm{H}_{2}$ a menor relação $(\mathrm{HBu} / \mathrm{HAc})(0,3-0,9)^{8}$. De fato, é mencionada associação entre maior produção de $\mathrm{H}_{2}$ à menor relação $\mathrm{HBu} / \mathrm{HAc}(<1,0)$ uma vez que a via acética leva (teoricamente) a maior rendimento de hidrogênio. No entanto, deve-se ressaltar que no presente estudo, menor relação $\mathrm{HBu} / \mathrm{HAc}$ não contribuiu para obtenção de maior produção de $\mathrm{H}_{2}$. Portanto, assumiu-se que a via principal de produção de hidrogênio foi a butírica, embora esta rota não seja considerada muito adequada devido a produção de metabólitos mais reduzidos, como o próprio $\mathrm{HBu}$, implicando em prejuízo para produção de $\mathrm{H}_{2}$ (Fernandes et al. 2010), além de requerer maior quantidades de energia metabólica ( $\Delta \mathrm{G}=$ $\left.257,1 \mathrm{~kJ} \mathrm{~mol}^{-1}\right)$, quando comparado a via acética $\left(\Delta \mathrm{G}=-184,1 \mathrm{~kJ} \mathrm{~mol}^{-1}\right)$ (Hwang et al., 2014).

Figura 5.34. Relação HBu/HAc e produção de hidrogênio nos ensaios do DCCR em reatores em batelada.

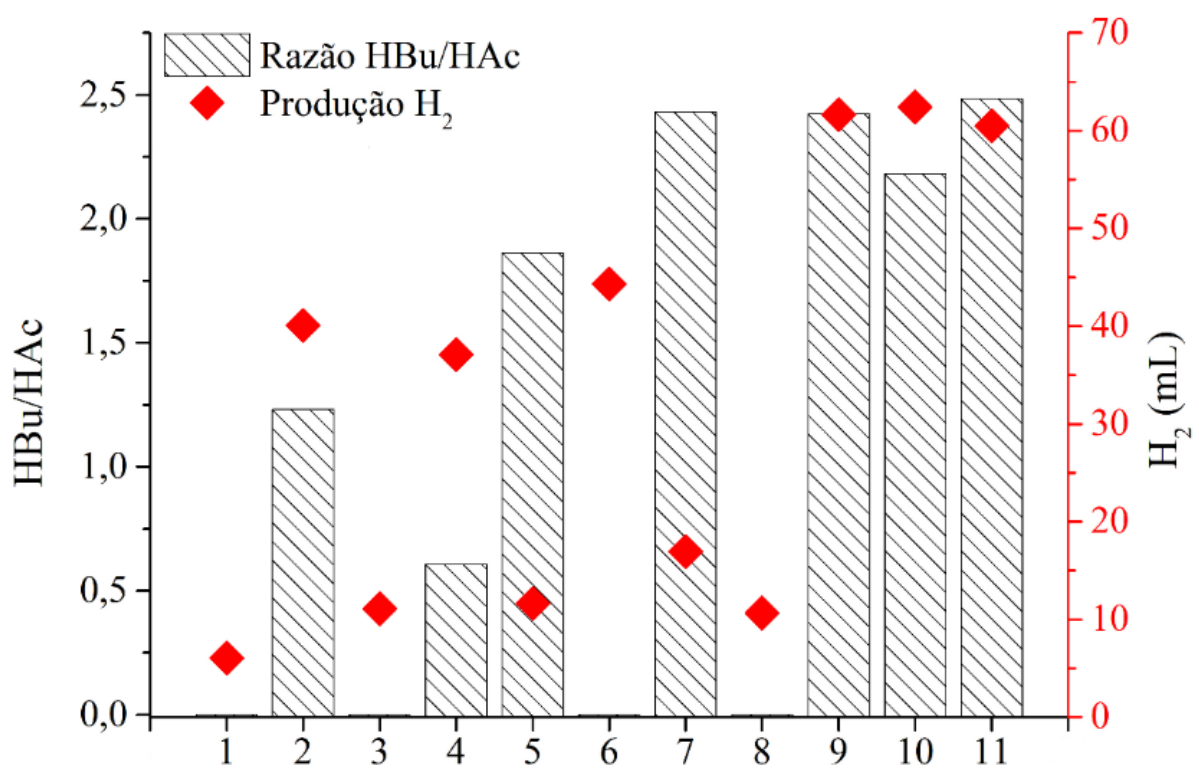

Ensaios

$\mathbf{E 1}=\mathrm{pH} 5,5$ e temperatura $30^{\circ} \mathrm{C}, \mathbf{E} 2=\mathrm{pH} 7,5$ e temperatura $30^{\circ} \mathrm{C}, \mathbf{E} \mathbf{3}=\mathrm{pH} 5,5$ e temperatura $44^{\circ} \mathrm{C}, \mathbf{E} 4=\mathrm{pH} 7,5$ e temperatura $44^{\circ} \mathrm{C}, \mathbf{E 5}=5,09$ e temperatura $37^{\circ} \mathrm{C}, \mathbf{E 6}=7,91$ e temperatura $37^{\circ} \mathrm{C}, \mathbf{E} 7=\mathrm{pH} 6,5$ e temperatura $27,10^{\circ} \mathrm{C}, \mathbf{E 8}=6,5$ e temperatura $46,90^{\circ} \mathrm{C}, \mathbf{E 9}, \mathbf{E 1 0}$ e $\mathbf{E 1 1}=\mathrm{pH} 6,5$ e temperatura $37^{\circ} \mathrm{C}$.

\footnotetext{
${ }^{8}$ Essa relação deve ser avaliada com cautela, pois o ácido acético pode ser produzido via metabolismo heterotrófico ou autotrófico, e essa afirmação refere-se apenas ao HAc produzido por micro-organismos produtores de hidrogênio (Barca et al., 2015).
} 


\section{Universidade de São Paulo \\ Escola de Engenharia de São Carlos \\ Programa de Pós-graduação em Hidráulica e Saneamento}

Em relação ao ácido propiônico (HPr) verificou-se produção uniforme em todos as condições avaliadas, sendo seu possível consumo observado após $10 \mathrm{~h}$ de fermentação (Figura 5.18). Concentração máxima de $\operatorname{HPr}$ de 0,4 g. $\mathrm{L}^{-1}$ foi observada nos ensaios em pH ácido (5,56,5). Este resultado corrobora com aqueles obtidos por Dareioti et al., (2014), no qual valor de pH ácido favoreceu o estabelecimento da rota fermentativa do ácido propiônico.

É importante ressaltar que neste estudo, não foi observada relação expressiva entre menor produção de hidrogênio e aumento da concentração de HPr, em vista que maior concentração de HPr foram obtidas nos ensaios $\left(9,10\right.$ e 11) com maior produção de $\mathrm{H}_{2}$.

A presença deste ácido está relacionada, principalmente, à conversão direta do substrato (Reação 10) ou a conversão de outros metabólitos, como o HLa, em HPr (Reação 9), sendo esta última comumente observada em sistemas cuja a concentração de HLa é elevada (Saady, 2013, Fues et al., 2018). No entanto, em sistemas onde há produção e/ou acúmulo de etanol, a produção de HPr também pode ser obtida a partir da fermentação do etanol (Reação 22; Tholozan et al., 1992), correspondendo a uma via alternativa para a obtenção de energia.

$3 \mathrm{CH}_{3} \mathrm{CH}_{2} \mathrm{OH}+\mathrm{CO}_{2} \rightarrow 2 \mathrm{CH}_{3} \mathrm{CH}_{2} \mathrm{COOH}+\mathrm{CH}_{3} \mathrm{COOH}+\mathrm{H}_{2} \mathrm{O}$

Reação 22

O acúmulo de etanol (EtOH) também foi observado no resíduo de banana acidificado (Tabela 5.17). Tanto, o termo quadrático da temperatura $\left(\mathrm{x}_{2}^{2}\right)$, quanto a interação entre $\mathrm{pH}$ e temperatura $\left(\mathrm{x}_{1} \mathrm{x}_{2}\right)$ foram estatisticamente significativas $(\mathrm{p}<0,05)$ para produção de etanol, indicando que o aumento da temperatura contribui para o aumento da produção de etanol, principalmente nos ensaios com baixo pH. Desta forma, produção máxima de EtOH de 0,14 g. $\mathrm{L}^{-1}$ foi obtida no ensaio 3 e 8 , correspondendo aos ensaios em $\mathrm{pH}$ ácido $(5,5$ e 6,5) e temperaturas elevadas $\left(44\right.$ e $\left.46,90^{\circ} \mathrm{C}\right)$, respectivamente. Provavelmente nestas condições, o metabolismo das bactérias produtoras de etanol foi favorecido quando comparado aos valores de $\mathrm{pH}$ elevados e baixas temperaturas. Isso explicaria as baixas concentrações de etanol (0-0,06 g. $\mathrm{L}^{-1}$ ) nos ensaios 2 e 7, correspondentes aos ensaios com $\mathrm{pH}$ próximo a neutralidade ( $\mathrm{pH}$ 7,5 e 6,5) e temperatura de 30 e $27,1^{\circ} \mathrm{C}$, respectivamente. Portanto, pode-se inferir que as condições operacionais ( $\mathrm{pH}$ e temperatura) foram associadas ao predomínio de algumas rotas metabólicas e que o aumento da temperatura associada ao baixo valor de $\mathrm{pH}$ beneficiou a microflora natural produtora de etanol.

Resultados similares ao presente estudo foram obtidos por Wu et al. (2017). Os autores avaliaram o efeito do $\mathrm{pH}(4,0,5,0,5,5$ e 6,0) na produção de etanol na fermentação de resíduo 
de frutas e vegetais e verificaram que as concentrações máximas obtidas $\left(5,6\right.$ e 6,7 g.L $\left.\mathrm{L}^{-1}\right)$ foram em $\mathrm{pH}$ de 5,5 e 4,0. Os autores concluíram que, o controle do $\mathrm{pH}$ na faixa entre 4,0 e 5,5 pode contribuir com a fermentação contínua etanólica. Resultados divergentes foram obtidos por Lay et al. (2012) onde relataram maior produção de EtOH de 14,65 g. $\mathrm{L}^{-1} \mathrm{em} \mathrm{pH} \mathrm{8,5} \mathrm{e} \mathrm{temperatura}$ $37^{\circ} \mathrm{C}$ na fermentação de resíduos de batata doce a partir do consórcio microbiano, evidenciando o potencial dos resíduos constituídos por amido na produção de bioetanol. Balat et al. (2008) e Lin et al. (2008) também reportaram que resíduos com alto teor de amido são considerados importantes para a fermentação etanólica.

A presença de etanol na fermentação da banana pode ter contribuído com uma parcela de $\mathrm{H}_{2}$ nos ensaios (Reação 13). A contribuição do etanol para produção de $\mathrm{H}_{2}$ também foi reportada por Ferraz Jr. et al. (2015b) e Fues et al. (2018) para ambas as faixas mesofílica $\left(25^{\circ} \mathrm{C}\right)$ e termofílica $\left(55^{\circ} \mathrm{C}\right)$, demonstrando a viabilidade relevante da co-produção de $\mathrm{H}_{2}$ e HAc a partir de resíduos contendo altas concentrações de etanol (Reação 18).

Ademais, a produção de etanol também pode estar associada ao metabolismo de bactérias heteroláticas, no qual fermentam carboidratos primariamente em HLa e etanol (Reação 14). Evidências da fermentação heterolática em sistemas acidogênicos também foram relatadas por Ren et al. (2007), Gomes et al. (2015) e Fues et al. (2018). Os autores relataram a possível associação de bactérias láticas na regeneração da molécula de NADH, determinando importante papel no transporte de elétrons no metabolismo celular (Budinich et al., 2011).

\subsubsection{Fenóis}

Quando substratos contendo fração de hemicelulose e celulose são degradados, ocorre despolimerização da lignina com aumento do conteúdo de elementos fenólicos livres decorrente da ruptura das ligações $\beta$-O-4 (Waldron, 2010). A liberação dos compostos fenólicos pode ocorrer após aplicação de pré-tratamentos, incluindo hidrólise ácida ou básica, tratamentos hidrotérmicos ou até mesmo durante a fermentação natural do resíduo (Bundhoo e Mohee, 2016), como é o caso do presente estudo.

A variável $\mathrm{pH}$ foi estatisticamente significativa $(\mathrm{p}<0,05)$ para produção de fenóis, tanto o termo linear $\left(\mathrm{x}_{1}\right)$ quanto o quadrático $\left(\mathrm{x}_{1}{ }^{2}\right)$. A maior concentração de fenóis $\left(20 \mathrm{mg} . \mathrm{L}^{-1}\right)$ foi obtida em E5 ( $\mathrm{pH} 5,09$ e $37^{\circ} \mathrm{C}$ ), enquanto que a concentração mínima (3,49 mg.L $\mathrm{L}^{-1}$ ) foi

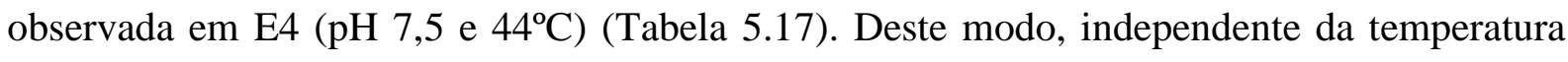
aplicada, a liberação de fenóis a partir da degradação do resíduo de banana aumentou principalmente em $\mathrm{pH}$ ácido, quando comparado ao $\mathrm{pH}$ neutro ou superior a 7,0. 


\section{Universidade de São Paulo \\ Escola de Engenharia de São Carlos \\ Programa de Pós-graduação em Hidráulica e Saneamento}

Outro fato importante a ser considerado é que normalmente a presença de fenóis (>600 mg. $\mathrm{L}^{-1}$ ) tem sido associada a redução e/ou inibição da produção de $\mathrm{H}_{2}$ (Kumar et al., 2015; Madigou et al., 2016), por afetarem membranas citoplasmáticas de bactérias, resultando na redução da taxa de crescimento microbiano e mudanças de rotas metabólicas em processos fermentativos. No entanto, a inibição destes compostos é dependente de vários fatores, incluindo as condições de pré-tratamento. Neste caso é recomendável a aplicação de técnicas de desintoxicação do hidrolisado utilizando diferentes técnicas biológicas, físicas ou químicas (Palmqvist e Hahn-Heagerdal, 2000). Todavia, neste estudo não foi verificado efeito inibitório de fenóis em nenhum ensaio, em vista que as concentrações finais observadas foram inferiores a $21 \mathrm{mg} \cdot \mathrm{L}^{-1}$.

Neste sentido, o melhor substrato utilizado em processos fermentativos é aquele constituído de alta concentração de carboidratos prontamente disponíveis e cujo método de prétratamento inicial é relativamente simples (Bartacek et al., 2007). Portanto, a utilização de resíduo de banana como substrato na fermentação é vantajosa em vista que, possui altas concentrações de carboidratos solúveis além de requerer pré-tratamento simples, como trituração e peneiramento.

Considerando o custo-benefício da produção de metabólitos solúveis (ácidos carboxílicos, etanol e até mesmo fenóis) a partir da fermentação da banana utilizando biomassa autóctone, a presente fermentação não só dispensou o envolvimento de enzimas exógenas, no qual reduziria o benefício ganho pela utilização de matérias-primas baratas (Jorgensen et al., 2007), bem como reutilizou um tipo de resíduo lignocelulósico com alta concentração de matéria orgânica solúvel (renovável e de baixo custo) e o converteu em produtos de interesse biotecnológico.

No entanto, a viabilidade do processo econômico para separar e purificar algum produto de interesse, como o HAc e o HPr, a jusante da fermentação também deve ser considerada para a possível aplicação desse processo fermentativo em grande escala. Para isso, pesquisas têm sido realizadas com intuito de desenvolver metodologias de remoção de ácidos orgânicos in situ, para que por fim, haja separação do metabólito de interesse, reduzindo a perda de produtos (Zigova e Sturdik, 2000). Desta forma, comparado com o método típico de síntese química para produção de ácidos carboxílicos, a fermentação é extremamente viável devido às condições de reação menos rigorosas, baixa emissão de poluentes e utilização de matéria-prima renovável (Luo et al., 2018). 


\subsubsection{Açúcares}

A conversão de substratos lignocelulósicos em açúcares solúveis é um dos fatores limitantes da hidrólise e fermentação (Sivagurunathan et al., 2017), sendo que alguns parâmetros como $\mathrm{pH}$, temperatura, substrato e inóculo podem influenciar diretamente na solubilização do resíduo.

$\mathrm{Na}$ presente pesquisa, o $\mathrm{pH}$ e temperatura tiveram efeito significativo $(<0,05)$ no aumento da concentração final de metabólitos solúveis (Figura 5.35). A maior concentração de DQO solúvel (DQOs) foi obtida em pH ácido (5,09 e 6,5) e em temperaturas mais elevadas (37 e 46, $9^{\circ} \mathrm{C}$ ), correspondendo aos ensaios E5 e E6. Enquanto, a menor concentração de DQOs foi obtida nos ensaios 9, 10 e $11\left(\mathrm{pH} 7\right.$ e $\left.37^{\circ} \mathrm{C}\right)$. Por meio da análise desses resultados, pode-se inferir que a maior solubulização do resíduo de banana foi obtida quando o $\mathrm{pH}$ ácido foi associado com altas temperaturas. No entanto, menor concentração de DQOs obtida nos ensaios 9, 10 e 11 também pode ser correlacionada com a maior produção de $\mathrm{H}_{2}$ obtida nestes ensaios (60-62 mL). Provavelmente, os metabólitos solúveis que foram produzidos durante a hidrólise, foram convertidos em biogás $\left(\mathrm{H}_{2}, \mathrm{CO}_{2}\right)$, enquanto o acúmulo de metabólitos solúveis nos demais ensaios podem ser relacionados ao favorecimento de outras rotas, principalmente as que envolvem produção de ácidos mais reduzidos e solventes.

Figura 5.35. Efeito do pH e temperatura na fermentação do resíduo da banana nos ensaios do DCCR em reator em batelada.

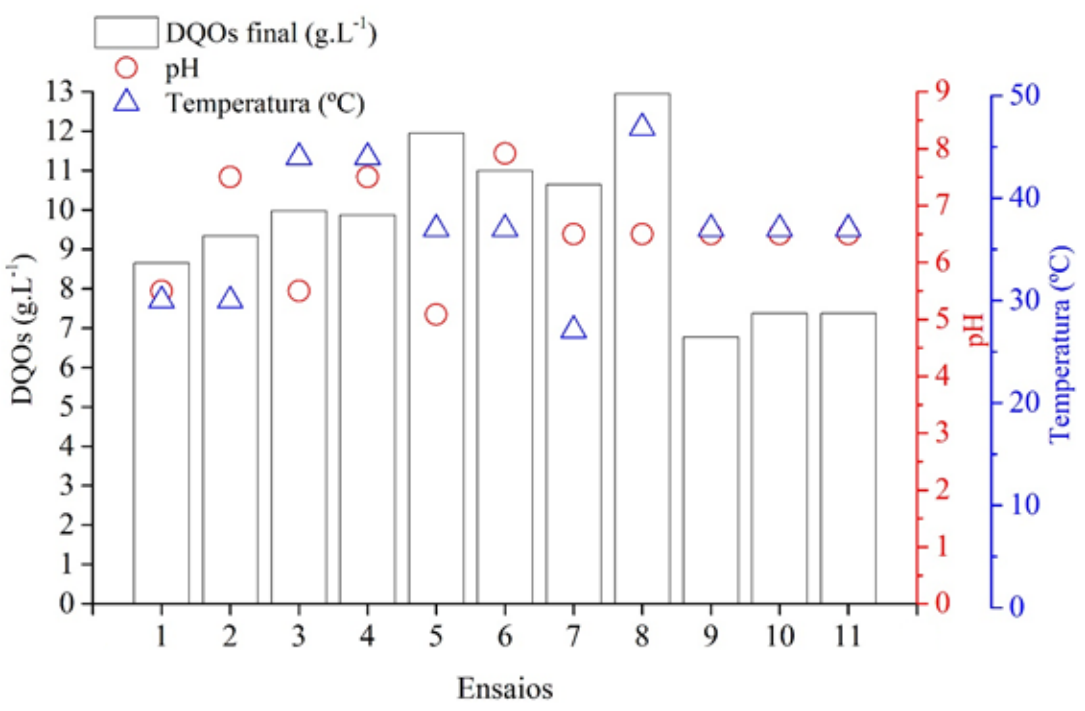

Nota: DQOs = demanda química de oxigênio solúvel; $\mathbf{E} 1=\mathrm{pH} 5,5$ e temperatura $30^{\circ} \mathrm{C}, \mathbf{E} 2=\mathrm{pH} 7,5$ e temperatura $30^{\circ} \mathrm{C}, \mathbf{E 3}=\mathrm{pH} 5,5$ e temperatura $44^{\circ} \mathrm{C}, \mathbf{E} 4=\mathrm{pH} 7,5$ e temperatura $44^{\circ} \mathrm{C}, \mathbf{E 5}=5,09$ e temperatura $37^{\circ} \mathrm{C}, \mathbf{E 6}=7,91$ e temperatura $37^{\circ} \mathrm{C}, \mathbf{E} 7=\mathrm{pH} 6,5$ e temperatura $27,10^{\circ} \mathrm{C}, \mathbf{E 8}=6,5$ e temperatura $46,90^{\circ} \mathrm{C}, \mathbf{E 9}, \mathbf{E 1 0}$ e $\mathbf{E 1 1}=\mathrm{pH}$ 6,5 e temperatura $37^{\circ} \mathrm{C}$. 


\author{
Universidade de São Paulo \\ Escola de Engenharia de São Carlos \\ Programa de Pós-graduação em Hidráulica e Saneamento
}

O acúmulo de DQOs no final dos ensaios em altas temperaturas pode ser resultante de duas razões: primeiro, altas temperaturas aceleram a hidrólise (Tang et al. 2016) e consequentemente aumentam a concentração de material solúvel, e segundo o aumento da temperatura retarda a acidogênese e menos carboidratos solúveis foram convertidos. Portanto, o aumento da temperatura pode influenciar diretamente na solubilidade de carboidratos e na taxa de hidrólise do substrato (Liu et al., 2012).

Como já mencionado, a banana (casca e fruto) é constituída por cerca de 50,15\% de celulose, $0,77 \%$ de hemicelulose e 17,74\% de lignina, além de fração de carboidratos solúveis (Guimarães et al., 2009). No caso da celulose, este é um polímero constituído basicamente de glicose (carboidrato homogêneo), enquanto a hemicelulose é polímero ramificado contendo principalmente açúcares C5 e C6, isto é, xilose, arabinose, manose, etc. na camada intermediária, sendo desta forma um carboidrato heterogêneo. A lignina por sua vez é um heteropolímero rígido, no qual não é constituído à base de açúcares (Sivagurunathan et al., 2017). Neste caso, é interessante que durante a fermentação do resíduo de banana, tanto a celulose, quanto a hemicelulose seja hidrolisada para liberação de açúcares.

Pode-se observar na Figura 5.36 concentrações variadas de açúcares em todos os ensaios do DCCR (E1-11), inferindo indiretamente no metabolismo de bactérias fermentativas. A concentração inicial de sacarose no início da fermentação foi em média de 0,08 g.L $\mathrm{L}^{-1}$ e obteve máxima eficiência de conversão (100\%) nos ensaios 7-11, correspondendo aos ensaios em pH inicial 6,5. Por outro lado, não houve conversão de sacarose no ensaio 3 (pH 5,5 e $44^{\circ} \mathrm{C}$ ) e 5 $\left(\mathrm{pH} \mathrm{5,09}\right.$ e $\left.37^{\circ} \mathrm{C}\right)$. Provavelmente, nestas condições não foi favorecido o metabolismo da sacarose, via onde este açúcar é degradado. O baixo valor de $\mathrm{pH}$ associado a alta temperatura afetou negativamente a atividade das bactérias celulolíticas. No entanto, quando altas temperaturas foram associadas a $\mathrm{pH}$ próximos ou superior ao neutro $\left(\mathrm{E} 4: \mathrm{pH} 7,5\right.$ e $44^{\circ} \mathrm{C}$; E6: $\mathrm{pH} 7,91 \mathrm{e} 37^{\circ} \mathrm{C}$ ) ou quando baixos valores de $\mathrm{pH}$ foram associados a temperaturas mais baixas (E1: $\mathrm{pH} 5,5$ e $30^{\circ} \mathrm{C}$ ) a eficiência de conversão obtida foi entre 11 e $70 \%$.

Os dissacarídeos são moléculas mais complexas quando comparados ao monocarídeos por serem constituídos de uma cadeia de carbono maior (12C). No caso da sacarose, é um dissacarídeo composto por glicose ligada a frutose via ligação éter entre $\mathrm{C} 1$ da unidade glicosil com o C2 da unidade frutosil (Myung et al., 2014), logo sua hidrólise resulta em uma molécula de glicose e uma de frutose (Reação 23). Neste sentido, maior produção de $\mathrm{H}_{2}(60-62 \mathrm{~mL})$ obtida principalmente nos ensaios 9, 10 e 11 pode ter sido beneficiada pelo aumento da 
concentração de glicose e frutose nesses ensaios (conversão da sacarose) ou decorrente da degradação direta da sacarose em ácidos orgânicos e $\mathrm{H}_{2}$ (Reações 24-27). Por outro lado, menor produção de $\mathrm{H}_{2}(11 \mathrm{~mL})$ obtida nos ensaios 3 e 5 podem ter sido desfavorecida devido a não conversão de sacarose (Figura 5.36).

Neste sentido, a utilização de sacarose como fonte de carbono pode ser alternativa viável para produção de $\mathrm{H}_{2}$. Lima et al. (2013) reportaram rendimento máximo de $\mathrm{H}_{2}$ de 3,22 mols $\mathrm{H}_{2}$.mol sacarose em reator anaeróbio de leito fixo a $25^{\circ} \mathrm{C}$ utilizando concórcio de bactérias, enquanto que Chen e Lin (2003) obtiveram rendimento inferior (2,87 mols $\mathrm{H}_{2}$.mol sacarose) a $35^{\circ} \mathrm{C}$. No entanto, os principais metabólitos intermediários obtidos por ambos os autores foram ácido acético, ácido butírico e etanol. Rendimento similar (3,39 mols $\mathrm{H}_{2}$.mol sacarose) foi obtido por Mota et al. (2018) em condição extrema de pH $(2,7)$ demonstrando que a produção de $\mathrm{H}_{2}$ utilizando sacarose como substrato pode ser obtida em condição de $\mathrm{pH}$ diferente daquela normalmente observada em outras pesquisas. Apesar de a biomassa utilizada na presente pesquisa ser diferente da biomassa utilizada pelos autores acima, verificou-se que a presença de sacarose no substrato do resíduo de banana levou a produção de ácidos e solvente (ácido acético, butírico e etanol) similar aos autores citados.

$$
\begin{array}{lr}
\mathrm{C}_{12} \mathrm{H}_{22} \mathrm{O}_{11} \text { (sacarose) }+\mathrm{H}_{2} \mathrm{O} \rightarrow \mathrm{C}_{6} \mathrm{H}_{12} \mathrm{O}_{6}(\text { glicose })+\mathrm{C}_{6} \mathrm{H}_{12} \mathrm{O}_{6}(\text { frutose }) & \text { Reação } 23 \\
\left.\mathrm{C}_{12} \mathrm{H}_{22} \mathrm{O}_{11}+\mathrm{H}_{2} \mathrm{O} \rightarrow 4 \mathrm{CH}_{3} \mathrm{CH}(\mathrm{OH}) \mathrm{COO}^{-} \text {(ácido lático }\right)+\mathrm{H}^{+} & \text {Reação } 24 \\
\mathrm{C}_{12} \mathrm{H}_{22} \mathrm{O}_{11}+5 \mathrm{H}_{2} \mathrm{O} \rightarrow 4 \mathrm{CH}_{3} \mathrm{COO}^{-}(\text {acetato ou formiato })+4 \mathrm{H}^{+}+4 \mathrm{CO}_{2}+8 \mathrm{H}_{2} &
\end{array}
$$

Reação $25^{9}$

$\mathrm{C}_{12} \mathrm{H}_{22} \mathrm{O}_{11}+\mathrm{H}_{2} \mathrm{O} \rightarrow 2 \mathrm{CH}_{3} \mathrm{CH}_{2} \mathrm{CH}_{2} \mathrm{COO}^{-}$(ácido butírico) $+2 \mathrm{H}^{+}+4 \mathrm{CO}_{2}+4 \mathrm{H}_{2}$

Reação 26

$\mathrm{C}_{12} \mathrm{H}_{22} \mathrm{O}_{11}+4 \mathrm{H}_{2} \rightarrow 4 \mathrm{CH}_{3} \mathrm{CH}_{2} \mathrm{COO}^{-}$(ácido propiônico) $+4 \mathrm{H}^{+}+3 \mathrm{H}_{2} \mathrm{O}$

Dentre as hexoses, a glicose e a frutose foram os principais monossacarídeos observados no resíduo de banana, entre 1,2-1,96 g.L $\mathrm{L}^{-1}$ e 2,07-2,58 g.L $\mathrm{L}^{-1}$, respectivamente, no início da fermentação para todas as condições dos ensaios DCCR. De acordo com Torquato et al. (2016), a glicose e frutose são as principais hexoses observadas em resíduos frutícolas, provavelmente,

\footnotetext{
${ }^{9} \mathrm{Na}$ fermentação mista, a Reação 26 é a soma da reação de produção de acetato e formiato $\left(1 \mathrm{C}_{12} \mathrm{H}_{22} \mathrm{O}_{11}+5 \mathrm{H}_{2} \mathrm{O}\right.$ $\left.=4 \mathrm{CHOO}^{-}+4 \mathrm{CH}_{3} \mathrm{COO}^{-}+8 \mathrm{H}^{+}+4 \mathrm{H}_{2}\right)$ e da reação seguida de quebra do formiato $\left(4 \mathrm{CHOO}^{-}+4 \mathrm{H}^{+}=4 \mathrm{CO}_{2}+\right.$ $4 \mathrm{H}_{2}$ ). Como no presente estudo a concentração de formiato no efluente foi $\sim 0$, estamos considerando apenas a ocorrência da reação via acetato.
} 


\section{Universidade de São Paulo \\ Escola de Engenharia de São Carlos \\ Programa de Pós-graduação em Hidráulica e Saneamento}

oriundos da degradação do amido e sacarose durante a maturação do fruto (Doerflinger et al., 2015).

Ao final da fermentação em todos os ensaios, observou-se $100 \%$ de conversão da glicose em produtos metabólicos, com exeção do ensaio 1 ( $\mathrm{pH} 5,5$ e $30^{\circ}$ ), no qual a EC foi de 85,64\% (Figura 5.36). Este resultado demonstra que a glicose pode ser metabolizada em uma variedade de condições operacionais, todavia, para aquelas em pH muito baixo essa eficiência foi menor. Maior conversão de glicose pode ter resultado em maior produção de $\mathrm{H}_{2}$, principalmente nos ensaios 9, 10 e 11, em vista que sua conversão (que ocorre em amplas condições operacionais, resulta em variedade de metabólitos e no aumento do rendimento de $\mathrm{H}_{2}$ (Reações 1, 10, 11, 12, $14,15,17$ e 19$)$.

Em relação a frutose, observou-se em todos os ensaios diminuição de cerca de 2 g.L ${ }^{-1}$ para valores inferiores a 1 g.L $\mathrm{L}^{-1}$. A maior conversão de frutose de 85 e $86 \%$, também foram obtidas nos ensaios 9, 10, 11 ( $\mathrm{pH} 6,5$ e $37^{\circ} \mathrm{C}$ ), correspondendo aos ensaios com maior produção de $\mathrm{H}_{2}$, em contrapartida, a menor conversão (23\%) foi obtida no ensaio 7 ( $\mathrm{pH} 6,5$ e $27,1^{\circ} \mathrm{C}$ ) (Figura 5.36). A partir desses resultados, pode-se inferir que a degradação da frutose é mais eficiente em temperaturas acima de $30^{\circ} \mathrm{C}$. Semelhante a glicose, a frutose pode ser eficientemente convertida em produtos metabólicos. As trioses (dihidroxiacetona-fosfato e gliceraldeído-3-fosfato, Reação 28) formadas a partir do metabolismo da frutose são intermediários da glicólise e glicogênese podendo ser convertidas em glicose, ácidos carboxílicos, além de poder ser oxidada a $\mathrm{CO}_{2}$ (via glicólise, desidrogenase do piruvato, ciclo de Krebs e fosforilação oxidativa) (Klurfeld, 2016). Deste modo, glicose e frutose no resíduo de banana podem ter sido primordiais para a produção de $\mathrm{H}_{2}$ em todos os ensaios avaliados.

Frutose +2 ATP $\rightarrow$ dihidroxiacetona $-\mathrm{P}+$ gliceraldeído $-3 \mathrm{P}+2 \mathrm{ADP}$

Reação 28

Em contrapartida, não foi observada, inicialmente, concentração de xilose no resíduo de banana, enquanto após a fermentação, observou-se concentrações entre 0,08 e 0,81 g.L-1, obtendo-se maior e menor concentração no $\mathrm{E} 1\left(\mathrm{pH} 5,5,30^{\circ} \mathrm{C}\right)$ e $\mathrm{E} 2\left(\mathrm{pH} 7,5,30^{\circ} \mathrm{C}\right)$, respectivamente (Figura 5.36). A fermentação da xilose pode resultar em rendimento teórico de 3,33 mol H $\mathrm{H}_{2}$.mol xilose juntamente com 1,67 mol ácido acético.mol xilose (Reação 29). No entanto, esse rendimento pode ser menor (1,67 mol $\mathrm{H}_{2} \mathrm{~mol}$ xilose) quando 0,83 mol ácido butírico.mol xilose também é produzido (Reação 30) (Kongjan et al., 2010). 
Universidade de São Paulo

Escola de Engenharia de São Carlos

Programa de Pós-graduação em Hidráulica e Saneamento

$\mathrm{C}_{5} \mathrm{H}_{10} \mathrm{O}_{5}+1,67 \mathrm{H}_{2} \mathrm{O} \rightarrow 1,67 \mathrm{C}_{2} \mathrm{H}_{3} \mathrm{O}_{2}^{-}+1,67 \mathrm{H}^{+}+3,33 \mathrm{H}_{2}+1,67 \mathrm{CO}_{2} \quad$ Reação 29

$\mathrm{C}_{5} \mathrm{H}_{10} \mathrm{O}_{5} \rightarrow 0,83 \mathrm{C}_{4} \mathrm{H}_{7} \mathrm{O}_{2}^{-}+0,83 \mathrm{H}^{+}+1,67 \mathrm{H}_{2}+1,67 \mathrm{CO}_{2} \quad$ Reação 30

Por ser uma pentose (5C), a xilose é um dos açúcares mais simples quando comparado aos demais monossacarídeos (6C), sendo reportada na literatura como sendo uma fonte de carbono adequada para produção de hidrogênio para consórcio microbiano (Makinen et al., 2012). A título de exemplificação, Kongjan et al. (2018) avaliaram a produção de $\mathrm{H}_{2}$ em reator anaeróbico de fluxo ascendente a partir de xilose utilizando culturas mistas. O rendimento máximo de $\mathrm{H}_{2}$ obtido pelos autores foi de $251 \mathrm{~mL} \mathrm{H}_{2}$. $\mathrm{g}^{-1}$ xilose com taxa de produção de 15,1 $\mathrm{L} \mathrm{H}_{2} \cdot \mathrm{L}^{-d^{-1}}$ a $55^{\circ} \mathrm{C}$. Lin et al. (2008) avaliaram o efeito da temperatura (30 a $\left.55^{\circ} \mathrm{C}\right)$ na produção de hidrogênio a partir de consórcio microbiano utilizando xilose $\left(20\right.$ g. $\left.\mathrm{L}^{-1}\right)$ como substrato e obtiveram maior produção de $\mathrm{H}_{2}(15 \mathrm{~L})$ à $40^{\circ} \mathrm{C}$. Na presente pesquisa, o aumento da concentração de xilose na fração líquida do reator resultante da fermentação do resíduo de banana também pode ter contribuído com a produção de $\mathrm{H}_{2}$ nos ensaios em reator em batelada (Reação 30), principalmente nos ensaios (E1, E3 e E5) com menor valor de $\mathrm{pH}(5,09-5,5)$ no qual a concentração de xilose foi menor $\left(0,08-0,14\right.$ g.L $\left.\mathrm{L}^{-1}\right)$. Tais resultados leva a considerar que essa pentose a medida que foi sendo liberada pela degradação da sacarose foi simultaneamente convertida em outros metabólitos. Por outro lado, nos ensaios (E2, E7, E8, E10 e E11) cujo pH foi próximo ao neutro $(6,5-7,5)$ a concentração final de xilose foi maior $\left(0,38-0,81\right.$ g.L $\left.\mathrm{L}^{-1}\right)$, havendo acúmulo deste açúcar no decorrer da fermentação. Tais resultados podem estar relacionados ao tipo de metabolismo das bactérias presente no inóculo, no qual consomem mais frutose em condições ácidas.

Observou-se também o aumento da concentração da galactose e arabinose do início para o final da fermentação. Provavelmente, a presença destes compostos no substrato inicial devese a ocorrência da fermentação natural do resíduo de banana em condições ambientes, no qual foi aumentando a medida que a hemicelulose foi hidrolisada. Deste modo, as concentrações iniciais de galactose observadas foram de $0,14-0,18 \mathrm{~g} . \mathrm{L}^{-1}$ para $0,16-0,24 \mathrm{~g} . \mathrm{L}^{-1}$, e arabinose de 0,32-0,48 g.L ${ }^{-1}$ para 0,56-0,8 g.L L $^{-1}$ (Figura 5.36). 
Figura 5.36. Açúcares solúveis nos ensaios do DCCR em reatores em batelada.

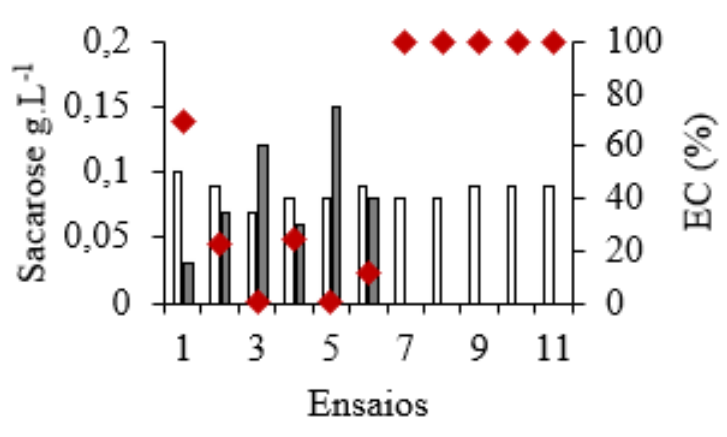

$\square$ Inicial $\square$ Final $\bullet$ Eficiência conversão

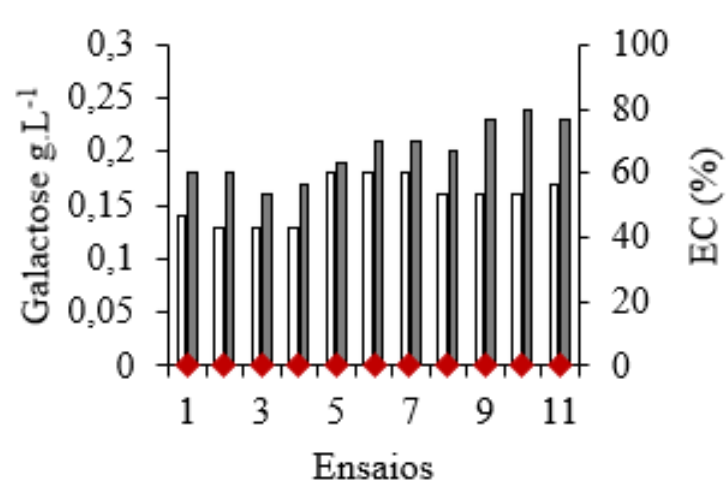

$\square$ Inicial $\square$ Final Eficiência conversão

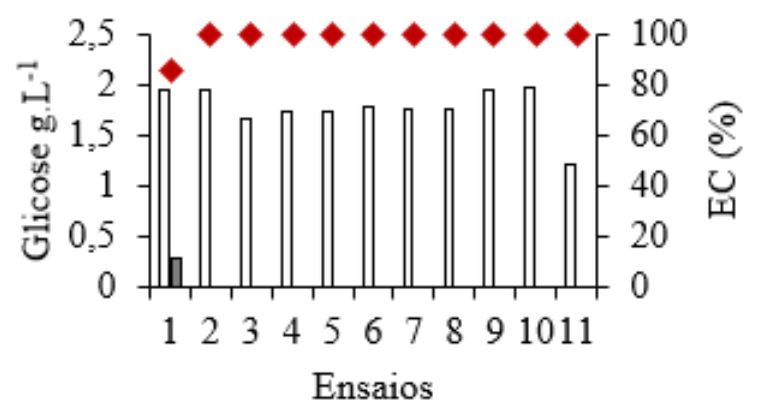

口Inicial $\square$ Final $\bullet$ Eficiência conversão

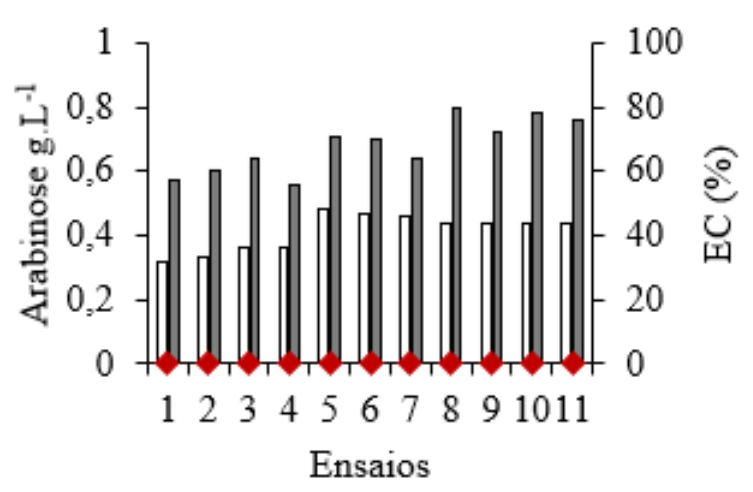

口Inicial $\square$ Final $\bullet$ Eficiência conversão

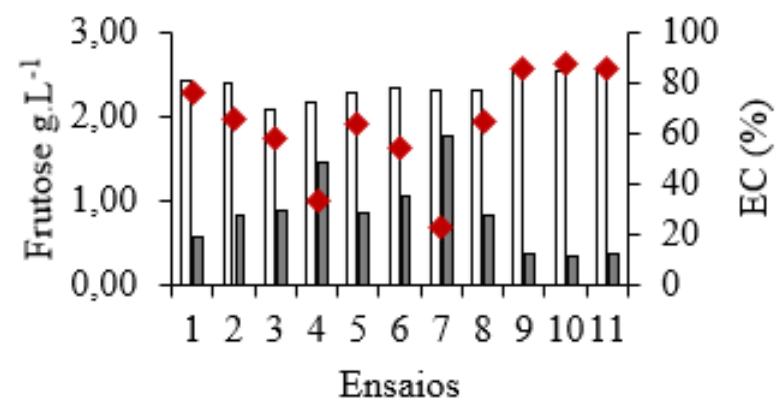

口Inicial $\square$ Final $\bullet$ Eficiência conversão

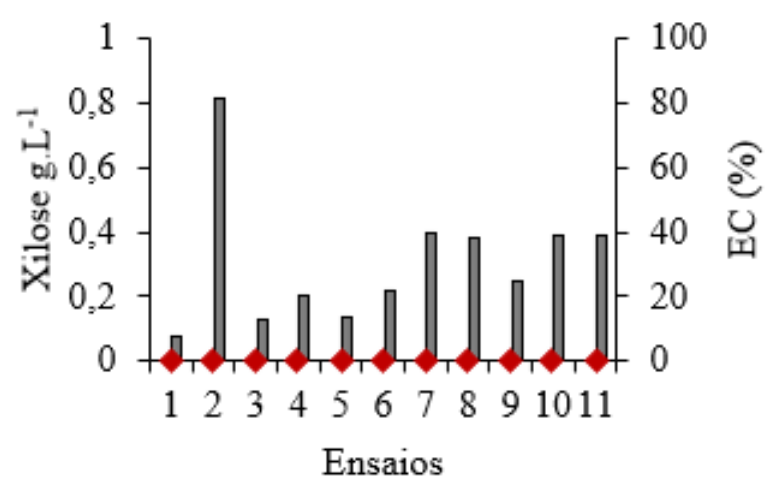

$\square$ Inicial $\square$ Final $\bullet$ Eficiência conversão

Notas: $\mathbf{E 1}=\mathrm{pH} 5,5$ e temperatura $30^{\circ} \mathrm{C}, \mathbf{E 2}=\mathrm{pH} 7,5$ e temperatura $30^{\circ} \mathrm{C}, \mathbf{E 3}=\mathrm{pH} 5,5$ e temperatura $44^{\circ} \mathrm{C}, \mathbf{E 4}=\mathrm{pH} 7,5$ e temperatura $44^{\circ} \mathrm{C}, \mathbf{E 5}=5,09$ e temperatura $37^{\circ} \mathrm{C}$, $\mathbf{E 6}=7,91$ e temperatura $37^{\circ} \mathrm{C}, \mathbf{E} 7=\mathrm{pH} 6,5$ e temperatura $27,10^{\circ} \mathrm{C}, \mathbf{E 8}=6,5$ e temperatura $46,90^{\circ} \mathrm{C}, \mathbf{E 9}, \mathbf{E 1 0}$ e E11 $=$ pH 6,5 e temperatura $37^{\circ}$. 
O aumento da concentração destes carboidratos no final da fermentação infere que a biomassa autóctone não metabolizou esses carboidratos, e, portanto, essas rotas foram desprezíveis para produção de $\mathrm{H}_{2}$. No caso da galactose, a conversão desse monossacarídeo em energia é possível devido a formação de glicose-1-fosfato que entra na via glicolítica, enquanto a arabinose pode ser convertida a xilulose 5-fosfato, para possível formação de ácido lático, ácido acético e etanol (Abdel-Rahman et al., 2013). Em todos os casos, esses produtos podem ser utilizados para produção de $\mathrm{H}_{2}$, no entanto, o gasto energético seria maior quando comparado aos demais carboidratos. Fonseca et al. (2016) reportaram maior produção de $\mathrm{H}_{2} \mathrm{de}$ $940 \mathrm{~mL}$ quando aumentaram a concentração de galactose de 1 para 15 g.L. $\mathrm{L}^{-1}$ a $\mathrm{pH}$ 7,0 e $35^{\circ} \mathrm{C}$ a partir de Clostridium beijerinckii Br21. Os autores observaram que os principais metabolitos produzidos foram o ácido acético, butírico e etanol. Danko et al. (2008) avaliaram o efeito da concentração da arabinose (0-100 mg. $\left.\mathrm{L}^{-1}\right)$ na produção de $\mathrm{H}_{2}$ a partir de consórcio microbiano. Os autores obtiveram produção máxima de $60 \mathrm{~mL}$ utilizando $30 \mathrm{~g} . \mathrm{L}^{-1}$ de arabinose a $\mathrm{pH}$ 6,5 e $37^{\circ} \mathrm{C}$. Neste caso, as maiores produções de hidrogênio $(60-62 \mathrm{~mL})$ obtidas nesta pesquisa foram obtidas nos ensaios (E9, 10 e 11) no qual houve maior acúmulo, tanto de galactose $\left(0,24\right.$ g.L $\left.\mathrm{L}^{-1}\right)$ quando de arabinose $\left(0,78 \mathrm{~g} . \mathrm{L}^{-1}\right)$, entretanto esses açúcares não tiveram relação com a produção de metabólitos produzidos em vista que sua concentração no decorrer da fermentação somente aumentou, e não diminuiu como esperado. Deste modo, pode-se inferir que em resíduos complexos, como o resíduo de banana, no qual há uma variedade de açúcares solúveis no meio, a galactose e arabinose não são os açúcares preferenciais no metabolismo das bactérias, podendo ser degradados em última opção no caso de os açúcares preferenciais (sacarosoe, glicose e frutose) terem sidos esgotados rapidamente.

De fato, a presença de açúcares solúveis no início e final da fermentação possibilita inferir que tanto a celulose quanto a hemicelulose presente no resíduo de banana foram hidrolisadas pelas bactérias autóctones do próprio resíduo. A utilização de consórcio bacteriano pode ter contribuído para a alta conversão destes carboidratos, considerando a diversidade metabólica existente entre as diferentes populações microbianas.

\subsubsection{Validação experimental}

A partir da análise de superfície de resposta foi possível determinar as condições do processo onde se obtêm simultaneamente aumento da produção $(P)$ e da velocidade de produção $(R m)$ de hidrogênio. Para confirmar a validação dos experimentos estatísticos, foi realizada a 


\section{Universidade de São Paulo \\ Escola de Engenharia de São Carlos \\ Programa de Pós-graduação em Hidráulica e Saneamento}

cinética de produção de $\mathrm{H}_{2}$ sob as condições ótimas pré-estabelecidas (Figura 5.37; Tabela 5.18). As variáveis $\mathrm{x}_{1}(\mathrm{pH})$ e $\mathrm{x}_{2}$ (temperatura) proporcionaram as características desejadas do processo, ou seja:

i) Produção de $\mathrm{H}_{2}$ superior a $64 \mathrm{~mL}$;

ii) velocidade de produção de $\mathrm{H}_{2}$ superior a $10 \mathrm{~mL} \cdot \mathrm{h}^{-1}$

Figura 5.37. Cinética de produção de $\mathrm{H}_{2}$ nas condições otimizadas (pH 7,0 e $37^{\circ} \mathrm{C}$ ).

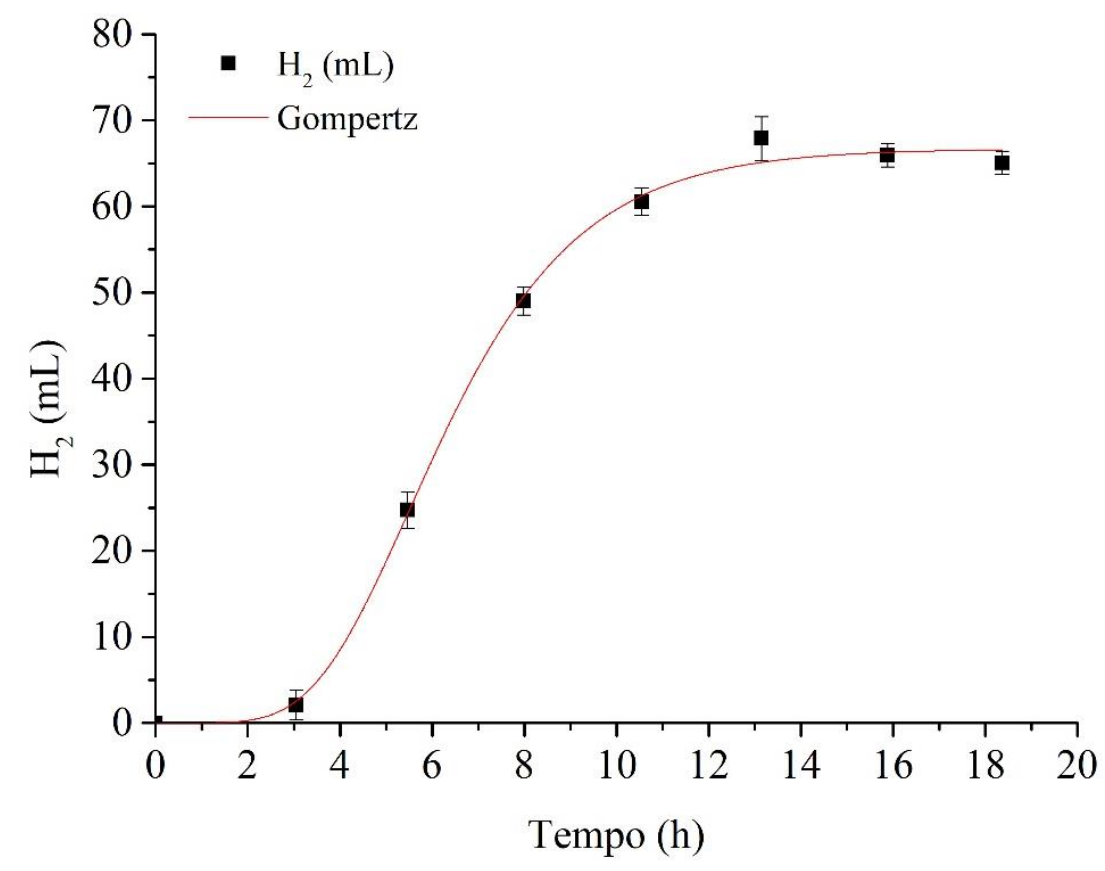

Tabela 5.18. Condições operacionais utilizadas no ensaio experimental para validação dos modelos.

\begin{tabular}{ccccc}
\hline Variável & $\begin{array}{c}\text { Condição } \\
\text { experimental }\end{array}$ & $\begin{array}{c}\text { Variável } \\
\text { reposta }\end{array}$ & $\begin{array}{c}\text { Valor } \\
\text { predito }\end{array}$ & $\begin{array}{c}\text { Resultado } \\
\text { experimental }\end{array}$ \\
\hline $\begin{array}{c}\text { pH } \\
\text { Temperatura }\end{array}$ & 7,0 & $P m L$ & $64,14 \pm 2,03$ & $70,19 \pm 1,5$ \\
& $37^{\circ} \mathrm{C}$ & $R m m L \cdot h^{-1}$ & $10,21 \pm 0,58$ & $12,43 \pm 2,50$ \\
& & $\mathrm{YH}_{2}$ & $85,52 \pm 2,71$ & $93,59 \pm 1,98$
\end{tabular}

(*) Modelos reparametrizados constituídos apenas dos parâmetros estatisticamente significativos.

Observou-se tanto, para variável resposta $P$ quanto $R m$, que os resultados experimentais foram semelhantes aos valores preditos. Em relação ao primeiro delineamento (PB12) a $P$ e $R m$ 
aumentou de 38,08 para $70,19 \mathrm{~mL}^{-1}$ e de 4,54 para $12,43 \mathrm{~mL} \cdot \mathrm{h}^{-1}$, ou seja, houve aumento de 1,8 e 2,73 vezes para $P$ e $R m$, respectivamente. Similar a presente pesquisa, Feng et al. (2010) obtiveram rendimento máximo de hidrogênio $\left(\mathrm{YH}_{2}\right)$ de $101,08 \mathrm{~mL} \cdot \mathrm{g}^{-1} \mathrm{ST}$ a $37^{\circ} \mathrm{C}$ e $\mathrm{pH}$ inicial 7,0 na fermentação de resíduos de maça, enquanto Argun e Dao (2017) obtiveram rendimento máximo de $123,27 \mathrm{~mL} \cdot \mathrm{g}^{-1} \mathrm{COT}$ a $37^{\circ} \mathrm{C}$ na fermentação de resíduos de pêssego. AlvarezGuzman et al. (2017) obtiveram condições ótimas para produção de hidrogênio na fermentação de glicose a $26,30{ }^{\circ} \mathrm{C}$ e $\mathrm{pH}$ inicial de 6,24 . Os valores predito e experimental obtidos pelos autores foram 503 e $513 \mathrm{~mL}$, respectivamente.

A máxima produção de $\mathrm{H}_{2}$ por litro obtida nesta pesquisa a partir das condições de otimização (467,93 mL H2. $\mathrm{L}^{-1}$ de meio) foi 1,48 vezes superior a obtida por Turhal et al. (2018). Esses autores obtiveram concentração máxima de $315,95 \mathrm{~mL} \mathrm{H}_{2} \cdot \mathrm{L}^{-1}$ na fermentação da mistura de resíduos de melão e melancia a $36^{\circ} \mathrm{C}$ e pH 5,5-6,0, utilizando como inóculo a biomassa natural do resíduo. No entanto, a $R m$ obtida neste estudo $\left(82,86 \mathrm{~mL} \mathrm{H}_{2} \cdot \mathrm{L}^{-1} \cdot \mathrm{h}\right)$ foi similar a obtida pelos autores $\left(80,86 \mathrm{~mL} \mathrm{H}_{2} \cdot \mathrm{L}^{-1} \cdot \mathrm{h}\right)$. Ademais, os autores obtiveram longos $\lambda \mathrm{H}_{2}(27,25-76,40 \mathrm{~h})$ enquanto que neste trabalho o $\lambda \mathrm{H}_{2}$ foi de $1,95 \mathrm{~h}$.

A conversão de carboidratos totais $\left(\mathrm{EC}_{\mathrm{CT}}\right)$ foi alta $(92 \%)$. Apesar dos valores de $\mathrm{C}_{\mathrm{CT}}$ máxima terem sido praticamente iguais entre o DCCR (91\%) e a validação (92\%), houve aumento do rendimento de hidrogênio do DCCR para a validação. Portanto, verificou-se aumento do rendimento de $\mathrm{H}_{2}\left(\mathrm{YH}_{2}\right)$ de $83 \mathrm{~mL} \cdot \mathrm{g}^{-1} \mathrm{CT}$ nos ensaios de DCCR para $93 \mathrm{~mL} \cdot \mathrm{g}^{-1} \mathrm{CT}$ nos ensaios de validação. Semelhante ao presente trabalho, a faixa de $\mathrm{pH}$ inicial e temperatura ótima obtido por Wang e Wan et al. (2008) para maior rendimento de hidrogênio e eficiência de conversão do substrato foi entre 5,3-8,7 e 31,6-48, $4^{\circ} \mathrm{C}$, respectivamente, na fermentação de glicose utilizando consórcio de bactérias, sendo que a condição otimizada para $\mathrm{YH}_{2}$ foi $\mathrm{pH} 7,2$ e $38,6^{\circ} \mathrm{C}$ e para eficiência de conversão foi $\mathrm{pH} 7,0$ e $39,3^{\circ} \mathrm{C}$. Por outro lado, Mu et al. (2006) relataram $\mathrm{pH}$ e temperatura ótimo de 5,5 e $34,8^{\circ} \mathrm{C}$ no rendimento de hidrogênio. Enquanto, que Wang et al. (2005) obtiveram condição ótima de rendimento de hidrogênio em pH 5,5 e 35, $1^{\circ} \mathrm{C}$. Diferentemente da presente pesquisa, ambos os autores (Mu et al. e Wang et al.) obtiveram ótimos rendimentos em pH 5,5 enquanto neste trabalho a condição ótima foi em pH 7,0. Provavelmente, as características do inóculo e substrato influenciam na obtenção dos parâmetros operacionais, resultando em diferentes condições ótimas de produção de $\mathrm{H}_{2}$

Ao final do ensaio de validação observou-se diminuição do $\mathrm{pH}$ de 7 para 3,2; provavelmente, relacionado ao acúmulo de metabólitos solúveis. Os principais metabólitos acumulados no final da fermentação foram ácido lático $\left(3,11 \mathrm{~g} \cdot \mathrm{L}^{-1}\right)$, acético $\left(0,64 \mathrm{~g} . \mathrm{L}^{-1}\right) \mathrm{e}$ 


\section{Universidade de São Paulo \\ Escola de Engenharia de São Carlos \\ Programa de Pós-graduação em Hidráulica e Saneamento}

propiônico $\left(0,26\right.$ g. $\left.\mathrm{L}^{-1}\right)$. Em relação ao ácido butírico observou-se sua produção e consumo no decorrer da operação (Figura 5.38). Tais metabólitos podem estar associados ao metabolismo de algumas bactérias, semelhantes a Bacteroides, no qual convertem muitos metabólitos, gerados por grupos celulolíticos, em acético, isobutírico e butírico (Song et al., 2010). Ademais, de acordo com Saady (2013) bactérias acetogênicas podem sintetizar ácido acético e produzir $\mathrm{H}_{2}$ durante o crescimento heterotrófico a partir de variedade de substratos, o que talvez explicaria a produção simultânea de $\mathrm{H}_{2}$ e ácido acético nesses ensaios.

Figura 5.38. Cinética de produção de ácidos carboxílicos no ensaio de validação experimental em reatores em batelada.

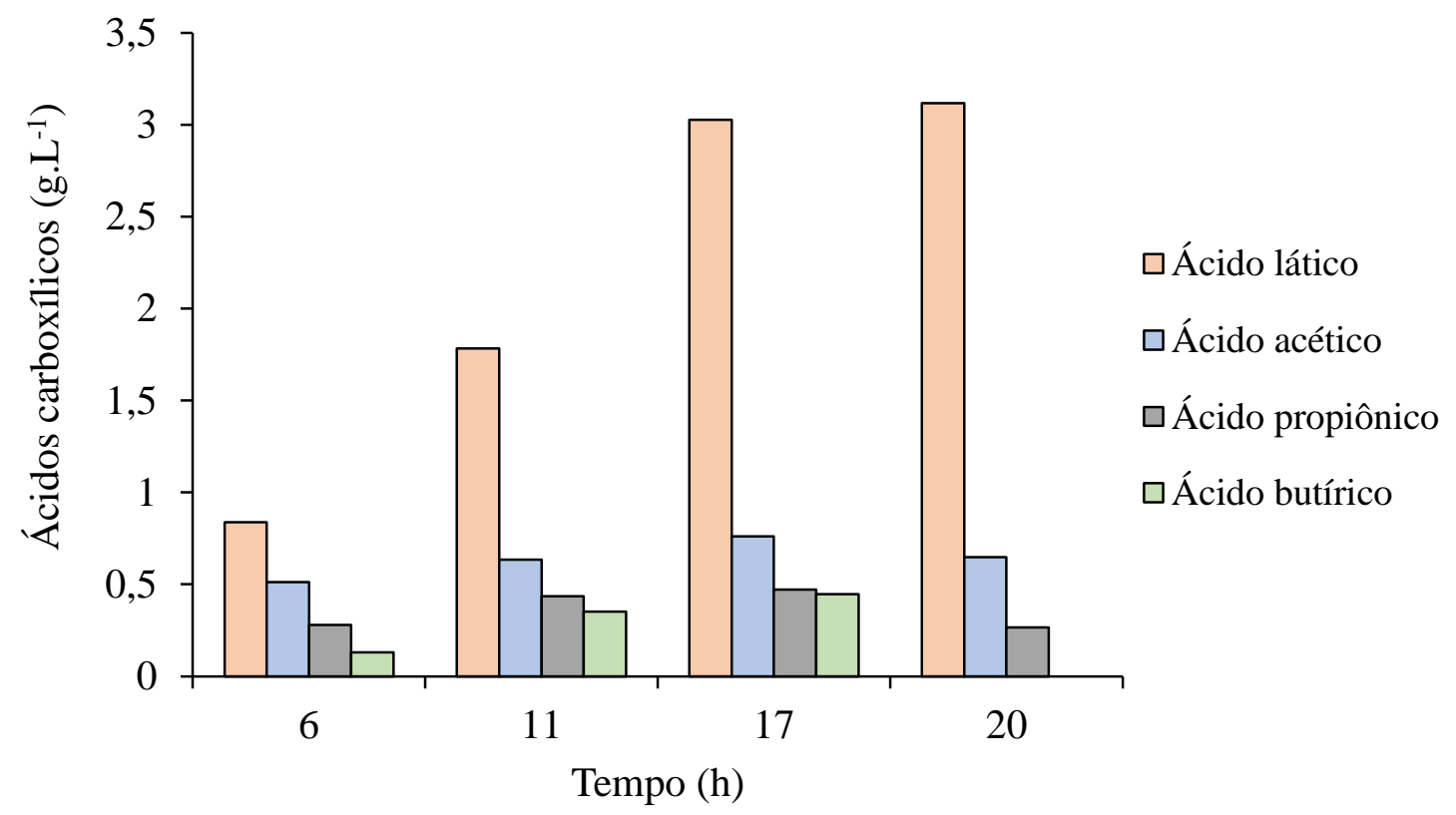

Observou-se que em 6 horas de operação, a conversão do substrato pelo consórcio de bactérias já havia gerado quantidade de ácidos $\left(<1\right.$ g.L. $\left.\mathrm{L}^{-1}\right)$, os quais podem ter contribuído para o tempo reduzido de ínicio de produção de $\mathrm{H}_{2}\left(\lambda \mathrm{H}_{2}\right)$ de $1,92 \mathrm{~h}$. Verificou-se expressiva concentração de HLa na fase exponencial (entre 6 e 17 h), cerca de 4 vezes superior em relação aos demais ácidos (HAc, HBu e HPr) (Figura 5.38), acumulando-se no final da fermentação. Tal resultado pode ser justificado pela vantagem competitiva de bactérias ácido láticas sob as produtoras de $\mathrm{H}_{2}$, quando as concentrações de substrato são mantidas em baixos níveis (Park et al., 2018).

Com execessão do $\mathrm{HBu}$, que foi totalmente consumido, em $20 \mathrm{~h}$ de fermentação verificou-se para os demais ácidos orgânicos estabilização da produção. Contudo, no ensaio de validação, assume-se que a principal via de produção e rendimento de $\mathrm{H}_{2}$ foi a via do ácido 
acético/butírico, corroborando com as demais pesquisas (Feng et al., 2010; Alibardi e Cossu, 2016; Chi et al., 2018; Rabelo et al., 2018; Soares et al., 2018). No entanto, a produção de $\mathrm{H}_{2}$ também pode ter sido favorecida pela alta produção de HLa.

Como houve redução de HAc no final da fermentação, pode-se inferir que este ácido pode ter sido convertido em $\mathrm{H}_{2}$. No entanto, é fundamental ressaltar que a reação de conversão do ácido acético em $\mathrm{H}_{2}$ e $\mathrm{CO}_{2}$ não é uma reação espontânea $\left(\Delta \mathrm{G}^{\mathrm{o}}\right.$, positivo $\left(+104 \mathrm{KJ} \mathrm{mol}^{-1}\right)$, sendo assim não é termodinamicamente favorável (Thauer et al. 1997). Para ocorrência desta reação a pressão parcial de hidrogênio no meio deve ser baixa. Para tanto, é necessário, relação sintrófica entre as bactérias fermentativas e as consumidoras de $\mathrm{H}_{2}$ (arqueias metanogênicas hidrogênotróficas e homoacetogênicas). Porém, neste estudo não foi observado metano durante a operação dos reatores. Sendo assim, a possível conversão de ácido acético em $\mathrm{H}_{2}$ pode ter ocorrido devido a baixa pressão parcial de $\mathrm{H}_{2}\left(\mathrm{pH}_{2}\right)$ no meio. A pressão de $\mathrm{H}_{2}$ pode ter sido aliviada pelo consumo de $\mathrm{H}_{2}$ no meio para formação de compostos reduzidos como o HPr, HLa e etanol (Kumar et al., 2012).

$\mathrm{O}$ aumento de ácidos não-dissociados $\left(\mathrm{HX}^{-}\right)$no meio e consequente diminuição do $\mathrm{pH}$, provavelmente reduziu a biomassa hidrogenogênica favorecendo outras rotas metabólicas (Abdel-Rahman et al., 2013; Bermudes-Penabed et al., 2017), como a do etanol (103,62 mg.L${ }^{1}$ ), quando as condições ácidas foram estabelecidas.

Além dos ácidos orgânicos e etanol, os fenóis também foi subproduto da fermentação do resíduo de banana. Observou-se em condições otimizadas (pH 7 e $37^{\circ} \mathrm{C}$ ) 41,27 mg.L $\mathrm{L}^{-1}$ de fenóis. Nos ensaios de DCCR a maior concentração de fenóis $\left(20,93 \mathrm{mg} . \mathrm{L}^{-1}\right)$ foi observada em pH 5,09 e $37^{\circ} \mathrm{C}$. Considerando que os fenóis são provenientes da degradação da lignina, o ensaio com condições otimizadas favoreceu a atividade das bactérias hidrolíticas, tornando o substrato (resíduo de banana) passível de ser hidrolisado, aumentando a concentração de matéria orgânica dissolvida e consequentemente aumentou da concentração de fenóis na fração líquida como um dos subprodutos da fermentação.

Em relação aos açúcares solúveis, observou-se que tanto as concentrações de sacarose, glicose e frutose diminuíram do início para o final da fermentação, correspondendo as eficiências de conversão de 72, 100 e 82\% (Figura 5.39). Esses foram os principais metabólitos utilizados para produção de $\mathrm{H}_{2}$ e ácidos organicos. Em contrapartida, verificou-se aumento da concentração de galactose e arabinose. Provavelmente, esses açúcares não foram metabolizados pelos micro-organismos. A xilose, não foi observada no início da fermentação, porém foi observada em 0,3 g. $\mathrm{L}^{-1}$ no final da fermentação. Provavelmente, maior concentração de 


\section{Universidade de São Paulo \\ Escola de Engenharia de São Carlos \\ Programa de Pós-graduação em Hidráulica e Saneamento}

galactose, arabinose e xilose no resíduo de banana fermentado seja resultado da hidrólise do substrato, principalmente da hemicelulose (Matheri et al., 2018).

Figura 5.39. Açúcares solúveis no ensaio de validação dos reatores em batelada.

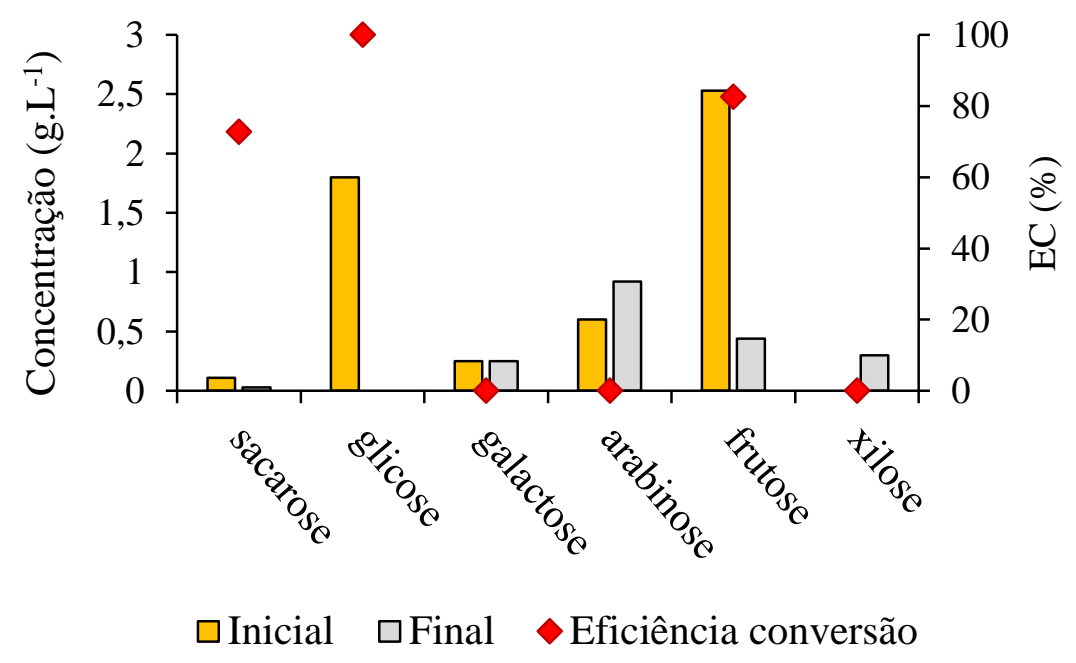

\subsubsection{Balanço de massa para a condição otimizada}

A partir dos dados obtidos da fermentação do resíduo de banana nas condições

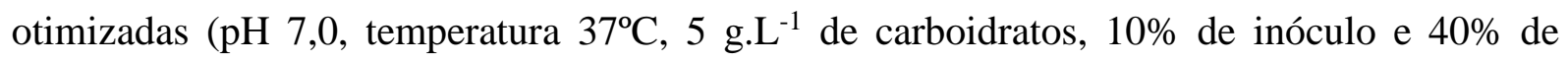
headspace) foi possível determinar o balanço de massa da fase solúvel (BMS), em termos de DQO. Considerando-se o BMS, os valores obtidos para as condições iniciais (BMS - I) e finais (BMS - F) (Tabela 5.19), foram de 57 e 38\%, respectivamente. Os percentuais de acidificação do resíduo de banana estão mostrados na Figura 5.40.

Tabela 5.19. Balanço de massa da fase solúvel (BMS) do reator em batelada nas condições otimizadas

\begin{tabular}{|c|c|c|c|c|c|}
\hline \multirow[b]{2}{*}{ BMS } & \multicolumn{5}{|c|}{ Composição DQO (\%) } \\
\hline & $\begin{array}{c}\text { Ácidos } \\
\text { carboxílicos }^{\mathrm{a}} \mathrm{e} \\
\text { etanol }\end{array}$ & $\begin{array}{c}\text { Carboidratos } \\
\text { totais }\end{array}$ & Fenóis & $\begin{array}{c}\text { Fração } \\
\text { quantificada }^{b}\end{array}$ & $\begin{array}{c}\text { Fração não } \\
\text { quantificada }\end{array}$ \\
\hline BMS (I) & 57 & 0 & 0 & 57 & 43 \\
\hline $\mathrm{BMS}(\mathrm{F})$ & 33 & 4 & 1 & 38 & 62 \\
\hline
\end{tabular}

Nota: MBS (I) = Balanço de massa da fase solúvel em relação a DQO inicial; MBS (F) = Balanço de massa da

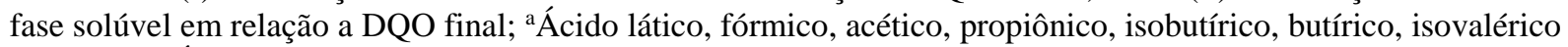
e valérico, ${ }^{\text {b }}$ Ácidos carboxílicos e etanol + carboidratos totais + fenóis. 
Figura 5.40. Percentuais de acidificação dos metabólitos utilizados para o balanço de massa solúvel.

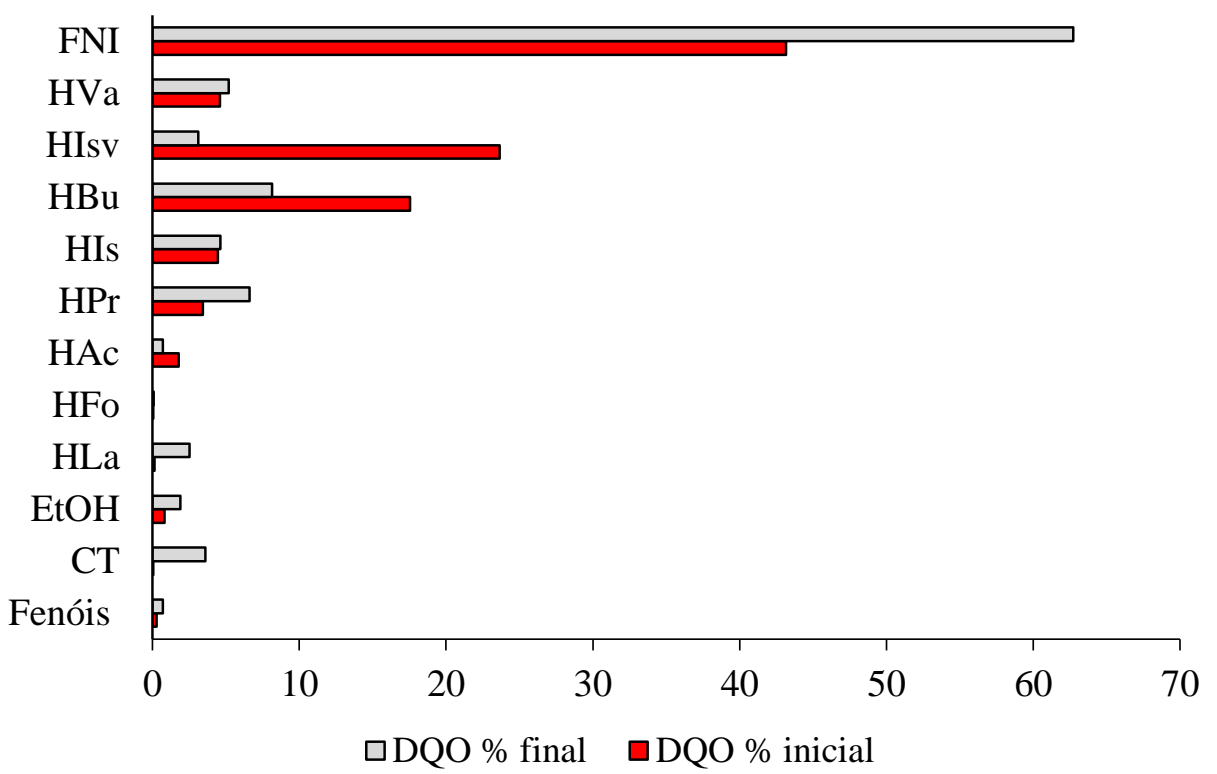

Nota: $\mathrm{CT}=$ carboidratos totais, $\mathrm{EtOH}=$ etanol, $\mathrm{HLa}=$ ácido lático, $\mathrm{HFo}=$ ácido fórmico, $\mathrm{HAc}=$ ácido acético, $\mathrm{HPr}=$ ácido propiônico, HIs = ácido isobutírico, $\mathrm{HBu}=$ ácido butírico, HIsv = ácido isovalérico, HVa = ácido valérico e FNI = fração não identificada.

Comparando-se a contribuição relativa de cada composto, verificou-se que os metabólitos que mais contribuíram para o BMS foi o HPr, HIs, HBu, HIsv e HVa. O aumento da fração não identificada de 38 para 57\% no resíduo de banana acidificado é decorrente de reações metabólicas em que se formam outros produtos diferentes dos analisados. Deste modo, os baixos valores (57 e 38\%) do BMS estão associados, principalmente, a não quantificação de outros compostos orgânicos do resíduo de banana, tais como, ácido cítrico, gálico, vanílico, cinâmico (Kandasamy e Aradhya, 2014), carotenóides e fitoesteróides (Singh et al., 2016).

Além destes compostos, materiais resultantes da lise celular, como DNA, cristais protêicos e lipopeptídeos sintetizados por algumas espécies de bactérias, como o Bacillus thuringiensis, podem ter contribuído para a parcela não quantificada do BMS, principalmente na banana fermentada (Yim et al., 2011). Normalmente, em sistemas acidogênicos as bactérias são submetidas a condições de estresse, tais como, acidez e escassez de substrato no final da fermentação, levando ao aumento da lise celular. Neste sentido, pode-se inferir a partir do aumento da concentração de sólidos suspensos voláteis (SSV) de 0,25 para 1,40 g.L $\mathrm{L}^{-1}$ do início para o final da fermentação a expressiva contribuição de materiais celulares na fração solúvel dos reatores, cooperando para os baixos valores do BMS, principalmente no BMS - F). 


\author{
Universidade de São Paulo \\ Escola de Engenharia de São Carlos \\ Programa de Pós-graduação em Hidráulica e Saneamento
}

\title{
5.5.5. Avaliação da comunidade bacteriana do delineamento composto central rotacional.
}

As populações de bactérias do inóculo foram comparadas com aquelas dos ensaios com maior produção de ácido lático (E5), maior (E11) e menor (E1) produção de $\mathrm{H}_{2}$ e ensaio de validação. Objetivou-se, com as escolhas destas amostras, analisar os cluster do DGGE (Eletroforese em Gel de Gradiente Desnaturante) (Figura 5.41) e verificar se as condições impostas aos reatores influenciaram no estabelecimento de algumas rotas metabólicas.

Figura 5.41. Análise de Cluster do perfil de bandas dos DGGE dos fragmentos de RNAr 16s para o inóculo e os ensaios 1, 5 e 11 do DCCR e ensaio de validação experimental.

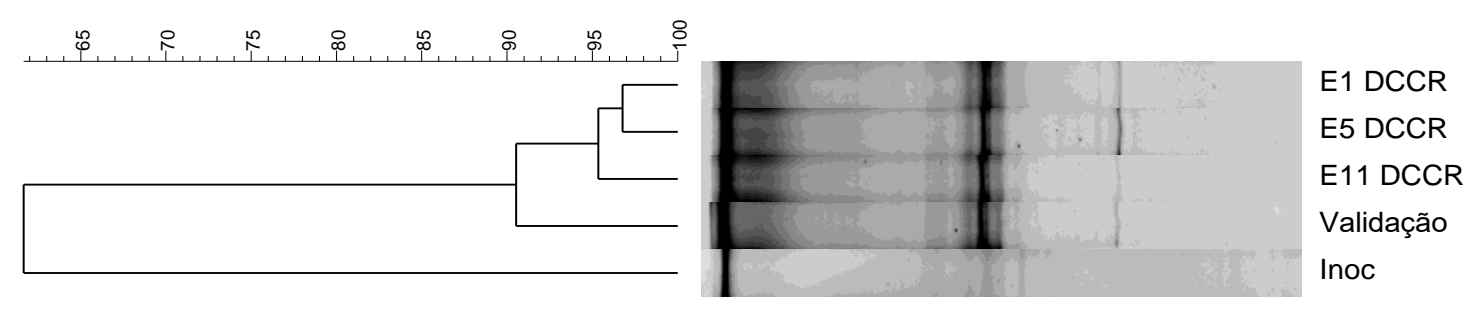

Nota: $\mathbf{E 1}=$ pH 5,5 e temperatura $30^{\circ} \mathrm{C}, \mathbf{E 5}=5,09$ e temperatura $37^{\circ} \mathrm{C}, \mathbf{E 1 1}=$ pH 6,5 e temperatura $37^{\circ} \mathrm{C}$, Validação $=\mathrm{pH} 7,0$ e temperatura $37^{\circ} \mathrm{C}$.

O menor índice de similaridade $(62 \%)$ foi obtido em relação ao inóculo e os ensaios avaliados (1, 5, 11 e validação). Provavelmente, as condições operacionais impostas aos reatores podem ter contribuído para essa diferença do coeficiente de similaridade entre o inóculo e os ensaios. A diminuição do valor de $\mathrm{pH}$ do inóculo $(\mathrm{pH}$ 6,5) para valores próximos a pH 5,0 pode ter contribuído com a predominância de diferentes populações de bactérias, acarretando na menor similaridade.

Por outro lado, verificou-se menor alteração das populações entre os ensaios E1 e E5, com $97 \%$ de similaridade. Provavelmente, essa alta similaridade foi decorrente, principalmente, do fato de que em ambos os ensaios as condições foram bem similares (E1: pH 5,5 e $30^{\circ} \mathrm{C}$ e E5: $\mathrm{pH} 5,09$ e $37^{\circ} \mathrm{C}$ ), principalmente em relação ao $\mathrm{pH}$. Como o $\mathrm{pH}$ foi estatisticamente significativo ( $\mathrm{p}<0,05)$ para produção de $\mathrm{H}_{2}$ e HLa, assume-se que as condições ácidas destes ensaios podem ter favorecido o crescimento de bactérias não produtoras de hidrogênio em $\mathrm{pH}$ ótimo próximo de 5,0 (Lynd et al., 2002) resultando em menor produção de $\mathrm{H}_{2}$ de 6,06 e 11,65 mL em E1 e E5, respectivamente. Sendo assim, o valor de $\mathrm{pH}$ inicial contribuiu para o estabelecimento de algumas rotas metabólicas e consequentemente na predominância de populações não hidrogenogênica. 
Observou-se alta similaridade (95\%) entre as populações do ensaio com maior produção de $\mathrm{H}_{2}$ (E11) com os ensaios 1 e 5, correspondendo aos ensaios com menor produção de $\mathrm{H}_{2} \mathrm{e}$ maior produção de HLa, respectivamente, inferindo que não há diferença filogenética entre os microrganismos dos ensaios 1, 5 e 11. Provavelmente, a mudança de rotas metabólicas pode ter ocorrido devido a mudança de $\mathrm{pH}$, temperatura e também ao esgotamento de substrato ao longo da fermentação. Do mesmo modo, observou-se alta similaridade (90\%) entre as populações do ensaio de validação e os ensaios 1, 5 e 11, mesmo com predomínio de rotas metabólicas diferentes. De acordo com Saady (2013) muitos micro-organismos filogeneticamente iguais, desenvolvem diferentes papeis funcionais dependendo da condição do meio. A título de exemplificação, bactérias heterotróficas podem mudar seu metabolismo para autotrófica diante de condições de estresse, como mudança de pH e baixa concentração de substrato. Tal afirmação explicaria o estabelecimento da mesma população de bactérias nos ensaios cujos produtos metabólicos foram divergentes.

Portanto, a mudança de $\mathrm{pH}$ e/ou temperatura pode ter contribuído com a mudança de rota metabólica (produção de HLa e produção de $\mathrm{H}_{2}$ ) e não com a mudança na população de bactérias, sendo que as mesmas podem desempenhar diferentes papéis funcionais de acordo com as condições do meio.

A amostra de maior produção de HLa (E5) e o ensaio de validação foram selecionadas para análise metagenômica e foi comparada com o inóculo. A fim de avaliar a diversidade da comunidade bacteriana foram estimados os índices de diversidade Shannon (H), Simpson (1D) e dominância (D) e estimador de riqueza Chao-1 (Figura 5.42). Em relação ao estimador de riqueza (Chao-1) notou-se maior riqueza para a amostra referente a validação experimental (condição otimizada) quando comparado ao inóculo (biomassa inicial) e ao ensaio com maior produção de HLa (E5). Provavelmente, as condições operacionais no ensaio de validação (pH 7,5 e $37^{\circ} \mathrm{C}$ ) representou forte pressão seletiva sobre as bactérias hidrogenogênicas resultando em maior produção de $\mathrm{H}_{2}(70,19 \mathrm{~mL})$, enquando as condições ácidas no $\mathrm{E} 5$ (pH 5,09) favoreceu o estabelecimento de bactérias acidogênicas, principalmente as ácido láticas resultando em maior quantidade de ácido lático acumulado $\left(3,98 \mathrm{~g} . \mathrm{L}^{-1}\right)$ no final da fermentação. Tal resultado corrobora com o obtido por Wu et al. (2016), no qual condições ácidas (pH 4,0) cooperou para o estabelecimento de bactérias produtoras de ácido lático, resultando em produções máximas entre 10-20 g.L. ${ }^{-1}$.

Em relação aos índices de diversidade (Shannon e Simpson) observou-se pouca variação entre as amostras. Para ambos os índices, verificou-se alta diversidade. Para o índice de 


\section{Universidade de São Paulo \\ Escola de Engenharia de São Carlos \\ Programa de Pós-graduação em Hidráulica e Saneamento}

Shannon $(\mathrm{H})$ verificou-se valores acima de 7 , portanto alta diversidade, principalmente para o ensaio de validação, seguido do E5 e inóculo. Além disso, observou-se valores de Simpson (1D) próximos a $1(0,99)$ indicando elevada diversidade e distribuição pouco equânime.

Apesar de semelhantes, os índices de diversidade da validação foram superiores as demais amostras, inferindo que de certa forma a condição otimizada contribuiu para maior diversidade e riqueza. Os menores valores dos índices de diversidade do inóculo, provavelmente esteja relacionado a condições de $\mathrm{pH}$ neutro e temperatura mesofílica no qual abrange maior comunidade bacteriana. Desta forma, provavelmente, pode ter ocorrido competição entre as bactérias produtoras de hidrogênio (ensaio de validação) e as ácido láticas (E5), limitando o estabelecimento de rotas metabólicas específicas. Portanto, pode-se concluir que a definição de condições ótimas além de promover maior produção de $\mathrm{H}_{2}$ também contribuiu para o aumento da riqueza e diversidade da amostra.

Figura 5.42. Estimadores de riqueza e índices de diversidade para as amostras de inóculo, maior produção de etanol (E11) e ensaio de validação experimental.

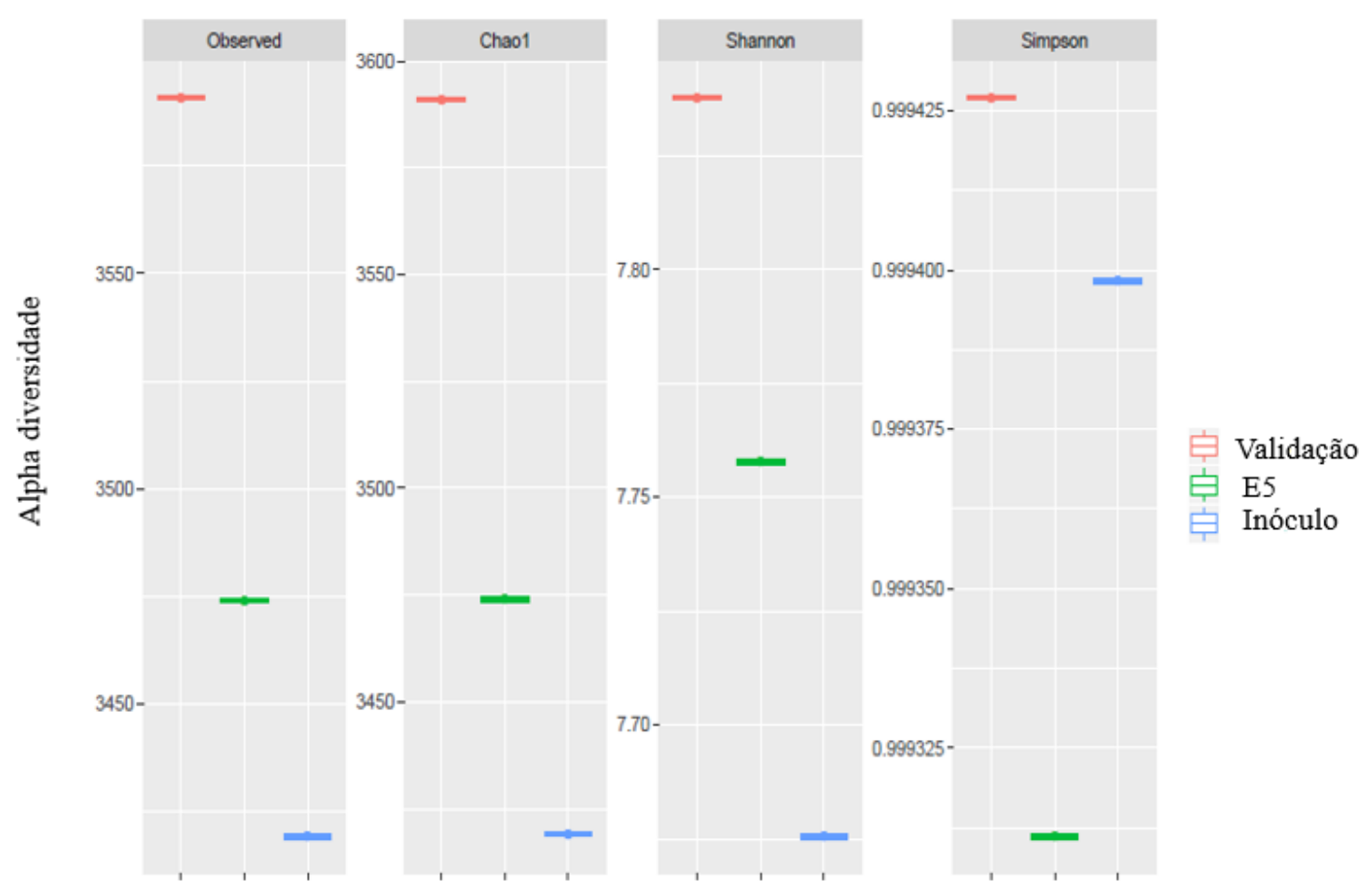

\subsubsection{Efeito do pH e temperatura no perfil taxonômico}

O ensaio 5 (maior produção de HLa) e o ensaio validação (condição otimizada) foram comparados com o inóculo, no sentido de avaliar se o $\mathrm{pH}$ e temperatura tiveram efeito na comunidade microbiana foram identificadas nas 3 amostras, cuja abundância relativa foi de 
96,21, 98,41 e 95,98\% para o inóculo, E5 e validação, respectivamente. Ziara et al. (2019) reportaram que representantes do filo Firmicutes também constituíram a maior parte da comunidade bacteriana na biomassa de reatores de tratamento de água residuária de abatedouro de bovinos. Além disso, verificaram aumento da abundância relativa de representantes desse filo em valores de $\mathrm{pH}$ ácido $(<5,0)$. No entanto, na presente pesquisa não foi verificado mudança de filos em relação ao valor de pH. No filo Firmicutes estão incluídas bactérias reconhecidamente fermentativas (Ohnishi et al., 2010). Desse modo, essa possibilidade metabólica permite inferir sobre o favorecimento e predominância dessas bactérias no RB em função das condições nutricionais.

Verificou-se que para a biomassa identificada das três amostras, representantes de bactérias de duas classes foram dominantes, Clostridia e Bacilli. Observou-se diminuição das bactérias pertencentes a classes Clostridia quando o pH foi de 6,5 (inóculo) (42,13\%) para 5,09 (E5) $(16,21 \%)$, por outro lado, observou-se aumento da abundância relativa de bactérias pertencentes a classe Bacilli de 53,68 para 82,14\% quando o $\mathrm{pH}$ diminuiu de 6,5 para 5,09. No ensaio de validação, cujo pH foi igual a 7,0, a abundância relativa de Clostridia e Bacilli foram iguais a $23,58 \%$ e $72,04 \%$, respectivamente. Deste modo, pode-se inferir previamente que a mudança de pH no meio influência no estabelecimento de diferentes classes de bactérias.

Para cada classe (Clostridia e Bacilli), as ordens predominantes foram as seguintes: Clostridiales, Lactobacillales e Bacillalles, sendo observada maior abundância relativa de bactérias pertencentes a Lactobacillales no E5 (82,04\%), quando comparado ao inóculo (53\%) e validação (71,33\%). Por outro lado, representantes de Clostridiales e Bacillalles foram predominantemente no inóculo $(41,77 \%)$ e ensaio de validação $(0,71 \%)$, respectivamente (Figura 5.43). Obteve-se para a classe "outros" abundância de 4,50, 1,73 e 4,73\% para inóculo, ensaio E5 e ensaio de validação, incluindo as sequencias não-identificadas.

Dentre as ordens mais abundantes, observou-se maior abundância relativa da família Clostridiaceae, Lactobacillaceae, seguida de Bacillaceae. Verificou-se forte influência do $\mathrm{pH}$ na comunidade bacteriana, onde a mudança de pH de 6,5 (inóculo) para 5,09 (E5) e 7,0 (validação) resultou na diminuição da abundância relativa de representantes de Clostridiaceae de 34,57\% (inóculo) para 14,87 e 16,68\% no E5 e validação, respectivamente, enquanto observou-se aumento da abundância de representantes de Lactobacillaceae de 52,70\% (inóculo) para $81,96 \%$ (ensaio E5) e 70,87\% (ensaio de validação). Ademais, observou-se diminuição da abundância de representantes de Bacillaceae do inóculo $(0,47 \%)$ para E5 $(0,07 \%)$, e ligeiramente maior $(0,50 \%)$ nas condições do ensaio de validação. 
Figura 5.43. Abundância relativa dos representantes das Ordens mais abundantes na biomassa do inóculo, ensaio E5 e ensaio de validação experimental.

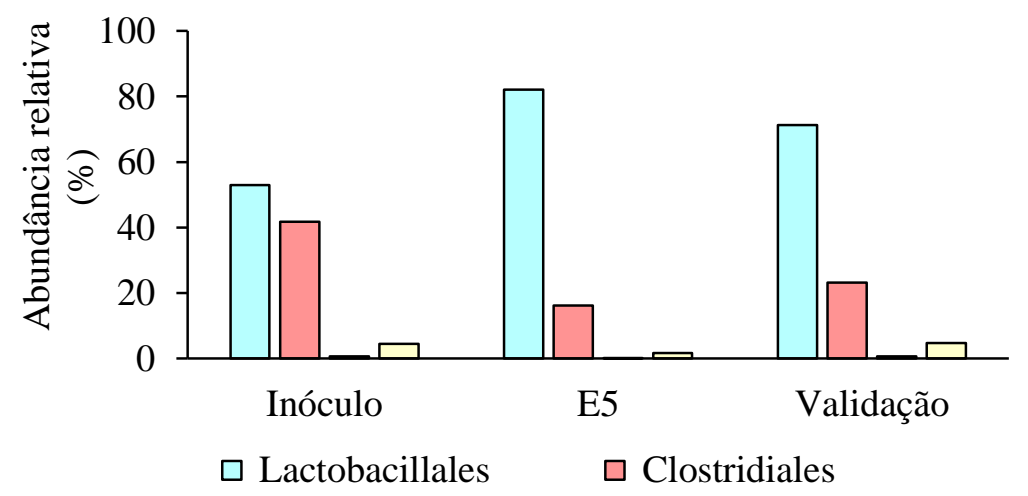

Bactérias semelhantes a Lactobacillus, Clostridium, Clostridioides, Fusobacterium, Gottschalkia e Bacillus foram identificadas nas amostras do inóculo, ensaio E5 e de validação, representando os gêneros mais abundantes (Figura 5.44).

Figura 5.44. Abundância relativa dos representantes semelhantes aos gêneros do domínio Bacteria da amostra do inóculo, E5 e validação experimental.

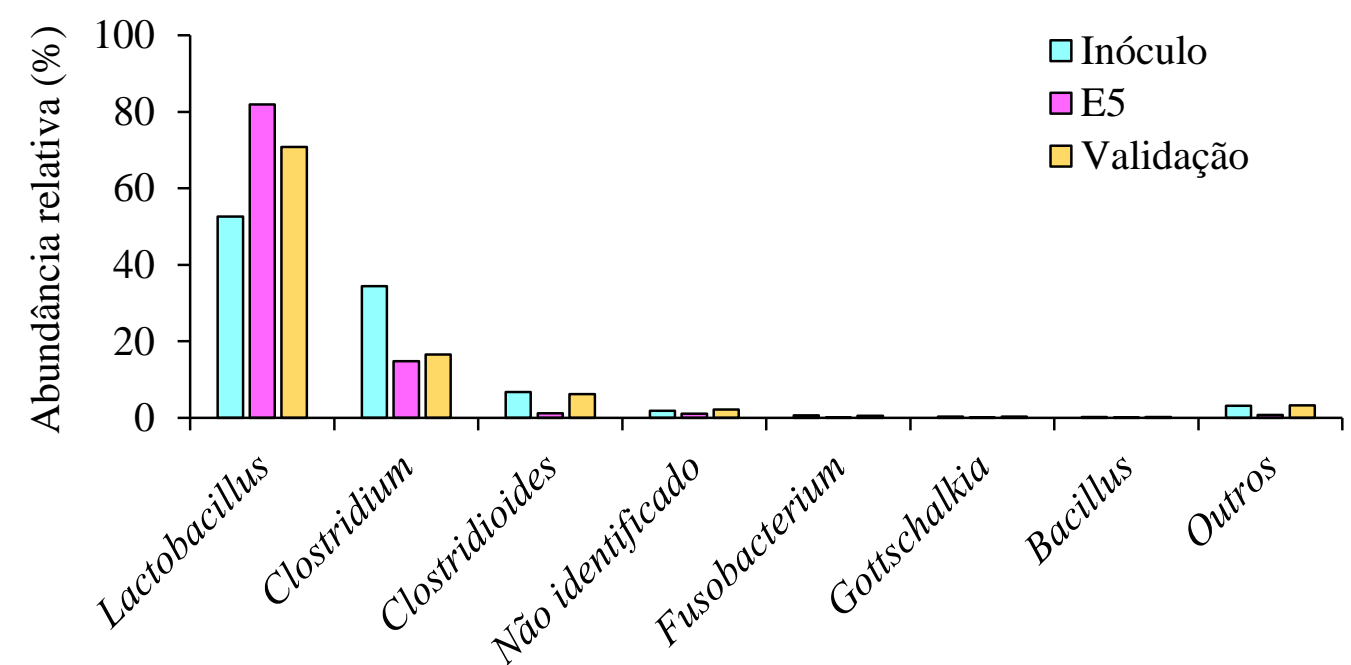

Observou-se que os Lactobacillus, conhecidos como principais produtores de ácido lático, foi o gênero mais abundante tanto no inóculo, quanto no E5 e ensaio de validação. No E5, sua abundância foi correspondente a $81,95 \%$, sendo 1,5 vezes superior que no inóculo e 1,1 vezes maior que no ensaio de validação. Deste modo, sua predominância no E5 pode ser responsável pela maior produção de $\mathrm{HLa}\left(3,98\right.$ g.L $\left.\mathrm{L}^{-1}\right)$ e baixa produção de $\mathrm{H}_{2}(11,65 \mathrm{~mL})$ neste ensaio. A predominância de BAL nos ensaios pode ser decorrente de bacteriocinas sintetizadas 
por essas bactérias, uma vez que estes peptídeos inibem microrganismos produtores de $\mathrm{H}_{2}$. Rúbia et al. (2015) reportaram que em pH 5,0, cerca de 46,6\% de cepas de Lactobacillus sp. demostraram atividade inibitória a outras bactérias, resultando na diminuição da produção de $\mathrm{H}_{2}$ de 0,5 - 2 para $0,01-1,53 \mathrm{mmol} \mathrm{H}_{2} \mathrm{~g}^{-1} \mathrm{DQO}$, durante a operação de reator de leito fluidizado anaeróbio alimentado com água residuária do processamento de mandioca. Além disso, menor valor de pH no final de todos os ensaios pode ter favorecido a predominância de Lactobacillus, uma vez, que essas bactérias têm afinidade por pH ácido (Wu et al., 2015). Corroborando com a presente pesquisa, Mota et al. (2018) reportaram a identificação de Lactobacillus, com abundância relativa de $27 \%$, em reatores com pH ácido $(\sim 3,0)$ na fermentação de sacarose, reforçando a ideia de que as BAL são resistentes e predominantes em sistema cujo o pH é extremamente ácido. Contudo, considerando que no final das fermentações, a concentração de RB foi baixa (devido a sua conversão em $\mathrm{H}_{2}$ e metabólitos solúveis), pode se inferir que os Lactobacillus tiveram vantagens competitivas sob outras bactérias, como o Clostridium, em condições de esgotamento do substrato (Park et al., 2018).

Para condição de pH inicial 7,0 (ensaio validação) verificou-se aumento da população de Clostridium, correspondendo a abundância relativa de 16,56\% e diminuição de Lactobacillus quando comparado ao ensaio E5 (pH 5,09) (Figura 5.44). Neste caso, ficou claro que o pH ácido afetou a microbiota hidrogenogênica (Clostridium) e favoreceu as acidogênicas (Lactobacillus), resultando no desvio de rotas metabólicas. Resultado semelhante foi obtido por Ziara et al. (2019) no qual reportaram predominância de Clostridium em pH 6,5, 7,5 e 8,5 a 35 ${ }^{\circ} \mathrm{C}$. Neste sentido, o aumento da abundância relativa de Clostridium no ensaio de validação pode ser resultante do aumento do $\mathrm{pH}$ inicial para 7,0. A energia livre de Gibbs, assim como as taxas de reação metabólica, são afetadas pelo valor de $\mathrm{pH}$, deste modo, dependendo da biomassa, em condições onde o pH não é favorável, o crescimento de algumas bactérias pode ser afetado. Neste caso, para aumentar a produção de $\mathrm{H}_{2}$ durante a fermentação do resíduo de banana utilizando biomassa autóctone, torna-se imprescindível a manutenção do valor de $\mathrm{pH}$ próximo a 7, uma vez que favorece as bactérias do gênero Clostridium.

Por sua vez, observou-se que o tanto o gênero Clostridioides quanto o Fusobacterium estiveram presentes nas três amostras avaliadas (inóculo, E5 e validação), sendo que ambos os gêneros foram mais abundantes quando o $\mathrm{pH}$ foi ajustado próximo a neutralidade, sendo assim, em pH 6,5 (inóculo) a abundância de Clostridioides e Fusobacterium foi de 6,80 e 0,62\%, respectivamente. No E5 cujo pH reduziu para 5,09 a abundância destes gêneros diminuiu para 1,19 e $0,06 \%$ e voltou a aumentar para $6,18 \%$ (Clostridioides) e $0,50 \%$ (Fusobacterium) no 


\section{Universidade de São Paulo \\ Escola de Engenharia de São Carlos \\ Programa de Pós-graduação em Hidráulica e Saneamento}

ensaio de validação quando o $\mathrm{pH}$ foi ajustado a 7,0, valores estes semelhantes as condições iniciais do inóculo.

Do mesmo modo, para os demais gêneros menos abundantes (Gottschalkia e Bacillus) observou-se diminuição da abundância $(0,05 \%$ e $0,04 \%)$ no E5 (pH 5,09) e em seguida aumento da abundância $(0,29$ e 0,24\%) nas condições otimizadas (validação). Provavelmente, as condições ótimas para o metabolismo destes gêneros são similares em vista que as abundâncias foram iguais tanto para Gottschalkia quanto para Bacillus.

$\mathrm{O}$ alinhamento das sequências analisadas revelou a identidade ao nível de espécie (Figura 5.45). Observou-se a predominância de C. butyricum, seguido de C. botulinum e perfringens, principalmente no inóculo $(28,90 \%)$, entretanto, a abundância relativa diminiu para 13,94 e 11,70\% no E5 e validação (Figura 5.45 (A)). C. butyricum, C. perfringens e $C$. beijerinckii têm sido fortemente associados a produção de $\mathrm{H}_{2}$ (Aly et al., 2018; Wong et al., 2018; Fonseca et al., 2018), e, portanto, assumem seu papel principal como produtores de $\mathrm{H}_{2}$ na fermentação da banana. As demais espécies menos abundantes, tais como C. pasteurianum têm sido associadas a produção de ácidos carboxílicos, etanol e butanol (Sun et al., 2018; Krasnan et al., 2018) contribuindo com a diversidade metabólica durante a fermentação do resíduo de banana.

Os Lactobacillus são bactérias gram positivas, anaeróbias facultativas e produzem ácido lático, acético, fórmico e etanol como principais metabólitos da fermentação de carboidratos, entretanto, seu duplo papel, tanto como produtora de $\mathrm{H}_{2}$ (acetato + lactato $\rightarrow$ butirato $+\mathrm{H}_{2}$ ) como não produtora de $\mathrm{H}_{2}$ (lactato $\rightarrow$ propionato + acetato) tem sido alvo de especulações para estabelecer sua correlação na dinâmica e metabolismo na comunidade bacteriana (Fuess et al., 2018 e Sikora et al., 2013). No presente estudo, seu crescimento foi favorecido pelo baixo valor de $\mathrm{pH}$ sendo as espécies mais abundantes o L. casei, L. paracasei, L. fermentum, L. kefiranofaciens, L. rhamnosus e L. plantarum (Figura 3 (B)). O L. casei e L. paracasei foram os mais abundantes no inóculo (27,91 e 21,62\%) do que no E5 (16,89 e 13,03\%) e na validação (16,09 e 12,67\%). Por outro lado, L. fermentum foi menos abundante no inóculo $(1,85 \%)$ e aumentou sua abundância no E5 $(51,34 \%)$ e na validação $(40,76 \%)$. As demais espécies $(L$. kefiranofaciens, L. rhamnosus e L. plantarum) menos abundantes também foram identificadas em outros estudos na fermentação de resíduos orgânicos (Probst et al., 2013; Yang et al., 2016), ademais tem sido associadas a microflora natural de resíduos de frutas nos quais podem crescer em pH baixo e produzir maior quantidade de ácido lático (Wu et al., 2015). 
Figura 5.45. Principais espécies de Clostridium (A) e Lactobacillus (B) pertencentes a amostra de inóculo, E5 e validação experimental.
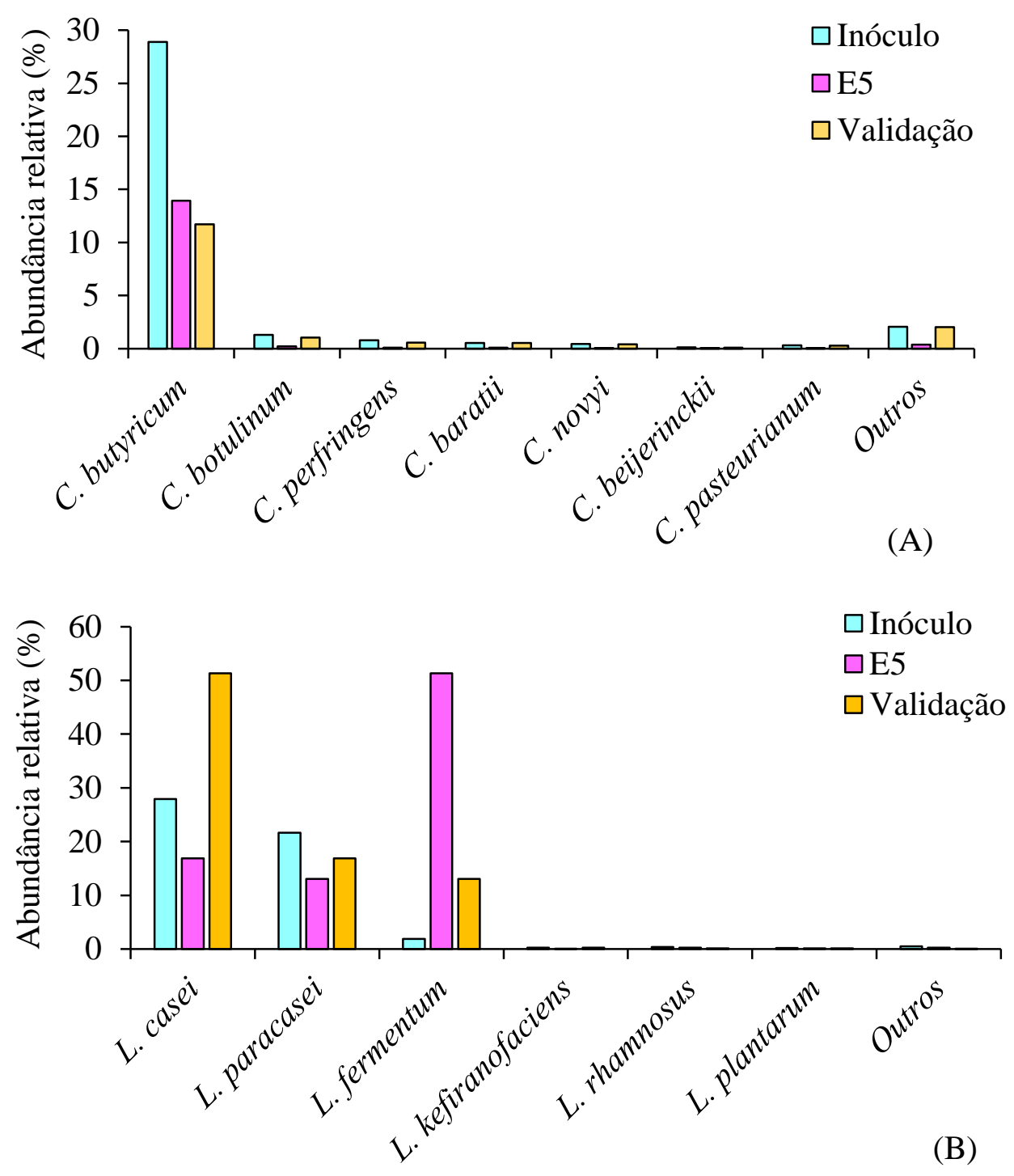

Além Lactobacillus e Clostridium, também foram identificados os genes, em menor abundância $(<1 \%)$, associados a espécies de Bacillus nas três amostras (inóculo, E5 e validação), incluindo Bacillus cellulosilyticus, Bacillus cereus, Bacillus coagulans e Bacillus thuringiensis. Membros deste gênero tem sido amplamente estudados e reportados com sendo bons produtores de hidrogênio e de ácidos carboxílicos (Lukajtis et al., 2018). Ademais, Sikora et al. (2013) reportaram a possibilidade de espécies de Bacillus serem acetogênicas, por sintetizarem etanol e ácido acético a partir de compostos orgânicos, deste modo, a presença de Bacillus na biomassa fermentativa durante a fermentação da banana pode ter contribuído com a produção de ácido acético e etanol nos ensaios. 


\author{
Universidade de São Paulo \\ Escola de Engenharia de São Carlos \\ Programa de Pós-graduação em Hidráulica e Saneamento
}

\title{
5.5.5.2. Metabolismo de carboidratos associado ao ensaio com maior produção de ácido lático (E5) e hidrogênio (validação experimental)
}

Para análise do efeito do $\mathrm{pH}$ e temperatura na atividade enzimática do consórcio bacteriano no E5 e no ensaio de validação foi realizada análise funcional dos genes, incluindo tipo de metabolismo, enzimas e principais rotas metabólicas em que as bactérias atuaram. Todas as informações foram obtidas através da utilização do banco de dados KEEG em nível de função através do número do KO (KEGG Orthology) de cada sequência e sua respectiva abundância relativa.

Por meio dos números de KO obteve-se curva de rarefação referente as sequencias do E5 e ensaio de validação (Figura 5.46). Pode-se inferir que a qualidade do sequenciamento foi satisfatória, abrangendo toda a capacidade funcional da biomassa contida nestas amostras. Deste modo, por meio da relação assintótica entre os números de KO e as sequências, obtevese um platô. Portanto, ampla cobertura amostral e funcional foi obtida, inferindo em alta diversidade de funções metabólicas (>3000).

Figura 5.46. Curva de rarefação estável abrangendo o número total de $\mathrm{KO}$ atribuído pelo aumento do número de sequências no E5 (A) e validação experimental (B).
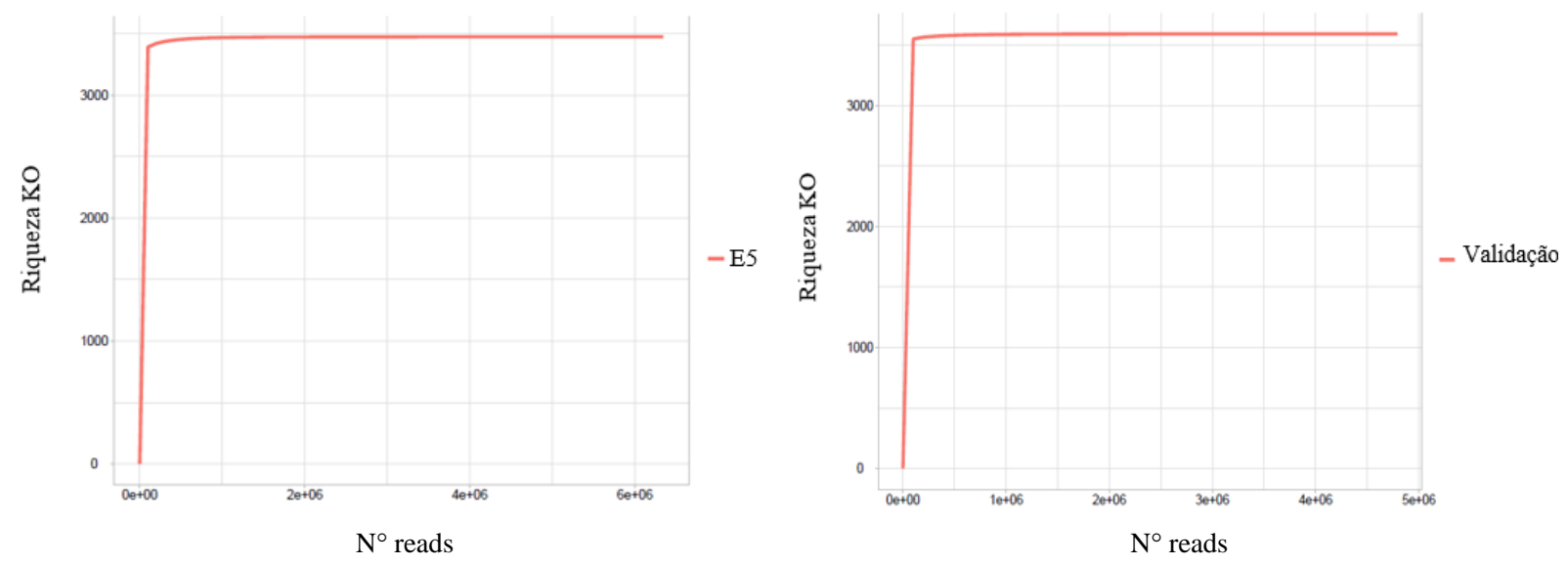

Observou-se que as três principais categorias funcionais dos genes relacionados aos tipos de metabolismo (Nivel 2 KEGG) identificados na amostra no E5 e na validação são bem similares e estão relacionadas principalmente com o processo de replicação e reparação celular (29,8\% E5 e 30,6\% validação), transportes de membrana e catabolismo (15,5\% E5 e 14,8\% validação) e metabolismo de aminoácidos (8,8\% E5 e validação) (Figura 5.47). Como discutido anteriormente, a predominância destes metabolismos é importante pois são associados ao 
crescimento bacteriano, absorção, consumo e eliminação de substâncias endocelulares, síntese de novas proteínas e ácidos nucleicos e na regulação de vias metabólicas (Cesari et al., 2005; Wu, 2009; Li et al., 2018). Demais funções metabólicas como metabolismo enzimático, de energia, nucleotídeos, de cofatores e vitaminas, entre outros, também foram identificados na amostra, no entanto as abundâncias relativas foram inferiores a 5\% (Figura 5.47).

A abundância relativa de genes relacionados ao metabolismo de carboidratos (8,3\% E5 e 8,6\% validação) infere que durante o processo fermentativo, a produção de $\mathrm{H}_{2}$, ácidos carboxílicos (acético, lático, butírico e propiônico) (Reação 24-27) e solvente (etanol) nos ensaios foram sub-produtos do metabolismo de açúcares, como a sacarose, frutose e glicose (Figura $5.48(\mathrm{~A})$ ).

Neste sentido, com ênfase no Metabolismo de carboidratos, os genes relacionados as enzimas mais abundantes associadas a produção de $\mathrm{H}_{2}$ e ácidos carboxílicos, com suas respectivas abundâncias relativas, estão apresentadas na Figura 5.48 (B). Os genes relacionados a enzima piruvato-ferredoxina oxidorredutase (PFOR) (EC 1.2.7.1; K03737), foi mais abundante no ensaio de validação (11,30\%) quando comparado ao E5 (4,12\%). O fato de que no ensaio de validação as condições operacionais dos reatores foram otimizadas $(\mathrm{pH}$ 7,0 e $\left.37^{\circ} \mathrm{C}\right)$, resultando na maior produção de $\mathrm{H}_{2}(70 \mathrm{~mL})$, pode se inferir que a maior abundância dos genes da enzima PFOR presentes na biomassa no ensaio de validação esta relacionada a produção de $\mathrm{H}_{2}$, uma vez que esta enzima realiza a conversão de piruvato em acetil-CoA, transferindo elétrons para a síntese desta molécula (Hallenbeck and Benemann, 2002). Ademais, o piruvato pode ser oxidado pela PFOR a acetil-CoA para produção de etanol e ácido acético (Reação 17). Tanto o ácido acético como etanol, são sub-produtos que podem ser metabolizados para produção de $\mathrm{H}_{2}$ (Reação 13), neste sentido, a PFOR assume importante papel no metabolismo de carboidratos, como enzima catalisadora de reações que levam a produção de $\mathrm{H}_{2}$, ácidos e etanol.

Outra enzima que pode ter contribuído com a produção de $\mathrm{H}_{2}$ nos ensaios foi a 3hidroxibutiril-CoA desidrogenase (EC 1.1.1.157; K00074), cuja abundância relativa foi de 2,41 e 2,32\% no E5 e ensaio de validação, respectivamente. Esta enzima catalisa a síntese de butirilCoA, molécula intermediaria para a geração de butanol ou ácido butírico. Como houve produção de ácido butírico em ambos os ensaios (E5 e validação) durante a fermentação da banana, pode-se inferir que parte da produção de $\mathrm{H}_{2}$ pode ter sido via ácido-butírica (Reação 11) por intermédio da reação catalisada pela 3-hidroxibutiril-CoA desidrogenase. 


\section{Universidade de São Paulo \\ Escola de Engenharia de São Carlos \\ Programa de Pós-graduação em Hidráulica e Saneamento}

A formiato-tetrahidrofolato ligase (EC 6.3.4.3; K01938) e acetato quinase (EC 2.7.2.1; K00925) tiveram abundância relativa similar, cerca de 9\%, tanto no E5 quanto na validação, indicando que a mudança de $\mathrm{pH}$, de 5,09 para 7,0, não influenciou no metabolismo desta enzima. A acetato quinase catalisa a reação reversível (acetil fosfato $+\mathrm{ADP} \leftrightarrow$ acetato $+\mathrm{ATP}$ ), no qual pode disponibilizar ácido acético para possível conversão em $\mathrm{H}_{2}$ (Abdel-Rahman et al., 2013). Por outro lado, a formiato-tetrahidrofolato ligase catalisa a reação reversível de 10formiltetra-hidrofolato a partir de formiato e tetra-hidrofolato, na presença de ATP (ATP + formiato + tetrahidrofolato $\leftrightarrow$ ADP + fosfato +10 -formiltetrahidrofolato (Sikora et al., 2013). A formiato-tetrahidrofolato ligase pode atuar no metabolismo homoacetogênico, no qual os principais sub-produtos destas vias são o ácido acético, lático, propiônico, butírico, etanol, entre outros (Saady, 2013). Neste sentido, ambas as enzimas tiveram seu importante papel durante a fermentação do resíduo de banana em ambos os ensaios.

Do mesmo modo, a atividade da enzima álcool desidrogenase (EC:1.1.1.1; K00001) e da acetaldeído desidrogenase (EC 1.2.1.10; K04072) estão relacionadas a produção final de ácido acético (Sikora et al., 2013). O papel da álcool desidrogenase é oxidar o álcool em acetaldeído, que por sua vez, é convertido em ácido acético pela acetaldeído desidrogenase. Em relação a enzima álcool desidrogenase, esta foi abundante de modo similar no E5 $(4,77 \%)$ e na validação (3,69\%), enquanto a acetaldeído desidrogenase foi mais abundante no E5 (10,84\%) (Figura $15(\mathrm{~B}))$.

A acetil-CoA sintase (ACS) (EC 2.3.1.169; K14138) catalisa a reação irreversível, no qual converte o acetato e ATP ao intermediário acetiladenilato para formar acetil-CoA (Krivoruchko et al., 2015). O acetil-CoA, por sua vez, pode seguir diversas vias, incluindo a via heterolática (Abdel-Rahman et al., 2013) e vias de produção de etanol, acetato, butano e butirato (Lukajtis et al., 2018). Portanto, essas enzimas podem ter atuado na etapa acidogênica, contribuindo com a produção de hidrogênio, ácido acético, etanol e ácido butírico nos ensaios. 
Universidade de São Paulo

Escola de Engenharia de São Carlos

Programa de Pós-graduação em Hidráulica e Saneamento

Figura 5.47. Distribuição funcional metabólica dos genes observados na amostra do inóculo, E5 e ensaio de validação

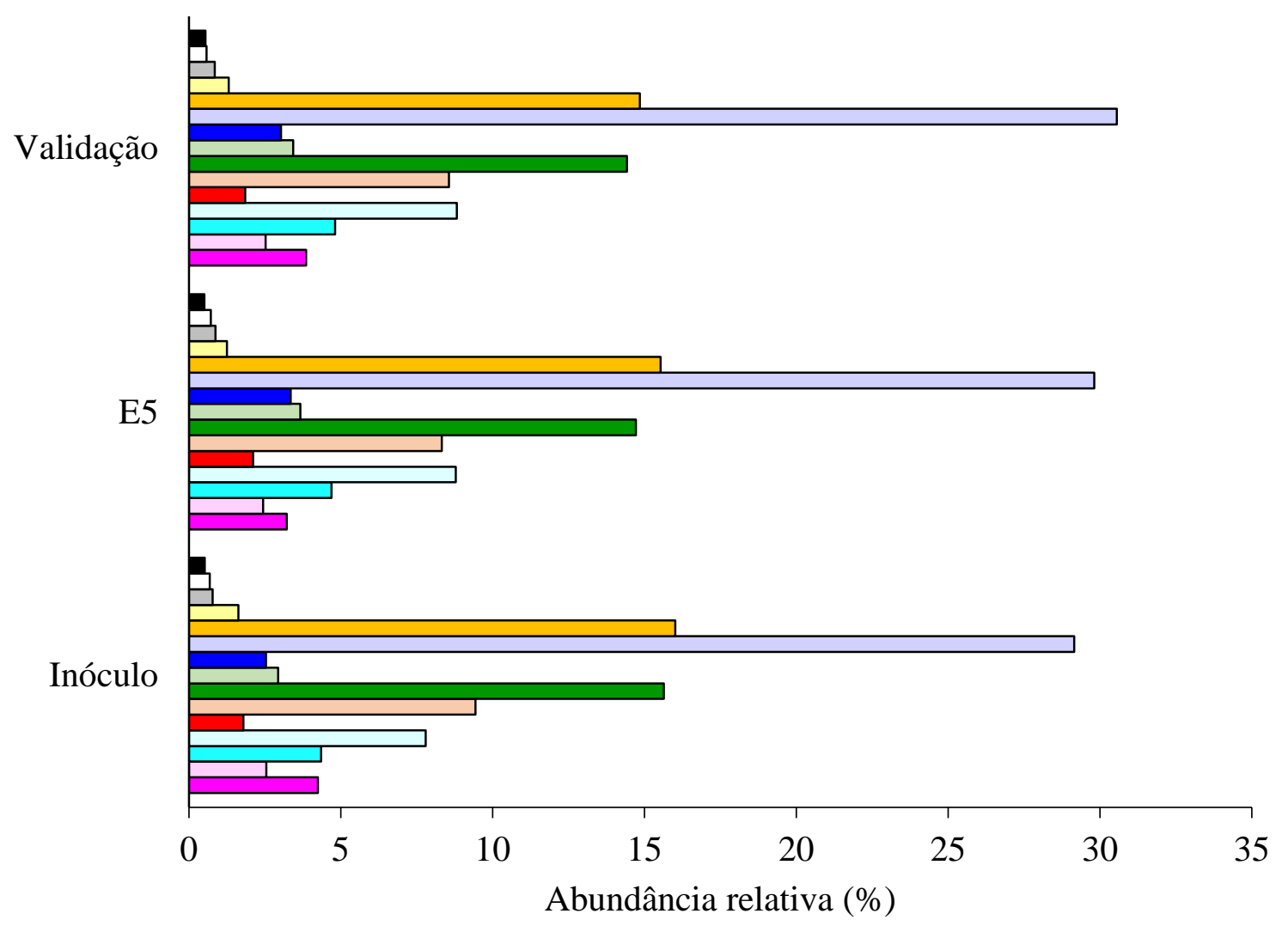

- Biodegradação de Xenobióticos

$\square$ Biossíntese de outros metabolitos secundários

$\square$ Metabolismo de terpenoides e policetídeos

$\square$ Motilidade, crescimento e morte celular

$\square$ Transporte de membrana e catabolismo

$\square$ Replicação e reparação celular

- Metabolismo enzimático

$\square$ Metabolismo de cofatores e vitaminas

口Outros

$\square$ Metabolismo de Carboídratos

- Biossíntese e metabolismo de glicanas

$\square$ Metabolismo de aminoácidos

$\square$ Metabolismo de nucleotídeos

$\square$ Metabolismo de Lipideos

$\square$ Metabolismo de energia 


\section{Universidade de São Paulo \\ Escola de Engenharia de São Carlos \\ Programa de Pós-graduação em Hidráulica e Saneamento}

Tanto a L-lactato desidrogenase (K00016), quanto D-lactato desidrogenase (K03778) foram mais abundantes no E5 (17,12 e 16,16\%) do que na validação (13,53 e 10,06\%), respectivamente. Esses resultados são condizentes com a alta produção de ácido lático $(3,98$ g. $\mathrm{L}^{-1}$ ) no E5, em vista que a enzima lactato desidrogenase catalisa a conversão do piruvato em ácido lático (Abdel-Rahman et al., 2013). A maior concentração de HLa (3,98 g.L $\left.{ }^{-1}\right)$ no E5 pode ter contribuído com uma parcela da produção de $\mathrm{H}_{2}$ neste ensaio $(11,65 \mathrm{~mL})$, em vista que a presença de HLa pode implicar na ocorrência da Reação 20, no qual há concomitante produção de $\mathrm{H}_{2}$ e HBu através de HLa e HAc (Fues et al., 2018).

No geral, todas estas enzimas atuam de forma significante no metabolismo de carboidratos, contribuindo com a produção de metabólitos gasosos e solúveis. Como todas as enzimas tem sua atividade ótima em determinadas condições de $\mathrm{pH}$ e temperatura, pode-se

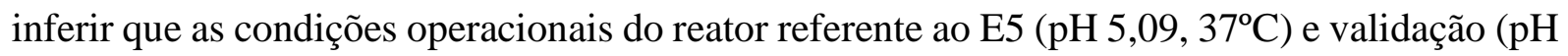
$5,09,37^{\circ} \mathrm{C}$ ) cooperaram com a atuação catalítica destas enzimas durante a fermentação da banana. 
Universidade de São Paulo

Escola de Engenharia de São Carlos

Programa de Pós-graduação em Hidráulica e Saneamento

Figura 5.48. Rota de produção de $\mathrm{H}_{2}$ e ácidos carboxílicos associadas a degradação do resíduo de banana (A) e principais KO e genes das enzimas associadas ao metabolismo de carboidratos obtidos no E5 e ensaios de validação.

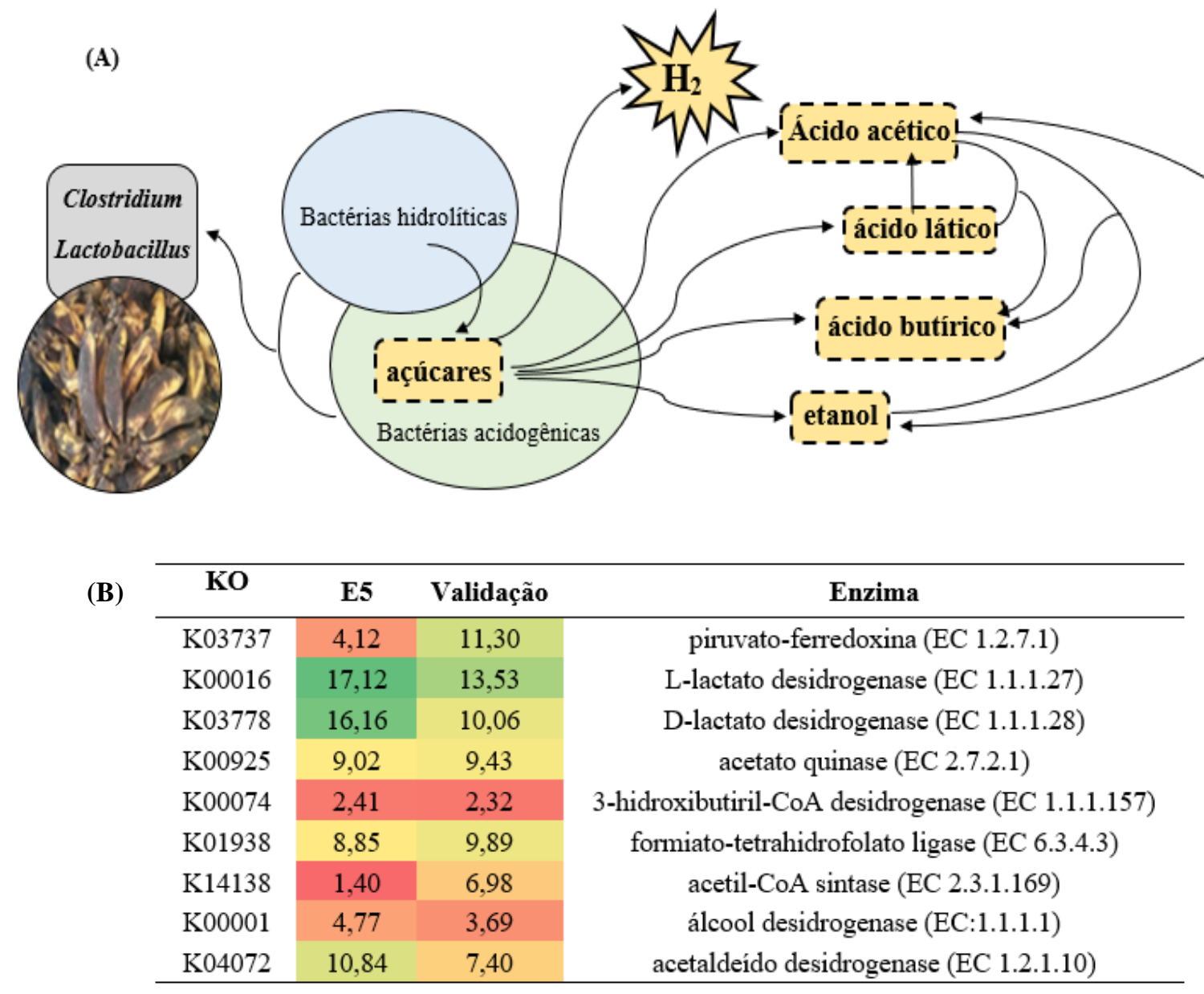




\section{Universidade de São Paulo \\ Escola de Engenharia de São Carlos \\ Programa de Pós-graduação em Hidráulica e Saneamento}

\subsubsection{Conclusão sub-hipótese 3}

As variáves $\mathrm{pH}$ e temperatura foram identificadas pelo método de Plackett-Burman como fatores significativos para produção de $\mathrm{H}_{2}$ utilizando resíduo de banana e biomassa autóctone e por isso foram avaliadas na faixa de $\mathrm{pH}(5,09-7,91)$ e temperatura $\left(27,10-46,90^{\circ} \mathrm{C}\right)$ a partir do delineamento do composto central rotacional (DCCR). Observou-se que o aumento do valor de $\mathrm{pH}$ favoreceu, tanto a produção, quanto a velocidade de produção de hidrogênio, enquanto, altas temperatura associada ao menor $\mathrm{pH}$ foram condições desfavoráveis para $P$ e $R m$. Por outro lado, altas temperaturas associadas ao menor valor de $\mathrm{pH}$ reduziram o tempo de início de produção de $\mathrm{H}_{2}\left(\lambda \mathrm{H}_{2}\right)$. As condições operacionais ótimas estimadas via modelo foram em pH 7,0 e $37^{\circ} \mathrm{C}$, obtendo-se valores otimizados de 70,09 mL H $2,12,43 \mathrm{~mL} \mathrm{H}_{2} \cdot \mathrm{h}^{-1}$ e de 93 mL.g $\mathrm{g}^{-1} \mathrm{CT}$, para produção, velocidade de produção e rendimento de hidrogênio, respectivamente. As principais vias metabólicas de produção de $\mathrm{H}_{2}$ foram do ácido acético, butírico, seguido pela via do ácido lático, utilizando principalmente a glicose e frutose como fonte de carbono.

O perfil da comunidade bacteriana mostrou que as comunidades foram dominadas pelos gêneros Lactobacillus, Clostridium e Clostridioides. No ensaio onde teve maior produção de ácido lático a população de Lactobacillus foi mais abundante, ao mesmo tempo que houve redução do gênero Clostridium e Clostridioides. Por outro lado, quando aumentou o valor de pH inicial de 5,09 para 7,0 verificou-se aumento da população de Clostridium e Clostridioides e diminuição de Lactobacillus, inferindo na forte influência do $\mathrm{pH}$ na dinâmica populacional das bactérias. Os principais genes identificados foram relacionados a enzimas associadas ao metabolismo de carboidratos, no qual contribuíram com a produção de $\mathrm{H}_{2}$, ácidos orgânicos e etanol a partir dos açúcares presente no resíduo de banana.

Deste modo, a terceira sub-hipótese elencada "Estratégias sequenciais por meio de delineamento experimental auxiliará a maximização da produção de hidrogênio" pode ser confirmada, em vista que os valores de produção e velocidade de produção de $\mathrm{H}_{2}$ obtidos no DCCR foram superiores aos obtidos no PB, aumentando de 38,08 para 70,19 $\mathrm{mL} \mathrm{H}_{2}$ e de 4,54 para $12,43 \mathrm{~mL} \cdot \mathrm{h}^{-1}$, cerca de 1,8 e 2,73 vezes para $P$ e $R m$, respectivamente. Portanto, por meio da utilização do planejamento fatorial obtém-se a otimização para mais de uma resposta ao mesmo tempo, estabelecendo condições experimentais ótimas, certificadas pela validação experimental. 


\subsection{Produção de hidrogênio a partir do isolado - Sub-hipótese 4}

\subsubsection{Isolamento e Caracterização}

A colônia isolada do resíduo de banana era em formato circular, opaca e lisa na superfície e bordas. As células em forma de bacilos estavam dispostas isoladas ou, em duplas e/ou trios. A sequência nucleotídica da linhagem isolada foi semelhante a Bacillus sp. com 100\% de similaridade com o banco de dados (https://blast.ncbi.nlm.nih.gov/Blast.cgi e https://rdp.cme.msu.edu/seqmatch) (Figura 5.49). Valores de bootstrap (1000 replicate runs) são mostrados entre os nós $(\%)$. A barra de escala $(0,10)$ indica a distância filogenética.

Figura 5.49. Dendograma de distância genética da sequência de DNAr 16S da cepa isolada.

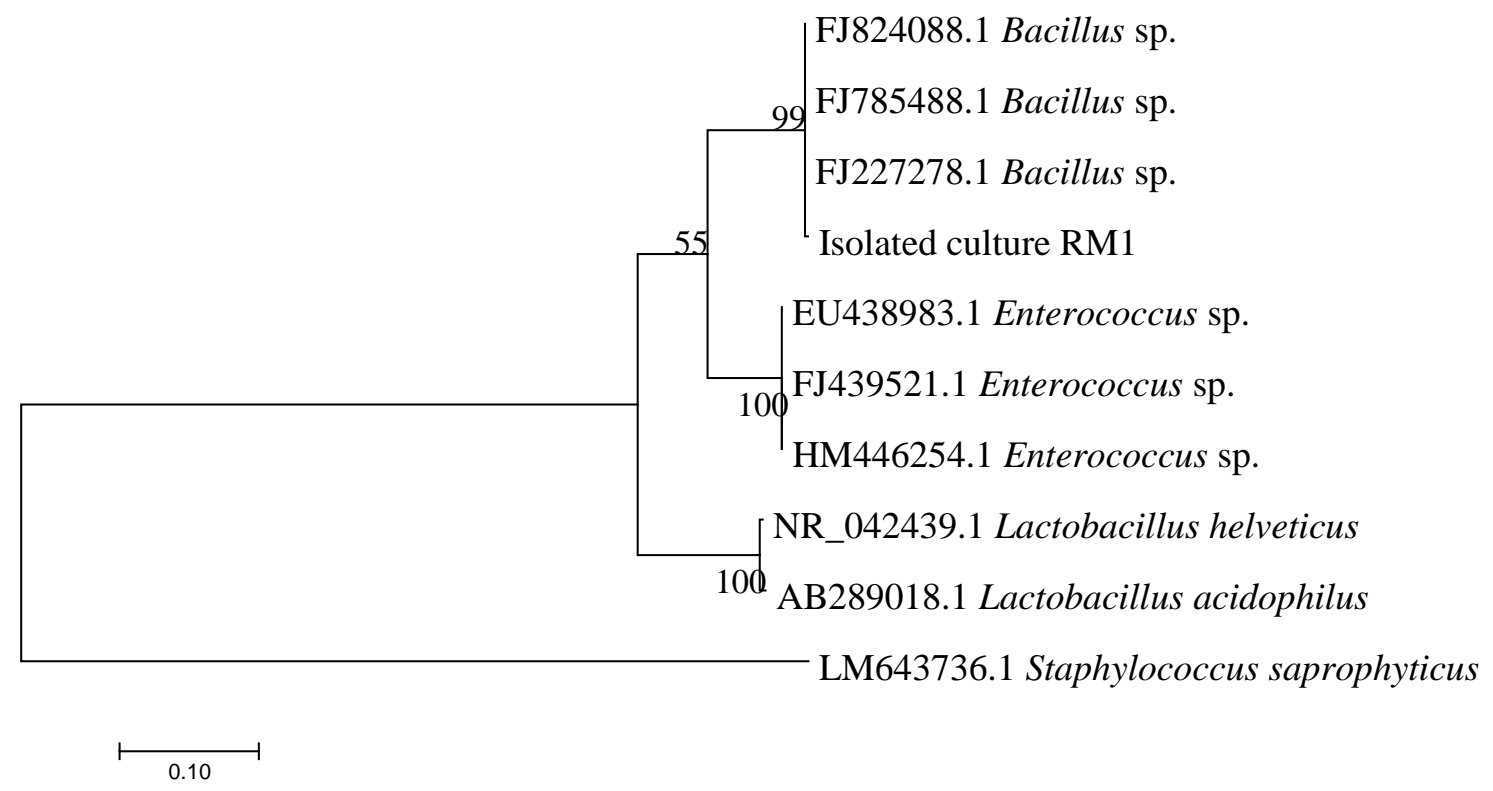

As bactérias do gênero Bacillus são Gram-positivas e reconhecidas por suas diversas aplicações, como secreção de proteínas, síntese química, biopolímeros, desenvolvimento de fármacos e nutracêuticos, como condroitina, nacetilglucosamina e ácido poligam-glutâmico (Yim et al. ., 2011; Liu et al., 2015; Mohapatra et al., 2017). Além dessas aplicações, algumas cepas, incluindo Bacillus macerans, Bacillus cloacae, Bacillus macerans, Bacillus licheniformis e Bacillus polymyxa, têm sido consideradas eficientes produtoras de hidrogênio e ácidos orgânicos (Lukajtis et al., 2018).

$\mathrm{O}$ uso de cepas isoladas tem contribuido para maiores rendimentos de $\mathrm{H}_{2}$ a partir de diferentes substratos lignocelulósicos, além de inferir em possíveis rotas metabólicas no processo biotecnológico. O uso do consórcio microbiano também é relevante em termos de 
Universidade de São Paulo

Escola de Engenharia de São Carlos

Programa de Pós-graduação em Hidráulica e Saneamento

aplicação prática, entretanto, a diversidade de bactérias implica na competição de substrato e consumo de $\mathrm{H}_{2}$ por arqueas metanogênicas, bactérias acetogênicas e bactérias redutoras de sulfato (Lee et al., 2011). Além disso, com base na compreensão fisiológica de uma determinada bactéria, é possível prosseguir com sua aplicação em um processo de bioaumentação (Kumar et al., 2016b) para obter hidrogênio a partir de substratos complexos, como RB (Gong et al., 2017).

A cepa de Bacillus sp. RM1 foi isolada em glicose, sendo obtido tempo de geração (Tg) e velocidade de crescimento de $0,43 \mathrm{~h} \mathrm{e} 1,60 \mathrm{~h}^{-1}$, respectivamente, a partir da curva de crescimento apresentada na Figura 5.50 (A).
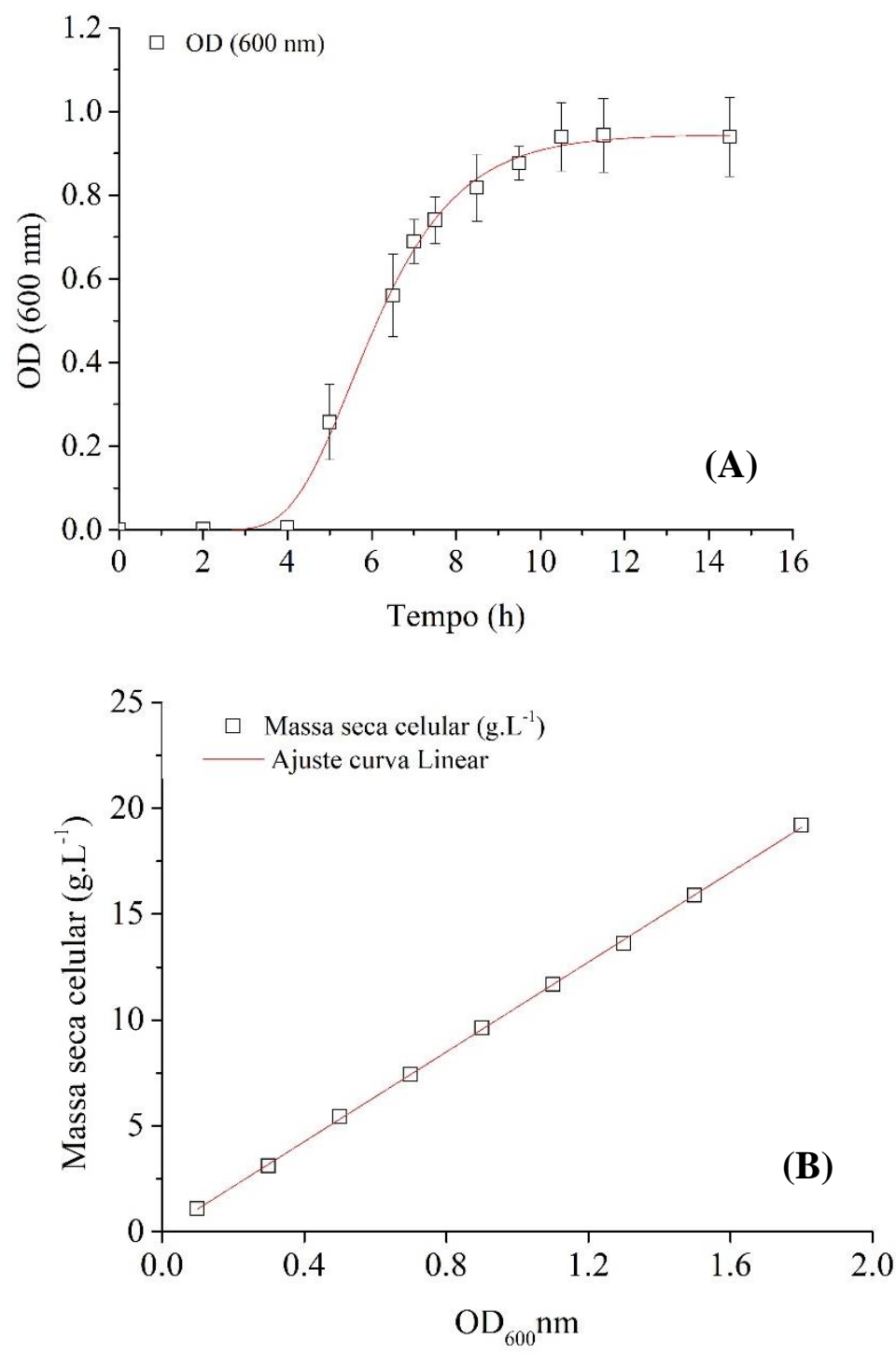

Figura 5.50. Curva de crescimento (A) e Concentração de massa seca celular (B). 
A massa seca celular (MSC g.L ${ }^{-1}$ ) da cultura de Bacillus sp. RM1 nas condições de isolamento foi proporcional a absorbância a $600 \mathrm{~nm}\left(\mathrm{~A}_{600}\right)$ e pôde ser calculada com a seguinte relação: $\mathrm{MSC}_{\text {Bacillus sp. RM1 }}=2,19 \mathrm{~A}_{600}$ (Figura 5.50 (B)). A velocidade de crescimento e concentração celular (MSC) de 1,60 h ${ }^{-1}$ e 12,65 g.L. $\mathrm{L}^{-1}$, respectivamente, obtida neste estudo em $48 \mathrm{~h}$ foi maior quando comparada a velocidade de crescimento $\left(0,16 \mathrm{~h}^{-1}\right)$ e concentração celular (8,5 g.L L $\left.^{-1}\right)$ obtida por Sakthiselvan e Madhumathi (2018) utilizando Bacillus safensis EBT1 como inóculo na fermentação de bagaço de cana e glicose, a $33^{\circ} \mathrm{C}$ e pH 7,0. Patel et al. (2011) avaliaram o crescimento celular de cepas de Bacillus variando a porcentagem de glicose $(0.5$, 1 e $2 \%$ ) em pH inicial ajustado a 7 e temperatura de incubação de $37^{\circ} \mathrm{C}$. $\mathrm{O}$ aumento para $2 \%$ da glicose favoreceu o crescimento celular obtendo-se concentrações máximas de MSC de 1,12 e 1,19 g.L $\mathrm{L}^{-1}$ para Bacillus cereus EGU43 e Bacillus thuringiensis EGU45, respectivamente.

\subsubsection{Efeito da fonte de carbono}

A produção de $\mathrm{H}_{2}$ por Bacillus sp. RM1 foi avaliada utilizando variedade de substratos orgânicos incluindo mono, di e polissacarídeo (Tabela 5.20). Dentre os monossacarídeos (glicose, xilose, manose, galactose e frutose) avaliados, a melhor produção (16,92 mmol $\mathrm{H}_{2} . \mathrm{L}^{-}$ 1 e $\left.13,49 \mathrm{mmol} \mathrm{H}_{2} \cdot \mathrm{L}^{-1}\right)$ rendimento de $\mathrm{H}_{2}$ (75,81 $\mathrm{mL} \cdot \mathrm{g}^{-1}$ carboidrato add e 60,44 mL.g${ }^{1}$ carboidrato add) foi obtida a partir de xilose e glicose, respectivamente. A quantidade estequiométrica máxima de hidrogênio molecular por mol de glicose é igual a 4 e 2 mols, quando há formação de ácido acético e ácido butírico, respectivamente (Reação 12 e 11) (Lukajtis et al., 2018).

Assim como a glicose, a xilose pode ser convertida em hidrogênio com um rendimento máximo de 3,33 mol- $\mathrm{H}_{2} /$ mol-xilose quando o ácido acético é produzido (reação 29). Alternativamente, a xilose pode ser convertida em hidrogênio por via butirato como mostrado na reação (30), com menor rendimento de 1,67 mol- $\mathrm{H}_{2} / \mathrm{mol}$-xilose.

Na presente pesquisa, a fermentação a partir de xilose e glicose resultaram em 485,66 mg.L $\mathrm{L}^{-1}$ e 546,94 mg.L $\mathrm{L}^{-1}$ de ácido acético (HAc), respectivamente. É sabido que o HAc pode servir como substrato para a produção de outros metabólitos, como etanol (reação 16) e ácido butírico (reação 20). A ocorrência da reação 16 e 20 pode resultar em baixo rendimento de $\mathrm{H}_{2}$, uma vez que, $\mathrm{HBu}$ e etanol podem ser produzidos ao invés de $\mathrm{H}_{2}$ a partir de HAc. No ensaio utilizando glicose obteve-se maior produção de etanol (114,65 mg. $\left.\mathrm{L}^{-1}\right)$ quando comparado ao ensaio utilizando xilose $\left(27,69 \mathrm{mg} \cdot \mathrm{L}^{-1}\right)$. A partir disso, pode-se inferir que o menor rendimento 


\section{Universidade de São Paulo \\ Escola de Engenharia de São Carlos \\ Programa de Pós-graduação em Hidráulica e Saneamento}

de hidrogênio $\left(40,29 \mathrm{~mL} \cdot \mathrm{g}^{-1}\right.$ carboidrato adicionados) from glicose pode ser decorrente da alta produção de etanol.

Por outro lado, observou-se valor ligeiramente maior em relação ao ácido butírico (622.56 mg. $\left.\mathrm{L}^{-1}\right)$ na fermentação da xilose quando comparado a glicose (614.64 mg.L $\left.\mathrm{L}^{-1}\right)$. Na presença de xilose foi observado maior rendimento de $\mathrm{H}_{2}$ de $50,53 \mathrm{~mL} \cdot \mathrm{g}^{-1}$ carboidratos adicionados em relação a glicose $\left(50,53 \mathrm{~mL} \cdot \mathrm{g}^{-1}\right.$ carboidratos adicionados $)$. Ademais, observou-se que a fermentação de glicose by Bacillus sp. RM1 resultou em maior concentração de ácidos carboxílicos (ácido acético e butírico) em relação a xilose. A alta concentração de ácidos carboxílicos pode ter causado inibição da biomassa hidrogenogênica. Este efeito negativo na biomassa pode estar relacionado a inibição causada pela permeabilidade de ácidos não dissociados através da membrana celular. Nessa situação, com o objetivo de manter o pH intracelular, as células gastam energia metabólica para excretar esses prótons contra um gradiente de concentração (Infantes et al., 2011).

Tabela 5.20. Efeito de diferentes fontes de carbono na produção e rendimento de hidrogênio e conversão de carboidratos a partir Bacillus sp. RM1.

\begin{tabular}{|c|c|c|c|c|c|c|c|}
\hline \multirow{2}{*}{$\begin{array}{c}\text { Fontes de } \\
\text { Carbono }\end{array}$} & \multirow{2}{*}{$\begin{array}{c}\mathrm{H}_{2} \\
\text { acumulado } \\
\text { mmol.L } \mathrm{L}^{-1}\end{array}$} & \multirow{2}{*}{$\begin{array}{c}\mathrm{YH}_{2} \\
\mathrm{~mL} \cdot \mathrm{g}^{-1} \\
\text { carboidrato add }\end{array}$} & Etanol & $\mathrm{H}_{\mathrm{Ac}}$ & $\mathrm{H}_{\mathrm{Bu}}$ & $\mathrm{H}_{\mathrm{Ca}}$ & \multirow{2}{*}{$\begin{array}{l}\mathrm{C}_{\mathrm{CT}} \\
(\%)\end{array}$} \\
\hline & & & $\mathrm{mg} \cdot \mathrm{L}^{-1}$ & & $\mathrm{mg} \cdot \mathrm{L}^{-1}$ & & \\
\hline glicose & $13,49^{\mathrm{bc}}$ & $60,44^{\mathrm{bc}}$ & 114,65 & 546,94 & 614,64 & 15,51 & 61,0 \\
\hline xilose & $16,92^{\mathrm{a}}$ & $75,81^{\mathrm{a}}$ & 27,69 & 485,66 & 622,56 & 14,76 & 37,0 \\
\hline amido & $16,55^{\mathrm{ab}}$ & $74,13^{\mathrm{ab}}$ & 14,74 & 303,16 & 466,26 & 16,29 & 28,5 \\
\hline maltose & $17,75^{\mathrm{a}}$ & $79,54^{\mathrm{a}}$ & 75,19 & 508,92 & 630,06 & 16,23 & 63,5 \\
\hline celobiose & $16,08^{\mathrm{ab}}$ & $72,04^{\mathrm{ab}}$ & 70,34 & 329,59 & 578,68 & 17,76 & 49,5 \\
\hline manose & $10,81^{\mathrm{c}}$ & $48,44^{\mathrm{c}}$ & 96,99 & 307,88 & 413,82 & 20,24 & 10,5 \\
\hline galactose & $12,21^{\mathrm{c}}$ & $54,73^{c}$ & 26,01 & 291,9 & 418,04 & 18,14 & 46,5 \\
\hline frutose & $11,26^{\mathrm{c}}$ & $50,46^{\mathrm{c}}$ & 34,07 & 234,16 & 404,02 & 18,54 & 29,0 \\
\hline sacarose & $11,16^{\mathrm{c}}$ & $50,88^{c}$ & 31,26 & 243,85 & 345,13 & 17,57 & 28,0 \\
\hline
\end{tabular}

Notas: Valores Médios seguidos de pelo menos uma letra em comum não diferem entre si, pelo teste de Tukey, ao nível de significância de $5 \%$ de probabilidade $(\mathrm{p}<0,05)$. $\mathrm{YH}_{2}=$ rendimento de hidrogênio, $\mathrm{H}_{\mathrm{Ac}}=$ ácido acético, $\mathrm{H}_{\mathrm{Bu}}=$ ácido bútirico, $\mathrm{H}_{\mathrm{Ca}}=$ ácido capróico, $\mathrm{C}_{\mathrm{CT}}=$ conversão de carboidratos totais.

Esse transporte ativo consome energia, limitando o metabolismo das células. $\mathrm{O}$ valor de pH obtido na fermentação de xilose e glicose foram 5,0 e 4,2. Portanto, o maior rendimento de hidrogênio utilizando xilose quando comparado a glicose, pode ser explicado pelo efeito 
causado pelo $\mathrm{pH}$ nas condições de fermentação do último substrato. Assim como na presente pesquisa, An et al. (2014) reportaram maior rendimento de hidrogênio $\left(91,9 \mathrm{~mL} \mathrm{H} \cdot \mathrm{g}^{-1}\right.$ substrato) na fermentação de xilose quando comparado ao rendimento de $80,3 \mathrm{~mL} \mathrm{H} \cdot \mathrm{g}^{-1}$ substrato na fermentação de glicose.

Em relação aos dissacarídeos (maltose, celobiose e sacarose) avaliados, o maior rendimento de $\mathrm{H}_{2}$ foi obtido com maltose $\left(53,01 \mathrm{~mL} \mathrm{H}_{2} \cdot \mathrm{g}^{-1}\right.$ carboidratos add) e celobiose $(48,02$ $\mathrm{mL} \mathrm{H} \mathrm{H}^{-1}$ carboidratos add). Ambas as moléculas, maltose e celobiose, são obtidas a partir da degradação de amido e celulose, respectivamente, e com as mesmas propriedades químicas, sendo que suas hidrólises resultam em duas moléculas de glicose, o que justifica a similaridade na produção de $\mathrm{H}_{2}$. É interessante que Bacillus sp. RM1 teve maior eficiência na utilização de carboidratos complexos ao invés de glicose $\left(40,29 \mathrm{~mL} \mathrm{H}_{2} \cdot \mathrm{g}^{-1}\right.$ carboidratos). No entanto, o mecanismo para este fenômeno não é claro, uma das razões pode ser decorrente da pressão osmótica. A pressão osmótica a partir de monossacarídeos é maior do que a de polissacarídeos podendo exercer efeito na produção e rendimento de hidrogênio (An et al., 2014). Ademais, a razão pelo qual o rendimento de hidrogênio foi maior utilizando-se maltose, xilose e celobiose pode ser atribuída à sua natureza dual na via metabólica. Em primeiro lugar, serve como única fonte de carbono para o crescimento celular e em segundo lugar, ajuda na maturação enzimática durante a glicosilação, processo que acelera a atividade do metabolismo microbiano (Sinha e Pandey, 2014). Além disso, a variação nos estados redox destas moléculas de açúcares também pode ser atribuída a diferentes níveis de rendimento de hidrogênio (Duangmanee et al., 2007).

A produção inferior de $\mathrm{H}_{2}$ de 11,16 mmol. $\mathrm{L}^{-1}$ a partir de sacarose quando comparada a maltose $\left(17,75 \mathrm{mmol} \mathrm{H}_{2} \cdot \mathrm{L}^{-1}\right)$ e celobiose $\left(16,08 \mathrm{mmol} \mathrm{H}_{2} \cdot \mathrm{L}^{-1}\right)$, pode ser resultante da baixa assimilação de frutose por Bacillus sp. RM1, já que a hidrólise da sacarose resulta em glicose e frutose. Por meio de tais resultados pode-se justificar a baixa produção de $\mathrm{H}_{2}$ de 11,26 mmol.L $L^{-1}$ nos ensaios utilizando somente frutose como fonte de carbono. Maintinguer et al. (2017) também obtiveram produção de hidrogênio a partir de maltose $\left(7,03 \mathrm{mmol} . \mathrm{L}^{-1}\right)$ e amido $\left(7,09\right.$ mmol. $\left.\mathrm{L}^{-1}\right)$ maior do que utilizando glicose $\left(6,78 \mathrm{mmol} . \mathrm{L}^{-1}\right)$. Sinha e Pandey (2014) reportaram que dentre todos os substratos (glicose, arabinose, lactose, amido, e bagaço de cana hidrolisado) a máxima produção de $\mathrm{H}_{2}\left(22,58 \mathrm{mmol} \mathrm{H}_{2} \mathrm{~L}^{-1}\right)$ foi obida utilizando amido como substrato. Desta forma, a produção de $\mathrm{H}_{2}$ por Bacillus sp. RM1 utilizando amido (16,55 mmol. $\left.\mathrm{L}^{-1}\right)$ e maltose $\left(17,75 \mathrm{mmol} . \mathrm{L}^{-1}\right)$ foi maior que utilizando glicose $\left(13,49 \mathrm{mmol} . \mathrm{L}^{-1}\right)$.

A baixa produção de $\mathrm{H}_{2}$ de 11,16 mmol. $\mathrm{L}^{-1}$ a partir de sacarose quando comparado a maltose $\left(17,75 \mathrm{mmol} \mathrm{H}_{2} \cdot \mathrm{L}^{-1}\right)$ e celobiose $\left(16,08 \mathrm{mmol} \mathrm{H}_{2} \cdot \mathrm{L}^{-1}\right)$, deve ser resultante do baixo 


\section{Universidade de São Paulo \\ Escola de Engenharia de São Carlos \\ Programa de Pós-graduação em Hidráulica e Saneamento}

consumo de frutose por Bacillus sp. RM1, uma vez que, a hidrólise da sacarose resulta em uma molécula de glicose e frutose. Estes resultados explicam a baixa produção de 11,26 mmol.:-1 no ensaio utilizando somente frutose como fonte de carbono. A produção de $\mathrm{H}_{2}$ de 16.55 mmol. $\mathrm{L}^{-1}$ a partir de amido (polissacarídeo) foi similar a produção a partir de celobiose e maltose (dissacarídeo) e xilose (monossacarídeo) (Tabela 5.20). An et al. (2014) também obtiveram rendimento máximo de hidrogênio de 125,9 e $91,9 \mathrm{~mL} \mathrm{~g}^{-1}$ carboidrato utilizando frutose e xilose, respectivamente, como substrato orgânico a partir de Clostridium beijerinckii YA001 isolado de esterco de vaca. Tais resultados são superiores aos obtidos para Bacillus sp. RM1 utilizando os monossacarídeos frutose $\left(50,46 \mathrm{~mL} \cdot \mathrm{g}^{-1}\right.$ carboidrato) e glicose $\left(75,81 \mathrm{~mL} \cdot \mathrm{g}^{-}\right.$ ${ }^{1}$ carboidrato). No entanto, o rendimento de hidrogênio por Bacillus sp. RM1 com amido foi 2,2 vezes maior que o obtido por C. beijerinckii YA001.

O estabelecimento de condições ácidas em processos fermentativos, como verificado no final de todas as fermentações neste estudo possibilita alterações metabólicas da biomassa e oportuniza a retenção de prótons $\left(\mathrm{H}^{+}\right)$para formação de moléculas mais reduzidas, tais como etanol e ácido propiônico reduzindo a produção de $\mathrm{H}_{2}$ (Infantes et al., 2011). Observou-se que em todos os ensaios, houve acúmulo de etanol e ácidos carboxílicos no final da fermentação. A produção concomitante de $\mathrm{H}_{2}$, etanol e ácido acético durante o processo fermentativo pode ter ocorrido via ácido acético etanol através da acetogênese, com conversão do etanol em ácido acético e $\mathrm{H}_{2}$ (Reação 13). De acordo com Saady (2013), bactérias acetogênicas podem sintetizar ácido acético e produzir $\mathrm{H}_{2}$ durante o crescimento heterotrófico a partir de variedade de substrato, incluindo etanol. Espécies de Bacillus tem sido reportada como possíveis acetogênicas por sintetizarem etanol e ácido acético a partir de compostos orgânicos (Sikora et al., 2013) justificando os resultados obtidos nesta pesquisa.

A produção de etanol ocorreu principalmente a partir dos monossacarídeos glicose (114, $\left.65 \mathrm{mg} . \mathrm{L}^{-1}\right)$ e manose $\left(96,99 \mathrm{mg} . \mathrm{L}^{-1}\right)$, em contrapartida, menor concentração de etanol $(14,74$ mg. $\mathrm{L}^{-1}$ ) foi obtida a partir do amido (polissacarídeo). Provavelmente, a complexidade da molécula de amido pode ter contribuído com o desvio de rota para produção de ácidos carboxílicos ao invés de etanol. A partir da produção de etanol verificou-se diminuição efetiva da produção de hidrogênio, visto que durante a formação de etanol não há produção de $\mathrm{H}_{2}$, e sim de $\mathrm{CO}_{2}$ (Reação 15). No ensaio com manose verificou-se menor produção de $\mathrm{H}_{2}(10,81$ mmol.L $\left.\mathrm{L}^{-1}\right)$ e maior concentração de etanol (96,99 mg.L $\left.\mathrm{L}^{-1}\right)$ (Tabela 5.20).

Foi observado ácido capróico (HCa) na fermentação de todos os diferentes substratos orgânicos avaliados. Durante a fermentação que leva a produção de $\mathrm{HCa}$, há consumo de ácido 
acético como rota principal. Tal reação biológica pode ocorrer através do alongamento da cadeia carboxílica do HAc e HBu com o etanol (Reação 31 e 32), que é ainda mais reduzido (Barker et al., 1945; Agler et al., 2012). Além disso, o próprio hidrogênio $\left(\mathrm{H}_{2}\right)$ residual na fração líquida pode ter sido utilizado como doador de elétrons para formação do HCa a partir de ácido acético e ácido butírico (Reação 33, 34 e 35) (Zhang et al., 2013).

$$
\begin{array}{ll}
2 \mathrm{CH}_{3} \mathrm{CH}_{2} \mathrm{OH}+\mathrm{CH}_{3} \mathrm{COOH} \rightarrow \mathrm{C}_{6} \mathrm{H}_{11} \mathrm{COOH}+\mathrm{H}_{2} \mathrm{O} & \text { Reação 31 } \\
\mathrm{CH}_{3} \mathrm{CH}_{2} \mathrm{OH}+\mathrm{CH}_{2} \mathrm{CH}_{2} \mathrm{CH}_{2} \mathrm{COOH} \rightarrow \mathrm{C}_{6} \mathrm{H}_{11} \mathrm{COOH}+\mathrm{H}_{2} \mathrm{O} & \text { Reação 32 } \\
\mathrm{CH}_{3} \mathrm{COOH}+\mathrm{CH}_{2} \mathrm{CH}_{2} \mathrm{CH}_{2} \mathrm{COOH}+2 \mathrm{H}_{2}+\mathrm{H}^{+} \rightarrow \mathrm{C}_{6} \mathrm{H}_{11} \mathrm{COOH}+2 \mathrm{H}_{2} \mathrm{O} & \text { Reação 33 } \\
\mathrm{CH}_{2} \mathrm{CH}_{2} \mathrm{CH}_{2} \mathrm{COOH}+2 \mathrm{CO}_{2}+6 \mathrm{H}_{2} \rightarrow \mathrm{C}_{6} \mathrm{H}_{11} \mathrm{COOH}+4 \mathrm{H}_{2} \mathrm{O} & \text { Reação 34 } \\
3 \mathrm{CH}_{3} \mathrm{COOH}+2 \mathrm{H}^{+}+4 \mathrm{H}_{2} \rightarrow \mathrm{C}_{6} \mathrm{H}_{11} \mathrm{COOH}+4 \mathrm{H}_{2} \mathrm{O} & \text { Reação 35 }
\end{array}
$$

A maior produção de ácido capróico (HCa) de 20,24 mg. $\mathrm{L}^{-1}$ foi obtida a partir da fermentação utilizando manose (6C), enquanto a menor produção $\left(14,76 \mathrm{mg} . \mathrm{L}^{-1}\right)$ foi obtida a partir da xilose (5C). Observou-se que quanto maior a produção de $\mathrm{HCa}$ menor o rendimento de hidrogênio (Tabela 5.20). Neste caso, o etanol pode ter sido utilizado como doador de elétrons para produção de $\mathrm{HBu}$ e $\mathrm{HCa}$ ao invés de $\mathrm{H}_{2}$ (Spirito et al., 2014), já que nos ensaios com baixos rendimentos de $\mathrm{H}_{2}$ foram os mesmos ensaios nos quais a produção de ácido capróico e ácido butírico foram mais elevadas. Para as demais condições com hexoses, tais como glicose, manose, galactose e frutose, observou-se 15,51 e $18,54 \mathrm{mg} . \mathrm{L}^{-1}$ de HCa. Tal produção foi semelhante aquela obtida utilizando maltose, celobiose e sacarose, ou seja, açúcares de 12 carbonos (12C).

Maior conversão de carboidratos foi obtida nos ensaios com maltose $(63,5 \%)$, glicose (61\%) e celobiose (49,5\%), correspondendo aos ensaios com maiores rendimentos de hidrogênio e produção de ácido acético e butírico (Tabela 5.20). Por outro lado, baixa conversão de substrato foi obtida nos ensaios utilizando sacarose (28\%), amido (28,5\%), frutose (29\%) e principalmente manose $(10,5 \%)$. Por meio desses resultados verificou-se que a glicose hidrolisada, a partir da maltose, celobiose e sacarose, foi consumida em maior taxa, enquanto o consumo de frutose foi reduzido, acarretando no acúmulo de frutose e menor conversão do substrato.

Portanto, verificou-se para Bacillus sp. RM1 maior afinidade na degradação de substratos contendo glicose. Provavelmente, pode-se inferir sob tais condições alta atividade da fosfatase maltose (MP) durante o período de crescimento exponencial da biomassa, resultando na hidrólise da maltose em glicose e $\beta$-G-1-P ( $\beta$ glicose 1 fosfato), ambos podendo ser convertidos em glicose-6-fosfato (G-6-P) por $\beta$-PGM ( $\beta$-fosfoglicomutase) antes de entrar na 


\section{Universidade de São Paulo \\ Escola de Engenharia de São Carlos \\ Programa de Pós-graduação em Hidráulica e Saneamento}

via glicolítica e/ou utilizadas para a síntese de UDP (Uridina difosfato)-glicose. Em contrapartida, a necessidade da ativação de enzimas associadas na conversão da frutose em glicose-6-fosfato (G6P) por reações metabólicas e à baixa e alta atividade da $\alpha$ fosfoglicomutase ( $\alpha$-PGM) e 6-fosfofrutoquinase (6-PFK), respectivamente, na fermentação de frutose pode ter fornecido mais frutose-6-fosfato (F-6-P), fluindo para F-1,6-P (Frutose 1,6 fosfato), o que não é propício para biossíntese celular, devido ao tempo gasto para ocorrência desta reação (Velasco et al. 2007).

A partir da curva-padrão de crescimento celular (Figura 5.50 B) foi possível determinar a concentração de MSC (Massa Seca Celular) nos ensaios com diferentes substratos orgânicos (Figura 5.51).

Figura 5.51. Efeito da fonte de carbono no crescimento de Bacillus sp. RM1

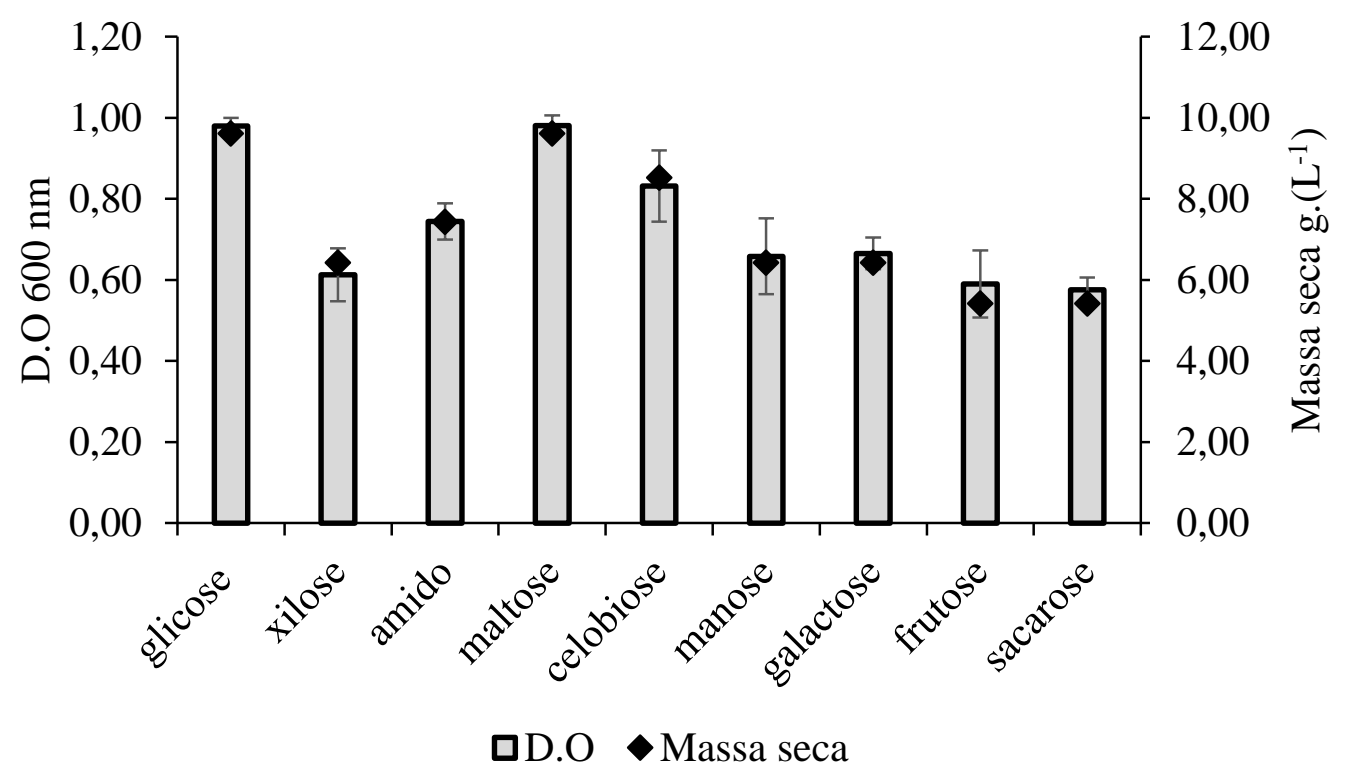

Dentre todos os substratos, observou-se menor valor de biomassa no final da fermentação de 5,42 $\mathrm{g}_{\mathrm{MSC} . \mathrm{L}^{-1}}\left(0.6 \mathrm{OD}_{600}\right)$ e 6,43 gMSC.L $\mathrm{L}^{-1}\left(0.66 \mathrm{OD}_{600}\right)$ utilizando os monossacarídeos xilose, manose, galactose, frutose e sacarose. Todavia, para maltose e glicose verificou-se valores maiores de 9,62 g $_{\mathrm{MSC}} \mathrm{L}^{-1}$, correspondendo a $0.98 \mathrm{OD}_{600}$. Pode-se inferir que devido a alta conversão de carboidratos, produção de $\mathrm{H}_{2}$ e ácidos orgânicos nos ensaios com maltose e glicose, a taxa de biossíntese e produtividade foi alcançada utilizando esses açúcares como fonte de carbono para manutenção do metabolismo celular. Resultado similar foi obtido por Sinha e Pandey (2014), no qual observaram maior crescimento celular $(1,8$ $\mathrm{OD}_{600}$ ) utilizando glicose como substrato orgânico, seguido de amido (1.6 OD 600$)$. No entanto, 
a xilose e sacarose não foram consideradas como boas fontes de carbono para o crescimento celular. Nesses casos, os autores observaram crescimento máximo entre 0.80-0.82 OD 600 . Além disso, os autores, observaram que a sacarose não foi considerada boa fonte de carbono para produção de hidrogênio (22 mmol.L $\mathrm{L}^{-1}$ ) por B. firmus NMBL-03, provavelmente devido a natureza dissacarídica da sacarose e/ou a ausência de enzima metabolizadora de sacarose no isolado.

Mishra et al. (2017) avaliaram o efeito de diferentes substratos orgânicos no crescimento celular e produção de $\mathrm{H}_{2}$ por Bacillus anthracis PUNAJAN 1. Os autores relataram que na presença de glicose, a concentração de biomassa celular $\left(2,26\right.$ g. $\left.\mathrm{L}^{-1}\right)$ foi relativamente igual à manose, amido, sacarose e maltose. Todavia, com galactose a concentração de biomassa celular foi menor, 1,5 g. $\mathrm{L}^{-1}$. Contudo, a acessibilidade de várias fontes de carbono como substrato por Bacillus sp. RM1 para produção de hidrogênio e ácidos orgânicos reforça a aplicação desta cepa na degradação de vários tipos de carboidratos presente na biomassa renovável.

No entanto, a acessibilidade de várias fontes de carbono como substrato por Bacillus sp. RM1 para produção de hidrogênio e ácidos orgânicos reforça a aplicação desta cepa em diversos tipos de degradação de carboidratos presentes na biomassa renovável.

\subsubsection{Efeito da concentração de celobiose}

Micro-organismos que metabolizam a celobiose em vez de glicose oferece vantagens significativas na biotecnologia ajudando a desvendar paradigmas que envolvem a hidrólise enzimática completa da celulose. Neste sentido, dentre os carboidratos testados, a celobiose foi eleita para se avaliar o efeito da sua concentração na produção de $\mathrm{H}_{2}$ e ácidos carboxílicos a partir de Bacillus sp. RM1 isolado da banana.

A Figura 5.52 ilustra o crescimento de Bacillus sp. RM1 ao longo do tempo nos ensaios de fermentação conduzida em diferentes concentrações iniciais de celobiose $(0,5,2,0,3,5,5,0$ e 6,5 g.L $\left.\mathrm{L}^{-1}\right)$. Geralmente, nas primeiras horas da fermentação as bactérias consomem o substrato para crescimento celular. O aumento da concentração de celobiose de 0,5 para 6,5 g.L.-1 favoreceu o aumento do tempo de fase lag de 6 para 9 h, indicando a necessidade de adaptação da biomassa frente a maior concentração de substrato inicial. Após o período de fase lag, iniciou-se o crescimento exponencial da Bacillus sp. RM1, obtendo-se maiores velocidades de crescimento $(\mu)$ de 2,5 e 2,7 $\mathrm{h}^{-1}$ nos ensaios com maior concentração de substrato ( 5 e 6,5 g.L-

${ }^{1}$ ), quando comparada as velocidades de $0,9,0,6$ e 1,0 $\mathrm{h}^{-1}$ nos ensaios com menor concentração $\left(0,5,2,0\right.$ e 3,5 g.L $\left.\mathrm{L}^{-1}\right)$, respectivamente. Valores de $\mu_{\max }$ obtidos para Bacillus sp. RM1 estão na 


\section{Universidade de São Paulo \\ Escola de Engenharia de São Carlos \\ Programa de Pós-graduação em Hidráulica e Saneamento}

mesma ordem de grandeza dos valores de $\mu_{\max }$ relatados para outras bactérias produtoras de $\mathrm{H}_{2}$ como Clostridium.

Figura 5.52. Curva de crescimento de Bacillus sp. RM1 com diferentes concentrações de celobiose.

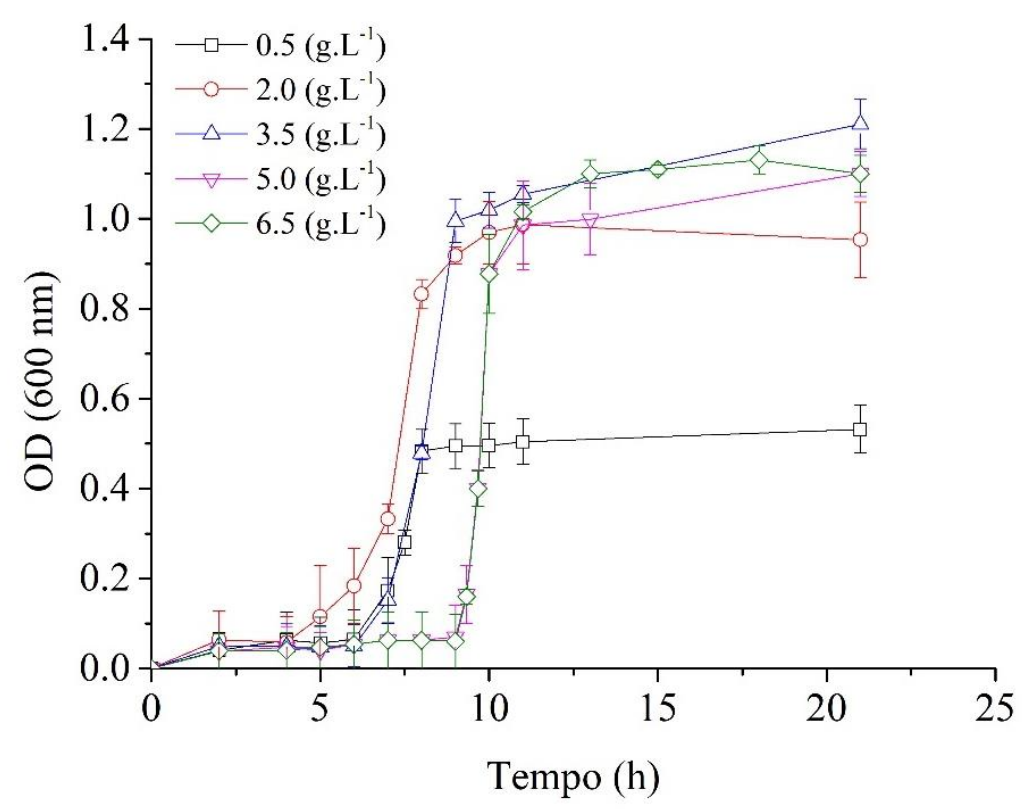

A título de exemplificação, para 6 g. $\mathrm{L}^{-1}$ de glicose a $\mu_{\max }$ obtida para $C$. beijerinckii NCIMB8052 (ATCC51743) e C. beijerinckii SA-1 (ATCC35702) foi de 0,32-0,29 h ${ }^{-1}$ e 0,23$0,2 \mathrm{~h}^{-1}$, respectivamente (Sandoval-Espinola, et al. 2015). Yao et al. (2016) relataram maior $\mu_{\max }$ de $0,345 \mathrm{~h}^{-1}$ para C. acetobutylicum CICC 8012 cultivado em concentração inicial de glicose 9 vezes maior $\left(60\right.$ g. $\left.\mathrm{L}^{-1}\right)$ que o presente estudo.

A produção de hydrogênio observada foi de 1,72 mmol.L ${ }^{-1}, 18,77$ mmol. $\mathrm{L}^{-1}$ e 17,25 mmol.L ${ }^{-1}$, respectivamente para 0,5 g.L $\mathrm{L}^{-1}, 3,5$ g.L $\mathrm{L}^{-1}$ e 6,5 g.L $\mathrm{L}^{-1}$ of celobiose. No entanto, como citado na Tabela 5.21, as médias seguidas de pelo menos uma letra em comum não diferem entre si, pelo teste de Tukey, ao nível de significância de $5 \%$ de probabilidade $(\mathrm{p}<0,05)$. Neste caso, somente o ensaio com 0,5 g.L $\mathrm{L}^{-1}$ celobiose diferiu dos demais ensaios pelo teste de Tukey, sendo estatisticamente significativo. Portanto, em relação a produção de $\mathrm{H}_{2}$, numericamente, a maior produção foi observada no ensaio com 3,5 g. $\mathrm{L}^{-1}$, mas não diferiu estatisticamente dos ensaios com 2,0, 5,0 e 6,5 g.L. $\mathrm{L}^{-1}$ de cellobiose, assumindo-se que houve aumento da produção de hidrogênio from 0,5 to 6,5 g. $\mathrm{L}^{-1}$. Semelhante ao presente estudo, Eker e Sarp (2017) avaliaram a produção de hidrogênio com diferentes concentrações de resíduo de papel, e observaram aumento da produção de $\mathrm{H}_{2}$ de 3,84 até 45,5 g.L $\mathrm{L}^{-1}$ de substrato. Neste intervalo, a 
maior produção de hidrogênio acumulada $\left(57,6 \mathrm{mmol} . \mathrm{L}^{-1}\right)$ foi obtida para 18,9 g.L $\mathrm{L}^{-1}$ de resíduo de papel. Song et al. (2013) observaram efeito adverso; isto é, diminuição na produção de $\mathrm{H}_{2}$ de 253,8 para $107 \mathrm{~mL}$ de Bacillus sp. FS2011 utilizando 5 e 30 g.L.-1 de glicose. Segundo Yin e Wang (2016), o aumento na concentração de substrato pode levar ao aumento da produção de hidrogênio; no entanto, um nível muito mais alto de concentração de substrato pode afetar a atividade bacteriana.

Tabela 5.21. Efeito da concentração de celobiose nos parâmetros cinéticos na produção de hidrogênio, rendimento de $\mathrm{H}_{2}$, conversão do substrato, $\mathrm{pH}$ e crescimento celular.

\begin{tabular}{cccccccc}
\hline $\begin{array}{c}\text { Concentração } \\
\text { celobiose } \\
\left(\mathrm{g} . \mathrm{L}^{-1}\right)\end{array}$ & $\begin{array}{c}\text { Produção } \\
\text { acumulada } \\
\mathrm{H}_{2} \\
\mathrm{mmol} \cdot \mathrm{L}^{-1}\end{array}$ & $\begin{array}{c}\mathrm{Rm} \\
\mathrm{mmol}\end{array}$ & $\begin{array}{c}\lambda \mathrm{H}_{2} \\
(\mathrm{~h})\end{array}$ & $\begin{array}{c}\mathrm{YH}_{2} \\
\mathrm{~mL} \cdot \mathrm{L}^{-1} \\
\text { carb add }\end{array}$ & $\begin{array}{c}\mathrm{C}_{\mathrm{CT}} \\
(\%)\end{array}$ & $\begin{array}{c}\mathrm{pH} \\
\text { final }\end{array}$ & $\mathrm{A}_{600}$ \\
\hline 0,5 & $1,72 \pm 0,0^{\mathrm{b}}$ & $0,28 \pm 0,0^{\mathrm{b}}$ & $4,62 \pm 0,8^{\mathrm{a}}$ & $77,05^{\mathrm{c}}$ & $87,6 \pm 0,0$ & $6,7 \pm 0,0$ & 0,5 \\
2,0 & $17,00 \pm 0,6^{\mathrm{a}}$ & $4,72 \pm 1,3^{\mathrm{a}}$ & $5,68 \pm 0,3^{\mathrm{a}}$ & $190,46^{\mathrm{a}}$ & $93,0 \pm 0,0$ & $4,4 \pm 0,0$ & 0,9 \\
3,5 & $18,77 \pm 0,3^{\mathrm{a}}$ & $5,25 \pm 0,6^{\mathrm{a}}$ & $5,92 \pm 0,4^{\mathrm{a}}$ & $120,13^{\mathrm{b}}$ & $63,6 \pm 0,0$ & $4,3 \pm 0,0$ & 1,2 \\
5,0 & $17,25 \pm 2,3^{\mathrm{a}}$ & $3,80 \pm 0,4^{\mathrm{a}}$ & $5,80 \pm 0,2^{\mathrm{a}}$ & $77,30^{\mathrm{c}}$ & $62,0 \pm 0,1$ & $4,4 \pm 0,1$ & 1,1 \\
6,5 & $17,25 \pm 1,3^{\mathrm{a}}$ & $4,08 \pm 0,4^{\mathrm{a}}$ & $5,79 \pm 0,1^{\mathrm{a}}$ & $59,46^{\mathrm{c}}$ & $60,8 \pm 0,1$ & $4,6 \pm 0,1$ & 1,1 \\
\hline
\end{tabular}

Notas: Médias seguidas de pelo menos uma letra em comum não diferem entre si, pelo teste de Tukey, ao nível de significância de $5 \%$ de probabilidade $(\mathrm{p}<0,05) . R m=$ velocidade de produção de hidrogênio, $\lambda \mathrm{H}_{2}=$ tempo de início de produção de hidrogênio, $\mathrm{YH}_{2}=$ rendimento de hidrogênio, $\mathrm{C}_{\mathrm{CT}}=$ conversão de carboidratos totais, $\mathrm{A}_{600}=$ absorbância $600 \mathrm{~nm}$.

A conversão de carboidratos foi quase completa (>90\%) nos ensaios com baixa concentração de celobiose inicial, ou seja, de $93 \%$ para 2 g.L L $^{-1}$ de celobiose (Figura 5.53). A medida que aumentou a concentração de celobiose de 2,0 para $6,5 \mathrm{~g} \cdot \mathrm{L}^{-1}$ a conversão do substrato foi reduzida de $93 \%$ para $60,8 \%$. Ademais, para concentração de substrato acima de 2,0 g.L $\mathrm{L}^{-1}$ observou-se que a conversão de celobiose na faixa de 60-63\%. Pode-se inferir sob tais condições que a eficiência de conversão de carboidratos por Bacillus sp. RM1 foi inalterada entre 3,5 à 6,5 g.L $\mathrm{L}^{-1}$ de substrato. Provavelmente, para maior concentração de substrato inicial pode-se obter aumento da concentração celular. Tais condições contribuíram com a rápida estabilização do crescimento bacteriano e produção de $\mathrm{H}_{2}$, fazendo com que cessasse a conversão do substrato logo nas primeiras 13 horas de fermentação (Figura 5.53). Portanto, independente da concentração inicial de celobiose verificou-se para todos os ensaios concentração residual de celobiose, principalmente nos ensaios com $>3.5$ g. $\mathrm{L}^{-1}$ de celobiose inicial. 


\section{Universidade de São Paulo \\ Escola de Engenharia de São Carlos \\ Programa de Pós-graduação em Hidráulica e Saneamento}

Figura 5.53. Produção de hidrogênio e conversão de carboidratos a partir de Bacillus sp. RM1 em diferentes concentrações de celobiose (A) 0,5 g.L $\mathrm{L}^{-1}$ (B) 2,0 g.L $\mathrm{L}^{-1}$ (C) 3,5 g.L (D) $^{-1}$ (D) 5,0 g.L $\mathrm{L}^{-1}$ (E) 6,5 g.L. ${ }^{-1}$.
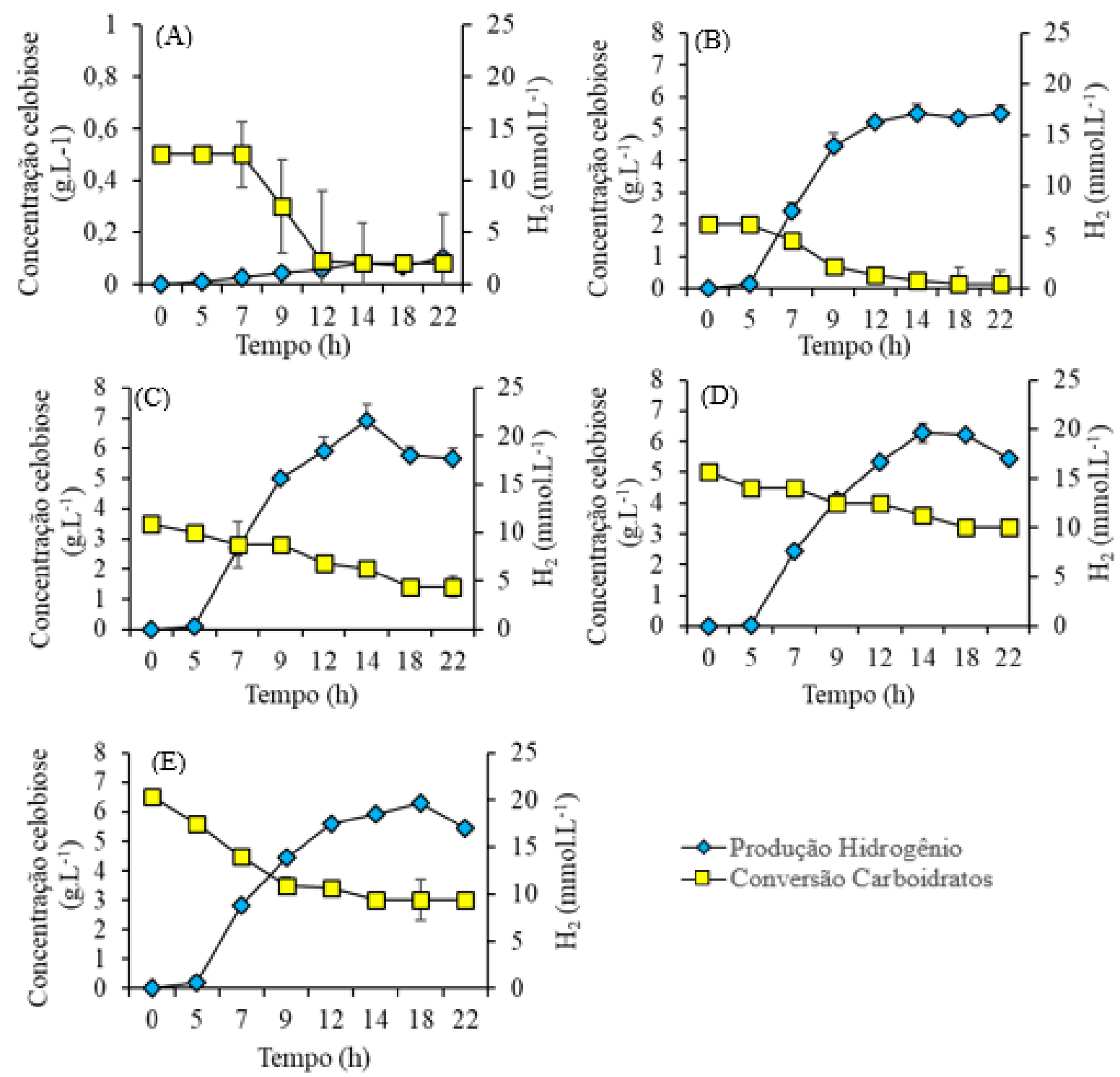

\section{$\multimap-$ Produção Hidrogênio \\ $\dashv-$ Conversão Carboidratos}

Observou-se aumento do rendimento de hidrogênio $\left(\mathrm{YH}_{2}\right)$ de 51,37 para 126,93 mL.g${ }^{1}$ carboidratos quando aumentou a concentração de celobiose de 0,5 para 2,0 g.L $\mathrm{L}^{-1}$. Entretanto, quando aumentou a concentração de celobiose de 2,0 g.L $\mathrm{L}^{-1}$ para 3,5, 5,0 e 6,5 g.L $\mathrm{L}^{-1}$ verificou-se redução do $\mathrm{YH}_{2}$ para 80,08, 51,52 e 39,63 mL.g ${ }^{-1}$, respectivamente. Alguns autores (Sharma e Li, 2009; Cappelletti et al., 2011; Rosa e Silva, 2017; Fonseca et al., 2018) também observaram diminuição do rendimento do hidrogênio quando aumentaram a concentração da fonte inicial de carbono. Esses autores concluíram que o aumento da concentração do substrato favorece a síntese de ácidos carboxílicos, por sua vez, o acúmulo destes ácidos pode levar a diminuição do pH e consequentemente inibição da biomassa fermentativa, justificando a diminuição do 
valor do pH inicial de 7 para abaixo de 5,0 nos ensaios com maior concentração de celobiose (2-6,5 g.L $\left.\mathrm{L}^{-1}\right)$, enquanto no ensaio com menor concentração $\left(0,5\right.$ g.L $\left.\mathrm{L}^{-1}\right)$ o $\mathrm{pH}$ foi de 7 para 6,7 (Tabela 5.21). Diminuição do pH com aumento da concentração do substrato também foi relatada por Sharma e Li (2009). Os autores verificaram diminuição do pH de 5,5 para 3,5 utilizando 20 g.L $\mathrm{L}^{-1}$ de glicose e de 5,5 para 5,4 utilizando 1 g.L $\mathrm{L}^{-1}$ de glicose. Sendo assim, podese inferir que o aumento da concentração do substrato influencia diretamente no processo de acidificação do meio, estabelecendo relação inversa entre o rendimento de $\mathrm{H}_{2}$ e a concentração de substrato.

A diminuição do rendimento de hidrogênio com aumento da concentração inicial de celobiose também pode ser justificada pela pressão parcial de $\mathrm{H}_{2}$ exercida no headspace, ou seja, o aumento da concentração de substrato de 0,5 para 6,5 g. $\mathrm{L}^{-1}$ proporcionou o aumento da produção de $\mathrm{H}_{2}$ de 1,72 para 17,25 mmol.L ${ }^{-1}$, cerca de 10 vezes mais. A alta produção de $\mathrm{H}_{2}$ nesses ensaios pode ter contribuído com o aumento da pressão parcial de $\mathrm{H}_{2}$ inibindo as reações de fermentação refletindo em baixos rendimentos de hidrogênio (Rosa e Silva, 2017).

Os principais metabólitos observados a partir desta cepa foram ácido acético (HAc), butírico $(\mathrm{HBu})$, capróico $(\mathrm{HCa})$ e etanol $(\mathrm{EtOH})$ (Figura 5.54). Observou-se que o HCa foi o primeiro ácido a ser produzido $(2 \mathrm{~h})$ após o início da fermentação e manteve-se até o final da fermentação em todos os ensaios. Nas primeiras $6 \mathrm{~h}$ de fermentação pouco substrato foi convertido em ácidos carboxílicos consistindo com a baixa produção de $\mathrm{H}_{2}$ neste mesmo período. Observou-se predominância do HAc e HBu após 9 h de fermentação, exceto no ensaio com maior concentração de celobiose $\left(6,5 \mathrm{~g} \cdot \mathrm{L}^{-1}\right)$, em que houve maior produção destes ácidos com $11 \mathrm{~h}$ de operação. A maior concentração de ácidos $\mathrm{HAc}$ e $\mathrm{HBu}$ foram obtidas principalmente com 2 e 3,5 g.L.-1 de celobiose, correspondendo aos ensaios com maior produção de $\mathrm{H}_{2}$ e conversão de carboidratos. Com a predominância destes ácidos nos ensaios, ficou evidente que o processo de produção de hidrogênio seguiu a rota ácido acético/butírico.

A rota do ácido butírico é considerada a principal via fermentativa de produção de $\mathrm{H}_{2}$, em contraste com a produção de ácido propiônico (Zhao et al., 2010). Neste trabalho, valores abaixo do limite de detecção do método cromatográfico foram obtidos para o ácido propiônico $\left(<5 \mathrm{mg} . \mathrm{L}^{-1}\right)$. Isso provavelmente ocorreu devido à alteração da via metabólica com a produção de etanol, ácido acético, butírico e capróico. Segundo Dareioti et al., (2014) a produção de ácido propiônico é favorecida em pH superior a 7,0. Neste caso, as fermentações com Bacillus sp. RM1 foram realizados em $\mathrm{pH}$ inicial 7,0. 
Figura 5.54. Ácidos carboxílicos e etanol na fermentação com celobiose a partir de crescimento de Bacillus sp. RM1 (A) 0,5 g.L $\mathrm{L}^{-1}$, (B) 2,0 g.L $\mathrm{L}^{-1}$ (C) 3,5 g.L $\mathrm{L}^{-1}$, (D) 5,0 g.L $\mathrm{L}^{-1}$ e (E) 6,5 g.L $\mathrm{L}^{-1}$.
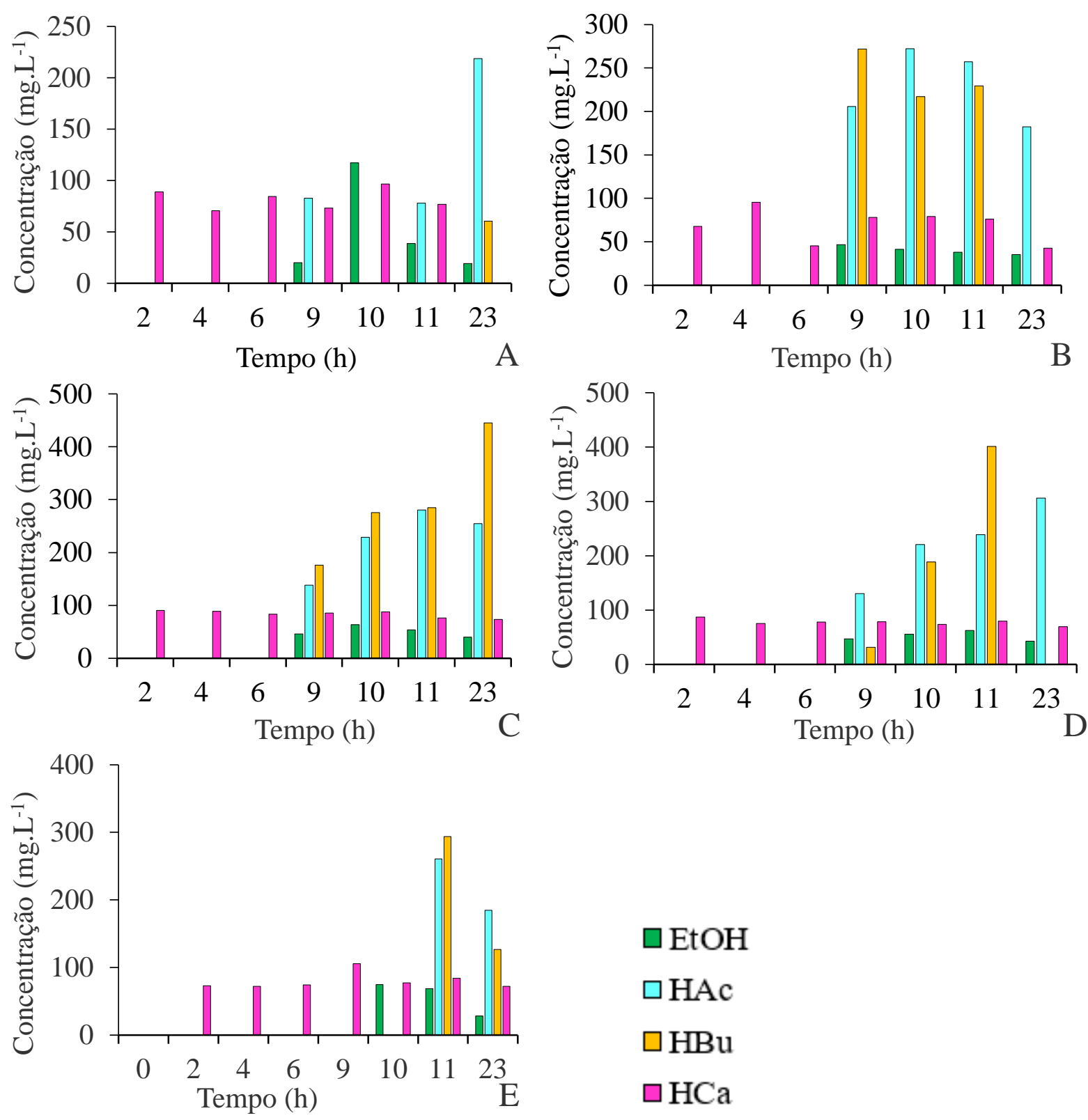

De acordo com Fonseca et al. (2018), o início da solventogênese tem sido principalmente correlacionada com a concentração de ácido butírico não dissociado no meio em baixos valores de $\mathrm{pH}(<5.0)$. Nesta pesquisa, foi observada menor concentração de etanol em todos os ensaios, com produção máxima de 117,19 mg. $\mathrm{L}^{-1}$ no ensaio com 0,5 g.L $\mathrm{L}^{-1}$ de celobiose, correspondendo ao ensaio com menor produção de $\mathrm{H}_{2}$. Sob tais condições pode-se inferir que em menor concentração de substrato o fluxo de carbono foi direcionado para a 
Universidade de São Paulo

Escola de Engenharia de São Carlos

Programa de Pós-graduação em Hidráulica e Saneamento

produção de álcool favorecendo a rota solventogênica, divergindo dos resultados obtidos por Ginkel et al. (2001), em que obtiveram maior produção de etanol e menor rendimento de hidrogênio nos ensaios com maior concentração de substrato.

\subsubsection{Substituição de açúcares simples por resíduo de banana na produção de hidrogênio}

O uso de matéria-prima rica em amido, que é prontamente hidrolisada em carboidratos simples, é particularmente conveniente para produção de hidrogênio. Sendo assim, o melhor substrato orgânico a ser utilizado deve conter alto conteúdo de carboidratos prontamente disponíveis.

Observou-se que o aumento da produção de $\mathrm{H}_{2}$ ocorreu simultaneamente ao crescimento de Bacillus sp. RM (Figura 5.55). A produtividade máxima de hidrogênio (31,7 mmol H foi obtida para velocidade de produção $(R m)$ igual a $2,7 \mathrm{mmol} \mathrm{H}_{2} \cdot \mathrm{L}^{-1}$.h. Do mesmo modo, Saidi et al. (2018) obtiveram produção total de $\mathrm{H}_{2}$ de 139 mmol.L $\mathrm{L}^{-1}$ utilizando resíduos de frutas e vegetais como fonte de carbono e energia. Os autores relataram também que o uso de resíduo de frutas e vegetais pode substituir componentes $\left(\mathrm{CaCl}_{2}, \mathrm{MgCl}_{2}\right.$, extrato de levedura, $\mathrm{KH}_{2} \mathrm{PO}_{4}$ e $\mathrm{K}_{2} \mathrm{HPO}_{4}$ ) presentes em meios de cultivo. A alta produção de $\mathrm{H}_{2}$ obtida pelos autores pode ser decorrente da utilização de variedade de frutas e vegetais misturados (tomate, batata, cenoura, maça, pera e ameixa) aumentando a variedade de açúcares disponíveis.

Figura 5.55. Curva de crescimento e produção de hidrogênio a partir de Bacillus sp. RM1 utilizando resíduo de banana em reator em batelada.

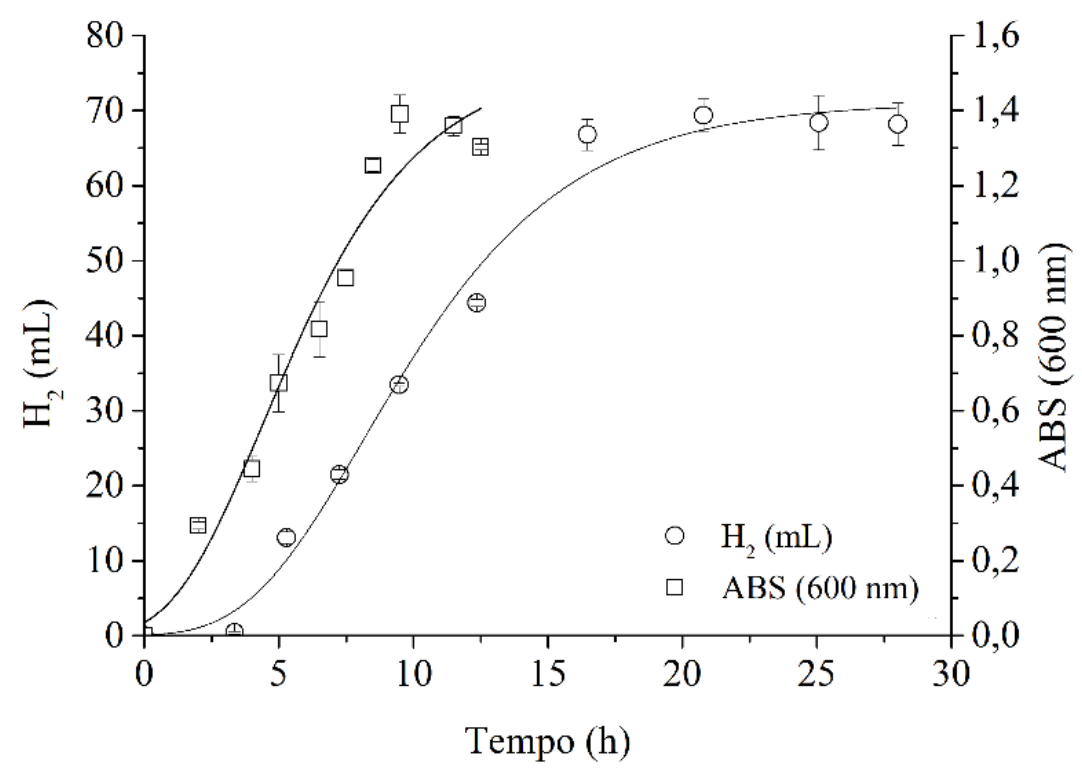




\section{Universidade de São Paulo \\ Escola de Engenharia de São Carlos \\ Programa de Pós-graduação em Hidráulica e Saneamento}

O perfil de crescimento celular seguiu a mesma tendência da produção de $\mathrm{H}_{2}$, cujos valores máximos foram obtidos após 20 horas de fermentação. O tempo reduzido de início da fermentação $\left(\lambda \mathrm{H}_{2}\right)$ de 3,9 h pode ser devido a utilização de biomassa proveniente do próprio resíduo, propiciando a rápida adaptação da biomassa ao substrato (RB). De acordo com Lin et al. (2017) bactérias autóctones tem maior capacidade de adaptação ao usar sua própria biomassa vegetal para seu crescimento e metabolismo, quando comparado a aplicação em outros tipos de substrato.

$\mathrm{O}$ rendimento de hidrogênio $\mathrm{YH}_{2}\left(\mathrm{~mL} \mathrm{H}_{2} \mathrm{~g}^{-1}\right.$ carboidrato adicionado) neste estudo foi calculado baseando-se na concentração de carboidratos totais iniciais contidos no RB em relação a produção acumulada de hidrogênio. $\mathrm{O} \mathrm{YH}_{2}$ máximo foi de 94,66 $\mathrm{mL} \mathrm{H}_{2} \mathrm{~g}^{-}$ ${ }^{1}$ carboidratos, demonstrando o potencial da cepa isolada na conversão de resíduo frutícula em $\mathrm{H}_{2}$. Comparando-se o rendimento de $\mathrm{H}_{2}$ desta pesquisa aos reportados na literatura utilizando diferentes resíduos vegetais (Tabela 5.22) verificou-se que Feng et al. (2010) e Keskin et al. (2018) obtiveram rendimentos de $101,08 \mathrm{~mL} \mathrm{H}_{2} \mathrm{~g}^{-1} \mathrm{ST}$ e $76 \mathrm{~mL} \mathrm{H}_{2} \mathrm{~g}^{-1} \mathrm{SV}$, respectivamente, na fermentação de resíduos de maça e resíduos de frutas e vegetais em reatores em batelada, pH inicial 7,0 e consórcio de bactérias como inóculo.

Tabela 5.22. Rendimento de hidrogênio em reatores em batelada utilizando diferentes resíduos vegetais como fonte de carbono.

\begin{tabular}{cccccc}
\hline Substrato & $\mathbf{p H}$ & Temperatura & Inóculo & Rendimento $\mathrm{H}_{2}$ & Referência \\
\hline Maça & 7,0 & $37^{\circ} \mathrm{C}$ & $\begin{array}{c}\text { consórcio de } \\
\text { bactérias }\end{array}$ & $101,08 \mathrm{ml} \cdot \mathrm{g}^{-1} \mathrm{ST}$ & $\begin{array}{c}\text { Feng et al. } \\
\text { (2010) }\end{array}$ \\
\hline $\begin{array}{c}\text { Resíduo de } \\
\text { alimentos }\end{array}$ & 6,0 & $37^{\circ} \mathrm{C}$ & Co-cultura & $362 \mathrm{~mL} \mathrm{H}_{2} \mathrm{~g}^{-1} \mathrm{VS}$ & $\begin{array}{c}\text { Kanchanasuta } \\
\text { et al. (2017) }\end{array}$ \\
\hline $\begin{array}{c}\text { Resíduo de } \\
\text { palma }\end{array}$ & 6,5 & $35^{\circ} \mathrm{C}$ & $\begin{array}{c}\text { Bacillus } \\
\text { anthracis }\end{array}$ & $236 \mathrm{~mL} \mathrm{H}_{2} \mathrm{~g}^{-1} \mathrm{DQO}$ & $\begin{array}{c}\text { Mishra et al. } \\
\text { (2017) }\end{array}$ \\
\hline $\begin{array}{c}\text { Resíduos de } \\
\text { frutas e } \\
\text { vegetais }\end{array}$ & 7,0 & $55^{\circ} \mathrm{C}$ & $\begin{array}{c}\text { consórcio de } \\
\text { bactérias }\end{array}$ & $76 \mathrm{~mL} \mathrm{H}_{2} \cdot \mathrm{g}^{-1} \mathrm{VS}$ & $\begin{array}{c}\text { Keskin et al. } \\
(2018)\end{array}$ \\
\hline $\begin{array}{c}\text { Resíduo de } \\
\text { banana }\end{array}$ & 7,0 & $37^{\circ} \mathrm{C}$ & Bacillus sp. & $142,02 \mathrm{~mL} \mathrm{H}_{2} \cdot \mathrm{g}^{-1} \mathrm{CT}$ & $\begin{array}{c}\text { Presente } \\
\text { pesquisa }\end{array}$ \\
\hline
\end{tabular}


Universidade de São Paulo

Escola de Engenharia de São Carlos

Programa de Pós-graduação em Hidráulica e Saneamento

A temperatura está intimamente relacionada ao metabolismo microbiano, afetando as vias metabólicas relacionadas a taxa de crescimento do microrganismo, hidrólise do substrato e taxa de produção de hidrogênio (Elsharnouby et al., 2013). Assim como na presente pesquisa, Kanchanasuta et al. (2017) e Mishra et al. (2017) evidenciaram que condições mesofílicas são ideais para a produção de $\mathrm{H}_{2}$ utilizando resíduos vegetais como fonte de carbono. Além disso, a utilização de cepas isoladas ao invés de consórcio de bactérias tem contribuído com rendimentos de $\mathrm{H}_{2}$ superiores, evitando os desvios de rotas metabólicas, competição por substrato e consumo de $\mathrm{H}_{2}$. Antonopoulou et al. (2007) estudaram o papel das culturas puras e mistas na produção de hidrogênio a partir de extrato de sorgo. Os autores relataram maior rendimento de hidrogênio utilizando Ruminococcus albus do que utilizando consórcio de bactérias.

No presente estudo verificou-se que após 20 h de fermentação ocorreu estabilização da produção de hidrogênio e do crescimento celular, além de diminuição gradual em função do tempo (Figura 5.55) Esta diminuição na produção pode ser devido à acumulação de metabólitos que reduziram a atividade metabólica da biomassa.

Verificou-se maior concentração de ácidos carboxílicos e etanol após $6 \mathrm{~h}$ de fermentação, correspondendo a fase exponencial de crescimento celular e produção de $\mathrm{H}_{2}$ (Tabela 5.23).

Tabela 5.23. Distribuição dos principais produtos de fermentação observados durante a operação de reatores anaeróbios em batelada alimentados com resíduos de banana $\left(5 \mathrm{~g} \mathrm{~L}^{-1}\right)$ inoculados com Bacillus sp. RM1.

\begin{tabular}{ccccc}
\hline \multirow{2}{*}{$\begin{array}{c}\text { Metabólitos } \\
\left(\mathrm{g} . \mathrm{L}^{-1}\right)\end{array}$} & $4 \mathrm{~h}$ & $6 \mathrm{~h}$ & $10 \mathrm{~h}$ & $24 \mathrm{~h}$ \\
\cline { 2 - 5 } & 0,06 & 0,24 & 0,08 & 0,03 \\
\hline Etanol & 0,34 & 0,46 & 0,35 & 0,48 \\
$\mathrm{HAc}$ & 0,22 & 0,40 & 0,53 & 0,39 \\
$\mathrm{HBu}$ & 0,07 & 0,77 & 0,84 & 0,81 \\
$\mathrm{HCa}$ & & & & \\
\hline
\end{tabular}

A maior concentração de $\operatorname{HAc}\left(0,48\right.$ g.L $\left.\mathrm{L}^{-1}\right)$ e $\mathrm{HBu}\left(0,53\right.$ g.L $\left.\mathrm{L}^{-1}\right)$ foi obtida em 24 e $10 \mathrm{~h}$ de fermentação, respectivamente, indicando o predomínio desta rota e sua importância com a produção de $\mathrm{H}_{2}$. Além disso, nas primeiras $6 \mathrm{~h}$ de fermentação verificou-se aumento do etanol 


\author{
Universidade de São Paulo \\ Escola de Engenharia de São Carlos \\ Programa de Pós-graduação em Hidráulica e Saneamento
}

e depois diminuição gradual até o final da fermentação. Choonut et al (2014) também relataram a produção de etanol a partir de casca de abacaxi hidrolisado, sugerindo esse tipo de resíduo como fonte de carbono para produção deste solvente. Provavelmente, o etanol foi convertido em ácido acético e $\mathrm{H}_{2}$ através da acetogênese e/ou pode ter sido utilizado como doador de elétrons para produção de ácido butírico e ácido capróico como já mencionado anteriormente. Sob tais condições, observou-se aumento da concentração de metabólitos, quando houve diminuição da concentração de etanol com o tempo de fermentação. Houve aumento gradativo da produção de ácido capróico durante a fermentação de resíduo de banana, obtendo-se concentração máxima de 0,84 g.L $\mathrm{L}^{-1}$. Como a produção de HCa está intimamente relacionada com o consumo de ácido acético, o aumento da concentração do $\mathrm{HCa}$ de 0,77 para 0,84 g.L -1 $^{-1}$ em 10 h de fermentação justifica a redução de HAc de 0,46 para 0,35 g.L $\mathrm{L}^{-1}$ no mesmo período.

Corroborando com esta pesquisa, Feng et al. (2010) também relataram a produção de $\mathrm{H}_{2}$ acoplada a produção de ácido acético, propiônico, butírico e etanol ao final da fermentação utilizando bagaço de maça (BM) como substrato. Nathoa et al. (2014) também observaram que o principal produto da fermentação a partir de casca de banana foi o ácido acético, embora etanol e ácido propiônico também tenham sidos observados em pequenas concentrações durante a rota de produção de $\mathrm{H}_{2}$. Alibardi e Cossu (2016) relataram a predominância da via butírica/acética em substratos com alto teor de carboidratos quando comparada aos substratos com baixos teores, reforçando que a utilização de resíduo de frutas em processos fermentativos é ótima alternativa para obtenção de subprodutos de interesse biotecnológico.

\title{
5.6.5. Conclusão sub-hipótese 4
}

Bactérias anaeróbias facultativas semelhantes a Bacillus sp. foi identificada, com tempo de geração (Tg) e taxa de crescimento de $0,43 \mathrm{~h} \mathrm{e} 1,60 \mathrm{~h}^{-1}$, respectivamente, a partir da glicose. Entre os substratos orgânicos puros avaliados (glicose, xilose, manose, galactose, frutose, maltose, celobiose, sacarose e amido), obteve-se o melhor rendimento em $\mathrm{H}_{2}$ de 53,01 $\mathrm{mL} \mathrm{H}_{2} \cdot \mathrm{g}^{-}$ ${ }^{1}$ carboidratos com dissacarídeo maltose. O menor rendimento de hidrogênio foi observado com monossacarídeo manose $\left(32,28 \mathrm{~mL} \mathrm{H}_{2} \cdot \mathrm{g}^{-1}\right.$ carboidrato adicionado). No ensaio utilizando resíduos de banana, foram obtidos $P$ e $\mathrm{YH}_{2}$ máximos de 31,7 mmol.L $\mathrm{L}^{-1}$ e 94,66 mL de $\mathrm{H}_{2} \mathrm{~g}^{-1}$ carboidratos, respectivamente. Maiores concentrações iniciais de celobiose (3,5-6,5 g.L $\left.\mathrm{L}^{-1}\right)$ favoreceram a produção de $\mathrm{H}_{2}$, mas diminuíram o rendimento de $\mathrm{H}_{2}\left(80,08-39,63 \mathrm{~mL} \mathrm{H} \mathrm{H}_{2} \cdot \mathrm{g}^{-1}\right.$ carboidrato adicionado) e conversão de substrato $(63,6-60,8 \%)$. A via metabólica da produção 
Universidade de São Paulo

Escola de Engenharia de São Carlos

Programa de Pós-graduação em Hidráulica e Saneamento

de hidrogênio por Bacillus sp. RM1 do resíduo de banana foi a via acética/butírica com produção máxima de 487,69 g HAc.L ${ }^{-1}$ e 535,88 g HBu.L ${ }^{-1}$ e etanol (248,74 g.L L $\left.^{-1}\right)$.

Neste ponto, os resultados obtidos nesta etapa permitem desdizer a quarta e última subhipótese "A produção de hidrogênio utilizando uma cepa bacteriana pura é maior quando comparado a produção utilizando consórcio de bactérias a partir do resíduo de banana.", uma vez que a produção de $\mathrm{H}_{2}$ para o isolado $(71 \mathrm{~mL})$ foi similar a produção obtida utilizando o consórcio de bactérias $(70 \mathrm{~mL})$. Portanto, foi demonstrada que a maior ou menor produção de hidrogênio nesta pesquisa não esta unicamente ligada à utilização de cepas isoladas ou consórcio de bactérias, mas principalmente ao tipo de substrato utilizado como fonte de carbono e as condições operacionais impostas ao reator. 


\author{
Universidade de São Paulo \\ Escola de Engenharia de São Carlos \\ Programa de Pós-graduação em Hidráulica e Saneamento
}

\title{
6. CONSIDERAÇÕES FINAIS - HIPÓTESES
}

A fim de comparar a produção de hidrogênio obtidas durante as etapas dessa pesquisa, buscou-se compilar os resultados e relacioná-los aos objetivos previamente elaborados. Para facilitar, de modo geral, a comparação dos resultados, os dados de produção de $\mathrm{H}_{2}\left(\mathrm{~mL} \mathrm{H} \mathrm{H}_{2}\right)$ foram convertidos em concentração de $\mathrm{H}_{2}\left(\mathrm{~mL} \mathrm{H}_{2} \cdot \mathrm{L}^{-1}\right)$ e suas respectivas condições experimentais estão apresentados na Tabela 5.24.

$\checkmark \quad$ Primeiramente, o cumprimento do objetivo 1 "Avaliar as características fisicoquímicas dos resíduos de banana como única fonte de carbono para fermentação" contribuiu para elucidação da constituição nutricional no RB, no qual possibilitou avaliar o emprego deste substrato na produção de $\mathrm{H}_{2}$ e metabólitos solúveis (ácidos carboxílicos e etanol) (Objetivo 2 “Avaliar a produção de $\mathrm{H}_{2}$ e metabólitos orgânicos a partir de bactérias autóctones dos resíduos da banana" no qual resultou em concentração máxima de $\mathrm{H}_{2}$ de $10 \mathrm{~mL} \cdot \mathrm{L}^{-1}$. No entanto, como essa concentração não foi satisfatória, surgiu a necessidade de avaliar se a adição de componentes nutricionais beneficiaria o consórcio de bactérias hidrogenogênicas e por fim aumentaria a produção de $\mathrm{H}_{2}$. Neste momento foi cumprido o objetivo 3 "Avaliar a produção de hidrogênio em reatores em batelada sob diferentes condições nutricionais" no qual obtevese resultado positivo, com aumento significativo de 12,04 vezes na produção de hidrogênio, passando de 10 para 120,4 $\mathrm{mL} \mathrm{H}_{2} \cdot \mathrm{L}^{-1}$ quando o meio de cultivo PCS foi utilizado.

Com esse resultado satisfatório, optou-se por utilizar o meio de cultivo PCS para as próximas etapas da pesquisa. Com o objetivo de maximizar a produção de $\mathrm{H}_{2}$, propôs-se avaliar o efeito das variáveis $\mathrm{pH}$, temperatura, concentração de carboidratos, headspace e inóculo na produção de $\mathrm{H}_{2}$ e estabelecer os intervalos adequados a serem estudados em planejamento fatorial completo (DCCR). A concentração máxima obtida nesta etapa foi de $253,86 \mathrm{~mL} \mathrm{H}_{2} \cdot \mathrm{L}^{-}$ ${ }^{1}$ nas condições de operação de $\mathrm{pH} 7,5,44^{\circ} \mathrm{C} .15$ g.L $\mathrm{L}^{-1}$ de carboidratos totais, $40 \%$ headspace e $15 \%$ inóculo. Esta concentração foi superior a obtida nas etapas anteriores, sendo 2,11 vezes maior que a etapa na qual avaliou-se os diferentes meios de cultivo, demonstrando que o estudo prévio das condições operacionais do reator é importante quando se deseja melhorar o processo em questões operacionais. Contudo, verificou-se que dentre as variáveis avaliadas $\mathrm{pH}$, temperatura e headspace foram estatisticamente significativas $(\mathrm{p}<0,05)$, enquanto as demais variáveis (concentração de carboidratos e inóculo) não tiveram efeito significativo $(p>0,05)$ na produção de $\mathrm{H}_{2}$. Portanto, através de planejamento de Plackett-Burman (PB) foi estabelecido que dentre a faixa estudada, a concentração de carboidratos se fixaria a 5 g.L $\mathrm{L}^{-1}$ e que o volume de inóculo seria de $10 \%$ em relação ao meio reacional. Além disso, optou-se por fixar o 
headspace em $40 \%$ (v/v) e otimizar somente as condições operacionais relacionadas ao $\mathrm{pH}$ e temperatura.

Deste modo, para otimização da produção de hidrogênio foi utilizado o delineamento composto central rotacional (DCCR) cujas variáveis estudadas foram apenas aquelas estatisticamente significativas no planejamento de Plackett-Burman. A partir disso, $\mathrm{pH}$ e temperatura foram avaliadas em faixa de $\mathrm{pH}$ entre 5,09 e 7,91 e de temperatura entre 27,1 e $46,9^{\circ} \mathrm{C}$. A maior produção de $\mathrm{H}_{2}$ de $416,2 \mathrm{~mL}^{-1} \mathrm{~L}^{-1}$ foi obtida na condição operacional de $\mathrm{pH} 6,5$ e temperatura $37^{\circ} \mathrm{C}$. Tal resultado foi 1,64 vezes superior ao obtido no planejamento anterior (PB) demonstrando que o emprego de estratégias experimentais possibilita a maximização da produção de $\mathrm{H}_{2}$. A partir da análise de superfície de resposta foi possível verificar que a faixa ótima de $\mathrm{pH}$ esteve entre 6,42 e 7,40 e para temperatura entre 34,30 e $39,8^{\circ} \mathrm{C}$. Com isso, obtevese 467,93 mL.L ${ }^{-1}$ de $\mathrm{H}_{2}$ nas condições otimizadas ( $\mathrm{pH}$ 7,0 e $37^{\circ} \mathrm{C}$ ), sendo 1,12 vezes superior a máxima obtida no DCCR. Tal condição foi satisfatória e confiável $\left(\mathrm{R}^{2}=99,47 \%\right)$ e pode-se concluir o objetivo 4 "Otimizar a produção de hidrogênio a partir do resíduo de banana como fonte de carbono." no qual foi atingido máxima produção de $\mathrm{H}_{2}$ por meio da otimização das condições operacionais.

A partir da análise dos genes das bactérias presente no consórcio fermentativo, observou-se que o consórcio foi predominantemente constituído por bactérias do gênero Lactobacillus e Clostridium, nas quais foram responsáveis pela produção de $\mathrm{H}_{2}$, ácidos carboxílicos e etanol durante a operação dos reatores. Observou-se que em condições ácidas $(\mathrm{pH}<5,5)$ houve predominância de Lactobacillus no qual resultou na alta produção de ácido lático e etanol, enquanto o aumento do $\mathrm{pH}$ para 6,5-7,5 contribuiu com a predominância de Clostridium, no qual resultou em maiores produções de $\mathrm{H}_{2}$. Com estas observações finalizamos o objetivo 5 "Avaliar o perfil taxonômico e funcional da biomassa fermentativa sob efeito das condições operacionais do reator" e concluímos que o pH é uma variável importante, no qual influência no estabelecimento de uma comunidade microbiana e favorece algumas rotas metabólicas.

Por último, foi isolada a bactéria Bacillus sp. e aplicou-se a fermentação com resíduo de banana em $\mathrm{pH} 7,0$ e $37^{\circ} \mathrm{C}$ afim de comparar a produção de $\mathrm{H}_{2}$ com o consórcio de bactérias. Obteve-se 473,38 $\mathrm{mL} \mathrm{H} \mathrm{H}_{2} \cdot \mathrm{L}^{-1}$, cerca de 1 vez superior que a obtida pelo consórcio de bactérias, inferindo que não houve diferença significativa na produção entre o isolado e o consórcio de bactérias. Com isso, finaliza-se o objetivo 6 "Isolar, identificar e caracterizar estirpe de bactéria produtora de $\mathrm{H}_{2}$ e comparar seu potencial na produção de hidrogênio com o consórcio 


\section{Universidade de São Paulo \\ Escola de Engenharia de São Carlos \\ Programa de Pós-graduação em Hidráulica e Saneamento}

de bactérias" e concluiu-se que, levando em consideração o alto custo experimental na utilização de cepas puras quando comparado a utilização de consórcios, o emprego do consórcio de bactérias autóctones é mais viável que o emprego de Bacillus sp. na fermentação de resíduo de banana para produção de $\mathrm{H}_{2}$.

Com o cumprimento de todos os objetivos propostos podemos então responder as subhipóteses formuladas nas etapas iniciais da presente pesquisa:

Sub-hipótese 1: O resíduo de banana in natura (casca e polpa) servirá como fonte de carbono e de bactérias fermentativas autóctones.

- Tendo em vista que a fermentação natural do resíduo de banana possibilitou a obtenção de biomassa fermentativa hidrogenogênica sem nenhuma necessidade de adição de fonte externa de inóculo ou fonte de carbono, pode-se concluir que a presente sub-hipótese foi aceita.

Sub-hipótese 2: A adição de componentes nutricionais ao resíduo de banana pode influenciar o metabolismo bacteriano e consequentemente aumentar a produção de hidrogênio.

- De fato, a produção de $\mathrm{H}_{2}$ foi melhor nos ensaios com adição de alguns componentes nutricionais, inferindo que a utilização de meio de cultivo na fermentação do resíduo de banana utilizando biomassa autóctone beneficia o metabolismo bacteriano resultando no aumento da produção de hidrogênio, e portanto, essa sub-hipótese também foi aceita.

Sub-hipótese 3: Estratégias sequenciais por meio de delineamento experimental auxiliará a maximização da produção de hidrogênio

- A utilização da metodologia de screening design para seleção de variáveis significativas, bem como o estabelecimento das faixas a serem estudadas, seguidas de planejmaneto fatorial completo (DCCR) foi extremamente importante e viável para chegar às condições operacionais ótimas e obter máxima produção de $\mathrm{H}_{2}$. Deste modo, esta sub-hipótese foi plenamente aceita.

Sub-hipótese 4: A produção de hidrogênio utilizando cepa bacteriana pura é maior quando comparad a produção utilizando consórcio de bactérias a partir do resíduo de banana.

- Neste caso, a máxima produção de $\mathrm{H}_{2}$ obtida utilizando Bacillus sp. e o consórcio de bactérias foram semelhantes, o que torna o processo vantajoso no ponto de vista econômico, em vista que a dificuldade na utilização de cepas puras está relacionada à necessidade de manter condições esterilizadas com consequentes requisitos energéticos. Deste modo, essa subhipótese não foi aceita. 
Universidade de São Paulo

Escola de Engenharia de São Carlos

Programa de Pós-graduação em Hidráulica e Saneamento

Tabela 6.1. Evolução da produção de hidrogênio mediante o emprego de estratégias experimentais previamente elaboradas pelas sub-hipóteses

\begin{tabular}{|c|c|c|c|c|c|}
\hline Etapa & Objetivo & $\begin{array}{c}\text { Condições } \\
\text { experimentais }\end{array}$ & $\begin{array}{c}\text { Produção de } \mathrm{H}_{2} \\
\left(\mathrm{~mL} . \mathrm{L}^{-1}\right)\end{array}$ & Resultado & $\begin{array}{c}\text { Conclusão sub- } \\
\text { hipóteses }\end{array}$ \\
\hline $\begin{array}{l}\text { Fermentação natural } \\
\text { (Sub-hipótese 1) }\end{array}$ & $\begin{array}{l}\text { Obter biomassa } \\
\text { fermentativa }\end{array}$ & $\begin{array}{c}37^{\circ} \mathrm{C} \\
\text { pH } 5,8 \\
\text { CT } 30 \text { g.L } \text { L }^{-1} \\
\text { Headspace } 50 \%\end{array}$ & 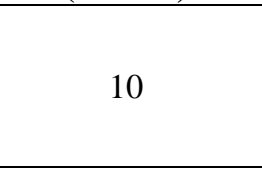 & - & \\
\hline $\begin{array}{l}\text { Seleção meio de cultivo } \\
\quad \text { (Sub-hipótese } 2)\end{array}$ & $\begin{array}{l}\text { Selecionar melhor meio de } \\
\text { cultivo para produção de } \\
\qquad \mathrm{H}_{2}\end{array}$ & $\begin{array}{c}\text { Meio de cultivo (PCS) } \\
37^{\circ} \mathrm{C} \\
\text { pH } 6,5 \\
\text { CT } 10 \text { g.L } \mathrm{L}^{-1} \\
\text { Inóculo } 10 \% \\
\text { Headspace } 50 \% \\
\end{array}$ & 120,4 & $12,04 \mathrm{x}$ & \\
\hline $\begin{array}{l}\text { Delineamento de Plackett-Burman } \\
\text { (PB) }\end{array}$ & $\begin{array}{l}\text { Selecionar variáveis } \\
\text { estatisticamente } \\
\text { significativas para } \\
\text { produção } \mathrm{H}_{2}\end{array}$ & $\begin{array}{c}44^{\circ} \mathrm{C} \\
\mathrm{pH} 7,5 \\
\mathrm{CT} 15 \mathrm{~g} . \mathrm{L}^{-1} \\
\text { Headspace } 40 \% \\
\text { Inóculo } 15 \%\end{array}$ & 253,86 & $2,11 \mathrm{x}$ & \\
\hline DCCR & Otimizar a produção de $\mathrm{H}_{2}$ & $\begin{array}{c}37^{\circ} \mathrm{C} \\
\text { Headspace } 40 \% \\
\text { Inóculo } 10 \% \\
\text { CT } 5 \text { g.L. } \\
\text { pH 6,5 }\end{array}$ & 416,2 & $1,64 x$ & \\
\hline $\begin{array}{l}\text { Validação experimental } \\
\text { (Sub-hipótese 3) }\end{array}$ & $\begin{array}{l}\text { Validar o modelo } \\
\text { mátematico obtido }\end{array}$ & $\begin{array}{c}\text { Headspace } 40 \% \\
\text { Inóculo } 10 \% \\
\text { CT } 5 \text { g.L.- } \\
37^{\circ} \mathrm{C} \\
\text { pH } 7,0 \\
\end{array}$ & 467,93 & $1,12 \mathrm{x}$ & \\
\hline $\begin{array}{l}\text { Isolamento e aplicação } \\
\text { (Sub-hipótese 4) }\end{array}$ & $\begin{array}{l}\text { Comparar a produção de } \\
\mathrm{H}_{2} \text { do isolado com o } \\
\text { consórcio de bactérias }\end{array}$ & $\begin{array}{c}\text { Headspace } 40 \% \\
\text { Inóculo } 10 \% \\
\text { CT } 5 \text { g.L } .^{-1} \\
37^{\circ} \mathrm{C} \\
\text { pH } 7,0\end{array}$ & 473,38 & $1,01 \mathrm{x}$ & \\
\hline
\end{tabular}

Nota: Em todas as etapas o resíduo de banana foi utilizado unicamente como fonte de carbono; $\mathbf{X}=$ resultado "x" vezes superior ao anterior. 


\section{Universidade de São Paulo \\ Escola de Engenharia de São Carlos \\ Programa de Pós-graduação em Hidráulica e Saneamento}

\section{CONCLUSÕES}

Não foi necessário a adição de fonte externa de inóculo, uma vez que a partir da da fermentação natural do resíduo de banana obteve-se consórcio microbiano, incluindo bactérias hidrolíticas, acidogênicas e acetogênicas.

A suplementação com meio de cultivo PCS $\left(\mathrm{NaCl}, \mathrm{CaCO}_{3}\right.$, peptona e extrato de levedura) resultou no aumento da produção de hidrogênio na fermentação do resíduo de banana utilizando biomassa autóctone.

$\checkmark \quad$ Houve aumento da produção de $\mathrm{H}_{2}$ mediante o emprego de estratégias experimentais (PB e DCCR).

$\mathrm{pH}$, temperatura e headspace foram as principais variáveis que afetaram a produção de $\mathrm{H}_{2}$ na fermentação de resíduo de banana utilizando biomassa autóctone.

$\checkmark \quad$ Foi obtida produção máxima de $\mathrm{H}_{2}$ de $70,19 \mathrm{~mL}$ nas condições otimizadas (pH 7,0 e $37^{\circ} \mathrm{C}$ ) utilizando o consórcio de bactérias fermentativas.

$\checkmark \quad$ Foi obtida produção máxima de $\mathrm{H}_{2}$ de $71 \mathrm{~mL}$ nas condições otimizadas (pH 7,0 e $37^{\circ} \mathrm{C}$ ) utilizando Bacillus sp. isolado do resíduo de banana.

$\checkmark \quad$ Independente das condições operacionais, os principais metabólitos solúveis observados durante a fermentação do resíduo de banana foram o ácido lático, acético e butírico.

$\checkmark \quad$ Em baixas condições de $\mathrm{pH}(<4,0)$ houve o desvio das rotas acidogênicas para a rota solventogênica, com produção de etanol.

$\checkmark$ As principais bactérias identificadas no inóculo foram associadas ao gênero Lactobacillus e Clostridium, sendo estas responsáveis pela produção de $\mathrm{H}_{2}$ e metabólitos solúveis em todos os ensaios, independentemente das condições operacionais dos reatores. Os principais genes identificados foram relacionados a enzimas associadas ao metabolismo de carboidratos, no qual contribuíram com a produção de $\mathrm{H}_{2}$, ácidos orgânicos e etanol a partir dos açúcares (glicose, frutose e sacarose) presente no resíduo de banana. 


\section{REFERÊNCIAS BIBLIOGRÁFICAS}

Abdel-Rahman, M., Tashiro, Y., Sonomoto, K. (2013). Recent advances in lactic acid production by microbial fermentation processes. Biotechnology advances, 31, 6, 877-902.

Abram, F. (2015) Systems-based approaches to unravel multi-species mirobial community functioning. Computational and Structural Biotechnology Journal, 13, 24-32. DOI: https://doi.org/10.1016/j.csbj.2014.11.009.

Adam, D., Lietzan, Yi., Lin, Martin St. Maurice. (2014) The role of biotin and oxamate in the carboxyltransferase reaction of pyruvate carboxylase. Archives of Biochemistry and Biophysics 562 (2014) 70-79.

Adorno, M.A.T., Hirasawa, J.S., Varesche, M.B.A. (2014) Development and Validation of Two Methods to Quantify Volatile Acids (C2-C6) by GC/FID: Headspace (Automatic and Manual) and Liquid-Liquid Extraction (LLE). American Journal of Analytical Chemistry., 5, 406-414.

Agler, M. T., Spirito, C. M., Usack, J. G., Werner, J. J., Angenent, L. T. (2012) Chain elongation with reactor microbiomes: upgrading dilute ethanol to medium-chain carboxylates. Energy and Environmental Science, 5, 8189-8192. DOI: 10.1039/c2ee22101b.

Akhlaghi, M., Bonia, M.R., De Gioannis, G. Muntoni, A., Polettini, A., Raffaella Pomi, R., Rossi, A., Spiga, D. (2017) A parametric response surface study of fermentative hydrogen production from cheese whey. Bioresource Technology., 244, 473-483.

Akolkar, S. K., Sajgure, A., Lele, S. S. (2005) Lactase production from Lactobacillus acidophilus. World J. Microbiol. Biotechnol, 21, 1119-1122.

Al-Shorgani, N. K. N., Mohd Isa, M. H., Wan Mohtar Wan Yusoff, W. M. W., Kalil, M. S., Hamid, A. A. (2016) Isolation of a Clostridium acetobutylicum strain and characterization of its fermentation performance on agricultural wastes. Renewable Energy, 86, 459-465.

Algapani, D. E., Wei Qiao, W. Q., Su, M., Pumpo, F., Wandera, S. M., Adani, F., Dong, R. (2016) Bio-hydrolysis and bio-hydrogen production from food waste by thermophilic and hyperthermophilic anaerobic process. Bioresource Technology, 216, 768-777. DOI: https://doi.org/10.1016/j.biortech.2016.06.016

Alibardi, L. and Cossu, R. (2016) Effects of carbohydrate, protein and lipid content of organic waste on hydrogen production and fermentation products. Waste Management. 47, 69-77. DOI: https://doi.org/10.1016/j.wasman.2015.07.049.

Aljundi, I. H., Belovich, J. M., Talu, O. (2005) Adsorption of lactic acid from fermentation broth and aqueous solutions on Zeolite molecular sieves. Chemical Engineering Science, 60, 5004-5009. DOI: https://doi.org/10.1016/j.ces.2005.04.034.

Aly, S. S., Imai, T., Salah Hassouna, M. S., Nguyen, D. M. K., Higuchi, T., Ariyo Kanno, A., Yamamoto, K., Akada, R., Sekine, M. (2018) Identification of factors that accelerate hydrogen production by Clostridium butyricum RAK25832 using casamino acids as a nitrogen source. Int. J. of hydrogen energy, 43, 53005313.

Amulya, K., Reddy, M.V., Venkata Mohan, S. (2014) Acidogenic spent wash valorization through polyhydroxyalkanoate (PHA) synthesis coupled with fermentative biohydrogen production. Bioresour. Technol. 158, 336-342.

An, D., Li, Q., Wang, X., Yang, H., Guo, L. (2014) Characterization on hydrogen production performance of a newly isolated Clostridium beijerinckii YA001 using xylose. International journal of hydrogen energy, 39, 19928-19936. DOI: https://doi.org/10.1016/j.ijhydene.2014.10.014. 


\author{
Universidade de São Paulo \\ Escola de Engenharia de São Carlos \\ Programa de Pós-graduação em Hidráulica e Saneamento
}

An, Q., Wang, J. L., Wang, Y. T., Lin, Z. L., \& Zhu, M. J. (2018) Investigation on hydrogen production from paper sludge without inoculation and its enhancement by Clostridium thermocellum. Bioresource Technology, 263, 120-127. DOI: https://doi.org/10.1016/j.biortech.2018.04.105.

Andrade, P. F de S. Análise da conjuntura agropecuária safra 2016/17 (2017) Fruticultura. Acesso em: http://www.agricultura.pr.gov.br/modules/conteudo/conteudo.php?conteudo=32 (20/08/2018).

Angenent, L. T., Karim, K., Al-Dahhan, M. H., Wrenn, B. A., Domiguez-Espinosa, R. (2004) Production of bioenergy and biochemicals from industrial and agricultural wastewater. Trends in Biotechnology, 4; 22, 477-485. DOI: https://doi.org/10.1016/j.tibtech.2004.07.001.

Alvarez-Guzman, C.L.; Balderas-Hernandez, V.E.; Gonzalez-Garcıa, R.; Ornelas-Salas, J.T.; Vidal-Limon, A.M.; Cisneros-dela Cueva, S.; De Leon-Rodriguez, A. (2017) Optimization of hydrogen production by the psychrophilic strain G088. International journal of hydrogen energy., 42, 3630-3640.

Antonopoulou, G., Ntaikou, I., Gavala, H. N., Skiadas, I. V., Angelopoulos, K., and Lyberatos, G. (2007) Biohydrogen production from sweet sorghum biomass using mixed acidogenic cultures and pure cultures of Ruminococcus albus. Global NEST Journal, 9, 144-151.

Antonopoulou, G., Vayenas, D., Lyberatos, G. (2016). Ethanol and hydrogen production from sunflower straw : The effect of pretreatment on the whole slurry fermentation. Biochemical Engineering Journal, 116, 116, $65-74$.

Anzola-Rojas, M. P., Fonseca, S. G., Silva, C. C., Oliveira, V. M., Zaiat, M. (2015) The use of the carbon/nitrogen ratio and specific organic loading rate as tools for improving biohydrogen production in fixed-bed reactors. Biotechnology Reports, 5, 46-54. DOI: https://doi.org/10.1016/j.btre.2014.10.010.

APHA. (2005) Standard Methods for the Examination of Water and Wastewater, $21^{\text {st }}$ ed. Am. Public Health Assoc., Washington D.C.

Argun, H. e Dao, S. (2016) Hydrogen gas production from waste peach pulp by dark fermentation and electrohydrolysis. International Journal of Hydrogen Energy., 41, 11568-11576.

Associação brasileira de empresas de limpeza pública e resíduos especiais (ABRELP). Panorama dos resíduos sólidos no brasil 2014. (2014). Grappa Editora e Comunicação, 28, 2014.

Atlas, R. M. Handbook of Media for Environmental Mycrobiology (2005).

Auta, H. S., Emenike, C. U., Jayanthia, B., Fauziah, S. H. (2018) Growth kinetics and biodeterioration of polypropylene microplastics by Bacillus sp. and Rhodococcus sp. isolated from mangrove sediment. Marine Pollution Bulletin, 127, 15-21. DOI: https://doi.org/10.1016/j.marpolbul.2017.11.036.

Baghchehsaraee, B., Nakhla, G., Karamanev, D., Margaritis, A., 2009. Effect of extrinsic lactic acid on fermentative hydrogen production. Int. J. Hydrogen Energy 34, 2573-2579.

Balat, M., Balat, H., Cahide, O. (2008) Progress in bioethanol processing. Progress in energy and combustion Science, 34, 5, 551-573. DOI: https://doi.org/10.1016/j.pecs.2007.11.001.

Bankevich, A., et al. (2012). SPAdes: A New Genome Assembly Algorithm and Its Applications to Single-Cell Sequencing. Journal of Computational Biology, 19, 455-477, doi: 10.1089/cmb.2012.0021.

Bao, M.D., Su, H.J., Tan, T.W. (2013) Dark fermentative bio-hydrogen production: effects of substrate pretreatment and addition of metal ions or L-cysteine. Fuel., 112, 38-44.

Barker, H. A., Kamen, M. D., Bornstein, B. T. (1945) The synthesis of butyric and caproic acids from ethanol and acetic acid by clostridium kluyveri. Proceedings of the national academy of sciences, 31, 373-381. DOI: https://doi.org/10.1073/pnas.31.12.373.

Barros, B. N., Scarminio, I. S., Bruns, R. E. (1996) Planejamento e otimização de experimentos. 2 ed. Campinas: Ed. UNICAMP, 299. 
Universidade de São Paulo

Escola de Engenharia de São Carlos

Programa de Pós-graduação em Hidráulica e Saneamento

Bartacek, J., Zabranska, J., Lens, P. N. L. (2007) Developments and constraints in fermentative hydrogen. Biofuels, Bioproducts \& Biorefining, 1, 201-214. http://dx.doi.org/10.1002/bbb.17.

Berg, J. M., Tymoczko, J. L., Gatto, G. J., Stryer, L. (2015) Biochemistry. 8th ed. New York: W.H. Freeman \& Company.

Bezerra, V. S.; Dias, J. S. A. Avaliação físico-química de frutos de bananeiras. Acta Amazonica, v. 39, 423 - 428, 2009.

Bolger, A. M., Lohse, M, Usadel, B (2014). Trimmomatic: A flexible trimmer for Illumina Sequence Data. Bioinformatics, 30, 2114-2120. https://doi.org/10. 1093/bioinformatics/btu170.

Britten, J. S. (1969) Oxaloacetate inhibition of aconitate hydratase. Biochimica et Biophysica Acta (BBA). Enzymology, 178, 370-375.

Buainain, A.M., Batalha, M.O. Cadeia produtiva de frutas. Ministério da Agricultura, Pecuária e Abastecimento, Secretaria de Política Agrícola, Instituto Interamericano de Cooperação para a Agricultura; Brasília: IICA: MAPA/SPA. (2017). 102 . Agronegócios; v. 7.

Buchanan, I. D., NICELL, J. A. (1997) Model Development for Horseradish Peroxidase Catalyzed Removal of Aqueous Phenol. Biotechnology and Bioengineering, 54, 251-261.

Budinich, M. F., Perez-Díaz, I., Cai, H., Rankin, S. A., Broadbent, J. R., Steele, J. L. (2011) Growth of Lactobacillus paracasei ATCC 334 in a cheese model system: a biochemical approach. Journal of dairy Science, 94, 5263-5277. DOI: https://doi.org/10.3168/jds.2009-2512.

Burniol-Figols, A., Cenian, K., Skiadas, I. V., Gavala, H. N. (2016) Integration of chlorogenic acid recovery and bioethanolproduction from spent coffee grounds. Biochemical engineering journal, 116, 54-64. DOI: https://doi.org/10.1016/j.bej.2016.04.025.

Cai, M., Chua, H., Zhao, Q., Sin, N. S., Ren, J. (2009). Optimal production of polyhydroxyalkanoates (PHA) in activated sludge fed by volatile fatty acids (VFAs) generated from alkaline excess sludge fermentation. Bioresour. Technol. 100, 1399-1405.

Cai, G., Jin, B., Monis, P., \& Saint, C. (2011). Metabolic flux network and analysis of fermentative hydrogen production. Biotechnology Advances, 29, 375-387.

Campanaro, S., Treu, L., Kougias, P. G., Luo, G., Angelidaki, I. (2018) Metagenomic binning reveals the functional roles of core abundant microorganisms in twelve full-scale biogas plants. Water Research, 140, 123-134. DOI: https://doi.org/10.1016/j.watres.2018.04.043.

Cappelletti, B. M., Reginatto, V., Amante, E. G., Antônio, R. V. (2011) Fermentative production of hydrogen from cassava processing wastewater by Clostridium acetobutylicum. Renewable Energy, 36, 3367-3372. DOI: https://doi.org/10.1016/j.renene.2011.05.015.

Castro, J. F., Razmilic, V., \& Gerdtzen, Z. P. (2013). Genome based metabolic flux analysis of Ethanoligenens harbinense for enhanced hydrogen production. International Journal of Hydrogen Energy, 38, pp. 12971306.

Cazier, E. A., Trably, E., Steyer, J. P., Escudie, R. (2015). Biomass hydrolysis inhibition at high hydrogen partial pressure in solid-state anaerobic digestion, Bioresource technology 190 (2015): 106-113.

Cesari, M., Rossi, G. P., Sticchi, D., Pessina, A. C. (2005) Is homocysteine important as risk factor for coronary heart disease? Nutr. Metab. Cardiovasc. Dis., 15, 140-147.

Chandrasekar, B., Van der Hoorn, R. A. (2016) Beta galactosidases in Arabidopsis and tomato - a mini review. Biochem. Soc. Trans., 44, 150-158. 


\author{
Universidade de São Paulo \\ Escola de Engenharia de São Carlos \\ Programa de Pós-graduação em Hidráulica e Saneamento
}

Chen, C. C., Lin, C. Y. (2003) Using sucrose as substrate in an anaerobic hydrogen-producing reactor. Advances in Environmental Research, 7, 3, 695-699. DOI: https://doi.org/10.1016/S1093-0191(02)00035-7.

Chi, X., Li, J., Wang, X., Zhang, Y., Leu, SY., Wang, Y. (2018) Bioaugmentation with Clostridium tyrobutyricum to improve butyric acid production through direct rice straw bioconversion. Bioresource Technology, 263, $562-568$.

Chitarra, M.I.F e Chitarra, A.B. (2005) Pós-Colheita de frutos e hortaliças: Fisiologia e manuseio, 2a ed., UFLA, Lavras, 785.

Chojnacka, A., Błaszczyk, M. K., Szczęsny, P., Latoszek, K., Sumińska, M., Tomczyk, K., Zielenkiewicz, U., Sikora, A. (2011) Comparative analysis of hydrogen-producing bacterial biofilms and granular sludge formed in continuous cultures of fermentative bacteria. Bioresource technology, 102, 21, 10057-10064. DOI: https://doi.org/10.1016/j.biortech.2011.08.063.

Choonut, A., Saejong, M., Sangkharak, K. (2014) The Production of Ethanol and Hydrogen from Pineapple Peel by Saccharomyces cerevisiae and Enterobacter aerogenes. Energy Procedia, 52, 242-249. DOI: https://doi.org/10.1016/j.egypro.2014.07.075.

Ciranna, A., Pawar, S. S., Santala, V., Karp, M., Niel, E. W. J. Van. (2014). Assessment of metabolic flux distribution in the thermophilic hydrogen producer Caloramator celer as affected by external $\mathrm{pH}$ and hydrogen partial pressure. Microbial Cell Factories, 13, 48, 1-15.

Cox, G. F., Davies, D. D. (1967) Nicotinamide-adenine dinucleotidespecific isocitrate dehydrogenase from pea mitochondria. Purification and properties. Biochem. J., 105, 729-734.

Dai, N., Cohen, S., Portnoy, V. (2011) Metabolism of soluble sugars in developing melon fruit: a global transcriptional view of the metabolic transition to sucrose accumulation. Plant Mol. Biol., 76, 1-18.

Dahiya, S., Sarkar, O., Swamy, Y. V., \& Mohan, S. V. (2015) Acidogenic fermentation of food waste for volatile fatty acid production with co-generation of biohydrogen. Bioresource Technology, 182, 103-113. DOI: https://doi.org/10.1016/j.biortech.2015.01.007.

Dalziel, K. (1980) Isocitrate dehydrogenase and related oxidative decarboxylases. FEBS Lett. (Suppl), 117, 4555 .

Dareioti, M. A., Vavouraki, A. I., Kornaros, M. (2014). Effect of pH on the anaerobic acidogenesis of agroindustrial wastewaters for maximization of bio-hydrogen production: A lab-scale evaluation using $\begin{array}{lllll}\text { batch tests. } \quad \text { Bioresource } & \text { Technology, }\end{array}$ http://dx.doi.org/10.1016/j.biortech.2014.03.149

Dionisi, D., Silva, I. M. O. (2016). Production of ethanol, organic acids and hydrogen: an opportunity for mixed culture biotechnology? Reviews in Environmental Science and Biotechnology, 15, 2, 213-242.

Doerflinger, F. C., Miller, W. B., Nock, J. F., Watkins, C. B. (2015) Variations in zonal fruit starch concentrations of apples-a developmental phenomenon or an indication of ripening. Horticulture Research, 2, 1-9. DOI:10.1038/hortres.2015.47.

Duangmanee, T., Padmasiri, S., Simmons, J., Raskin, L., Sung, S. (2007) Hydrogen production by anaerobic microbial communities exposed to repeated heat treatments. Water Environment Research, 79, 975-983. DOI: https://doi.org/10.2175/193864702784247224.

Dubois, S. M., Gilles, K. A., Hamilton, J. K., Rebers, P. A., Smith, F. (1956) Colorimetric methods for determination of sugar and related substances. Analytical. Chemistry, 228, 13-21. DOI:10.1021/ac60111a017.

Eker, S., Sarp, M. (2017) Hydrogen gas production from waste paper by dark fermentation: Effects of initial substrate and biomass concentrations. International journal of hydrogen energy, 42, 2562-2568. DOI: https://doi.org/10.1016/j.ijhydene.2016.04.020. 
Universidade de São Paulo

Escola de Engenharia de São Carlos

Programa de Pós-graduação em Hidráulica e Saneamento

Elsharnouby, O., Hafez, H., Nakhla, G., El Naggar, M. H. (2013) A critical literature review on biohydrogen production by pure cultures. International journal of hydrogen energy, 38, 4945-4966. DOI: https://doi.org/10.1016/j.ijhydene.2013.02.032.

FAO. Food Loss Reduction Strategy. Food and Agriculture Organization of the United Nations, Rome, Italy, 2011.

FAO. Food Loss Reduction Strategy. Food and Agriculture Organization of the United Nations, Rome, Italy, 2014.

Favaro, L., Alibardi, L., Lavagnolo, M. C., Casella, S., Basaglia, M (2013) Effects of inoculum and indigenous microflora on hydrogen production from the organic fraction of municipal solid waste. International Journal of hydrogen energy, 38, 11774-11779.

Ferraz Júnior, A. D., Etchebehere, C., e Zaiat, M. (2015). Mesophilic Hydrogen Production in acidogenic packedbed reactors (APBR) using raw sugarcane vinasse as substrate: influence of support materials. Anaerobe, 34, 94-105.

Food And Agriculture Organization of the United Nations - FAO (2018) Crops, FAOSTAT. Disponível em: http://faostat3.fao.org/browse/Q/QC/E. Acessado em: 01/12/2018.

Feng, X., Wang, H., Wang, Y., Wang, X., Huang, J. (2010) Biohydrogen production from apple pomace by anaerobic fermentation with river sludge. International Journal of Hydrogen Energy, 35, 3058-3064. DOI: https://doi.org/10.1016/j.ijhydene.2009.07.015.

Fernandes, E. R. K., Marangoni, C., SOUZA, O., Sellin, N. (2013) Thermochemical characterization of banana leaves as a potential energy source. Energy Conversion and Management, 75, 603-608. DOI: https://doi.org/10.1016/j.enconman.2013.08.008.

Ferreira-Leitão, V., Gottschalk, L.M.F., Ferrara, M.A., Nepomuceno, A.L., Molinari, H.B.C.; Bon, E.P.S. (2010) Biomass residues in Brazil: availability and potential uses. Waste Biomass Valoriz., 1, 65-76.

Fonseca, B. C., Guazzaroni, M. E., Reginatto, V. (2016) Fermentative production of H2 from different concentrations of galactose by the new isolate Clostridium beijerinckii $\mathrm{Br} 21$. International Journal of hydrogen energy, 41, 21109 -21120. DOI: https://doi.org/10.1016/j.ijhydene.2016.09.110.

Fonseca, B. C., Schmidell, W., Reginatto, V. (2018) Impact of Glucose Concentration on Productivity and Yield of Hydrogen Production by the New Isolate Clostridium beijerinckii Br21. The Canadian Journal of Chemical Engineering. DOI: https://doi.org/10.1002/cjce.23327.

Fowler, M. L., Ingram-Smith, C., Smith, K. S. (2012) Novel pyrophosphate-forming acetate kinase from the protist Entamoeba histolytica. Eukaryot. Cell, 11, 1249-1256.

Fu, H., Yang, S. T., Wang, M., Wang, J., Tang, I. C. (2017) Butyric acid production from lignocellulosic biomass hydrolysates by engineered Clostridium tyrobutyricum overexpressing xylose catabolism genes for glucose and xylose co-utilization. Bioresource technology, 234, 389-396. DOI: https://doi.org/10.1016/j.biortech.2017.03.073.

Fuess, L. T., Júnior, A. D. N. F., Machado, C. B., \& Zaiat, M. (2018) Temporal dynamics and metabolic correlation between lactate-producing and hydrogen-producing bacteria in sugarcane vinasse dark fermentation: The key role of lactate. Bioresource Technology, 247, 426-433. DOI: https://doi.org/10.1016/j.biortech.2017.09.121.

Garczarek, F., Dong, M., Typke, D., Witkowska, H. E., Hazen, T. C., Nogales, E., Biggin, M. D., Glaeser, R. M. (2007) Octomeric pyruvate-ferredoxin oxidoreductase from Desulfovibrio vulgaris. Journal of Structural Biology, 159, 9-18.

Ghimire, A., Frunzo, L., Pirozzi, F., Trably, E., Escudie, R., Lens, P. N. L., Esposito, G. (2015). A review on dark fermentative biohydrogen production from organic biomass: process parameters and use of by-products. Applied Energy,144, 73-95. DOI: https://doi.org/10.1016/j.apenergy.2015.01.045.

Gibson, M. I., Chen, P. Y.-T., Drennan C. L. (2016) A structural phylogeny for understanding 2-oxoacid oxidoreductase function. Current Opinion in Structural Biology, 41, 54-61. 


\author{
Universidade de São Paulo \\ Escola de Engenharia de São Carlos \\ Programa de Pós-graduação em Hidráulica e Saneamento
}

Ginkel, S. V., Sung, S., Lay, J. J. (2001) Biohydrogen production as a function of pH and substrate concentration. Environmental Science \& Technology, 35, 4726-30. DOI: 10.1021/es001979r.

Gissén, C.; Prade, T.; Kreuger, E.; Nges, I.A.; Rosenqvist, H.; Svensson, S.E.; Lantz, M.; Mattsson, J.E.; Börjesson, P.; Björnsson, L. (2014) Comparing energy crops for biogas production - Yields, energy input and costs in cultivation using digestate and mineral fertilisation. Biomass and Bioenergy., 64, 199-210.

Gómez, R. J. C., Tamburini, E. R., \& Vidal, J. C. (1988) Álcool de resíduos de frutas tropicais. Pesquisa Agropecuária Brasileira, 23, 10,1151-1159.

Gomez-Romero, J., Gonzalez-Garcia, A., Chairez, I., Torres, L., Garcia-Pena, E.I. (2014) Selective adaptation of an anaerobic microbial community: Biohydrogen production by codigestion of cheese whey and vegetables fruit waste. International Journal of Hydrogen Energy., 39, 12541-12550.

Gomes, B. C., Rosa, P. R. F., Etchebehere, C., Silva, E. L., Varesche, M. B. A. (2015) Role of homo- and heterofermentative lactic acid bacteria on hydrogen-producing reactors operated with cheese whey wastewater. International Journal of Hydrogen Energy,40, 8650-8660. DOI: https://doi.org/10.1016/j.ijhydene.2015.05.035.

Gondim, J. A. M., Moura, M. F. V., Dantas, A. S., Medeiros, R. L. M., Santos, K. M. (2005) Composição centesimal e de minerais em cascas de frutas. Ciência e Tecnologia de Alimentos, 25, 825-827. DOI: http://dx.doi.org/10.1590/S0101-20612005000400032.

Guimarães, J.L.; Frollini, E.; Silva, C.G.; Wypychc, F.; Satyanarayana, K.G. (2009) Characterization of banana, sugarcane bagasse and sponge gourd fibers of Brazil. Industrial Crops and Products., 30, 407-415.

Guo, X. M., Trably, E., Latrille, E., Carrère, H., Steyer, J. P. (2010) Hydrogen production from agricultural waste by dark fermentation: a review. International Journal of Hydrogen Energy, 35, 10660-10673. DOI: https://doi.org/10.1016/j.ijhydene.2010.03.008.

Guo, L., Zong, Y., Lu, M., Zhang, J. (2014) Effect of different substrate concentrations and salinity on hydrogen production from mariculture organic waste (MOW). International journal of hydrogen energy., 39, 736743.

Gustavsson, M., Lee, S. Y. (2016) Prospects of microbial cell factories developed through systems metabolic engineering. Microbial Biotechnology, 9, 610-7. DOI:https://doi.org/10.1111/1751-7915.12385.

Hallenbeck, P. C., Benemann, J. R. (2002). Biological hydrogen production; fundamentals and limiting processes. International Journal of Hydrogen Energy, 27, 1185-1193.

Hallenbeck, P. C. (2005) Fundamentals of the fermentative production of hydrogen. Water Science \& Technology, 52, 21-29. DOI: 10.2166/wst.2005.0494.

Hallenbeck, P. C. (2012) Microbial technologies in advanced biofuels production. New York: Springer Science+Business Media, 53-75. DOI: 10.1007/978-1-4614-1208-3_4.

Haruta, S., Cui, Z., Huang, Z., Li, M., Ishii, M., Igarashi, Y. (2002) Construction of a stable microbial community with high cellulose-degradation ability. Applied Microbiology and Biotechnology, 59, 529-534. DOI: 10.1007/s00253-002-1026-4.

Hasan, Md. M., Marzan, L. W., Asamul Hosna, A., Hakim, A., Aza, A. K. (2017) Optimization of some fermentation conditions for the production of extracellular amylases by using Chryseobacterium and Bacillus isolates from organic kitchen wastes. Journal of Genetic Engineering and Biotechnology, 15, 59-68. DOI: https://doi.org/10.1016/j.jgeb.2017.02.009.

Heywood, J.B. (1988) Internal combustion engine fundamentals. 1a ed., McGraw-Hill Education, New York, 960.

Hohmann, S., Meacock P. A. (1998) Thiamin metabolism and thiamin diphosphatedependent enzymes in the yeast Saccharomyces cerevisiae: genetic regulation. Biochim. Biophys. Acta, 1385, 201-219. 
Universidade de São Paulo

Escola de Engenharia de São Carlos

Programa de Pós-graduação em Hidráulica e Saneamento

Huang, Y., Li, W., Zhao, L., Shen, T., Sun, J., Chen, H., Kong, Q., Nawaz, M.A., Bie, Z. (2017) Melon fruit sugar and amino acid contents are affected by fruit setting method under protected cultivation. Sci. Hortic., 214, 288-294.

Hwang, J.H., Choi, J.A., Abou-Shanab, R.A.I., Min, B., Song, H., Kim, Y., Lee, E.S., Jeon, B.H. (2011) Feasibility of hydrogen production from ripened fruits by a combined two-stage (dark/dark) fermentation system. Bioresour. Technol., 102, 1051-1058.

Infantes, D., del Campo, G. A., Villasenor, J., Fernandez, F. J. (2011) Influence of pH, temperature and volatile fatty acids on hydrogen production by acidogenic fermentation. International Journal of hydrogen energy, 36, 15595-15601. DOI: https://doi.org/10.1016/j.ijhydene.2011.09.061.

Islam, R., Sparling, R., Cicek, N., Levin, D. B. (2015). Optimization of Influential Nutrients during Direct Cellulose Fermentation into Hydrogen by Clostridium thermocellum. International Journal of Molecular Sciences, 16, 3116-3132.

Itoh, Y., Tada, K., Kanno, T., Horiuchi, J. I. (2012) Selective production of lactic acid in continuous anaerobic acidogenesis by extremely low pH operation. Journal of bioscience and bioengineering, 114, 5, 537-539. DOI: https://doi.org/10.1016/j.jbiosc.2012.05.020.

Jayasinghearachchi, H. S., Sarma, P. M., Singh, S., Aginihotri, A., Mandal, A. K., Lal, B. (2009) Fermentative hydrogen production by two novel strains of Enterobacter aerogenes HGN-2 and HT 34 isolated from sea buried crude oil pipelines. International Journal of Hydrogen Energy, 34, 7197-7207. DOI: https://doi.org/10.1016/j.ijhydene.2009.06.079.

Jesus, S.C., Folegatti, M.I.S., Matsuura, F.C.A.U., Cardoso, R.L. (2004) Caracterização física e química de frutos de diferentes genótipos de bananeira. Bragantia., 63, 315-323.

Jiang, L., Long, C., Wu, X., Xu, H., Shao, Z., Long, M. (2014) Optimization of thermophilic fermentative hydrogen production by the newly isolated Caloranaerobacter azorensis H53214 from deep-sea hydrothermal vent environment. International journal of hydrogen energy., 39, 14154-14160.

Jin, B., Monis, P., Saint, C. (2011) Metabolic flux network and analysis of fermentative hydrogen production. Biotechnology Advances, 29, 375-8. DOI: https://doi.org/10.1016/j.biotechadv.2011.02.001.

Jo, J. H., Lee, D. S., Park, J. M. (2008) The effects of pH on carbon material and energy balances in hydrogenproducing Clostridium tyrobutyricum JM1. Bioresource technology, 99, 17, 8485-8491. DOI: https://doi.org/10.1016/j.biortech.2008.03.060.

Jorgensen, H., Kristensen, J. B., Felby, C. (2007) Enzymatic conversion of lignocellulose into fermentable sugars: challenges and opportunities. Biofuels, Bioproducts and Biorefining, 1, 2, 119-134. DOI: https://doi.org/10.1002/bbb.4.

Kanchanasuta, S., Prommeenate, P., Boonapatcharone, N., Pisutpaisal, N. (2017) Stability of Clostridium butyricum in biohydrogen production from non-sterile food waste. International Journal of hydrogen energy, 42, 3454-3465. DOI: https://doi.org/10.1016/j.ijhydene.2016.09.111.

Kandasamy, S., and Aradhya, S. M. (2014). Polyphenolic profile and antioxidant properties of rhizome of commercial banana cultivars grown in India. Food Bioscience, 8, 22-32. DOI: https://doi.org/10.1016/j.fbio.2014.10.001.

Kanehisa, M., Goto, S. (2000) KEGG: Kyoto Encyclopedia of Genes and Genomes. Nucleic Acids Res. 28, 2730 .

Kanehisa, M., Sato, Y., Kawashima, M., Furumichi, M., Tanabe, M (2016). KEGG as a reference resource for gene and protein annotation. Nucleic Acids Res. 4, D457-D462. doi:10.1093/nar/gkv1070.

Kanehisa, M., Furumichi, M., Tanabe, M., Sato, Y., Morishima, K (2017). KEGG: new perspectives on genomes, pathways, diseases and drugs. Nucleic Acids Res. 4, D353-D361. doi: 10.1093/nar/gkw1092. 


\author{
Universidade de São Paulo \\ Escola de Engenharia de São Carlos \\ Programa de Pós-graduação em Hidráulica e Saneamento
}

Kanwal, N., Shah, A. A., Qayyum, S., Hasan, F. (2015) Optimization of pH and temperature for degradation of tyre rubber by Bacillus sp. strain S10 isolated from sewage sludge. International Biodeterioration \& Biodegradation, 103, 154-160. DOI: https://doi.org/10.1016/j.ibiod.2015.05.009.

Keskin, T., Arslan, K., Abubackar, H. N., Vural, C., Eroglu, D., Karaalp, D., Yanik, J., Ozdemir, G., Azbar, N. (2018) Determining the effect of trace elements on biohydrogen production from fruit and vegetable wastes. International Journal of hydrogen energy, 43, (23), 10666-10677. DOI: https://doi.org/10.1016/j.ijhydene.2018.01.028.

Khanna, N., Kotay, S. M., Gilbert, J. J., Das, D. (2011) Improvement of biohydrogen production by Enterobacter cloacae IIT-BT 08 under regulated pH. Journal of biotechnology, 152, 1-2, 9-15. DOI: https://doi.org/10.1016/j.jbiotec.2010.12.014.

Kim, D. H., Wu, J., Jeong, K. W., Kim, M. S., Shin, H. S. (2011) Natural inducement of hydrogen from food waste by temperature control. International J. of hydrogen energy, 36, 10666-10673.

Kim, J., Kim, M.S., Koh, A.Y., Xie, Y., Zhan, X (2016). FMAP: Functional Mapping and Analysis Pipeline for metagenomics and metatranscriptomics studies. BMC Bioinformatics, 10, 420. https://doi.org/10.1186/s12859-016-1278-0

Kleinsteuber, S. (2018) Metagenomics of methanogenic communities in anaerobic digesters. Biogenesis of hydrocarbons. In: Stams, A. J. M., Sousa, D. Z., editors. Biogenesis of Hydrocarbons, Handbook of Hydrocarbon and Lipid Microbiology. Springer Nature Switzerland: Springer International Publishing AG; 2018.

Klurfeld, D. M. (2016) Fructose: Sources, Metabolism, and Health. Encyclopedia of Food and Health, 125-129. DOI: http://dx.doi.org/10.1016/B978-0-12-384947-2.00332-9.

Kochetov G. A., Solovjeva O. N. (2014) Structure and functioning mechanism of transketolase. Biochim. Biophys. Acta, 1844, 1608-1618.

Kongjan, P., O-Thong, S., Kotay, M., Min, B., Angelidaki, I. (2010) Biohydrogen production from wheat straw hydrolysate by dark fermentation using extreme thermophilic mixed culture. Biotechnology and bioengineering, 105, 899-908. DOI: https://doi.org/ 10.1002/bit.22616.

Korhonen, J. (2010). Antibiotic resistance of lactic acid bacteria. Dissertations in Forestry and Natural Sciences, Publications of the University of Eastern Finland, Kuopio.

Knowles, J. R. (1991) Enzyme catalysis: not different, just better. Nature, 350, 121-124.

Kraemer, J. T., Bagley, D. M. (2007) Improving the yield from fermentative hydrogen production. Biotechnology Letters, 29, 685-695. DOI: 10.1007/s10529-006-9299-9.

Kumar, S., Stecher, G., Tamura, K. (2016) MEGA7: molecular evolutionary genetics analysis version 7.0 for bigger datasets. Molecular biology and evolution, 33, 1870-1874. DOI: https://doi.org/10.1093/molbev/msw054.

Laothanachareon, T., Kanchanasuta, S., Mhuanthong, W., Phalakornkule, C., Pisutpaisal, N., e Champreda, V. (2014) Analysis of microbial community adaptation in mesophilic hydrogen fermentation from food waste by tagged 16S rRNA gene pyrosequencing. Journal of Environmental Management, 144, 143-151. DOI: https://doi.org/10.1016/j.jenvman.2014.05.019.

Latif, H., Zeidan, A. A., Nielsen, A. T., Zengler, K. (2013). Trash to treasure : production of biofuels and commodity chemicals via syngas fermenting microorganisms. Current Opinion in Biotechnology, 27, 7989.

Lay, C. H., Lin, H. C., Sen, B., Chu, C. Y., Lin, C. Y. (2012) Simultaneous hydrogen and ethanol production from sweet potato via dark fermentation. Journal of Cleaner Production, 27, 155-164. DOI: https://doi.org/10.1016/j.jclepro.2011.12.027. 
Universidade de São Paulo

Escola de Engenharia de São Carlos

Programa de Pós-graduação em Hidráulica e Saneamento

Lee, D.Y., Li, Y.Y., Oh, Y.K., Kim, M.S., Noike, T. (2009) Effect of iron concentration on continuous $\mathrm{H}_{2}$ production using membrane bioreactor. International journal of hydrogen energy, 34, 1244-1252.

Lee, H. S., Vermaas, W. F. J., Rittmann, B. E. (2010) Biological hydrogen production: Prospects and challenges. Trends in Biotechnology, 28, 5, 262-271. DOI: https://doi.org/10.1016/j.tibtech.2010.01.007.

Lee, D-J., Show, K-Y., Su, A. (2011) Dark fermentation on biohydrogen production: Pure cultures. Bioresource Technology, 102, 18, 8393-8402. DOI: https://doi.org/10.1016/j.biortech.2011.03.041.

Lettinga, G., Hulshof, P. L., e Zeeman, G. (1996). Biological Wastewater Treatment. Part I: Anaerobic wastewater treatment. Lecture Notes, Wageningen Agricultural University.

Levantamento Sistemático da Produção Agrícola: pesquisa mensal de previsão e acompanhamento das safras agrícolas no ano civil/Julho 2017 (LSPA). (2017) Fundação Instituto Brasileiro de Geografia e Estatística. Rio de Janeiro, 30, 1-83.

Li, F., Hinderberger, J., Seedorf, H., Zhang, J., Buckel, W., Thauer, R. K. (2008) Coupled ferredoxin and crotonyl coenzyme A $(\mathrm{CoA})$ reduction with NADH catalyzed by the butyryl-CoA dehydrogenase/Etf complex from Clostridium klyuveri. Journal of Bacteriology, 190, 843-850. DOI: 10.1128/JB.01417-07.

Li, X., Chen, H., Hu, L. F., Yu, L., Chen, Y., Gu, G. (2011) Pilot-scale waste activated sludge alkaline fermentation, fermentation liquid separation, and application of fermentation liquid to improve biological nutrient removal. Environmental science \& technology, 45, 5, 1834-1839. DOI: 10.1021/es1031882.

Li, Y., Hua D., Mu, H., Xu, H., Jin, F., Zhang, X. (2017) Conversion of vegetable wastes to organic acids in leaching bed reactor: Performance and bacterial community analysis. Journal of Bioscience and Bioengineering, 124, 2, 195-203. DOI: https://doi.org/10.1016/j.jbiosc.2017.02.020.

Li, L., Peng, X., Wang, X., Wu, D. (2018) Anaerobic digestion of food waste: A review focusing on process stability. Bioresource Technology, 248, 20-28.

Liakou, V., Pateraki, C., Palaiogeorgou, A. M., Kopsahelis, N., de Castro, A. M., Freire, D. M. G., Nychas, G. J. E., Papanikolaou, S., Koutinas, A. (2018) Valorisation of fruit and vegetable waste from openmarkets for the production of 2,3-butanediol. Food and Bioproducts Processing, 108, 27-36. DOI: https://doi.org/10.1016/j.fbp.2017.10.004.

Liao H. H., Myung, S., Zhang, Y.-H. P. (2012) One-step purification and immobilization of thermophilic polyphosphate glucokinase from Thermobifida fusca YX: glucose-6-phosphate generation without ATP. Appl. Microbiol. Biotechnol., 93, 1109-1117.

Lim, S. J., Kim, B. J., Jeong, C. M., Choi, J., Ahn, Y. H., Chang, H. N. (2008) Anaerobic organic acid production of food waste in once-a-day feeding and drawing-off bioreactor. Bioresource Technology, 99, 16, 78667874. DOI: https://doi.org/10.1016/j.biortech.2007.06.028.

Lima, D. M. F., Moreira, W. K., Zaiat, M. (2013) Comparison of the use of sucrose and glucose as a substrate for hydrogen production in an upflow anaerobic fixed-bed reactor. International Journal of Hydrogen Energy, 38, 35, 15074-15083. DOI: https://doi.org/10.1016/j.ijhydene.2013.09.003.

Lin, C. Y., Chang, C. C., Hung, C. H. (2008) Fermentative hydrogen production from starch using natural mixed cultures. International Journal of Hydrogen Energy, 33, 10, 2445-2453. DOI: https://doi.org/10.1016/j.ijhydene.2008.02.069.

Lin, C. Y., Lay, C. H., Sung, I. Y., Sen, B., Chen, C.C. (2017) Anaerobic hydrogen production from unhydrolyzed mushroom farm waste by indigenous microbiota. Journal of Bioscience and Bioengineering, 124, 425429. DOI: $\underline{\text { https://doi.org/10.1016/j.jbiosc.2017.05.001. }}$.

Liu, Y., Zhang, Y., Quan, X., Li, Y., Zhao, Z., Meng, X., Chen, S. (2012) Optimization of anaerobic acidogenesis by adding $\mathrm{Fe} 0$ powder to enhance anaerobic wastewater treatment. Chemical Engineering Journal, 192, 179-185. DOI: https://doi.org/10.1016/j.cej.2012.03.044. 


\author{
Universidade de São Paulo \\ Escola de Engenharia de São Carlos \\ Programa de Pós-graduação em Hidráulica e Saneamento
}

Liu, H., Chen, G., Wang, G. (2015) Characteristics for production of hydrogen and bioflocculant by Bacillus sp. XF-56 from marine intertidal sludge. International $\mathrm{J}$ of hydrogen energy, 40, 1414-1419. DOI: https://doi.org/10.1016/j.ijhydene.2014.11.110.

Lobo, K. S., Soares-da-Silva, J., Silva, M. C., Tadei, W. P., Polanczyke, R. A., Pinheiro, V. C. S. (2018) Isolation and molecular characterization of Bacillus thuringiensis found in soils of the Cerrado region of Brazil, and their toxicity to Aedes aegypti larvae. Revista Brasileira de Entomologia, 62, 5-12. DOI: https://doi.org/10.1016/j.rbe.2017.11.004.

Logan, B. E. (2004) Extracting hydrogen and electricity from renewable resources. Environmental Science \& Technology,38, 4-8.

Lu, C.; Zhang, Z.; Ge, X.; Wang, Y.; Zhou, X.; You, X.; Liu, H.; Zhang, Q. (2016) Bio-hydrogen production from apple waste by photosynthetic bacteria HAU-M1. International Journal of Hydrogen Energy., 41, 1339913407.

Lukajtis, R., Hołowacz, I., Kucharska, K., Glinka, M., Rybarczyka, P., Przyjaznyc, A., Kamiński, M. (2018) Hydrogen production from biomass using dark fermentation. Renewable and Sustainable Energy Reviews, 91, 665-694. DOI: https://doi.org/10.1016/j.rser.2018.04.043.

Ma, L., Cheng, Q. (2018) Inhibiting 6-phosphogluconate dehydrogenase reverses doxorubicin resistance in anaplastic thyroid cancer via inhibiting NADPH dependent metabolic reprogramming. Biochemical and Biophysical Research Communications, 498, 912-917.

Madigou, C., Poirier, S., Bureau, C., Chapleur, O. (2016) Acclimation strategy to increase phenol tolerance of an anaerobic microbiota. Bioresource Technology., 216, 77-86.

Mahmoud, N., Zeeman, G., Gijzen, H., Lettinga, G. (2004) Anaerobic stabilisation and conversion of biopolymers in primary sludge - effect of temperature and sludge retention time. Water Research, 38, 4, 983-991. DOI: https://doi.org/10.1016/j.watres.2003.10.016.

Maintinguer, S. I., Fernandes, B. S., Duarte, I. C. S., Saavedra, N. K., Adorno, M. A. T., Varesche, M. B. A. (2011) Fermentative hydrogen production with xylose by Clostridium and Klebsiella species in anaerobic batch reactors. International Journal of hydrogen energy, 36, 13508-13517. DOI: https://doi.org/10.1016/j.ijhydene.2011.07.095.

Maintinguer, S. I., Lazaro, C. Z., Pachiega, R., Varesche, M. B. A., Sequinel, R., Oliveira, J. E. (2017) Hydrogen bioproduction with Enterobacter sp. isolated from brewery wastewater. International Journal of hydrogen energy, 42, 152-160. DOI: https://doi.org/10.1016/j.ijhydene.2016.11.104.

Majidian, P., Tabatabaei, M., Zeinolabedini, M., Naghshbandi, M. P., Chisti, Y. (2018) Metabolic engineering of microorganisms for biofuel production. Renewable and Sustainable Energy. Reviews, 82, 3863-3885. DOI: 10.1016/j.rser.2017.10.085.

Marcano, I. E., Díaz-Alcántara, C. A., Urbano, B., González-Andrés, F. (2016) Assessment of bacterial populations associated with banana tree roots and development of successful plant probiotics for banana crop. Soil Biology \& Biochemistry, 99, 1-20. DOI: https://doi.org/10.1016/j.soilbio.2016.04.013.

Marone, A., Izzo, G., Mentuccia, L., Massini, G., Paganin, P.; Rosa, S., Varrone, C., Signorini, A. (2014) Vegetable waste as substrate and source of suitable microflora for bio-hydrogen production. Renewable Energy., 68, 6-13.

Maru, B. T., Bielen, A. A. M., Constantí, M., Medina, F., Kengen, S. W. M. (2013) Glycerol fermentation to hydrogen by Thermotoga maritima: Proposed pathway and bioenergetic considerations. International Journal of Hydrogen Energy, 38, 5563-5572.

Mascarenhas, G.C.C. (1999) Banana: comercialização e mercados. Informe Agropecuário., 20, 97-108. 
Universidade de São Paulo

Escola de Engenharia de São Carlos

Programa de Pós-graduação em Hidráulica e Saneamento

Matheri, A. N., Ntuli, F., Ngila, J. C., Seodigeng, T., Zvinowanda, C., Njenga, C. K. (2018) Quantitative characterization of carbonaceous and lignocellulosic biomass for anaerobic digestion. Renewable and Sustainable Energy Reviews, 92, 9-16. DOI: https://doi.org/10.1016/j.rser.2018.04.070.

Matsumoto, M., Nishimura, Y. (2007) Hydrogen production by fermentation using acetic acid and lactic acid. Journal of bioscience and bioengineering, 103, 236-241. DOI: https://doi.org/10.1263/jbb.103.236.

Menezes, J. M. C., Leite, V. D., Barros, A. J. M., Lopes, W. S., Sousa, J. T., Campos, A. R. C. (2015) Influence of temperature on the anaerobic stabilization of organic solid residues. African Journal of Biotechnology, 14, 500-508. DOI: 10.5897/AJB2014.14008.

Mishra, P., Thakur, S., Singh, L., Krishnan, S., Sakinah, M., Wahid, Z. A. B. (2017) Fermentative hydrogen production from indigenous mesophilic strain Bacillus anthracis PUNAJAN 1 newly isolated from palm oil mill effluent. International Journal of hydrogen energy, 42, 16054-16063. DOI: https://doi.org/10.1016/j.ijhydene.2017.05.120.

Mitschke, L., Parthier, C., Schröder-Tittmann, K., Coy, J., Lüdtke, S., Tittmann, K. (2010) The crystal structure of human transketolase and new insights into its mode of action. J. Biol. Chem., 285, 31559-31570.

Mohapatra, M. S., Dash, H. R., Das S., Pattnaik, S., Rathd, C. C., Samantaray, D. (2017) Bacillus and biopolymer: Prospects and challenges. Biochemistry and Biophysics Reports, 12, 206-213. DOI: https://doi.org/10.1016/j.bbrep.2017.10.001.

Mor, I., Cheung, E.C., Vousden, K.H. (2011) Control of glycolysis through regulation of PFK1: old friends and recent additions. Cold Spring Harb. Symp. Quant. Biol., 76, 211-216.

Mota, V. T., Ferraz Junior, A. D. N., Trably, E., Zaiat, M. (2018) Biohydrogen production at pH below 3.0: Is it possible? Water Research 128, 350-361. DOI: https://doi.org/10.1016/j.watres.2017.10.060.

Muyzer, G., De Waal, E. C., Uitierlinden, A. G. (1993) Profiling of Complex Microbial Populations by Denaturing Gradient Gel Electrophoresis Analysis of Polymerase Chain Reaction-Amplified Genes Coding for 16S rRNA. Applied and Environmental Microbiology, 695-670.

Nakahara K., Yamamoto H., Miyake C., Yokota A. (2003) Purification and characterization of class-I and classII fructose-1,6-bisphosphate aldolases from the cyanobacterium Synechocystis sp. PCC 6803. Plant Cell Physiol, 44, 326-333.

Nathoa, C., Sirisukpocab, U., Pisutpaisal, N. (2014) Production of Hydrogen and Methane from Banana Peel by Two Phase Anaerobic Fermentation. Energy Procedia, 50, 702-710. DOI: https://doi.org/10.1016/j.egypro.2014.06.086.

Noparat, P., Prasertsan, P., O-thong, S. Isolation and characterization of high hydrogen-producing strain Clostridium beijerinckii PS-3 from fermented oil palm sap. International journal of hydrogen energy, v. 36, p. 14086-14092, 2011.

Nubel, U., Engelen, B., FELSKE, A., Snaidr, J., Wieshuber, A., Amann, R. I., LUDWIG, W., Backhaus, H., Engelen, B., Felske, A., Snaidr, J., Wieshuber, A. Sequence heterogeneities of genes encoding 16S rRNAs in Paenibacillus polymyxa detected by temperature gradient gel electrophoresis. Sequence Heterogeneities of Genes Encoding 16S rRNAs in Paenibacillus polymyxa Detected by Temperature Gradient Gel Elect. v. 178, n. 19, p. 5636-5643, 1996.

Nurk, S. et al. (2013) Assembling Genomes and Mini-metagenomes from Highly Chimeric Reads. In: DENG, M.; JIANG, R.; SUN, F.; ZHANG, X. (eds) Research in Computational Molecular Biology. RECOMB 2013. Lecture Notes in Computer Science, vol 7821. Springer, Berlin, Heidelberg.

Odnell, A., Recktenwald, M., Stensen, K., Jonsson, B. H., Karlsson, M. (2016) Activity, life time and effect of hydrolytic enzymes for enhanced biogas production from sludge anaerobic digestion. Water Research, 103, 462-471. DOI: https://doi.org/10.1016/j.watres.2016.07.064. 


\author{
Universidade de São Paulo \\ Escola de Engenharia de São Carlos \\ Programa de Pós-graduação em Hidráulica e Saneamento
}

Ohnishi, A., Bando,. Y, Fujimoto, N., Suzuki, M. (2010) Development of a simple bio-hydrogen production system through dark fermentation by using unique microflora. International Journal of Hydrogen Energy, 35, 8544-8553. DOI: https://doi.org/10.1016/ j.ijhydene.2010.05.113.

Oost, J. V., Huynen, M. A., Verhees, C. H. (2002) Molecular characterization of phosphoglycerate mutase in archaea. FEMS Microbiology Letters, 212, 111-120.

Palmqvist, E., Hahn-Heagerdal, B. (2000) Fermentation of lignocellulosic hydrolysates. I: inhibition and detoxification. Bioresource technology, 74, 17-24. DOI: http://dx.doi.org/10.1016/ S09608524(99)00160-1.

Pan, J., Zhang, R., El-Mashad, H. M., Sun, H., Ying, Y. (2008) Effect of food to microorganism ratio on biohydrogen production from food waste via anaerobic fermentation. International Journal of Hydrogen Energy, 33, 6968-6975. DOI: https://doi.org/10.1016/j.ijhydene.2008.07.130.

Pancholi, V. (2001) Multifunctional $\alpha$-enolase: its role in diseases. Cellular and Molecular Life Sciences, 58, 902920.

Paniagua C., Blancoportales, R., Barcelómuñoz, M., Garcíagago, J. A., Waldron K.W., Quesada, M. A., Muñozblanco J., Mercado, J. A. (2016) Antisense down-regulation of the strawberry $\beta$-galactosidase gene FaßGal4 increases cell wall galactose levels and reduces fruit softening. J. Exp. Bot., 67, 619-631.

Park, J. H., Kim, D. H., Kim, S. H., Yoon, J. J., Park, H. D. (2018) Effect of substrate concentration on the competition between Clostridium and Lactobacillus during biohydrogen production. Int. J. of hydrogen energy, 43, 11460-11469.

Patel, S. K. S., Singh, M., Kalia, V. C. (2011) Hydrogen and Polyhydroxybutyrate Producing Abilities of Bacillus spp. From Glucose in Two Stage System. Indian Journal of Microbiology, 51, 418-423. DOI: 10.1007/s12088-011-0236-9.

Patsalou, M., Menikea, K.K., Makri, E., Vasquez, M.I., Drouza, C., Koutinas, M., 2017. Development of a citrus peel-basedbiorefinery strategy for the production of succinic acid. Journal of Cleaner Production, 166, 706-716. DOI: https://doi.org/10.1016/j.jclepro.2017.08.039.

Pattra, S., Sangyoka, S., Boonmee, M., Reungsang, A. (2008) Bio-hydrogen production from the fermentation of sugarcane bagasse hydrolysate by Clostridium butyricum. International Journal of Hydrogen Energy, 33, 5256-5265. DOI: https://doi.org/10.1016/j.ijhydene.2008.05.008

Paul, J. S., Lall, B. M., Jadhava, S. K., Tiwari, K. L. (2017) Parameter's optimization and kinetics study of amylase enzyme of Bacillus sp. MB6 isolated from vegetable waste. Process Biochemistry, 52, 123-129. DOI: https://doi.org/10.1016/j.procbio.2016.10.005.

Pendyala, B., Chaganti, S. R., Lalman, J. A., Heath, D. D., Shanmugam, S. R., e Veeravalli, S. S. (2013) Using a food and paper-cardboard waste blend as a novel feedstock for hydrogen production: Influence of key process parameters on microbial diversity. International Journal of Hidrogen Energy, 38, 6357- 6367. DOI: https://doi.org/10.1016/j.ijhydene.2013.03.003.

Penteado, E. D., Lazaro, C. Z., Sakamoto, I. K., Zaiat, M. (2013) Influence of seed sludge and pretreatment method on hydrogen production in packed-bed anaerobic reactors. International Journal of Hydrogen Energy, 38, 6137-6145. DOI: https://doi.org/10.1016/j.ijhydene.2013.01.067.

Perna, V., Castello, E., Wenzel, J., Zampol, C., Fontes Lima, D. M., Borzacconi, L., Varesche, M. B., Zaiat, M., Etchebehere, C (2013) Hydrogen production in an upflow anaerobic pecked bed reactor used to treat cheese whey. Int. J. Hydrogen Energy, 38, 54-62.

Rabelo, C. A. B. S., Soares, L. A., Sakamoto, I. K., Silva, E. L., Varesche, M. B. A. (2018) Optimization of hydrogen and organic acids productions with autochthonous and allochthonous bacteria from sugarcane bagasse in batch reactors. Journal of Environmental Management 223, 952-963. DOI: https://doi.org/10.1016/j.jenvman.2018.07.015. 
Universidade de São Paulo

Escola de Engenharia de São Carlos

Programa de Pós-graduação em Hidráulica e Saneamento

Rafrafi, Y., Trably, E., Hamelin, J., Latrille, E., Meynial-Salles, I., Benomar, S., GiudiciOrticoni, M., Steyer, J. (2013) Sub-dominant bacteria as keystone species in microbial communities producing bio-hydrogen. International Journal of Hydrogen Energy, 38, 4975-4985. DOI: https://doi.org/10.1016/j.ijhydene.2013.02.008.

Ragsdale S. W. (2003) Pyruvate ferredoxin oxidoreductase and its radical intermediate. Chem Rev., 103, 2333 2346.

Ren, N., Xing, D., Rittmann, B. E., Zhao, L., Xie, T., Zhao, X. (2007) Microbial community structure of ethanol type fermentation in bio-hydrogen production. Environmental Microbiology, 9, 1112-1125. DOI: https://doi.org/10.1111/j.1462-2920.2006.01234.x.

Rodrigues, M.I. e Lemma, A.F. (2014) Planejamento de experimentos e otimização de processos., 3a ed., Editora Cárita, Campinas, 358.

Ros, M., de Souza Oliveira Filho, J., Murcia, M. D. P., Bustamante, M. A., Moral, R., Coll, M. D., SantisimaTrinidad, A. B. L., Pascual, J. A. (2017) Mesophilic anaerobic digestion of pig slurry and fruit and vegetable waste: Dissection of the microbial community structure. Journal of Cleaner Production, 156, 757-765. DOI: https://doi.org/10.1016/j.jclepro.2017.04.110.

Rosa, P. R. F., Silva, E. L. (2017) Review of Continuous Fermentive Hydrogen-Producing Bioreactors from Complex Wastewater. Frontiers in Bioenergy and Biofuels, E. Jacob-Lopez, Eds. DOI: 10.5772/65548.

Ruggeri, B., Tommasi, T., Sanfilippo, S. (2015) BioH2 \& BioCH4 through Anaerobic Digestion: from Research to Full-scale Applications. Springer-Verlag.

Saady, N. M. C. (2013) Homoacetogenesis during hydrogen production by mixed cultures dark fermentation: Unresolved challenge. International Journal of Hydrogen Energy, 38, 13172-13191. DOI: https://doi.org/10.1016/j.ijhydene.2013.07.122.

Saidi, R., Liebgott, P. P., Gannoun, H., Gaida, L. B., Miladi, B., Hamdi, M., Bouallagui, H., Auria, R. (2018) Biohydrogen production from hyperthermophilic anaerobic digestion of fruit and vegetable wastes in seawater:Simplification of the culture medium of Thermotoga maritima. Waste Management, 71, 474484.DOI: https://doi.org/10.1016/j.wasman.2017.09.042.

Sakthiselvan, P., Madhumathi, R. (2018) Kinetic evaluation on cell growth and biosynthesis of polyhydroxybutyrate (PHB) by Bacillus safensis EBT1 from sugarcane bagasse. Engineering in Agriculture, Environment and Food, 17, 30018-6. DOI: https://doi.org/10.1016/j.eaef.2018.03.003.

Sandoval-Espinola, W. J., Chinn, M., Bruno-Barcena, J. M. (2015) Inoculum optimization of Clostridium beijerinckii for reproducible growth. FEMS Microbiology Letters, 362, 164 . DOI: https://doi.org/10.1093/femsle/fnv164.

Saraphirom, P. Reungsang, A. (2010) Optimization of biohydrogen production from sweet sorghum syrup using statistical methods. International Journal of Hydrogen Energy., 35, 13435-13444.

Seyis, I., Aksoz, N. (2004) Production of lactase by Trichoderma sp. Food Technol. Biotechnol., 42, $121-124$.

Sharma, Y., Li, B. K. (2009) Optimizing hydrogen production from organic wastewater treatment in batch reactors through experimental and kinetic analysis. International Journal of Hydrogen Energy, 34, 6171. DOI: https://doi.org/10.1016/j.ijhydene.2009.06.031.

Shanmugam, S. R., Chaganti, S. R., Lalman, J. a., Heath, D. D. (2014). Statistical optimization of conditions for minimum $\mathrm{H} 2$ consumption in mixed anaerobic cultures: Effect on homoacetogenesis and methanogenesis. International Journal of Hydrogen Energy, 39, 28, 15433-15445. DOI: http://dx.doi.org/10.1016/j.ijhydene.2014.07.143

Sinha, P. e Pandey, A. (2011) An evaluative report and challenges for fermentative biohydrogen production. International journal of hydrogen energy., 36, 7460-7478. 


\author{
Universidade de São Paulo \\ Escola de Engenharia de São Carlos \\ Programa de Pós-graduação em Hidráulica e Saneamento
}

Silva, F. C., Serafim, L. S., Nadais, H., Arroja, L., Capela, I. (2013) Acidogenic fermentation towards valorisation of organic waste streams into volatile fatty acids. Chem. Biochem. Eng. Q. 27, 467-476.

Singh, B. Singh, J.P. Kaur, M. Singh, N. (2016) Bioactive compounds in banana and their associated health benefits - A review. Food Chemistry., 206, 1-11.

Singhania, R. R., Patel, A. K., Christophe, G., Fontanille, P., Larroche, C. (2013) Biological upgrading of volatile fatty acids, key intermediates for the valorization of biowaste through dark anaerobic fermentation. Bioresour. Technol. 145, 166-174.

Sigurbjornsdottir, M. A. and Orlygsson, J. (2012) Combined hydrogen and ethanol production from sugars and lignocellulosic biomass by Thermoanaerobacterium AK54, isolated from hot spring. Applied Energy, 97, 785-791. DOI: https://doi.org/10.1016/j.apenergy.2011.11.035.

Sikora, A., Błaszczyk, M., Jurkowski, M., Zielenkiewicz, U. (2013) Lactic acid bacteria in hydrogen producing consortia: On purpose or by coincidence? In: Kongo, M., editor. Lactic Acid Bacteria-R \& D for Food, Health and Livestock Purposes. Rijeka, InTech, 487-514. DOI: http://dx.doi.org/10.5772/50364.

Sinha, P. e Pandey, A. (2014) Biohydrogen production from various feedstocks .by Bacillus firmus NMBL-03. International Journal of Hydrogen Energy, 39, 7518-7525. DOI: https://doi.org/10.1016/j.ijhydene.2013.08.134.

Siqueira, M.R., Reginatto, V. (2015) Inhibition of fermentative $\mathrm{H}_{2}$ production by hydrolysis byproducts of lignocellulosis substrates. Renew Energy., 80, 109-116.

Srikanth, S. e Mohan, S.V. (2012) Regulatory function of divalent cations in controlling the acidogenic biohydrogen production process. RSC Advances., 2, 6576-6589.

Soares, L.A., Braga, J.K., Motteran, F., Sakamoto, I.K., Silva, E.L., Varesche, M.B.A. (2017) Design and optimization of hydrogen production from hydrothermally pretreated sugarcane bagasse using response surface methodology. Water Science \& Technology., in press, 2017.

Soares, L. A., Rabelo, C. A. B. S., Sakamoto, I. K., Delforno, T. P., Silva, E. L., \& Varesche, M. B. A. (2018) Metagenomic analysis and optimization of hydrogen production from sugarcane bagasse. Biomass and Bioenergy, 117, 78-85. DOI: https://doi.org/10.1016/j.biombioe.2018.07.018.

Song, Y., Liu, C., Finegolg, S. M. (2010) Genus I. Bacteroides. In: Krieg, N. R., Staley, J. T.,Brown, D. R., Hedlund, B. P., Paster, B. J., Ward, N. L., Ludwig, W., Whitman, W. B.

Song, Z. X., Li, W. W., Li, X. H., Dai, Y., Peng, X. X., Fan, Y.T., Hou, H. W. (2013) Isolation and characterization of a new hydrogenproducing strain Bacillus sp. FS2011. International Journal of Hydrogen Energy, 38, 3206-3212. DOI: https://doi.org/10.1016/j.ijhydene.2013.01.001.

Souza, A.T.; Peixoto, A. da N.; Waachholz, D. (1995) Banana. 2a ed., Instituto de planejamento e economia agrícola de Santa Catarina-CEPA/SC, Florianópolis, 103.

Spirito, C. M., Richter, H., Rabaey, K., Stams, A. J. M., Angenent, L. T. (2014) Chain elongation in anaerobic reactor microbiomes to recover resources from waste. Current Opinion in Biotechnology, 27, 115-122. DOI: https://doi.org/10.1016/j.copbio.2014.01.003.

Suo, Y., Luo, S., Zhang, Y., Liao, Z., Wang, J. (2017) Enhanced butyric acid tolerance and production by Class I heat shock protein-overproducing Clostridium tyrobutyricum ATCC 25755. Journal of Industrial Microbiology \& Biotechnology, 44, 1145-1156. DOI: 10.1007/s10295-017-1939-7.

Suzek B. E., Wang, Y., Huang, H., McGarvey, P.B., Wu, C.H (2015). UniRef clusters: a comprehensive and scalable alternative for improving sequence similarity searches. Bioinformatics, 31, 926-932. https://doi.org/10.1093/bioinformatics/btu739. 
Universidade de São Paulo

Escola de Engenharia de São Carlos

Programa de Pós-graduação em Hidráulica e Saneamento

Tam, A. D., Nguyen, Jun., Pyo, Kim., Mi, Sun, Kim., You, Kwan., Oh., Sang, Jun, Sim (2008) Optimization of hydrogen production by hyperthermophilic eubacteria, Thermotoga maritima and Thermotoga neapolitana in batch fermentation. International Journal of Hydrogen Energy, 33, 1483-1488.

Tandon, M., Thakur, V., Tiwari, K. L., Jadhav, S. K. (2018) Enterobacter ludwigii strain IF2SW-B4 isolated for bio-hydrogen production from rice bran and de-oiled rice bran. Environmental Technology \& Innovation, 10, 345-354. DOI: https://doi.org/10.1016/j.eti.2018.03.008.

Tang, G-L., Huang, J., Sun, Z-J., Tang, Q-Q., Yan, C-H., Liu, G-Q. (2008) Biohydrogen production from cattle wastewater by enriched anaerobic mixed consortia: influence of fermentation temperature and $\mathrm{pH}$. Journal of Bioscience and Bioengineering, 106, 80-87. DOI: https:// doi.org/10.1263/jbb.106.80.

Tang, J., Wang, X., Hu, Y., Zhang, Y., Li, Y. (2016) Lactic acid fermentation from food waste with indigenous microbiota: Effects of $\mathrm{pH}$, temperature and high OLR, Waste Management, 52, 278-285. DOI: https://doi.org/10.1016/j.wasman.2016.03.034.

Tapia-Venegas, E., Ramirez-Morales, J. E., Silva-Illanes, F., Toledo-Alarcón, J., Paillet, F., Escudie, R., Lay, C. H., et al. (2015). Biohydrogen production by dark fermentation: scaling-up and technologies integration for a sustainable system. Reviews in Environmental Science and Biotechnology, 14, 4, 761-785.

Tholozan, J. L., Touzel, J. P., Samain, E., Grivet, J. P., Prensier, G., Albagnac, G. (1992) Clostridium neopropionicum sp. nov., a strict anaerobic bacterium fermenting ethanol to propionate through acrylate pathway. Archives of microbiology, 157, 249-257. DOI: 10.1007/bf00245158.

Torrezan, R., Eiroa, M. N. U., Pfenning, L. (2000) Identificação de microrganismos isolados em frutas, polpas e ambiente industrial. Boletim do Centro de Pesquisa de Processamento de Alimentos, 18, 1, 2738.

Torquato, L. D. M., Pachiega, R., Crespi, M. S., Nespeca, M. G., Oliveira, J. E., Maintinguer, S. I. (2016) Potential of biohydrogen production from effluents of citrus processing industry using anaerobic bacteria from sewage sludge. Waste Management, 59, 181-193. DOI: https://doi.org/10.1016/j.wasman.2016.10.047.

Uyeda K. (1979) Phosphofructokinase. Adv. Enzymol. Relat. Areas Mol. Biol., 48, 193-244.

Van Heerden, J. H., Wortel, M. T., Bruggeman, F. J., Heijnen, J. J., Bollen, Y. J., Planque’, R., Hulshof, J., O'Toole, T. G., Wahl, S. A., Teusink, B. (2014) Lost in transition: start-up of glycolysis yields subpopulations of nongrowing cells. Science, 343, 1245114. DOI: 10.1126/science.1245114.

Vasconcelos, E. A. F., Leitão, R. C., Santaella, S. T. (2016). Factors that affect bacterial ecology in hydrogenproducing anaerobic reactors. BioEnergy Research, 9, 4, 1260-1271. DOI: http://dx.doi.org/10.1007/s12155-016-9753-z.

Velasco, S. E., Yebra, M. J., Monedero, V., Ibarburu, I., Duenas, M. T., Irastorza, A. (2007) Influence of the carbohydrate source on beta-glucan production and enzyme activities involved in sugar metabolism in Pediococcus parvulus 2.6. International Journal of Food Microbiology. 115, 325-334. DOI: https://doi.org/10.1016/j.ijfoodmicro.2006.12.023.

Verzeaux, J., Alahmad, A., Habbib, H., Nivelle, E., Roger, D., Lacoux, J., Decocq, G., Hirel, B., Catterou, M., Spicher, F., Dubois, F., Duclercq, J., Tetu, T. (2016) Cover crops prevent the deleterious effect of nitrogen fertilisation on bacterial diversity by maintaining the carbon content of ploughed soil. Geoderma., 281, 49-57.

Wan, J.; Jing, Y.; Zhang, S.; Angelidaki, I.; Luo, G. (2016) Mesophilic and thermophilic alkaline fermentation of waste activated sludge for hydrogen production: Focusing on homoacetogenesis. Water Research, 102, 524-532.

Wang, B., Wan, W., Wang, J. (2008) Inhibitory effect of ethanol, acetic acid, propionic acid and butyric acid on fermentative hydrogen production. International Journal of Hydrogen Energy., 33, 7013-7019. 


\author{
Universidade de São Paulo \\ Escola de Engenharia de São Carlos \\ Programa de Pós-graduação em Hidráulica e Saneamento
}

Wang, C., Zuo, J., Chen, X., Xing, W., Xing, L., Li, P., Lu, X., Li, C. (2014) Microbial community structures in an integrated two-phase anaerobic bioreactor fed by fruit vegetable wastes and wheat straw. Journal of Environmental Sciences, 26, 2484-2492. DOI: https://doi.org/10.1016/j.jes.2014.06.035.

Wang, S., Zhang, T., Su, H (2016) Enhanced hydrogen production from corn starch wastewater as nitrogen source by mixed cultures. Renewable Energy, 96, 1135-1141.

Wang, X., He, Q., Yang, Y., Wang, J., Haning, K., Hua, Y., Wu, B., He, M., Zhang, Y., Bao, J., Contreras, L. M., Yang, S. (2018) Advances and prospects in metabolic engineering of Zymomonas mobilis. Metabolic Engineering. DOI: https://doi.org/10.1016/j.ymben.2018.04.001.

Wilson W. A., Roach P. J., Montero M., Baroja-Fernández E., Muñoz F. J., Eydallin G., Viale A. M., PozuetaRomero J. (2010) Regulation of glycogen metabolism in yeast and bacteria. FEMS Microbiol. Rev., 34, 952-985.

Wong, Y. M., Wu, T. Y., Juan, J. C. (2014) A review of sustainable hydrogen production using seed sludge via dark fermentation. Renewable and Sustainable Energy Reviews, 34, 471-482. DOI: https://doi.org/10.1016/ j.rser.2014.03.008.

Wu, G. (2009) Amino acids: metabolism, functions, and nutrition. Amino Acids, 37, 1-17. http://dx.doi.org/10.1007/s00726-009-0269-0.

Wu, S.Y.Y., Chu, C.Y.Y., Shen, Y.C.C. (2012) Effect of calcium ions on biohydrogen production performance in a fluidized bed bioreactor with activated carbon-immobilized cells. International Journal of Hydrogen Energy., 37, 15496-15502.

Yang, P., Zhang, R., McGarvey, J. A., Benemann, J. R. (2007) Biohydrogen production from cheese processing wastewater by anaerobic fermentation using mixed microbial communities. International Journal of Hydrogen Energy, 32, 18, 4761-4771. DOI: https://doi.org/10.1016/j.ijhydene.2007.07.038.

Yang, J., Tan, H., Cai, Y. (2016) Characteristics of lactic acid bacteria isolates and their effect on silage fermentation of fruit residues. J. Dairy Sci., 99, 1-10.

Yang, G., Wang, J. (2018) Various additives for improving dark fermentative hydrogen production: A review. Renewable and Sustainable Energy Reviews, 95, 130-146.

Yao, P., Xiao, Z., Chen, C., Li, W., Deng, Q. (2016) Cell growth behaviors of Clostridium acetobutylicum in a pervaporation membrane bioreactor for butanol fermentation. Biotechnology Applied Biochemistry, 63, 101. DOI: https://doi.org/10.1002/bab.1318.

Yim, H., Haselbeck, R., Niu, W., Pujol-Baxley, C., Burgard, A., et al. (2011) Metabolic engineering of Escherichia coli for direct production of 1,4-butanediol. Nature Chemical Biology, 7, 445-452. DOI: 10.1038/NChemBio.580

Yin, Y., Wang, J. (2016) Characterization and hydrogen production performance of a novel strain Enterococcus faecium INET2 isolated from gamma irradiated sludge. International Journal of Hydrogen Energy, 41, 22793-22801. DOI: https://doi.org/10.1016/j.ijhydene.2016.10.059.

Yin, Y., Wang, J. (2017) Isolation and characterization of a novel strain Clostridium butyricum INET1 for fermentative hydrogen production. Int. J. of hydrogen energy, 42, 12173-12 180.

Yin, Q., Yang, S., Wang, Z., Xing, L., Wua, G. (2018) Clarifying electron transfer and metagenomic analysis of microbial community in the methane production process with the addition of ferroferric oxide. Chemical Engineering Journal, 333, 216-225.

Yokoyama, H., Waki, M., Moriya, N., Yasuda, T., Tanaka, Y., Haga, K. (2007) Effect of fermentation temperature on hydrogen production from cow waste slurry by using anaerobic microflora within the slurry. Applied Microbiology and Biotechnology, 74, 474-483. DOI: 10.1007/s00253-006-0647-4. 
Universidade de São Paulo

Escola de Engenharia de São Carlos

Programa de Pós-graduação em Hidráulica e Saneamento

Yu, J., Zheng, M., Tao, T., Zuo, J., Wang, K. (2013) Waste activated sludge treatment based on temperature staged and biologically phased anaerobic digestion system. Journal of Environmental Sciences, 25, 10, 20562064. DOI: https://doi.org/10.1016/S1001-0742(12)60266-6.

Yuan, Q., Sparling, R., Oleszkiewicz, J. A. (2011) VFA generation from waste activated sludge: effect of $\begin{array}{lllll}\text { temperature and } & \text { Chemosphere, }\end{array}$ https://doi.org/10.1016/j.chemosphere.2010.10.084.

Zheng, X.J., Yu, H.Q. (2004) Biological hydrogen production by enriched anaerobic cultures in the presence of copper and zinc. J Environ Sci Heal Part A Toxic/Hazardous Subst Environ Eng., 39, 89-101.

Zhang, P., Chen, Y., Zhou, Q., Zheng, X., Zhu, X., Zhao, Y. (2010) Understanding shortchain fatty acids accumulation enhanced in waste activated sludge alkaline fermentation: kinetics and microbiology. Environmental Science \& Technology, 44, 24, 9343-9348. DOI: 10.1021/es102878m.

Zhang, F., Ding, J., Zhang, Y., Chen, M., Ding, Z. W., Van Loosdrecht, M. C. M., Zeng, R. J. (2013) Fatty acids production from hydrogen and carbon dioxide by mixed culture in the membrane biofilm reactor. Water Research, 47, 6122-6129. DOI: https://doi.org/10.1016/j.watres.2013.07.033.

Zhao, P., Fan, S. Q., Tian, L., Pan, C. M., Fan, Y. T., Hou, H. W. (2010) Hydrogen production characteristics from dark fermentation of maltose by an isolated strain F.P 01. International Journal of Hydrogen Energy, 35, 7189-7193. DOI: https://doi.org/10.1016/j.ijhydene.2009.12.188.

Zhao, X., Xing, D., Liu, B., Lu, L., Zhao, J., Ren, N. (2012) The effects of metal ions and L-on hydA gene expression and hydrogen production by Clostridium beijerinckii RZF-1108. International Journal of Hydrogen Energy, 37, 13711-1377.

Ziara, R. M., Miller, D. N., Subbiah, J., Dvorak, B. I. (2019) Lactate wastewater dark fermentation: The effect of temperature and initial $\mathrm{pH}$ on bio-hydrogen production and microbial community, International Journal of Hydrogen Energy, 44, 661-673. DOI: https://doi.org/10.1016/j.ijhydene.2018.11.045.

Zigova, J., Šturdík, E. (2000) Advances in biotechnological production of butyric acid. Journal of industrial Microbiology and Biotechnology, 24, 153-160. DOI: 10.1038/sj.jim.2900795.

Zwietering, M. H., Jongenburger, I., Rombouts, F. M., Van`t Riet, K. (1990) Modeling of the bacterial growth curve. Applied and Environmental Microbiology, 56,1875-1881. 